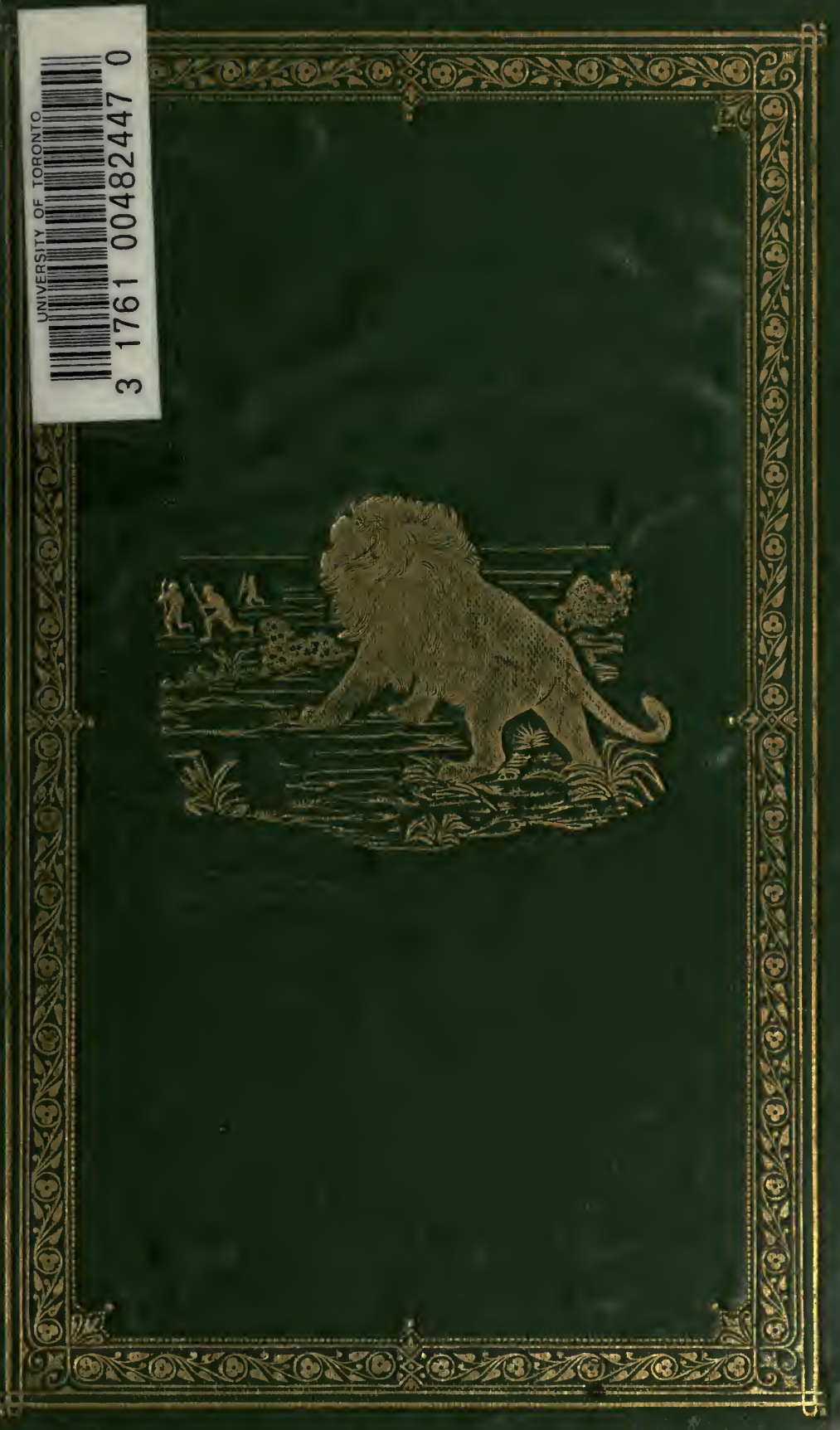




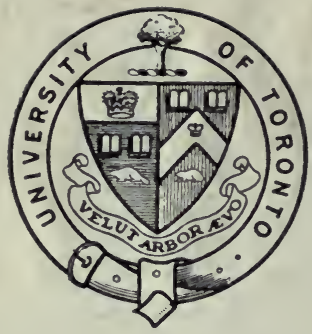

罗resented to

The Tillharary of the

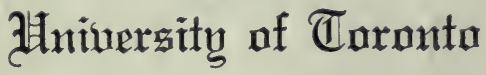

by

Mr. Hugo Holland 


$$
\begin{aligned}
& \begin{array}{l}
x+4 \\
\sin
\end{array}
\end{aligned}
$$

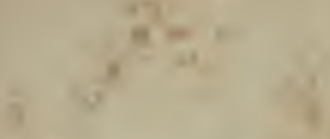

$$
\begin{aligned}
& +8 \\
& 18 \\
& \text { (1) }
\end{aligned}
$$

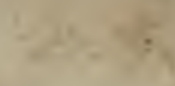

$$
\begin{aligned}
& \text { Y } \\
& \cdot 4 x=5 \\
& 7 x-1= \\
& \text { t }
\end{aligned}
$$

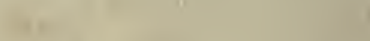

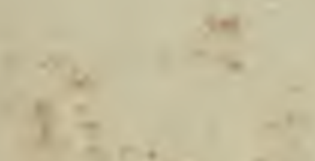

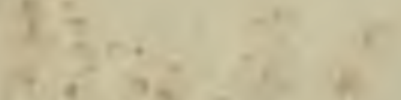

$$
\begin{aligned}
& +2
\end{aligned}
$$

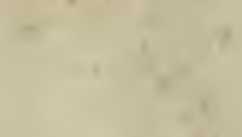

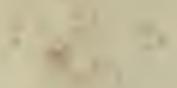

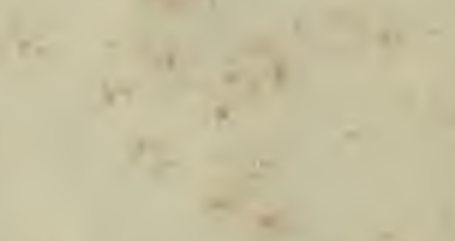

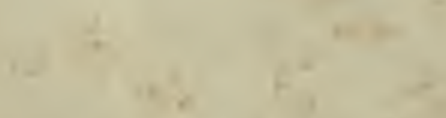

$$
\begin{aligned}
& 4 \\
& \text { I }
\end{aligned}
$$

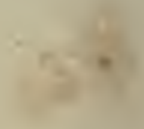

1

125.$$
+2
$$ 


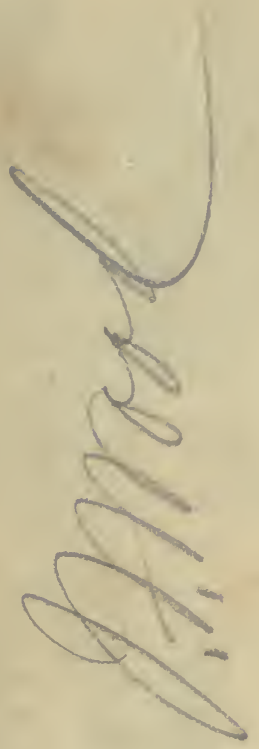

x

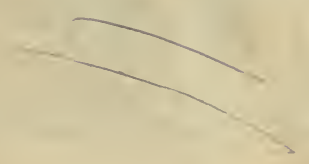




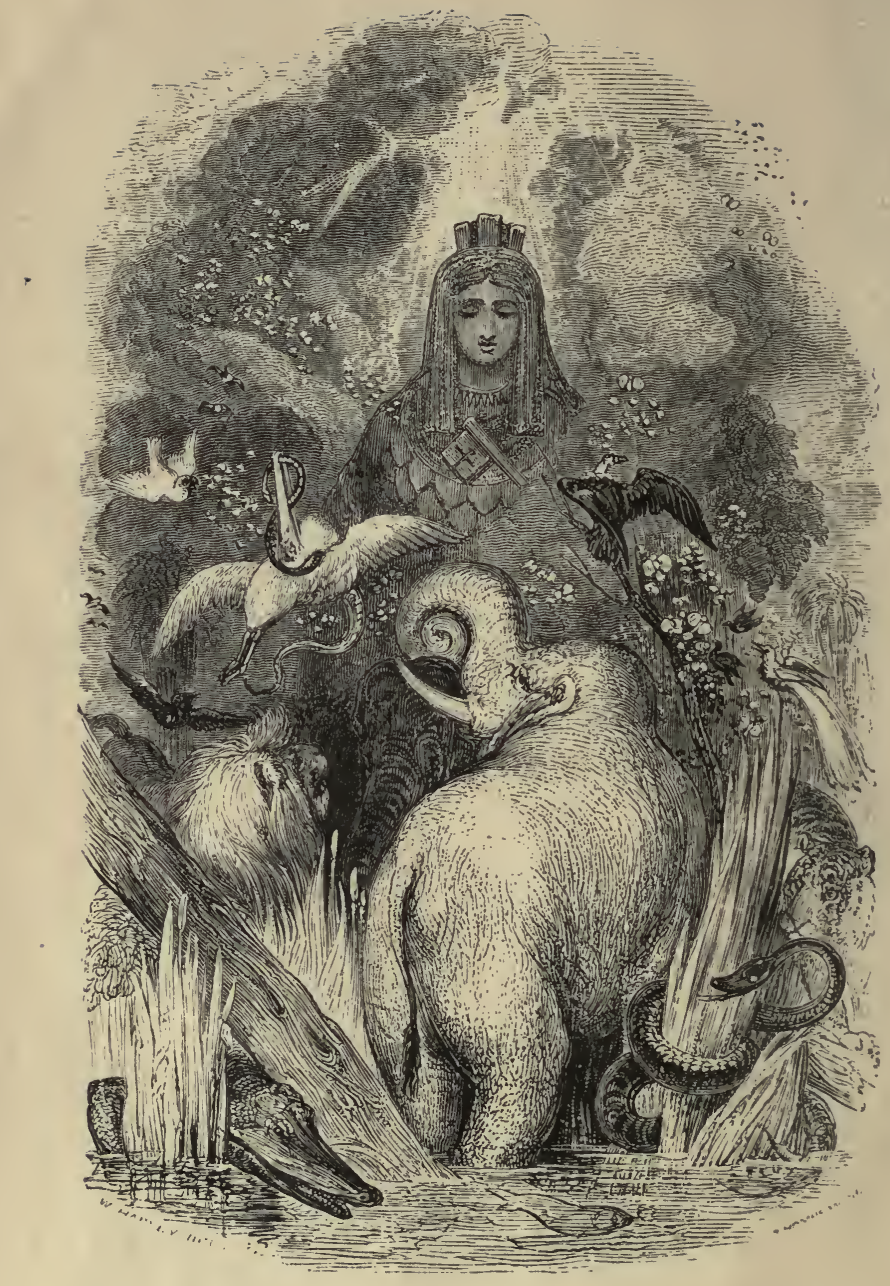




\section{MRS. LOUDON'S}

\section{ENTERTAINING NATURALIST,}

BEING

\section{POPULAR DESCRIPTIONS, TALES, AND ANECDOTES}

\section{OF MORE THAN \\ FIVE HUNDRED ANIMALS.}

A NEW EDITION, REVISED AND ENLARGED.

BY

W. S. DALLAS, F.L.S.

LON DON :

BELL \& DALDY, 6, YORK STREET, COVEN'T GARDEN, I867. 


$$
\begin{aligned}
& \text { QL } \\
& 49 \\
& \text { Lo } \\
& 1867
\end{aligned}
$$

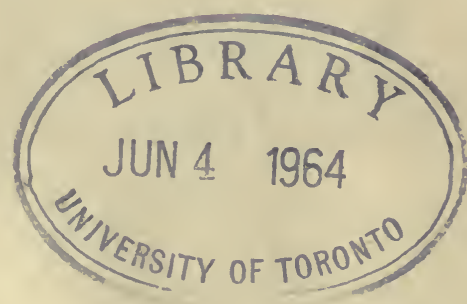

$$
903478 \text {. }
$$

LONDON: PRINTED BY WILLIAM CLONES AND SONS, STAMFORD STREET 


\section{$P R E F A C E$.}

Mrs. Loudon's Entertaining Naturalist has been so deservedly popular that the publishers, in preparing a new edition, have striven to render it still more worthy of the reputation it has obtained. For this purpose, it has been very thoroughly revised and enlarged by Mr. W. S. Dallas, Member of the Zoological Society, and Curator of the Museum of Natural History at York, and several illustrations have been added.

In its present form, it is not only a complete Popular Natural History of an entertaining character, with an illustration of nearly every animal mentioned, but its instructive introductions on the Classification of Animals adapt it well for use as an elementary Manual of the Natural History of the Animal Kingdom for the use of the Young. 



\section{INTRODUCTION.}

ZooLOGY is that branch of Natural History which treats of animals, and embraces not only their structure and functions, their habits, instincts, and utility, but their names and systematic arrangement.

Various systems have been proposed by different naturalists for the scientific arrangement of the animal kingdom, but that of Cuvier, with some modifications, is now thought the best, and a sketch of it will be found under the head of the Modern System in this Introduction. As, however, the System of Linnæus was formerly in general use, and is still often referred to, it has been thought advisable to give a sketch of it first; that the reader may be aware of the difference between the old system and the new one.

\section{LINNAEAN SYSTEM.}

According to the system of Linnæus, the objects comprehended within the animal kingdom were divided into six classes: Mammalia or Mammiferous Animals, Birds, Amphibia or Amphibious Animals, Fishes, Insects, and Worms, which were thus distinguished :

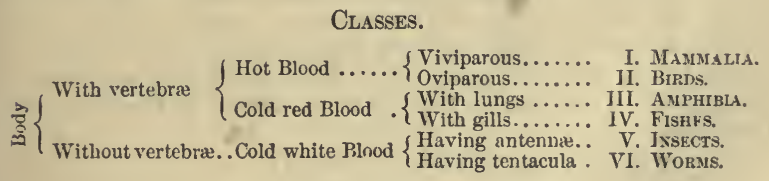

\section{ORDERS OF MAMMALIA.}

The first class, or Mammalia, consists of such animals as produce living offspring, and nourish their young ones with milk supplied from their own bodies; and it comprises both the quadrupeds and the cetacea.

This class was divided by Linnæus into seven Orders : viz. primates, bruta, ferce, glires, pecora, belluce, and cetacea (this order was called Cete by Linnæus) or whales. The characteristics of these were founded. for the most part, on the number and arrangement of the 
teeth; and on the form and construction of the feet, or of those parts in the seals, manati, and cetacea, which supply the place of feet :

I. Prinates.-Having the upper front teeth, generally four in number, wedge-shaped, and parallel; and two teats situated on the breast, as the apes and monkeys.

II. BruTA.-Having no front teeth in either jaw; and the feet armed with strong hoof-like nails, as the elephant.

III. FER.s.-Having in general six front teeth in each jaw; a single canine tooth on each side in both jaws; and the grinders with conic projections, as the dogs and cats.

IV. Gisres.-Having in each jaw two long projecting front teeth, which stand close together; and no canine teeth in either jaw, as the rats and mice.

V. PECora.- Having no front teeth in the upper jaw ; six or eight in the lower jaw, situated at a considerable distance from the grinders; and the feet with hoofs, as cattle and sheep.

VI. BeLLUx.-Having blunt wedge-shaped front teeth in both jaws; and the feet with hoofs, as horses.

VII. Cetacea.-Having spiracles or breathing-holes on the head; fins instead of fore feet; and a tail flattened horizontally, instead of hind feet. This order consists of the narvals, whales, cachalots, and dolplins.

\section{ORDERS OF BIRDS.}

The second class, or Birds, comprises all such animals as have their bodies clad with feathers. Their jaws are elongated, and covered $\in \mathrm{x}$ ternally with a horny substance, called a bill or beak, which is divided into two parts called mandibles. Their eyes are furnished with a thin, whitish, and somewhat transparent membrane, that can at pleasure be drawn over the whole external surface like a curtain. Their organs of motion are two wings and two legs; and they are destitute of external ears, lips, and many other parts which are important to quadrupeds. That part of Zoology which treats of Birds is called Ornithology.

Linmæus divided this class into six Orders:

\section{Land Birds.}

I. Rapacious Birns (Accipitres).-Having the upper mandible hooked, and an angular projection on each side near the point, as the eagles, hawks, and owls.

II. Pies (Pica).-- Having their bills sharp at the edge, somewhat compressed at the sides, and convex on the top, as the crow.

III. Passerine Biros (Passeres).-Having the bill conical and pointed, and the nostrils oval, open, and naked, as the sparrow and linnet. 
IV. Gallivaceous Birds (Galline).-Having the upper mandible arched, and covering the lower one at the edge, and the nostrils arched over with a cartilaginous membrane, as the common poultry.

\section{Water Birds.}

V. WADERS (Gralla).-Having a roundish bill, a fleshy tongue, and the legs naked above the knees, as the herons, plovers, and snipes.

VI. Swimmers (Anseres).-Having their bills broad at the top, and covered with a soft skin, and the feet webbed, as ducks and geese.

\section{ORDERS OF AMPHIBIA.}

Under the third class, or Amphibia, Linnæus arranged such animals as have a cold, and, generally, naked body, a lurid colour, and nauseous smell. They respire chielly by lungs, but they have the power of suspending respiration for a long time. They are extremely tenacious of life, and can repair certain parts of their bodies which have been lost. They are also able to endure hunger, sometimes even for months, without injury.

The bodies of some of them, as the turtles and tortoises, are protected by a hard and horny shield or covering; those of others are clad with scales, as the serpents, and some of the lizards; whilst others, as the frogs, toads, and most of the water-lizards, are entirely naked, or have their skin covered with warts. Many of the species shod their skins at certain times of the year. Several of them are furnished with a poison, which they eject into wounds that are made by their teeth. They chiefly live in retired, watery, and marshy places; and, for the most part, feed on other animals, though some of them eat water-plants, and many feed on garbage and filth. None of these species chew their food; they swallow it whole, and digest it very slowly.

The off'spring of all these animals are produced from eggs, which, after they have been deposited by the parent animals in a proper place, are hatched by the heat of the sun. The eggs of some of the species are covered with a shell; those of others have a soft and tough skin or covering, not much unlike wet parchment; and the eggs of several are perfectly gelatinous. In those few that produce their offspring alive, as the vipers and some other serpents, the eggs are regularly formed, but are hatched within the bodies of the females.

This class Linnæus divided into three Orders :

I. ReptiLes.-Having four legs, and walking with a crawling pace, as the tortoises, toads, and lizards.

II. Serpents.-Having no legs, but crawling on the body.

III. NANTES.-Living in the water, furnished with fins, and breathing by means of gills. These are true Fishes, principally of the group termed Chondropterygii, or Cartilaginous Fishes, by Cuvier. 


\section{ORDERS OF FISHES.}

Fishes constituted Linnæus's fourth class of animals. 'They are all inhabitants of the water, in which they move by certain organs called fins. Those situated on the back are called dorsal fins; those on the sides, bchind the gills, pectoral fins; those below the body, near the head, are ventral; those behind the vent are anal; and that which forms the tail is called the caudal fin. Fishes breathe by gills, which, in most species, are situated at the sides of the head. Fishes rise and sink in the water, generally by a kind of bladder in the interior of the body, called an air-bladder. Some of them do not possess this organ, and consequently are seldom found but at the bottom of the sea, from which they can only rise by an effort. The bodies of these animals are usually covered with scales, which keep them from injury by the contact of the water.

The fishes were divided by Linnæus into four Orders :

I. Apodal.-Having no ventral fins, as the eel.

1I. Jugular.- Having the ventral fins situated in front of the pectoral fins, as the cod, haddcok, and whiting.

III. Thoracic.- Having the ventral fins situated directly under the pectoral fins, as the perch and mackerel.

IV. Abdominal. - Having the ventral fins on the lower part of the body below the pectoral fins, as the salmon, herring, and carp.

\section{ORDERS OF INSECTS.}

The fifth class of Linnæus comprised the Insects; and the branch of Zoology which treats of them is calledEntomology. Nearly all insects go through certain great changes at different periods of their existence. From the egg is hatched the larva, which is a grub or caterpillar, and destitute of wings; this aftérwards changes to a pupa, or chrysalis, wholly covered with a hard shell, or strong skin, from which the perfect or winged insect bursts forth. Spiders and their allies, which were included by Linnæus in the insects, issue from the egg in nearly a perfect state.

Linnæus divided his class of insects into seven Orders :

I. Coleopterous.-Having elytra, or crustaceous cases covering the wings; and which, when closed, meet in a straight line along the middle of the back, as the cockchafer.

II. Hemiptenous.-Having four wings, the upper ones partly crustaceous, and partly membranous; not divided straight down the middle of the back, but crossed, or incumbent on each other, as the cockroach.

III. Lepidopterous.-Having four wings covered with fine scales almost like powder, as the butterflies and moths.

IV. Neuropterous.-Having four membranous and semi-transparent wings, veined like network; and the tail without a sting, as the dragon-fly and ephemera. 
V. HyMenopterous.-Having four membranous and semi-transparent wings, veined like network; and the tail armed with a sting, as the wasp and bee.

VI. Dipterous.-Having only two wings, as the common house-flies.

VII. Apterous.-Having no wings, as the spiders.

\section{ORDERS OF VERMES, OR WORMS.}

The sixth and last Linnæan class consisted of Worms, or Vermes. These are slow of motion, and have soft and fleshy bodies. Some of them have hard internal parts, and others have crustaceous coverings. In some of the species, eyes and ears are very perceptible, whilst others appear to enjoy only the senses of taste and touch. Many have no distinct head, and most of them are destitnte of feet. They are, in general, so tenacious of life, that parts which have been destroyed will be reproduced. These animals are principally distinguished from those of the other classes by having tentacula, or feelers, and are divided by Jinnæus into five Orders:

I. Intestrina.-Are simple and naked, without limbs; some of them live within other animals, as the ascarides and tape-worms; others in water, as the leeches; and a few in the earth, as the earth-worm.

II. Mollusca.-Are simple animals, without shells, and furnished with limbs, as the cuttle-fish, medusa, star-fish, and sea-urchin.

III. Testacea.-Are animals similar to the last, but covered with shells, as oysters, cockles, snails, and limpets.

IV. Lithophyta. - Are composite Polyps, dwelling in cells in a calcareous base which they produce, as corals and madrepores.

r. ZoophyтA.-Are usually composite animals, but do not reside in stony cells. 'The coral, sponge, and polyps are instances of this order, which also includes the Infusorial Animalcules.

\section{MODERN SYSTEM.}

It will be found by reading the following sketch of the Modern System that the greatest change has taken place in the latter two classes. The others remain nearly the same in effect, though their distinctions are different, and the classes are not arranged in the same order.

According to Cuvier, all animals are arranged in four great divisions, which are subdivided into classes and orders, as follows :-

Division3

Classes

No. of Orders

$\left.\begin{array}{c}\text { I. Vertebrata. } \\ \text { Four Classes. 'Twenty- } \\ \text { seven Orders. }\end{array}\right\}$

1. Mammalia ..... Nine.

2. Aves........ Six.

3. Reptilia ..... Four.

4. Pisces ....... Eight. 
Divisions

Classes

No. of Orders

II. Mollusca.

Six Classes. Fifteen Orders.

1. Cephalopoda .... One.

2. Pteropoda . . . . One.

3. Gasteropoda .... Nine.

4. Acephala . . . . Two.

5. Brachiopoda .... One.

6. Cirrhopoda ..... One.

III. Articulata.

Four Classes. Twenty-
four Orders.

1. Annelides ..... Three.

2. Crustacea ..... Seven.

3. Arachnida ..... Two.

4. Insecta . . . . . Twelve.

IV. Radiata.

Five Classes. Eleven

1. Echinodermata ... Two.

2. Entozoa ...... Two.

3. Acalephæ ..... Two.

Orders.

4. Polypi ...... Three.

5. Infusoria ...... Two.

\section{THE VERTEBRATED ANIMALS}

Have a backbone divided into vertebræ or joints, whence they take their name. They have also separate senses for hearing, sceing, tasting, smelling, and feeling; a distinct head, with a mouth opening by two horizontal jaws; a muscular heart, and red blood. The four classes of Vertebrata and their orders are as follow :-

I. The Mammalia are all furnished with mammæ, or teats, through which they give milk to their young, which they bring forth ulive. They have warm blood, which all circulates from the heart through the lungs, and returns to the heart before it passes through the body. Their skins are naked, or covered with wool or hair, and their mouths are generally furnished with teeth. There are eleven orders, which are thus distinguished :-

Section I.-Unguiculated Animals, or Mammalia having Nails or Claws.

I. Bimana, or two-handed. This order contains only the human species.

II. Quadrumana, or four-handed. This order contains the apes, baboons, and monkeys, and the lemurs.

IIJ. Cheiroptera, the bat family.

IV. Carnivora, or beasts of prey. This order is divided into the following three tribes:-

1. The Insectivora, consisting of those animals which live upon insects, as the hedgehog, the shrew, and the mole.

2. The Carnivora proper, consisting chiefly of the cat family, including lions, tigers, and their allies; the bear family, including the badger, the coati-mondi, the racoon, \&c.; the dog family, including the wolf and the fox; the weasel family; the civet-cats; and the hyæna.

3. The Amphibia, consisting of the seals, and other allied animals. 
V. Marsupialia, including the opossums and the kangaroos.

VI. Monothrema, containing the Echidna and Ornithorhynchus of Australia.

VII. Rodentia, or gnawing animals. The principal of these are the squirrel family, mice and rats, hares and rabbits, the beaver, the porcupine, and the guinea-pig.

VIII. Edentata, or toothless animals, that is, without front teeth. The principal of these are the sloths, the armadillos, and the ant-eaters.

\section{Section II.-Ungulated or Hoofed Mammalia.}

IX. Pachydermata, or thick-skinned animals. The principal of these are the elephant, the hippopotamus, the rhinoceros; the horse family, including the ass, the mule, the zebra, and the quagga ; the wild boar family, and the tapir.

X. Ruminantia, or ruminating animals, the principal of which are the camel family, the deer family, the giraffe, the antelope family, the goat family, the sheep family, and the ox family.

\section{Section III.-Aquatic Mammalia, having no Hind Limbs, and the Fore Limbs converted into Fins.}

XI. Cetacea, or sea mammalia, the principal of which are the whale family, the dolphin family, the manati, the porpoise family, and the narwhal, or sea-unicorn.

\section{THE AYES, OR BIRDS,}

Lay eggs from which their young are hatched by what is called incubation. Their skins are covered with feathers; and their jaws are horny, without teeth. Their blood is warm, and circulates like that of the mammalia. The six orders of Aves are as follow :-

1. Raptores, or birds of prey. These birds are distinguished by a very strong and sharp bili more or less curved, but always hooked at the extremity of the upper mandible, which is covered at the base with a kind of skin called the cere. The nostrils are usually open. The legs are very strong, the feet are large, and the toes, which are four in number, are armed with very strong, sharp, curved claws. The principal raptorial birds are the vultures, including the condor; the falcon family, including the eagles, hawks, kites, and buzzards ; and the owls.

2. Insessores, or perching birds. 'These birds have all feet formed for perching, the hind toe springing from the same place as the other toes, which gives them great power of grasping. 'Their legs are of moderate length, and their claws not sharply curved. 'This order includes the thrushes, nightirgales, and all the finest songsters of our groves, with the robin-redbreast, the sparrow, and other birds seen about dwellings, the swallows, the larks, the crow family, the kingfishers, the birds of paradise, and the humming birds. 
3. Scansores, or climbers. These birds have two toes before and two behind. This construction gives them such great power of climbing, that they can ascend the perpendicular trunk of a tree. The principal birds in this order are the parrots, the cuckoos, and the woodpeckers.

4. Rasores, or gallinaceous birds. These birds have the head small in proportion to the body. The bill is generally short, with the upper mandible somewhat curved. The nostrils have usually a protecting fleshy membrane. The tarsus, or lower part of the leg, is long and bare, and there are four toes, those in front being united by a slight membrane, while that behind is generally higher up the leg, and smaller than the others. This order comprises most of the birds used as food, and includes the peacock, the turkey, the common cock and hen, the partridge, the pheasant, and the pigcon family.

5. Giallatores, or Waders. These birds are characterised by their long and slender legs, and by the thighs being more or less bare. There are three anterior toes, more or less united at the base by a membrane, or rudimentary web. The hind toe is wanting in some members of the order. This order contains the ostrich family, the bustards and plovers; the cranes, herons, and storks ; and the snipes and woodcocks.

6. Palmipedes, or web-footed birds. These birds have the legs and feet short, and placed behind, with their fore toes united by a thick and strong membrane. The neck is much longer than the legs, and their bodies are covered with a dense layer of down beneath the outer plumage, which is close, and imbued with an oily fluid that repels the water. The principal birds in this order are the grebes, the auks and penguins, the petrels, the pelican and cormorant. and the swans, ducks, and geese.

By many ornithologists the pigeons and ostriches are considered to form distinct orders, called respectively Columbe and Cursores.

\section{THE REPTILIA,}

Or Reptiles, have neither hair, wool, nor feathers, and their bodies are either naked, or covered with scales. Some lay eggs, and some bring forth their young alive. Some have gills, and others lungs, but the latter have only a portion of the blood passing through them; and thus the blood of reptiles is cold, as it is respiration which gives the blood heat. The senses of reptiles are dull, and their movements are either slow or laborious. The following are the four orders into which this class is divided :-

1. Chelonian Reptiles. These animals have four legs. The body is enclosed in an upper buckler, called the carapace, and an under one, called the plastron. They have lungs which are much expanded; but they have no teeth, though they have hard horny jaws. The females lay eggs covered with a hard shell. The principal animals belonging to this division are the tortoises, which live on land or in fresh waters, and the turtles, which inhabit the sea. 
2. The Saurian Reptiles. These animals have also expanded lungs, and generally four legs, but some have only two. Their bodies are covered with scales, and their mouths filled with teeth. This order includes all the crocodiles and lizards. The crocodiles have broad flat tongues, attached throughout to the jaws, and the lizards have long narrow tongues, which many of them can extend to a great distance from the mouth.

3. The Ophidian Reptiles are the snakes and serpents. The body is covered with scales, but it is destitute of feet. 'The lungs are generally well developed, only on one side. Serpents are frequently furnished with poison-bags at the base of some of their teeth.

4. The Batrachian Reptiles include the frogs and toads. The body is naked. 'The greater part of these reptiles undergo a transition from a fish-like tadpole furnished with gills to a four-legged animal with lungs. Others never lose their gills, though they acquire lungs, and of this kind are the siren and the proteus.

\section{THE PISCES,}

Or Fishes, are defined by Cuvier to be vertebrated animals with red blood, breathing through the medium of water by means of their branchiæ or gills. To this definition may be added, that fishes have no neck, and that the body generally tapers from the head to the tail; that most of the species are furnished with air-bladders which enable them to swim; and that their bodies are generally covered with scales. The heart has only one auricle, and the blood is cold. The gills require to be kept moist to enable the fish to breathe, and as soon as they become dry, the fish dies. Thus fishes with large gill openings die almost as soon as they are taken out of the water; while those with very small openings, like the eel, live a long time. Fishes have no feet, but are furnished with fins. The scientific knowledge of Fishes is called Ichthyology. Fishes are first divided into two great series, viz. the Bony Fishes, and the Cartilaginous Fishes, and these are again subdivided into nine orders, as follows :-

\section{Osseous or Bony Fishes.}

1. Acanthopterygii, or fishes with hard fins.

2. Malacopterygii abdominales, or scft-finned fishes, with the ventral fins on the abdomen behind the pectorals.

3. Malacopterygii sub-brachiati, or soft-finned fishes, with the ventral fins under the gills.

4. Malacopterygii apodes, or soft-finned fishes, without ventral fins.

5. Lophobranchii, or fishes with tufted gills.

6. Plectognathii, or fishes with the upper jaw fixed.

\section{Chondropterygir, or Cartilaginous Fishes.}

7. Cyclostomi, or fishes with jaws fixed in an immovable ring, and with holes for the gills.

8. Selachii, or fishes with movable jaws and holes for the gills.

9. Sturiones, with the branchiæ in the usual form. 
Of the bony fishes the Acanthopterygii, or fishes with hard spiny fins, are divided into fifteen families, the principal of which are the perch family, the mailed cheek fishes, including the gurnards, the flying fish of the Mediterranean, and the sticklebacks, or jack banticles; the mackerel family, including the tunny, bonito, and sword-fish; the pilot-fish, the dolphin of the Mediterranean, so celebrated for the beauty of its dying tints, and the John Dory. Among the Malacopterygii abdominales, or sott-finned fishes, that have their ventral fins suspended from the abdomen, the most interesting are the carp family, the pike family, the flying-fish of the ocean, the salmon family, and the herring family, including the sprat, pilchard, and anchovy.

The Malacopterygii sub-3rachiati are soft-finned fishes, with the ventral fins beneath the pectorals; the principal of which are the cod family, including the haddock, whiting, and ling; the flat-fish family, including soles, turbots, plaice, and flounders; and the suckers or lump-fish.

The Malacopterygii apodes are confined to the eel family.

The Lopliolranchii include the pipe fish, and other fishes of similar form.

The Plectognathi comprise the very singular forms of the balloonfish, the sun-fish, and other similar fishes.

The Chondropterygii, or Cartilaginous fishes, are divided into three orders, viz. the Sturiones, or sturgeon family; the Selachi, or sharks and rays, including the torpedo; and the Cyclostomi, or lamprey family. 'The last two orders were included by Cuvier in a single one.

\section{THE MOLLUSCOUS ANIMAIS}

Have no bones except their shells. Their sense of feeling appears to be very acute, but the organs for the other senses are either wanting or very imperfect. The blood is cold and white, and the heart often consists of only one ventricle; a few of them have imperfect lungs, but the greater number breathe through gills. They have all the power of remaining a long time in a state of rest, and their movements are either slow or violently laborious. Some of them appear incapable of locomoticn. They produce their young from eggs, but some lay their eggs on a part of their own body, where the young are hatched. The following are Cuvier's six classes:-

1. Cephalopodo, or Head-footed Mollusca. These animals are furnished with long fleshy arms or feet, proceeding from the head, which is not distinct from the bo.ly, and on which they crawl. There is only one order, which includes the cuttle-fish, nautilus, and belemnites.

2. Pteropoda, or Wing-footed Mollusca. These animals have two membranous feet or arms, like wings, proceeding from the neck. There is only one order, which contains six genera, the best known of which is the Hyalæa, the shell of which is commonly called Venus's chariot.

3. Gasteropoda, or Body-footed Mollusca. All these animals crawl with the flat part of the body, which acts as a kind of sucker. There are nine orders in Cuvier's system. 'The common snail will give an idea of the habits oi the class. 
4. Acephala, or Headless Mollusca. These animals have no apparent head, and breathe by means of branchiæ, which are generally ribbon-shaped. Most of them are enclosed in a bivalve shell, but some are naked; the former are the Testacea of Cuvier, and the Conchifera of Iamarck; the latter are the Tunicata of Lamarck. They form two orders.

5. Brachiopoda, or Arm-footed Mollusca. These animals also have a bivalve shell; but they have no true branchiæ, and their respiration is effected by the agency of the mantle. They have two spiral arms.

6. Cirrhopoda, or Curled-footed Mollusca. These are generally attached, and enclosed in a shell of several pieces; they are furnished with a mouth, armed with jaws, and with several pairs of jointed and fringed organs, called cirri, by the protrusion and retraction of which they capture their prey. Examples of this class are the Barnacles and Acorn shells. These animals have long ceased to be regarded as Mollusca, the investigations of modern naturalists having proved them to be true articulated animals most nearly related to the Crustacea.

\section{THE ARTICULATED ANIMALS}

Have no back-bone. The covering of the body is sometimes hard and sometimes soft, but it is always divided into segments by a number of transverse incisions. The limbs, when the body is provided with any, are jointed; and they can be separated from the body without any serious injury being sustained by the animal, new limbs being shortly after formed to replace them. The senses of tasting and seeing are more perfect than those of the Mollusca, though that of feeling seems much less acute. In other respects the four classes differ considerably from each other.

[The Entozoa, or Intestinal Worms, placed by Cuvier and others among the Radiata, are now arranged amongst the lowest forms of articulated animals, as are also those animalcules known as Rotifera.]

I. The Annelida, or Red-blooded Worms, have no heart, properly so called, but have sometimes one or more fleshy ventricles. They breathe through branchiæ. Their bodies are soft, and more or less elongated, being divided into numerous rings or segments. The head, which is at one extremity of the body, can scarcely be distinguished from the tail, except by having a mouth. These animals have no feet, properly so called, but they are furnished with little fleshy projections, bearing tufts of hairs or bristles, which enable them to move. They are generally of carnivorous habits. They lay eggs, but the young are frequently hatched before exclusion, and hence these creatures are said to be ovoviviparous. Their study is called Helminthology. As examples of the three orders of this class may be mentioned the serpulæ or worm-like animals, of ten found on shells, the common earthworm, and the leech family.

II. The Crustacea comprise the shell-fish commonly called crabs, lobsters, shrimps, and prawns. They have a distinct head, furnished with antennæx, eyes, and mouth; and their bodies are 
covered with a crust or shell, divided into segments by transverse incisions, the segments being united by a strong membrane. Once a year the larger species of these animals moult, throwing off their old crust or shell, and forming a new one, the animal remaining in a naked and greatly weakened statc during the intermediate time. Many of the Crustacea swim with great ease, but on land their motions are generally cramped and awkward; and they are confined to crawling, or leaping by means of the tail. When a limb is injured they possess the extraordinary power of throwing it off, and forming a new one. The Crustacea lay eggs, and the young of some of the species undergo a transformation before they attain their full size. The Crustacea were divided into two sections and seven orders by Latreille, which are as follow:-

\section{Section I. Malacostraca.}

Shell solid, legs ten or fourteen, foot-jaws six or ten, mandibles two, maxillæ four; mouth with a labrum.

Sub-section I. Podophthalma, eyes on foot-stalks.

Order 1. Decapoda, legs ten.

Sub-order 1. Brachyura, the crabs.

Sub-order 2. Macroura, the lobsters.

OrDer 2. Stomapoda, legs more than ten.

Sub-section II. Edriophthalma, eyes not on foot-stalks.

Order 3. Amphipoda, body compressed; mandibles palpigerous.

Order 4. Lamodipoda, abdomen rudimental, with only the rudiments of one or two pairs of appendages.

Order 5. Isopoda, body depressed; abdominal appendages flat; mandibles not palpigerous.

\section{SECTION II. Entomostraca.}

Shell not solid; legs variable in number; mouth variable.

ORder 6. Branchiopoda. Integuments horny, branchiæ feathery, forming part of the feet.

It is to this division of the Crustacea that the Cirrhopoda are now referred.

Order 7. Pacilopoda, mouth suctorial.

Sub-order 1. Xiphosura, or king-crabs.

Sub-order 2. Siphonostoma, or fish parasites.

III. The Arachnida are defined by Lamarck to be oviparous animals, provided with six or more articulated legs, not subject to metamorphosis, and never acquiring any new kinds of organs. It is now known, however, that some mites undergo a sort of metamorphosis, having only six legs when first hatched, and passing through a quiet pupa stage before acquiring their perfect form. 'Their respiration is either by means of air-sacks, which serve for lungs, or of a kind of tube with circular openings for the admission of air. 'There is a rudimentary heart and circulation in most of the species. There are two orders; those with lungs, and those without.

Order I. Pulmonaria. The Arachnides comprised in this division have air-sacks, which serve for lungs, a heart with distinct vessels, and from six to eight simple eyes. There are two 
distinct families: viz. Aruneides, comprising all the spiders and spinners; and Pedipalpi, comprising the tarantula and scorpions.

Order II. Trachearice. These Arachnides are distinguished by theil respiratory organs, which consist of radiated or branched tracheæ, receiving air by two circular openings. Their eyes vary from two to four. The principal animals belonging to this division are the long-legged spiders (Phalangium), and the mites (Acarus), including the gardener's pest, the little red spider (Acarus telarius), the cheese mite (Acarus Siro), and the harvest bug (Acarus or Leptus autumnalis).

IV. The Insecta form the fourth and last class of articulated animals, and they derive their name from the Latin word insectum, which signifies "cut into," in allusion to the distinct divisions of head, thorax, and abdomen in the true insects: and in contradistinction to the Annelides, the bodies of which present no such divisions. The true insects are defined as animals without vertebræ, possessing six feet, with a distinct head furnished with antennæ, and breathing through stigmatic openings, which lead to interior tracheæ. The Myriapoda have, however, more feet. The following are the twelve orders into which this class is divided.

\section{Section I. Insects undergoing Metamorphosis.}

1. Coleoptera (from two Greek words signifying sheathed wings). These are the beetles, which are all furnished with membranous wings, with which they fly, and which are protected by horny upper wings, or wing-cases, called elytra. They are all masticators, and are all provided with mandibles or projecting jaws, and maxillæ.

2. Orthoptera, or straight-winged insects. This order comprises the crickets, grasshoppers, locusts, and similar insects. 'They have their upper wings of the consistence of parchment, and have mandibles and maxillæ.

3. Hemiptera, or half-winged insects, have frequently half the upper wing membranous, like the under ones, while the other half is leathery. To this division belong the bugs, the water-scorpions, the cicadæ or froghoppers, and the aphides. These insects have neither mandibles nor rnaxillæ, but in their place have a sheath and sucker.

4. Neuroptera, or nerved-winged insects, such as the dragon-flies, have both pairs of wings membranous, naked, and finely reticulated. The mouth is adapted for mastication, and furnished with mandibles and maxillæ.

5. Hymen.ppteru, membranous winged insects, such as bees, wasps, ichneumon flies, \&c. All the four wings are membranous, but they have fewer nervures, and are not reticulated like those of the preceding order. The mouth is furnished with mandibles and maxillæ, and the abdomen is terminated either by an ovipositor or a sting.

6. Lepidoptera, or scaly-winged insects. These are the butterflies and moths, which are characterised by the farinaceous or scaly aspect of their wings, and the tubular or thread-like extension of the parts of the mouth. 
7. Strepsiptera or Rhipiptera, with twisted wings. These creatures resemble the ichneumon, in laying their eggs in the bodies of other insects, though they generally attack wasps and bees. The principal genera are Xenos and Stylops. They are generally considered to be closely allied to the Beetles.

8. Diptera, or two-winged insects, including the flies. The mouth is furnished with a proboscis, and there are two small wings called halteres placed behind the true wings, which act as balancers.

9. Suctoria, or sucking insects, such as the flea, which have no wings, but are furnished with an apparatus for sucking blood.

\section{SeCtion II. Insects not undergoing Metamorphosis.}

10. Thysanoura, or spring-tail insects. These creatures are of small size, and without wings; they are found in crevices of woodwork, or under stones. The principal genera are Lepisma and Podura.

11. Parasita, or parasitical insects, such as the louse. They are also without wings.

12. Myriapoda. This order is made a separate class by many naturalists, as the creatures contained in it are distinguished from the true insects by the great number of their feet; by the want of distinct divisions into thorax and abdomen; and by the great number of segments into which the body is divided. The principal insects in this order are included in the Linnæan genera Julus and Scolopendra, commonly called centipedes.

The term larva is applied to the young of all insects, included in the first nine orders, when first hatched. The different kinds have, however, other names; that is to say, the larva of a butterfly, or moth, is called a caterpillar; that of a beetle, a grub; and that of a fly, a maggot. The larva changes its skin several times, and at last goes into the pupa state, when it is called a chrysalis, an aurelia, or a nyniph. Sometimes the pupa is wrapped up in a loose outer covering called a cocoon. From the pupa in time bursts forth the imago, or perfect insect. The Apterous, or wingless true insects, and the Myriapoda, which are also without wings, do not undergo any metamorphosis.

\section{THE RADIATED ANIMALS}

Are so called because their organs of locomotion, and even their internal viscera, are generally arranged in a circle round a centre, so as to give a radiated appearance to the whole body. The animals included in this class are the very lowest in the scale; they have scarcely any external senses; their movements are slow, and almost their only sign of life is a craving for food. Some of them, however, have a distinct mouth and alimentary canal, with an anal orifice; others have a baglike stomach with a kind of mouth, through which they both take their food and reject their excrements; while others have no mouth, and appear only to absorb nourishment through pores. In the like manner, though some are oviparous, others may be propagated by division into plants. (If these Cuvier makes five classes: 
1. Echinodermata, or sea-urchins. These animals have a lcathery or crustaceous skin or shell, commonly covered with numerous tubercles. The mouth is generally in the centre of the animal, and is often armed with five or more pieces of bone, which serve as teeth; the stomach is a loose bag; the organs for respiration are vascular; and the animals are oviparous. They are furnished with tentacular tubes, which serve as arms or feet, and which they can push out and draw back at pleasure; and they have yellowish or orange-coloured blood, which appears to circulate. Cuvier divides this class into those with feet, and those without; but Lamarck, whose arrangement has been more generally followed, divides them into three orlers; viz. :

1. The Fistuloides, or Holothurida, which have cylindrical bodies, leathery skins, and mouths surrounded by tentacula. These creatures live in the sea, or in the sands on the sea-shore; the trepang, or eatable worm of the Chinese, is one of them.

2. The Echinides. These are the sea-urchins, properly so called, and the shells, when the animals are out of them, are called seaeggs. The Echinides live in the sea. They lay eggs, and the roe, or imperfect eggs, occupy a large portion of the space within the shell when the animal is still alive.

3. The Stellerides, or Asterias, are the star-fish. The mouth in these creatures is in the middle of the lower surface, and it has a membranous lip, capable of great dilation, but furnished with angular projections for capturing its prey. The skin is soft, but leathery, and it is covered on the back with spongeous tubercles, or scales. The rays are hollow beneath, and furnished with tentacula, by the aid of which the star-fish manages to crawl backwards, forwards, or sideways, as the case may be, any of the rays serving as a leader. These animals are found on the seashore, forming large beds, which are washed over by the sea. The Crinoidea, or stone-lilies, of which such curious fossil specimens have been found, are nearly allied to the star-fish.

II. The Intestina, or Entozoa. The intestinal worms were divided into two kinds by Cuvier, viz. the Cavitaires, including the worms of children, and other cylindrical worms; and the Parenchymateux, or flat worms; such as the fluke in sheep and the tapeworm in human beings. The Entozoa are now universally regarded as belonging to the Articulated or Annulose division of the animal kingdom.

III. Aculepha, or Sea-Jellies. These creatures are of a soft and jellylike substance, with a thin skin, and an unarmed mouth. The Medusides are very numerous, and produce that beautiful phosphorescent light noticed by voyagers in the Australian seas. The most interesting of the Acalephes is the Portuguese manof-war, or Physalia.

IV. Polyps, or Anthozoa, according to Cuvier, were divided into thrce orders; namely :

1. Fleshy Polyps (Sea anemones);

2. Gelatinous Polyps (Hydra); and

3. Polyps with Polyparies, the latter including all the various compound zoophytes, with the Sponges. Of these the Flustra, or Sea Mats, and numerous allied species, have since been recog- 
nised as belonging rather to the Mollusca, and the Sponges to a distinct and lower group of animals than the Radiata; the remainder have generally been divided into the following three orders :-

1. Helianthoida. This order includes the actinia, or sea-anemone; and the madrepores, sea-mushrooms, and brainstones, which live in communities, and possess the power of secreting calcareous matters, which they emit to form these stony substances.

2. Asteroida. Some of the animals belonging to this division are called sea-pens, and others form some of the different kinds of coral, particularly that used for necklaces, \&c.

3. Hydroida. This order includes the fresh-water polypi, which, it is well known, by the experiments that have been tried, may be cut in pieces and even turned inside out without destroying life. It must be observed that the contents of this group in Cuvier's system consisted of all those forms of animals which he could not, in accordance with the knowledge possessed in his day, conveniently place anywhere else. Within the last few years, however, great progress has been made in the arrangement of the animals placed in this group by Cuvier. One of the most important changes has been the establishment of a fifth group of animals for the Infusoria and Sponges, together with certain other creatures of very low organisation. To these the name of ProtozoA has been given. The Entozoa have been removed amongst the articulate animals, and there is a growing conviction that the Echinodermata will have to be transferred to the same section. There remain, consequently, the Acalepha and Polyps of Cuvier, which form a group characterised by their soft and generally gelatinous texture; by the existence of peculiar cells, called thread cells, in the skin ; and by their possession of an alimentary cavity with only a single orifice. To these the name of Cocenterata has been given. They are divided into two classes: I. The Anrmozo A, or Polyps, including the orders Helianthoida and Asteroida; and II. The HxprozoA, composed of the Hydroid Polyps and Acalephæ, the connection between which, as indicated in the text (p. 609), is very intimate.

V. The Infusoria, or Animalcula, are so small as to be invisible to the naked eye, and they are all inhabitants of liquids. Cuvier arranged them in two orders, one of which he called Les Rotifêres, and the other Les Infusories homogenes, but the first of these divisions is now included among the Articulata. The remainder of the Infusoria of Cuvier, with the exception of some which are now known to be of vegetable nature, are arranged, with the Sponges and some other animals, in a separate division, called Protozoa, the classification of which is still in a somewhat uncertain state. The three principal classes are those of the Infusoria, the Sponges, and the Rhizopoda; but there are other forms which will not admit of being brought under any of these denominations. Nearly all the Protozoa are microscopic, except when, as in the case of the Sponges, they form an aggregation of individuals. They are very numerous, and, although exceedingly simple in their structure, their history often possesses much interest. 


\title{
EXPLANATION
}

\author{
OF \\ TERMS USED IN NATURAL HISTORY.
}

Abdomen. The part of the body containing the organs of digestion.

Abdominal. Pertaining to the abdomen.

Amphibious. Capable of living both on the land and in the water.

Animalcules. Small animals, visible only with the assistance of the microscope.

Annulated. Marked with rings.

Antenne. The horns or feelers of insects.

Apex. The top or summit of anything.

Apical. Situated at, or belonging to, the apex.

Apodal. Footless.

Apterous. Wingless.

Aquatic. Living or growing in the water.

Bicuspid. Having two points.

Bifid. Divided into two parts.

Bifurcated. Divided into two prongs.

Bisulcous. Cloven-hoofed.

Bivalve. With two shells.

Branchia. Gills, or organs for aquatic respiration.

Buccal. Pertaining to the mouth.

Byssus. A tuft of silky filaments produced by some Mollusca.

Callosity. A hard lump, an excrescence.

Campanulate. Bell-shaped.

Canine. Of the dog kind.

Carinated. Keeled.

Carnivorons. Feeding on flesh.

Caudal. Pertaining to the tail.

Cere. A skin over the base of the bill of birds. 
xxiv

Cervical.

Cetaceous.

Cilia.

Cinereous.

Clavate.

Cordiform.

Coriaceous.

Corneous.

Crustaceous.

Dentate.

Dorsal.

Elytra.

Emarginate.

Fintomoloay.

Exsanguineous.

Feline.

Ferruginous.

Filiform.

Foliaceous.

Frugivorous.

Furcated.

Fusiform.

Gallinaceous.

Gelatirous.

Gemmiparous.

Geniculate.

Gestation.

Granivorous.

Gregarious.

Hastate.

Haustellate.

Herbivorous.

Hexapod.

Hyaline.

Ichthyology.

Imbricated.

Incubation.

Insectivorous.

Intestinal.

Laminated.

Larva.

Lateral.

Loricated.

\section{Explanation of Terms.}

Belonging to the neck.

Of the whale kind.

Microscopic filaments. which, by their constant vibration, either cause currents in the water, or move the animals possessing them.

Of the colour of ashes.

Clubbed.

Heart-șhaped.

Leathery.

Horny.

Covered with a shell or crust; as lobsters, crabs, \&c. Toothed like a saw.

Belonging to the back.

The wing-cases of insente of the beetle tribe.

Notched.

A description of insects.

Without red blood, as worms.

Belonging to the cat kind.

Of an iron or rust colour.

Thread-like.

Leaf-like.

Feeding on fruits.

Forked.

Spindle-shaped.

Belonging to the hen kind.

Like jelly.

Capable of propagating by buds.

Bent like a knee.

The time of going with young.

- Feeding on grain.

Associating together.

Formed like an arrow-head.

Insects with a mouth adapted for suction.

Feeding on grass.

Having six legs.

Glassy.

A description of fishes.

'liled, or lying over each other.

The act of hatching eggs.

Feeding on insects.

Pertaining to the digestive organs.

Covered with or divided into plates or scales.

The young of insects.

Belonging to the side, placed sideways.

Covered with hard scales or plates like armour. 
Lunate. Crescent-shaped.

Mandibles. Upper and lower, the two divisions of a bird's beak, or the projecting jaws of an insect.

Migratory. Coming and going at certain seasons.

Multivalve. With many shells or openings.

Nacieous. Resembling mother-of-pearl.

Nictituting. Winking; applied to a membrane with which birds cover their eyes at pleasure.

Olfactory. Relating to smell.

Operculum. A shield or cover.

Ornithology. A description of birds.

Oviparous. That lays eggs.

Palmated. Webbed.

Parasitic. Attached to and dependent on some other living body.

Parturition. The act of bringing forth young.

Passerine. Belonging to the sparrow tribe.

Pectinate. Resembling a comb.

Pectoral. Belonging to the breast.

Pendulous. Hanging down.

Piscivorous. Feeding on fishes.

Plicate. Folded.

Predaceous. $\quad$ Formed to pursue prey.

Prehensile. Capable of grasping.

Quadrifid. Divided into four parts.

Quadruped. Four-footed.

Ramose.

Branching.

Reptiles.

Animals of the serpent tribe, with legs.

Rudimentary. Small ; imperfectly developed.

Rurninating. Chewing the cud.

Scabrous.

Rough.

Scapulars.

Shoulders.

Semilunar.

Serrated.

Sessile.

Setaceous.

Spiral.

Squamose.

Striated.

In the form of a half-moon.

Notched like a saw.

Attached without the intervention of a stalk.

Subulated.

Sulcated.

Suture.

Having bristles or strong hairs.

Tentacula.

Winding like a screw

Scaly.

Streaked or striped.

Testaceous.

Formed like an awl.

Furrowed.

The line of junction of two hind parts.

Trifurcated. The feelers of snails and other mollusca.

Truncated. Covered with a shell, as oysters.

Three-forked.

Appearing as if cut off: 
Tubicolar. Inhabiting a tube.

Univalve. With one shell or opening.

Ventral. Belonging to the belly.

Vertebrated. Having a jointed spine-bone.

Viscera. The organs contained in the cavities of the body.

Viviparous. Bringing forth the young alive.

Webbed. Connected by a membrane, as the toes of aquatic birds.

Xylophagous Wood-eating.

Zoologists. Writers on animated nature.

Zoology.

The history of animated nature. 


\section{TABLE OF CONTENTS.}

\section{BOOK I.}

\section{QUADRUPEDS, OR FOUR-FOOTED BEASTS.}

POPULAR AND SCIENTIFIO NAMES OF THE ANIMALS DESCRIBED.

** Where no synonyme is given, the Linnæan name is the only one in use; and when the synonymes are seldom used, they are marked thus*. When no Linnæan name is given, the animal was not described by Linnæus.

\section{SECTION I.-CARNIVOROUS, OR FLESH-EATING ANIMALS.}

English Name

Linnæan Name

Synonymes

Page

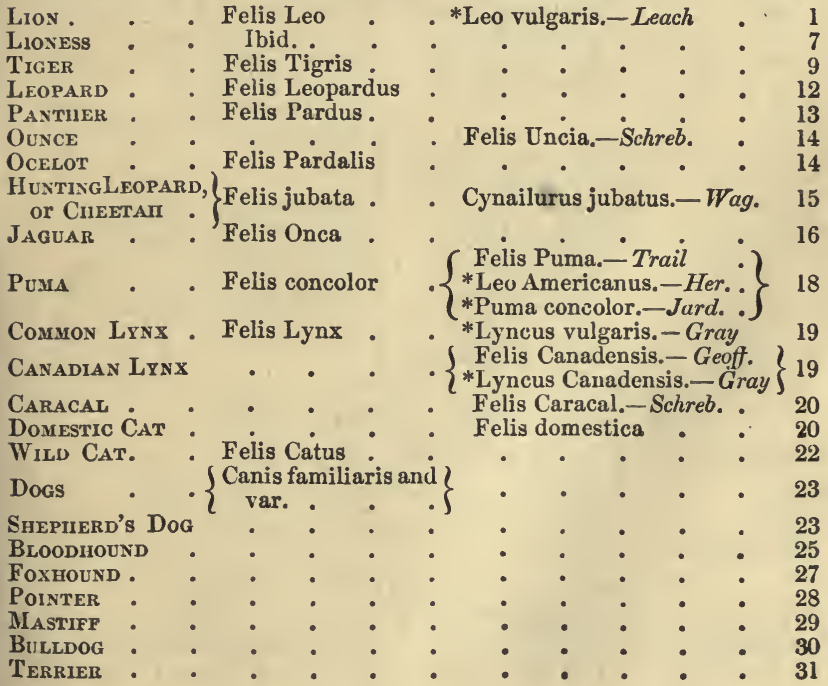


$\begin{array}{lll}\text { English Name } & \text { Linnæan Name } & \text { Synonymes }\end{array}$

SPANiet

Water SFAniel

NewFoundLAND

DoG

Greyhound

Fox

Arctic Fox

WOLF .

JACKAL . .

STRIPED HYANA

SPOTTED HYAENA

BLACK BEAR - Ursus Americanus

GrisLy BeAR

Brown Bear

Malayan Sun

Ursus Arctos

Bear o .

Polar Bear

RACOON : Ursus Lotor:
BA DGER

Coati-Mondi

Civet

Gener : Viverra Genetta

Oriental Civer Viverra Zibetha

ICHNEUMON, or

Egyptian Man-

GOUSTE

Weaser : Mustela vulgaris

Ferket - Mustela furo

Polecat - Mustela putorius

Eruine : : Mustela erminea

SkUNk

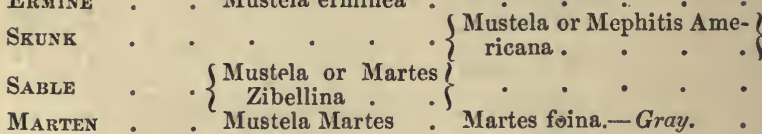

OTter : : Mustela Lutra

SeA OtTer. - Mustela Lutris

Vulpes vulgaris.--Briss. $\quad 36$

Vulpes lagopus . . $\quad 39$

*Lupus vulgaris . 40

Ursus Malayanus . . 48

Ursus maritimus.-Gmel. 50

Procyon Lotor. -Cuv. . 51

Meles Taxus.-Blum. $\quad 53$

Nasua narica. $-F$. Cuv. . 53

Viverra Civetta.-Schreb. 54

Genetta vulgaris.-Cuv, . 55

56

Herpestes Ichneumon 56

*Viverra furo.-Shaw

Putorius vulgaris.-Cuv. . 61

64

65

- Lutra vulgaris.-Errxl. • 66

SeAL . . Phoca vitulina $\cdot\left\{\begin{array}{c}* \text { Phoca variegata. Niel. } \\ \text { Calocephalus vitulinus. }\end{array}\right\} 69$

Walrus . $\left.\cdot \begin{array}{c}\text { Trichechus Rosma- } \\ \text { rus . . . . . . }\end{array}\right\}$

Section II.-INSECT-EATING ANIMALS.

HEDGEHOG .

- $\left\{\begin{array}{c}\text { Erinaceus Euro- } \\ \text { pæus }\end{array}\right\}$

\}$\cdot \cdot \cdot 74$

MoLE .. Talpa Europæa . Talpa vulgaris.-Briss. . 76

SHKEW .. . Sorex araneus . . • • •

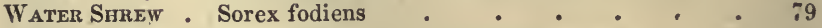

SECTION III.-CHEIROPTEROUS ANIMALS.

BAT . Vespertilio noctula

Pipistrelle

Vespertilio Pipistrellus

LoNG-EAREd BAT Vespertilio auritus. Plecotus auritus.-Gray . 
English Name Linnæan Name

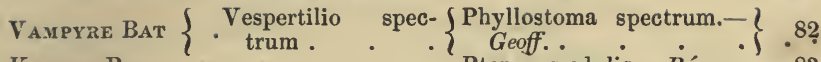
Kalong Bat . . . : . Pteropus edulis.-Péron. 83

Section IV.-MARSUPIALIA, OR POUCH-BEARING ANIMALS.

Kangaroo. . . . $\left\{\begin{array}{l}\text { Macropus giganteus. }- \\ \text { Shaw and Cuv. *Halma- } \\ \text { turus. -Ilig. and *Kan- } \\ \text { gurus.-Desm. }\end{array}\right\}$

Opossum . $\left\{\begin{array}{ccc}\text { Didelphis } & \text { Virgi- } \\ \text { niana. } & \cdot\end{array}\right\} . \quad . \quad{ }^{\circ} 86$

Phalanger . . . . . Phalangista vulpina.-Desin. 87

Section V.-RODENTIA, OR GNAWING ANIMALS.

Benver . . Castor Fiber . . . . . 88

Musk Rat . . . . . $\left\{\begin{array}{c}\text { Fiber zibethicus. - Des. } \\ \text { Ondatra zibethica. }-\end{array}\right\} 9$

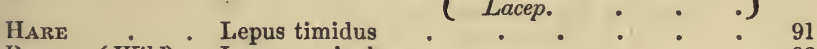

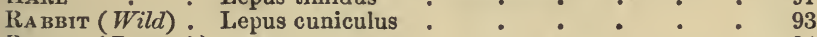

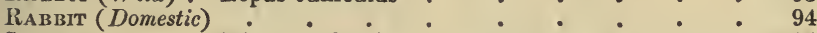

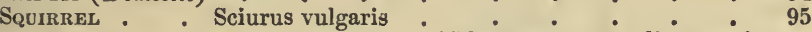

Dormouse. Mus avellanarius . $\left\{\begin{array}{c}\text { Myoxus muscardinus. }-\} \\ \text { Schreb. }\end{array}\right\} 6$

Marmot, or AL- $\}$ Mus marmotta $\quad\left\{\begin{array}{r}\text { Arctomys Marmotta. }-\{ \\ \text { Gmel. }\end{array} \quad 97\right.$

GuineA-PIG - Mus porcellus $\cdot\left\{\begin{array}{c}\text { Caviacobaya,-Pall. Cavia } \\ \text { aperea.Erxl. Hydro- } \\ \text { chuerus aperea }\end{array}\right\} 98$

Mouse . Mus musculus . . . . . . 99

RAT : : Mus decumanus : $::^{-}: 100$

Water Rat . Mus amphibius $\cdot\left\{\begin{array}{c}\text { *Lemmus aquaticus. }-F . \\ \text { Cuv.-Arvicola amphi- } \\ \text { bia.-Desm. and Jenyns. } \\ \text { Arvicola aquatica.-Flem. }\end{array}\right\} 102$

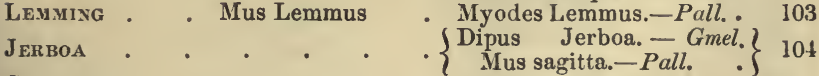

Chinchilla . . . Chinchilla lanigera . • 105

Porcupine - Hystrix cristata . . . 106

Couendou . - Hystrix prehensilis Synetheres prehensilis.-Cuv.106

SEction VI.-EDENTATA, OR TOOTHLESS ANIMALS.

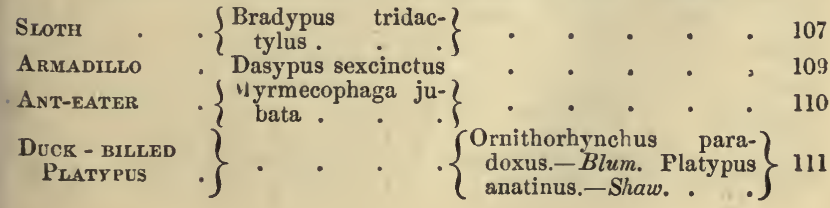


SECTION VII.-PACHYDERMATA, OR THICK-SKINNED ANIMALS.

English Name

Lirınæan Name

Synonymes

Page

ELEPHANT

- Elephas Indicus

ELEPHANT . Elephas Indicus -

113

116

RHiNoceros

$\left\{\begin{array}{c}\text { Rhinoceros unicor- } \\ \text { nis }\end{array}\right.$

HoG (Domestic). Sus scrofa .

WILD BOAR

BABIROUSSA

Pecchary.

TAPIR

Horse : Equus caballus

- Sus scrofa .

$$
\text { . }
$$

- Sus Babyrussa

- Sus aper.-Briss.

120

- Babirussa Alfurus.-Less. 122

- Dicotyles labiatus. - Cuv. 122

Ass . . Equus Asinus

MULE

KIANG

ZEBRA

- Tapirus A mericanus.-Schreb. 1:23

- D. . 124

- Asinus vulgaris.-Gray : 127

- * • • 130

Section VIII.-RUMINATING ANIMALS.

BulL

- $\left\{\begin{array}{c}\text { Bos Taurus, var. } \\ \text { domesticus, }\end{array}\right\}$

Cow .

$$
\text { - } \cdot \text {. }
$$

Wild BuLL

- $\left\{\begin{array}{c}\text { Bos Taurus, var. } \\ \text { Scoticus }\end{array}\right\}$

Bufralo . Bos Bubalus .

Bison : Bos Bonasus .

Brahmin Buli, $\{$ Bos Taurus, var.

or $\mathrm{ZEBU}$.

SHEEP

.\} Indicus .

RAM .

WALLACHLAN RAM : : :

$\left.\begin{array}{c}\text { Argali, or Wild } \\ \text { Sheep of Asia }\end{array}\right\}$ Uvis Ammon

GoAT. Ba or Boquetin Capra Ibex.

ANTELOPE - Capra Cervicapra

Gazelles - C Capra Dorcas

Chamois - . Capra rupicapra

NyL GHad.

GNU .

StaG: : Cervus Elaphus

WAPITI

Roeiveck .

FALLOW DEER

ELK.

REINDEER .

Axis .

Cervus capreolus

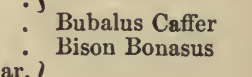

$\cdot$

134

136

137

139

141

143

144

146

146

147

147

148

Antilope Cervicapra.-Pall. 149

Antilope Dorcas-Pall. . 150

Antilope rupicapra.-Pall. 151

- Antilope picta.-Pall. . 152

Antilope Gnu.-Gmel. : 154

$\cdot\left\{\begin{array}{c}\text { Cervius Canadensis.-Gmel. } \\ \text { *Cervus strongyloceros.-. } \\ \text { Schres . }\end{array}\right\}$

155

$15 \%$

158

Cervus Dama

Cervus Alces $\bullet \bullet \bullet \cdot 159$

- Moschus . Cervus axis . . 163

Musk DeEr $\quad \cdot\left\{\begin{array}{l}\text { Moschus moschi- } \\ \text { ferus }\end{array}\right\} \quad \cdot \quad \cdot \quad \cdot \quad 163$

Girafre . $\left.\left\{\begin{array}{c}\text { Cervus Camelcpar- } \\ \text { dalis . }\end{array}\right\} \begin{array}{c}\text { Camelopardalis Giraffa. } \\ \text { Gmel } .\end{array}\right\}$ 
English Name

Camer . - Camelus Bactrianus . • . . . 168

DromedarT : Camelus Dromedarius : $\quad: \quad \cdot \quad 170$

Llama - . Camelus glama - Auchenia glama.-Illig. . 172

Section IX.-QUADRUMANA, OR FOUR-HANDED ANIMALS.

Ourang Otitan . Simia satyrus • • • • • • 173

Chimpanzee . . . - . Troglodytes niger.-Geoff. 174

Gorilla - . . . . Troglodytes Gorilla 176

Barbary Ape : Simia inuus : . Inuus sylvanus,-Cuv : 177

BABOoN . . . . $\left\{\begin{array}{c}\text { Cynocephalus poroarius. }-\} \\ \text { Desm. and Cuv. }\end{array}\right\} 174$

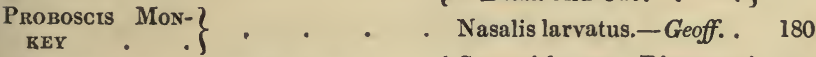

Diana Monker. Simia Diana. . $\left\{\begin{array}{c}\text { Cercopithecus Diana. } \\ \text { Geoff. . }\end{array}\right\} 180$

$\underset{\text { KeY }}{\text { Capurain Mon- }}\}$ Simia Capucina . Cebus capucinus.-Des. . 182

Spider Monkex . Simia Paniscus . Ateles Paniscus.-Geoff. . 182

OUISTIT orMAR- $\}$ Simia Jacchus . Jacchus vulgaris.-Geoff. 183

Marikina. . Simia Rosalia . Jacchus Rosalia . 183

Lemur . . Lemur Macaco . . . . . . 184

Mongoos - . - . Lemur albifrons.-Geoff. 184

BOOK II.

INHABITANTS OF THE AIR.

Section I.-RAptores.-DIURNAL BIRDS OF PREY.

GoLden EAGLE • Falco chrysaëtos • Aquila chrysaëtos . . 185

SeA EAGLE - Falco albicilla - Halixetus albicilla.-Sav. 188

BALD EAGLE - Falcoleucocephalus $\left\{\begin{array}{c}\text { Haliæetus leucocephalus. } \\ - \text { Sav. }\end{array}\right\} 189$

$\left.\begin{array}{c}\text { Osprex, or FrsH- } \\ \text { ING H AwR }\end{array}\right\}$ Falco haliaëtus . Pandion haliaëtus.-Cuv. 191

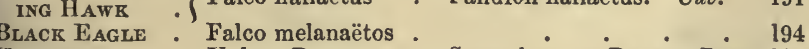

Vulture . Vultur Papa. Sarcorhampus Papa.-Dim. 195

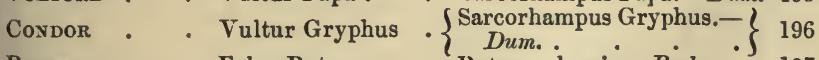

Buzzard . Falco Buteo . Buteo vulgaris.-Bech. : 197

Honex Buzzard. Falco apivoris . Pernis apivorus.-Cuv. . 199

GoshaWK - Falco palumbarius Astur palumbarius.-Bech. 200

SPARROW-HAWK . Falco Nisus . $\cdot\left\{\begin{array}{c}\text { Accipiter Nisus.-Pall. } \\ \text { Nisus communis-Cuv. }\end{array}\right\} 202$

KrTE . . Falco Milvus . Milvus regalis.-Cuv. • 203

Jer FALCon : Falco Gyrfalco : Falco islandicus : : 204

Peregrine Falconfalco peregrinus . 205

MERLiN - Falco æsslon. $\cdot\left\{\begin{array}{c}\text { Hypotriorchis } \\ - \text { Gray }\end{array}\right.$ 
English Name

Linnæan Name

Synonymes

Page

Kestrel - Falco Tinnunculus $\left\{\begin{array}{c}\text { Tinnunculus alaudarius. } \\ \text { - Gray. }\end{array} 210\right.$

SECRETARY BIRD

Serpentarius reptilivorus. $\}$

211

Hen Harrier - Falco cyaneus

SEction II.-NOCTURNAL BIRDS OF PREY.

Horned OwL . Strix Bubo . . Bubo maximus.-Flem. . 214

$\left.\begin{array}{l}\text { Harfang, or } \\ \text { SNowy OwL }\end{array}\right\}$ Strix nyctez . . Surnia Nyctea-Selby - 215

Barn OWL. . Strix flammea . . . • • . 216

Section III.-INSESSORES, OR PERCHING BIRDS.

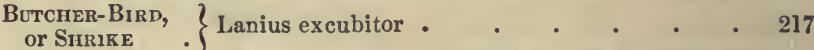

$\left.\begin{array}{l}\text { Watfr Ouzes, } \\ \text { or DipPer }\end{array}\right\}$ Sturnus Cinclus $\cdot \cdot\left\{\begin{array}{l}\text { Turdus Cinclus.-Lath. } \\ \text { Merula aquatica.-Briss. } \\ \text { Cinclus aquaticus.-Bech. }\end{array}\right\} 219$

Black Bikd . Turdus Merula . . . . . . 220

Missel Thrush . Turdus viscivorus . . . . . . . 221

Redwivg . . Turdus iliacus . • . . . . 222

Fieldfare - Turdus pilaris . . . . . . 223

Rivg Ouzer . Turdus torquatus . . . . . . 224

Mockivg Bird: Turdus polyglottus . . . $\quad . \quad 225$

REDBREAST Motacilla rubecula. $\left\{\begin{array}{l}\text { Sylvia rubecula.-Lath. } \\ \text { Frythacus rubecula }\end{array}\right\} 226$

Nightivgale - Motacilla luscinia. $\left\{\begin{array}{l}\text { Sylvia luscinia.-Lath. } \\ \text { Curruca luscinia-Bech. } \\ \text { Philomela luscinia }\end{array}\right\} 228$

BuAckcap $\{$ Motacilla atrica- S Sylvia.-Lath. and Cur- $\}$ $\left\{\begin{array}{c}\text { Motacilla atrica- }\left\{\begin{array}{c}\text { Sylvia. - Lath. and Cur- } \\ \text { pilla }\end{array}\right. \\ \text { ruca atricapilla - Bech }\end{array} \quad 231\right.$

Wren . $\left\{\right.$ Motacilla Troglo- $\left\{\begin{array}{r}\text { Sylvia. - Lath. Troglo- } \\ \text { dytes Europæus.-Cuv. }\end{array}\right.$

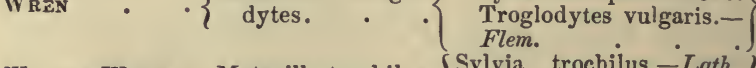

WinLow Wren . Motacilla trochilus $\left\{\begin{array}{l}\text { Sylvia trochilus,-Lath. } \\ \text { Regulus trochilus.-Cuv. }\end{array}\right\} 233$

Golden-Crested $\}$ Motacilla Regulus . Regulus cristatus.-Will. 235

GREY W $\left.\dot{W}_{\text {ATER }}\right\}$. . . Motacilla boarula . . 236

RED Wagtails . • • • • . . . . 237

Swallow . . Hirundo rustica . . . . . . 239

Martin . . Hirundo urbica . . . . . . 241

SwIFT - Hirundo apus - Cypselus apus : 243

Goatsucker $\cdot\left\{\begin{array}{c}\text { Caprimulgus Euro- } \\ \text { pæus. }\end{array}\right\} . . \quad . \quad . \quad 244$

SkTLARK . . Alauda arvensis . . . . . . 245

WoodLARK . Alauda arborea . . . . . . 247

Titmouse . . Parus cceruleus . . . . . . 248

Long-Tailei Tit Parus caudatus : $\quad . \quad \cdot \quad \cdot \quad \cdot \quad \cdot 248$

Yellow Hamer Emberiza citrinella . . . . • 249

Wheatear Motacilla Enanthe $\left\{\begin{array}{l}\text { Silvia EEnanthe.-Lath. } \\ \text { Saxicola WEanthe.-Bech. }\end{array}\right\} 250$ 
Einglish Name

Linuæan Name

Synonymes

Page

Whincilat

- Motacilla Rubetra

Saxicola rubetra.--Bech.

250

SPARROW

Fringilla domestica

*Pyrgita domestica.-Cuv.

252

LiNNET

Canary Bikd - Fringilla cannabina

Fringilla Linota.-Gmel.

253

Chaffinch

Fringilla Canaria .

Linaria Linota.-Cuv. .

Carduelis canaria .

254

Bullfinch.

Fringilla coelebs .

..$\quad 256$

GoLdFinch

- Loxia pyrrhula

Pyrrhula vulgaris.-Tem.

258

Crossbill . Loxia curvirostra .

Carduelis cornmunis.$\left.\begin{array}{l}\text { Cuv.; Carduelis ele- } \\ \text { gans.-Steph. . }\end{array}\right\}$

StARLING .

Sturnus vulgaris

SATIN Bower?

$\left\{\begin{array}{rr}\text { Ptilonorhynchus } & \text { Holose- } \\ \text { riceus }-K u h l & \text { Kitta. }\end{array}\right\}$

BIRD

RAven

\section{Corvus corax}

Cur.

263

Crow

Corvus corone

Rook

Corvus frugilegus .

JACKDAW . Corvus monedula .

Magple

- Corvus pica .

(.).

265

268

269

271

Chovin $\cdot$ Corvus graculus $\cdot\left\{\begin{array}{l}\text { Pyrrhocorax } \\ \text { Tem. }\end{array}\right.$ graculus. -$\}$

272

$\mathbf{J}_{\mathbf{A Y}}$

Corvus glandarius .

274

Roller Coracias garrula

$\left\{\begin{array}{l}\text { Garrulus glandarius. - } \\ \text { Briss }\end{array}\right.$

275

Kingfisher $\because$ Alcedo ispida

Bird of Paradise Paradisea apoda

Nuthatch - Sitta Europæa

\{ Briss. and Cuv. . . $\}$

276

Creeper . . Certhia familiaris .

Wall Creeper . Tichodroma muraria

LYRE BiRD

Tichodroma muraria

Hummisg-BıRn . Trochilus colubris

Hoopo: . . Upupa epops

\begin{tabular}{|c|c|}
\hline - & . \\
\hline - & - \\
\hline - & . \\
\hline - & . \\
\hline Menure & - $\quad$ i \\
\hline Menura & superba \\
\hline . & . \\
\hline
\end{tabular}

\section{Section IV.-SCANSORES, OR CLIMBERS.}

Cucкоo . . Cuculus canorus . . . . . . 290

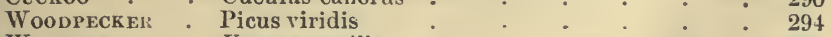

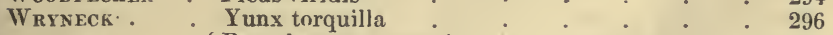

Toucan . $\left\{\begin{array}{l}\text { Ramphastos tuca- } \\ \text { nus . . . . . . }\end{array}\right.$

Grey Parrot . Psittacus erythacus . . . 298

Green Parrot . $\left\{\begin{array}{c}\text { Psittacus Amazoni- } \\ \text { cus . . . . . . } 300\end{array}\right.$

$\left.\begin{array}{c}\text { BLeE and YEL- } \\ \text { LOW MACAW }\end{array}\right\}$ Psittacus aracanga $\left\{\begin{array}{c}\text { Macrocereus aracanga. } \\ \text { Viell. }\end{array} 300\right.$

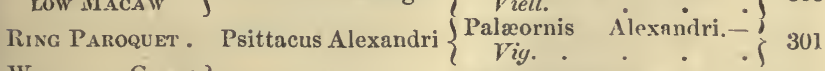

$\left.\begin{array}{l}\text { Warbling Grass } \\ \text { Paroquet }\end{array}\right\}$. . . Melopsittacus undulatus 302

Cockaton. - Psittacus galeritus Plyctolophus galeritus, 302 


\section{SECtion V.--GALLINACEOUS BIRDS.}

English Name

Linnæan Name

Synonymes

Page

Peacock . . Pavo cristatus . . . . 304

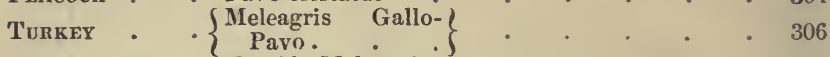

Guinea Fowl . Numida Meleagris . . . 308

Mound Birn : • . . Megapodius tumulus : 310

Pheasant . Phasianus Colchicus : . . 313

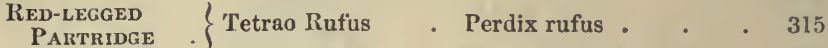

Partridge - Tetrao Perdix - Perdix cinerea,-Lath. - 316

Quall . Tetrao Coturnix $\left\{\begin{array}{l}\text { Flem. Coturnix Euro- } \\ \text { pæus. Wils. Perdix. } \\ \text { Coturnix.-Lath. Co- } \\ \text { turnix dactylisonans.- } \\ \text { Gould }\end{array}\right.$

American Quall . . . . Ortyx Virginianus - 319

$\left.\begin{array}{c}\text { Grouse, or Moor } \\ \text { FowL }\end{array}\right\} . \quad \cdot\left\{\begin{array}{c}\text { Lagopus Scoticus-Lath. } \\ * \text { Bonasa Scotica.Briss. }\end{array}\right\} 320$

Ptarmigan . Tetrao Lagopus.$\left\{\begin{array}{l}\text { Lagopus vulgaris.-Wils. } \\ \text { Tetrao rupestris.-Gmel. }\end{array}\right\} 321$

BцAск Cock . Tetrao Tetrix - *Uriogallis minor.-Ray. 322

Capercallzie . Tetrao Urogallus : . * 323

Cock. . . Phasianus Gallus . $\left\{\begin{array}{l}\text { Gallus domesticus.-Wils. } \\ \text { Gallus Sonnerati. }\end{array}\right\} 324$

BANKıIVA, Jago,

SPANish, and $\}$. . . . . . . 326

BantaM Cocks $\int$ Didus ineptus 328

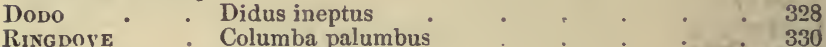

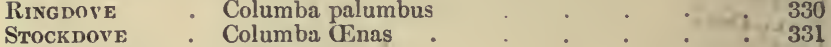

Rock Dove - Columba livia : $\quad . \quad+\quad \cdot \quad$. 332

Turtendove . Columba turtur . . . . . . 335

SEction VI.--GRALLATORES, OR WADERS.

Ostrich - . Struthio Camelus . • . . . . 337

RHEA - . Struthio Rhea - Rhea Americana - . 340

CAssowary - Struthio Casuarius. Casuarius galeatus.- Viel. 341

EMEU . . . . $\quad\left\{\begin{array}{l}\text { Dromaius ater-Viel. } \\ \text { Dromaius Novæ Hollan- } \\ \text { diæ }\end{array}\right\} 343$

APTERYX . . . Apteryx Australis.-Shaio 314

Bustard . Otis tarda . . . . . 345

Crane : Ardea Grus : Grus cinerea.-Bech. $\quad 347$

Balearic Crane Ardea pavonina $\cdot\left\{\begin{array}{c}\text { Anthropoides pavonina.- } \\ \text { Viel. Balearica pavo- } \\ \text { nina.-Vig. }\end{array}\right\} 349$

Stork . Ardea Ciconia . Ciconia alba.-Cuv. 350

Aujutant . $\quad . \quad$. Leptoptilus argala . 352

Heron : Ardea cinerea . . . 354

Bitrern : Ardea stellaris - Botaurus stellaris.-Siepli. 356

Spoonur.t. . Platalea leucorodia . . . 258 
English Name

Linnæan Name

Synonymes

Page

IBIS .

Ibis religiosa.-Sav.

359

Curlew : Scolopax arquata . Numenius arquatus.-Lath. 360

Redshank . - Scolopax calidris : Totanus calidris.-Bech. . 361

Godwit . $\left\{\begin{array}{c}\text { Scolopax } \\ \text { phala. }\end{array} . . \begin{array}{l}\text { Limosa melanura-Tem. } \\ \text { Limosa ægocephala }\end{array}\right\} 362$

Ruff and Reeve Tringa pugnax : Machetes pugnax . 363

SNIPE . . Scolopax Gallinago . . . . . 365

Woodcock. - Scolopax rusticola . • • . . . 366

Knot - Tringa Canutus - Tringa cinerea.-Gmel. $\quad 367$

Grex Plover $\left.\cdot\left\{\begin{array}{c}\text { Tringa squatarola } \\ \text { and T. helvetica }\end{array}\right\} \begin{array}{c}\text { Squatarola helvetica.-Cuv. } \\ \text { Squatarola cinerea }\end{array}\right\} 368$

Golden Plover . . . . Charadrius pluvialis • 369

Dotrrel . $\left\{\begin{array}{c}\text { Charadrius Mori- } \\ \text { nellus }\end{array}\right\} . \quad . \quad 370$

$\left.\begin{array}{l}\text { LAPWING, or PEE- } \\ \text { WIT }\end{array}\right\}$ Tringa vanellus . Vanellus cristatus.-Mey. 371

WATER HEN : Fulica chloropus Gallinula chloropus - 373

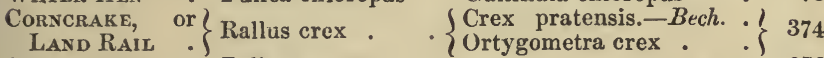

Соот . . . Fulica atra . . . . . . 376

Section VII.-PALMIPEDES, OR WEB-FOOTED BIRDS.

Pelican - $\left\{\begin{array}{c}\text { Pelicanus onocro- } \\ \text { talus . }\end{array}\right\}$ • . . .

Copmorant . Pelicanus Carbo

$\left\{\begin{array}{c}\text { Carbo Cormoranus. }- \text { Mey. } \\ \text { Phalacrocorax Carbo. } \\ \text { Cuv. }\end{array}\right\}$

$\left.\begin{array}{l}\text { Chesten Cormo- } \\ \text { Rant }\end{array}\right\}$ Pelicanus graculus

\{ Phalacrocorax graculus. -$\} 380$

$\left.\begin{array}{l}\text { Soran Goose, or } \\ \text { Gannet. }\end{array}\right\}$ Pelicanus Bassanus $\left\{\begin{array}{l}\text { Pelicanus maculatus. } \\ \text { Gmel. Anser bassanus. } \\ \frac{- \text { Ray. Sula alba.-Mey. }}{\text { Sula bassana.-Bris. }}\end{array}\right\}$

Tame Swan . Anas olor . . Cygnus olor--Ray. - 383

Wild Swan . Anas Cygnus. - Cygnus ferus.-Ray. - $38 t$

Goose . Anas anser . $\cdot\left\{\begin{array}{c}\text { Anser palustris. }- \text { Flem. } \\ \text { Anser ferus. }- \text { Wils. An- }\end{array}\right\} 386$

Duck . Anas Boschas - Anas fera.-Briss. 388

Eider Duck - Anas mollissima $\cdot\left\{\begin{array}{c}\text { Somateria mollissima. } \\ \text { Leach. }\end{array}\right\} 389$

Widgeon . Anas Penelope $\cdot\left\{\begin{array}{l}\text { Mareca fistularis.-Steph. } \\ \text { Anatra Mangiana.-Stor. }\end{array}\right\} 390$

Tear . Anas Crecca . . Querquedula Crecca.-Steph. 391

Сommon Gull . Laruscanus - • • • • • 392

Stormy Petrel Procellaria pelagica $\left\{\begin{array}{c}\text { Thalassidroma pelagica. } \\ \text { Vigors }\end{array}\right\} 393$

Fulmar . . Procellariaglacialis . . . . . 395

Azbatross . Diomedea exulans . . . . . . $\quad . \quad 396$

$\left.\begin{array}{l}\text { GreatNorthern } \\ \text { Diver . }\end{array}\right\}$ Colymbus glacialis . . . . . 397

Purfin : - Alca arctica . - Fratercula arctica.-Leuch. 398

Great Auk . Alca impennis . . . . 399

Penguin . . . . . . . . 400 


\section{BOOK III.}

\section{INHABITANTS OF 'THE WATER.}

\section{SEcTion I.-CETACEA, OR SEA MAMMALIA.}

\begin{tabular}{|c|c|c|c|}
\hline \multirow{2}{*}{$\begin{array}{c}\text { English Name } \\
\text { Commox WHA:E. }\end{array}$} & Linnaan Name & \multicolumn{2}{|c|}{ Synonymes } \\
\hline & Balæna mysticetus & & \\
\hline RORQUAL & - Balæna Boops & $\left\{\begin{array}{c}\text { Balænoptera } \\
\text { Lacep. }\end{array}\right.$ & Boops. \\
\hline SPERMACETI & ( Physeter macroce & & \\
\hline $\begin{array}{l}\text { WIIALE : } \\
\text { DOLPHIN }\end{array}$ & f phalus & $\cdot$ & 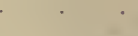 \\
\hline DOLPHIN • & Delphinus Delphis & Beluga leuca & - Gray.) \\
\hline White Whale & - & $\begin{array}{l}\text { Beluga arc } \\
\text { Delphinapt } \\
\text {-Lacep. }\end{array}$ & rus Beluga. \\
\hline
\end{tabular}

Porporse . . Delphinus Phocæna Phocæna vulgaris . . 41 SEA Unicorn . Monodon monoceros . . . . . 414 Manatee.

\section{Secrion II.-CARTILAGINoUS FISHES.}

S'rURGEON

SHARK SHARK.

Dog-Fish .

HAMMER-HEA DED

Shark

THORnBACK

SkATE, or Maid

TORPEDO .

Monk Fish, or

A NGEL Fisil . Squalus squatina . Squatina Angelus.-Dum.

SAW Fish .

LAMPREY .

HAG-Fish .

\section{Squalus Pristis. - Pristis antiquorum.-Luth.} \{ Petromyzon mari- $\}$ - Mysine glutinosa

\section{- Acipenser sturio}

Page 401 407 407

\section{SEcrion III.-BONY FISHES.}

Pilot Fish - Gasterosteus ductor Naucrates dustor.-Cuv. 429

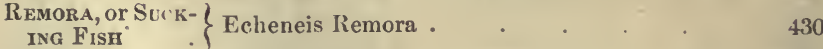

SEA WolF . . Inarrhichas lupus . . . . . 431

Horned Silure. Silurus militaris - Ageneiosis milit-Lacep. 43.2

Fatiler Lasher Cottus scorpius . . . . . . 4333

Sworo Fish . Xiphias gladius . . . . . . 433

Fryixg Scorpion $\quad . \quad$ : $\left\{\begin{array}{c}\text { Scorpæna volitans.--Emel. } \\ \text { Pteroïs volitans. - Cuv. }\end{array}\right\} 435$

LUMP-sUCKer - Cyclopterus lumpus . . . . . 436

Ocellated- \} \{Leparlogaster cornubicus. \}

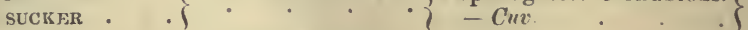


English Name

Limnean Name

Synonymes

Pange

Four - HORNED

$\left\{\begin{array}{c}\text { Ostracion quadri- } \\ \text { cornis }\end{array}\right.$

439

Trunk Fisil

Globe Fishi

Tetraodon hispidus

SUN FisH .

Tetraodon Mola
Syngnathus Hippo- Hippocampus brevirostris.

440

SEA HoRsE

Fexing Fish

$\{$ campus .. - Cuv.

Exocætus volitans

441

GuRnard .

Trigla cuculus

JoHN DoRY

BLEPHARIS

OpaH, or King

FISH

Zeus faber

CoD Fish .

HADDOCK .

WHITING

- Gadus Morrhua

.

Blepharis ciliaris. $-B l$.

443

444

446

Lampris guttatus.-Retz.

447

Morrhua vulgaris, -Cuv.

Morrhua Aglefinus.-Cuv.

447

448

449

Merlangus vulgaris.-Cuv .

451

LING . . Gadus molva .

- $\left\{\begin{array}{l}\text { Lota molva.-Cuv. Asel- } \\ \text { lus.-Will. Molva vul- } \\ \text { garis.-Flem. }\end{array}\right\}$

Mackerel

GAR Fish .

- Scomber Scomber . $\left\{\begin{array}{l}\text { Scomber Scombrus.-Cuv. } \\ \text { Scomber vulgaris.-Flem. }\end{array}\right\}$

HERRING

SPRAT

Pilchard:

WHITEBAIT

Esox Belone.

Belone vulgaris.-Cuv.

454

- Clupea Harengus .

Clupea Sprattus

Clupea pilchardus .

..$\quad 455$

456

457

Clupea alba.-Yarrell : 458

ANCHOVY .

Clupea epcrasicolus $\left\{\begin{array}{l}\text { Engraulis encrasicolus.- } \\ \text { Flem. Engraulis vul- } \\ \text { garis.-Cuv. }\end{array}\right\}$

Turbot

$\{$ Pleuronectes max-

Rhombus maximus.-Cuv.

459

$\left\{\begin{array}{c}\text { Pleuronectes pla- } \\ \text { tessa. }\end{array}\right.$

Plaice

Flounder . Pleuronectes flesus

a vulgaris. - Flem.

460

Sole .

Pleuronectes solea.

Platessa flesus. - Flem.

Salmon Pink

SALMON .

SaLMON Trout .

Trout

Salmo salar :

Salmo trutta .

Salmo fario

Cirar : Salmo salvelinus

Graylixg . . Salmo thymallus

Syzut . . Salmo eperlanus

Pleuronectes fluviatilis.
-Will.

Sulmo alpoinus.-Pen. $\quad 469$

Thymallus vulgaris.-Cuv. $\quad 470$

$\left\{\begin{array}{c}\text { Osmerus eperlanus.-Flem. } \\ \text { - Eperlanus Rondeletii. }\end{array}\right\} 471$

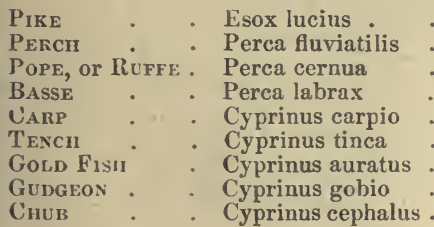

-Will. . . . $\}$

474

Acerina cernua.-Cuv. : 474

Labrax lupus.-Cuv. $\quad 475$

. . . . 477

Tinca vulgaris.-Cuv. . 478

. . . $47 y$

Gobio fluviatilis.- Will. 480

Leuciscus cephalus.-Flem. 481 
English Name

\begin{tabular}{|c|c|c|}
\hline & & \\
\hline BARBEL & - & - Cyprinus ba \\
\hline DACE & & Cyprinus leuciscus \\
\hline Roacil & ; & Cyprinus rutilus \\
\hline BLEAK & : & Cyprinus alburnus \\
\hline BREAM & • & us brama \\
\hline Minnow & . & us phoxinus \\
\hline LOACH & 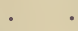 & is barbatula. \\
\hline Bullhead & & Cottus Gobio \\
\hline STICKLEI & & liatus \\
\hline ELECTR & & 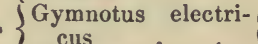 \\
\hline EL & & ræna Ang \\
\hline
\end{tabular}

. - Muræna Anguilla Anguilla vulgaris.-Thun. Syronymes

Page Barbus vulgaris.-- Cuv. . 482 Leuciscus vulgaris.-Cuv. 482 Leuciscus rutilus.-Cuv. 483 Leuciscus alburnus.-Cuv. 483 Abramis brama.-Cuv. . 484 Leuciscus phoxinus.-Cuv. 485

\section{BOOK IV.}

R E P T L E S.

\section{SECTION I.-SERPENTS, OR OPHIDIAN REPTILES.}

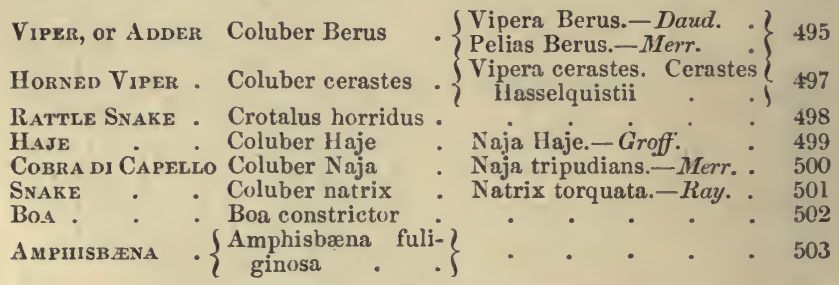

\section{Section II.-BATRACHIAN REPTILES.}

Frog - . Rana temporaria - • • . 505

ToAD : Rana Bufo - Bufo vulgaris.-Laur. 507

Surinam Toad . Rana Pipa : Pipa Americana.-Livur. 509

NewT . Lacerta aquatica . Triton aquaticus . . 510

Great NewT : . . . Triton balustris : 511

\section{Section III.-SAURIAN REPTILES.}

LIZARD . . Lacerta vivipara . $\left\{\begin{array}{l}\text { Lacerta agilis. }- \text { Briss. } \\ \text { Zootoca vivipara.-Wag. }\end{array}\right\} 512$

IgUANA - . Lacerta Iguana - Iguana tuberculata._Laur. 513

Flying Liziard . Draco volans • • • . . 514

Criameleon - Lacerta Chamæleon Chamæleo vulgaris.-Cuv. 515

Croconile - Lacerta Crocodilus Crocodilus vulgaris.-Cur. 517

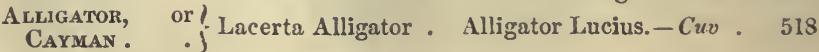


SECTION IV.-CHELONIAN REPTILES.

English Name Linnæan Name Synonymes Page

Tortoise - . Testudo Græca - • • . 520

Turtue - Testudo midas - Chelonia midas.-Briss. 521

HAwK's BiLL $\}$ Testudo imbricata Chelonia imbricata.-Briss. 523

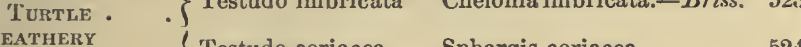

Turthe . Testudo coriacea . Sphargis coriacea . . 524

\section{BOOK V. \\ MOLLUSCOUS ANIMALS.}

Section I.-BIVALVES, OR THOSE HAVING TWO SHELLS.

Pearc Oyster . $\left.\left\{\begin{array}{c}\text { Mytilus Margari- } \\ \text { tiferus }\end{array}\right\} \begin{array}{c}\text { Avicula margaritifera. }- \\ \text { Lam. }\end{array}\right\} 525$

Orster . . Ostrea edulis . . . . . . 526

CockLE - . Cardium edule - Cardium fimbria : . 527

Prolas . . Pholas dactylus . . . . . 528

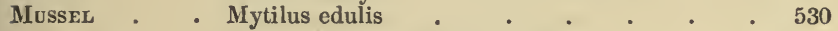

SEction II.-UNIVALVES.

Admirac . . Conus ammiralis . . . . . 530

'Tiger Cowry . Cypræa Tigris . $\quad . \quad$. $\quad . \quad$. 531

WHELK . . Buccinum undatum . . . . . 531

Snipe Shell . . Murex haustellus . . . . . . . 532

Periwinkle $\quad$ Littorina littorea . $\quad . \quad$. $\quad . \quad 532$

Limpet . . Patella vulgata . . . . . . 532

Snall . . Helix aspersa . . . . . 533

Currtefisil . Sepia officinalis . . . . . . $\quad . \quad 535$

Poulpe - Sepia octopodia - Octopus vulgaris.-Lam. 537

Argonaut . . Argonauta argo . . . . . . 537

Nautilus : . Nautilus Pompilius : : $\quad$ : 538

\section{BOOK VI.}

ARTICULA'TED ANIMALS.

Section I.-ANNELIDA, OR RINGED ANIMALS.

Eartiworms $\cdot\left\{\begin{array}{ccc}\text { Lumbricus terres- } \\ \text { tris }\end{array}\right\} \cdot . \quad . \quad . \quad 539$

LEECח . Hirudo medicinalis Sanguisuga officinalis . 540

Section II.-CRUSTACEA.

Loister . . Cancer gammarus . Astacus marinus.-Lench. 542 
English Name

Linnæan Name

Synonymes

Page

Crayfish . . Cancer astacus $\cdot\left\{\begin{array}{l}\text { Astacus fluviatilis.-Des. } \\ \text { Potamobius.-Leach. }\end{array}\right\}$ 543

С̆ав . . Cancer Pagurus . . . . . 543

LAND Cral

Soldier Cliab ． Pagurus Bempardus . . . . 54.5

SHRIMP . Cancer crangon Crangon vulgaris.-Fab. 546

Prawn . . . • . . Palæmon serratus.-Leach. 546

\section{SEction III.-ARACHNIDA.}

Garden Spider Aranea diadema . Fpeira diadema.-Walck. 548

Tarancula - Aranea Tarantula . Lycosa tarantula.-Lat. . 550

Chlese Mite - Acarus siro . • • • . • . 552

- Section IV.-INSECTS.

Order I.-Colfoptera, or Beetles.

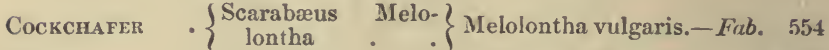

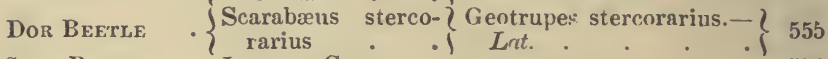

Stag Beetre . Lucanus Cervus ? . . . . • 556

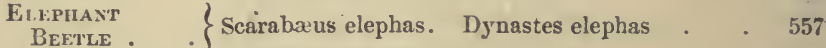

$\begin{array}{l}\text { Musk Beerle, or } \\ \text { Godt Chafrer }\end{array}$ Cerambyx moscha- tus $\}$ Aromia moschata.-Sert. 558

Ground BeErle Carabus clathratus . . . . . 558

GLow wокм $\quad$ Lampyris noctiluca $\quad . \quad \therefore \quad 559$

Deatr W

SPANiSH FLY $\cdot\left\{\begin{array}{c}\text { Cantharis vesica- } \\ \text { toria }\end{array}\right\} . .0561$

Corn Weevil . Curculio granarius $\left\{\begin{array}{c}\text { Calandra granaria. }-\ell \\ \text { Clairt. }\end{array} 561\right.$

L IADY BIRI $\quad \cdot\left\{\begin{array}{c}\text { Coccinella septem- } \\ \text { punctata }\end{array}\right\}$. . . . 562

Order II.-Orthoptera.

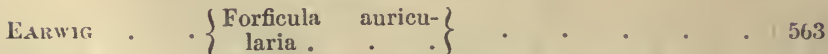

Leaf Mantis . Mantis gongylodes Empusa gongylodes-Ill. 564

Walking Leaf . Mantis siccifolia . Phyllium siccifolium.-Ill. 565

Grasshopper . . . . . Locusta flavipes . . 566

LocusT. - Gryllus migratorius Locusta migratoria . - 567

MoLe Cricket - Gryllus Gryllotalpa Gryllotalpa vulgaris.-Lat. 569

Скіскет . . Gryllus domesticus Acheta domestica . . 570

\section{Order III.-HeMuptera.}

LANTeín FLY 。 Fulgora lanternaria . . . . . 571

Cochinfal IN- $\}$ Coccus cacti . . . . . . . 571

SECT FuY . A phis rosa 
Order IV. - Neuroptera.

English Name

Linnæan Name

Synonymes

Page

ANT-Lion . $\cdot\left\{\begin{array}{c}\text { Myrmeleon formí- } \\ \text { carium }\end{array}\right\} . . \quad . \quad 574$

Dragon Fly . Libellula grandis . Eshna grandis.-Fab. $\quad 576$

\section{ORDER V.-HYMENoptera}

\begin{tabular}{|c|c|c|c|c|c|c|c|}
\hline BEE & & Apis mellifica & & & • & • & \\
\hline WASP & & Vespa vulgaris & & • & - & • & - \\
\hline ICHINEUNON & ( & $\cdot$. & & Pimpla & persi & uasoria & . \\
\hline ANT. & - & Formica rufa & - & . & - & - & - \\
\hline
\end{tabular}

Order Vi.-Lepidoptera, Moths and Butrterflies.

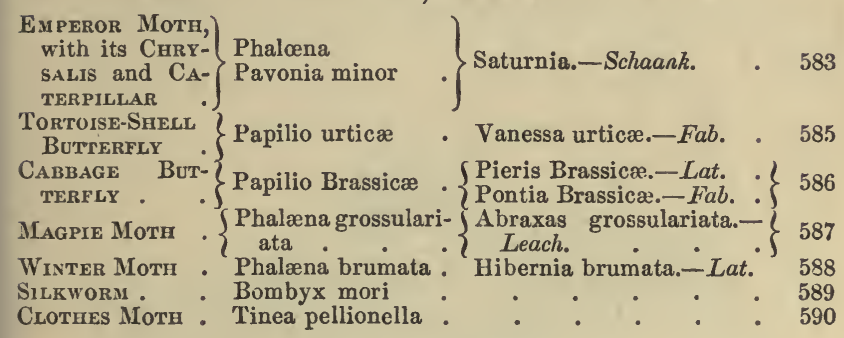

Order YII.-Diptera.

House FuY . Musca domestica . . . . . . 592

GNat : Culex pipiens : $:{ }^{\circ}:{ }^{\circ} 592$

Order VII,-Suctoria.

Flea - . Pulex irritans . . . . . 594

BOOK VII.

R A D I A TA.

STAR FIsII - Asterias rubens . Uraster rubens . . 595

Sea-Urchin . . . Echinus miliaris . . 596

RED Coral : Isis nobilis : * Gorgonia nobilis : * 597

Stony Corals . . . . . . . . . . 600

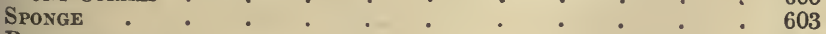

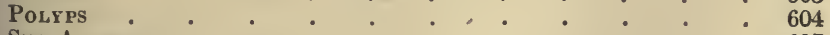

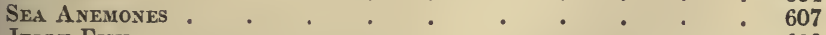

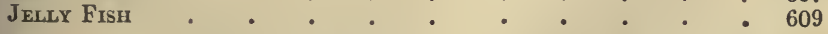

Appendix.-Faeulous Animals . . . . . . 611 

Quadrupeds.

genus by the uniformity of his colour, the mane which decorates the male, and a tuft of hair at the tip of the tail, which conceals a small prickle or claw.

Lions were formerly found in all the hot and warmer temperate parts of tho whole world; but they are now confined to A frica, and some parts of $A$ sia. 'I'he African Iion. stands four or five feet high, and his hody is from seven to nine feet long. The mane is thick, and somewhat curly; and the colour varies in different parts of Africa, but it is generally of a clear dark brown, deepening in some cases almost into black. The Asiatic Lions are smaller than those of Africa, and their colour paler. 'The Bengal Lion is of a light brown, with a long flowing mane; the Persian Lion is of a sort of cream-colour, with a short thick mane; and the Lion of Guzerat is of a reddish brown, without any mane. These varieties have been considered as distinct species by some naturalists.

All the varieties agree in their habits; they lie hid in jungles in the long grass, and when aroused either walk quietly and majestically away, or turn and look steadily. at their pursuers. Their roar is terrific : and in a wild state, the animal generally roars with his mouth close to the ground, which produces a low rumbling noise, like that of an earthquake. The effect is described by those who have heard it, as making the stoutest heart quail; and the feebler animals, when they hear it, fly in dismay, often in their terror falling in the way of their enemy, instead of avoiding him. Serpents, and sorne of the larger animals, will, however, fight with Lions, and vecasionally kill them; and Lions, when pursued by man, are sometimes hunted with dogs, but are oftener shot, or: speared. Those which are exhibited in menageries have generally been caught in pits. The pit is dug where traces have been discovered of a Lion's path; and it is then covered with sticks and turf. He is deceived by the appearance of solidity presented by the turf, anil attempts to walk over it; but the moment he sets his foot upon the covering of the trap, it breaks beneath his weight, and he falls into the pit. He is then kept without food for several days, shaking the gromnd with his 
roaring, and fatiguing himself by vainly attempting to escape ; till, at last, he becomes exhausted, and so tame as to permit his captors to put ropes round him, and drag him out. He is then put into a cage, and removed in a kind of waggon, wherever his captors may wish to take him.

'I'he generosity of the Lion has been much extolled; but the tales related of it appear to have had no other foundation than the fact, that, like many other beasts, when gorged with food he will not attack a man. A great amount of courage has also been so generally ascribed to him that the expression "as brave as a Lion," has become proverbial, and he has been regarded as a sort of symbol of that quality. For this respectable character, the Lion is no doubt mainly indebted to his possession of a mane, and to the boldness of appearance produced by his carrying his head elevated; for in all other respects he is a genuine cat, with neither nore nor less courage than belongs to the cats in general. As the Lion belongs to the cat tribe, his eyes are incapable of bearing a strong light; it is therefore generally in the night that he prowls about for prey, and when the sun shines in his face, he becomes confused and almost blinded. Lion hunters are aware of this fact. In the day-time they always consider themselves safe, so long as they have the sun on their backs. In the night, a fire has nearly the same effect; and travellers in Africa and the deserts of Arabia can generally protect themselves from Lions and Tigers by making a large fire near their sleeping-place. The strength of the African species is so great that he has been known to carry away a young heifer, and leap a ditch with it in his mouth. The power that man may acquire over this animal has been often shown in the exhibitions of Van Amburgh, Carter, and others; but the attachment which Lions sometimes form for. their keepers, was never more strongly exemplified than in the following anecdote.

M. Felix, the keeper of the animals in Paris, some years ago, brought two Lions, a male and female, to the national menagerie. About the beginning of the following June he was taken ill, and could no longer attend 
them; and another person was under the necessity of performing this duty. The male, sad and solitary, remained from that moment constantly seated at the end of his cage, and refused to take food from the stranger, whose presence was hateful to him, and whom he often menaced by bellowing. The company even of the female seemed now to displease him, and he paid no attention to her. The uneasiness of the animal led to a belief that he was really ill ; but no one dared to approach him. At length Felix recovered, and, with an intention to surprise the Lion, crawled softly to the cage, and showed his face between the bars: the Lion, in a moment, made a bound, leaped against the bars, patted him with his paws, licked his hands and face, and trembled with pleasure. 'I'he female also ran to him; but the Lion drove her back, and seemed angry, and fearful lest she should snatch any favours from Felix; a quarrel was about to take place, but Felix entered the cage to pacify them. He caressed them by turns; and was afterwards frequently seen between them. He had so great a command over these animals, that, whenever he wished them to separate and retire to their cages, he had only to give the order: when he wished them to lie down, and show strangers their paws or throats, they would throw themselves on their backs on the least sign, hold up their paws one after another, open their jaws, and, as it recompense, obtain the favour of licking his hand.

The Lion, like all animals of the cat kind, does not devour his prey the moment he has seized it. When those in cages are fed, they generally hide their food under them for a minute or two, before they eat it. Thus an instance is known of a man, who was struck down by a Lion, having time to draw his hunting-knife and stab the ferocious beast, who was growling over him, to the heart, before it had seriously injured him. The Lion also resembles a cat in his mode of stealing after, and watching his prey, a long time before seizing it.

Dr. Sparrman mentions a singular instance of the animal's habits in this respect. A Hottentot perceiving that he was followed by a Lion, and concluding that 
the creature only waited the approach of night to make him his prey, began to consider what was the best mode of providing for his safety, and at length adopted the following:- Observing a piece of broken ground with a precipitate descent on one side, he sat down by the edge of it; and found, to his great joy, that the Lion also made a halt, and kept at a distance behind him. As soon as it grew dark, the man, sliding gently forward, let himself down a little below the edge of the steep, and held up his cloak and hat on his stick, at the same time gently moving them backward and forward. The Lion, after a while, came creeping towards the object; and mistaking the cloak for the man himself, made a spring at it, and fell headlong down the precipice.

Many interesting anecdotes of Lions and lion-hunting may be found in the accounts of their travels published by Gordon Cumming, Anderssun, and Dr. Livingstone. From the latter we may extract the following account of an escape literally from the very jaws of death:- "Being about thirty yards off," says the doctor, "I took a good aim at his body through the bush, and fired both barrels into it. The men then called out, 'He is shot, he is shot!' Others cried, 'He has been shot by another man too; let us go to him!' I did not see any one else shoot at him, but I saw the Lion's tail erected in anger behind the bush, and turning to the people, said, 'Stop a little till I load again.' When in the act of ramming down the bullets I heard a shout. Starting and looking half round, I saw the Lion just in the act of springing upon me. I was upon a little height; he caught my shoulder as he sprang, and we both came to the ground below together. Growling horribly close to my ear, he shook me as a terrier-dog does a rat. The shock produced a stupor similar to that which seems to be felt by a mouse after the first shake of the cat. It caused a sort of dreaminess, in which there was no sense of pain nor feeling of terror, though quite conscious of all that was happening. It was like what patients partially under the influence of chloroform describe, who see all the operation, but feel not the knife. 'This singular condition was not the 
result of any mental process. The shake annihilated fear, and allowed no sense of horror in looking round at the beast. This peculiar state is probably produced in all animals killed by the carnivora; and if so, is a merciful provision by our benevolent Creator for lessening the pain of death. Turning round to relieve myself of the weight, as he had one paw on the back of my head, I saw his eyes directed to Mebalwe, who was trying to shoot him at a distance of ten or fifteen yards. His gun, a flint one, missed fire in both barrels ; the Lion immediately left me, and, attacking Mebalwe, bit his thigh. Another man, whose life I had sared before, after he had been tossed by a buffalo, attempted to spear the Lion while he was biting Mebalwe. He left Mebalwe, and caught this man by the shoulder; but at that moment the bullets he had received took effect, and he fell down dead. The whole was the work of a few moments, and must have been his paroxysm of dying rage." The interesting nature of this narrative of a most hair-breadth escape must be our excuse for its length.

lions have been sometimes known to attain a great age; thus Pompey, a large male Lion that died, in 1760 , in the Tower of London, was upwards of seventy years old. The usual period, however, seldom exceeds twenty years. 'The Lion is generally represented as the companion of Britannia, as a national symbol of strength, courage, and generosity. In ancient gems, paintings, and statuary, his skin is the attribute of Hercules. In Scriptural compositions, he is painted at the side of the evangelist St. Mark; and holds the fifth place among the signs of the zodiac, answering to the months of July and August.

In the various sculptured Lions discovered by Mr. Layard at Nineveh in 1848, the claw in the Lion's tail is distinctly marked, and is represented as being of large size. It is, however, really a very small, dark, horny prickle at the tip of the fleshy part of the tail, and entirely lidden by the hair. 


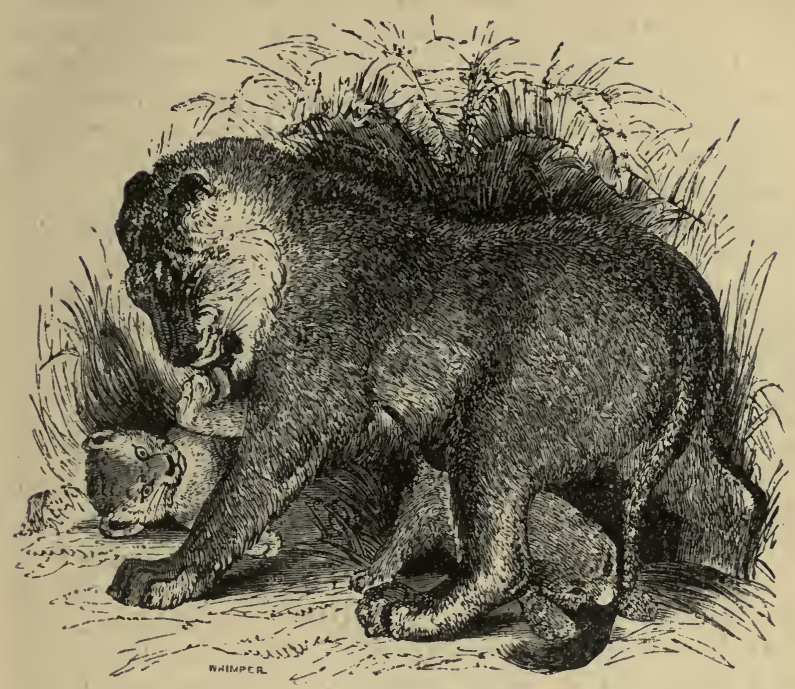

\section{THE LIONESS AND CUBS.}

The Lioness is in all her dimensions about one-third less than the male, and has no mane. She has generally from two to four cubs at a time, which are born blind, like kittens, which they greatly resemble, though they are as large as a pug-dog, when born. When quite young they are striped and spotted, but these marks soon disappear; they also at first mew like a cat, and do not begin to roar till they are about eighteen months old. About the same time the mane begins to appear on the males, and soon after the tuft of hair on the tail, though the animal is generally five or six years before it attains its full size.

The Lioness, though naturally less strong, less courageous, and less mischievous than the Lion, becomes terrible as soon as she has young ones to provide for. The ferocity of her disposition then appears with tenfold rigour; and woe be to the wretched intruder, 
whether man or beast, who should unwarily approach the precincts of her sanctuary. She makes incursions for food for her young with even more intrepidity than the Lion himself; throws herself indiscriminately among men and other animals; destroys without distinction; loads herself with the spoil, and brings it home reeking to her cubs. She usually brings forth her young in the most retired and inaccessible places; and when she fears the discovery of her retreat, often hides her track, by running back over tho ground, or by brushing it ont with her tail. She sometimes also, when her apprehensions are great, transports her young from one place to another, like a cat; and if obstructed, rlefends them with determined courage, and fights to the last.

Mr. Fennel, in his History of Quadrupeds, relates an interesting aneclote of a Lioness kept at the Tower in 1773. 'Ihis creature had become "greatly attached to a little dog, which was her constant companion. When the Lioness was about to whelp, the dog was removed; but shortly after her accouchement had taken place, the dog contrived to enter the den, and approached the Licruess with his usual fondness. She, alarmed for her eubs, immediately seized him, and seemed about to kill him : but, as if suddenly recollecting their former friendship, she carried him to the door of her den, and allowed him to escape unhurt." Mr. Fennel also tells us, that the first Lioness ever brought to England, died in the Tower in 1773 , after having attained a great age.

Another Lioness, which was kept at the Tower in 1806, became extremely attached to a little dog, and whenever he attempted to pass through the bars of the den, would draw him back by the hinder parts, and place her paw gently upon his body, as if entreating him not to leave her. 


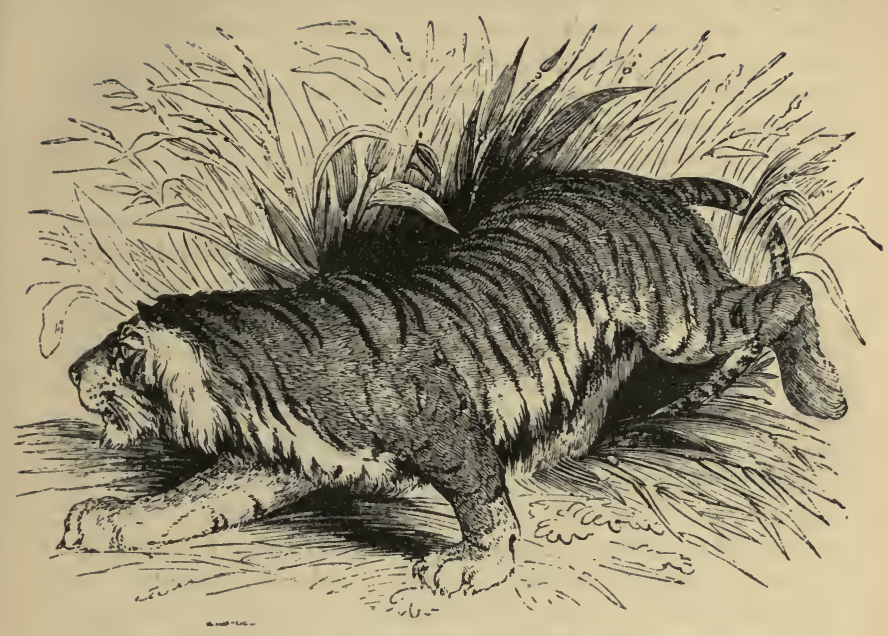

THE TIGER. (Felis Tigris.)

Though very inferior to the lion in majesty of appearance and deportment, this ferocious animal nearly equals him in size and strength. The Tiger is another of the feline species, and may be compared to an enormous cat, the whiskers and the fail being exactly similar: and both the Tiger and the lion resemble the cat in the form of their feet, and the power they possess of drawing in their claws. The 'Iiger, however, bears the strongest resemblance, and when pleased, purrs and curves up his back as he rubs himself against the nearest object. When enraged, he growls rather than roars; and springs up to a great height before he pounces on his prey.

The Tiger has a smaller and rounder head than the lion; he has no mane; his tail is without any tuft at the extremity, and his body much more slender and flexible. His colour is yellowish on the back and sides, becoming white beneath, with numerous lines of a very dark rich brown, or glossy black, sloping from the centre of the back down the sides, and over the head, and continued 
down the tail in the form of rings. Tigers are only found wild in Asia; but they are very abundant and very destructive in the East Indies, as from their enormous strength they can carry off a bullock with the greatest ease.

The attack of one of these animals upon Mr. Monro, son of Sir Hector Monro, was attended with the most tragical consequences. "We went," says an eye-witness, " on shore on Sawgar Island, to shoot deer, of which we saw innumerable tracks, as well as of 'ligers. We continued our diversion till near three o'clock, when sitting down by the side of a jungle to refresh ourselves, a roar like thunder was heard, and an immense Tiger seized our unfortunate friend, and rushed again into the jungle, dragging him through the thickest bushes and trees, everything giving way to his monstrous strength. All we could do was to fire on the Tiger; and our shots took effect, as in a few moments our unfortunate friend came up to us bathed in blood. Every inedical assistance was vain, and he expired in the space of twenty-four hours, having received such deep wounds from the teeth and claws of the animal as rendered his recovery hopeless. A large fire, consisting of ten or twelve whole trees, was blazing near us at the time this accident took place; and ten or more of the natives were with us. The human mind can scarcely form any idea of this scene of horror."

'Tiger-hunting, though very dangerous, is a very favourite sport in India. The hunters are mounted in carriages called howdahs, on the backs of elephants, wellarmed. The first indication is generally given by the elephants, who scent their enemy at some distance, and commencing a peculiar kind of snorting, become greatly agitated. As soon as the motion of the Tiger through the jungle is perceived, the nearest elephant is halted, and the hunter fires instantly. Should the Tiger be wounded, he will, in all probability, spring up with a hideous roar, and rush at the nearest elephant, his mouth open, his tail erect, or lashing his sides, and his whole fur bristled up. Sometimes, however, he endeavours to sneak away, artfully diminishing his size by drawing in his breath and creeping along the ground, and often with 
such success as to enable him to escape to ravines where it would be madness to attempt pursuit.

The 'Tiger is, however, such a formidable neighbour, that, apart from the excitement of hunting him, the natives of the countries which he inhabits have recourse to various modes of killing hin.. In Persia a large and strong wooden cage is often fastened firmly down to the ground, in the vicinity of the 'Tiger's haunts, and in this a man, accompanied by a dog or goat, to warn him of the approach of the Tiger, takes up his quarters at night. He is provided with a few strong spears, and when the 'Tiger comes, and in endeavouring to reach the enclosed prey rears himself against the cage, the man takes the opportunity of stabbing him in a mortal part. In Onde the peasants sometimes strew leaves smeared with birdlime in the Tiger's path, in order that as the animal walks on them they may adhere to his feet; in his efforts to disengage himself from these encumbrances he usually smears face and eyes with the sticky material, or rolls himself among the treacherous leaves, until finally becoming blinded and very uncomfortable he gives vent to his dissatisfaction in the most dismal howlings, which speedily bring his enemies about him, when taking advantage of his helpless condition they dispatch him without difficulty. 'I'he destruction of a Tiger is handsomely rewarded by the Indian governments, and many of the people make a regular trade of shooting them. 


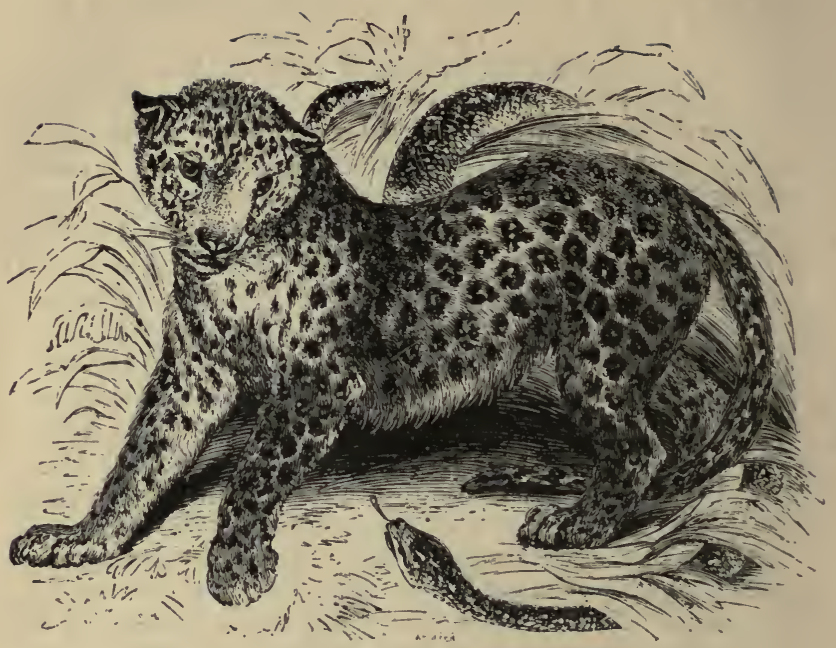

\section{THE LEOPARD, (Felis Leopardus,)}

DIFFERS from the tiger in being smaller, and in having the skin spotted instead of striped. His length from nose to tail is about four feet, the colour of the body is a lively yellow, and the spots of his skin are composed of four or five black dots arranged in a circle, and not imperfectly representing the print left by the animal's fuot upon the sand. It is found in the southern parts of Asia, and almost all over Africa. The panther is a variety of the Leopard.

Like all animals of the cat tribe, Leopards are a compound of ferocity and cunning; they prey upon the smaller animals, such as antelopes, sheep, and monkeys; and are enabled to secure their food with great success, from the extraordinary flexibility of their bodies. Kolben informs us that, in the year 1708, two of these animals, a male and female, with three young ones, broke into a sheepfold at the Cape of Good Hope. They killed nearly a hundred sheep, and regaled themselves with the 
blood; after which they tore a carcass into three pieces, one of which they gave to each of their offspring; they then took each a whole sheep, and, thus laden, began to retire; but having been observed, they were waylaid on their return, and the female and young ones killed, while the male effected his escape. T'hey appear afraid of man, and never attack him unless driven by hunger, when they spring upon him from behind. The Leopard is sometimes called the 'Tree-tiger from the ease with which he climbs trees.

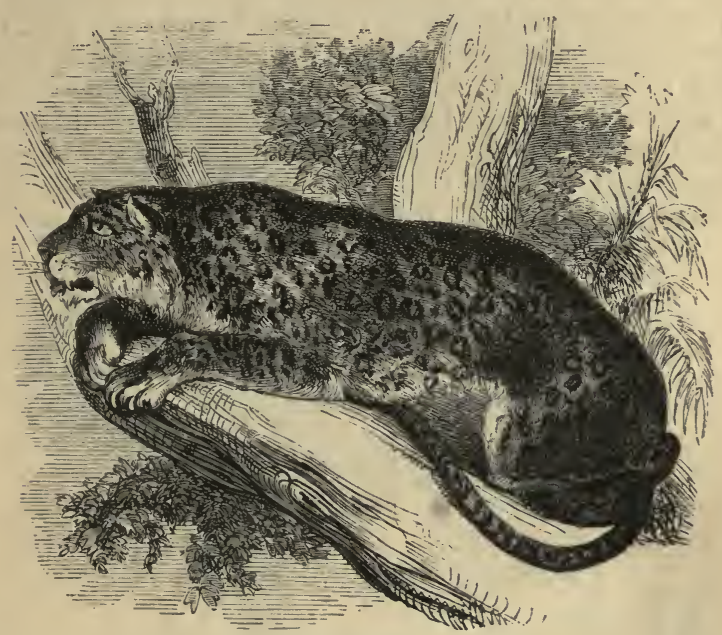

\section{THE PANTHER. (Felis pardus.)}

Although the Panther is generally savage, and always very uncertain in its disposition, instances have been known of its exhibiting a certain amount of gentleness and even playfulness in confinement. This was the case with a specimen which Mrs. Bowditch brought over with her from Africa. This animal was called Sai. One day, at Cape Coast Castle. he found the servant appointed to attend on lim sitting asleep, resting his 
back against a door; Sai instantly lifted up his paw, and gave the sleeper a tap on the side of the cheek, which knocked him over, and when the man awaked, he found Sai wagging his tail, and seeming to enjoy the fun. Another day, when a woman was scrubbing the floor, he jumped on her back; and when the woman screamed with fright, he sprang off, and began rolling over and over like a kitten. When put on board ship, he was first confined in a cage; and the greatest pleasure he had was when Mrs. Bowditch gave him a little twisted cup or cornet of stiff paper with some lavender-twater in it, and with this he was so delighted, that he would roll himself over and over, and rub his paws against his face. At first he used to put his claws out when he attempted to snatch anything; but as Mrs. Bowditch would never give him any lavender-water when this was the case, he soon learnt to keep his claws in. This Panther died soon after it reached England.

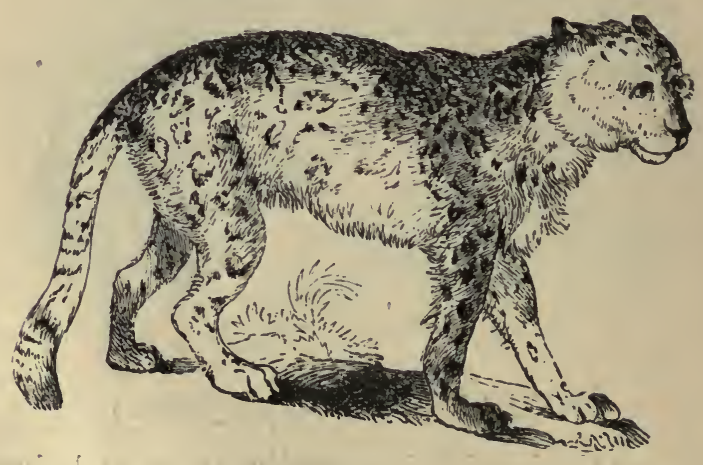

THE OUNCE. (Felis Uncia).

THE OUNce is a species of cat very nearly related to the Leopard, with which it agrees in size and in its general habits. It differs principally in the thickness of its fur, its greyish colour, the irregular form of the spots, and 
the great length of its tail, which, from being clothed with a long thick fur, corresponding with that of the body, appears to be also of great thickness. This thick and somewhat woolly-looking coat is rendered necessary by the coldness of the districts inhabited by the Ounce, which is found in 'Thibet and other mountairous regions of Asia.

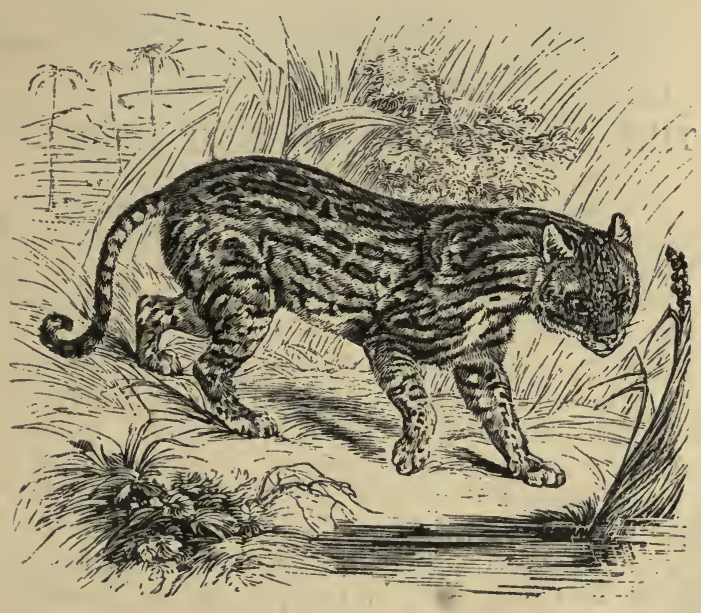

THE OCELO'T. (Felis pardalis).

'T'HIs species, which is often callerl the Tiger Cat, is described by Buffon as the most beautiful of the animals of its tribe, and it must be confessed that the great French naturalist had some reason for so speaking of it. It measures about three feet in length, exclusive of the tail ; the colour of the upper parts and sides is a tawny grey, beautifully marked with irregular streaks and spots of black, and the whole lower parts are nearly white: The Ocelot is a native of the forests of tropical America, where it climbs the trees with great agility in pursuit of monkeys and birds. 


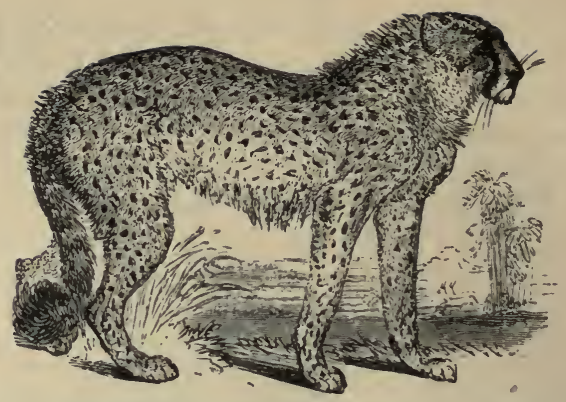

THE CHEETAH, OR HUNTING LEOPARD. (Felis jubata.)

The Hunting Leopard seems to form the connecting link between the cat and the dog tribes: as it has the long tail and flexible body of the cat, with the sharp nose and elongated limbs of the dog. Its claws also are not capable of being so completely drawn back into the toes as they can in other animals of the cat kind. The Cheetah is easily tamed, and Cuvier describes one which was accustomed to go at large in a park, and associated with the children and domestic animals, purring like a cat when pleased, and mewing when le wished to call attention to his wants. In the East the Cheetah is used in hunting, and is carried in a carriage, or chained on a pad behind the saddle of a horseman, with a hood over his eyes : when a herd of antelopes is found, the hood is taken off the Cheetah, who is let loose, and as soon as he sees the antelopes, steals cautiously along, till he comes within reach, when he springs suddenly upon them; making several bounds with the greatest rapidity, till he has killed his victim, when he begins instantly to suck its blood. The keeper then approaches, and throwing the Cheetah some pieces of raw meat, contrives to hoodwink and chain him again to his pad behind the saddle, on which he cronches like a dog. If the Cheetah is not successful in catching an antelope before the herd takes flight, he never pursues them, but returns to his keeper with a discontented and sullen air. 


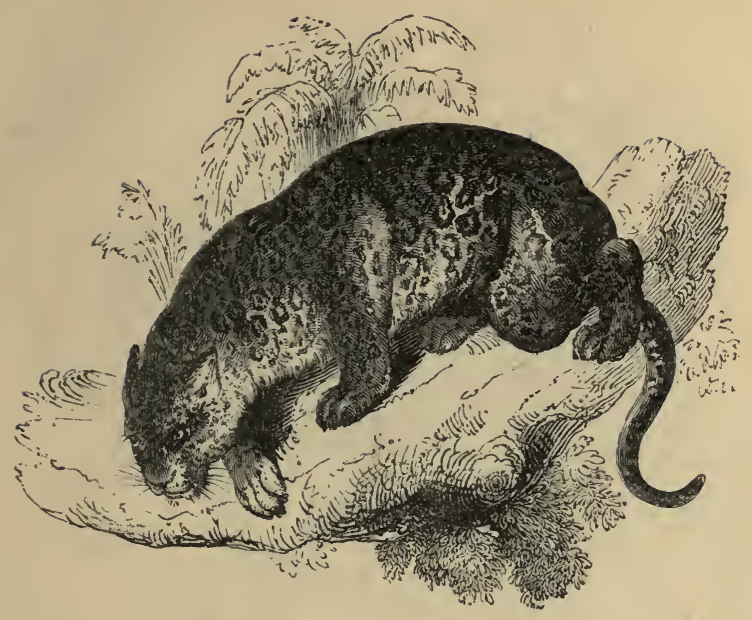

THE JAGUAR. (Felis Onca.)

The JAGUAR is a native of the New World, and is sometimes called the American Tiger. $\mathrm{He}$ is generally larger and stronger than the leopard, which he resembles in colour; but the black ring-like marks have always a spot in the centre, which is not the case with those of the leopard. The tail is also shorter, and the head larger and rounder. The Jaguar has great strength, and will kill a horse or an antelope, and carry it off. $\mathrm{He}$ is, however, a cowardly animal, always springing upon his prey from behind, and attacking in preference the hindmost of a herd. He fastens upon its neck, placing one paw upon the head, which he twists round with the other, and thus instantly deprives it of life. His principal haunt is the long grass on the banks of a river, where he often feeds upon turtles; turning them on their backs, and then insinuating his paw between the shells so as to scoop out the flesh. Ho climbs trees and swims with great facility. 


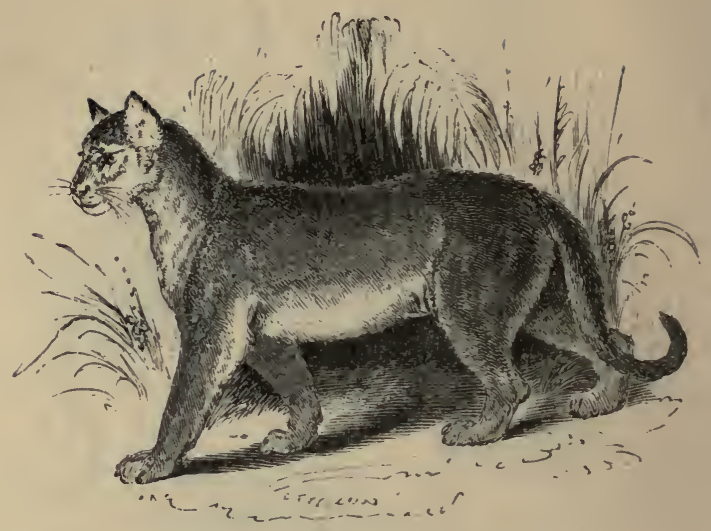

THE PUMA. (Felis concolor.)

The Puma, or American Lion, is smaller than the jaguar, and has a shrill hissing cry, very different from that of other animals of the cat kind. The fur is of a silvery fawn-colour, nearly white below, but becoming black at the head; the animal has no mane, and its tail is without any tuft at the tip. The cubs are spotted when young. The habits of the Puma are somewhat peculiar; when attacked, he climbs the nearest tree for safety, and there is generally shot by his hunters. When hunted with dogs, however, and cut off from all retreat, he stands at bay and fights furiously. The flesh is eaten by the Indians, and is said to be much prized by them. The Puma flies from the sight of man, and seldom attacks any animal larger than a sheep; but when he can surprise a flock of sheep, he kills as many as he can, only sucking the blood of each. He never devours the whole of his prey at once, carefully covering with leaves what he cannot eat : but if these should be removed, he will not touch the food again. In former times the Puma inhabited nearly the whole American continent, from Canada to Patagonia, but it is now extirpated in many places, especially in North 


\section{THE CARACAL. (Felis Caracal.)}

The Caracal is generally supposed to be the Lynx of the ancients, which was so celebrated for the keenness of its sight. The name of Caracal is derived from two Turkish words, signifying black-ears, and the animal is, in fact, remarkable for the blackness of the tips of its ears. $\mathrm{He}$ is somewhat larger and stronger than the fox; his body of a reddish brown, becoming white below, and the tail rather short, being only about eight or nine inches in length. The Caracal is both irritable and sulky in confinement, and is very seldom tamed; indeed, on the slightest irritation, it expresses its anger by a sort of snarl, like what is called swearing in a cat, but much louder, and sometimes ending in a scream.

When left to its own resources for support, it preys upon hares, rabbits, and birds; and will pursue the latter, of which it is immoderately fond, with remark. able activity, to the tops of the tallest trees. It is a native of Asia and Africa.

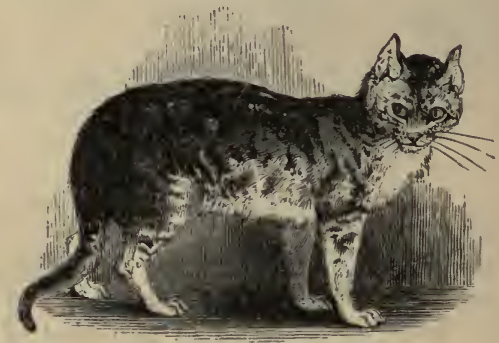

THE CAT. (Felis domestica.)

" Grimalkin, to domestic vermin sworn An everlasting foe, with watchful eye Lies nightly brooding o'er a chinkey gap, Protending her fell claws, to thoughtless mice Sure ruin."

John Philips.

IT was formerly supposed that the common domestic Cat was nothing more than the wild Cat of the woods, 
rendered tame by education. This opinion is, however. now doubted, on the ground that the tail of the wild Cat is thick and bushy, like that of a fox, while that of the domestic Cat tapers to the point. The Cat of the Egyptians, of which so many mummies have been found, differed still more in this respect, as its tail was long and slender, ending in a kind of tuft. There are four or five distinct varieties of the domestic Cat: the tabby, the tortoise-shell, the Chartreuse, and the Angora. Of these the tabby bears most resemblance to the wild Cat, and the black Cats are from this breed: the tortoise-shell is said to have been brought from Spain, the females of this race being generally of a pure tortoise-shell, and the males buff, with stripes of a darker hue. All the white and whitish Cats are descended from the Chartreuse breed; they have all a blue tinge in their fur, and reddish eyelids : the tailless Cats of Cornwall and the Isle of Man belong to this race. The Angoras are quite distinct, and are well known by their long silky hair. Cats are fond of warmth, and are generally affected by changes in the weather. They are very affectionate, purring at the sight of those who are kind to them; and will curve up their backs and rub themselves against a door when it is opened for them, as if to thank the kind friend who has done them this service, before they take advantage of it. The female Cat has generally five or six kittens at a time, which she carries about in her mouth, and hides, when she thinks them in danger. When a Cat is enraged, its hair stands erect, and its tail swells to an enormous size. Cats fight savagely, and often tear the skin off each other's necks : when two are about to fight, they stand for some time looking at each other, growling, and then dart at each other with the greatest fury, yelling with rage.

Most Cats are good mousers, and some bring everything they kill to their master or mistress, displaying their mice and rats with as much pride as a sportsman would his game. They are very fond of catmint and valerian, rolling themselves in a kind of ecstacy when they smell the latter plant. 'They are very cleanly, 
often sitting stroking their faces with their paws, as if washing themselves.

In the eye of the Cat, the pupil is perpendicularly oval, extending from above downwards, and when contracted appears like a straight line. This conformation is suited to the habits of these animals, for they are not content with prowling along the ground, but occasionally spring to great heights, their heads being directed upwards, and their eyes placed in front and more nearly parallel. This structure of the eyes occurs in all the Cat tribe.

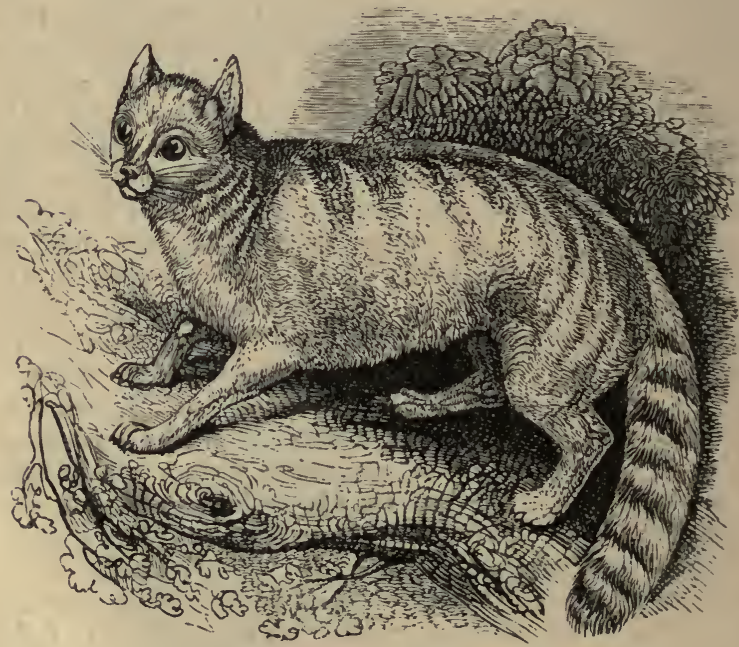

\section{THE WILD CAT. (Felis Catus.)}

The Wild Cat is a native of the forests of Europe, and was formerly abundant in Britain, but is now confined to some of the wilder parts of this country. It is a stouter and more powerful animal than the domestic Cat, and is of a greyish colour with black stripes, something like an ordinary tabby. It is a fierce creature, and is very destructive to birds and small quadrupeds. 


\section{THE DOG. (Canis familiaris.)}

To no animal is mankind so much indebted for its services and affection as to the Dog. Among all the various orders of brute creatures, none have hitherto been found so entirely adapted to our use, and even to our protection, as this. There are many countries, both of the old and new continent, in which, if man were deprived of this faithful ally, he would unsuccessfully resist the foes that surround him, seeking opportunities to encroach upon his property, destroy his labour, and attack his person. His own vigilance, in many situations, could not secure him, on the one hand, against their rapacity, nor, on the other, against thieir speed. 'The Dog, more tractable than any other animal, conforms himself to the movements and habits of his master. His diligence, his ardour, and his obedience are inexhaustible; and his disposition is so friendly, that, unlike every other animal, he seems to remember only the benefits he receives: he soon forgets our blows; and instead of discovering resentment while we chastise him, exposes himself, to torture, and even licks the hand from which it proceeds.

Dogs, even of the dullest kind, seek the company of other animals; and by instinct take to the care of flocks and herds.

\section{THE SHEPHERD'S DOG.}

The Shepherd's Dog has been considered the primitive stock, from whence all others are derived. This animal still continues nearly in its original state among the poor in temperate climates : being transported into the colder regions, it becomes smaller, and covered with a shaggy coat. Whatever differences there may be among the Dogs of these cold countries, they are not very considerable, as they all have straight ears, long and thick hair, a savage aspect, and do not bark either so often or so loud as Dogs of the more cultivated kind. The Shepherd's Dog, transported into temperate climates, and amung people entirely civilized, such as into England. 
France, and Germany, will be divested of his savage air, his pricked ears, his rough, long, and thick hair; though he will still retain his large skull, abundant brain, and consequent great sagacity.

Many interesting anecdotes are told of the shepherd's tyke or colley, as this kind of Dog is frequently called,

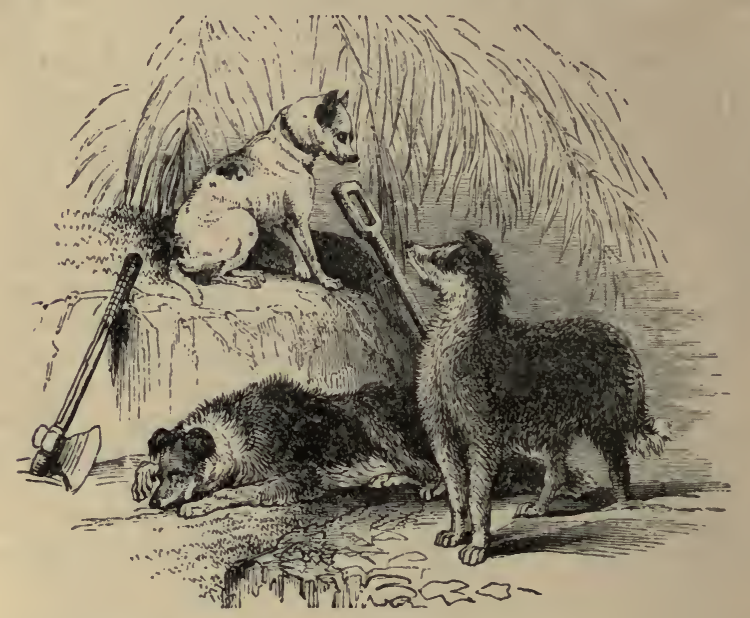

particularly of its sagacity in rescuing sheep from snowdrifts. When sheep are missing in a snow-storm, as is frequently the case in Scotland and the North of England, the shepherd arms himself with a spade, and watching the motions of his faithful Dog, digs into the snow wherever the Dog begins to scratch it away, and is thus sure to find his lost sheep.

This valuable boon to the shepherd is the least voracious of his kind, and endures fatigue and hunger with patience. 


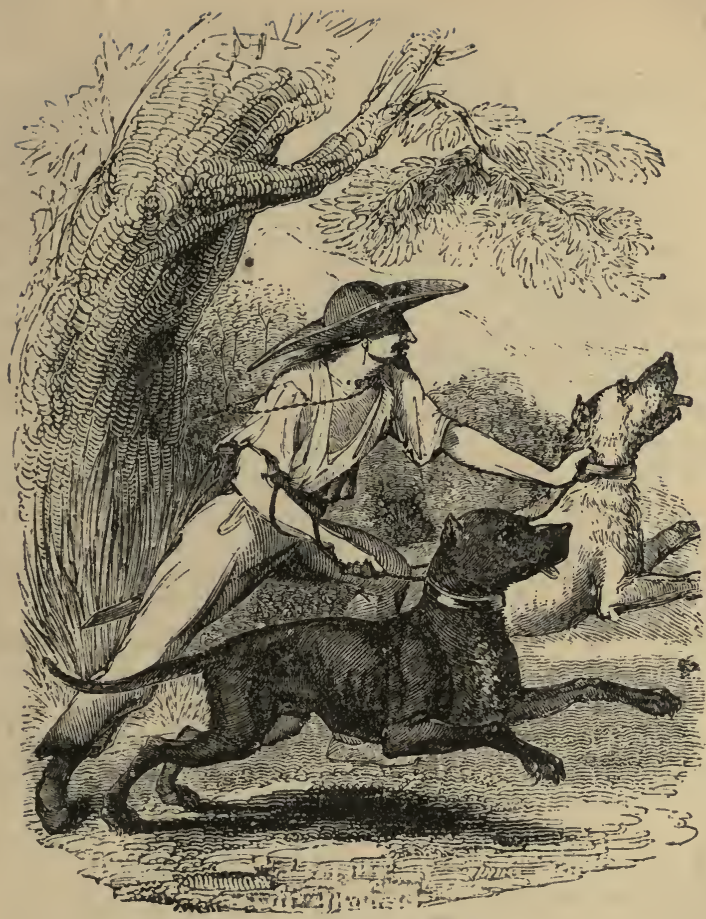

[Chasseur and Cuba Bloodhounds.]

\section{THE BLOODHOUND.}

"_ Conscious of the recent stains, his heart Beats quick; his snuffling nose, his active tail, Attest his joy : then with deep opening mouth, That makes the welkin tremble, he proclaims 'Th' audacious felon._—_"

The 13loodhound is taller than the old English hound. most beautifully formed, and superior to every other kind in activity, speed, and sagacity. It is commonly of a reddish or brown colour, with long ears. It seldom barks, except in the chase: and never leaves its game until it has caught and killed it. 
Bloodhounds were formerly used in certain districts lying between England and Scotland, which were much infested by robbers and murderers; and a tax was laid upon the inhabitants for keeping and maintaining a certain number of them. But as the arm of justice is now extended over every part of the country, and there are no secret recesses where villany may lie concealed, these services are no longer necessary. In furmer times these Dogs were used to hunt runaway negroes and others in the Spanish West Indies, and many surprising anecdotes are told of their wonderful sagacity and power of scent.

In Dallas's "History of the Maroons," an anecdote is given of the extent of their accomplishments in this way, which seems truly marvellous. A ship, attached to a fleet under convoy to England, was manned chiefly by Spanish sailors, who, as they passed Cuba, took the opportunity of running the vessel on shore, when they murdered the officers, and other Englishmen on board, and carried off all the available plunder into the mountains of the interior. The place was wild and unfrequented, and they fully expected to elude all pursuit. 'The moment, however, the news reached Havanna, a detachment of twelve chasseurs, with their Dogs, was sent off. The result was, that in a few days the whole of the murderers were brought in and executed, not a man having been injured by the Dogs in the capture.

The old English Hound, the original stock of this island, and used by the ancient Brituns in the chase, is a most valuable Dog; though the breed has been gradually declining, and the size studiously diminished by a mixture of other kinds, in order to increase their speed. It seems to have been accurately described by Shakspeare in the following lines:-

"My hounds are bred out of the Spartan kind, So flew'd, so sanded; and their heads are hung With ears that sweep away the morning dew ; Crook-kneed and dew-lapped, like Thessalian bulls; Slow in pursuit; but match'd in mouth like bells Each under each." 


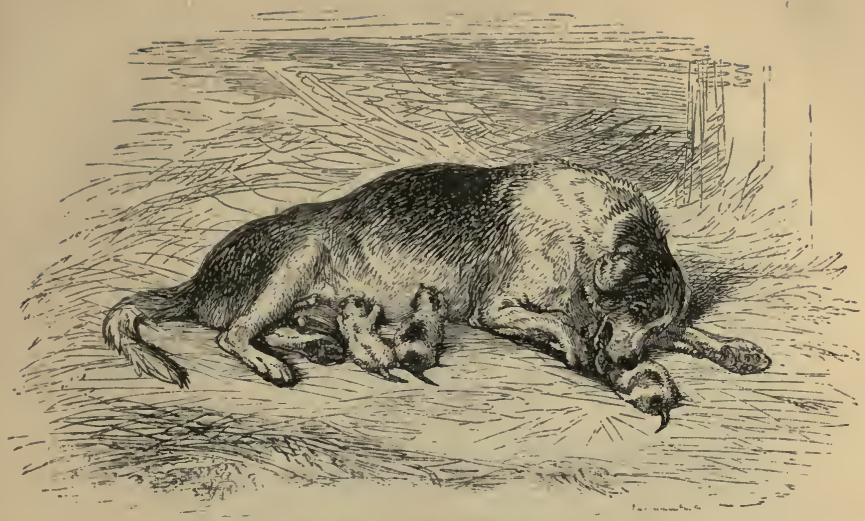

\section{THE FOXHOUND.}

This most valuable of all the Dogs of the chase, is smaller than the staghound, its average height being from twenty to twenty-two inches. No country in Europe can hoast of Foxhounds equal in fleetness, strength, and perseverance to those of Britain, where the utmost attention is paid to their breeding, education, and food. The climate also seems congenial to their nature, for when taken to France or Spain, and other southern countries of Europe, they quickly degenerate, and lose all the admirable qualities they possess in this country.

Our predilection for fox-hunting appears to have descended from our forefathers, and to have gone on increasing in ardour. Certainly, no other country can boast of such splendid establishments for this valuable breed: the Duke of Richmond's Kennel at Goodwood, cost no less than $£ 19,000$.

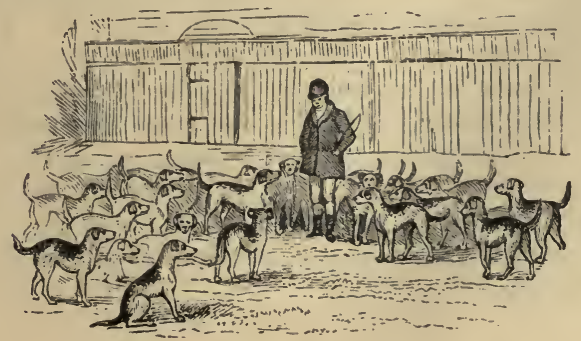




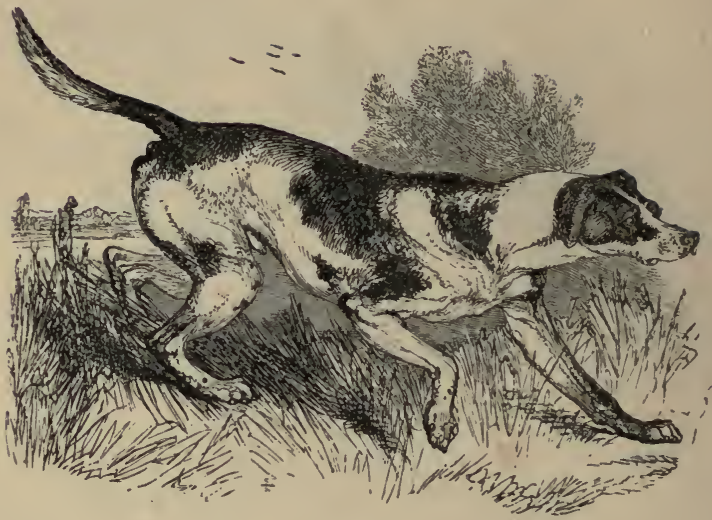

\section{THE POIN'TER}

Is docile in its disposition, and when trained, is of the greatest service to the sportsman who delights in shooting. It is astonishing to see to what a degree of obedience these animals may be brought. Their sight is equally acute with their scent, and they are enabled to perceive at a distance the smallest sign from their master. So admirably have they been trained, that their acquired propensities seem as inherent as a natural instinct, and appear to be transmitted from parent to progeny. When they scent their game, they fix themselves like statues, in the very attitude in which they happen to be at the moment. If one of their fore feet is not on the ground when they first scent, it remains suspended, lest, by putting it to the ground, the game might be too soon alarmed by the noise. In this position they remain, until the sportsman comes near enough, and is prepared to take his shot; when he gives the word, and the dog immediately springs the game. This attitude has often been selected by the artist. 


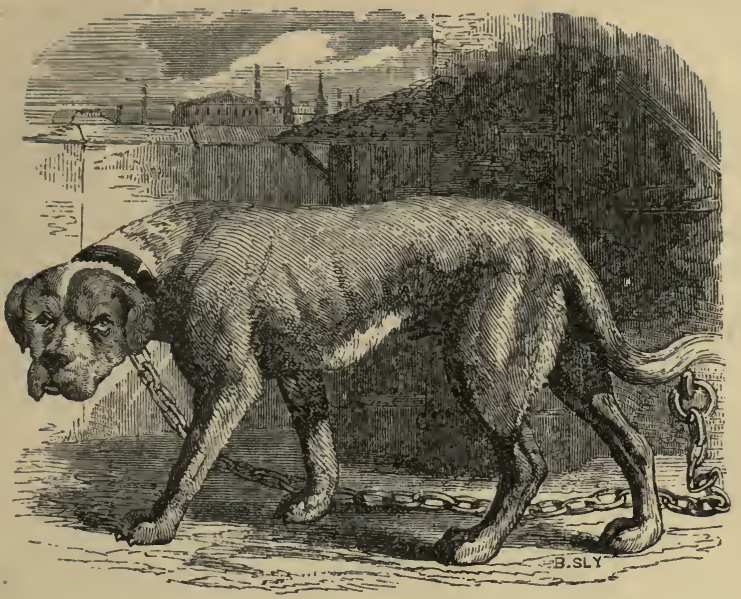

THE MAS'IIFF

Is the largest of the whole species : he is a strong and fierce animal, with short pendent ears and a large head, large and thick lips hanging on each side, and a noble countenance; he is a faithful guardian, and a powerful defender of the house.

A curious account is given by Stow, of an engagement between three Mastiffs and a lion, in the presence of James the First. "One of the Dogs being put into the den, was soon disabled by the lion, which took him by the head and neck, and dragged him about: another Dog was then let loose, and served in the same manner: but the third, being put in, immediately seized the lion by the lip, and held him for a considerable time; till, being severely torn by his claws, the Dog was obliged to quit his hold ; and the lion, greatly exhausted in the conflict, refused to renew the engagement; but, taking a sudden leap over the Dogs, fled into the interior part of the den. Two of the Dogs soon died of their wounds; the last survived, and was taken great care of by the king's son, who said, "He that had fought with the king of the 
beasts, should never after fight with any inferior creature." "

The following anecdote will show that the Mastiff, conscious of its superior strength, knows how to chastise the impertinence of an inferior:-A large Dog of this kind, belonging to a gentleman near Newcastle, being frequently molested by a mongrel, and teased by its continual barking, at last took it up in his mouth, by the back, and, with great composure, dropped it over the quay into the river, without doing any further injury to an enemy so much its inferior.

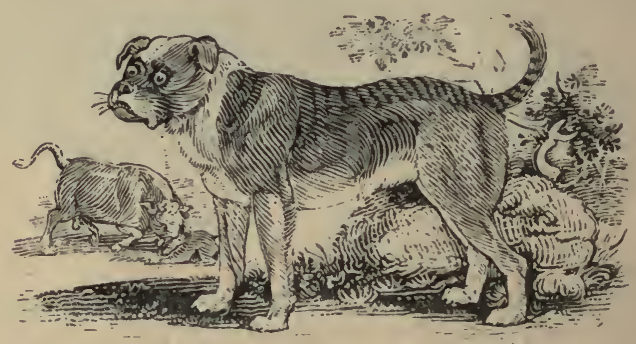

\section{THE BULLDOG}

Is much less than the mastiff, but the fiercest of all the Dog kind, and is probably the most courageous creature in the world. His short neck adds to his strength. Those of a brindled colour are accounted the best of the kind : they will run at and seize the fiercest bull without barking, making directly at his head, sometimes catch hold of his nose, pin the animal to the ground, and make him roar in a most tremendous manner, nor can they without difficulty, be made to quit their hold. Whenever a Bull-dog attacks in any of the extremities of the body, it is invariably considered a mark of his degeneracy from the original purity of blood.

Some years since, at a bull-baiting in the north of England, when this barbarous custom was very common, a young man, confident of the spirit of his Dog, laid a wager that he would, at separate times, cut off all the 
animal's feet, and that he would continue to attack the bull after each amputation. 'The experiment was tried, and the brutal wretch won his wager.

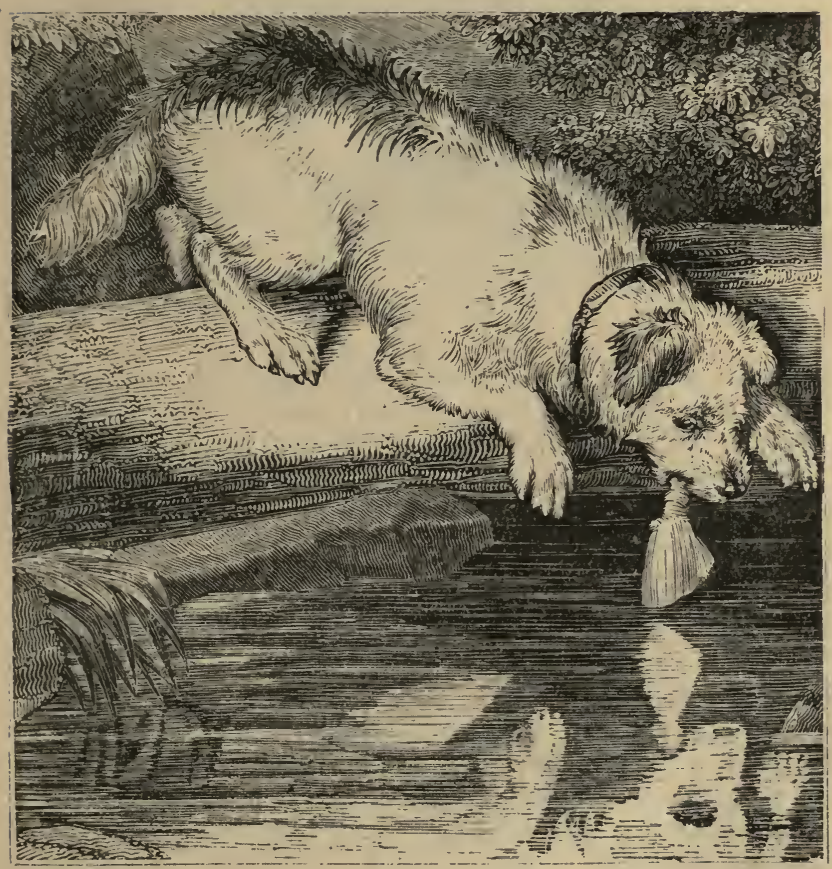

\section{THE TERRIER.}

The Terrier is a small variety of the Dog, but is of high value, from the pertinacity and courage with which he attacks rats and other vermin. His name of Terrier is evidently given to him on account of his habit of digging into the earth, which he does with great rapidity when in pursuit of any animal. The English Terrier is a smooth-haired dog, and the best are of a black colour, with tan-coloured legs, and spots on the eyebrows; the Scotch Terrier is covered with rough, wiry hair, which in the Skye Terriers becomes very long. 


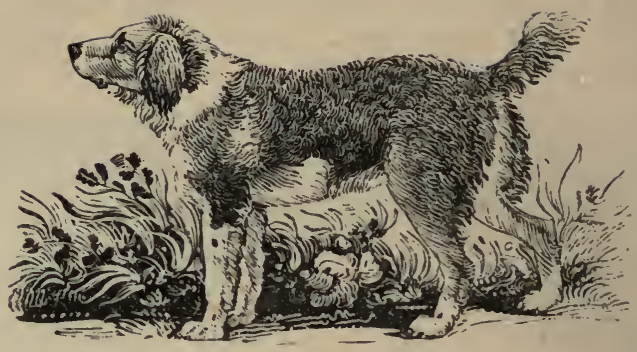

\section{THE SPANIEL.}

OF this elegant animal, said to be of Spanish extraction, there are several varieties in this country; but it is more than probable that the English Spaniel, the most common and useful breed, is indigenous. It has received from nature a very keen smell, good understanding, and uncommon docility, and is employed in setting for partridges, pheasants, quails, \&c. His steadiness in the field, his caution in approaching game, his patience in keeping the bird at bay till the fowler discharges his piece, are objects worthy of admiration. Many sportsmen prefer him to the pointer; and if water is plentiful he is more useful, for his feet are much better defended against the sharp cutting of the heath than those of the pointer, as he has a great deal of hair growing between the toes and round the ball of the feet, of which the pointer is almost destitute. He also ranges much faster, and can endure more fatigue.

"When milder autumn summer's neat succeeds, And in the new-shorn field the partridge feeds, Before his lord the ready spaniel bounds; Panting with hope, he tries the furrow'd grounds; But when the tainted gales the game betray, Couch'd close he lies and meditates the prey ; Secure they trust th' unfaithful field beset, Till hoveriug o'er them sweeps the swelling net." 


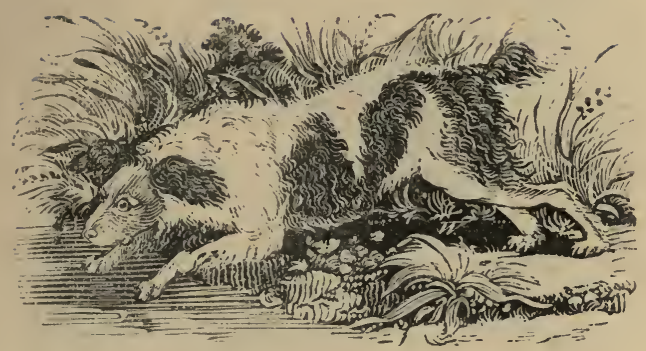

\section{THE WATER-SPANIEL}

Is excellent for hunting otters, wild ducks and other game whose retreat is among the rushes and reeds which cover the banks of rivers, the fens, and the ponds. He is very sagacious, and perhaps the most docile and tractable of all the canine tribe.

The Water-Spaniel will fetch and carry whatever he is bid, and often dives to the bottom of deep water in search of a piece of money, which he brings up in his mouth, and lays at the feet of whoever sent him. The best breed has black curly hair and long ears.

'The beautiful breed of Spaniels known as King Charles's, are highly prized for their diminutive size and length of ears. They are found of all colours, but those which are black, with tanned cheeks and legs, are considered the purest breed.

They derive their name from King Charles the Second, who, as Evelyn tells us, "took great delight in having a number of little spaniels follow him and lie in his bedchamber." 


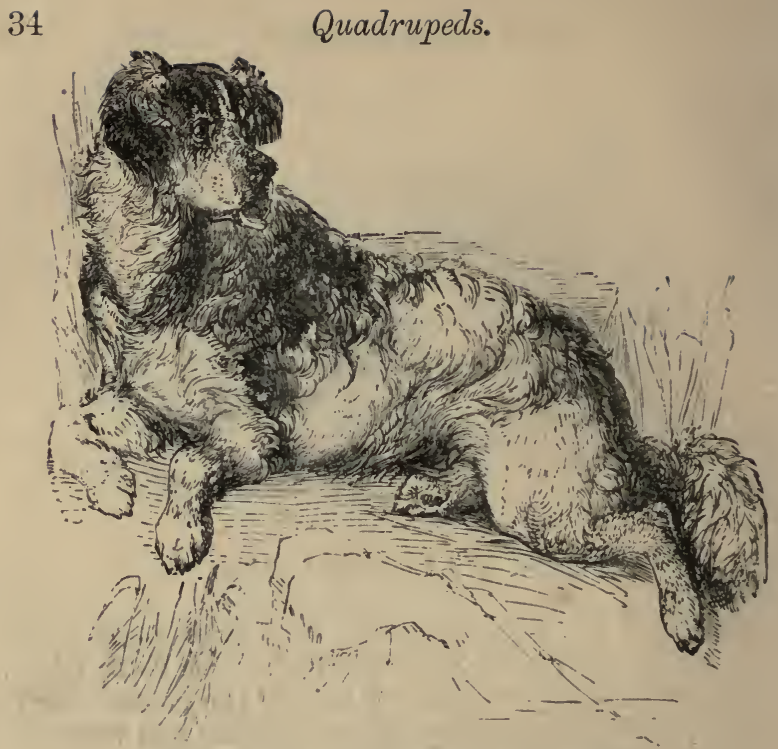

THE NEWFOUNDLAND DOG.

'THIs animal was originally brought into Europe from Newfoundland, whence it derives its name, and where it is extremely useful to the settlers, almost supplying the place of a horse. There are several varieties, differing slightly in size and appearance, but the full size is about six feet and a half from the nose to the tip of the tail, the length of which is two feet. He is noble in appearance, and covered with long shaggy hair of a black and white colour, in which the latter generally predominates.

The Newfoundland Dog is affectionate, sagacious, and docile beyond all others; and being web-footed is excellently adapted for the water; and there are innumerable instances of his rescuing man from a watery grave.

The anecdotes which illustrate the affection and sagacity of this animal would fill a volume, but we select one relating to the water, as that appears his noblest scene of action.

Some time ago a young woman was nursing an infant 
on one of the quays on the Liffey, when it made a sudden spring from her arms, and fell into the water. The screaming nurse and anxious spectators saw the child sink, as they thought, to rise no more; when at the very instant a Newfuundland Dog, which was accidentally passing, rushed to the spot, and at the sight of the child, who at that moment re-appeared, sprang into the water. The child again sunk, and the faithful aninal was seen anxiously swimming round the spot. Once more the child rose, and the Dog gently, but firmly, seized him and bore him to land. Meanwhile a gentleman arrived who appeared to take much interest in the affair, and on the person who had the child turning to show it him, he recognised the well-known features of his own son. A mixed sensation of horror, joy, and surprise struck him mute. When he recovered himself he lavished a thousand caresses on the faithful animal, and offered his master five hundred guineas for him; but the latter felt too much affection for the noble animal to part with him on any consideration whatever. We also subjoin another equally interesting.

A native of Germany, fond of travelling, was pursuing his course through Holland, accompanied by a large Newfoundland Dog. Walking one evening on a high bank, which formed one side of a dike, or canal, so common in that country, his foot slipped, and he was precipitated into the water, and being unable to swim he soon became senseless. When he recovered his recollection he found himself in a cottage on the other side of the dike, surrounded by peasants, who had been using means to restore suspended animation. The account given by them was, that one of them, returning home from his labour, observed at a considerable distance a large Dog in the water swimming, and dragging the body of a man into a small creek on the opposite side to which the men were.

The Dog having shaken himself, began industriously to lick the hands and face of his master, while the rustic hastened across; and, having obtained assistance, the body was conveyed to a neighbouring house, where the usual means of resuscitation soon restored him to sense 
and recollection. Two very considerable bruises, with the marks of teeth, appeared, one on his shoulder and the other on the nape of his neck; whence it was presumed that the faithful animal first seized his master by the shoulder, and swam with him in this manner some time; but that his sagacity had prompted him to let go this hold, and shift his grasp to the neck, by which he had been enabled to support the head out of water. It was in the latter position that the peasant observed the Dog making his way along the dike, which it appeared he had done for the distance of nearly a quarter of a mile.

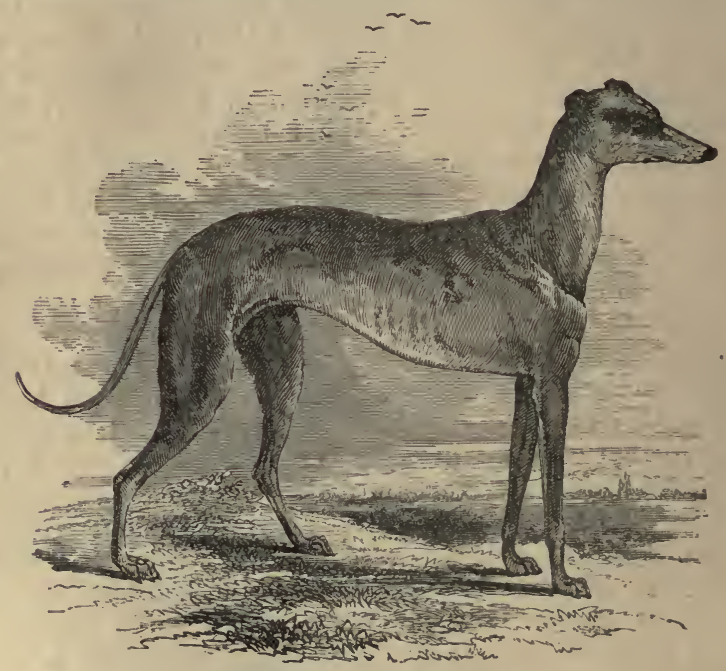

THE GREYHOUND

Is well known, and was formerly held in such estimation, that he was the especial companion of a gentleman, who, in ancient times, was distinguished by his horse, his hawk, and his Greyhound, and it was penal for any person of inferior rank to keep one. He is the fleetest of all Dogs, and can outrun every animal of the chase. He has a long body, and is of an elegant shape; his head is neat and sharp, with a full eye, a good mouth, 


\section{The Fox.}

sharp and very white teeth; his tail is long, and curls round above his hind part. There are several varieties; as the Italian Greyhound, the Oriental Greyhound, and the Irish Greyhound, or IVolf-dog. They are used for coursing; that is, hunting by sight instead of scent; and are principally employed in chasing hares. Daniel, in his Rural Sports, tells us, that a brace of Greyhounds have been known to course a hare four miles in twelve minutes; turning it sevəral times, till the poor creature dropped at last quite dead from fatigne.

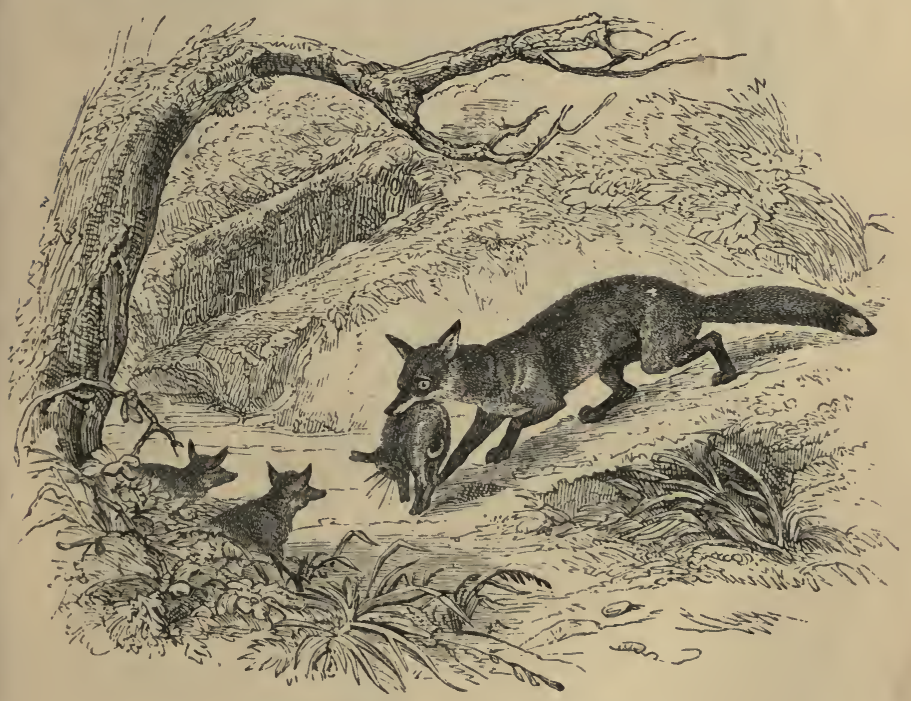

\section{THE FOX. (Canis Vulpes.)}

THIS well-known animal, which is found in most countries of Europe, is of a reddish-brown colour, with the tip of his bushy tail white. His abode is generally on the skirt of a wood, as near a farm-yard as possible, in a hole, of which some other animal has been dispossessed or which it has voluntarily deserted. Thence he issues at night, and cautiously approaching the poultry, kills all that he can find, conveying them one by one to different 
hiding places, which he visits when hungry. He will continue his depredations till day-break, or until he is alarmed, often depopulating a whole poultry-yard in one night. When, however, his choice food, the chicken, is not accessible, he devours animal foud of every description; and if his habitation be near the water he will even content himself with shell-fish. In France and Italy he does much damage to the vineyards, being very fond of grapes, and spoiling many for the sake of one bunch.

His name has passed into a proverb for cunning and deceitfulness; and, unlike the dog tribe to which he belongs, he is totally unsusceptible of any sentiment of gratitude.

His bite is tenacious and dangerous, as the severest blows cannot make him quit his hold; his eye is most significant, and expressive of almost every passion. $\mathrm{He}$ generally lives about twelve or fifteen years.

The female produces but once a year, and seldom has more than four or five cubs at a litter. The first year the young is called a Cub, the second year a Fox, and the third year an Old Fox. The tail is very bushy, and is called the brush.

In this country he is hunted with horses and hounds, and no animal affords greater diversion and occupation to the sportsman. When pursued he usually makes for his hole; but should his retreat be cut off, his stratagems and shifts to escape are singularly acute. He seeks woody

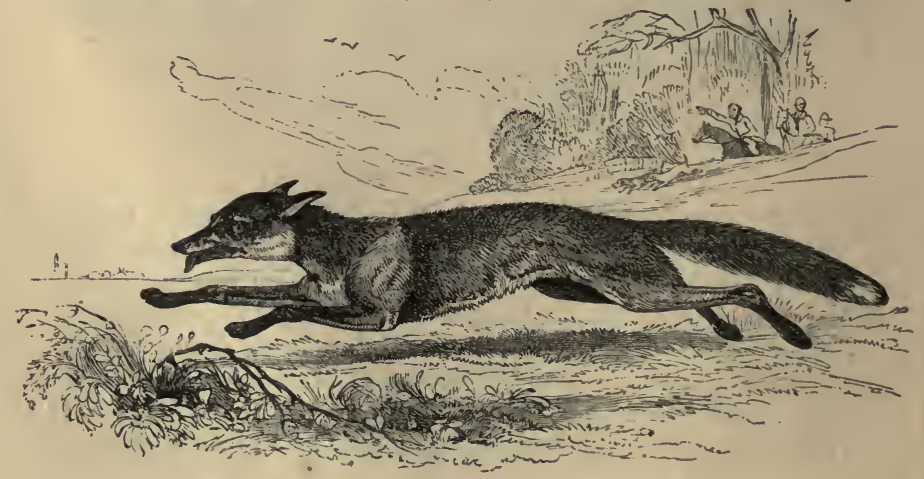


and uneven parts of the country, preferring the path, the most embarrassed by thorns and briars, and running in a straight line before the hounds, at no great distance from them; and, when overtaken, he turns on his assailants, and fighting with obstinate despair, dies in silence.

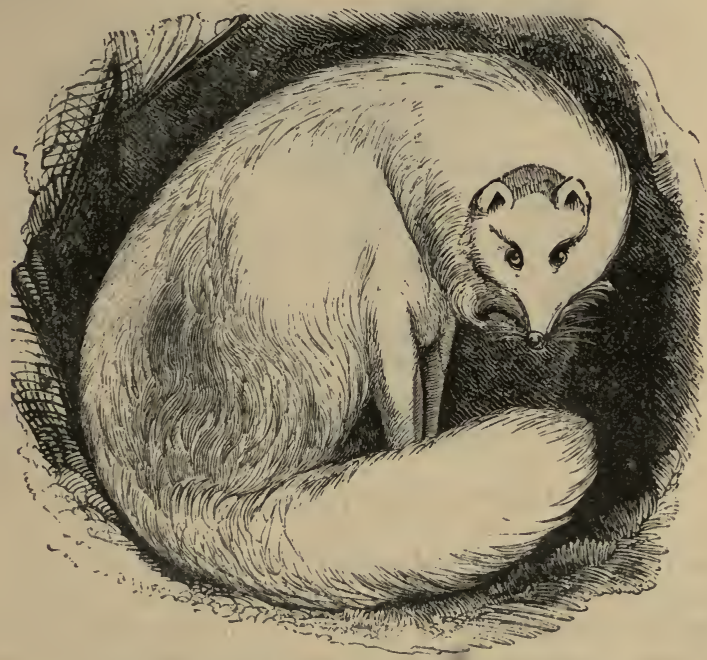

THE ARCTIC FOX, (Canis lagopus,)

Is a smaller species than the common Fox, and has a much longer fur to fit him for the severe cold which he necessarily experiences in the Polar regions which he inhabits. The colour of the fur is frequently a bluish leaden gray, from which circumstance it is sometimes called the Blue Fox; some specimens are brownish, others nearly black. The fur becomes pure white in the winter, and in this state the Arctic Fox is an exceedingly pretty animal. This species is captured for the sake of its skin, the bluish specimens being preferred. He is usually taken in pitfalls or traps, of which he is not nearly so suspicious as his sly English relative. The flesh of the young is said to be very good. 


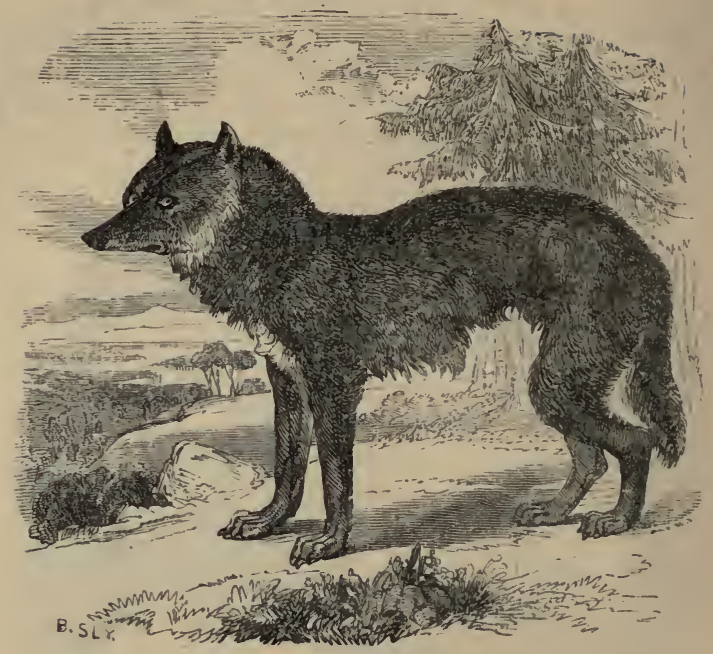

\section{THE WOLF, (Canis Lupus,)}

Whex hungry, is an undaunted and most ferocious inhabitant of the woods, but a coward when the stimulus of appetite is no longer in action. He delights to roam in mountainous countries, and is a great enemy to sheep and goats ; the watchfulness of dogs can hardly prevent his depredations, and he often dares to visit the haunts of men, howling at the gates of cities and towns. His head and neck are of a cinereous colour, and the rest of a pale yellowish brown. He commonly lives to the age of fifteen or twenty years. He possesses a most exquisite power of smelling his prey at a great distance. Wolves are found nearly everywhere, except in the British islands, where this noxious race has been entirely extirpated. King Edgar first attempted to effect this by remitting the punishment of certain crimes on producing a number of Wolves' tongues; and in Wales, the tax of gold and silver was commuted for an annual tribute of Wolves' heads. In the reign of Athelstan, Wolves abounded so 
much in Yorkshire, that a retreat was built at Flixton, to defend passengers from their attacks. They infested Ireland many centuries after their extinction in England : the last presentment for killing Wolves was made in the county of Cork about the year 1710. They abound in the immense forests of Germany, and they are also found in considerable numbers in the South of France. Everywhere that they are wild, so great is the general detestation of this destructive creature, that all other animals endeavour to avoid it. In a state of captivity, however, the Wolf is remarkably anxious to attract the attention of man, and rubs itself against the bars of its cage when nuticed. Indeed, the Wolf is by no means so untractable as is frequently suppised; but his temper is rather uncertain, and his destructive habits render him a dangerous pet. A curious instance of combined docility and destructiveness is related by Mr. Lloyd, which, as it also illustrates the cunning of this animal, we adduce here. Mr. Lloyd says-" I once had serious thoughts of training a fine female Wolf in my possession as a pointer; but was deterred, owing to the penchant she exhibited for the neighbours' pigs. She was chained in a little enclosure, just in front of my window, into which those animals, when the gate happened to be left open, ordinarily found their way. The devices the Wolf employed to get them in her power, were very amusing. When she saw a pig in the vicinity of her kennel, she, evidently with the purpose of putting him off his guard, would throw herself on her side or back, wag her tail most lovingly, and look innocence personified. And this amiable demeanour would continue until the grunter was beguiled within the length of her tether, when, in the twinkling of an eye, the prey was clutched." The Wolf is sumetimes affected with madness, in symptoms and consequences exactly similar to that which affects the dog; but this disease, as it generally happens in the depth of winter, cannot be attributed to the great heat of the dog-days. In the northern parts of the world, wolves are said, frequently, in the spring, to get upon the fields of ice adjoining the sea, for the purpose of preying upon the young seals, which 
they there find asleep; but vast pieces of the ice occasionally detaching themselves from the mass, they are carried with them to a great distance from the land, where they perish amidst the most hideous and dreadful howling. 'The language of the poet is beautifully descriptive of this creature's insatiable fury :-

"By wintry famine roused, from all the tract Of horrid mountains, which the shining Alps, And wavy Apennine, and Pyrenees, Brinch out, stupendous, into distant lands, Cruel as death! and limgry as the grave! Burning for blood! bony, and gaunt, and grim! A ssembling Wolves, in raging troops, descend; And, pouring o er the country, bear along, Kicen as the north wind sweeps the glossy snow : All is their prize."

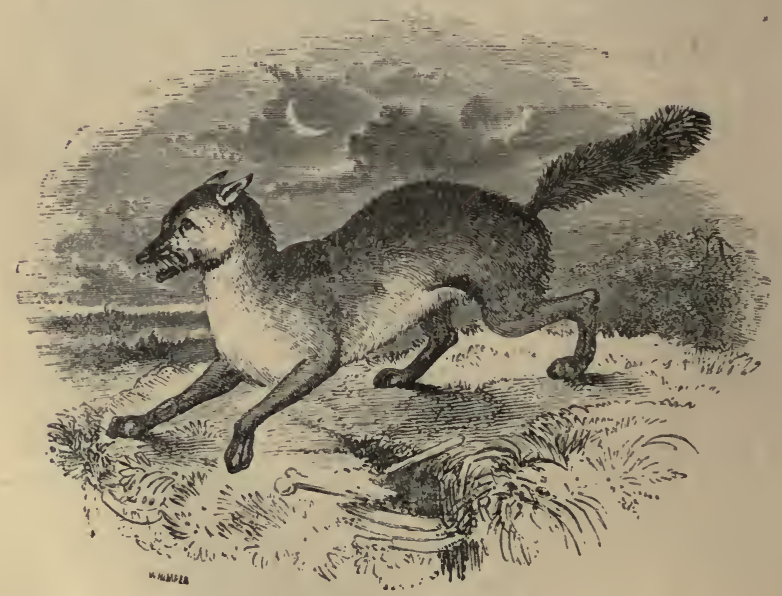

THE JACKAL, (Canis Aureus,)

Commonly called the lion's provider, is not much larger than the fox, which he resembles in the appearance of the fore part of his body. His skin is of a bright yellowish colour. The Jackals often unite to attack their prey, and make a most hideous noise, which, rousing the king of the forest from his slumbers, brings him to the place of food and plunder: at his arrival, the petty 
thieves, awed by the greater strength of their new messmate, retire to a distance; and hence the fabulous story of their attendance on the lion, to provide for his food. - These animals are always seen in large flocks of forty or fifty; and hunt, like hounds in full cry, from evening. till morning. In the absence of other food they drag the dead out of their tombs, and feed greedily on putrid corpses; but, notwithstanding their natural ferocity, it is said that, when taken young, they may be easily tamed, and, like dogs, they love to be fondled, wag their tails, and show a considerable degree of attachment to their masters. They are common in many parts of the East: and as they act as scavengers, the people do not annoy them in their nocturnal visits.

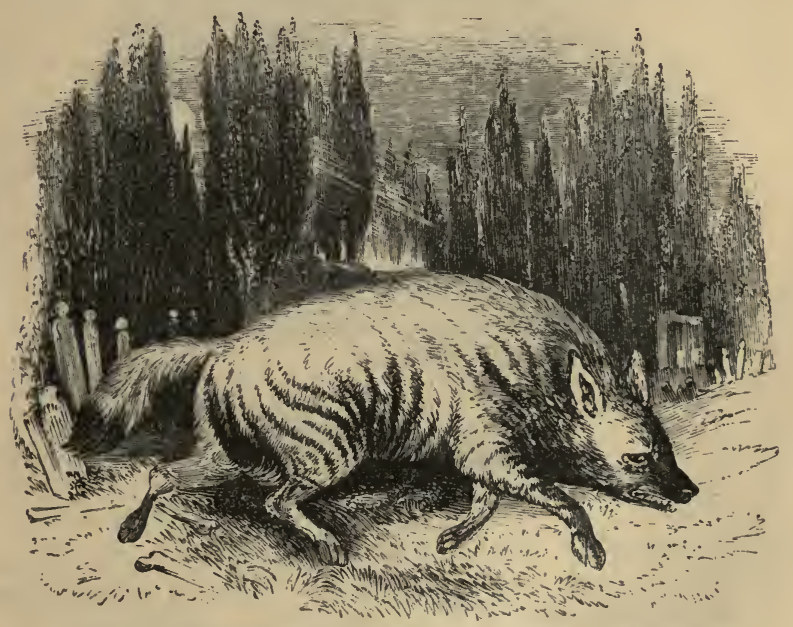

\section{THE STRIPED IIXXYA. (Hycena Striata.)}

This animal was long supposed to be the most savage and untractable of all quadrupeds : but it is now found that he may be tamed. He is covered with long, coarse, and rough ash-coloured hair, marked with long black stripes, from the back downwards; the tail is very hairy. His teeth and jaws are so constructed as to 
enable him to crush the largest bones with ease; and his tongue is as rough as a coarse file. Like the jackal, he attacks the flocks and herds, caring little for the watchfulness or strength of dogs, and when pressed with hunger, comes and howls at the gates of towns, and vio lates the repositories of the dead, tearing up the bodies from the graves, and devouring them. He is now only found wild in Asia and Africa, but is supposed to have formerly inhabited Europe. When receiving his food, the eyes of this fierce animal glisten, the bristles of his back stand erect, he grins fearfully, and utters a snarling growl.

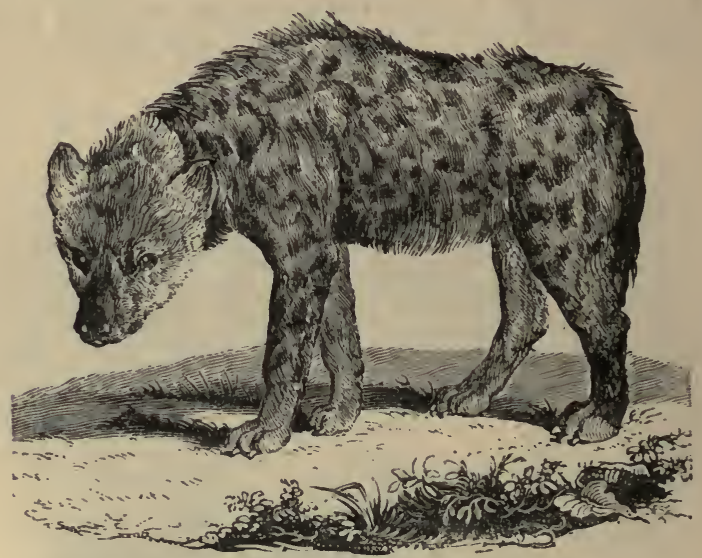

THE SPOTTED HYFIA. (Hycena Crocuta.)

THis is another species which is common in Southern Africa; it is known amongst the colonists at the Cape of Good Hope, as the Tiger-Wolf. He has none of the mane-like hair on his back, which distinguishes the Striped Hyæna, and his skin is marked with spots instead of stripes. He is a ferocious beast, and is exceedingly destructive to sheep and cattle; and also frequently attacks and carries off children from the huts of the natives, sometimes even stealing them from their sleeping mothers. 


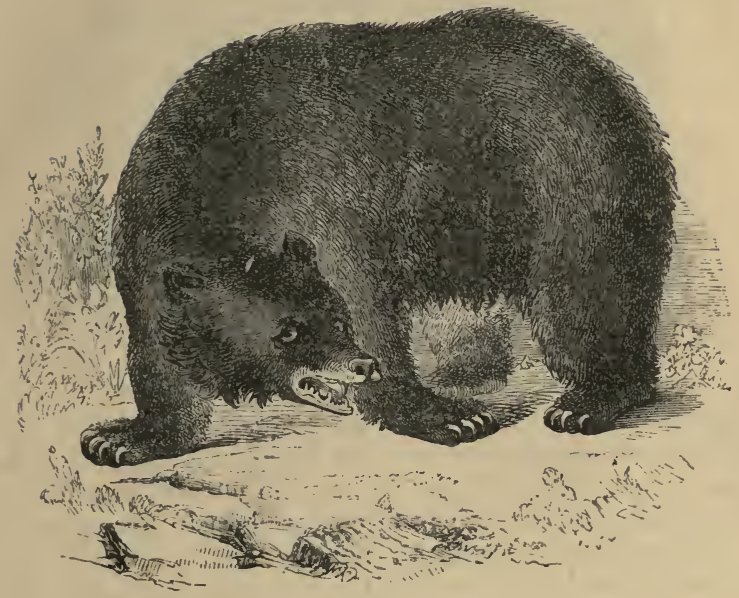

\section{AMERICAN BLACK BEAR. (Ursus Americanus.)}

T'His animal inhabits the Northern districts of America, where it is found in considerable numbers. It is somewhat smaller than the Brown or European Bear; its colour of an uniform and glossy black. Its food consists chiefly of fruits, the young shoots, and roots of vegetables and grain. In quest of these it occasionally emigrates from the northern to the more southern regions. Their retreats, during the period of gestation, are so impenetrable, that althongh immense numbers of Bears are annually killed in America, a female is rarely found among them. In autumn, when they are become exceedingly fat by feeding on acorns and other similar food, their flesh is extremely delicate, the hams in particular are highly esteemed, and the fat is remarkably white and sweet. At this time and during the winter, they are hunted, and killed in great numbers by the American Indians. 


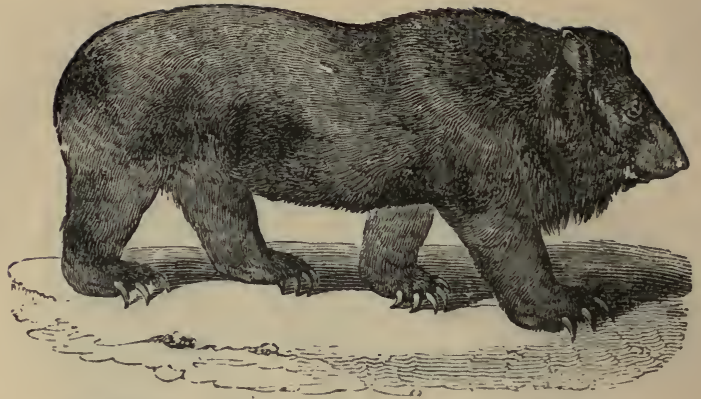

THE GRISLY BEAR, (Ursus Ferox,

WHich is also an inhabitant of North America, is a creature of enormous size and strength; a specimen has been measured and found to be nine feet in length; and it is capable of carrying the carcass of a bison, weighing probably about a thousand pounds. His ferocity corresponds with his powers of destruction; and he is altogether one of the most formidable of quadrupeds.

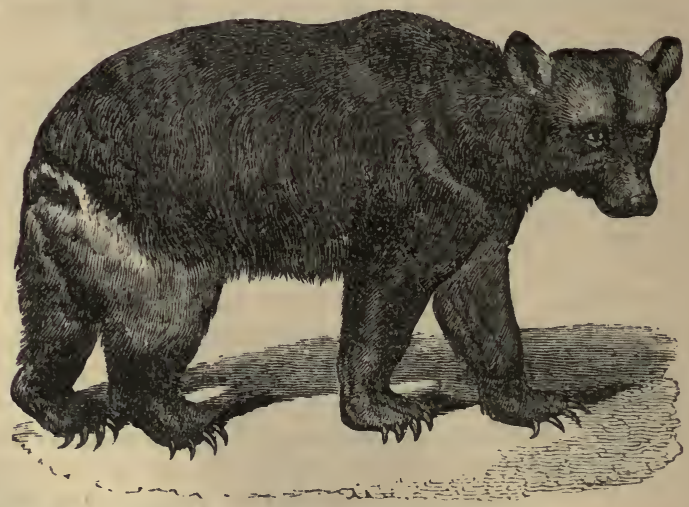

THE BROWN EUROPEAN BEAR, (Ursus Arctos,) Is a native of the North of Europe, and also of the mountainous parts of the South of that continent. He is a great sleeper, and passes the whole winter in his 
den, without any particular food: but if we consider his being at rest, losing little by perspiration, and never retiring to his winter quarters before he is properly fattened, his abstinence will cease to be wonderful. When tamed, this animal appears mild and obedient to his master; he may be taught to walk upright, to dance, to lay hold of a pole with his paws, and perform various tricks to entertain the multitude, who are highly pleased to see the awkward movements of this rugged creature, which it seems to suit to the sound of an instrument, or to the voice of its leader. The discipline Bears undergo in teaching them to dance is so severe, that they never forget it; and an amusing story is told of a gentleman who was pursued by a Bear, and who, when in despair he turned and raised his stick against his assailant, was astonished to see the Bear rear itself on its hind legs, and begin to dance. It had escaped from captivity, and had been taught to dance when a stick was held up by its keeper. But to give the Bear this kind of education, it must be taken when young, and accustomed early to restraint and discipline, as an old Bear will not suffer constraint without discovering the most furious resentment: neither the voice nor the menaces of his keeper have any effect upon him; he growls equally at the hand that is held out to feed, and that which is raised to correct him. The female Bears bring forth two or three young, and are very careful of their offspring. The fat of the Bear is reckoned very useful in rheumatic complaints, and for anointing the hair: his fur affords comfort to the inhabitants of cold climates, and ornaments to those of warm. It was anciently supposed, that the young Bear, when first brought forth, was merely an unformed mass, till its mother licked it into shape; and hence the expression, "he wants licking into shape," was frequently employed by the old dramatists, wher speaking of an awkward, clownish man.

The Brown Bear was at one time common in the British islands. "Many years ago it has been swept away so completely, that we find it imported for baiting, a sport in which our nobility, as well as the com- 
monalty, of the olden time-nay, even royalty itselfdelighted. A bear-bait was one of the recreations offered to Elizabeth at Kenilworth, and in the Earl of Northumberland's Household Book we read of twenty shillings for his bearward. In Southwark there was a regular bear-garden, that disputed popularity with the Globe and Swan theatres, on the same side of the water. Now, however, so much do tastes alter, (in this instance certainly for the better) such barbarous sports are banished from the metropolis."

The Bear is a flat-footed animal, and can stand easily. upon its broad hind feet, but is extremely awkward and sluggish in its movements. He possesses, however, the faculty of climbing to an extraordinary degree; and, in his native country frequently ascends lofty trees in pursuit of honey, of which he is excessively fond. Bears swim well, and will cross not only broad rivers, but sometimes even an arm of the sea.

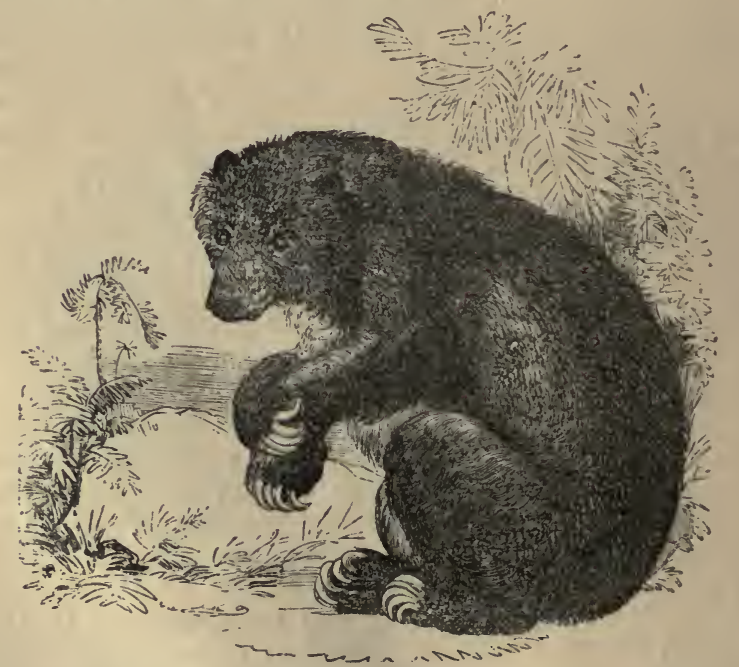

THE MALAYAN SUN-BEAR. (Ursus Malayanus.)

Is this Bear the hair is short and black, except on the 
breast, where there is a large triangular or heart-shaped spot of white or tawny. He is very easily tamed when taken young, and becomes rather an amusing pet. An individual in Sir Stamford Raffles' possession, was so tame, that he would play with children, and could be adinitted to the dinner-table, when he gave proof of the soundness of his judgment as an epicure, by refusing to eat any fruit but mangosteens, or to drink any wine but champagne. The only time that he was known to be out of humour was, when there was no champagne for him. In a wild state, this Bear feeds on vegetables and honey. It is a native of Malacca and the eastern islands.

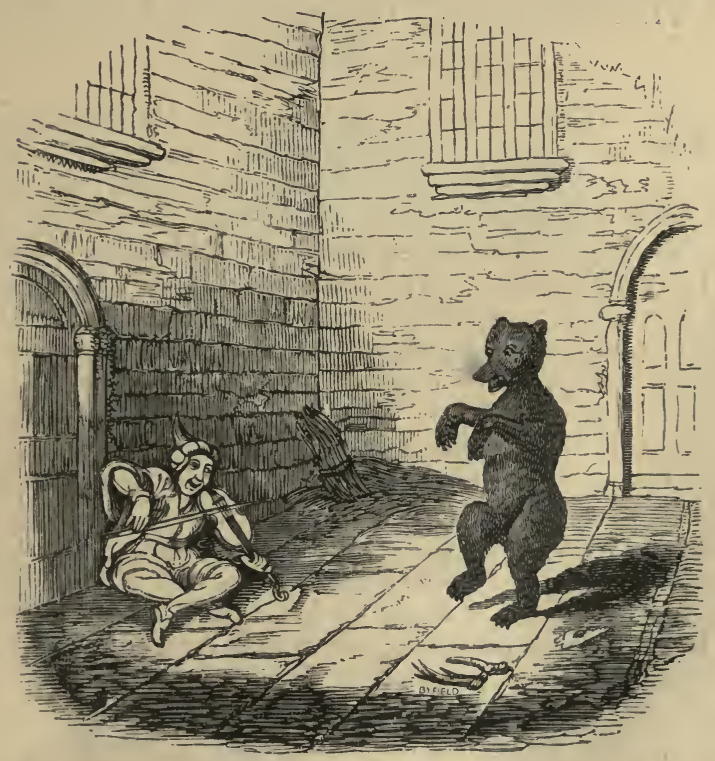


1

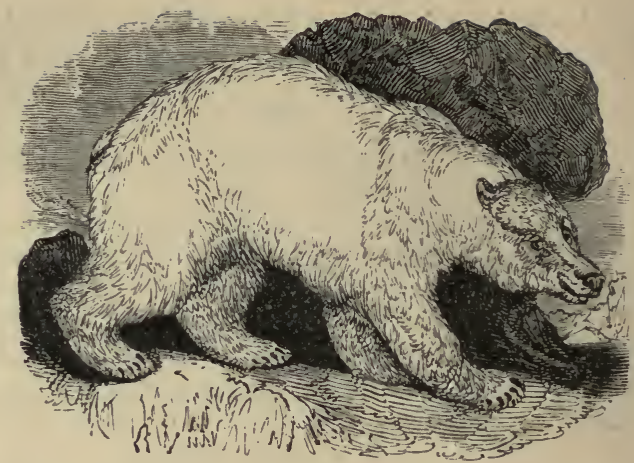

\section{'IHE POLAR, OR GREAT WHITE BEAR}

(Ursus maritimus.).

The Polar Bear is generally from six to eight feet long. The fur is long and white, with a tinge of yellow, which becomes darker as the animal advances in age; the ears are small and round, and the head long. It inhabits tho Arctic shores of. both hemispheres. It walks heavily, and is very clumsy in all its motions; its senses of hearing and seeing appear very dull, but its smell is very acute; and it does not appear destitute of some degree of understanding, or at least of cunning. Captain King, who visited the shores of the Arctic Ocean in 1835, relates a curious instance of the cunning of this animal: "On one occasion a Polar bear was seen to swim cautiously to a large piece of ice, on which two female walruses were lying asleep with their cubs. The lear crept up some hummocks behind them, and with his fore feet loosened a large block of ice, which, with the help of his nose and paws, he rolled and carried till it was immediately over the heads of the sleepers, when he let it fall on one of the old animals, which was instantly killed. The other walrus, with its cubs, rolled into the water, but the young one of the murdered female remained by its dam, and on this helpless creature tho Bear rushed, thus killing two animals at once." 
The ferocity of this kind of Bear is equal to its cunning. A few years since, the crew of a boat belonging to a ship in the whale-fishery, shot at a Bear at a shor't distance and wounded it. 'The animal immediately set up the most dreadful yells, and ran along the ice towards the boat. Before it reached it, a second shot was fired, and hit it. This served to increase its fury. It presently swam to the boat; and in attempting to get on board, placed its fore foot upon the gunwale; but one of the crew having a hatchet, cut it off. The animal still, however, continued to swim after them till they arrived at the ship, and several shots were fired at it, which also took effect; but on reaching the ship it immediately ascended the deck, and the crew having fled into the shrouds, it was pursuing them thither, when a shot from one of them laid it dead on the deck.

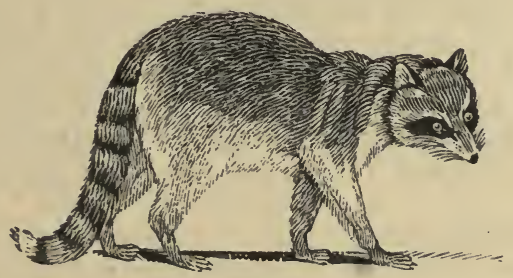

\section{THE RACOON. (Procyon lotor.)}

'T'HIs animal is a native of America, of the bear tribe: in Jamaica they are very numerous, and do incredible mischief to the plantations of sugar-cane and Indian corn, especially to the latter while it is young. The Racoon is less than the fox in size, and has a sharp-pointed nose. His fore legs are shorter than the others. 'The colour of his body is grey, with two broad rings of black round the eyes, and a dusky line running down the middle of the face. In the wild state the Racoon is savage and sanguinary, committing great destruction among both wild and domesticated birds, without consuming any part of them except the head, or the blood which flows from 
their wounds. It is a good climber, the form of its claws enabling it to adhere to the branches of trees with great tenacity. Racoons are easily domesticated, and then become very amusing animals. They are as mischievous as a monkey, seldom at rest, and extremely sensible of ill treatment, which they never forgive. They have great antipathy to sharp and harsh sounds, such as the bark of a dog, and the cry of a child. They eat of everything that is given them, and, like the cat, are good providers, hunting after eggs, fruit, corn, insects, snails, and worms; and generally dip their food in water before devouring it. A peculiarity which few other animals are found to possess is, that they drink as well by lapping like the dog, as by sucking like the horse. These animals are hunted for the sake of their fur, which is used by the hatters, and is considered next in value to that of the beaver; it is used also in linings for garments. The skins, when properly dressed, are made into gloves and upper-leathers for shoes. The negroes frequently eat the flesh of the Racoon, and are very fond of it, though it has a very disagreeable and rank smell. The American hunters pique themselves on their skill in shooting Racoons; which from the extraordinary vigilance and cunning of the animals, is by no means an easy task.

When eating they support themselves on their hind feet, and carry their food to the mouth with their fore paws. Some of them are very fond of oysters and other shell-fish, and show great dexterity in keeping the shells open, while they extract the contents. Their most remarkable peculiarity, however, is that already mentioned, of dipping their food in water when there is any within their reach; though when there is not, they seem quite contented to eat it dry. 


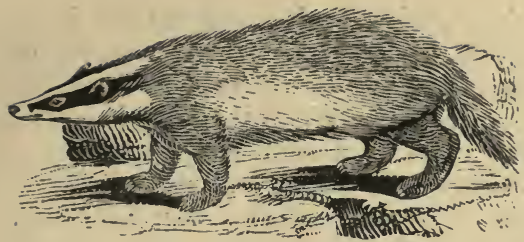

THE BADGER. (Meles Taxus.)

THIs animal inhabits most parts of Europe and Asia. The length of the body is about two feet six inches from the nose to the insertion of the tail, which is short, and black like the throat, breast, and belly; the hair of the other part of the body is long and rough, of a yellowish white at the roots, black in the middle, and greyish at the point: the toes are much enveloped in the skin, and the long claws of the fore feet enable the animal to dig with great effect: under the tail there is a receptacle, in which is secreted a white fetid substance, that constantly exudes through the orifice, and thus gives the body a most unpleasant smell. Being a solitary animal, it digs a hole for itself, at the bottom of which it remains in perfect security: it feeds upon young rabbits, birds and their eggs, and honey. The female has generally three or four young ones at a time.

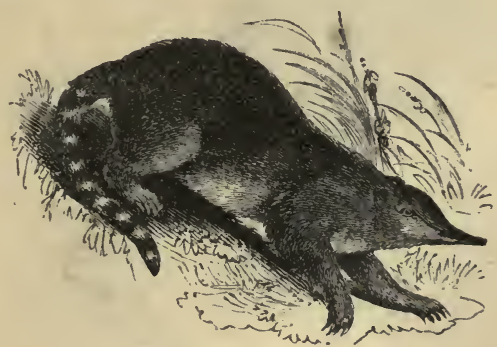

\section{THE COATI-MONDI. (Nasua Narica.)}

ThIs creature is a native of South America, not unlike the Racoon in the general form of the body, and, like that animal, frequently sits up on the hinder legs, and 
in this position, with both paws carries its food to its mouth. Even in a state of tameness, it will pursue poultry, and destroy every living thing that it has strength to conquer. When it sleeps it rolls itself into a ball, and remains immovable for fifteen hours together. Its eyes are small, but full of life; and, when domesticated, it is very playful and amusing. A great peculiarity belonging to this animal is the length of its snout, which is movable in every direction. 'The ears are round, and like those of a rat; the fore feet have five toes each. The hair on the back is short and rough and of a blackish hue; the tail marked with rings of black, like the wild cat; the rest of the body is a mixture of black and red. This animal is very apt to eat its own tail, which is very long; but this strange appetite is not peculiar to the Coati alone; the mococo and some of the monkey tribe do the same, and seem to feel no pain in wounding a part of the body so remote from the centre of circulation.

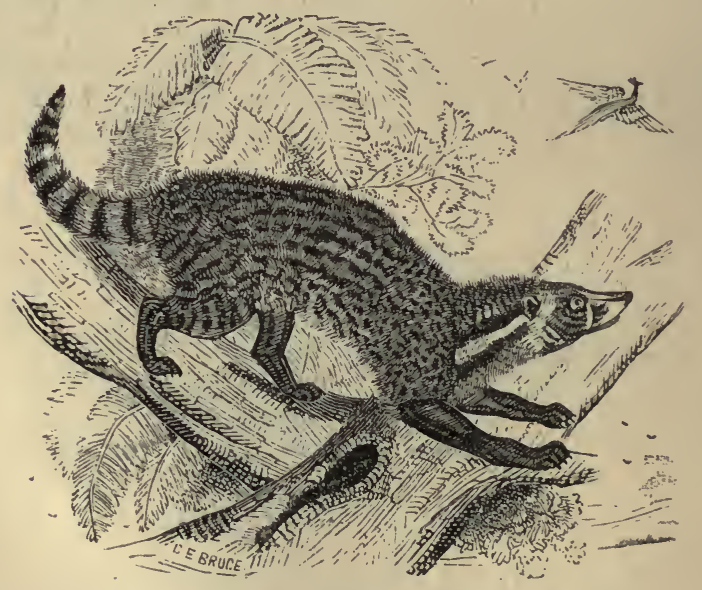

THE CIVET, (Viverra Civetta,)

Is found in Northern Africa and Guinea, and is famous for producing the perfume called civet. He is kept for 
the sake of this perfume, and fed with a kind of soup made of millet, or rice, with a little fish or flesh boiled with it in water. The civet is found in a large double glandular receptacle, situated at a little distance beneath the tail. When a sufficient time for the secretion has been allowed, one of these animals is put into a long wooden cage, so narrow that it cannot turn itself round. The cage being opened by a door behind, a small spoon is introduced through the orifice of the ponch, which is carefully scraped; this is done twice or thrice a week, and the animal is said always to produce the most civet after being irritated. The Civet, although a native of the warmest climates, is yet found to live in temperate, and even cold countries, provided it be defended carefully from the injuries of the air. In a wild state, the Civet lives entirely on birds and small quadrupeds ; and at any time a small quantity of salt is said to poison it.

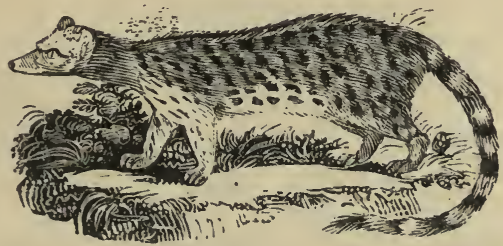

THE GENET. (Viverra Genetta.)

This animal is about the size of a small eat. The skin is spotted and beautiful, of a reddish grey colour. The spots on the sides are round and distinct, those on the back almost close; its tail is long, and marked with seven or eight rings of black. From an orifice beneath its tail "it yields a kind of perfume, which smells faintly of musk. This little animal is meek and gentle, except when provoked, and is easily domesticated. In Constantinople it strays from house to house like our cat, and keeps whatever house it is in perfectly free from mice and rats, which cannot endure its smell. It is found wild in various parts of the south of Europe, and also throughout the continent of Africa. Its fur is 
beautiful and soft, and valuable as an article of commerce. The eyes of the Genet contract when exposed to the light, like those of the cat; and it can draw in its claws in nearly the same manner.

\section{THE ORIENTAL CIVET, (Viverra Zibetha,)}

Is an inhabitant of the south of Asia and of the islands of the Indian Archipelago. It is rather smaller than the African Civet, but is very sanguinary in its habits, causing a great destruction of poultry and even of lambs and young pigs. 'I'he perfume furnished by this species is highly esteemed by the natives of eastern countries.

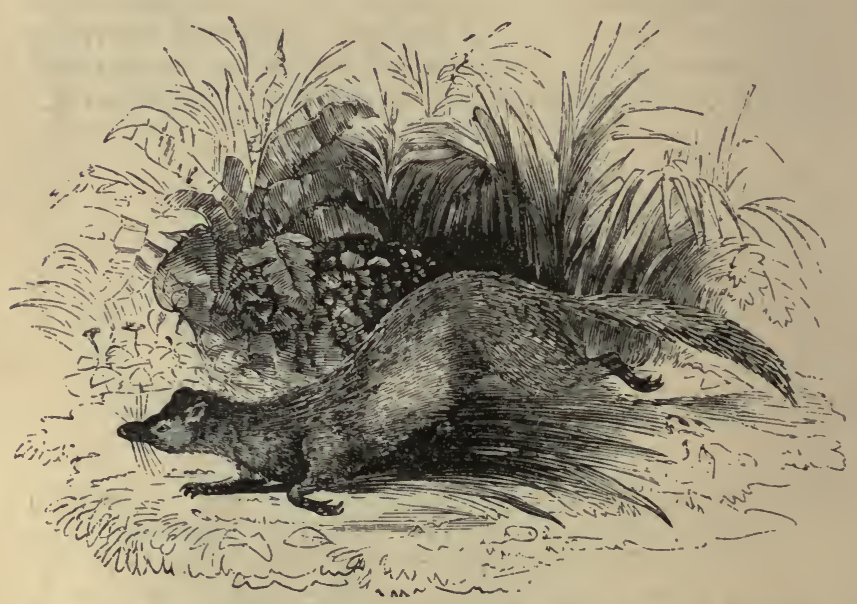

THE ICHNEUMON, OR EGYPTIAN MANGOUSTE, or PHARAOH'S RAT. (Herpestes Ichneumon.)

THIs animal bears a close resemblance to the weasel tribe, both in form and habits. From the tip of the nose to the root of the tail, it is about eighteen inches in length. At the base, the tail is very thick, tapering gradually towards the point, which is slightly tufted. It has a long, active body, short legs, lively and piercing 
eyes, and a puinted nose; the hair is rough and bristly, of a pale reddish grey.

The Ichneumon is celebrated in the mythology of ancient Egypt, where it has long been domesticated, and where it was ranked amongst the divinities, on account of its great utility in destroying serpents. snakes, rats, mice, and other vermin : it is also fond of crocodiles' eggs, which it digs out of the sand where they have been deposited. It is a very fierce, though small animal, and will fight with dogs, foxes, and even jackals, with great fury. It will not breed in confinement, but may be easily tamed when taken young.

The following particulars are related by M. D'Obsonville, in his Essays on the Nature of various foreign Animals :- "I had an Ichneumon very young, which I brought up. I fed it at first with milk, and afterward with baked meat mixed with rice. It soon became even tamer than a cat; for it came when called, and followed me, though at liberty, in the country. One day I brought this animal a small water-serpent alive, being desirous to know how far his instinct would carry him against a being with which he was as yet totally unacquainted. His first emotion seemed to be astonishment mixed with anger, for his hair became erect; but in an instant he slipped behind the reptile, and with remarkable swiftness and agility leaped upon its head, seized it, and crushed it between his teeth. This essay, and new food, seemed to have awakened in him his innate and destructive voracity, which till then had given way to the gentleness he had acquired from education. I had about my house several curious kinds of fowls, among which he had been brought up, and which, till then, he had suffered to go and come unmolested and unregarded: but a few days after, when he found himself alone, he strangled them every one, ate a little, and, as it appoared, drank the blood of two."

The Moongus (Herpestes griseus) and the Garangan (Herpestes Javanicus) are eastern species of Ichneumons ; the former inhabits India, and the latter the island of Java. Like the Egyptian Ichneumon, they are great эnemies of snakes and other reptiles, and also destroy 
rats, but unfortunately they often commit great havoc among poultry.

The mode in which the Ichneumon seizes a serpent is thus described by Lucan in his Pharsalia :-

"Thus oft the Ichneumon, on the banks of Nile,

Invades the deadly aspic by a wile;

While artfully his slender tail is played, 'The serpent darts upon the dancing shade, 'Then turning on the foe with swift surprise, Full on the throat the nimble traitor flies, And in lis grasp the panting serpent dies."

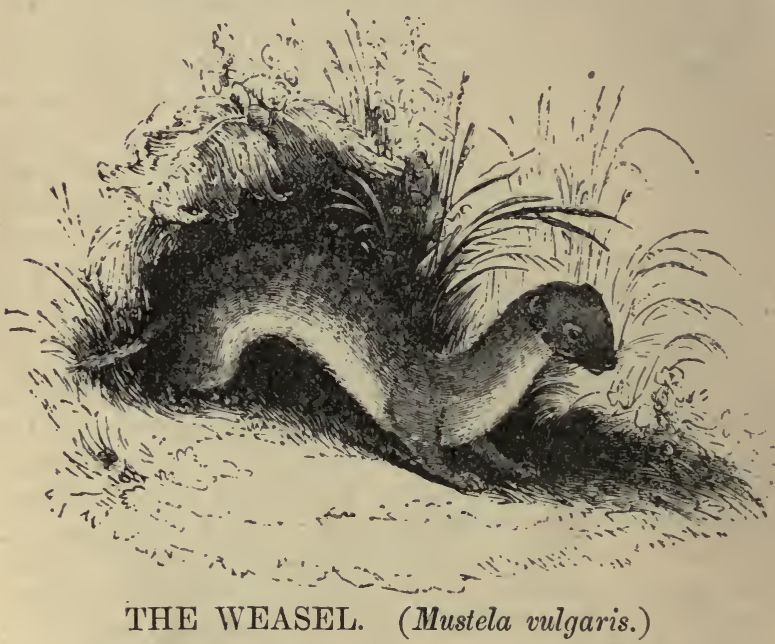

The animals belonging to this genus, notwithstanding their small size, are all carnivorous, and from their slender and lengthened bodies, short legs, and the very free motion in every direction, permitted by the loose articulations of the spine, are well formed for pursuing their prey into the deepest recesses. Constituted by nature to subsist on animals, many of which have great strength and courage, they possess an undaunted and ferocious disposition. The Weasel has a lnng and thin body; its length, with its tail, is ten inches, and its height not more than an inch and a half. In the northern parts of 


\section{The Weasel.}

Europe they are very numerous. Mice of every description, the field and the water-vole, rats, moles, and small birds, are their ordinary food, and occasionally rabbits and partridges. When driven by hunger, it will boldly attack the poultry-yard. The Weasel, when it enters a hen roost, never meddles with the cocks or old hens, but makes choice of the pullets and young chickens; these it kills with a single stroke on the head, and carries away one after tho other. It sucks the withs with avidity, making a small hole at one end, through which it draws out the yolk. In winter it resides in granaries and hay-lofts, and in summer chooses the low lands about the mills and streams, where it hides amang the bushes, and in the hollows of old trees.

It was formerly supposed that the Weasel was untamable; but Buffon, in a supplementary volume, corrects this error, and from a letter of a female correspondent, shows that it may be rendered as familiar as a cat or a lapdog. It frequently eat from his correspondent's hand, and seemed fonder of milk and fresh meat than of any other food. "If I present my hands," says this lady, "at the distance of three feet, it jumps into them without ever missing. It shows a great deal of address and cunning, in order to accomplish its ends, and seems to disobey certain prohibitions merely through caprice. During all its actions it seems solicitous to divert and be noticed, looking at every jump and at every turn to see whether it be observed or not. If no notice be taken of its gambols, it ceases them immediately, and betakes itself to sleep; and when awaked from the soundest sleep, it instantly resumes its gaiety, and frolics about in as sprightly a manner as before. It never shows any ill humour, unless when confined or too much teased, in which case it expresses its displeasure by a sort of murmur, very different from that which it utters when pleased."

Weasels and ferrets are used by rat-catchers to drive the rats out of their holes; and they kill a great many, the habit of the Weasel being to kill its prey by biting the head, so that the teeth penetrate the brain, and then to throw the body aside, or hide it till a future period. 


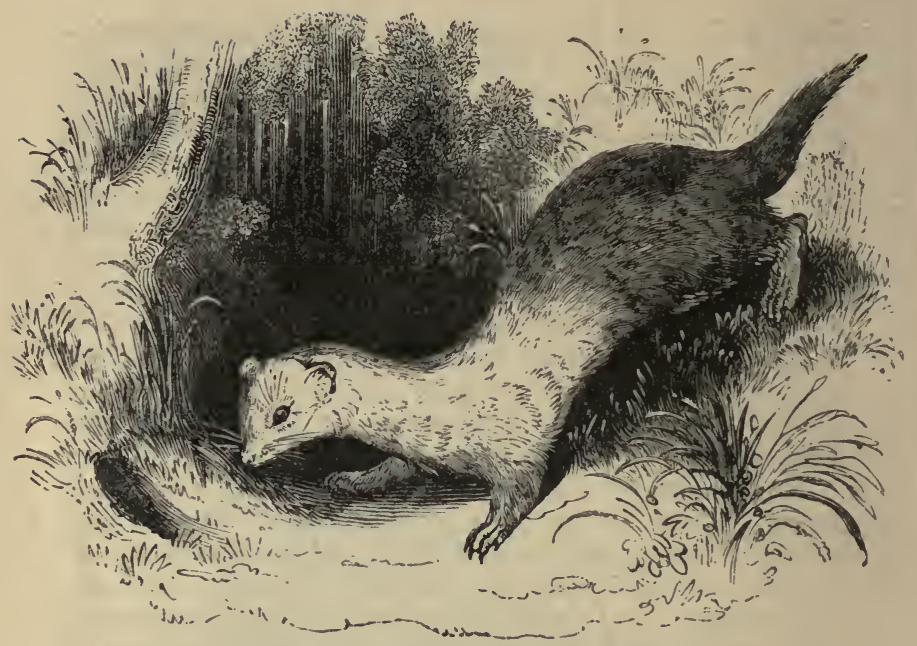

THE FERRET, (Mustela furo,)

Is a small, yet bold animal, and an enemy to all others but those of his own kind. He closely resembles the Polecat, and is considered by many naturalists, to be merely a domesticated variety of that animal. His eyes are remarkably fiery. He is much used to drive rabbits from their holes, and for this purpose is always muzzled, as otherwise he would feast upon the blood of the first rabbit he met with, and then quietly lay himself down in the burrow to sleep. $\mathrm{He}$ is such an inveterate enemy to the rabbit, that if a dead one be presented to a young Ferret, he instantly bites it with an appearance of rapacity ; or, if it be living, the Ferret seizes it by the neck, winds himself round it, and continues to suck its blood till he be satiated; indeed, his appetite for blood is so strong, that he has been known to attack and kill children in the cradle. He is very soon irritated; and his bite is very difficult to be cured.

Our figure is full large, as the length of the animal is usually about thirteen inches, exclusive of the tail, which is about five. 


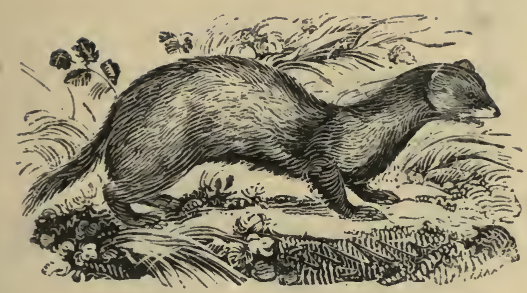

THE POLECAT. (Mustela putorius.)

THE strong and disagrecable smell of this animal is proverbial; its skin is stiff, hard, and rugged, and when well prepared, is very desirable as clothing. It is about seventeen inches in length, exclusive of the tail, which is about six inches. The breast, tail, and legs are of a blackish colour, but the belly and sides yellowish. It sometimes conceals itself in secret corners about houses, and is then a disastrous pest to the poultry-yard. 'I'hese animals usually frequent the woods and destroy a great quantity of game; and some, forsaking the haunts of man, retire to the rocks and crevices of the cliffs on the sea shore, preferring a meagre and scanty diet with security, to the daintiness of chicken-flesh and eggs, attended with trouble and fear. Rabbits seem to be their favourite prey, and a single Polecat is often suffcient to destroy a whole warren; for with that insatiable thirst for blood which is natural to all the weasel tribe, it kills much more than it can devour; and twenty rabbits have been found dead, which one Polecat had destroyed by a wound hardly perceptible. The Polecat is the same with the Fitchet or Foumart, the hair of which is made into fine brushes and pencils for the use of painters. This small animal is fierce and bold. When attacked by a dog, it will defend itself with great spirit, attack him in turn, fastening upon the nose of its enemy with so keen a bite, as frequently to oblige him to desist. When heated or enraged, the smell it emits is absolutely intolerable. 


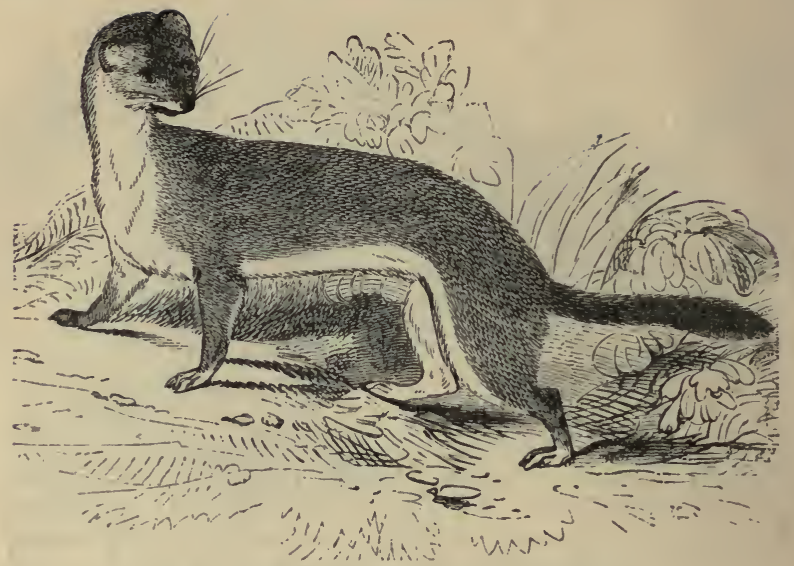

\section{THE ERMINE. (Mustela erminea.)}

T'ніs, which is also called the Sтолт, is a smaller species than the Polecat, and is less common in England than the latter, although in Scotland it is tolerably abundant. Its colour in summer, is reddish brown on the back and white underneath; but in winter the whole of the fur becomes pure white, except on the tail, which is always black, and it is in this state that the fur of the Ermine is so highly esteemed. In the North of Europe, Siberia, and the most northern parts of America, Ermines are found in immense numbers, and great quantities of them are killed for the sake of their skins, of which several hundred thousand are annually exported from those inclement northern regions, to serve for the adornment of ladies dress, and of the state rolues of peers and other high dignitaries, in more civilized countries. The pure white skin adorned with the jet black tails of the little ahimals, is indeed one of the most elegant of all furs ; but from the immense quantities in which the skins are imported, they have become so cheap that ermine can no longer be regarded as a fashionable fur, and it is chiefly employed for those purposes to which custom has, in a manner, consecrated its use.

Like the Polecat, and others of its kind, the Ermine 
is a bloodthirsty little creature, and so bold that it will attack animals much larger than itself. It is very destructive to poultry and game, and even pursues hares with success; those animals, although so fleet of foot appearing to be so fascinated by the approach of their little enemy, that they do not betake themselves to flight, but hop slowly along, until the fangs of the destroyer are fixed in the throat of its victim, when all efforts to shake him off are unavailing. The Ermine is also one of the great enemies of the water-rat, which it will follow into the water. The dwelling-place of the Ermine is a narrow burrow, usually in the midst of a thicket, or furze-bush ; it sometimes takes up its abode in a rabbit burrow. In this country the female produces four or five young at a birth; but in . North America the litter is said tu consist of ten or twelve little ones.

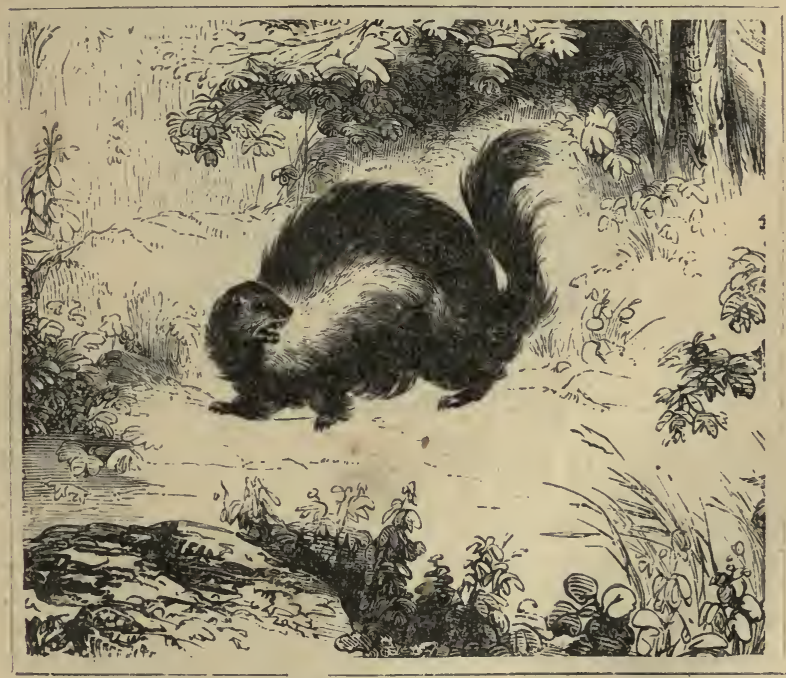

THE SKUNK, (II ustela, or Mephitis Americana,)

Wrich is found in most parts of North America, is curiously marked with a pair of white stripes running 
down the sides of the back. It feeds upon mice and other small quadrupeds, and also in summer upon froys. 'The Skunk is of a stout and rather heavy form, and runs but slowly, so that when pursued it would have but a small chance of making its escape, but for a singular provision with which it has been endowed by nature. This consists of a yellow fluid of the most horrible odour, contained in a small bag or pouch under the root of the tail; which the creature is enabled to discharge to a distance of more than fuur feet, so that even if the noisome discharge does not actually reach and smother the animal's pursuers, it forms between them and their intended victim, a sort of invisible barrier, which few noses are able to pass. The smell is so strong that it has been known to produce sickness at a distance of a hundred yards, and so persistent, that the spot where a Skunk has been killed, will retain the taint for many days. The flesh of this animal is, however, considered excellent food by the Indians.

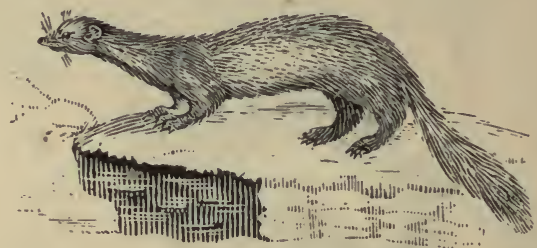

\section{THE SABLE. (Mustela, or Martes Zibellina.)}

This animal is a native of Siberia, Kamtschatka, and Asiatic Russia, and it frequents the banks of rivers, and the thickest parts of the woods. It lives in holes under the ground, and especially under the roots of trees; but sometimes makes its nest, like the squirrel, in the hollows of trees. 'The skin of the Sable is more valuable than that of any other animal of equal size. One of these skins, not more than four inches broad, has sometimes been valued at as high a rate as fifteen pounds; but the general price is from one to ten pounds, according to the quality. The Sable's fur is different 
from all others, its peculiarity being, that the hair turns with equal ease either way; on which account fur dealers sometimes blow the fur of any article they may be selling, to show that it is really Sable. The tails are sold by the hundred, at from four to eight pounds.

The American Sable (M. leucopus) is considered to be a distinct species.

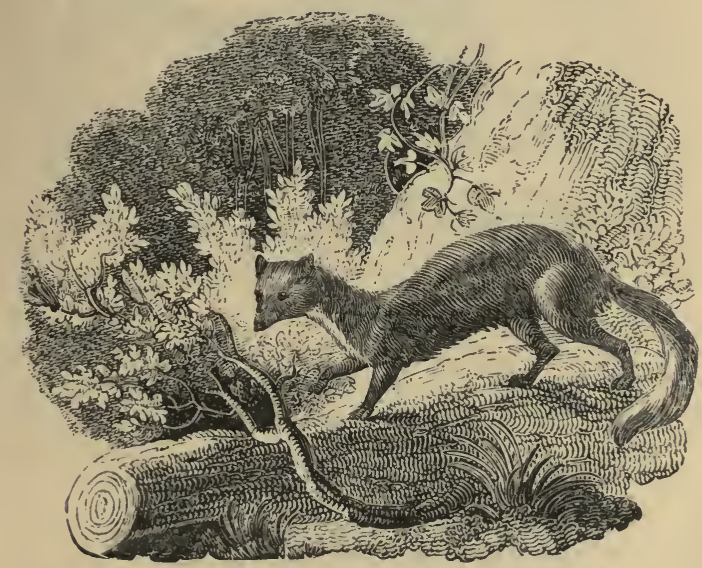

The common, or Beech Marten, (Mustela Martes or Martes foina, ) like the Sable, boasts the honour cf adorning with his fur the rich and the beautiful; as princes, ladies, and opulent people of all nations, pride them.selves in wearing his spoils. He is about as big as a cat, but his body is much longer proportionately, and the legs shorter. His skin is of a light brown, with white under the throat. The fur of the Marten fetches a good price, and is much used in European countries, though very far inferior to that of the Sable: the best, which is called Stone Marten fur by the furriers, is imported from Sweden and Russia. 


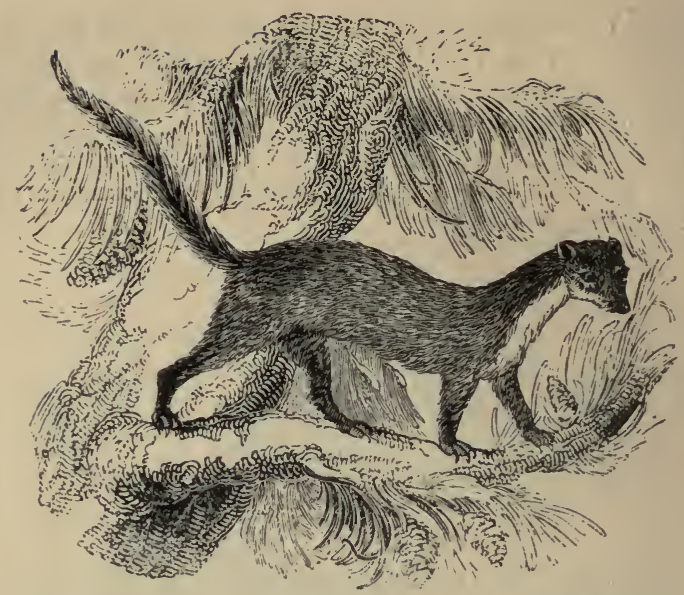

The Pine, or Yellow-breasten Marten (M. Abietum), is another species, the fur of which is nearly equal to that of the Sable, though it is much cheaper.

\section{THE O'TTER. (Lutra rulgaris.)}

"Forth from his den the Otter drew,Grayling and trout their tyrant knew, As between reed and sedge he peers, With fierce round snout and sharpened ears, Or, prowling by the moonbeam cool, Watches the stream or swims the pool."

Sсотт.

As the Otter lives principally on fish, the formation of his body is such as will enable him to swim with the greatest facility. His boily is flattened horizontally; his tail is flat and broad; his legs are short, and his toes ivebbed. His teeth are very strong and sharp; and his body, besides its fur, has an outer covering of coarse shining hair. The Otter is a perfect epicnre in his food; he seldom eats an entire fish, but beginning at the head, eats that, and about half the body, always rejecting the tail. When the rivers and ponds are frozen so that the Otter can get no fish, he will risit the neighbouring 
farm-yards, where he will attack the poultry, suckingpigs, and even lambs. - An Otter may be tamed, and taught to catch fish enough to sustain not only himself, but a whole family. Goldsmith states, that he saw an Otter go to a gentleman's pond at the word of command, drive the fish into a corner, and seize upon the largest of the whole, bring it off, and give it to his master.

Bewick, in his History of Quadrupeds, states, that a person of the name of Collins, who lived at Kilmerston, near Wooler, in Northumberland, had a tame Otter, which followed him wherever he went. He frequently took it to fish in the river; and, when satiated, it never failed to return to him. One day, in the absence of Collins, the Otter, being taken out to fish by his son, instead of returning as usual, refused to come at the accustomed call, and was lost. 'The father tried every means in his power to recover the animal; and, after several days' search, being near the place where his son had lost it, and calling it by name, to his inexpressible joy it came creeping to his feet, and showed many marks of affection and attachment.

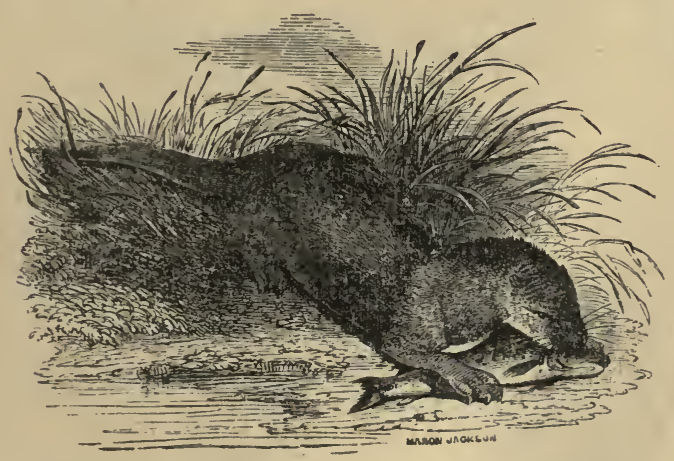

The female Otter produces four or five young ones at a birth, and these in the spring of the year. Where there have been ponds near a gentleman's house, instances have occurred of their littering in cellars or 
drains. The male utters no noise when taken, but the females sometimes emit a shrill squeak.

Otters are generally caught in traps placed near their landing-places, and carefully concealed in the sand. When hunted by dogs, the old ones defend themselves with great obstinacy. They bite severely, and do not readily quit their hold. Otter-hunting is a favourite sport in many parts of Great Britain; particularly in the midland counties of England, and in Wales.

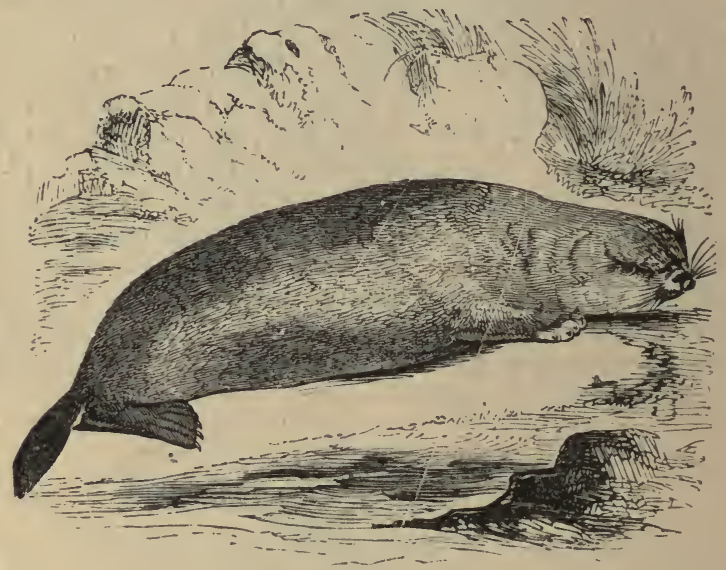

THE SEA OTTER. (Lutra or Enhdyralutris.)

THE common Otter sometimes takes to the sea; but, on the eastern coasts of Northern Asia and the opposite shores of North America, true Sea Otters are met with, chiefly about the numerous rocky islands which fringe those coasts. The Sea Otter in its habits resembles the seals more than the common species; it is about three feet long without the tail, and is covered with a thick, rich, dark brown, or nearly black fur, which is so highly prized that single fine skins have been known to sell for a sum equivalent to twenty pounds, and the animals have, in consequence, been pursued with such avidity, that their numbers are greatly reduced. 


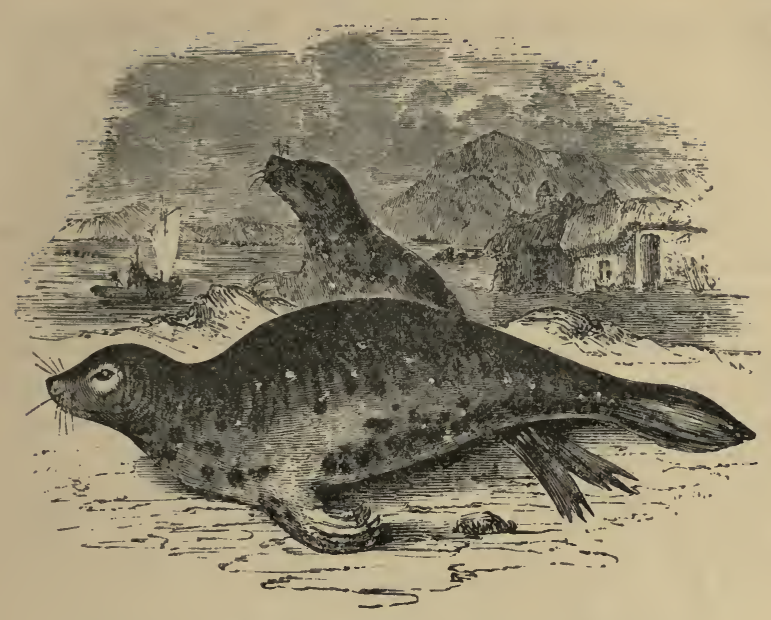

THE COMMON SEAL.' (Plioca viiulina.)

THE amphibious flesh-eating animals, though nearly allied to the otter in their habits, are very different in the construction of their bodies. Their feet are so short and so enveloped in skin, that they are of scarcely any use in assisting the animal on dry land; so that the Seal's progress on solid ground is only effected by a sort of half tumbling, jumping, and shuffling motion, excessively ridiculous to a looker-on. The feet, however, which are furnished with strong claws, are of use in enabling the animal to climb out of the water over a rocky shore. For swimming, the Seal is admirably adapted ; its long flexible body is shaped like that of a fish, tapering to the tail; and it is furnished with strong webs between the toes, so as to make the fore feet act as oars, and the hind feet, which the animal generally drags behind it like a tail, to serve as a rudder. The Common Seal lives generally in the water, and feeds entirely on fish; only coming to shore occasionally to bask on the sands, and to lie there to suckle its young. The usual length of a Seal is four or five feet. The head is large and round; the neck small and short; and on each side of the mouth 
there are several strong bristles. From the shoulders the body tapers to the tail, which is very short. The eyes are large: there are no external ears; and the tongue is cleft or forked at the end. The body is covered with short thick-set hair, which in the common species is generally grey, but sometimes brown or blackish. 'There are, however, several species; and one of them, which is called the sea-leopard, has the fur spotted with white or yellow.

Seals are hunted by the Greenlanders for the sake of their oil, and also for their skins, which are used for making waistcoats and other articles of clothing, and are much prized by the fishermen for their great warmth. The oil, of which a full grown specimen yields four or five gallons, is very clear and transparent, and destitute of the unpleasant odour and taste of whale-oil. When attacked, they fight with great fury; but when taken young, are capable of being tamed; they will follow their master like a dog, and come to him when called by the name given to them. Some years ago a young Seal was thus domesticated. It was taken at a little distance from the sea, and was generally kept in a vessel full of salt water: but sometimes it was allowed to crawl about the house, and even to approach the fire. Its natural food was regularly procured for it; and it was carried to the sea every day, and thrown in from a boat. It used to swim after the boat, and always allowed itself to be taken back. It lived thus for several weeks, and probably would have lived much longer, had it not been sometimes too roughly handled. The females in this climate bring forth in winter, and rear their young upon some sand-bank, rock, or desolate island, at some distance from the main land. When they suckle their young, they sit up on their hinder legs, while the little Seals, which are at first white, with woolly hair, cling to the teats, which are four in number. In this manner the young continue in the place where they are brought forth for twelve or fifteen days; after which the dam brings them down to the water, and accustoms them to swim and get their food by their own industry. 
In Newfoundland the Seal-fishery forms an important source of wealth, and numerous ships are sent out every season among the ice in search of Seals. One ship has been known to catch five thousand Seals, but about half that number is the usual quantity taken. As soon as the Seal is killed, it is skinned, and the pelt, as the skin and blubber together is called, being preserved, the body of the Seal is either eaten by the sailors, or left on the ice for the polar bears.

The aboriginal inhabitants of the northern regions have several strange superstitions about Seals. They believe that Seals delight in thunder-storms; and say, that during these times they will sit on the rocks, and contemplate, with apparent pleasure and gratification, the convulsion of the elements. The Icelanders, in particular, are said to believe that these animals are the offspring of Pharaoh and his host, who were converted into Seals when they were overwhelmed in the Rcd sea.

Several species of Seals are distinguished by curious appendages to the head, sometimes in the form of a hood, sometimes in that of a projection from the nose. One of the most singular is the Sea Elephant (Morunga proboscideo, , an inhabitant of the shores of the numerous islands scattered over the great Southern Ocean. In this curious animal, which often measures twenty-four feet in length, the nose of the male forms a proboscis about a foot long and capable of considerable distension. The female has no such appendage. The young of the Sea Elephant, when just born, is said to be as large as a full grown seal of the common species. The skin in the old animals is very thick, and forms an excellent leather for harness. 


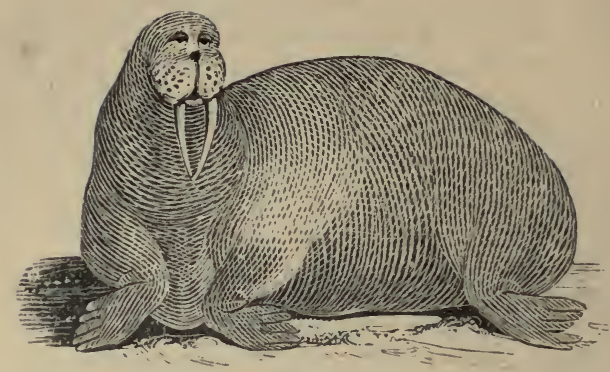

THE WALRUS, MORSE, OR SEA-COW.

(Trichechus Rosmarus.)

This very curious animal is nearly allied to the Seal, but is of much greater size, being frequently eighteen feet in length, and from ten to twelve feet in girth. The head is round, the eyes are small and brilliant, and the upper lip, which is enormonsly thick, is covered with pellucid bristles, as large as a straw. The nostrils are very large, and there are no external ears. 'The most remarkable part of the Walrus is, however, his two large tusks in the upper jaw; they are inverted, the points nearly uniting, and sometimes exceed twenty-four inches in length! the use which the animal makes of them is not easily explained, unless they help him to climb up the rocks and mountains of ice among which he takes up his abode, as the parrot employs his beak to get upon his perch. The tusks of the Walrus are superior in durability and whiteness to those of the elephant, and, as they keep their colour much longer, are preferred by dentists to any other substance for making artificial teeth.

The Walrus is common in some of the northern seas, and will sometimes attack a boat full of men. They are gregarious animals, usually found in herds of from fifty to one hundred or more, sleeping and snoring on the icy shores; but when alarmed they precipitate themselves into the water with great bustle and trepidation, 
and swim with such rapidity, that it is difficult to overtake them with a boat. One of their number always keeps watch while the others sleep. They feed on shell. is sh and sea-weeds, and yield an oil equal in goodness to that of the whale. The white bear is their greatest enemy. In the combats between these animals, the Walrus is said to be generally victorious, on account of the desperate wounds it inflicts with its tusks. The females have only one young one at a time, which, when born, resembles a good sized-pig.

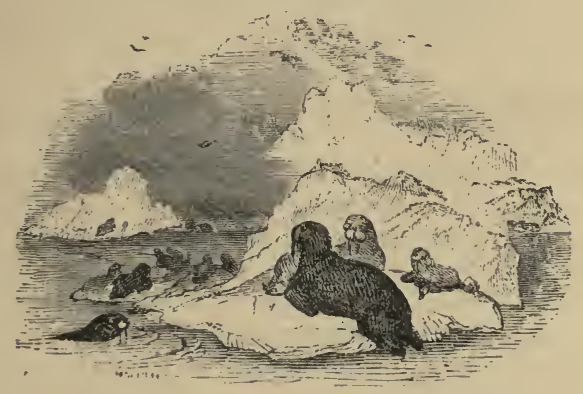


§ II. Insectivorous, or Insect-eating Animals.

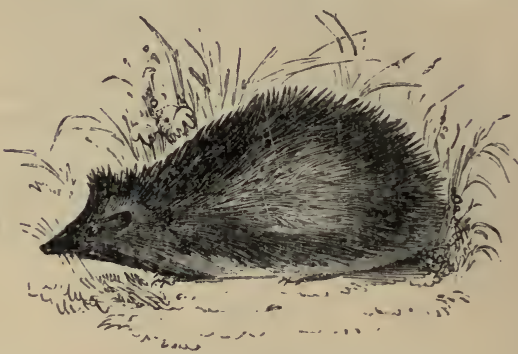

\section{THE HEDGEHOG. (Erinaceus Europcens.)}

THus animal is something like a porcupine in miniature, and is covered all over with strong and sharp spines or prickles, which he erects when irritated. His common food consists of worms, slugs, and snails; and thus, far from being a noxiuus animal in a garden, he is a very useful one, as he feeds upon all the insects he can find. Hedgehogs inhabit most parts of Europe. Notwithstanding its formidable appearance, it is one of the most harmless animals in the world. While other creatures trust to their force, their cunning, or their swiftness, this quadruped, destitute of all, has but one expedient for safety, and from this alone it generally finds protection. The instant it perceives an enemy, it withdraws all its vulnerable parts, rolls itself into a ball, and presents nothing to view but a round mass of spines, impervious on every side. When the Hedgehog is thus rolled up, the cat, the weasel, the ferret, and the marten, after wounding themselves with the prickles, quickly decline the combat; and the dog himself generally spends his time in empty menaces rather than in effectual efforts, while the little animal waits patiently till its enemy, by retiring, affords an opportunity for retreat.

The female produces from two to four young ones at a birth. When first born they are blind, and their spines white and soft, but they become hard in a few days. 
The Hedgehog is said to suck the milk from cows; but this is impossible, as the mouth of the Hedgehog would not admit the teat of the cow. The Hedgehog, however, sometimes destroys eggs, and has been known to attack frogs, mice, and even toads, when pressed by hunger; it will also occasionally eat the tuberous roots of plants, boring under the root, so as to devour it, and yet leave the stem and leares untonched. The Hedgehog makes himself a nest of leaves and soft wool for the winter, in the hollow trunk of an old tree, or in a hole in a rock or bank; and here, having coiled himself up, he passes the winter in one long unbroken sleep. Hedgehogs may easily be tamed, and are sometimes kept in the kitchens in London houses to destroy the blackbeetles. The flesh of the Hedgehog is sometimes eaten; especially by gipsies, who appear to consider it a delicacy. It is said to be well-tasted, and to have abundance of yellow fat.

In times when insect food is scarce he will also regale himself upon apples and pears which have fallen from the trees, but a glance at the structure of the creature ought to be sufficient to convince any one that the charges often brought against him of climbing trees to detach the fruit which he is said afterwards to carry off by the ingenious expedient of throwing himself down upon it from the branches so as to attach it to his spines, are totally without foundation.

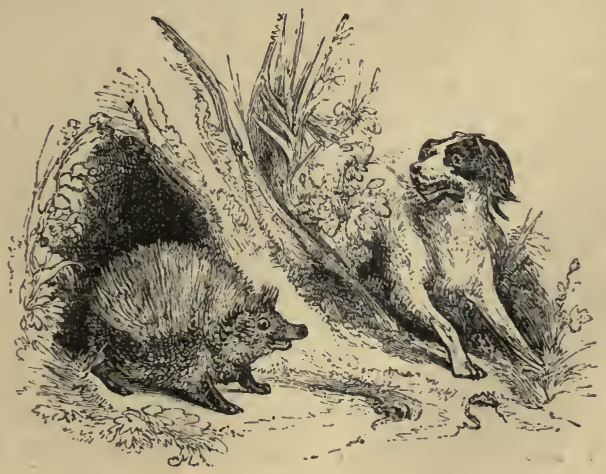




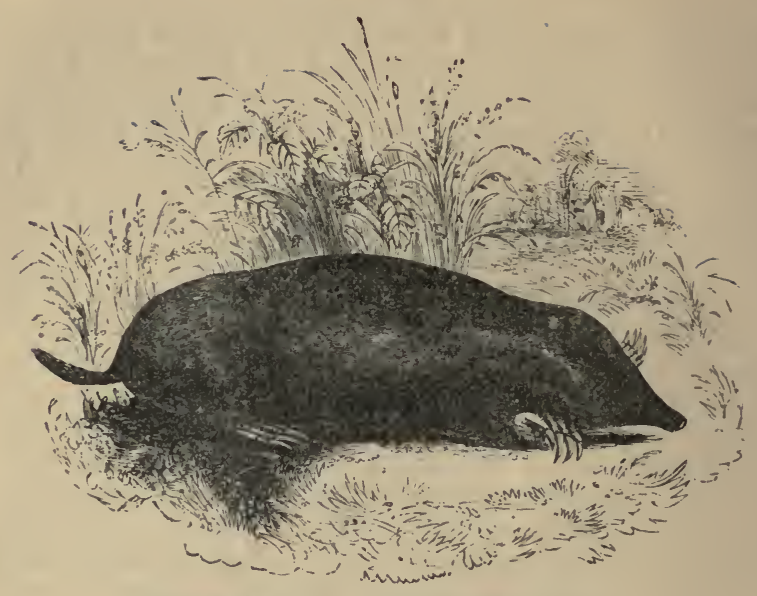

\section{THE MOLE. (Talpa Europcea.)}

The MoLe is a curious, awkwardly-shaped animal, with a long flexible snout, very small eyes, and hand-like fore feet, armed with very strong claws, with which it scrapes its way through the ground, when it is forming the subterranean passages in which it takes up its abode. The Mole, though it is supposed not to possess the advantage of sight, has the senses of hearing and feeling in great perfection; and its fur, which is short and thick, is set erect from its skin, so as not to impede its progress whether it goes forward or backwards along its runs. These runs are very curiously constructed: they cross each other at different points, but all lead to a nest in the centre, which the Mole makes his castle, or place of abode. The passages are made by the Mole in his search after the earth-worms and grubs, on which he lives; and the molehills are formed by the earth he scrapes ont of his runs. These molehills do a great deal of mischief to grass lands, as they render the ground very difficult to mow ; and on this account mole-catchers are employed to fix traps in the ground, so that when the mole is running through one of his passages, he passes through the trap, which instantly springs up out of 
the ground with the poor Mole in it. The female Mole makes her nest at a distance from the male's castle. She has young only once a year, but she has four or five at a time.

The following curions fact respecting a Mole is related by Mr. Bruce. "In visiting the Loch of Clunie, I observed in it a small island, at the distance of a hundred and eighty yards from the land. Upon this island Lord Airlie, the proprietor, had a castle and small shrubbery. I observed frequently the appearance of fresh molehills; but for some time touk it to be the water mouse, and one day I asked the gardener if it was so. He replied it was the Mole, and that he had caught one or two lately; but that five or six years ago he had caught two in traps, and for two years after this he had observed none. But about four years since, coming ashore one summer's evening in the dusk, he and Lord Airlie's butler saw, at a small distance upon the smooth water, an animal paddling to and not far distant from the island; they soon closed with the feeble passenger, and found it to be the Common Mole, led by a most astonishing instinct from the nearest point of land, (the castle-hill,) to take possession of this island. It was at this time, for about the space of two years, quite free from any subterraneous inhabitant; but the Mole has, for more than a year past, made its appearance again."

The Mole is very pugnacious, and sometimes two of the males will fight furiously till one of them is killed.

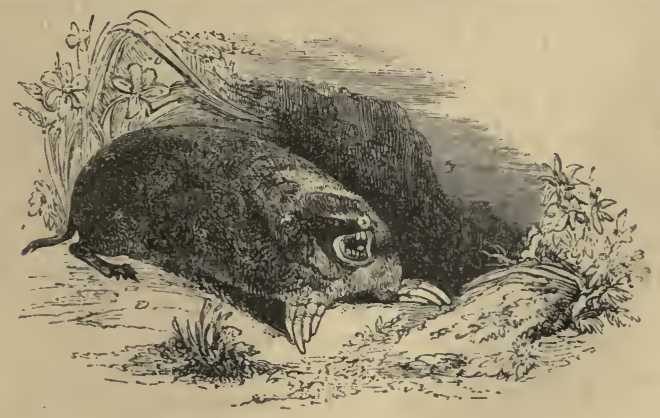




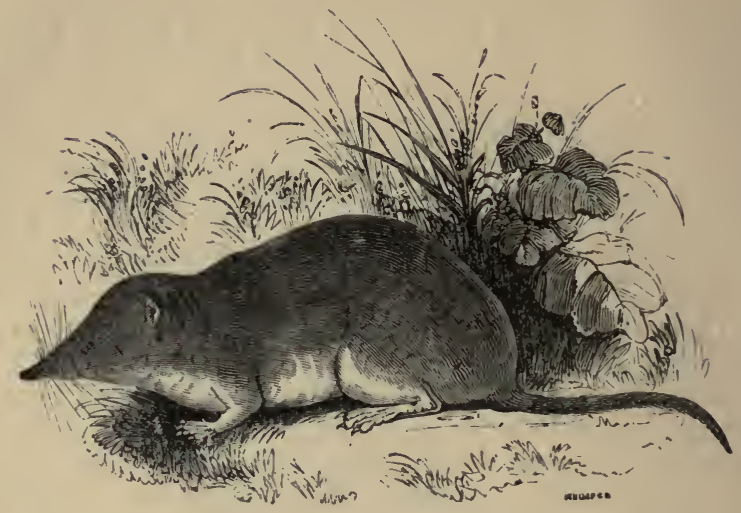

\section{THE SHREW. (Sorex araneus.)}

Tus curious little animal closely resembles a mouse, except in its snout, which is long and pointed, to enable it to grub in the ground for its food, which consists of earthworms, and the grubs of beetles. The Shrew, like the mole, is very fond of fighting; and when two are seen together, they are generally engaged in a furious battle. Like the hedgehog, it has been much scanda. lized by false reports, as will be seen by the following extract from that most amusing and interesting work, White's Selborne: "At the south corner of the area, near the church, there stood, about twenty years ago, a very old, grotesque, hollow pollard-ash, which for ages had been looked upon with no small veneration as a shrewash. Now a shrew-ash is an ash whose twigs and branches, when applied to the limbs of cattle, will immediately relieve the pains which a beast suffers from the running of a Shrew-mouse over the part affected; for it is supposed that a Shrew-mouse is of so baneful and deleterious a nature, that whenever it creeps over a beast, be it a horse, or cow, or sheep, the suffering animal is afflicted with cruel anguish, and threatened with the loss of the use of the limb. Against this acci- 
dent, to which they were continually liable, our provident forefathers always kept a shrew-ash at hand, which, when once medicated, would maintain its virtue for ever. A shrew-ash was made thus:-into the body of the tree a deep hole was bored with an auger, and a poor devoted Shrew mouse was thrust in alive, and plugged in." The cruelty of this, and many other practices of our ancestors, ought to make us thankful that we live in more enlightened days.

The body of the Shrew exhales a rank musky oduur, which renders the animal so offensive to cats, that though they will readily kill them, they will not eat their flesh. 'This noisome odour probably gave rise to the notion that the Shrew-mouse is a venomous animal, and its bite dangerous to cattle, particularly horses. It is, however, neither venomous nor capable of biting, as its mouth is not sufficiently wido to seize the double thickness of the skin, which is absolutely necessary in order to bite.

'The female Shrew makes her nest in a bank, or if on the ground, she covers it at the top, always entering on the side; and she has generally from five to seven young ones at a time.

'I'he Water Shrew (Sorex fodiens,) is a beantiful little creature, with somewhat differently formed feet and tail, to enable it to paddle through the water, in which it dives and swims with great agility. When fluating "on the calm surface of a quiet brook," or diving after its food, its black velvety coat becomes silvered over with the innumerable bubbles of air that cover it when submerged; though when it rises again, the fur is observed to be perfectly dry, repelling the water as completely as the feathers of a water-fowl. 


\section{§ III. Cheiropterous Animals.}

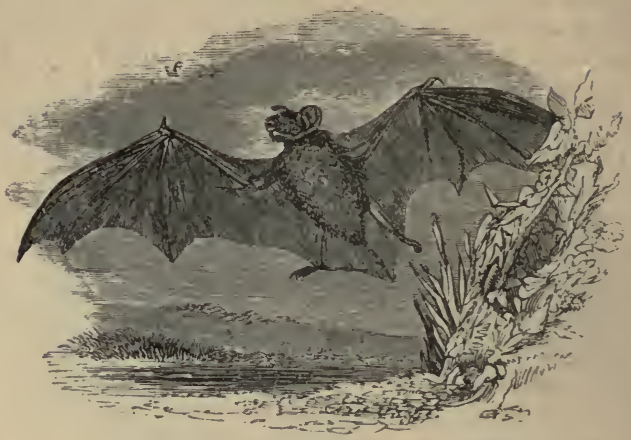

THE BAT. (Vespertilio Noctula.)

THe Bat has the body of a mouse, and the wings of a bird. It has an enormous mouth, and large ears, which are of a kind of membrane, thin and almost transparent. The pinions of its wings are furnished with hooks, by which it hangs to trees or the crevices in old walls during the day, a great number of them together, as they only fly at night. 'The wings of the Bat are very' large; those of the Great Bat measuring fifteen inches across. It feeds on insects of various kinds, particulirly on cockchafers and other winged beetles, part of which, however, it alway's throws away. A female Bat that was caught, and kept in a cage, ate meat when it was given to her in little bits, and lapped water like a cat. She was very particular in keeping herself clean, using her hind feet like a comb, and parting her fur so as to make a straight line down the back. Her wings she cleaned by thrusting. her nose into the folds, and shaking them. She had a young one born in the cage. It was blind, and quite destitute of hair, and its mother wrapped it in the membrane of her wing, pressing it so closely to her breast, that no one conld see her suckle it. The next day the poor mother died, and the little one was found alive, hanging to her breast. It was fed with milk from a sponge, hut only lived about a week. 


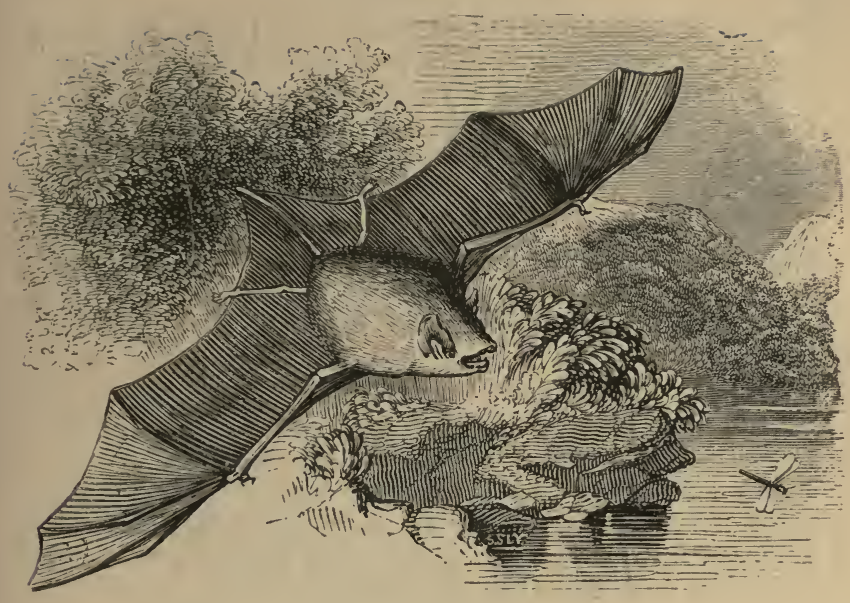

'I'HE PIPISTRELLE. (Vespertilio Pipistrellus.)

THIs little creature, which is only an inch and a half in length, appears to be the commonest of all Bats in most parts cf Britain. It usually resides in cracks and cavities in old brick walls and in sheltered corners about houses, and at the approach of evening quits its retreat, and flies about capturing the gnats and other small twilight-loving insects on which it feeds

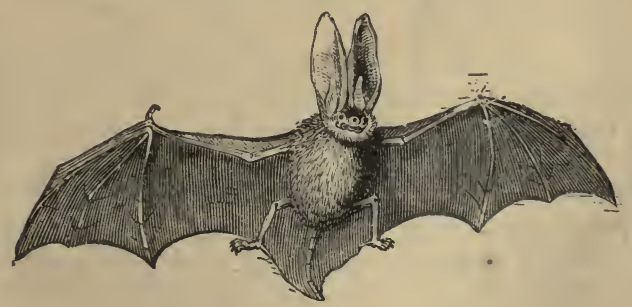

THE LONG-EARED BAT.

(Vespertilio or Plecotus auritus.)

The Losg-Eared Bat, which is not uneommon in many 
parts of our country, is remarkable for the large size of its ears, which are nearly as long as its little mouse-like body, and composed of a membrane so delicate as tu be almost transparent. In front of the concave part of each of these enormous ears there is a slender, pointed membrane, which gives the little creature a most singular appearance when reposing; for the great membranous ear's are then folded up, and carefully stuwed away under the wings, whilst these pointed lobes, being of a stronger substance, still project from the head, and look like a pair of little horns. The Long-eared Bat seems to be one of the most interesting and amiable species of its tribe; it may be easily tamed, and, indeed, exhibits great confidence from the first moment of its capture. When several are kept together they will play in an awkward manner, which is very diverting, and will soon learn to take their insect food not only from the hand, but eren from the lips of their owner.

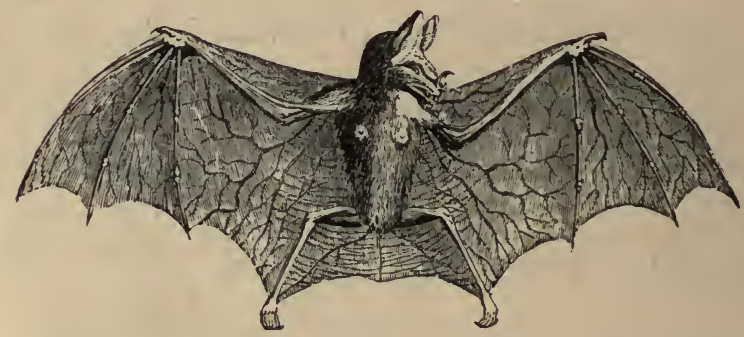

THE VAMPYRE BAT. (Plyllostoma Spectrum.)

i'he VAMryre Bat, which is a large species, is notorious for its very bad habit of sucking the blood of men and cattle. In making its attacks on man it exercises the greatest caution, alighting close to the feet of its intended victim during his slumbers, and fanning him with its broad wings to keep him cool and comfortable during the subsequent operations. Having made the proper arrangements, the Vampyre proceeds to bite a little piece out of the great toe of the slumberer, and although the wound thus caused is so small that it would not receive the head of a pin, it is deep enough 
to cause a free flow of blood, which the Vampyre sucks until it can suck no longer. Cattle are generally bitten in the ear. Although there seems to be some exaggeration in many of the accounts given by travellers of the ferocity and sanguinary disposition of the-Vampyre. there would appear to be little doubt that the loss of blood caused by its bite may occasionally prove fatal, the sucking being continued, as Captain Stedman says, until the sufferer sleeps "from time into eternity"

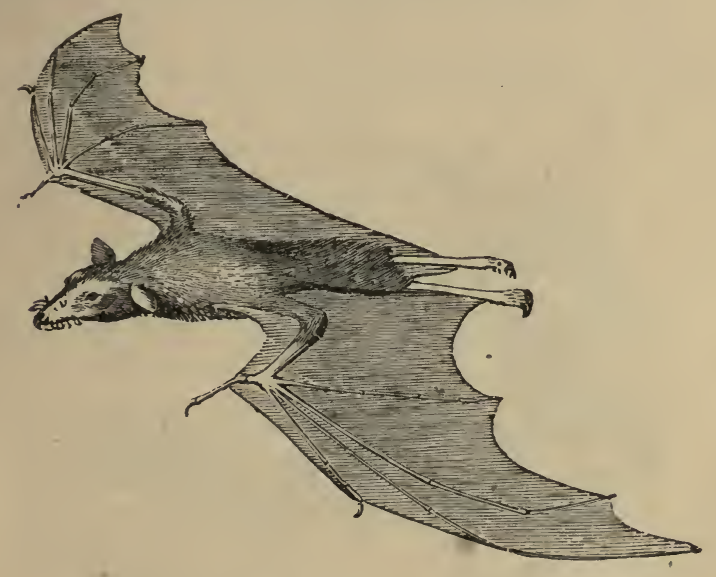

THE KALONG BAT. (Pteropus edulis.)

Trus Bat, which is also called the Flying Fox, is a native of the Indian Islands. It is a large species, measuring nearly two feet in length, whilst its large leathery wings, resembling those seen in the popular representations of flying demons, extend from tip to tip about five feet. During the day the Kalongs indulge in sleep, for which purpose they prefer an attitude which to our notions would seem very uncomfortable; they suspend themselves by their hind feet to the branches of trees, and thus hang with their heads downwards. They associate in large numbers, and when seen sleeping in the position above desoribed, they look so little like animals that Dr. Horsfield tells us they "are readily mistaken 
for a part of the tree, or for a fruit of uncommon size suspended from its branches." At the approach of evening, however, a very different scene presents itself. One by one these supposed fruits are seen to quit their hold upon the branches, and sail away to the plantations of various kinds, to which they do incalculable mischief by devouring every fruit that comes in their way.

§ IV. The Marsupialia, or Pouch-bearing Animals.

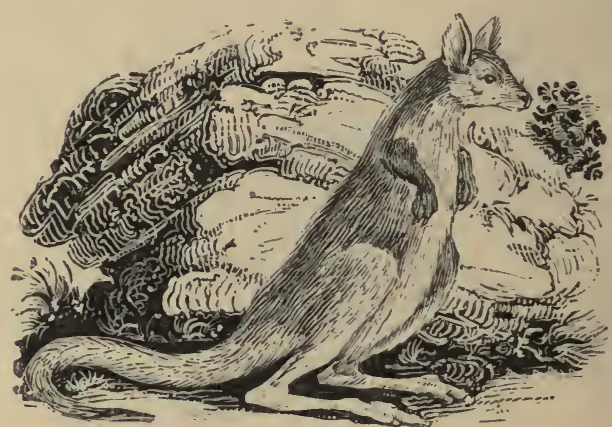

THE KANGAROO. (Macropus giganteuis.)

THis remarkable animal was first discovered by the celebrated Captain Cook, in New flolland: and as it was the only quadruped discovered on the island by the first settlers, they attempted to hunt it with greyhounds. The astonishing leaps it took, however, quite puzzled the colonists, who found it extremely difficult to catch. At first it was supposed that there was only one kind of Kangaroo, but now many species have been discovered, some of them not larger than a rat, and others as big as a calf. Kangaroos live in herds; one, older and larger. than thes rest, appearing to act as a kind of king. The ears of the Kangaroo are large, and in almost constant motion; it has a hare-lip, and a very small head. 'The 
fore legs, or rather paws, are short and weak, with five toes, each ending in a strong curved claw. The hind legs, on the contrary, are very large and strong, but the feet have only four toes, and much weaker claws. The tail is very long and tapering; but is so thick and strong near the body, that it forms a kind of third hind leg, and wonderfully assists the animal in supporting itself in its ordinary upright position. Its leaps are of extraordinary extent, being often from twenty to thirty feet in length, and six or eight feet high. When the animal is attacked. it uses its tail as a powerful instrument of defence, and also scratches violently with its hind feet. It generally sits upright, but brings its fore feet to the ground when it is grazing. It lives entirely on vegetable substances. 'The most curious part of the Kangaroo is the pouch which the female has in front for carrying her young. It is just below her breast, and the young ones sit there to suck; and even when they are old enough to leave the pouch, take refuge in it whenever they are alarmed.

The Kangaroo is easily tamed, and there are many in a tame state in England. In Australia, Kangaroo beef, as it is called, is eaten, and found very nourishing; but it is hard and coarse. The female has generally two young ones at a time, which do not attain their full growth until they are a year old.

When a large Kangaroo is pursued by dogs, it generally takes refuge in a pond, where, from the great length of its hind legs and tail, it can stand with its body half out of the water, while the dogs are obliged to swim. Thus the Kangaroo has a decided advantage; for, as each dog approaches him, he seizes it with his fore paws, and holds it under water, shaking it furiously till the dog is almost snffocated, and very glad to sneak off as soon as the Kangaroo lets him go.

The female, when pursued and hard-pressed by the dogs, will, while making her bounds, put her fore paws into her pouch, take a young one from it, and throw it as far out of sight as she possibly can. But for this manœuvre, her own life and that of her young one would be sacrificed; whereas, she frequently contrives to sscape, and returns afterwards to seek for her offspring. 


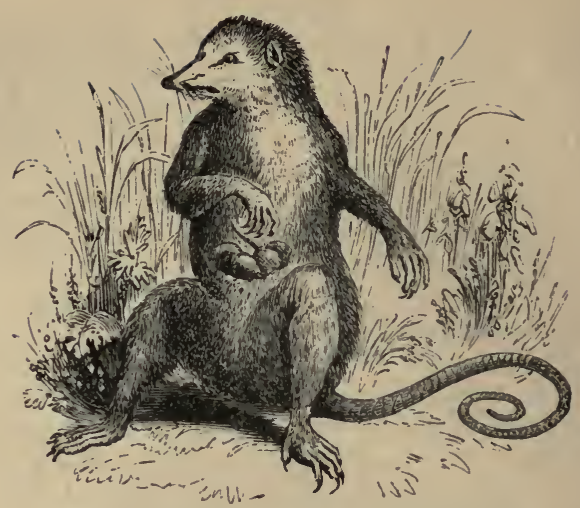

\section{THE VIRGINIAN OPOSSUM.}

(Didelphis virginiana.)

'This creature, which is a native of North America, is about the size of a cat, and its fur is of a dingy white, except the legs, which are brown. and the nose and ears, which are yellowish. There is also a brownish circle round each eye, and the ears are nearly black at the base.

The Opossum generally lives in trees, suspending itself by the tail, by means of which it swings from branch to branch. In this manner it catches the insects and small birds, on which it generally feeds; but sometimes it descends from the tree, and invades poultry-yards, where it devours the eggs, and sometimes the young fowls. It resembles the kangaroo in its pouch for carrying its young, but in no other particular, as it walks on four feet, and its legs are uniform in length; and it has a long flexible tail, which is of no use to it either in leaping, or as a weapon of defence. The tail is, however, of singular use to the young, as when they get too large to be carried in the pouch, they fly to their mother when alarmed, and twisting their long slender tails round hers, leap upon her back. The femsle Opossum may be sometimes seen thus carrying four or five at once. 


\section{The Phalanger.}

The Opossum may be easily tamed, but is an unpleasant inmate, from its awkward figure and stupidity, and its very disagreeable smell. The American Indians spin its hair and dye it red, and then weave it into girdles and other articles of clothing. 'The flesh of these animals is white and well tasted, and is preferred by the Indians to pork: that of the young ones eats very much like the sucking-pig.

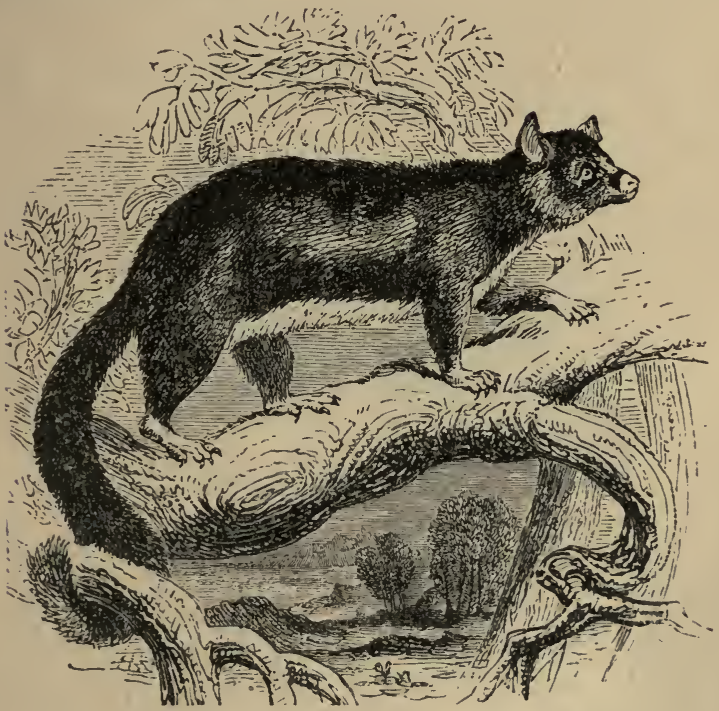

THE PHALANGER. (Phalangista vulpina.)

'THes animal, which is very common in Australia, has some resemblance in its aspect and colour to a fox; but is much smaller. It has a long, furred tail, very different from that of the opossum. The Phalanger lives amongst the branches of the trees, on which it climbs about at night with great agility; its food consists partly of fruits and partly of small birds, which it easily captures during its nocturnal excursions. It is called the Opossum by the colonists of Australia. There are 
several kinds of Phalangers, some of which are known as Flying I'halangers, from their having a broad loose fold of skin along each side, which, when stretched out by means of the legs, serves to support the little creature for a time in the air, and enables it to leap to great distances.

\section{$\S$ V.--Rodentia, or Gnauing Animals.}

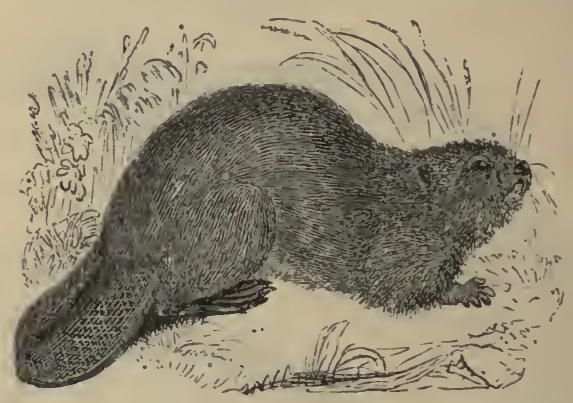

'THE BEAVER. (Castor Fiber.)

The Braver is about the size of the badger; his head short, his ears round and small, his fore teeth long, sharp, and strong, and well calculated for the part which Nature has allotted him: the tail is of an oval form, and covered with a scaly skin.

Beavers are natives of North America, and more particularly the north of Canada. They are also found in Europe, and were formerly abundant in many places. 'Their houses are constructed with earth, stones, and sticks, neatly arranged and worked together by their paws. 'The walls are aborit two feet thick, and are surmounted by a kind of dome, which generally rises about four feet above them. The entrance is on one side, always at least three feet below the surface of the water, so as to prevent it being frozen up. The number of 
Beavers in each house is from two to four old ones, and about twice as many young. When Beavers form a new settlement, they build their houses in the summer; and then lay in their winter provisions, which consist principally of bark and the tender branches of trees, cut into certain lengths, and piled in heaps on the outside of their habitation, and always under the water; though sometimes the heap is so large as to rise above the surface. One of these heaps will occasionally contain more than a cart-load of bark, young wood, and the roots of the water-lily.

Beavers are hunted for the sake of their skins, which are covered with long hairs, and a short thick fur beneath, which is used in making hats, after the long hairs have been destroyed.

A great many stories have long been believer respecting the Beaver, on the authority of a French gentleman who had resided a long time in North America; but it is now ascertained that the greater part of them are false. The house of the Beaver is not divided into rooms, but consists of only one apartment; and the animals do not use their tails either as a trowel or a sledge, but only as an assistance in swimming. Some years ago a Beaver was brought to this country from America, that had been quite tamed by the sailors, and was called Bunney. When he arrived in England, he was made quite a pet of, and used to lie on the hearthrug in his master's library. One day he found out the housemaid's closet, and his building propensities began immediately to display themselves. He seized a large sweeping brush, and dragged it along with his teeth to a room where he fornd the door open: he afterwards laid hold of a warming-pan in the same manner; and having laid the handles across, he filled up the walls of the angle made by the brushes with the wall, with hand-brushes, baskets, boots, books, towels, and anything he could lay hold of. As his walls grew high, he would often sit propped up by his tail (with which he supported himself admirably), to losk at what he had done; and if the disposition of ary of his building materials did not satisfy him, he would pull part of his 
work down, and lay it again more evenly. It was asto, nishing how well he managed to arrange the incon, gruous materials he had chosen, and how cleverly he contrived jo remove them, sometimes carrying them between his right fore-paw and his chin, sometimes dragging them with his teeth, and sometimes pushing them along with his chin. When he had built his walls, he made himself a nest in the centre, and sat up in it, combing his hair with the nails of his hind feet.

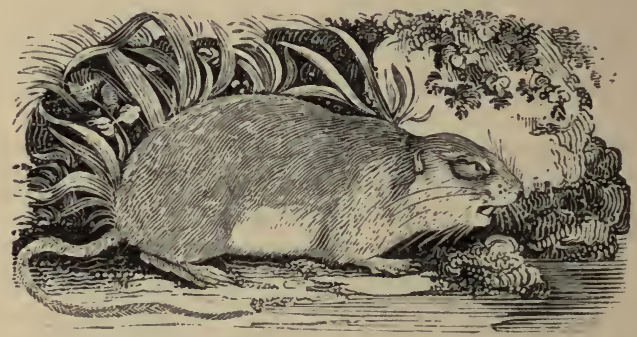

THE MUSK RAT, (Fiber Zibethicus,)

Is a native of Canada, and resembles the bearer in many of his habits. He has a fine musky scent, and makes his holes in marshes and by the waterside, with two or three ways to get in or go out, and several distinct apartments: he is said to contrive one entrance to his hole always below the water, that he may not be frozen out by the ice. 'This animal is called the Musquash in America, and its fur is used, like that of the beaver, in the manufacture of hats, four or five hundred thousand skins being said to be sent to Europe every year for that purpose. Musk liats are always seen in pairs; and though watchful, are not timid, as they will often approach quite close to a boat or other vessel. In spring they feed on pieces of wood, which they peel carefully; and they are particularly fond of the roots of the sweet flag (Acorus Calamus). In Canada this animal is called the Ondatra. 


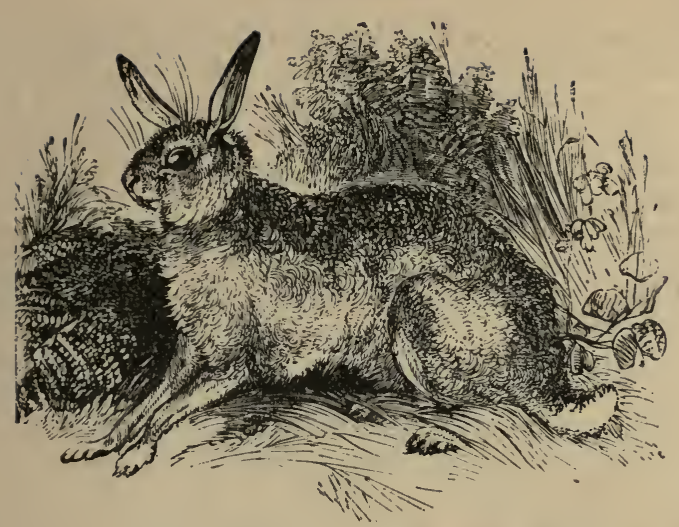

THE HARE. (Lepus timidus.)

THIs small quadruped is well known at our tables as affording a favourite food, notwithstanding the dark coluur of its flesh. Its swiftness cannot save it from the search of its enemies, among whom man is the most inveterate. Unarmed and fearful, the IIare appears almost to sleep with open eyes, so easily is it alarmed. Its hind legs are longer than its fore ones, to enable it to run up hills; its eyes are so prominently placed, that they can encompass at once the whole horizon of the plain where it has chosen its form, for so its seat or bed is called; and its ears so long, that the least noise cannot escape it. It seldom outlives its seventh year, and breeds plentifully. Naturally wild and timorous, the Hare may, however, be occasionally tamed. The following is from the entertaining account given by Cowper, of three Hares that he brought up tame in his house; the names he gave them were Puss, Tiney, and Bess. Tiney was a reserved and surly Hare; Bess, who was a Hare of great humour and drollery, died young. "Pnss grew presently familiar, would leap into my lap, raise himself upon his hinder feet, and bite the hair from my temples. He would suffer me to take him up and carry him about in my arms, and has more than once fallen fast asleep upon my knee. He was ill three days, 
during which time I nursed him, kept him apart from his fellows that they might not molest him, (for, like many other wild animals, they persecute one of their own species that is sick,) and by constant care, and trying him with a variety of herbs, restored him to perfect health. No creature could be more grateful than my patient after his recovery, a sentiment which he most significantly expressed by licking my hand, first the back of it, then the palm, then every finger separately, then between all the fingers, as if anxious to leave no part of it unsaluted; a ceremony which he never performed but once again upon a similar occasion.

"Finding him extremely tractable, I made it my custom to carry him always after breakfast into the garden, where he hid himself generally under the leaves of a cucumber vine, sleeping or chewing the cud, till evening; in the leaves also of that vine he found a favourite repast. I had not long habituated him to this taste of liberty, before he began to be impatient for the return of the time when he might enjoy it. He would invite me to the garden by drumming upon my knee. and by a look of such expression as it was not possible to misinterpret. If this rhetoric did not immediately succeed, he would take the skirt of my coat hetween his teeth, and pull at it with all his force. Thus l'uss might be said to be perfectly tamed, the shyness of his nature was done away, and, on the whole, it was visible, by many symptoms, which I have not room to enumerate, that he was happier in human society than when shut up with his natural companions."

Hares are included in the list of animals called game, and are hunted with greyhounds, which is called coursing; and also by packs of dogs called harriers and beagles. There are white Hares in the northem regions, the change in colour being the effect of cold. 


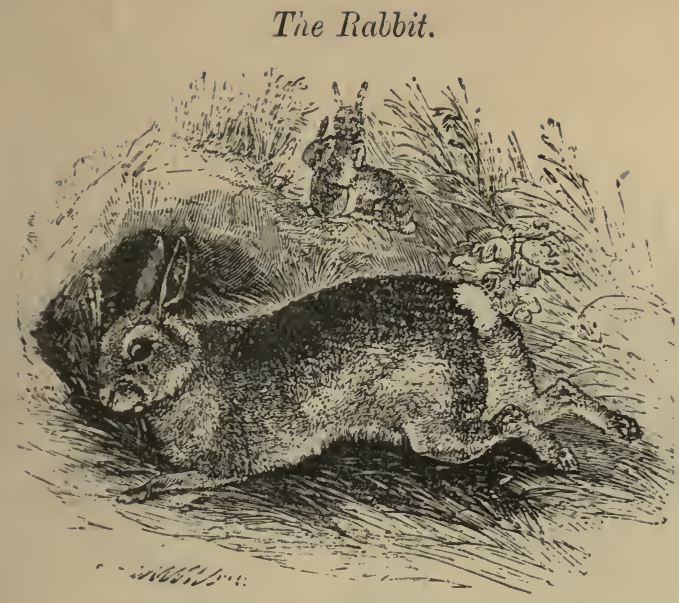

\section{THE RABBIT'. (Lepus cuniculus.)}

This animal, in a wild state, resembles the hare in all its principal characters, but is distinguished from it by its smaller size, the comparative shortness of the head and hinder legs, the grey colour of the body, the absence of the black tip to the ears, and the brown colour of the upper part of the tail. Its habits, however, are very different, as being from its organization unable to outstrip its enemies in the chase, it seeks its safety and shelter by burrowing in the ground; and instead of leading a solitary life, its manners are eminently social. Its flesh is white and good, though not so much prized as that of the hare.

The female begins to breed when she is about twelve months old, and bears at least seven times a year, generally eight at each time; now supposing this to happen regularly, a couple of Rabbits at the end of four years might see a progeny of almost a million and a half! Fortunately their destruction by various enemies is in proportion to their fecundity, or we might justly apprehend being overstocked by them. The young are born blind, and almost destitute of hair; while those of the hare can see, and are covered with hair. 


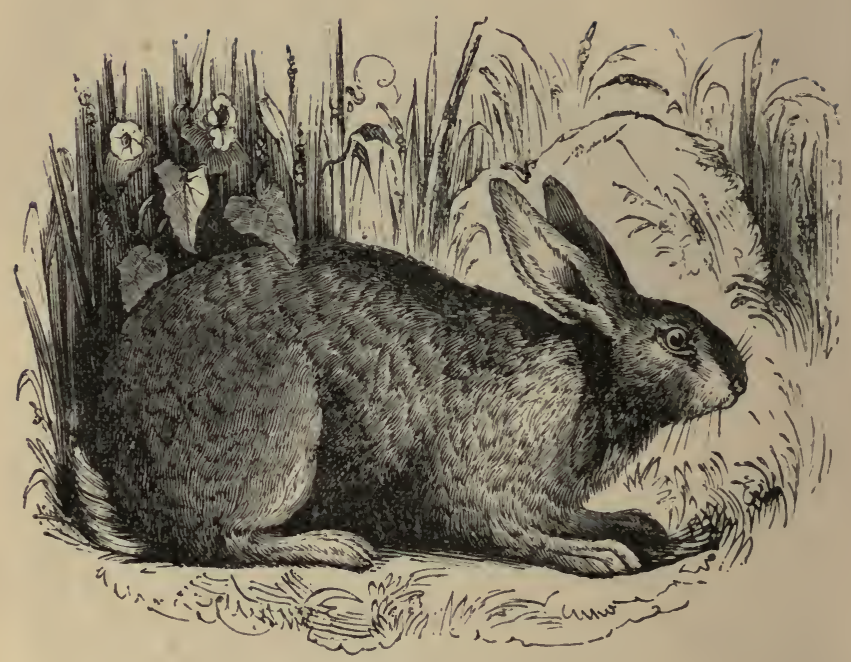

THE DOMESTIC RABBIT.

The Dosestic Rabit is larger than the wild species, owing to its taking more nourishment and less exercise (our example, however, is drawn disproportionately large). Like pigeons, they have their regular fanciers, and are bred of various colours-grey, reddish brown, black more or less mixed with white, or perfectly white. The ears are considered to constitute a principal feature of their beauty, and the animal is most valued when both ears hang down by the side of the head; the animal is then called a double lop; when only one ear drops, it is called a single or horn lop, and when both stretch out horizontally, an oar-lop. 


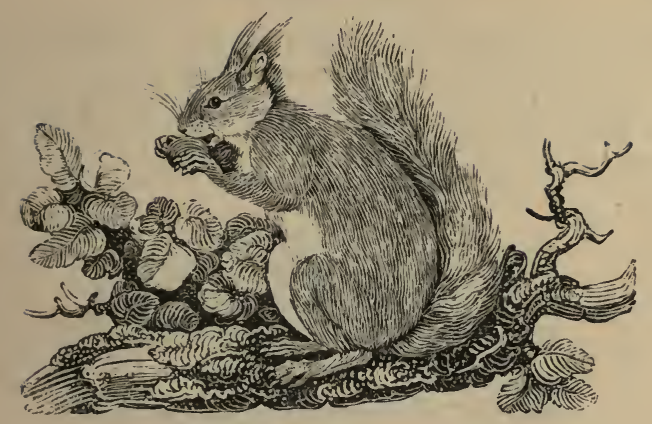

THE SQUIRREL. (Sciurus vulgaris.)

ELEGANCE of shape, spiritedness, and agility to leap from bough to bough in the forest, are the principal characteristics of this pretty animal. The Squirrel is of a deep reddish brown colour, his breast and belly white. He is lively, sagacious, docile, and nimble: he lives upon nuts, and has been seen so tame as to dive into the pocket of his mistress, and search after an almond or a lump of sugar. In the woods he leaps from tree to tree with surprising agility, living a most frolicsome life, su: rounded with abundance, and having but few enemies. His time. however, is not entirely devoted to idio enjoyment, for in the luxuriant season of autumn he gathers provisions for the approaching winter, as if conscious that the forest would then be stripped of its fruits and foliage. His tail serves him as a parasol to defend him from the rays of the sun, as a parachute to secure him from dangerous falls when leaping from tree to tree, and, some say, as a sail in crossing the water, which he sometimes does in Lapland on a bit of ice or bark inverted in the manner of a boat.

'The American Flying Squirrel (Pteromys volucella) has a large membrane proceeding from the fore feet to the hind legs, which answers the same purpose as the Squirrel's tail, and enables him to give surprising leaps that almost resemble flying. In the act of leaping, the loose skin is stretched out by the feet, whereby the surface of the body is augmented, its fall is retarded, and it 
appears to sail or fly from one place to another. Where number's of them are seen at a time leaping, they appear like leaves blown off by the wind. There are many other kinds of Squirrels in various parts of the world; most of the Flying Squirrels are found in the eastern islands.

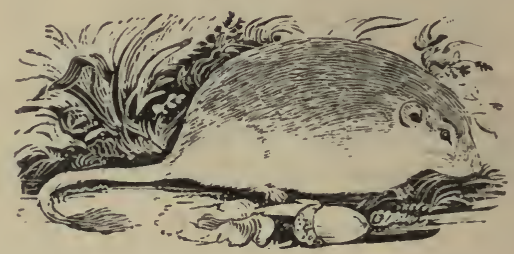

'TIE DURMOUSE, OR SLEEPER. (Myoxus avellanarius.)

These animals build their nests either in the hollow parts of trees, or near the bottom of thick shrubs, and line them most industriously with moss, soft lichens, and dead leaves. Conscious of the length of time they have to pass in their solitary cells, Dormice are very particular in the choice of the materials they employ to build and furnish them; and generally lay up a store of food, consisting of nuts, beans, and acorns; and on the approach of cold weather rold themselves in balls, their tail curled up over their head between the ears, and in a state of apparent lethargy pass the greatest part of the winter, till the warmth of the sun, pervading the whole atmosphere, kindles their congealed blood, and calls them back again to the enjoyment of life. Except in the time of breeding and bringing up' its young, the Dormouse is generally found alone in its cell. This animal is remarkable for the very small degree of heat its body possesses during its torpid state, when it appears actually frozen with the cold, and it may be tossed or rolled about without being roused, though it may be quickly revived by the application of gentle heat, such as that of the hands. If a torpid Dormouse, however, be placed hefore a large fire, the sudden change will kill it. 
The American Dormouse, or Ground Squirrel, is a very beautiful animal, striped down the back, and resembling the squirrel in its habits, except that instead of living in trees it burrows in the ground.

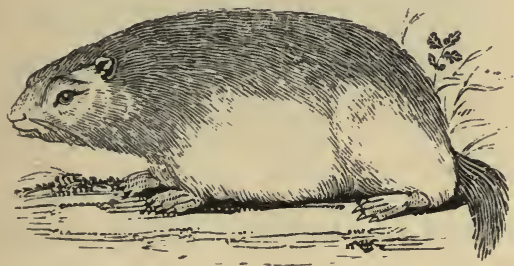

THE MARMOT, OR ALPINE RAT.

\section{(Arctomys Marmotta.)}

This is a harmless, inoffensive animal, and seems to bear enmity to no creature but the dog. He is caught in Savoy, and carried about in several countries for the amusement of the mob. When taken young, he is easily tamed, and possesses great muscular power and agility. He will often walk on his hinder legs, and uses his fore paws to feed himself, like the squirrel. The Marmot makes his hole very deep, and in the form of the letter $Y$, one of the branches serving as an avenue to the innermost apartment, and the other sloping downwards, as a kind of sink or drain; in this safe retreat he sleeps throughout the winter, and if discovered may be killed without appearing to undergo any great pain. These animals produce but once a year, and bring forth three or four at a time. They grow very fast, and the extent of their lives is not above nine or ten years. They are about the size of a rabbit, but much more corpulent. When a number of Marmots are feeding together, one of them stands sentinel upon an elevated position; and on the first appearance of a man, a dog, an eagle, or any dangerous animal, utters a loud and shrill cry, as a signal for immediate retreat. The Marmot inhabits the highest regions of the Alps; other species are found in Poland, Russia, Siberia, and Canada. 


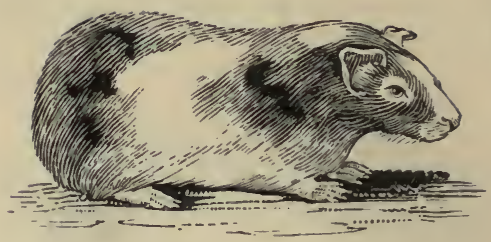

\section{THE GUINEAPIG. (Cavia Cobaya.)}

THis animal is generally white, variegated with red and black. It is a native of the Brazils, but now dumesticated in most parts of Europe, and is about the size of a large rat, though more stoutly made, and without any tail; and its legs and neck are so short, that the former are scarcely seen, and the latter seems stuck upon its shoulders. Guineapigs, though they have a disagreeable smell, are extremely cleanly, and the male and female may be often seen alternately employed in smoothing each other's skins, disposing their hair, and improving its gloss. They sleep like the hare with their eyes half open, and continue watchful if they apprehend any danger. They are very fond of dark retreats; previously to their quitting which, they look round, and seem to listen attentively: then, if the road be clear, they sally forth in quest of food, but run back on the slightest alarm. They utter a sound like the snore of a young pig. The female begins to produce young when only two months old, and as she does so every two or three months, and has sometimes as many as twelve at a time, a thousand might be raised from a single pair in the course of a year. They are naturally gentle and tame; as incapable of mischief as they seem to be of good, although rats are said to avoid their locality. The upper lip is only half divided; it has two cutting teeth in each jaw, and large and broad ears. They feed on bread, grain, and vegetables. 


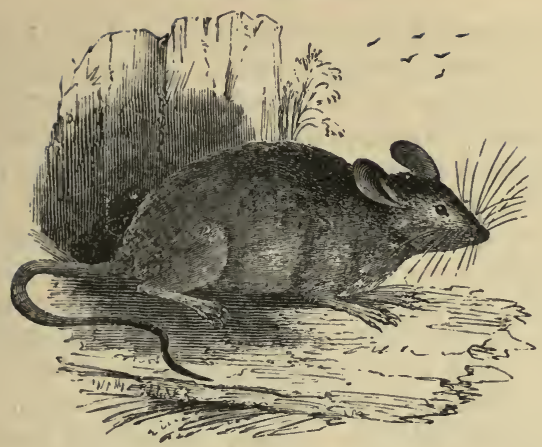

THE MOUSE. (Mus musculus.)

THIs is a lively, active animal, and the most timid in nature, except the hare, and a few other defenceless species. Although timid, he eats in the trap as soon as he is caught; yet he never can be thoroughly tamed, nor does he betray any affection for his assiduous keeper. He is beset by a number of enemies, among which are the cat, the hawk, and owl, the snake, and weasel, and the rat himself, though not unlike the mouse in his habits and shape. The mouse is one of the most prolific of animals, sometimes producing seventeen at a birth ; but it is supposed that the life of this small inmate of our habitations does not extend much further than three years. This creature is known all over the world, and breeds wherever it finds food and tranquillity. There are Mice of various colours, but the most common kind is of a dark, cinereous hue: white mice are not uncommon, particularly in Savoy and some parts of France.

A remarkable instance of sagacity in a long-tailed Field Mouse (Mus sylvaticus) occurred to the Rev. Mr. White, as his people were pulling off the lining of a hotbed, in order to add some fresh dung. From the side of this bed something leaped with great agility, that made a most grotesque appearance, and was not caught without much difficulty. It proved to be a large Field Mouse, with three or four young ones clinging to her teats by their mouths and feet. It was amazing that the various 
and rapid motions of the dam did not oblige her litter to quit their hold, especially when it appeared that they wore so young as to be both naked and blind. Mr. White appears to be the first to describe and accurately examine that diminutive creature the Harvest Mouse (Mus messorius), the least of all the British quadrupeds. $\mathrm{He}$ measured some of them, and found that from the nose to the tail they were two inches and a quarter long. 'Two of them in a scale only weighed down one copper halfpenny, about the third of an ounce avoirdupoise! Their nest is a great curiosity, being made in the form of a ball, and either suspended between the stems of rushes and other tall slender plants, or placed amongst the leaves of some large thistle.

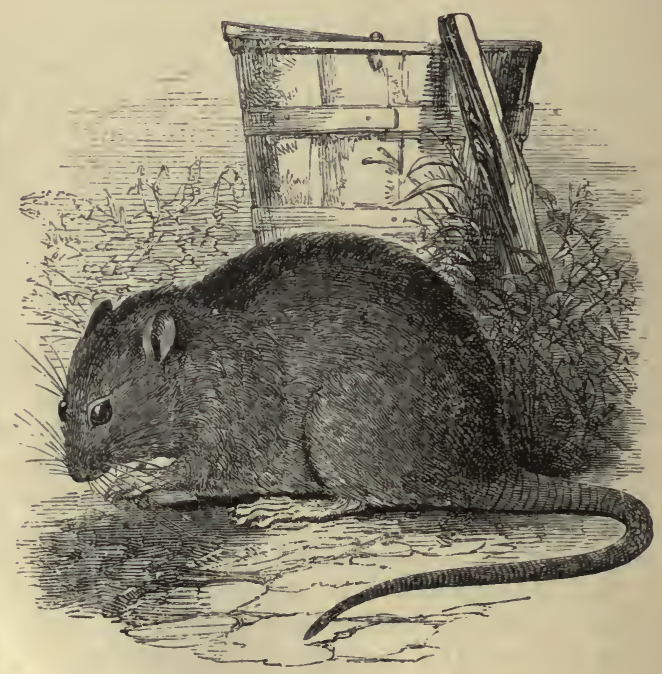

THE RAT. (Mus decumanus.)

The Rat is about four times as large as the mouse, but of a dusky colour, with white under the body; his head is longer, his neck shorter, and his eyes comparatively larger. These animals are so attached to our dwellings, 
that it is almost impossible to destroy the breed, when they have once taken a liking to any particular place. Their produce is enormous, as they have from ten to twenty young ones at a litter, and this thrice a year. Thus their increase is such, that it is possible for a single pair (supposing food to be sufficiently plentiful, and that they had no enemies to lessen their numbers) to amount at the end of two years to upwards of a million; but an insatiable appetite impels them to destroy each other; the weaker always fall a prey to the stronger; and the large male Rat, which usually lives by itself, is dreaded by those of its own species as their most formidable enemy. The Rat is a bold and fierce little animal, and when closely pursued, will turn and fasten on its assailant. Its bite is keen, and the wound it inflicts is painful and difficult to heal, owing to the form of its teeth, which are long, sharp, and of an irregular form.

It digs with great facility and vigour, making its way with rapidity beneath the floors of our houses, between the stones and bricks of walls, and often excavating the foundations of a dwelling to a dangerous extent. 'There are many instances of their totally undermining the most solid mason-work, or burrowing through dams which had for ages served to confine the waters of rivers and canals.

A gentleman, some time ago, travelling through Mecklenburgh, was witness to a very singular circumstance respecting one of these animals, in the post-house at New Hargarel. After dinner, the landlord placed on the floor a large dish of soup, and gave a loud whistle. Immediately there came into the room a mastiff, an Angora cat, an old raven, and a large Rat with a bell about its neck. They all four went to the dish, and without disturbing each other, fed together; after which, the dog, cat, and Rat lay before the fire, while the raven hopped about the room. The landlord, after accounting for the familiarity which existed among these animals, informed his guest that the Rat was the most useful of the four; for that the noise he made had completely freed the house from the $\mathrm{Ra}^{+} \mathrm{s}$ and mice with which it had been before infested. 


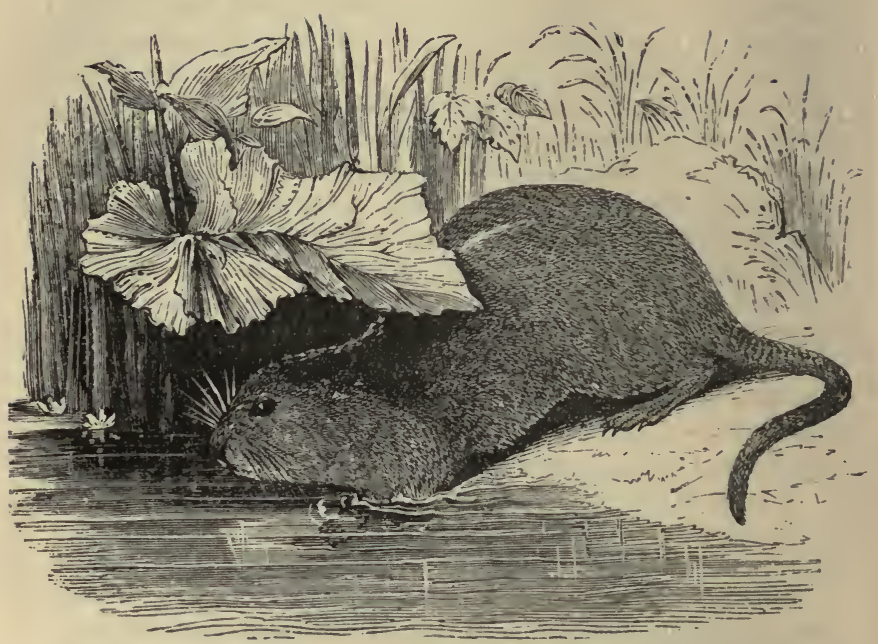

THE WATER RAT, (Arvicola amphibia,)

INHABITs the banks of river's and ponds, where he digs holes, always above the water-mark, and feeds on roots and aquatic plants.

This animal is nearly as large as the brown Rat, but has a larger head, a blunter nose, and smaller eyes; its ears are very short, and almost hidden in the fur, and the tip of its tail is whitish; the cutting-teeth are of a deep yellow colour in front, very strong, and much resembling those of the beaver. Its head and back are covered with long black hair, and its belly with iron gray. Tail more than half the length of the body, covered with hairs. Fur thick and shining; of a rich reddish brown, mixed with gray above, yellowish gray beneath. 'The female produces a brood of five or six young ones once (and sometimes twice) a year. 


\section{THE LEMMING, (Myodes Lemmus,)}

Which is a near relation of the water-rat, and of about the same size, is covered with fur of a yellowish colour variegated with black. 'This animal resides in the mountains of Norway and Sweden, and is remarkable for performing extraordinary migrations in vast bodies at the approach of a severe winter, and making their appearance so suddenly and unexpectedly that people formerly asserted they had fallen from the clouds. Notwithstanding their supposed celestial origin, they are, however, very unwelcome visitors, as they devour everything eatable that comes in their way, and commit devastations almost as serious as those of the locusts.

\section{THE SHORT-TAILED FIELD-MOUSE, OR FIELD-VOLE.}

THis little animal has most wonderful powers of reproduction, and, as it is extremely voracious, it often causes an amount of destruction quite out of proportion to its size and insignificant appearance. It burrows in the ground, like the lemming and water-rat; and as it gnaws through the roots of trees that lie in its way, it has been known to cause very serious loss of property. In the year 1813 such immense numbers of these creatures were collected in some of the forests of the South of England, that it was feared all the young trees would be destroyed, and it was found necessary to organise a war of extermination against the invaders. It is said that in Now Forest alone not less than eighty or a hundred thousand mice were killed in one season, and the slaughter in other places was quite as great.

The Field-Vole's favourite food is the bark of trees and roots, but, if pressed by hunger, it will attack and devour its own kind. 


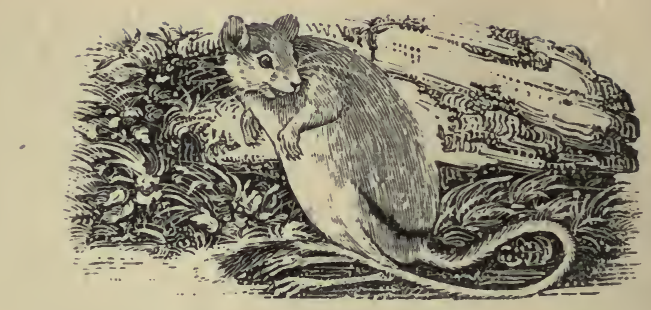

\section{THE JERBOA. (Dipus agyptius.)}

THE principal peculiarity of this animal consists in its having very short fore legs, and very long hinder ones: a bird divested of its feathers and wings, and jumping upon its legs, would give us the nearest resemblarce to the figure of a Jerboa when pursued. It uses, however, all its four feet upon ordinary occasions, and it is only when pursued that it presses its fore feet close to its body, and leaps on its hind ones. The ancients called it the two-footed rat. 'This creature is about the size of a rat; the head resembles that of a rabbit, with long whiskers; the tail is ten inches long, and terminated by a tuft of black hair. The fur of the body is tawny, except the breast and throat, and part of the belly, which are white. The Jerboa is very active and lively, and jumps and springs, when pursued, six or seven feet from the ground, with the assistance of its tail; but if this useful member be in any manner injured, the activity of the Jerboa is proportionately diminished; and one which had been accidentally deprived of its tail, was found unable to leap at all. It lurrows like the rabbit, and feeds like the squirrel: it is a native of Egypt and the adjacent countries, and is also found in eastern Europe. 


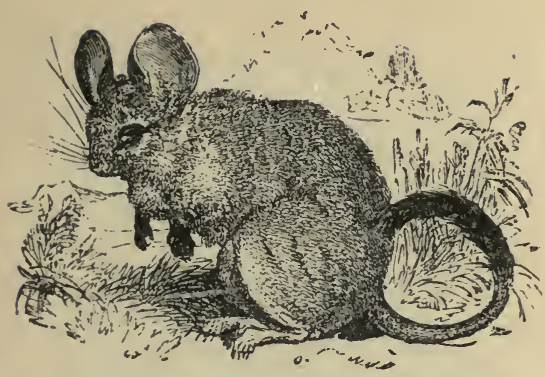

THE CHINCHILLA. (Chinchilla lanigera.)

The CHinchilla is a native of America, and its coat produces the beantiful fur known by its name. The length of the body of this little animal is about nine inches, and its tail nearly five; its limbs are comparatively short, the hind legs being much the longest. The fur is of a remarkably close and fine texture, somewhat crisped, and entangled together; of a grayish or ash colour above, and paler beneath. It is used for muffs, tippets, and linings of cloaks, and is perhaps prettier than the Sable, although less durable, and less valuable in commerce, excepting when fashion rules. The form. of the head resembles that of the rabbit; the eyes are full, large, and black; and the ears broad, naked, round at the tips, and nearly as long as the head. The whiskers are plentiful and strong, the longest being twice as long as the head, some of them black, others white. Four short toes, with an appearance of a thumb, terminate the fore feet; the hinder have the same number of toes, but have less the appearance of hands : on all the claws are short, and nearly hidden by tufts of bristly hairs. The tail is about half the length of the body, of equal thickness throughout, and covered with long bushy hairs. It resembles in some degree the jerboa, and takes its food, like that animal, in its fore paws, sitting on its haunches. The temper of the Chinchilla is mild and tractable. It dwells in burrows under ground, and produces young twice a year, bringing forth five or six at a time. It feeds upon the roots of bulbous plants. 


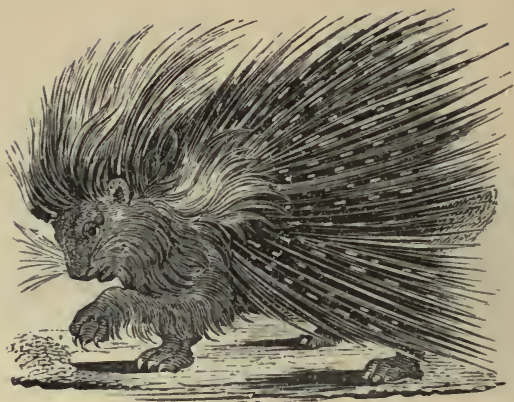

THE P(ORCUPINE. (Hystrix cristata.)

WHEN full grown this animal measures about two feet in length, and his body is covered with hair and sharp quills, from ten to fourteen inches long, and bent backwards. When he is irritated, they stand erect; but the story that the Porcupine can shoot them at his enemies, is only one of the many fables formerly related as facts in Natural History. The female has only one young one at a time. It is reported to live from twelve to fifteen years. The Porcupine is dull, fretful, and inoffensive; it feeds upon fruits, roots, and vegetables; and inhabits the south of Europe, and almost every part of Africa, particularly Barbary.

\section{THE COUENDOU, (Hystrix, or Synetheres prehensilis,)}

Wнгсн is also called the Brazilian Porcupine, is chiefly found in Guiana, and differs from the common Porcupine, not only in the shortness of its spines, but also in the great length of its tail. This organ, which is a mere stump in the common species, and only of use to him by producing a rattling of its spines when shaken, in which he seems to take great delight, is nearly as long as the body in the Couendou, and as its extremity is nearly naked, and can be curled up very tightly, the animal makes use of it to cling to the branches of trees, amongst which he is fond of climbing. 
§ VI.-Edentata, or Toothless Animals.

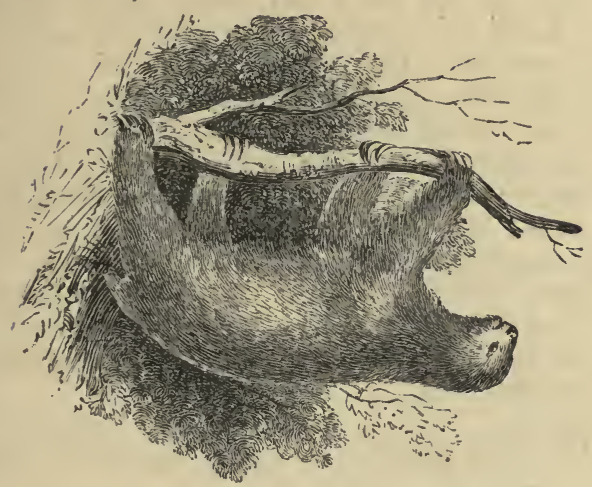

\section{THE SLOTH. (Bradypus tridactylus.)}

THrs animal, which is sometimes also called the $\mathrm{Ai}$, in reference to a noise it makes when caught, and frequently when 'moving through the forest, is most curiously formed. The arms or fore legs are nearly twice as long as the hind legs: the claws also are larger than the foot, and bent inwardly, so as to prevent the animal from placing the ball of its foot on the ground. From these peculiarities in its construction the progress of the Sloth on land is extremely slow and laborious, for being incapable of supporting himself on his feet, he is compelled to take advantage of every little inequality in the ground to drag himself along; but he is not intended to be a terrestrial animal. He lives in trees, al ways hanging below the branch, with its back to the ground; and for a life of this kind, its long arms and hooked claws are admirably adapted. Mr. Waterton, whose long residence in the wilds of South America, and whose habits of close observation, render him an excellent authority, observes, that when the Sloth travels from branch to branch of the tree which it inhabits, particu- 
larly in windy weather, it moves with such rapidity as to make it quite a misnomer to call it a Sloth. "The Sloth," says Mr. Waterton, "in its wild state, spends its whole life in the trees, and never leaves them; but through force or accident; and what is more extraordinary, not upon the branches, like the squirrel and monkey, but under them. He moves suspended from the branch, he rests suspended from the branch, and he sleeps suspended from the branch. Hence his seemingly bungled composition is at once accounted for ; and in lieu of the Sloth leading a painful life, and entailing a melancholy existence upon its progeny, it is but fair to conclude, that it enjoys life just as much as any other animal, and that its extraordinary formation and singular habits are but further proofs to engage us to admire the wonderful works of Omnipotence."

The common Sloth has always three toes; but there is another kind, called the Unau, which has only two toes, and much shorter fore legs.

The female Sloth has only one young one at a time, which hangs to her breast, and makes a kind of cradle of her body, during her journeys from branch to branch ; in fact, it appears never to quit her, till it is able to provide for itself. When hanging from the branch, she hides her young one in her thick, matted hair, which resembles in texture and appearance dry withered grass, and, indeed, is so like the rough bark and moss on old trees, as to render the animal scarcely distinguishable. It was formerly asserted, when the Sloth has got possession of a tree, it will not descend while a leaf or bud is remaining: and, that in order to obviate the necessity of a slow and laborious descent, it suffers itself to fall to the ground; the toughness of its skin and the thickness of its hair securing it from any unpleasant consequences. This, however, like many other statements regarding this much maligned animal, is erroneous; in the dense tropical forests which he inhabits the Sloth has rarely any occasion to descend to the earth; but he takes advantage of a windy night, when the branches of the trees become interlaced, to make his way with great ease from one place to another. 


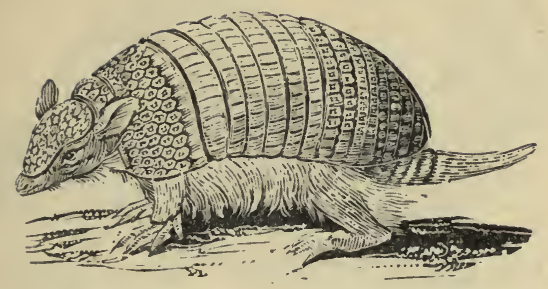

THE ARMADILLO. (Dasypus sexcinctus.)

NATURE seems to have been singularly careful in the preservation of this animal, for she has surrounded it with a strong coat of armour to protect it from its enemies. When closely pursued, it assumes the shape of a ball; and, if near a precipice, rolls from one rock to another, and escapes without receiving any injury. The shell, which covers the whole of the body, is composed of numerous bony plates, very hard, and of a square shape, united by a kind of cartilaginous substance, which gives flexibility to the whole. The Armadillo lives principally on roots, carrion, and ants; and in a wild state resides in subterranean burrows, like the rabbit. It is a native of South America. There are several species differing chiefly in the number of their bands. When naturalists wish to obtain a specimen of the Armadillo in its native country, they are obliged to employ an Indian to dig one out of its hole; and as the holes are almost innumerable, only a few of them containing Armadillos, the Indians try them first by putting a stick down, when, if a number of musquitos rise, the Indians know the hole contains an Armadillo, as, if there were none, there would be no musquitos. 


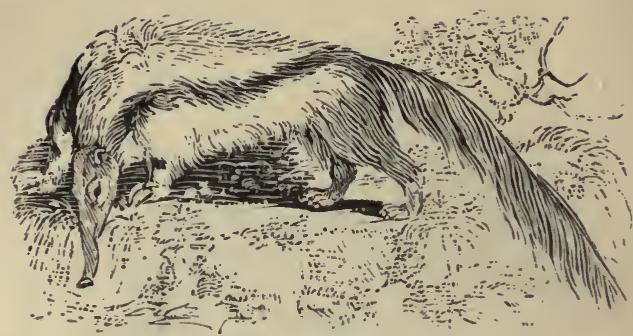

\section{'THE GREAT ANT-EATER. (Myrmecophaga jubata.)}

The body of the Great Ant-eater is covered with exceedingly coarse and shaggy hair. Its head is very long and slender, and the mouth but just large enough to admit its tongue, which is cylindrical, nearly two feet in length, and lies folded double within it. The tail is of enormous size, and covered with long black hair, somewhat like the tail of a horse. The whole length of the animal, from the end of the snout to the tip of the tail, is sometimes seven or eight feet. Its food consists principally of ants, which it obtains in the following manner:- When it comes to an ant-hill, it scratches it up with its long claws, and then unfolds its slender tongue, which much resembles an enormously long worm. This being covered with a glutinous matter or saliva, the ants adhere to it in great numbers: these it swallows alive, repeating the operation till no more are to be caught.

He also tears up the nests of wood-lice, which it in like manner discovers; but should it meet with little success in its pursuit of food, it is able to fast for a considerable time without inconvenience. The motions of the Ant-eater are in general very slow. It swims, however, over great rivers with ease; and, on these occasions, its tail is always thrown over its back. With this extraordinary member, when asleep, or during heavy showers of rain, the animal is also said to cover its back; but at other times he carries it extended behind him. The Ant-eater is a native of South America. 


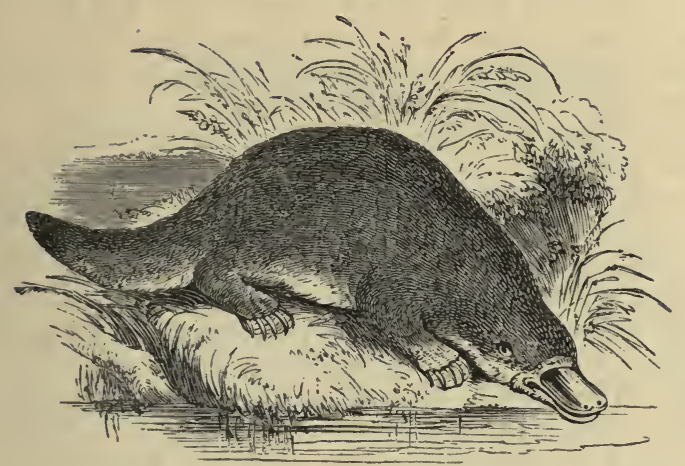

\section{THE DUCK-BILLED PLATYPUS, OR WATER}

\section{MOLE. (Ornithorhynchus paradoxus.)}

This extraordinary creature has the bill and webbed feet of a duck, united to the body of a mole. It is a native of Australia, where it is found on the banks of rivers, in the sides of which it burrows and forms its nest. It feeds on aquatic insects and small molluscous animals, always, however, rejecting the shells of the latter, after crushing them in its mouth, so as to extract the body. A number of these animals are always found together; but it is very difficult to watch their habits, as their sense of hearing is so acute, that they disappear at the slightest noise, plunging into the water, in which they swim so low, that they only look like a mass of weeds floating on the surface.

When the animal feeds, he plunges his beak into the mud, just like a duck; and appears to be equally at home on land and in water. Two young ones that were kept for some time at Sydney, by Mr. Bennet, were very fond of rolling themselves up like a hedgehog, in the form of balls. They often slept in this position, and " awful little growls" issued from them when dis- 
turbed. They were fed with worms, and bread and milk; but captivity did not seem to agree with them, and they soon died. They dressed their fur by combing it with their feet, and pecking at it with their beaks, seeming to take great delight in keeping it smooth and clean.

The shape of this animal is so extraordinary, that when a specimen was first sent to Europe, it was supposed to have been manufactured, by fixing the beak of a duck into the head of some small quadruperl, with the intention to deceive. Subsequent experience has proved, beyond the possibility of a doubt, the existence of the animal, without in the smallest degree diminishing the wonder excited by its first appearance, as it seems to partake, in almost equal parts, of the nature of quadrupeds, birds, and reptiles.

The Australian Hedgehog (Echidna hystrix), has a long and very slender muzzle, at the end of which is a very small mouth, containing a long tongue, which the creature can extend at pleasure. The body is short and rounded: it is covered with strong sharp spines mixed with hair; and its tail is so short that it was at first doubted whether it had one. The male has a spur upon each hind leg, which was long supposed, but it seems erroneously, to possess venomous properties. Both the Platypus and the Australian Hedgehog, although arranged here with the toothless quadrupeds, are generally considered by zoologists to be most closely related to the Marsupials, or Pouched Mammalia. 
§ VII.-Pachydermata, or Thick-skinned Animals.

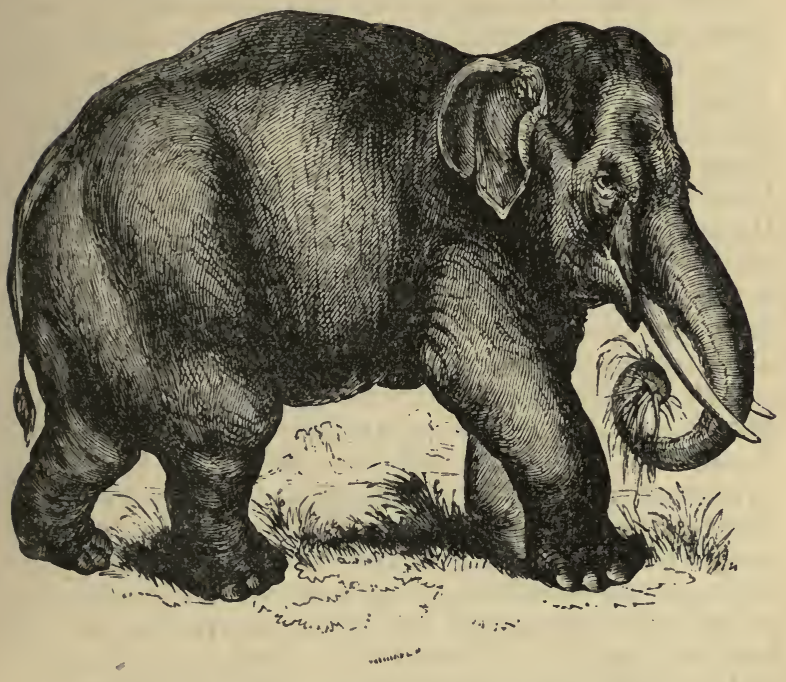

THE ELEPHANT. (Elephas indicus.)

Providence, always impartial in the distribution of its gifts, has given this bulky quadruped a quick instinct nearly approaching to reason, in compensation for the uncouthness of his body. The Ceylon Elephant is about ten or twelve feet high, and is much the largest of all living quadrupeds. His skin is in general a mouse colour, but is sometimes white and sometimes black. His eyes are rather small for the size of his head, and his ears, which are very expanded and of a peculiar shape, have the flaps hanging down, instead of standing up, as in most quadrupeds. The Elephant is a gregarious animal in his wild state, and when domesticated is susceptible of attachment and gratitude, as well as of anger and revenge. Several anecdotes are related 
of his quick apprehension, and particularly of his rindictive treatment of those who have either scoffed at or abused him. To disappoint him is dangerous, as he seldom fails to be revenged. 'The following instance is given as a fact, and deserves to be recorded:- An Elephant, disappointed of his reward, out of revenge, killed his governor. The poor man's wife, who beheld the dreadful scene, took her two children and thrust them towards the enraged animal, saying, "Since you have slain my husband, take my life also, as well as those of my children!" 'The Elephant instantly stopped, relented, and, as if stung with remorse, took the eldest boy in his trunk, placed him on his neck, adopted him for his governor, and would never afterwards allow any other person to mount him.

The Elephant's mouth is armed with broad and strong grinding teeth, and two large tusks, which measure sometimes nine or ten feet, and from which the finest ivory is produced. The ivory from the tusks of the female is thought the best, as the tooth, being smaller, admits less porosity in the cellular part of the mass.

Becoming tame under the mild treatment of a good master, the Elephant is not only a most useful servant, for the purposes of state or war, but is also of great assistance in taming the wild ones that have been recently caught. Indian superstition has paid great honours to the white race of this quadruped; and the island of Ceylon is supposed to breed the finest of the kind. 'This immense beast, by the wisdom of Providence, has not been placed among the carnivorous animals : and vegetable food being much more abundant than animal, he is destined to live on grass and the tender shoots of trees. This noble creature bears in state on his back the potentates of the East, and seems to delight in pompous pageantry : in war he carries a tower filled with archers; and in peace lends his assistance in domestio operations. The female is said to go a year with young, and to bring forth one at a time. The Elephant lives a hundred and twenty or a hundred and thirty years, though they have been known to live to the great age of four hundred. When Alexander the Great had conquered Porus, King 
of India, he took a large Elephant which had fought very valiantly for the king, and naming him Ajax, dedicated him to the sun, and then let him loose with this inscription:- "Alexander, the son of Jupiter, hath dedicated Ajax to the sun." This Elephant was found with this inscription 350 years after.

The greatest wonder the Elephant presents to the admiration of the intelligent observer of nature is his proboscis, or trunk, which attains a length of six or eight feet, and is so flexible that he uses it almost as dexterously as a man does his hand. It was erroneously said, that the Elephant could receive nourishment through his trunk; this sort of pipe is nothing but a prolongation of the snout, for the. purpose of breathing, into which the animal can by the strength of his lungs draw up a great quantity of water or other liquid, which he spouts out again, or brings back to his mouth by inverting and shortening his proboscis for this purpose.

Captain Marryat, in his very entertaining work called Masterman Ready, relates a curious instance of the sagacity of an Elephant in India, which had fallen into a deep tank. The tank was so deep that it was impossible to hoist the Elephant up, but when the people threw down several bundles of faggots, the sagacious animal laid one bundle above another, always standing on each tier as he arranged it, till at last he raised the pile high enough to allow him to walk out of the tank. But instances of the sagacity of this noble creature might be cited ad infinitum. In the East, where they are made available in the service of man, they will load a boat with singular dexterity, carefully keeping every article dry, and disposing and balancing the cargo with the utmost precision.

Its strength is proportionate to its bulk : it will carry three or four thousand pounds weight on its back, and upwards of a thousand pounds on its tusks.

The African Elephant is a distinct species (E. africanus) readily distinguished from his Asiatic brother, by the enormous size of his flapping ears. He is abundant in the southern part of Africa and is killed annually in great numbers for the sake of his tusks. 


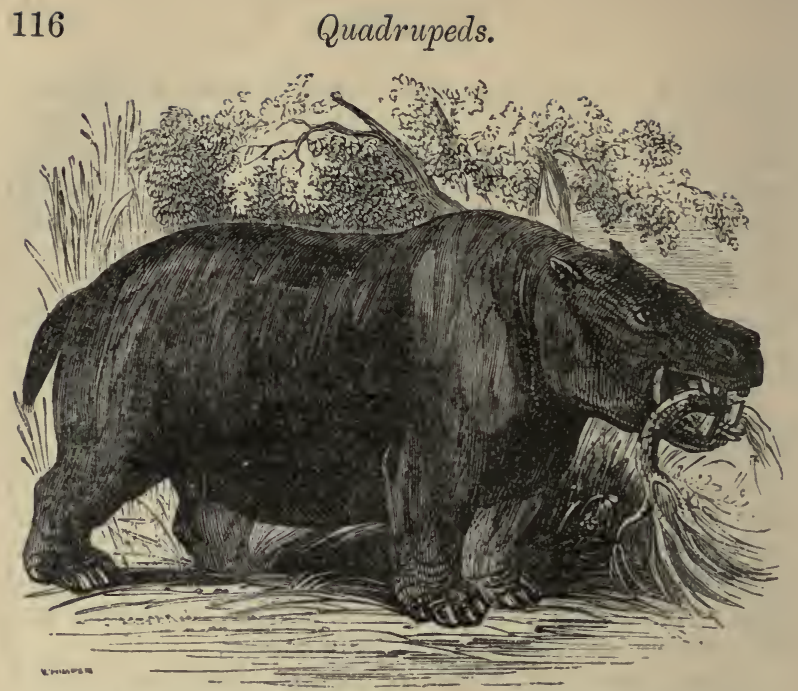

THE HIPPOPOTAMUS, OR RIVER-HORSE. (Hippopotamus amphibius.)

THrs animal lives as well on land as in water, and yields in size to none but the elephant: he weighs sometimes more than fifteen hundred pounds. His skin is naked, and of a blackish brown colour, tinged with red about the muzzle and on the lower surface of the body. The head is flattish on the top, about four feet long and nine in circumference; the lips are large, the jaws open about two feet wide, and the cutting-teeth, of which it has four in each jaw, are nearly a foot long; he has broad ears, and large eyes, a thick neck, and a short tail, tapering like that of a hog. He grazes and eats the leaves and young branches of trees on shore, but retires to the water if pursued, and will sink down to the bottom, where he can remain five or six minutes at a time. When he rises to the surface and remains with his head out of the water, he makes a bellowing noise which may be heard at a great distance. The female brings forth her young upon land, and it is supposed that she seldom prodnces more than one at a time. The calf at the 
instant that it comes into the world, flies to the water for shelter, if pursued; a circumstance which has been noticed as a remarkable instance of pure instinct. Fine specimens of this remarkable animal are to be seen in the Zoological Gardens in London; and in Paris they have been known to breed twice, but on both occasions the mother destroyed her offspring, either intentionally or by accident. The Hippopotamus is supposed to be the Behemoth of the Scripture. See Job, chap. xl.

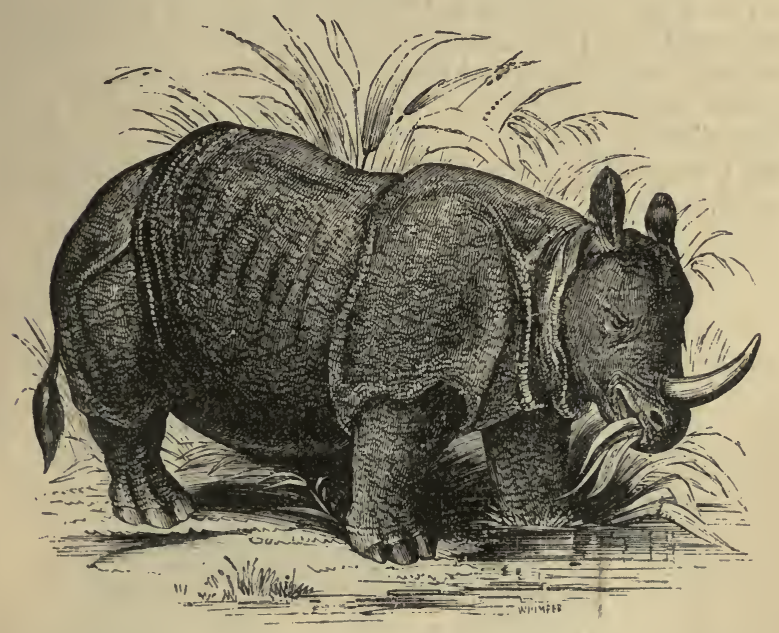

THE INDIAN RHINOCEROS, (Rhinoceros unicornis,)

So called because of the horn on his nose, is bred in India, is of a dark slate-colour, and nearly as large as the elephant, as he measures about twelve feet in length, but has short legs. His skin, which is not penetrable by any ordinary weapon, is folded upon his body, in the manner represented in the figure above; his eyes are small and half closed, and the horn on his nose is attached to the skin only. In confinement he often wears it to a mere stump, by rubbing it against his crib. $\mathrm{He}$ is perfectly indocile and untractable; a natural 
enemy to the elephant, to whom he often gives battle, and is said never to go out of his way, but to endeavour to destroy whatever obstacles present themselves, rather than turn about. He lives on the coarsest vegetables, and frequents the banks of rivers, and marshy grounds; his hoofs are divided into four, and he grunts like a hog, which he resembles in many other particulars. The female produces but one at a time, and during the first month her young are not bigger than a large dog. The Rhinoceros is supposed by some to be the Unicorn of holy writ, and possesses all the properties ascribed to that animal,-rage, untamableness, great swiftness, and immense strength. It was known to the Romans in very early times. Augustus introduced one into the shows, on his triumph over Cleopatra. Some Rhinoceroses have two horns.

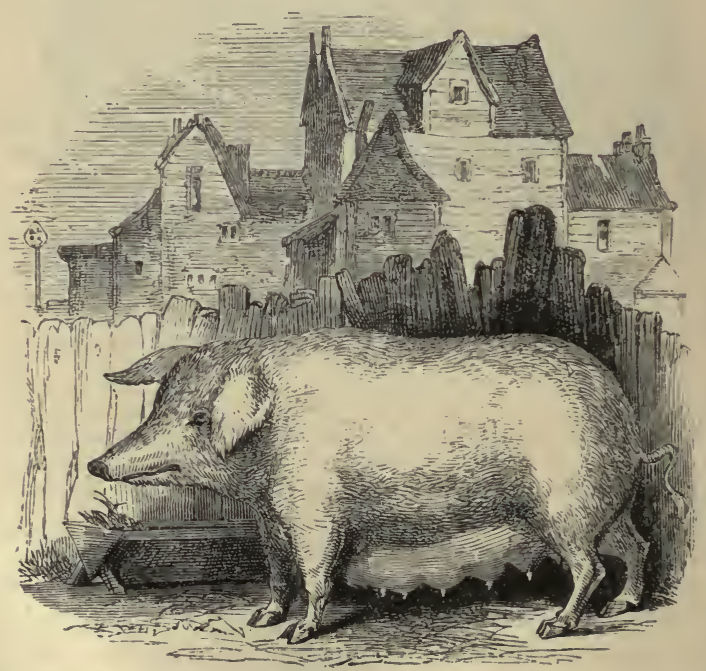

THE COMMON OR DOMESTIC HOG, (Sus scrofa,)

DIFFERS chiefly from the wild animal in having smaller tusks, and large and pendant ears. Of all domestic 
quadrupeds this is the most filthy and impure. Its form is clumsy and unsightly, and its appetite gluttonous and excessive. Nature, however, has fitted its stomach to receive nutriment from a variety of things that would be otherwise wasted, as the refuse of the field, the garden, and the kitchen, afford it a luxurious repast. The Hog is naturally stupid, inactive, and drowsy ; much inclined to increase in fat, which is disposed in a different manner from that of other animals, forming a thick, distinct, and regular layer between the flesh and skin. Their flesh, Linnæus observes, is a wholesome food for those that use much exercise, but improper for such as lead a sedentary life. It is of great importance to this country, as a naval and commercial nation, for it salts better than any other flesh, and is capable of being longer preserved.

The domestic Sow brings forth twice a year, producing from ten to twenty at a litter. She goes four months with young, and brings forth in the fifth. At that time she must be carefully watched, to prevent her from devouring her young. Still greater attention is necessary to keep off the male, as he would destroy the whole litter. Jews and Mahommetans not only abstain from the flesh of swine from a religious principle, but consider themselves defiled by eren touching it.

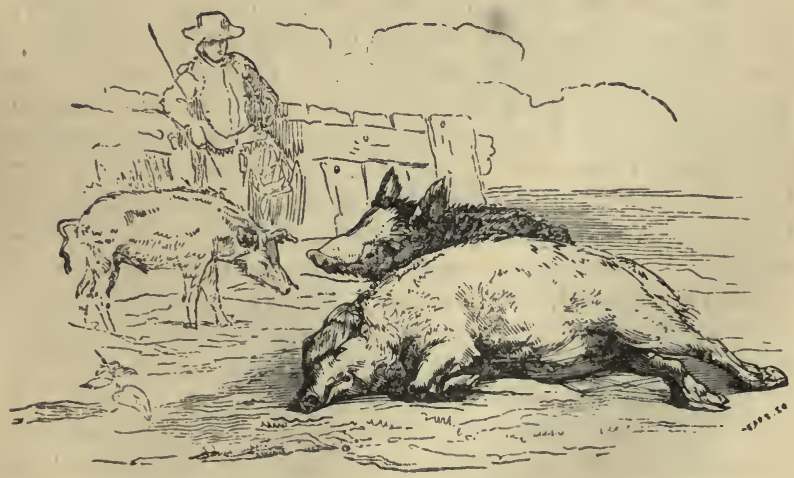




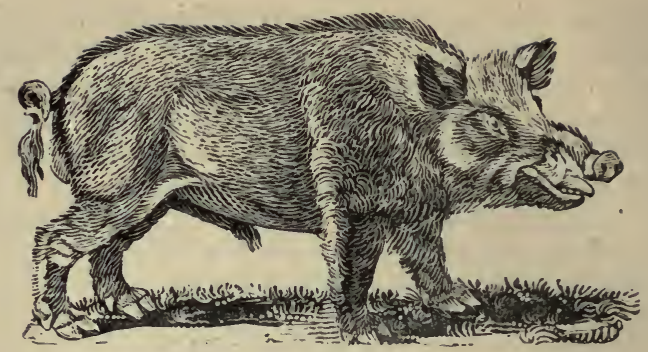

THE WILD BOAR, (Sus scrofa, )

INHABITS, for the most part, marshes and woods, and is of a black or brown colour: his flesh is very tender and good for food. The Wild Boar has tusks, which are sometimes nearly a foot in length, and have often proved dangerous to men, as well as to dogs in the chase. His life is confined to about thirty years; his food consists of vegetables; but when pressed by hunger, he devours animal flesh. This creature is strong and fierce, and undauntedly turns against his pursuers. To hunt him is one of the principal amusements of the grandees in those countries where he is to be found. The dogs provided for this sport are of the slow, heavy kind. Those used for hunting the stag, or the roebuck, would be very improper, as they would too soon come up with their prey, and, instead of a chase, would only furnish an engagement. Small mastiffs are therefore chosen; nor do the hunters much regard the goodness of their nose, as the Wild Boar leaves so strong a scent that it is impossible for them to mistake his course. They never hunt any but the largest and the oldest, which are known by their tusks. When the boar is reared, as is the expression for driving him from his covert, he goes slowly and sullenly forward, without any indication of fear, not very far before his pursuers. At the end of every halfmile, or thereabouts, he turns round, stops till the hounds come up, and offers to attack them. These, on the other hand, knowing their danger, keep off and bay him at a distance. After they have for a while gazed unon each other, with mutual animosity, the Boar again 
slowly goes on his course, and the dogs renew the pursuit. ln this manner the charge is sustained, and the chase continues, till the boar is quite tired, and refuses to go any further. 'I'he dugs then attempt to close in upon him from behind; those which are young, fierce, and unaccustomed to the chase, are generally the foremost, and often lose their lives by their ardour. 'Thuse which are older, and better trained, are content to wait until the hunters come up, who despatch him with their spears.

In former times, the Wild Boar was a native of Britain, as appears from the laws of the Welsh prince, Howell the Good, who permitted his grand huntsman to chase that animal from the iniddle of November to the beginning of December; and in the reign of William the Conqueror, those who were convicted of killing the Wild Boars, in any of the royal forests, were punished with the loss of their eyes. Our domestic pigs are descended from the wild race; but the tame Boar has two tusks, smaller than those of the wild ones, and the sow has none.

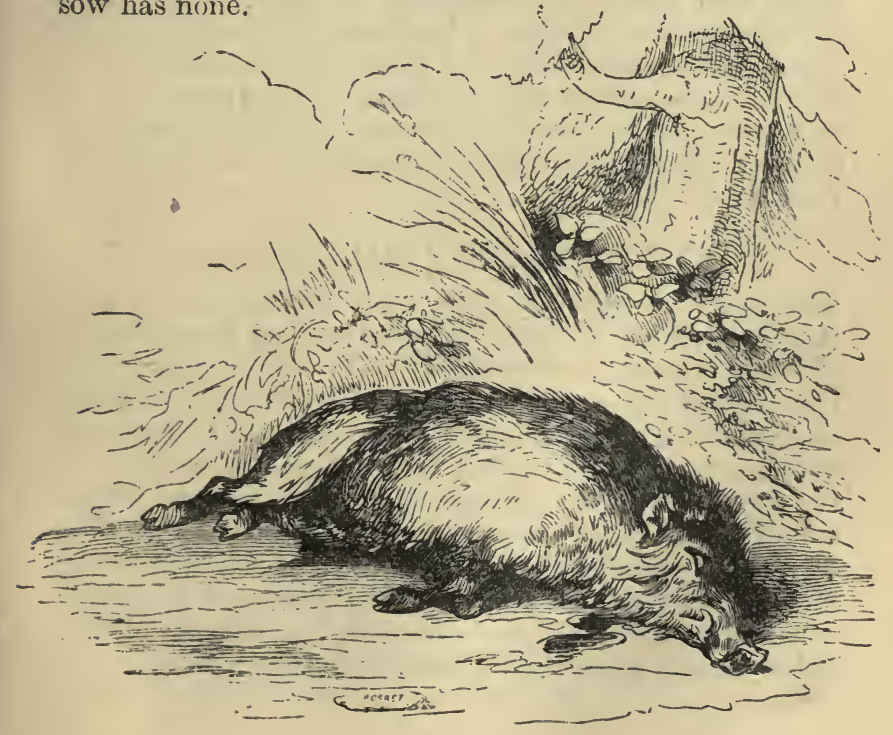




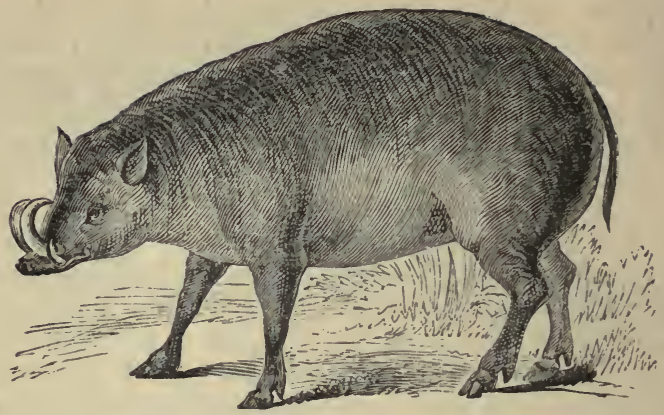

THE BABIROUSSA, (Babirussa alfurus,)

Is a singular species of hog, which dwells in many of the islands of the eastern Archipelago. His four tusks are of enormous size, especially those of the upper jaw, which are turned completely upwards and bent back, like horns, towards the forehead, which they sometimes even touch. These singular tusks are only found in the male; they do not seem, from their construction, to be of much use to him as weapons; and it was formerly supposed that he employed them as hooks to hang himself up to the branch of a tree for his night's rest.

\section{THE PECCARY. (Dicotyles labiatus.)}

This is a little species of pig, of a brown colour, with pale lips, which is found in great troops in the forests of South America. These bands of Peccaries are said to travel from place to place under the guidance of a sort of chief, who places himself at the head of his troop and marches forward in a direct line, swimming boldly over the rivers, and often devastating the plantations. When one of these troops meets with any unusual object, they all stop to examine it, making a dreadful clattering with their teeth, which they are quite ready to use in their own defence, and will soon tear an assailant to pieces, unless he can succeed in climbing up into a tree. 


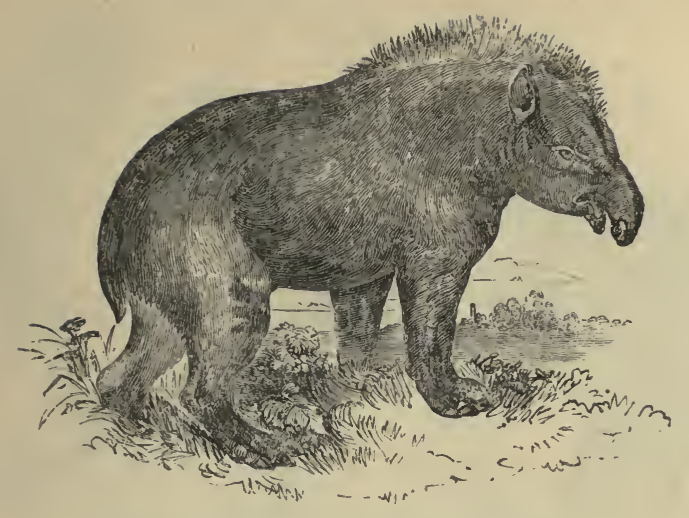

THE TAPIR. (Tapirus americanus.)

Trus animal bears considerable resemblance to the wild boar, but is without tusks, and has its snout prolonged into a small fleshy proboscis, or trunk. This trunk, however, has not the flexibility of that of the elephant, and is incapable of holding anything. The colour of the Tapir is of a deep brown, and the male has a small mane on the upper part of lis neck. It stands about three feet and a half high, and measures nearly six feet in length. It lies in thickets, the thorny branches of which cannot affect it frem the thickness of its skin, while they lacerate the skins of its pursuers. Its favourite food is the water-melon. It is generally found alone, and always roams in search of food at night; and it is easily tamed if taken young. It possesses the same power of remaining under water as the hippopotamus, and when it enters a pond, can descend to the bottom, and remain there five or six minutes.

The Malayan Tapir (T. malayanus), is very similar to the American species in form; but is larger and has no mane. It is very remarkable for the distribution of its colours, the anterior part and the legs being deep black, and the rump, back, and sides, white. This animal is found chiefly in Sumatra and Borneo. 


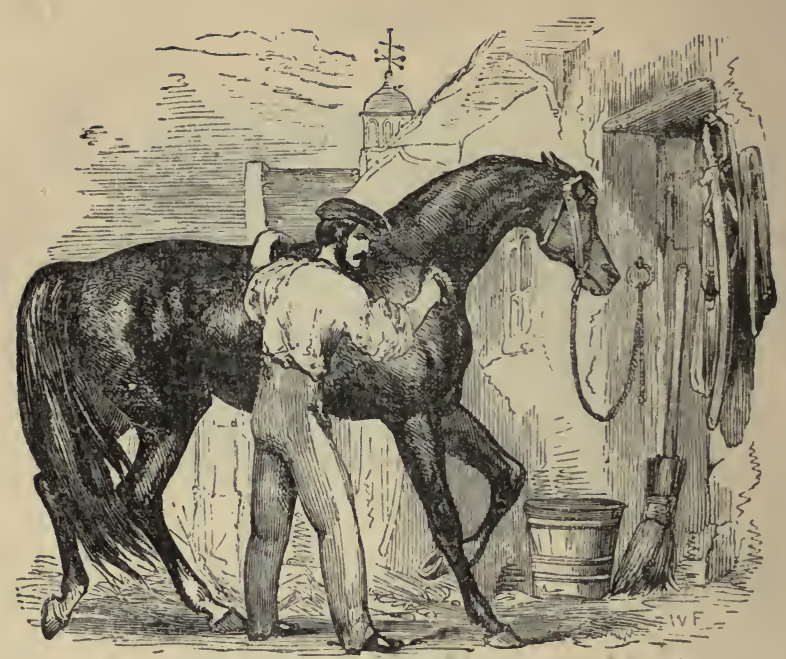

THE HORSE. (Equus caballus.)

THe noblest conquest that man ever made over the brute creation was the taming of the Horse, and adapting him to his service. He lessens the labours of man and adds to his pleasures: shares, with equal docility and cheerfulness, the fatigues of hunting or the dangers of war; and draws with appropriate strength, rapidity, or grace, the heavy ploughs and carts of the husbandman, the light vehicles of the fashionable, and the stately carriages of the aristocratic.

The Horse is now bred in most parts of the world: those of Arabia, Turkey, and Persia are accounted better proportioned than many others; but the English RaceHorse may justly claim the precedence over all the other European breeds, and is not inferior to any in strength and symmetry.

The beautiful Horses produced in Arabia are in general of a brown colour ; their mane and tail are very short, with the hair black and tufted. The Arabs, for the most part, use the Mares in their ordinary excursions ; experience having taught them that they are less vicious than the males, and more capable of sustaining abstinence and fatigue. As the Arabs have no other 
residence than a tent, this also serves for a stable; the husband, the wife, the child, the mare, and the foal, lie together indiscriminately, and the younger branches of the family may be often seen embracing the neck, or reposing on the body of the Mare, without any idea of fear or danger.

Of the remarkable attachment which the Arabs have to these animals, St. Pierre has given an affecting instance in his Studies of Nature.- "The whole stock of a poor Arabian of the desert consisted of a beautiful Mare: this the French consul at Said offered to purchase, with an intention to send her to Louis XIV. The Arab, pressed by want, hesitated a long time, but at length consented, on condition of receiving a very considerable sum of money, which he named. The consul wrote to France for permission to elose the bargain; and having obtained it, sent the information to the Arab. The man, so indigent as to possess only a miserable covering for his body, arrived with his magnificent courser: he dismounted, and first looking at the gold, then steadfastly at his Mare, heaved a sigh, 'To whom is it,' exclaimed he, 'that I am going to yield thee up? To Europeans? who will tie thee close, who will beat thee, who will render thee miserable! Return with me, my beauty, my jewel! and rejoice the hearts of my children :' as he pronounced the last words, he sprung upon her back, and was out of sight almost in a moment."

The intelligence of the Horse is next to that of the elephant, and he obeys his rider with so much punctuality and understanding, that the Americans, who had never seen a man on horseback, thought, at first, that the Spaniards were a kind of centaurs, half men and half horses. The Horse, in a domestic state seldom lives longer than twenty years; but it is supposed that in a wild state he attains a much greater age. The Mare is as elegant in her shape as the Horse; and her young is called a foal. The age of the Horse is known frum his teeth; and his colour, which varies from black to white, and from the darkest brown to a light hazel tint, has been reckoned a criterion by which to judge of his strength. 
The Horse feeds upon grass, either fresh or dry, and corn : he is liable to many diseases, and often dies suddenly. In the state of nature. he is a gregarious animal, and even when domesticated, his debased situation of slavery has not entirely destroyed his love of society and friendship; for Horses have been known to pine at the loss of their masters, their stable fellows, and even at the death of a dng which had been bred near the manger. Virgil, in his beautiful description of this noble animal, seems to have imitated $\mathrm{J} 0 \mathrm{~b}$ :

“ The fiery courser, when he hears from far

The spriglitly trumpets, and the shouts of war, Pricks up his ears, and trembling with delight, Shifts place, and paws, and liopes the promised fight. On lis right slsoulder lis thick mane reclined, Iiuffles at spced, and dances in the wiud. His horny lionfs are jetty black and round, His chine is double; starting with a bound, He turns the turf and shakes the solid ground. Fire from his eyes, clouds from lis nostrils flow; He bears lis rider lieadlong on the foe."

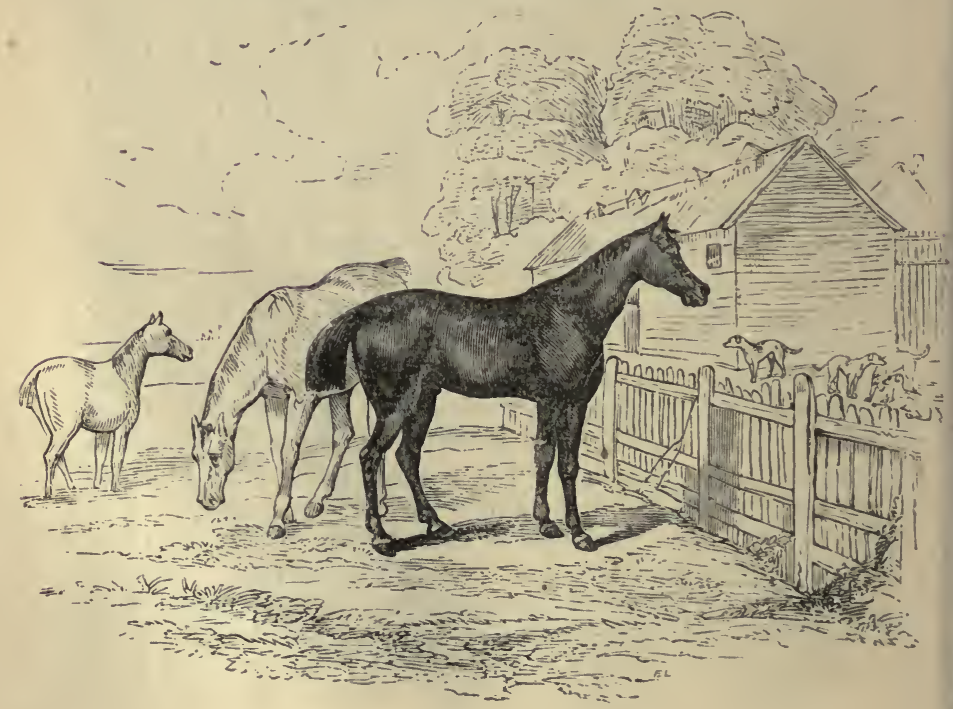




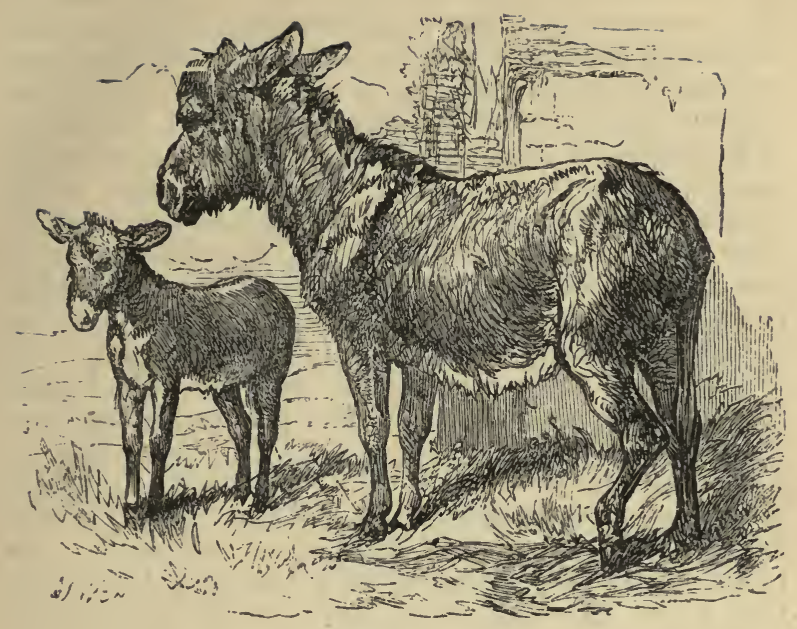

THE ASS. (Equus Asinus.)

THe Ass is a beast of burden, and extremely serviceable to man. Of greater strength than most animals of his size, he bears fatigue with patience, and hunger with apparent cheerfulness. A bundle of dried herbs, or a thistle on the road, is sufficient for his daily meal, and he is content with the clear and pure water of a neighbouring brook (in the choice of which he is particularly nice) in the absence of better fare. It is probable that the Ass was originally a native of Arabia, and other parts of the East: the deserts of Libya and Numidia, and many parts of the Archipelago, contain vast herds of wild Asses, which run with such amazing swiftness, that even the fleetest horses of the country can hardly overtake them. At present, perhaps, the best breed in Europe is the Spanish ; and very valuable Asses are still to be had in the southern continent of America, where, during the existence of the Spanish dominion, the breed 
was very carefully attended to. In the time of Elizabeth, we are informed, there were no Asses in this country. Our treatment of this very useful animal is both wanton and cruel, and most ungrateful, considering the great services he renders us at so little expense. 'The ears of the Ass are of an uncommon length; and he is of a grevish or dun colour, with a black cross on his back and shoulders. When very young, the Ass is sprightly, and even tolerably handsome; but he soon loses these qualifications, either by age or ill-treatment, and becomes slow, sullen, and headstrong. The female is passionately fond of her young one; and it is said she will even cross fire and water to protect or rejoin it. The Ass is also sometimes greatly attached to its owner, whom he scents at a distance, and plainly distinguishes from others in a crowd.

The female goes with young eleven months, and seldom produces more than one foal at a time: the teeth follow the same order of appearance and renewal as those of the horse. Asses' milk has long been celebrated for its sanative qualities; invalids suffering from debility of the digestive and assimilative functions make use of it with great advantage; and to those also who are consumptive it is very generally recommended.

An old man who, a few years ago, sold vegetables in London, used in his employment an Ass, which conveyed his baskets from door to door. Frequently he gave the poor industrious creature a handful of hay, or some pieces of bread, or greens, by way of refreshment or reward. The old man had no need of any goad for the animal, and seldom, indeed, had he to lift $\mathrm{up}$ his hand to drive it on. His kind treatment was one day remarked to him, and he was asked if his beast was apt to be stubborn? "Ah! master," replied he, "it is of no use to be cruel, and as for stubbornness, I cannot complain; for he is ready to do anything and go anywhere. I bred him myself. He is sometimes skittish and playful, and once ran away from me; you will hardly believe it, but there were more than fifty people after him, attempting in vain to stop him; yet he turned back of himself, 


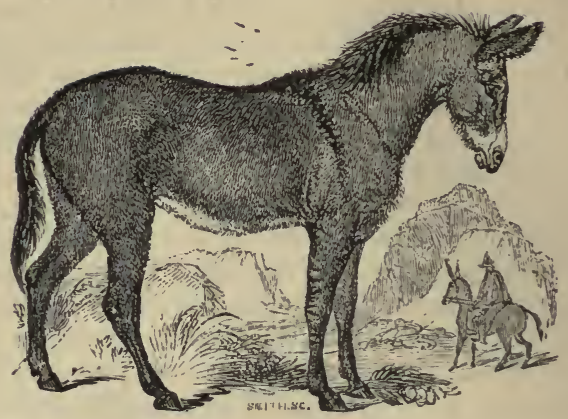

THE MULE.

T'Hs useful and hardy animal is the offspring of the horse and the ass, and partakes of the good qualities of both. T'he common Mule is very healthy, and will live above thirty years. 'The size and strength of our breed have been much improved by the importation of Spanish male asses; and it is much to be wished that the useful qualities of this animal were more attended to; for, by proper care in its breaking, its natural obstinacy would in a great measure be corrected; and it might be furmed with success for the saddle, the draught, or the burden. People of the first quality are drawn by Mules in Spain, where fifty and sixty guineas is no uncommon price for them; nor is it surprising, when we consider how far they excel the horse in travelling in a mountainous country, the Mule being able to tread securely where the former can hardly stand. It is much less dainty in its food than the horse, and not so liable to disease; and has been known to go a distance of eighty or a hundred miles in one day, with a heavy weight on its back, without much fatigue. 
T'he Kiang.

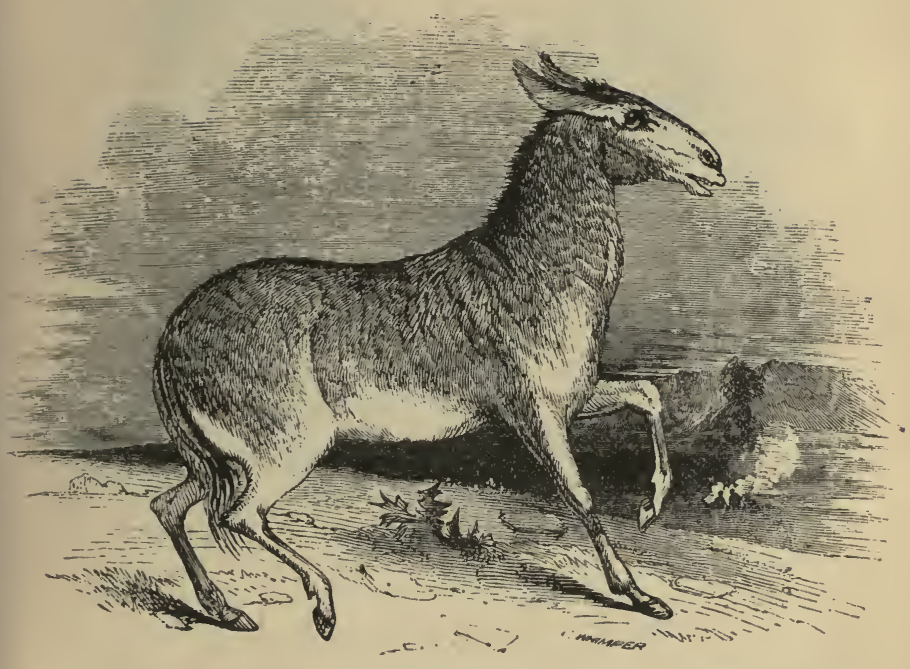

\section{THE KIANG. (Equus Hemionus.)}

The Kiang, which is also called the Djiggetai, is a kind of wild ass, found in small herds on the great plains of Central Asia. It is a good deal larger than the common ass, and its fur is of a peculiar pale reddish chestnut tint, except on the legs and muzzle, which are nearly white. The ears are not so long as in the ass, and there is a black streak down the middle of the back. 


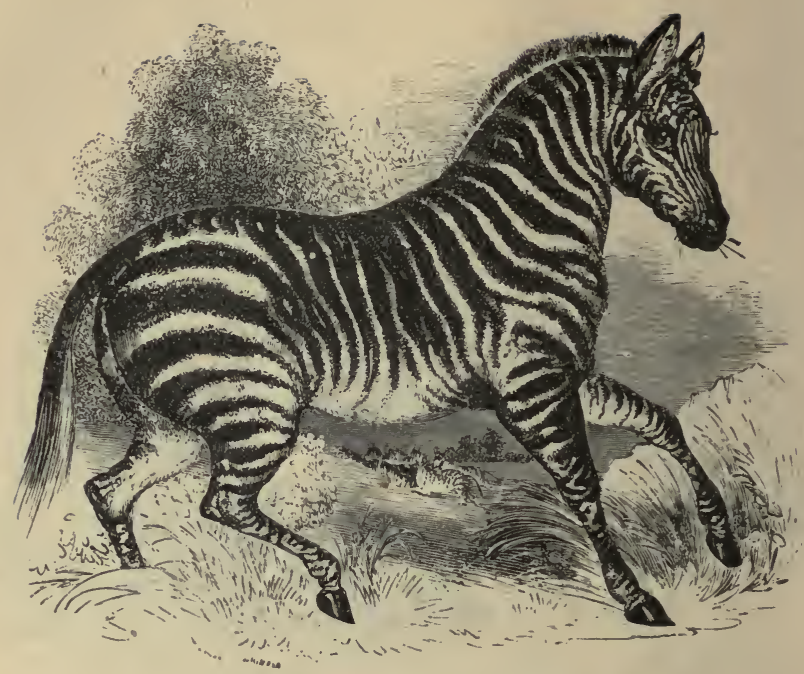

THE ZEBRA. (Equus Zebra.)

THis is one of the most elegantly marked quadrupeds in nature. He is striped all over with the most pleasing regularity ; in size he resembles the mule, being smaller than the horse, and larger than the ass. 'The hair of his skin is uncommonly smooth, and he louks at a distance like an animal that some fanciful hand has surrounded with ribbons of white or buff, and jet black. He is a native of Southern Africa-chiefly of the Cape of Good Hope, where he resides amongst the mountains. In these solitudes the Zebra has nothing to restrain his liberty. He is too shy to be caught in traps, and therefore seldom taken alive. Were the Zebra inured to our climate, there is little doubt but he might be soon domesticated. The black cross which the ass bears on his back and shoulders indicates the affinity between these two animals. The Zebra feeds in the same manner as the horse, ass, and mule; and seems to delight 
in having clean straw and dried leares to sleep upon. His voice can hardly be described; it is thought by some persons to have a distinct resemblance to the sound of a post-horn, and is more frequently exerted when the animal is alone than at other times. In former times, Zebras were often sent as presents to the oriental princes. A governor of Batavia is said to have given one to the emperor of Japan, for which he received as an equivalent a. present to the value of sixty thousand crowns; and Teller informs us, that the Great Mogul gave two thousand ducats for one of these animals. It is usual with the African ambassadors to the court of Constantinople to bring Zebras with them as presents for the Grand Seignior. In a wild state they live in herds, and can only be tamed when taken young, or bred in captivity.

Another kind of Zebra (Equus Burchellii) inhabits the plains of Southern Africa; it is known as the Zebra of the plains, and is also called Burchell's Zebra, after the distinguished African traveller. This Zebra is less beautifully marked than the mountain species.

Instinct having taught these beautiful animals that in union consists their strength, they combine in a compact body when menaced by an attack either from man or beast; and if overtaken by the foe, they unite for mutual defence, with their heads together in a close circular band, presenting their heels to the enemy, and dealing out kicks in equal force and abundance. Beset on all sides, or partially erippled, they rear on their hinder legs, fly at their adversary with jaws distended, and use both teeth and heels with the greatest freedom.

The Quagga is also a native of Southern Africa. It is more wild than the Zebra, and less beautifully marked; the stripes, indeed, do not extend over the whole body, but only over the head and neck. The colour is a reddish brown above and white beneath. The Quagga is less than the Zebra, and not so elegantly formed, the hind quarters being higher than the shoulders. The ears are also much shorter. The Quagga bears the reputation of being naturally vicious, and so treacherous that it is said that, like a cat, it will bite the hand that feeds and caresses it. 
§ VIII.-Ruminating Animals.

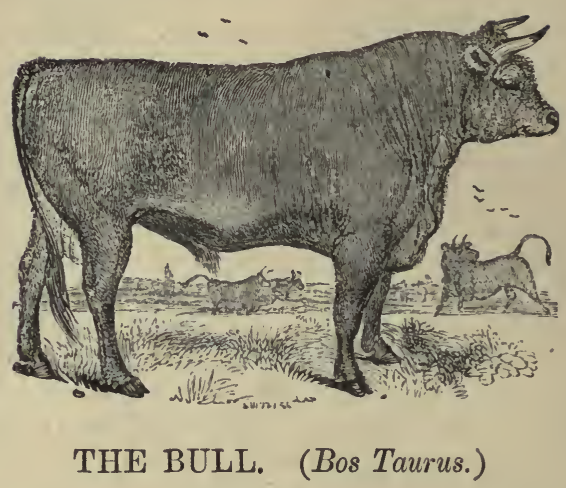

THERE are, perhaps, no animals more generally useful to mankind than the race of oxen, in all their states of existence. They are called ruminating animals ; that is, after they have eaten their food they possess the power of returning it from the first stomach into the mouth, to be again masticated before it is finally digested. This is called chewing the cud; and as the animal generally lies down, and looks very thoughtful while the operation is performing, it is said to be ruminating.

The Bull is a very fierce creature, and when enraged, runs about, tossing up his tail, and roaring most fearfully. When attacked by men or dogs, he tears up the ground with his feet, and then gallops after his assailants, endeavouring to toss them with his horns; and very often pursues in this manner any one he sees, particularly if they appear frightened. When in danger of being attacked by a Bull, the best course is to stand still, and open an umbrella. or flap a shawl, or something of that kind, in the Bull's face ; as with all his fierceness he is a great coward, and only pursues those who fly from him.

The $\mathrm{Ox}_{\mathrm{x}}$, or Bullock, is used in some parts of the 
country for drawing carts and waggons, and ploughing; and its flesh is called beef. The skin is tanned and made into leather; the hair is mixed with mortar; the bones are used for knife-handles, chess-men, counters, and other things, as a substitute for ivury; from its horns are made combs, and various other articles; the fat is used in making candles; the blood in refining sugar: and, in short, every part has some important nise.

The common charge of stupidity urged against the $\mathrm{Ox}$ is wholly unfounded, as the following anecilote, recorded by Mr. Bell, will show. A cow, feeding in a pasture, the gate of which was open, was much annoyed by a mischievous boy, who amnsed himself by throwing stones at her. The peaceful animal, after enduring this patiently for some time, went up to him, and hooking the end of her horn into his clothes, carried him out of the field and laid him down in the road. She then returned calmly to her pasture, leaving him quit for a severe fright and a torn gurment

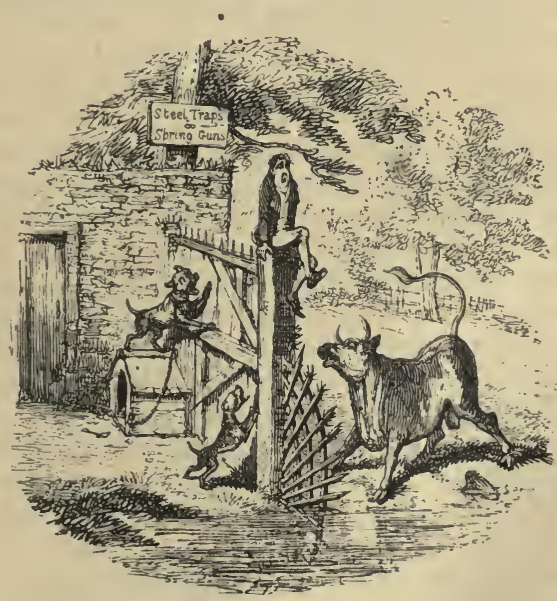




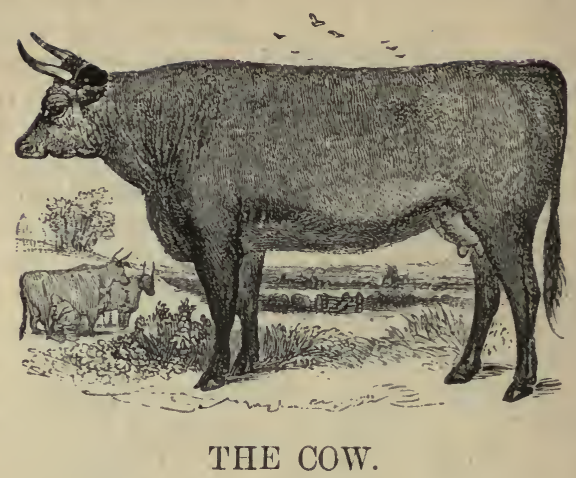

THE Cow is the female of the ox tribe, and her young is called a calf.' A young Cow, when under two years old, is called a heifer. 'The Cow is as useful to mankind as the ox, except in ploughing and drawing; but to make amends, she supplies us with milk, from which butter and cheese are made. The Cow gives from six to twenty quarts of milk in a day : and the faculty of giving it in such abundance, and with so much ease, is a striking peculiarity, for this animal differs in this part of its organization from most others, having a large udder, and longer and thicker teats, than the largest animal we know of ; it has likewise four teats, whilst all other animals of the same nature have but two; it also yields the milk freely to the hand, whilst all other animals, at least those that do not ruminate in the same manner, refuse it, unless their young, or some adopted animal, be allowed to partake it. The age of the Cow is known by her horns; at four a ring is formed at their roots, and every succeeding year another ring is added. Thus, by allowing three years before their appearance, and then reckoning the number of rings, the creature's age may be exactly known.

Calves, when quite young, are helpless creatures, from the great length and weakness of their legs. Sometimes they are killed when young, and their flesh is then called 
veal. The stomach of the calf, when it is killed, is taken out, and cleaned and salted; it is then hung up to dry, and is called rennet. In making cheese, a bit of rennet is soaked in water, which when poured into milk, turns it to curd. The curd is then separated from the whey, and put into a press, when it becomes cheese.

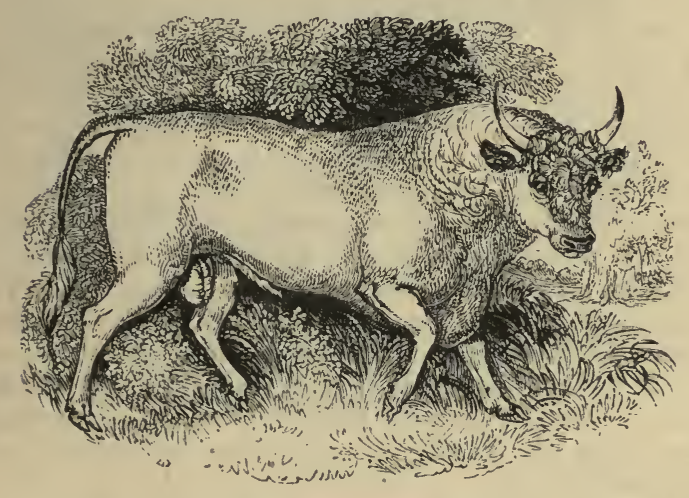

\section{THE WILI BULL.}

Is the Duke of Hamilton's park in Scotland, Lord Tankerville's at Chillingham, in Northumberland, and some other places, there is a breed of wild cattle, possibly the last remains of those which at one period overran this island. 'The colour is white, with muzzle and ears black, or very dark red.

At the first appearance of any person near them, these animals set off at full gallop; and at the distance of two or three hundred yards wheel round and come boldly up again, tossing their heads in a menacing manner. On a sudden they make a full stop at the distance of forty or fifty yards, and look wildly at the object of their surprise; but on the least motion they all turn round, and gallop off again with equal speed, but not to the same distance, forming a smaller circle; and again returning, with a bolder and more threatening aspect than before, 
they approach much nearer, when they make another stand, and again gallop off. This they do several times, shortening their distance, and advancing nearer till they come within a few yards, when most persons consider it prudent to leave them, not choosing to provoke them further, as it is probable that in a few turns more they would make an attack.

The mode of killing these animals, as was practised a few years ago, was the only remnant of the ancient mode of hunting that existed in this country. On notice being given that a Wild Bull would be killed on a certain day, the inhabitants of the neighbourhood assembled, sometimes to the number of a hundred horsemen, and four or five hundred foot, all armed with guns or other weapons. Those on foot stood upon the walls, or climbed into trees, while the horsemen separated a Bull from the rest of the herd, and chased him until he stood at bay, when they dismounted and fired. At some of these huntings, twenty or thirty shots have been discharged before the animal was subdued. On such occasions the bleeding victim grew desperately furious from the smarting of his wounds, and the shouts of savage joy echoing from every side.

When the Cows calve, they hide their young ones for a week or ten days in some sequestered retreat, and go to suckle them two or three times in a day. If any person comes near one of the calves it crouches close upon the ground, and endeavours to hide itself, a proof of the native wildness of the animals. In one instance where a calf was disturbed, it pawed the ground like an old Bull, and attempted to butt with its head, till it fell from weakness. It had done enough, however, to raise an alarm, and the whole herd came to its rescue, compelling the intruder to decamp: for the dams will allow no one to touch their young without attacking him with impetuosity. In the Duke of Hamilton's park, in the summer of 1841 , a calf, which was disturbed by the passing of a carriage near it, bellowed so fearfully as to rouse the whole herd, though they were at a considerable distance. 


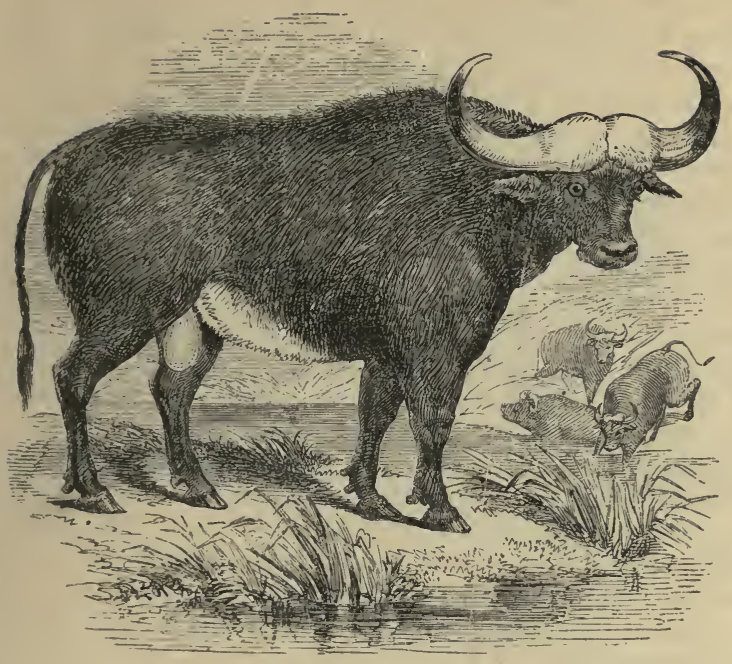

\section{THE AFRICAN BUFFALO (Bubalus Caffer.)}

Is its general form the Buffalo has a great resemblance to the ox; but it differs from that animal in its horns, and in some particulars of its internal structure. It is larger than the ox ; the head is also bigger in proportion, the forehead higher, and the muzzle longer. The horns are large, and of a compressed form, with the exterior edge sharp; they are straight for a considerable length from their base, and then bend slightly upward. The general colour of the animal is blackish, except the forehead and the tip of the tail, which are of a dusky white. The hunch is not, as many have supposed it, a large fleshy lump, but is occasioned by the bones that form the withers being continued. to a greater length than in most other animals. Buffaloes are found in most parts of the torrid zone, and of almost all warm climates; always dwelling in moist and marshy places, where they delight to roll in the mire. In a wild state, the Buffalo is exceedingly fierce; but in some of the tropical countries he 
is perfectly domestic, and very useful for many purposes, being an animal of patience and great strength. II hen employed in the labours of agriculture, he has a brass ring put through his nose, by which means he is led at pleasure. Buffaloes are common in the Pontine Marshes near Rome, where they were brought from India in the sixth century. In India they constitute the riches and food of the poor, who employ them in their fields, and make butter and cheese from their milk. 'They are much valued for their hides; of which, in several countries, and especially in England, military belts, boots, and other implements of war are made. 'There are various species of Buffaloes, of which the Cape Buffalo, from South Africa, is the best known, and most valuable.

Buffaloes, in their native country, fight so fiercely with each other, that African travellers have remarked that they are seldom found without toin ears, and scars of various kinds on the neck and body. And they are no less treacherous than ferocious, lurking among the trees in concealment until some unfortunate passenger passes. The animal will then suddenly rush upon him, and there is little chance of the victim escaping unless a tree be at hand. 'The furious beast, not contented with throwing him down and killing him, stands over him for a long time, trampling on and tearing the body to pieces; he then strips off the skin with his rough and prickly tongue. Even after all this he repeatedly returns to the body to gratify afresh his savage disposition.

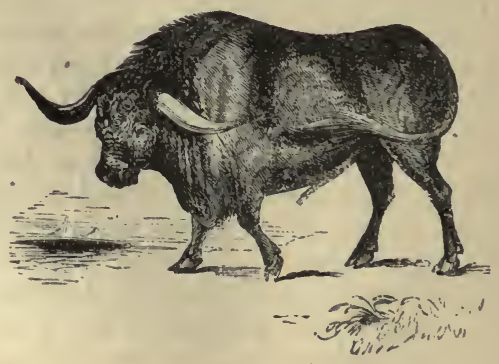




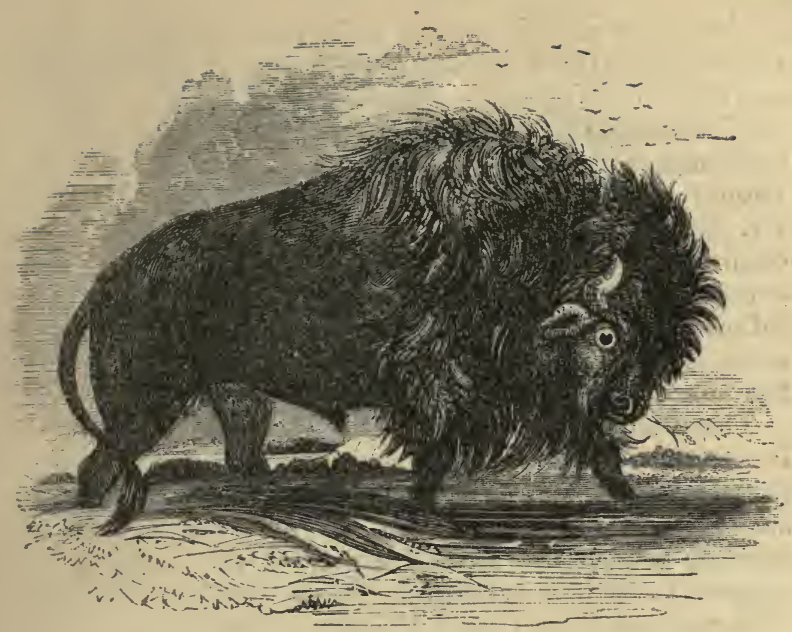

\section{THE BISON. (Bos ur Bison Bunasus.)}

THERE are two kinds of Bison; one a native of Europe, and the other of America. The European Bison, or Bonasus, is as large as a bull or ox; maned about the back and neck like a lion; and his hair hanging down under his chin, or nether jaw, like a large beard. 'The fore parts of his body are thick and strong, but the hinder parts are comparatively slender. He has a little ridge along his face from his forehead down to his nose, which is very hairy; his horns are large, very sharp, and turning towards his back, like those of a wild goat. The American Bison (B. Americanus), attains a size far superior to that of the largest breeds of our common oxen, and is met with thronghout nearly the whole of the uninhabited parts of North America, from Hudson's Bay to Louisiana and the frontiers of Mexico. Captains Lewis and Clarke, and Dr. James, bear frequent testimony to the almost incredible numbers in which these animals assemble on the banks of the Missouri. "Such was their multitude," say the first-named travellers, "that, although the river, including an island over 
which they passed, was a mile in breadth, the herd stretched, as thick as they could swim, completely from one side to the other." And again they say: "If it bo not impossible to calculate the moving multitude which darkened the whole plains, we are convinced that twenty thousand would be no exaggerated number." Dr. James tells us that, "in the middle of the day countless thousands of them were seen coming in from every quarter to the stagnant pools ;" their paths, as he informs us elsewhere, being " as frequent, and almost as conspicuous, as the roads in the most populous parts of the United States."

These wild cattle defend themselves from the wolves in the most admirable manner. When they hear their savage enemies approaching they form themselves adroilly into a circle. The weakest are left in the middle, whilst the strongest are on the outside, and present to their foes an impenetrable phalanx of horns. 'The vignette is an illustration of this subject.

Exciting stories of the buffalo hunt, both American and African, will be seen in Catlin's North American Indians, and Harris's Wild Animals and Sports of Southern Africa.

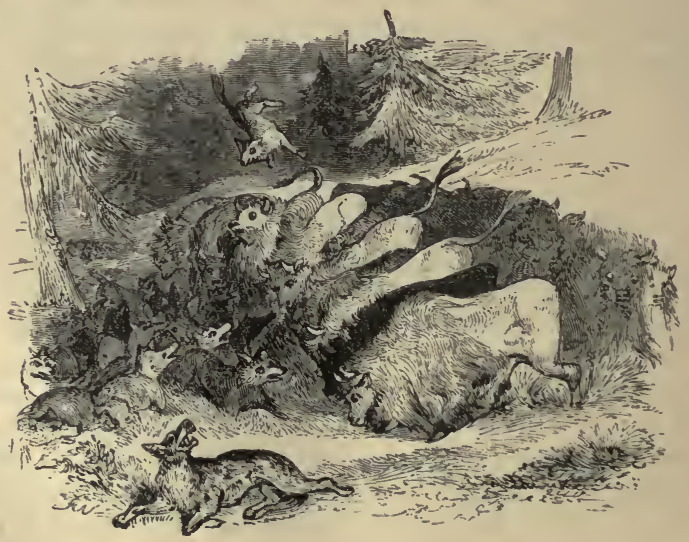




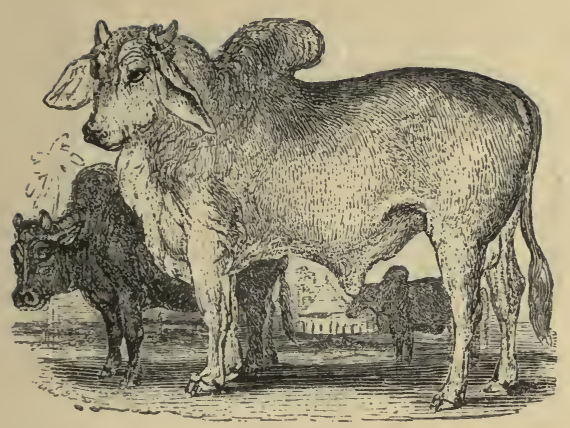

THE ZEBU, OR BRAHMIN BULL. (Bos Indicus.)

Pennant describes the Zebu, or Indian $\mathrm{Ox}$, as sometimes surpassing in size the largest of the European breeds, and the hunch on his shoulders as weighing frequently fifty pounds. 'There are many varieties, with and without horns, differing in size from that above-named, down to the dimensions of an ordinary hog. They are spread over the whole of Southern Asia, and also in Africa. In all these countries the Zebu supplies the place of the $\mathrm{Ox}$, both as a beast of burden and as an article of food. $\mathrm{By}$ the Hindons they are treated with great veneration, and it is held sinful to deprive them of life, or eat their flesh. A select number are exempted from all labour, and allowed to wander about, and subsist on the voluntary and pious contributions of the devotees of their faith.

Emboldened by the toleration they experience, they make free with every vegetable to which they take a fancy, no one daring to resist or drive them away ; often they lie down in the street; no one must disturb them: every one must give place to the sacred Ox of Brahma; thus they are frequently nuisances, which superstition alone would endure. 


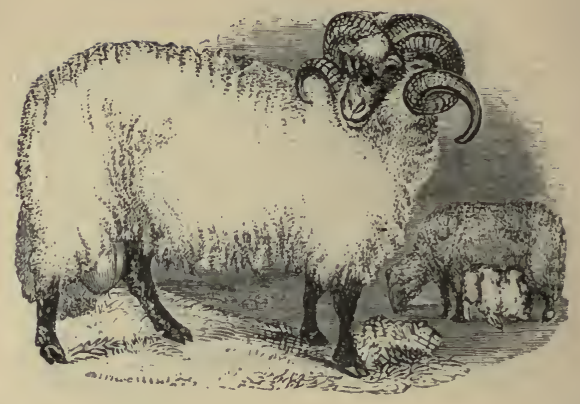

THE SHEEP. (Oris Aries.)

THE Sheep has been so long subjected to the empire of man that it is not known with certainty from what race our domestic species has been derived. It is supposed, however, to be from the Mouflon, or Musmon, of Sardinia and Crete. This animal is one of the most useful ever bestowed on us by a bountiful Providence; and in patriarchal times the number of Sheep constituted the riches of kings and princes. It is universally known, its flesh being one of the chief kinds of human food, and its wool being of great use for clothing. Althongh of a moderate size, and well covered, it does not live more than nine or ten years. 'The Ewe has one or two young at a time, and the young one, which is called a lamb, has always been an emblem of innocence.

In its domestic state it is too well known to require a detail of its peculiar habits, or of the methods which have been adopted to improve the breed. No country produces finer Sheep than England, either with larger fleeces or better adapted for the business of clothing. Those of Spain have confessedly finer wool, sume of which we generally require to work up with our own, but the weight of a Spanish fleece is much inferior to one of Lincoln or Tees Water. Merino, or Spanish Sheep, have of late years been introduced with some 
success into our English pastures, and the wool of the hybrids, raised between the Merino Sheep and the South Down Sheep, is thought nearly equal to that of Spain.

In stormy weather, these animals generally hide themselves in caves from the fury of the elements; but if such retreats are not to be found, they collect themselves together, and, during a fall of snow, place their heads near each other, with their muzzles inclined to the ground. In this situation they sometimes remain till hunger compels them to gnaw each other's wool, which forms into hard balls in the stomach and destroys them. But in general they are sought out and extricated soon after the storm has subsided.

"The Sheep," Mr. Bell observes, " is one of the most interesting of all animals as regards its historical relations with man. It was the subject of the first sacrifices, and was used in its typical character as an offering of atonement; and the relation which existed between the patriarchal shepherds and their flock was of so intimate and even affectionate a nature as to have afforded the subject of many beautiful passages in the Holy Scriptures."

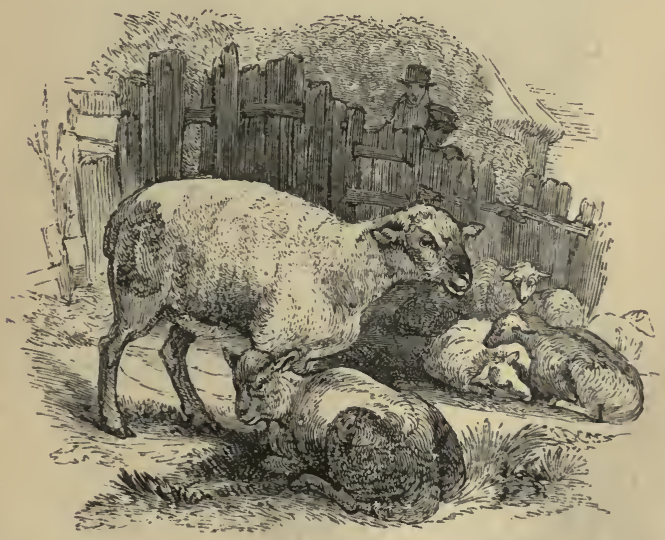




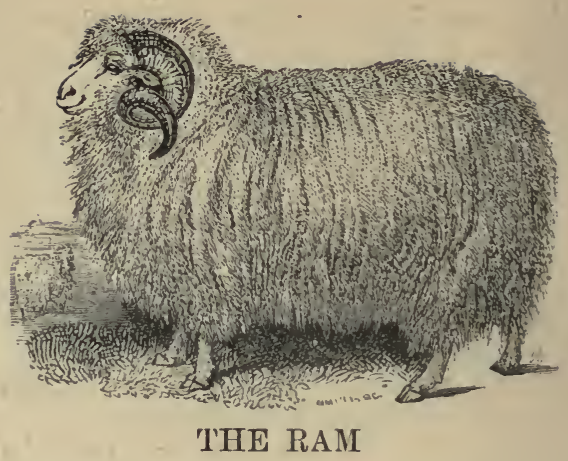

Is the male Sheep, and is so strong and fierce that he will boldly attack a dog, and often comes off victorious : he has even been known, regardless of danger, to engage a bull; and his forehead being much harder than that of any other animal, he seldom fails to conquer. $\mathrm{He}$ overcomes the bull, who, by lowering his head, receives the stroke of the Ram between his eyes, which usually brings him to the ground.

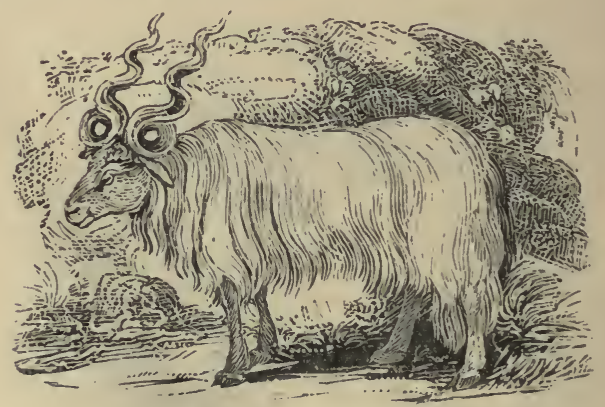

\section{THE WALLACHIAN RAM.}

THE singular conformation of the horns, which adorn the head of this breed of Sheep, has induced us to insert a figure of the animal in this work, though it is only a 
variety of the common species. The horns of the Ewe are twisted also, but not so much as those of the Ram, which form, near the head, a spiral line. The wool is much longer than that of the common Sheep, and resembles the hair of the goat. A fine Ram of this species was presented some years since to the Zoological Gardens in the Regent's park, by Dr. Bowring. It is there called the Parnassian Sheep, having been brought from Mount Parnassus.

\section{THE ARGALI, OR WILD SHEEP OF ASIA,}

in figure somewhat resembles a ram, but his wool is rather like the hair of a goat. His horns are large and bent backwards, and his tail is short. He is of the size of a small deer, actire, swift, wild, and found in flocks in the rocky, dry deserts of Asia. His flesh and fat are delicious. He is called also the Siberian Sheep or Goat, and is considered by some to be the parent stock of the domestic Sheep.

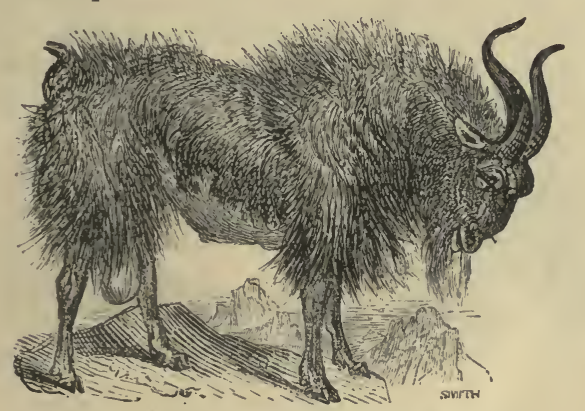

THE GOAT. (Capra hircus.)

'THe Goat, next to the cow and the sheep, has been always reckoned, especially in ancient and patriarchal times, the most useful domestic animal. Its milk is sweet, nourishing, and medicinal, and better adapted for persons of weak digestion than that of the cuw, as it is not so apt to curdle on the stomach. The female has generally two young ones at a time, which are called kids. This animal is admirably adapted for living in 
wild places; it delights in climbing precipices, and is often seen reposing in peaceful security on rocks overhanging the sea. Nature indeed has in some measure fitted it for traversing these eminences; the hoof being hollow underneath, with sharp edges, so that it can walk as securely on the ridge of a house as on the level ground. The flesh of the goat is seldom eaten; but that of the kid is esteemed a very delicate food, and is frequently eaten on the Continent. In the East, the long soft hair of the goat is used in making the beautiful Cashmere shawls; and from the skin is manufactured morocco leather. The skin of the kid is well known for its use in making gloves.

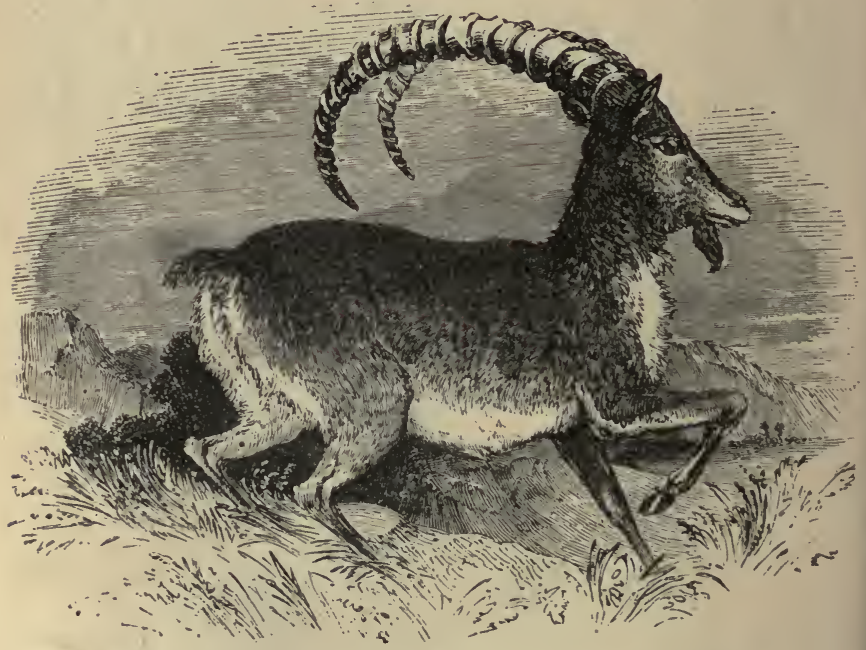

\section{THE IBEX, OR BOQUETIN, (Capra Ibex,)}

Is a Wild Goat, which inhabits the Pyrenean mountains, the Alps, and the highest mountains of Greece. $\mathrm{He}$ is of an admirable swiftness; his head is armed with two long, knotted horns, inclining backwards; his hair is rough, and of a deep brown colour. The male only 
has a beard, and the female is less than the male. This animal skips from rock to rock, and often, when pursued, leaps down enormous precipices, and is said to bend his head between his fore legs while springing, so as to break his fall, by alighting partly on his horns. The Ibex has been known to turn on the incautious huntsman, and tumble him down the precipice, unless he has time to lie down, and let the animal pass over him.

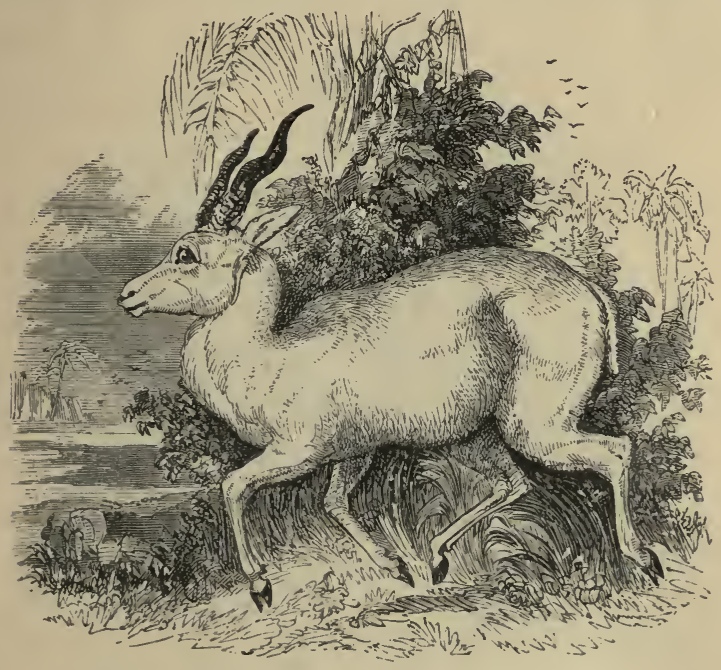

THE ANTELOPE. (Antilope cervicapra.)

THese beautiful inhabitants of the temperate regions of Africa, and southern Asia, possess swiftness and elegance of shape in an eminent degree. They are timid, inoffensive, and gregarious. The males have horns like those of the goat, and never shed them; they are smooth, long, twisted spirally, and annulated. The general colour of the hair is brown, and, in some species, a beautiful yellow. - The eyes are exceedingly bright, and have often been compared to those of a beautiful nymph by Persian and other poets. Enjoying perfect li" rty, they 
range in herds through the deserts of Arabia, and bound from rock to rock with wonderful agility. Their long and slender legs are peculiarly suited to their habits and manners of life, and are, in some of the species, so slender and brittle as to snap with a very trifling blow. The Arabs, taking advantage of this circumstance, catch them by throwing sticks at them, by which their legs are broken.

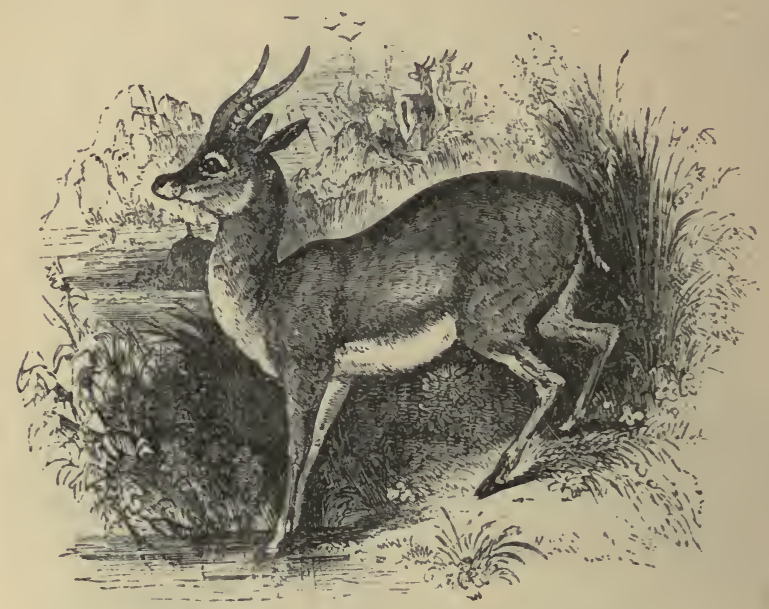

THE GAZELLE. (Antilope Dorcas.)

"The wild Gazelle, on Judah's hills, Exulting yet may bound, And drink from all the living rills

That gush on holy ground.

Its airy step and glorious eye

May glance in tameless transport by."-Byron.

The Gazelle is the most elegant of antelopes. The Arabian poets have applied their choicest epithets to the beauty of this animal, and their descriptions have been adopted into our own poetry. Byron, in speaking of the dark eyes of an eastern beauty, says :

"Go look on those of the Gazelle." 
When the Persian describes his mistress, she is "an antelope in beauty,"- " his Gazelle employs all his soul ;" and thus, in their figurative language, perfect beauty and Gazelle beauty are synonymous. These animals are spread, in innumerable herds, from Arabia to the river Senegal in Africa. Lions and panthers feed upon them: and man chases them with the dog, the cheetah, and the falcon. The height of the Gazelle is about twenty inches, the skin beautifully sleek, its body extremely graceful, its head unusually light, its ears flexible, its eyes most brilliant and glancing, and its legs as slender as a reed.

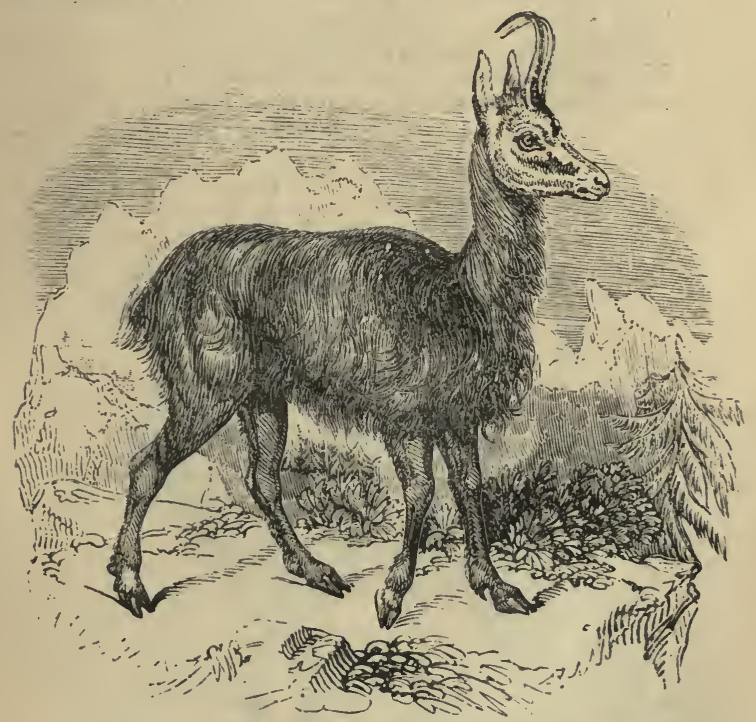

THE CHAMOIS. (Antilope Rupicapra.)

The Chamois is about three feet in length and two in height; its horns six or seven inches long, its ears small, and its head resembling that of the goat. The body is covered with long, brown hair, the hue of which varies with the season. 
The flesh is considered a savoury food, and the skin is wrought into a soft pliable leather, well known in domestic economy.

The Chamois is found only in the mountainous regions of Europe, where they herd together on lofty and almost inaccessible cliff's and precipices. They are so acute and shy, that it is only by the greatest patience and skill that the hunter can approach near enough to shoot them ; and they are so swift, and leap with such extraordinary sureness of foot, that to overtake them is impossible.

But beasts have reason too,

And that we know, we men that hunt the Chamois, They never turn to feed-sagacious creatures'Till they have placed a sentinel a-head, Who pricks his ears whenever we approach, And gives alarm with clear and piercing pipe."

Schiller's Williair Tell.

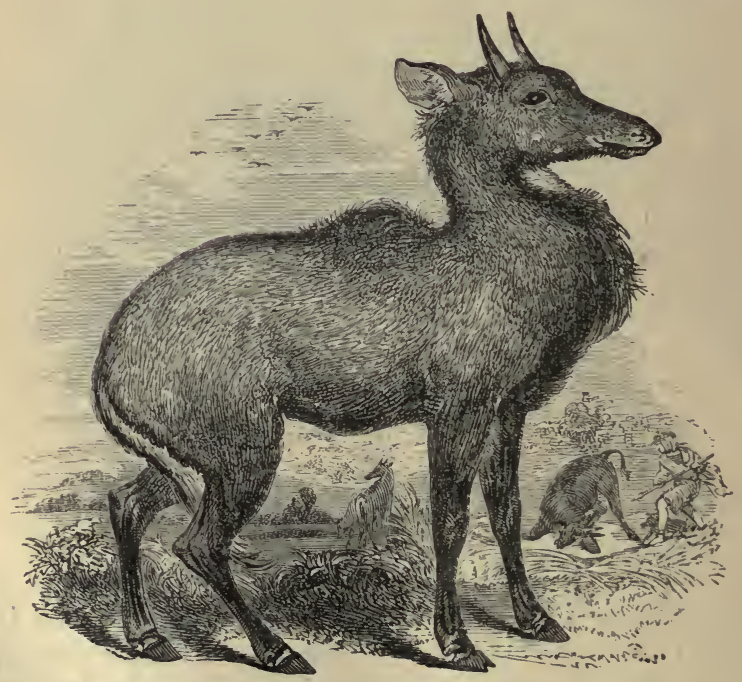

THE NYL GHAU, OR BLUE OX. (Antilope picta.)

Thus is a large kind of antelope, found in India. In the 
wild state these animals are very ferocious, but they may be domesticated, and in that condition give frequent tokens of familiarity, and even of gratitude, to those under whose care they are placed. The female, or doe, is much smaller than the male, and of a yellowish colour, by which she is easily distinguished from the buck, who is of a grey tint.

Its manner of fighting is very peculiar, and is thus described:-Two of the males, at Lord Clive's, being put into an enclosure, were observed, while they were at some distance from each other, to prepare for the attack, by falling down upon their knees; they then shuffled towards each other, still keeping upon their knees; and, at the distance of a few yards, they made a spring, and darted against each other with great force.

The following anecdote will serve to show that these animals are sometimes fierce and vicious, and not to be depended upon:-A labouring man, without knowing that the animal was near him, went up to the outside of the enclosure; the Nyl Ghau, with the quickness of lightning, darted against the woodwork with such violence that he dashed it to pieces, and broke one of his horns close to the root. The death of the animal soon after was supposed to be owing to the injury he sustained by the blow.

The Nyl Ghau usually keeps closely concealed in the jungle, but in the night or early morning it sometimes passes into the open ground, to feed in the cornfields belonging to the neighbouring villages. This is the moment chosen by the natives to attack it. A platform is erected near the spot the Nyl Ghau is known to frequent, from which the hunters can take aim with precision and safety. 


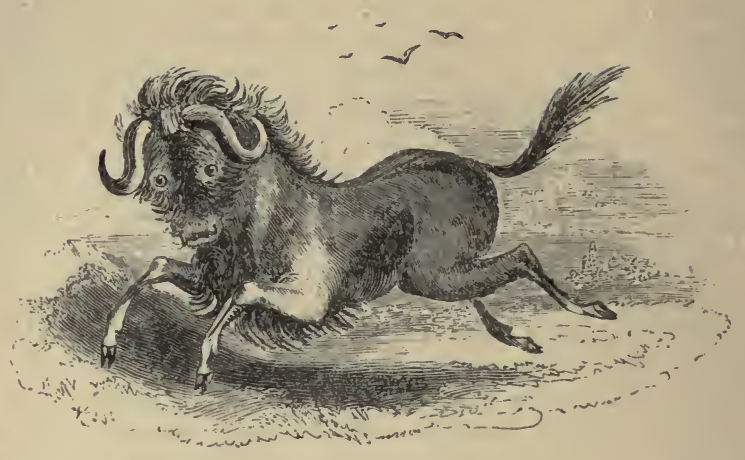

\section{THE GNU. (Antilope Gnu.)}

This very singular animal is sometimes called a horned horse; as it has the shape and mane of a horse, with the addition of a formidable pair of horns, a kind of beard below the chin, and a fringe of hair below the body, along the breastbone. The Gnus live together in herds, and when alarmed, fling up their heels, and plunge and rear, tossing their heads and tails, before they gallop off; which they do, the whole herd following their leader singly, like a troop of soldiers. The Gnu inhabits the sandy deserts of South Africa; and its flesh, which is said to resemble beef, is sometimes eaten by the colonists near the Cape of Good Hope. When caught young the Gnu may be tamed, but its disposition is always uncertain, and when offended it throws itself on its knees, like the nyl ghau, and then springing up, butts furiously with its horns. 


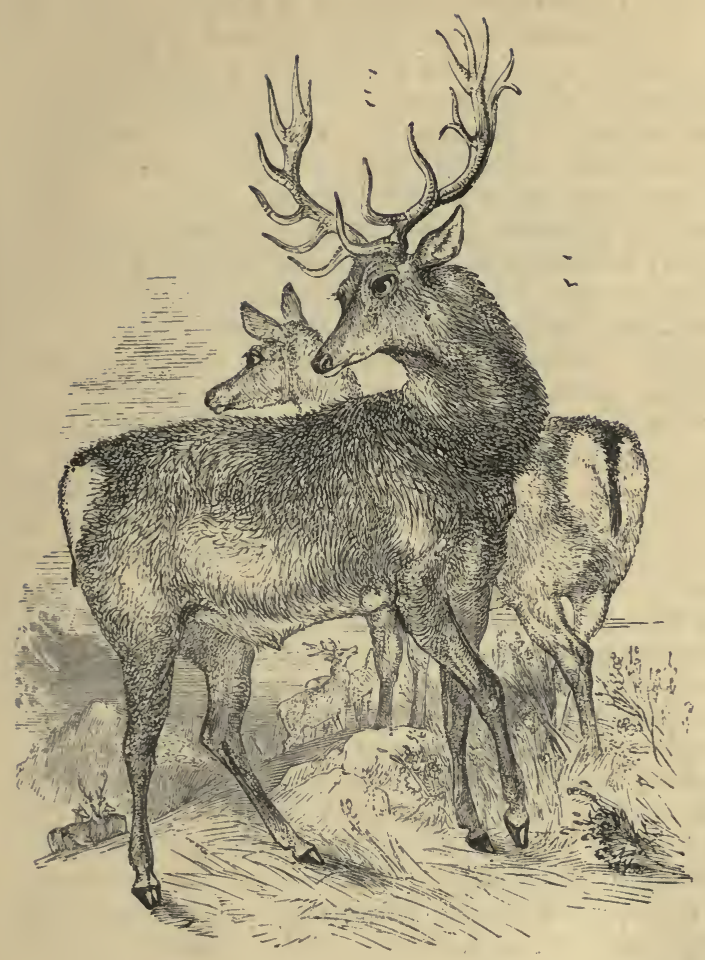

THE STAG. (Cervus Elaphus.)

Tris animal is the male of the red Deer, and is generally famed for long life, though upon no certain authority. Naturalists agree, however, upon this point, that his life may exceed forty years : but that his existence, as it has been asserted, reaches to three centuries, is too absurd to be believed. His horns are at first very small, but gradually increase in size, as they are yearly shed and renewed, till the stag has completed his fifth year, when they become very large and branching, and 
remain so during the remainder of his life. The Stag is one of the tallest of the deer kind, and is called a Hart after he has completed his fifth year; the female, called the Hind, is without horns. Every year, in the month of April, when the Stag has lost his horns, he appears conscious of his temporary weakness, and hides himself till his new ones have grown and are hardened. T'his is generally in about ten weeks, even when the Stag is full grown; his horns at this age weigh between twenty and thirty pounds. Little need be said of the pleasure taken in hunting the Stag, the Hart, and the Roebuck, it being a matter well known in this country, and in all parts of Europe. The following fact, recorded in history, will serve to show that the Stag is possessed of an extraordinary share of courage, when his personal safety is concerned:- In the reign of George the Second, William, Duke of Cumberland, eaused a tiger and a Stag to be enclosed in the same area; and the Stag made so bold a defence, that the tiger was at length obliged to give up. The flesh of the Stag is accounted excellent food, and his horns are useful to cutlers; even their shavings are used to make ammonia, so much esteemed in medicine under the name of hartshorn. The swiftness of the Stag has become proverbial, and the diversion of hunting this creature has, for ages, been looked upon as a royal amusement. In the time of William Rufus and Henry the First, it was less criminal to destroy a human being than a full-grown Stag. This animal, when fatigued in the chase, often throws himself into a pond of water, or crosses a river; and, when caught, sheds tears like a child.

"To the which place a poor sequestered Stag,

That from the hunter's aim had ta'en a liurt, Did come to languish; and indeed, my lord, The wretched animal heaved forth such groans That their discharge did stretch his leathern coat Almost to bursting; and the big round tears Coursed one another down his innocent nose In piteous chase." 


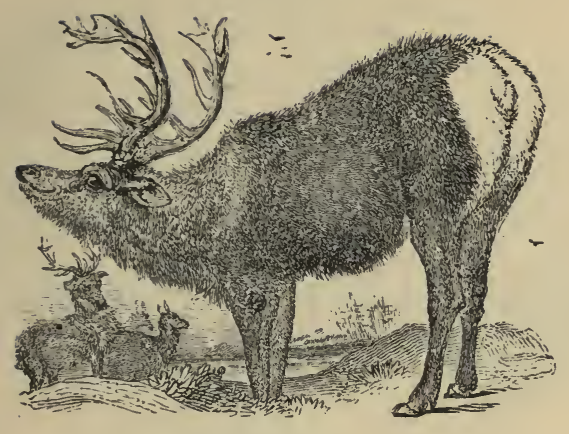

THE WAPITI, (Cervus Canadensis,)

Is a native of Canada and other northern parts of America, and is one of the most gigantic of the Deer tribe, growing to the height of our tallest oxen, and uniting great activity to streugth of body and limbs. His horns, which he sheds annually, are very large, branching in serpentine curves, and measuring from tip to tip upwards of six feet. 'These animals make a shrill noise, resembling the braying of an ass, and are supposed to be the most stupid of the Deer kind. The flesh is coarse, and little esteemed, but the hide, when made into leather, is said not to become hard in drying after being wetted, a quality which entitles it to a preference over almost every other kind. There are several of these splendid animals in the collection of the Zoological Society, in the Regent's Park, where they continue to form objects of singular interest and attraction. The male is, however, very fierce, always endeavouring to attack those who approach him; and on one occasion seriously injured one of the visitors to the gardens. 


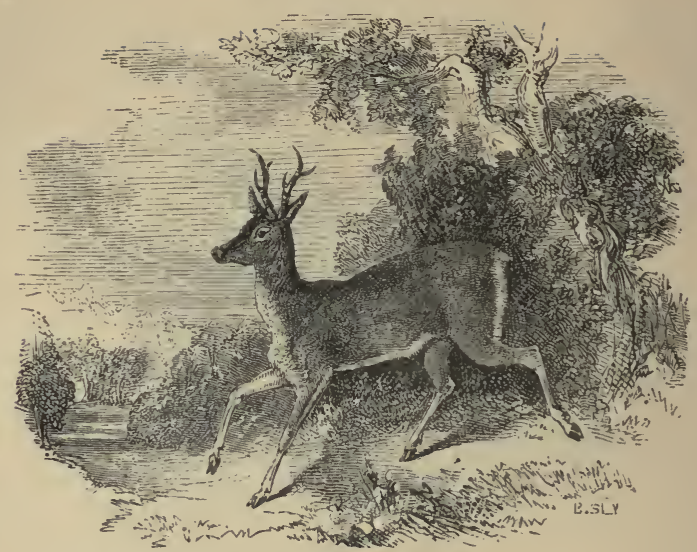

\section{THE ROEBUCK, (Cervus capreolus,)}

Is one of the least of the Deer kind known in these climates, being not above three feet in length, and two in height, and seldom lives more than fifteen years. His horns are about, nine inches long, round, and divided into three small branches, and his colour is of a brown shade on the back, his face partly black and partly ash-colour, the chest and belly yellow, and the rump white; his tail is short. The Roebuck is more graceful, more active, more cunning, and comparatively swifter than the stag; his flesh is much esteemed. He is very delicate in the choice of his food, and requires a larger tract of country, suited to the wildness of his nature, which can never be thoroughly subdued. No arts can teach him to be familiar with his keeper, nor in any degree attached to him. These animals are easily terrified; and in their attempts to escape will run with such force against the walls of their enclosure, as sometimes to disable themselves: they are also subject to capricious fits of fierceness; and, on these occasions, will strike furiously with their horns and feet at the object of their dislike. The only parts of Great Britain where they are now found are the Highlands of Scotland. 


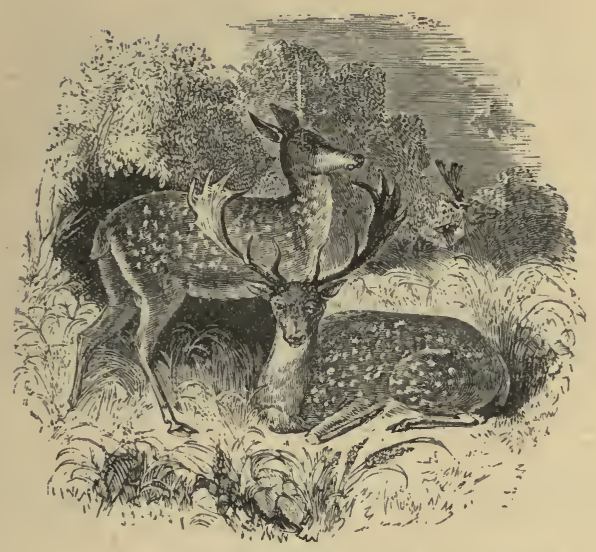

THE FALLOW DEER. (Cervus dama.)

Trese are the Deer now usually kept in our parks. The beautifully spotted kind are said to have been brought from Bengal, and the very deep brown from Norway by King James I. Their horns are broad and flat; the male is called a buck, the female a doe, and the young one a fawn. The buck casts his horns every spring, and they increase in size annually till he has attained his fifth year. The venison of this Deer is very far superior to that of the red deer, which is coarse and tough. The buck-skin and doe-skin are well known, as furnishing a peculiarly soft and warm leather, which is used for gloves, gaiters, \&c. The horns are used for the handles of knives, \&c., like those of the stag; and the refuse is, in the like manner, used in the manufacture of ammonia. The buck stands about three feet high, and measures about five feet in length; the doe is somewhat smaller. The tail is much longer than either that of the stag or the roebuck, being nearly seven inches and a half long. 


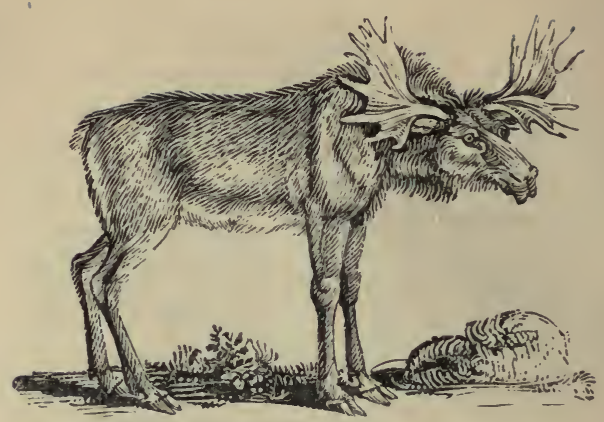

THE ELK, (Cervus Alces,)

Is the largest of all the Deer kind. The antlers, at first simple, and then divided into narrow slips, assume in the fifth year the form of a triangular blade, dentated on the external edge and very thick at the base ; they increase with age, till they weigh fifty or sixty pounds, and have fourteen branches to each horn. The Elk lives in forests, feeding upon branches and sprouts of trees, and inhabits Europe, Asia, and America : in the last-named country he is known by the name of the Moose Deer. There is very little difference between the European Elk and the American Moose Deer, though they are larger in the New World than with us, owing perhaps to the extensive forests in which they range. In all places, however, they are timorous and gentle; content with their pasture, and never willing to disturb any other animal. The pace of the Elk is a high, shambling trot, but it runs with great swiftness. Formerly these animals were made use of in Sweden to draw sledges, but their swiftness gave criminals such means of escape, that this employment of them was prohibited under great penalties. The female is less than the male, and has no horns. 


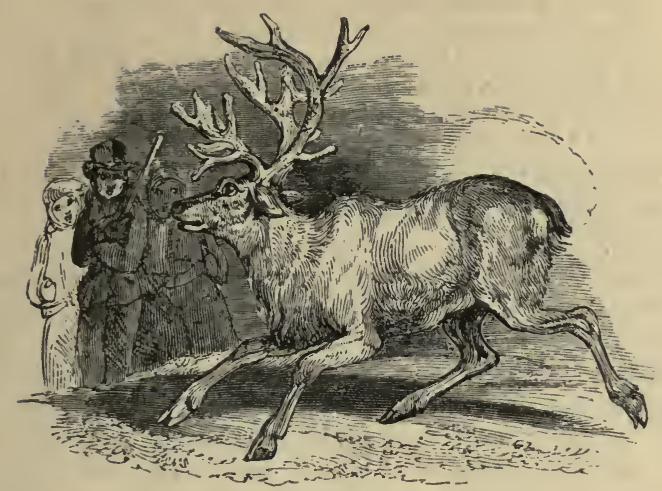

THE REIN-DEER, (Cervus Tarandus, or Rangifer Tarandus,)

Is found in most of the northern regions of Europe, Asia, and.America, and its general height is about four feet and a half. The colour is brown above and white beneath; but as the animai advances in age, it often becomes of a greyish white. The hoofs are long, large, and black. Both sexes are furnished with horns, but those of the male are much the largest. To the Laplanders this animal supplies the place of the horse, the cow, the goat, and the sheep, it is their only wealth. The milk affords them cheese, the flesh, food; the skin, clothing; of the tendons they make bowstrings, and when split, thread; of the horns, glue; and of the bones, spoons. During the winter, the Reindeer supplies the want of a horse, and draws sledges with amazing swiftness over the frozen lakes and rivers, or over the snow, which at that time covers the whole country. Innumerable are the uses, the comforts, and advantages which the poor inhabitants of this dreary climate derive from this animal. We cannot sum them up better than in the beautiful language of the peet:

"Their Rein-deer form their riches. These their tents, Their robes, their beds, and all their homely wealth 
Supply, their wholesome fare, and cheerful cups :

Obsequious at their call, the docile tribe

Yield to the sled their necks, and whirl them swift

O'er hill and dale, heaped into one expanse

Of marbled snow, as far as eye can sweep,

With a blue crest of ice unbounded glazed."

The mode of hunting the wild Rein-deer by the Laplanders, the Esquimaux, and the Indians of North America, has been accurately described by late travellers. Captain Franklin gives the following interesting account of the mode practised by the Dog-rib Indians, to kill these animals. "The hunters go in pairs, the foremost man carrying in one hand the horus and part of the skin of the head of a Deer, and in the other a small bundle of twigs, against which he, from time to time, rubs the horns, imitating the gestures peculiar to the animal. His comrade folluws, treading exactly in his footsteps, and holding the guns of both in a horizontal position, so that the muzzles project under the arms of him who carries the head. Buth hunters have a fillet of white skin round their foreheads, and the foremost has a strip of the same round his wrists. They approach the herd by degrees, raising their legs very slowly, but setting them down somewhat suddenly, after the manner of a Deer, and always taking care to lift their right or left feet simultaneously. If any of the herd leave off feeding to gaze upon this extraordinary phenomenon, it instantly stops, and the head begins to play its part, by licking its shoulders, and performing other necessary movements. In this way the hunters attain the very centre of the herd without exciting suspicion, and have leisure to single out the fattest. The hindmost man then pushes forward his comrade's gun, the head is dropped, and they both fire nearly at the same instant. The Deer scamper off, the hunters trot after them; in a short time the poor animals halt, to ascertain the cause of their terror; their foes stop at the same moment, and having loaded as they ran, greet the gazers with a second fatal discharge. The consternation of the Deer increases; they run to and fro in the utmost confusion; and sometimes a great part of the herd is destroyed within the space of a few hundred yards." 


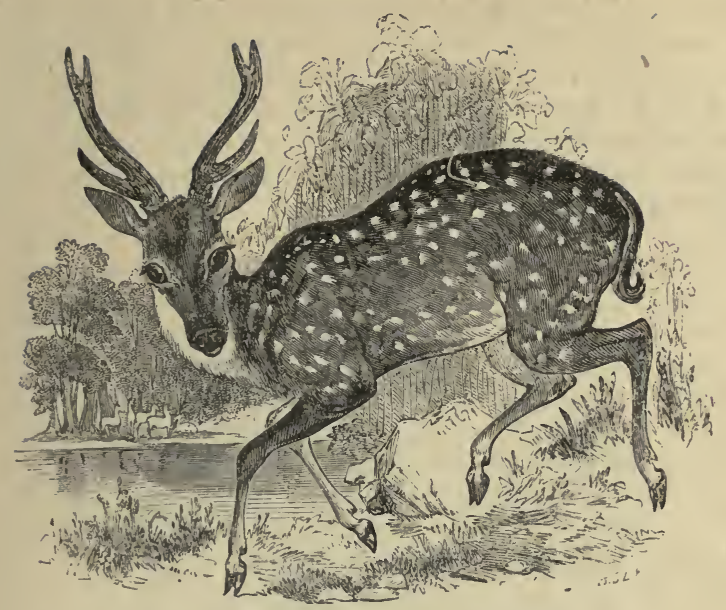

THE AXIS. (Cervus Axis.)

A VERY beautiful species of the Deer is found in the East Indies, of a light red colour, though some of the kind are of a deeper red. It is about the size of a fallow deer, and often variegated with beautiful spots of bright white. The horns are slender and triple-forked. 'T'he Axis is a timid and harmless creature, more ornamental to the landscape, where it skips and plays in a wild state, than useful to man. It is extremely ducile, and possesses the sense of smelling to an exquisite degree. Though it is a native of the banks of the Ganges, it appears to bear the climates of Europe without injury.

\section{THE MUSK DEER. (Moschus moschiferus.)}

THrs is a small species of Deer, quite destitute of horns, which lives on the vast plains of Central Asia. It is distinguished by possessing a pair of canine teeth or tusks in the upper jaw; and these teeth, which are not found in the ruminant animals generally, are so long in the Musk Deer that they project from the sides of the 
mouth and descend below the chin. The Musk Deer is exceedingly active, and leaps to an astonishing height. The male is remarkable for possessing a pouch about the size of an egg, near the navel; this contains a brown, oily matter, of a most powerful odour, which is the wellknown perfume called musk, so highly esteemed amongst Eastern nations.

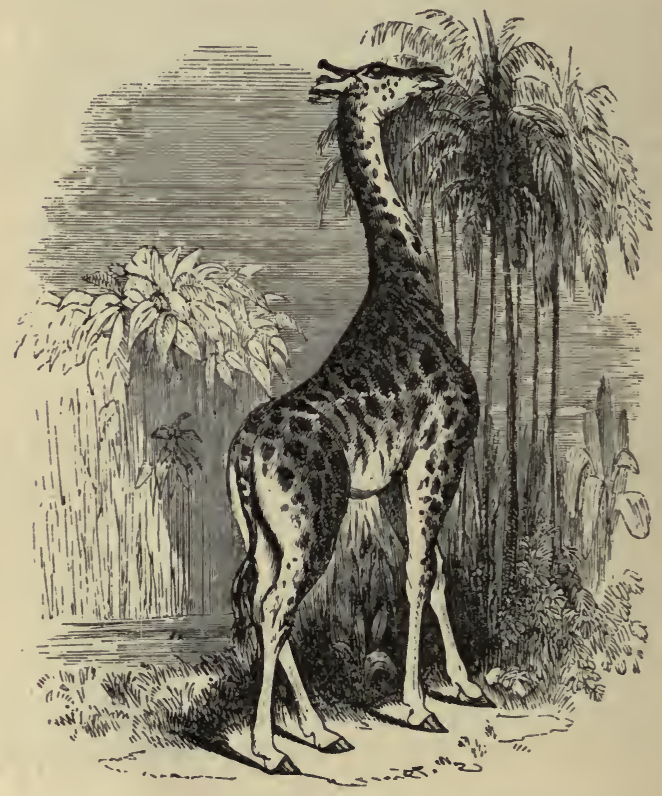

THE GIRAFFE, OR CAMELOPARD.

(Camelopardalis Giraffa.)

THis most remarkable ruminant, which in its general structure nearly approaches the Deer, has points of affinity also with the antelopes and camels, besides very striking peculiarities of its own. 


\section{The Giraffe.}

The head is the most beautiful part of the animal : it is small, and the eyes are large, brilliant, and very full. Between the eyes, and above the nose, is a swelling very prominent and well-defined. This prominence is not a fleshy excrescence, but an enlargement of the bony substance; and it seems to be similar to the two little lumps, or horns, with which the top of the head is armed, and which, being several inches in length, spring on each side of the head, just above the ears, and are terminated by a thick tuft of stiff upright hairs. The neck is remarkably elongated, and it is furnished with a very short, stiff mane, which stands out erect frora the skin. The height of a full-grown Giraffe in a wild state is said to be seventeen or eighteen feet, measuring from the hoofs to the tip of the ears; but none of those in England exceed fourteen feet. At first sight, the fore legs appear much longer than the hind ones; but the fact is, that the legs are of the same length, and it is only the height of the withers that occasions the apparent disproportion. Le Vaillant was the first well-informed naturalist who studied the habits of the Giraffe in its wild state. "If," he says, "among the known quadrupeds, precedency be allowed to height, the Giraffe withoint doubt must hold the first rank. A male which I have in my collection measured, after I killed it, sixteen feet four inches from the hoof to the extremity of its horns. I use this expression in order to be understood; for the Giraffe has no real horns; but between its ears, at the upper extremity of the head, arise in a perpendicular and parallel direction two excrescences from the cranium, which without any joint stretch to the height of eight or nine inches, terminating in a convex knob, and are surrounded by a row of strong straight hair, which overtops them by several lines. 'I'he female is generally lower than the male. . . . . In consequence of the number of these animals which I killed, or had an opportunity of seeing, I may establish as a certain rule that the males are generally fifteen or sixteen feet in height, and the females from thirteen to fourteen feet." The colour of the Giraffe is a light fawn, marked with spots only a few shades darker. 'The legs are very 
slender; and, notwithstanding the length of the neck, it manifests great difficulty in taking anything from the ground. To do this, it puts out first one foot, and then the other; repeating the same process several times; and it is only after several of these experiments that it at length bends down its neck, and applies its lips and tongne to the object in question. In fact, the neck of the Giraffe, although so enormously long, is not very flexible, as it contains only the same number of yertebre or joints (seven) that is found in other quadrupeds with a much shorter neck; it is admirably adapted for enabling the animal to browse upon the branches of trees, but is not intended to fit it for grazing. It willingly accepts fruit and branches of a tree when offered to it; and seizes the foliage in a most singular manner, thrusting forth a long, reddish, and very narrow tongue, which it rolls round whatever it wishes to secure. Indeed, the tongue is a most remarkable organ in this animal, and we have been witness of sume amusing exploits with it. In the Zoological Gardens at Regent's Park, many a fair lady has been robbed of the artificial flowers which have adorned her bonnet, by the nimble, filching tongue of the rare object of her admiration.

'The Giraffe is a native of Africa; and it was for a long time known only by the descriptions of travellers. It was first sent to Europe in 1829 ; but since that time many have been introduced, and several young ones have been born in the Zoological Gardens in the Regent's Park.

Le Vaillant, in his entertaining Travels in Africa, gives an animated account of a Giraffe hunt:- "After several hours' fatigue, we discovered, at the turn of a hill, seven Giraffes, which my pack instantly pursued. Six of them went off together; but the seventh, cut off by my dogs, took another way. I followed it at full speed, but, in spite of the efforts of my horse, she got so much ahead of me that, in turning a little hill, I lost sight of her altogether. My dogs, however, were not so easily put out. They were soon so close upon her, that she was obliged to stop to defend herself. From the place where 
I was, I heard them give tongue with all their might; and, as their voices appeared all to come from the same spot, I conjectured that they had got the animal in a corner, and I again pushed forward. I had scarcely got round the hill, when I perceived her surrounded by the dogs, and endeavouring to drive them away by heavy kicks. In a moment I was on my feet, and a shot from my carbine brought her to the earth. Enchanted with my victory, I returned to call my people about me, that they might assist in skinning and cutting up the animal. On my return I found her standing under a large ebonytree, assailed by my dogs. She had staggered to this place, and fell dead at the moment I was about to take a second shot."

The horns of the Giraffe, small as they are, and muffled with skin and hair, are by no means the insignificant weapons they seem. We have seen them wielded by the males against each other with fearful and reckless force; and we know that they are the natural arms of the Giraffe, most dreaded by the keeper of the present living Giraffes in the Zoological Gardens, because they are most commonly and suddenly put in use. The Giraffe does not butt by depressing and suddenly elevating the head, like the deer, ox, or sheep; but strikes the callous obtuse extremities of the horns against the object of his attack, with a sidelong sweep of the neck.

The Giraffe has a peculiarly awk ward manner of trotting, as it moves both the legs on one side at the same time. In galloping, the Giraffe separates its hind legs widely, and at each stride brings them far forward on each side of the fore feet; in this way the animal makes rapid progress, although its appearance is rather extraordinary, and the stones cast backwards by the force of the "hind feet not unfrequently assist in protecting it when closely pursued. The female Giraffe in the Regent's Park was a very bad mother to her first young one, as she would not let it suck, and beat it away whenever it approached. The poor thing was fed with cow's milk, but it soon died. Later young ones have been more kindly treated, and have in consequence thriven well. 


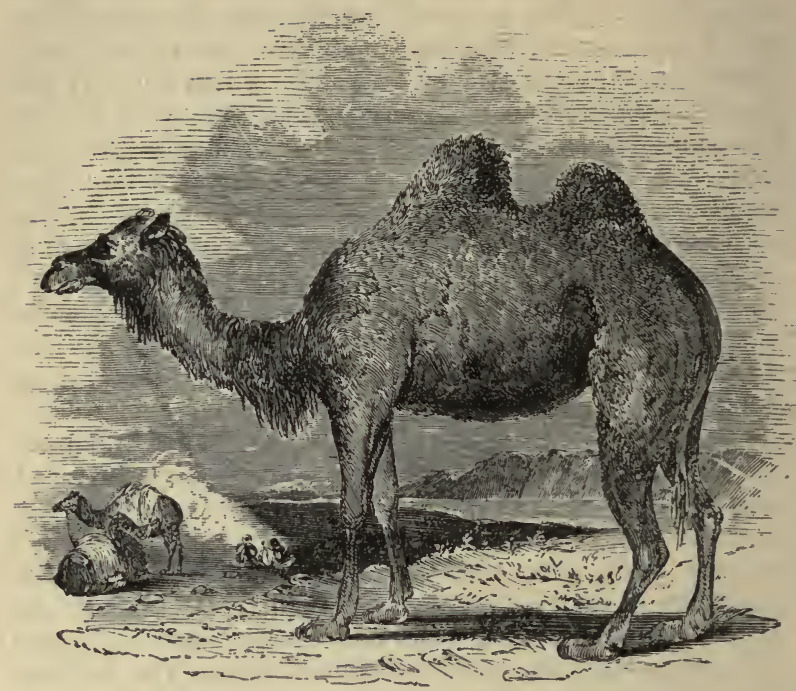

\section{THE BACTRIAN CAMEL. (Camelus Bactrianus.)}

"In silent horror, o'er the boundless waste, The driver Hassan with his Camels pissed: One cruse of water on his back lie bore, And his light scrip contained a scanty store: A fan of painted feathers in his hand, To guard his shaded face from scorching sand; The sultry sun had gained the middle sky, And not a tree, and not a herb was nigh: The beasts with pain their dusty way pursue, Shrill roar'd the winds, and dreary was the view !'

Colmixs.

The Bactrian Camer is a native of the deserts of Asia, and is generally of a brown or ash colour. His height is about six feet. He is one of the most useful quadrupeds in oriental countries; his docility and strength, his endurance of hunger and thirst, and his swiftness, make him a most valuable acquisition to the inhabitants of those pesert places. The principal characteristics of the Camel 
are these:- He has two large and hard bunches on his back, and is destitute of horns; the upper lip is divided like that of the hare; and the hoofs small and placed at the end of two long toes, which are united below by a pad-like sole. But the peculiar and distinguishing characteristic of the Camel is its faculty of abstaining from water for a greater length of time than any other animal ; for which nature has made a wonderful provision, by adapting the surface of one of the four stomachs, which it has in common with all ruminating animals, to serve as a reservoir for water, where it remains without corrupting or mixing with the other aliments. By this singular structure it can take a prodigious quantity of water at one draught, and is enabled to pass as much as fifteen days without drinking again. But besides this reservoir of water the animal is said in cases of emergency to draw sustenance from the humps on his back, which are of a fatty substance : thus, after long privation, they become absorbed. A large Camel is capable of carrying ten or even twelve hundredweight, and, like the elephant, is tame and tractable; but, like him, he has his periodical fits of rage, and at these times has been known to take up a man in his teeth, throw him on the ground, and trample him under his feet. Like the horse, he gives security to his rider; and, like the cow, he furnishes his owner with meat for his table, and the female with milk for his drink. The flesh of the young Camel is esteemed a delicacy, and the milk of the female, diluted in water, is the common drink of the Arabians. The hair or fleece, which falls off entirely in the spring, is superior to that of any other domestic animal, and is made into very fiue stuffs, for clothes, coverings, tents, and other furniture. 'The female goes one year with young, and produces but one at a time. The Camel kneels to receive his burthen, and it is said that he refuses to rise if his master imposes upon him a weight above his strength. He has callosities on his knees and on his breast, which prevent him from being hurt by kneeling to take up his load; and sleeps with his knees bent under him, and his breast on the ground. He arrives at maturity in about five years, and the duration of his life is frum forty to fifty years. 


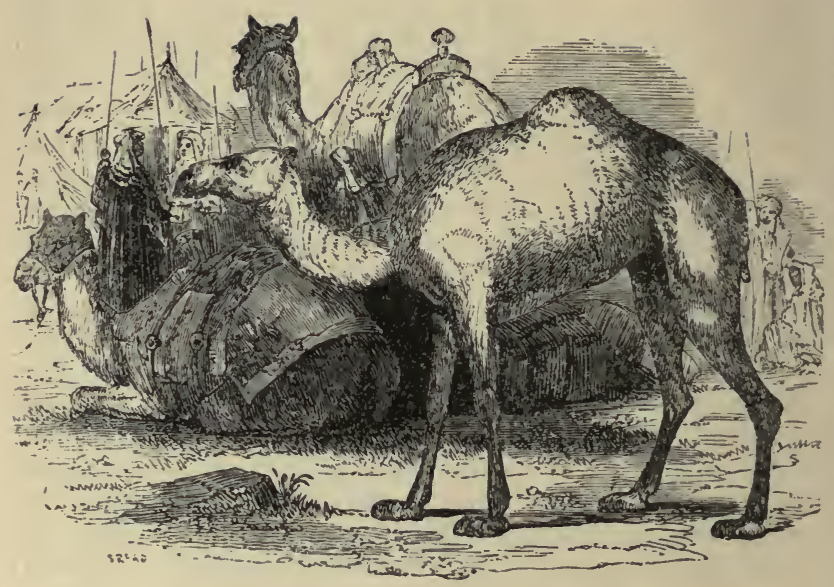

THE ARABIAN CAMEL, OR DROMEDARY.

(Camelus Dromedarius.)

Avother species of Camel, of less stature than the former, but much swifter, and having but one hard bunch on nis back, is domesticated throughout Africa, as well as in Asia. It is said that a Dromedary can travel one hundred miles a day, and carry fifteen hundredweight. Attempts have been made to introduce the Camel and Dromedary into our West India islands, but they have not succeeded ; they have, however, been comparatively naturalized near Pisa in Italy. The Camels used as beasts of burden in Egypt are all Dromedaries; and the first experiment which an European makes in bestriding one is generally a service of some little danger, from the peculiarity of the animal's movement in rising. Denon, the French traveller, has described this with his usual vivacity : "During the French invasion of Egrpt, a part of Dessaix's division," to which the scientific traveller was 
attached, "was sent with Camels to a distant post across the desert. 'The Camel, slow as he generally is in his actions, lifts up his hind legs very briskly at the instant the rider is in the saddle; the man is thus thrown for.. ward; a similar movement of the fore legs throws him backward; each motion is repeated; and it is not till the fourth movement, when the Dromedary is fairly on his feet, that the rider can recover his balance. None of us could resist the first im pulse, and thus nobody could laugh at his companions." Macfarlane, in his work on Constantinople, tells us that upon his first Camel adventure he was su unprepared for the probable effect of the creature's rising behind, that he was thrown over his head, to the infinite amusement of the 'Turks, who laughed heartily at his inexperience.

Though the name of Dromedary is very generally applied to all the one-humped camels, both in common parlance and books on Natural History, it is said that the true Dromedary (El Herie) is merely a peculiarly swift camel. The name of Dromedary, indeed, appears to be applied in the East to all the higher bred camels, the genealogy of which is kept by the Arabs as carefully as that of their horses.

Possessing strength and activity surpassing that of most beasts of burthen, docile, patient of hunger and thirst. aud contented with small quantities of the coarsest provender, the camel is one of the most valuable gifts of Providence. There is nothing, however, in the exterior appearance of the animal to indicate the existence of any of its excellent qualities. In form and proportions it is very opposite to our usual ideas of perfection and beauty. A stout body, having the back disfigured by a great hump; limbs long, slender, and seemingly too weak to support the trunk; a long, thin, crooked neck, surmounted by a heavily-proportioned head, are all ill-suited to produce favourable impressions. Nevertheless, there is no creature more excellently adapted to its situation, nor is there one in which more of creative wisdom is displayed in the peculiarities of its organization. To the Arabs, and other wanderers of the desert, the Camel is at once wealth, subsistence, and protection. 


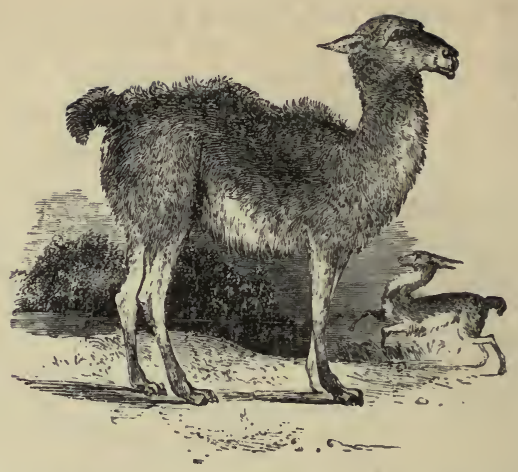

THE LLAMA, OR CAMEL OF AMERICA,

(Auchenia glama,)

Is a mild, timorous creature, not above four feet and a half in height, and usually of a brown colour. It bears in form a general resemblance to the Camel ; but, instead of a protuberance on the back, it has one on the breast. Llamas are used as beasts of burden by the South Americans, and are so capriciously vindictive, that, if their drivers strike them, they immediately squat down, and nothing but caresses can induce them to rise again. They have been known to kill themselves by striking their heads against the ground in their rage, when by blows they have been urged forward against their will. They express their anger by spitting at their adversary. The Alpacas are much smaller than the Llamas, and of different colours in a domestic state. They are used for the same purposes, and differ little in habits and nature. The wool of both these animals is made use of for several purposes, and is a principal ingredient in the composition of hats in several parts of the new and old continent; and the flesh of the young Llamas is, in their native country, considered a great delicacy, and is as good as that of the fat sheep of Castile. In Pern, where the animals are found, there are public shambles for the sale of their flesh. 
§ IX.-Quadrumana, or Four-handed Animals.

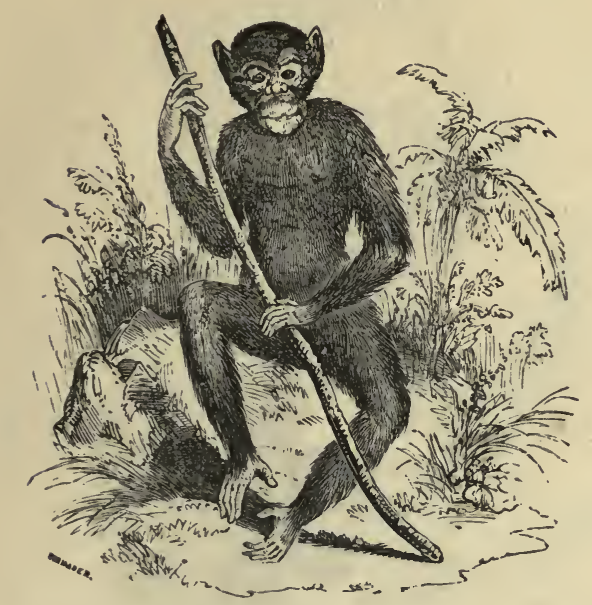

THE OURANG OUTAN. (Simia satyrus.)

Animals of the Monkey tribe are furnished with hands instead of paws ; their ears, eyes, eyelids, lips, and breasts resemble those of the human species. For greater facility of description, the animals of this extensive tribe are usually arranged in the three divisions of Apes, Baboons, and Monkeys. Apes are destitute of tails, and the chief of this kind is the Ourang Outan, or Wild Man of the Woods : he is found in the forests of Borneo and Sumatra. $\mathrm{He}$ is a solitary animal, and avoids mankind. 'I'he largest are said to be six feet high, very active, strong, and intrepid, capable of overcoming the strongest man: they are likewise exceedingly swift, and cannot easily be taken alive. When young, however, the Ourang Outan is capable of being tamed: one of them, shown in London some years ago, was taught to sit at table, make . use of a spoon or fork in eating, and drink wine out of a glass. It was mild and affectionate, much attached to its keeper, and obedient to his commands. 


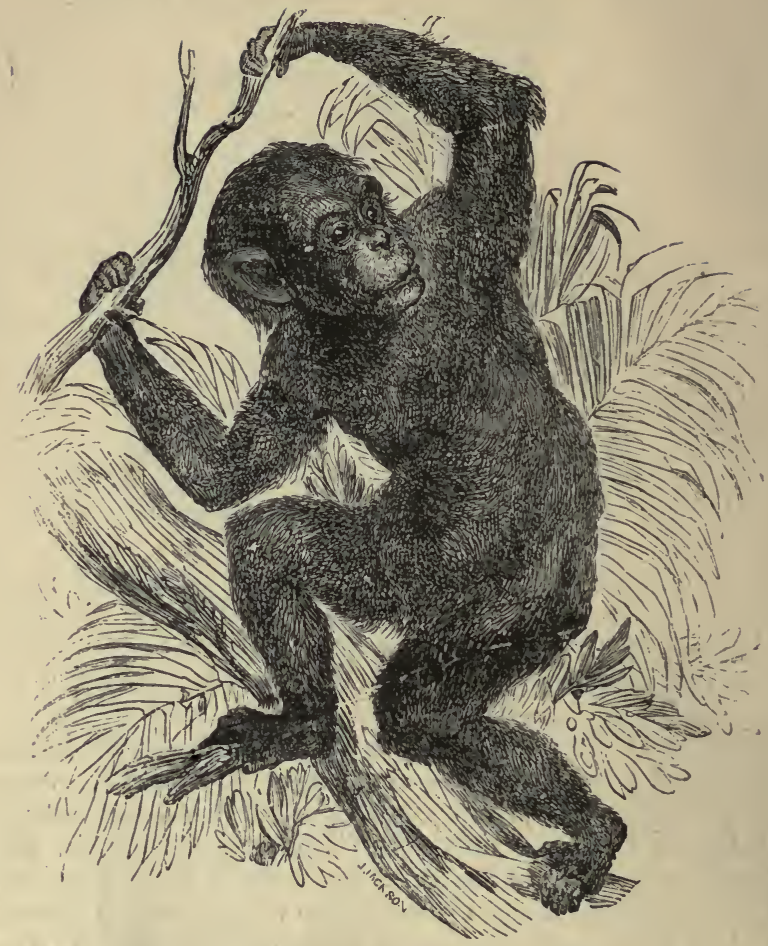

THE CHIMPANZEE.

(Simia Troglodytes, or Troglodytes niger.)

Tris Ape, which is an inhabitant of the great forests of Western Africa, is generally considered to be that which approaches nearest to the human species in its conformation. When full-grown, he measures about five feet in - height, standing erect, but this is a posture which he does not naturally prefer, and when on the ground he usually walks upon all fours, applying the outside of his hinder feet and the knuckles of his fore limbs to the 
earth. His skin is clothed with long coarse black or dark-brown hair, which becomes scanty on the lower surface of the body and on the limbs; the face is naked and of a flesh colour, and at each side there hangs down a great bush of long hair like a whisker. The Chimpanzee lives in the trees, upon the branches of which he is very active, and he has intelligence enough to build himself a sort of hut of branches, usually about thirty or forty feet from the ground. His food consists chiefly of fruits, and he is said to fly frem the presence of man.

Young Chimpanzees have frequently been brought to this and other European countries, and sereral of them have been exhibited in our Zoological Gardens. They are generally gentle and rather melancholy in their deportment, and often show much affection for those who have the charge of them. Of a specimen exhibited in France in his time, Buffon gives the following interesting account: "I have seen this animal," he says, " present its hand to lead out its visitors, or walk about with them gravely as if it belonged to the company. I have seen it seat itself at table, unfold its napkin and wipe its lips, use its spoon and fork to carry its food to its mouth, pour its drink into a glass, and touch glasses when invited; fetch a cup and saucer to the table, put in sugar, pour out its tea, and leave it to cool betore drinking it; and all this without any other instigation than the signs and words of its master, and often of, its own accord." Buffon adds that it had a taste which, no doubt, some of our young readers partake: "It was excessively fond of sugar-plums." 
Quadrupeds.

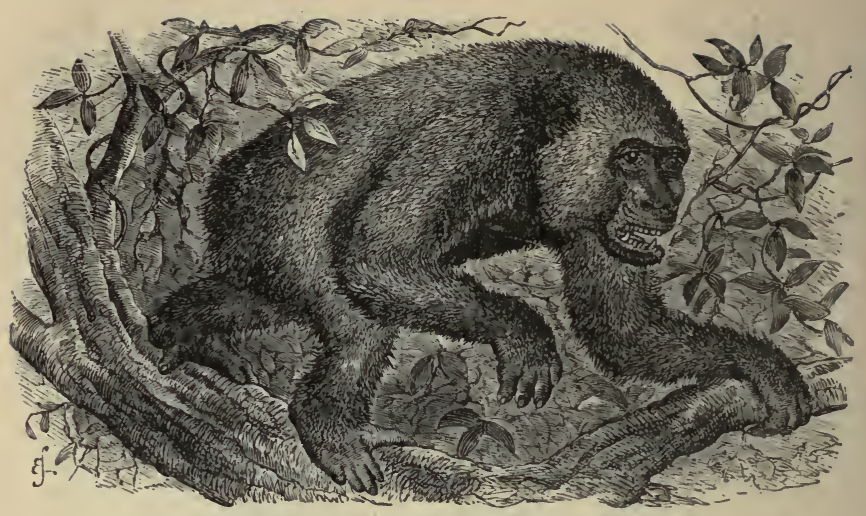

\section{THE GORILLA. (Troglodytes Gorilla.)}

This wonderful Ape, which has lately been discovered in the same region inhabited by the Chimpanzee, is thought, in some respects, to possess even a greater resemblance to our own species. He is said to attain a height of seven feet, but the largest. specimens hitherto obtained have been rather less than six feet high. By some travellers the Gorilla is said to walk upright, with his hands resting on the nape of his neck, but the state of his knuckles shows that he usually goes, like the Chimpanzee, on all fours. His skin is covered with short grizzled hair, and the naked skin of his face and hands is black. The Gorilla is much dreaded by the negroes who have to pass through the forests frequented by him when engaged in hunting the Elephant ; this is not on account of his teeth, although they are sufficiently formidable, but of the enormous strength of his hands, with which he can strangle a man in a moment, and it is even said that the old males never miss an opportunity of performing this operation. It is even said, that as a party of hunters is passing through the forest, one of their number will sometimes disappear suddenly, being caught up by a Gorilla lurking upon the low branches of a tree; the monster speedily strangles his victim and then lets the body fall. 


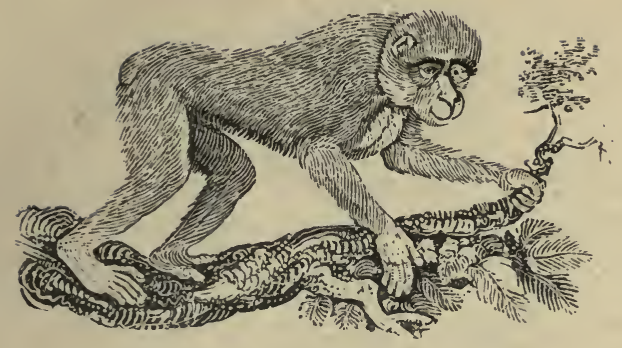

THE MAGOT, OR BARBARY A'PE, (Inuus sylvanus,)

Is a species of Monkey quite destitute of a tail, which inhabits the northern parts of Africa, and is also found on the Rock of Gibraltar. Caubasson relates a laughable anecdote of one of these animals, which he brought up tame, and which became so attached to him as to be desirous of accompanying him wherever he went: when, therefore, he had to perform divine service, he was under the necessity of shutting him up. One day, however, the animal escaped, and followed the father to church, where, silently mounting on the top of the soundingboard, above the pulpit, he lay perfectly quiet till the sermon began. He then crept to the edge, and, overlooking the preacher, imitated his gestures in so grotesque a manner, that the whole congregation were convulsed with laughter. Caubasson, surprised and displeased at this ill-timed levity, reproved his auditors for their inattention; and on the obvious failure of his reproof, he, in the warmth of zeal, redoubled his gesticulations and his vociferations. These the Ape so exactly imitated that all respect for their pastor was swallowed up in the scene before them, and they burst into a loud and continued roar of laughter. A friend of the preacher at length stepped up to him; and on perceiving the cause of this hilarity, it was with the utmost difficulty he could ccmmand a serious countenance while he ordered the Ape to be taken away. 


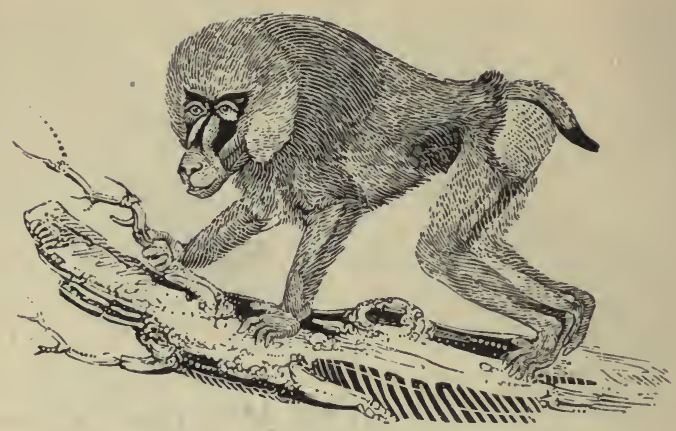

THE BABOON. (Cynocephalus.)

A GENus of Quadrumana, which comprises a large, fierce, and formidable race of animals, who, though they in a slight degree partake of the human conformation, like the Ourang Outan, \&c., are in their dispositions and habits the very reverse of gentleness and docility. 'The Baboons are the ugliest of all the Quadrumana. Their eyes are small, and sunk underneath their eyebrows. Their forehead is low, and the development of the snout and face is enormously disproportioned to the size of the skull. Their great strength and fierce disposition make them very much dreaded in the countries they inhabit. Baboons differ from the apes on the one hand, and the monkeys on the other, by having short tails.

The Common Baboon is of a sandy colour, with a reddish shade on the shoulders. head, and back. It is playful and good-tempered when young, but becomes morose and savage with age. Buffon thus describes a full-grown specimen he saw:- "It was not altogether hideous, and yet it excited horror. It seemed to be always in a state of savage ferocity, grinding its teeth, perpetually restless, and agitated by unprovoked fury. It was a stout-built animal, whose nervous limbs and compressed form indicated great force and agility; and, 


\section{The Baboon.}

though the length and thickness of its shaggy coat made it appear much larger than it really was, it was so strong and active that it might easily have repelled the attacks of several unarmed men."

The Cape Baboon, or Chacura (Cynocephalus porcarius), is as big as a large mastiff, covered with hair of an oliveblack colour on the back, and with paler hair beneath. He has a canine face; the snout resembles that of a hog, and the nails are flat, but sharp and very strong. It is said that he follows goats and sheep in order to drink their milk; he partakes of human dexterity in getting the kernels out of nuts, and loves to be covered with garments; he stands upright, and imitates with ease many human actions. The cunning of these animals is well exemplified in their mode of plunder. They form long lines, extending from their retreat to the object in view, and then pitch the produce of their theft from hand to hand till it is secure.

The Mandrill is the largest kind of Baboon, being nearly five feet high when it stands upright. It is distinguished from other Baboons by having a large protuberance on either cheek, which is marked with numerous red, blue, and purple stripes.

" Those which have been observed in a domestic state are generally remarked to have had a strong taste for fermented and spirituous liquors. A remarkably fine individual which was long kept at Exeter Change, and afterwards at the Surrey Zoological Gardens, drank his pot of porter daily, and evidently enjoyed it; it was a most amusing sight to see him seated in his little armchair with his quart pot beside him, and smoking his short pipe with all the gravity and perseverance of a Dutchman. In a state of nature his great strength and malicious character render the Mandrill a truly formidable animal. As they generally march in large bands they prove more than a match for the other inlabitants of the forest. The inhabitants themselves are afraid to pass through the woods unless in large companies and well armed." 


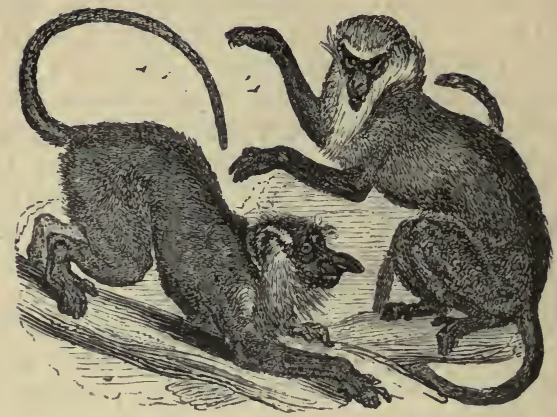

THE PROBOSCIS. THE DIANA MONKEY.

(Nasalis larvatus.)

(Cercopithecus Diana.)

The Proboscis Monkey is so called from its long projecting and disproportionate nose ; it is an inhabitant of the island of Borneo, where it lives in troops on trees in the vicinity of its rivers. It is of a savage disposition. The Diana Monkey is called after the goddess of that name, from the crescent of white hair which ornaments its brow. It is very playful, and one of the most graceful of the tribe; it is found in the hottest parts of Africa. Monkeys are less in stature, and more numerous, than the apes and baboons. They live almost entirely in trees. 'Their natural food is vegetable - fruit of all sorts, corn, and even grass; but when domesticated, they learn to eat almost anything that is served on our tables.

There are few persons that are not acquainted with the various mimicries of these animals, and their capricious feats of activity. Anecdotes of this kind are very numerous; we shall content ourselves by giving the following:-Captain Stedman, while hunting among the woods of Surinam for provisions, says, that he shot at two of these animals, but that the destruction to one of them was attended with such circumstances as to ever afterwards deter him from going monkey hunting. "Seeing me nearly on the bank of the river, in the 
canoe," says he, "the creature made a halt from skipping after his companions, and, being perched on a branch that overhung the water, examined me with the strongest marks of curiosity; while he chattered prodigiously, and kept shaking the boughs on which he rested, with incredible strength and agility. At this time I laid my piece to my shoulder and brought him down from the tree : but may I never again be witness to such a scene! The miserable animal was not dead, but mortally wounded. I seized him by the tail, and taking him in both my hands, to end his torment swung him round, and hit his head against the side of the canoe; but the poor creature still continued to live, and looked at me in the most affecting manner that can be conceived. I therefore knew no other means of ending his nurder than to hold him under water till he was drowned: but even in doing this, my heart sickened; for his little dying eyes still continued to follow me with seeming reproach, till their light gradually forsook them, and the wretched animal expired."

The manner in which some of the Monkey tribe capture shell-fish is remarkably indicative of their cunning and ingenuity. The oysters of the tropical climates, being larger than ours, the Monkeys, when they reach the sea-side, pick up stones, and thrust them between the opening shells, which being thus prevented from closing, the cunning animals eat the fish at their ease. In order to attract crabs, they put their tails before the holes in which they have taken refuge; and when the creatures have fastened on the lure, the Monkeys suddenly withdraw their tails, and thus drag their prey on shore.

The Moukey generally brings forth one at a time, and sumetimes two. They are rarely found to breed when brought over into Europe; but those that do exhibit a very striking picture of parental affection. The male and female are never tired of fondling their young one. They instruct it with no little assiduity; and often severely correct it, if stubborn, or disinclined to profit by their example. They hand it from one to the other, and when the male has done showing his regard the female takes her turn in the work of affection. 


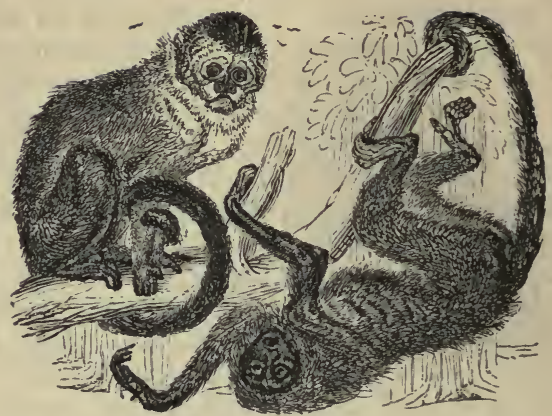

THE CAPUCHIN AND SPIDER MONKEYS,

(Cebus Capucinus and Ateles paniscus,)

ARE both natives of South America; they live in large troops, feeding on roots, fruits, and insects, and are much more gentle than those of the old world. Of the Capuchin there are many species, differing from each other in colour only; they are very lively, active, and amusing, and about a foot long. The Spider Monkey, like the Capuehin, has a long prehensile tail, which it uses like a fifth hand. Nature seems by this addition to have more than recompensed them for the want of a thumb, for by it, when they are unable to leap from one tree to another, on account of the distance, they form a kind of chain, with their young upon their backs, hanging down by each other's tails. One of them holds the branch above, and the rest swing to and fro like a pendulum, until the undermost is enabled to catch hold; the first then lets go his hold, and thus comes undermost in his turn; in this way they can travel a great distance without ever touching the ground. Curious illustrations of this are daily seen at the Zoological Gardens, where there are several of these Monkeys. 


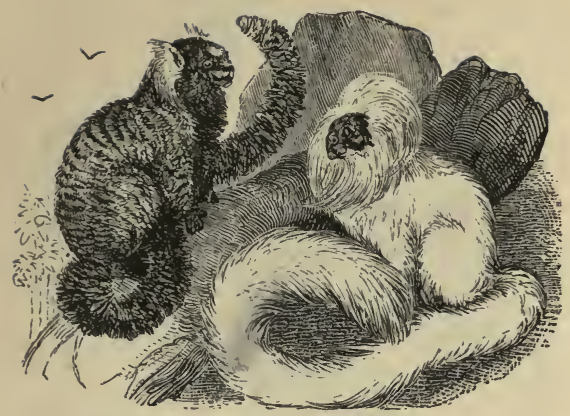

\section{THE OUISTITI AND MARIKINA MONKEYS.}

\section{(Jacchus vulgaris and Rosalia.)}

'I'he Outstiti, or Marmozet, inhabits the Brazils, and is of small size, not measuring more than seven inches, though his tail is near eleven; he weighs about six ounces, and, like others of his kind, lives not only on vegetables, but also upon insects, the eggs of birds, and even small birds. His face is almost naked, of a swarthy flesh colour, with a white spot ahove the nose: the tail is full of hair, and annulated with ash-colonred and black rings alternately; his nails are sharp, and his fingers like those of a squirrel.

The Marikina is a beautiful little animal, not above nine inches long, and is sometimes called the Lion Monkey; his hair is long, soft, and glossy; his head is round. his face brown, and his ears hid under the long hairs which surround his face, and which are of a bright red, while those on his body and tail are of a beautiful pale yellow, or gold colour. Ho is very playful, and of a seemingly robust temperament, for we have seen one which lived five or six years in Paris, without any other particular care than keeping it during the winter in a chamber in which there was a fire every day. 


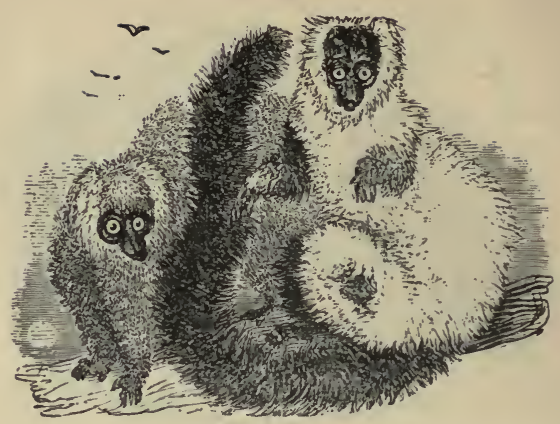

\section{THE LEMUR AND THE MONGOOS,}

(Lemur macaco and Lemur albifrons,)

MAY be considered as the connecting link between the Monkeys and the genuine quadruped. 'I'heir habits are nocturnal, whence they have been called Lemurs, or ghosts. They pass a considerable portion of the day in sleep, rolled up like a ball, with the large tail passed between the hind legs, and twisted round the neck. They live in troops, more or less numerous, like the apes and monkeys, on trees, and climb with great quickness, and leap with so much force as frequently to rise ten feet at a single bound. They feed on fruits, roots, \&c., and carry their food to their mouth with their hands, like the apes; their voice, when not alarmed, is a quick grunt. 'Their nocturnal and unobtrusive habits may probably account in some degree for the rarity of their appearance. They are all inhabitants of Madagascar, but allied species are also found in Bengal, and other parts of Hindostan, in Ceylon, and Java. The above specimens are from the Zoological Gardens, and are the White-fronted and the Black and White Lemurs. 


\section{Book II.}

\section{INHABITANTS OF THE AIR.}

\section{§ I. Raptores. Diurnal Birds of Prey.}

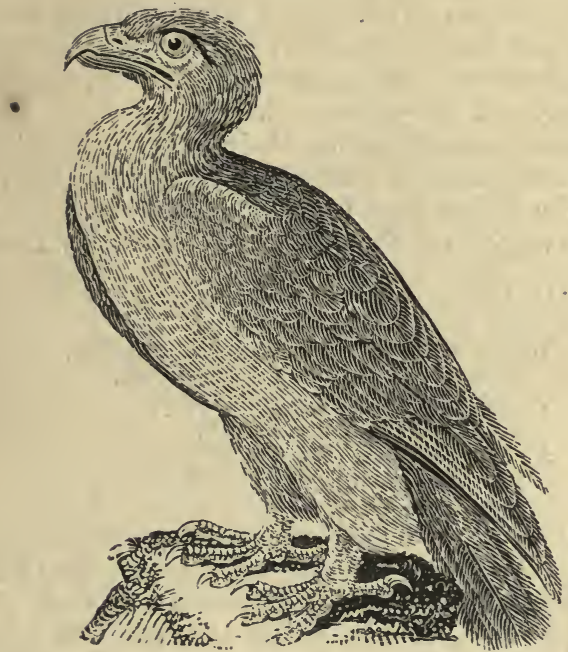

\section{THE GOLDEN EAGLE. (Aquila chrysaëtos.)}

"But who the various nations can declare,

That plough with busy wing the peopled air?

These cleave the crumbling bark for insect food,

Those dip the crooked beak in kindred blood :

Some haunt the rushy moor, the lonely woods;

Some bathe their silver plumage in the floods;

Some fly to man, his household gods implore,

And gather round his hospitable door,

Wait the known call, and find protection there

From all the lesser tyrants of the air.

- The tawny Eagle seats his callow brood

High on the cliff, and feasts his young with blood."

BARBAULD.

The Golden EAGLe is one of the largest and most powerful of all those birds that have received the name of Eagle. It weighs above twelve pounds. Its length, from the point of the beak to the end of the tail, is 
about three feet; the breadth, when the wings are extended, is seven or eight feet. The beak is horny, crooked, and very strong. The feathers of the neck are of a rusty colour, and the rest dark brown. The feet are feathered down to the claws, which have a wonderful grasp; the toes are yellow, and the four talons are crooked and strong. As in all birds of prey, the female is the larger, and more powerful.

Eagles are remarkable for their longevity, and their faculty of sustaining a long abstinence from food. Of all birds the Eagle flies highest; and from thence the ancients have given it the epithet of the Bird of Heaven:

"Bird of the broad and sweeping wing,

Thy home is high in heaven,

Where wide the storms their banners fling,

And the tempest's clouds are driven.

Thy throne is on the mountain top,

Thy fields the boundless air;

And hoary peaks, that proudly prop

The skies, thy dwellings are."

This formidable bird may be considered among its own species what the lion is among quadrupeds ; and in many respects they have a strong similitude to each other. Solitary, like the lion, he keeps the wilds to himself alone; it is as extraordinary to see two pairs of Eagles in the same mountain, as two lions in the same plain.

The Eagle is found in Great Britain and Ireland, in Germany, and nearly all parts of Europe. It is carnivorous, and, when unable to obtain the flesh of larger animals, feeds on serpents and lizards. The story of the Eagle, brought to the ground after a severe conflict with a cat, which it had seized and taken up into the air with its talons, is very remarkable; Mr. Barlow, who was an eye-witness of the fact, made a drawing of it, which he afterwards engraved. Two instances are said to have occurred in Scotland of the Eagle having flown away with infants to its nest; but in both cases it is added that the children were recovered, without being materially injured. This bird has been often tamed, but in this situation it still preserves an innate love of liberty. The nest of the Eagle is composed of strong 
sticks, and generally built on the point of an inaccessible rock, whence it darts upon its prey with the rapidity of lightning. The period of incubation is said to be thirty days; and when the young are hatched, both the male and female exert all their industry to provide for their wants. In the county of Kerry a peasant is said once to have formed the resolution of plundering an Eagle's nest built upon a small island in the beautiful lake of Killarney. $\mathrm{He}$ accordingly swam to the island while the parents, were away; and, after robbing the nest of the young, was preparing to swim back with the Eaglets tied in a string; but while he was yet up to the chin in the water, the old Eagles returned, and, missing their family, fell upon the invader with such fury, that, in spite of all his resistance, they despatched him with their beaks and talons.

Another native of Kerry was more fortunate in his dealings with the Eagles. During a season of scarcity he obtained sustenance for himself and his family by plundering an Eagle's nest of the food brought in by the parents for their young ones: and he was so artful as to prolong the supply by cutting the wings of the Eaglets so as to prevent their flying, and thus compelled the old birds to continue their attention to their progeny.

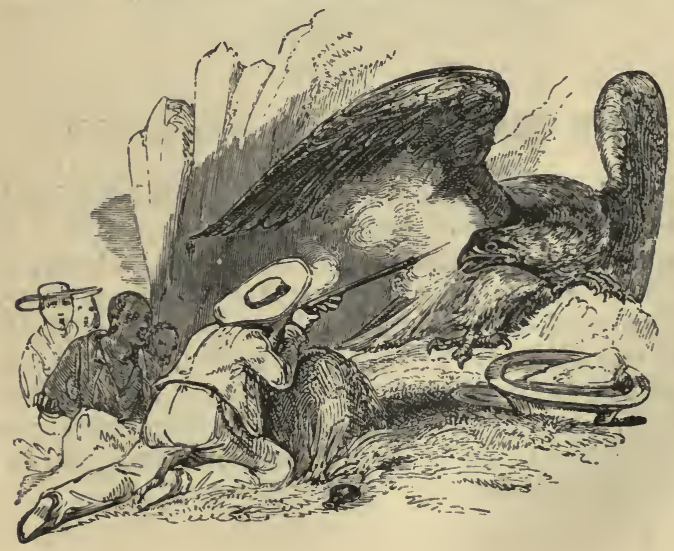




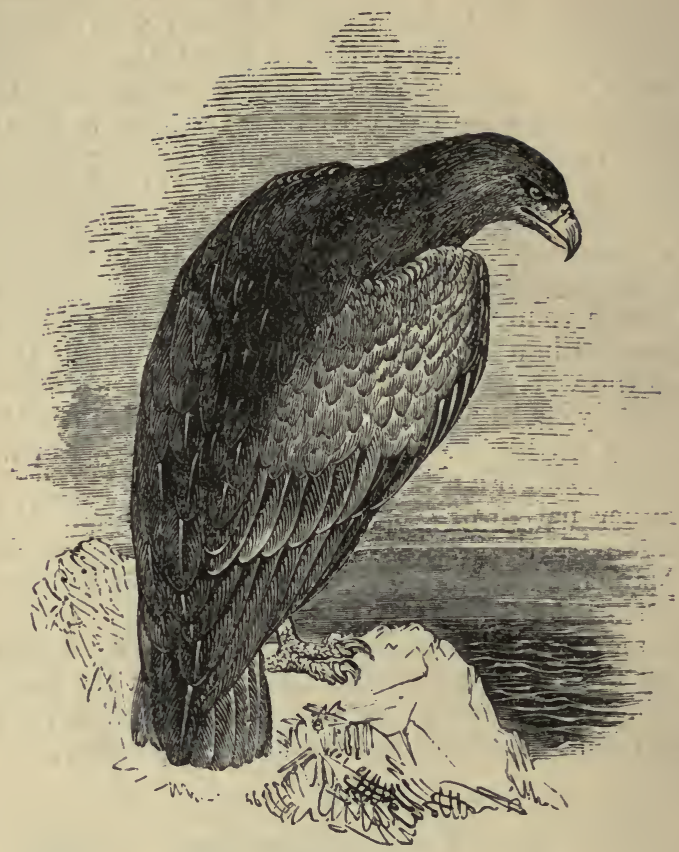

THE SEA EAGLE. (Haliaëtus albicilla.)

This bird, known also as the White-tailed Eagle, from the inside feathers of its tail being white, differs from the golden eagle in the greater length of its beak, in its sluggish and cowardly habits, and in its coarser taste. It is a native of Great Britain, where it inhabits the high rocks and cliffs that overhang the sea, and whence it pounces on the birds, fish, or seals that it can procure for its prey. It is smaller than the golden eagle, rarely reaching three feet in length; and in young birds the tail feathers are brown. 


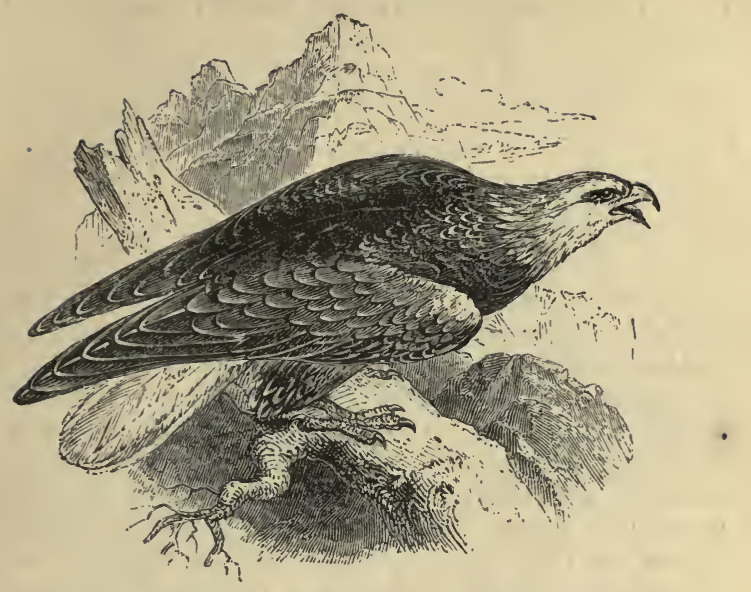

THE WHITE-HEADED, OR BALD EAGLE.

\section{(Haliaëtus leucocephalus.)}

This bird is about three feet long, and seven feet broad, measuring to the tips of the extended wings. The bill resembles that of the golden eagle, and from the chin hang some small hairy feathers like a beard. As it is found alike in the frigid and the torrid zone, it is provided for enduring rapid changes of temperature, and its whole body is clothed under the feathers with a kind of down, white and soft like that of the swan. This bird. builds its nest on lofty cliffs by the sea-shore, and on the hanks of rivers or lakes, and feeds almost entirely upon fish.

It is generally regarded by the Anglo-Americans with peculiar respect, as the chosen emblem of their native land. The great cataract of Niagara is mentioned as one of its favourite places of resort, not merely as a fishing station, where it is enabled to satiate its hunger upon its most congenial food, but also in consequence of the vast quantity of four-footed beasts, which, unwarily venturing into the stream above, are borne away by 
the torrent, and precipitated down those tremendous falls :

"High o'er the watery uproar silent seen,

Sailing sedate in majesty serene,

Now 'midst the pillar'd spray sublimely lost,

And now emerging, down the rapids toss d,

Glides the Bald Eagle, gazing calm and slow

O'er all the horrors of the scene below;

Intent alone to sate himself with blood,

From the torn victim of the raging flood."

The number of birds of prey of various kinds which assemble at the foot of the rocks to glut themselves upon the banquet thus provided for them, is said to be incredibly great, but they are all compelled to give place to the Eagle when he deigns to feed on dead animals; and the crow and the vulture submit without a struggle to the exercise of that tyranny, which they know it would be in vain to resist. "We have ourselves," says Wilson, "seen the Bald Eagle, while seated on the dead carcase of a horse, keep a whole flock of vultures at a respectful distance, until he had fully sated his own appetite:" and he adds another instance, in which many thousands of tree squirrels having been drowned, in one of their migrations, in attempting to pass the Ohio, and having furnished for some length of time a rich banquet to the vultures, the sudden appearance among them of the Bald Eagle at once put a stop to their festivities, and drove them to a distance from their prey, of which the Eagle kept sole possession for several successive days.

These Eagles sometimes hunt in pairs in a manner which shows their great sagacity. Aware that water-fowl have the power of eluding their grasp by diving, they hover at a distance fromeach other over their prey. One of them then darts towards it with great swiftness, but the water-fowl easily avoids the first attack by diving. The pursuer then rises into the air, and his mate resumes the attack just as the fowl is emerging to breathe, and compels it to plunge again. The Eagles continue alternately to proceed in this manner till their victim is so exhausted that it falls an easy prey.

This Eagle also frequently attacks the Usprey or Fish Hawk, when he is returning from a successful 
excursion loaded with a large fish, and compels him to drop his prey; the Eagle then descends with wonderful rapidity, and generally succeeds in seizing the fish before it reaches the water.

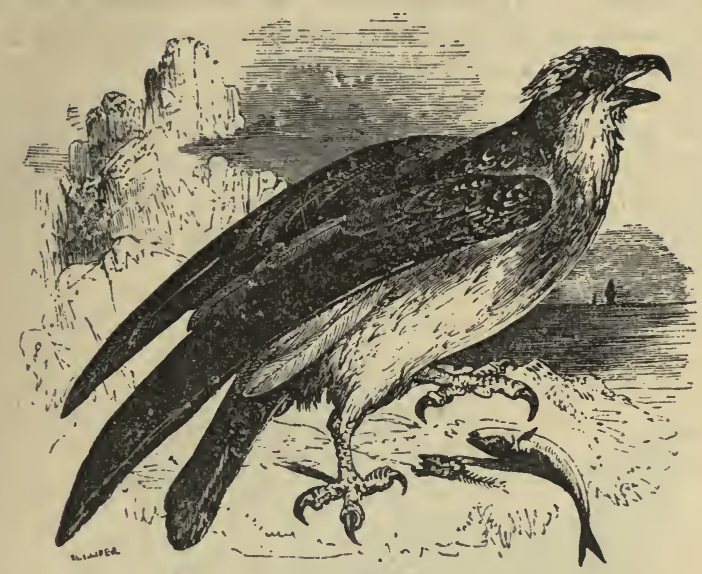

THE OSPREY, OR FISHING HAWK.

(Pandion haliaëtus.)

"True to the season, o'er our sea-beat shore

The sailing Osprey high is seen to soar

With broad unmoving wing; and circling slow,

Marks each loose straggler in the deep below ;

Sweeps down like lightning, plunges with a roar,

And bears its struggling victim to the shore."

This bird is always found on the sea-shore, or near rivers or lakes, as it feeds entirely on fish. It is common in Great Britain, and also in America, where large colonies of it are found, the birds living together like rooks. "When looking out for its prey," says Dr. Richardson, "it sails with great ease and elegance, in undulating and curved lines, at a considerable height ahove the water, till it perceives its prey, when it pounces down upon it. It seizes the fish with its claws, sometimes scarcely appearing to dip its feet in the 
water, and at others plunging entirely under the surface with force sufficient to throw up a considerable spray. It emerges again, however, so speedily, as to render it evident that it does not attack fish swimming at any great depth." The toes are armed beneath with numerous sharp points, evidently intended to assist the bird in getting a firm hold of its slippery prey.

The Osprey builds a large nest either on trees or rocks, and lays two or three eggrs, which have a reddish tinge, and are spotted with brown at the larger end. The old birds feed the young ones even after they have left the nest, and only rear one brood in the year.

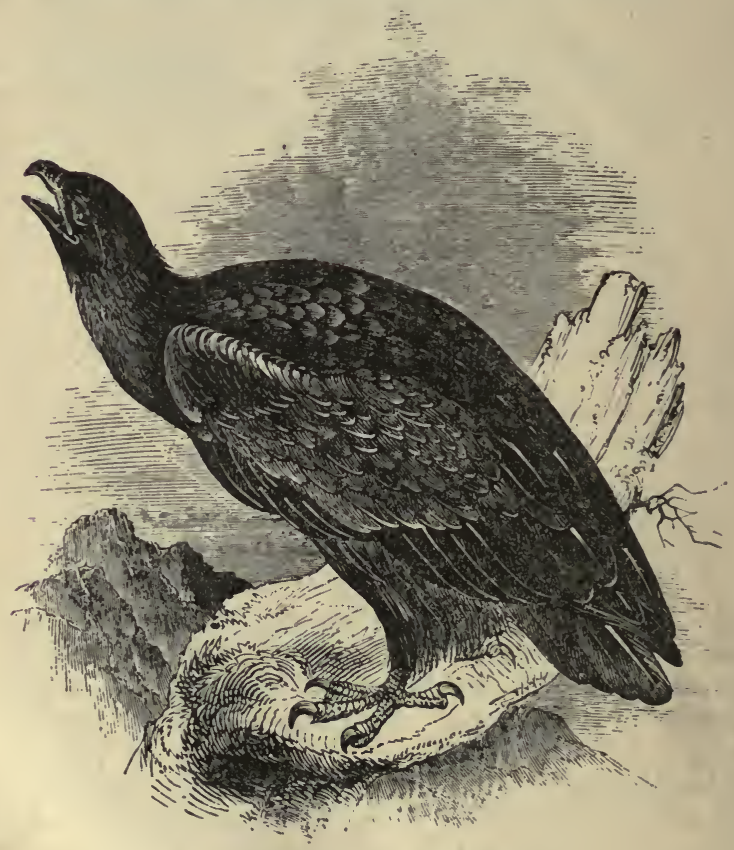

THE BLACK EAGLE.

Some ornithologists suppose this to be merely the golden 
eagle in its young state, but others make it a distinct species. It is about twice as large as the raven. The parts about the beak and the eye are bare of feathers, and somewhat reddish; the head, neck, and breast black; in the middle of the back, between the shoulders, there is a large white spot, dashed with red; a black streak sweeps along the feathers, and is followed by a white one; the remaining part of the wing to the tip is of a dark ash-colour. This bird has beautiful hazel eyes, full of animation: his legs are feathered down a little below the tarsal joint, the naked part being red; his talons are very long. He is found in France, Germany, Poland, and delights in Alpine mountains, where he makes the vales and woods resound with his incessant screamings when in search of prey.

The Abbé Spallanzani had an eagle of this species, so powerful as to be able to kill dogs that were much larger than itself. When a dog was placed before it, the bird would ruffle up the feathers on its head and neck, cast a dreadful look at its victim, take a short flight, and immediately alight on its back. It held the head firmly with one foot, and thus secured the dog from biting, and with the other grasped one of his flanks, at the same time driving its talons into the body; and in this attitude it continued, till the dog expired with fruitless outcries and efforts.

The eyes of eagles are celebrated for their brilliancy and strength, which has given rise to the popular opinion that they can gaze or the sun without shrinking: though this, from the overhanging eyebrow of the Eagle, would be an extremely difficult feat for the bird to perform. The eyes of all birds are curiously constructed, so as to enable them to see both distant objects and near ones with equal facility; and for this purpose the $y^{-}$are furnished with a membrane placed near the edge of the crystalline lens of the eye, by which it can be moved at pleasure. The orbit of the eye is formed of about twelve or sixteen bony plates, which slide over each other when necessary. Birds are also furnished with an additional eyelid, of extremely thin texture, with which they occasionally appear to shade their eyes. 


\section{THE VULTURE. (Vultur Monachus.)}

'THe first rank in the description of birds has been given to the eagle, not on account of its size, but because it is nobler in its habits and more delicate in its appetites. But it belongs to the falcon tribe, and should be placed after the Vultures. The eagle, unless pressed by famine, will not stoop to carrion; and generally devours only what he has earned by his own pursuit. The Vulture, on the contrary, is disgustingly voracious; and seldom attacks living animals when it can be supplied with dead. The eagle meets and singly opposes his enemy: the Vulture, if he expects resistance, calls in the aid of its kind, and overpowers its prey by combination. Putrefaction, instead of deterring, only serves to allure it. The Vulture seems among birds what the jackal and hyæna are among quadrupeds, who prey upon carcases, and root up the dead.

Vultures may be easily distinguished from eagles by the nakedness of their heads and necks, which are without feathers, and only covered with a very slight down, or a few scattered hairs; their eyes are more prominent; those of the eagle being buried more in the socket, and shaded by an overhanging eyebrow. Their claws are shorter and less hooked. The inside of the wing is covered with a thick down, which is different in them from all other birds of prey. 'Their attitude is not so upright as that of the eagle, and their flight is more difficult and heavy.

In this description we may include the Golden, the Ash-coloured, and the Brown Vulture, which are inhabitants of Europe ; the Spotted and the Black Vulture of Egypt; the Bearded Vulture, the Brazilian Vulture and the King of the Vultures, of South America. They all agree in their nature, being equally indolent, rapacious, and unclean.' The Condor also belongs to the Vulture tribe. 


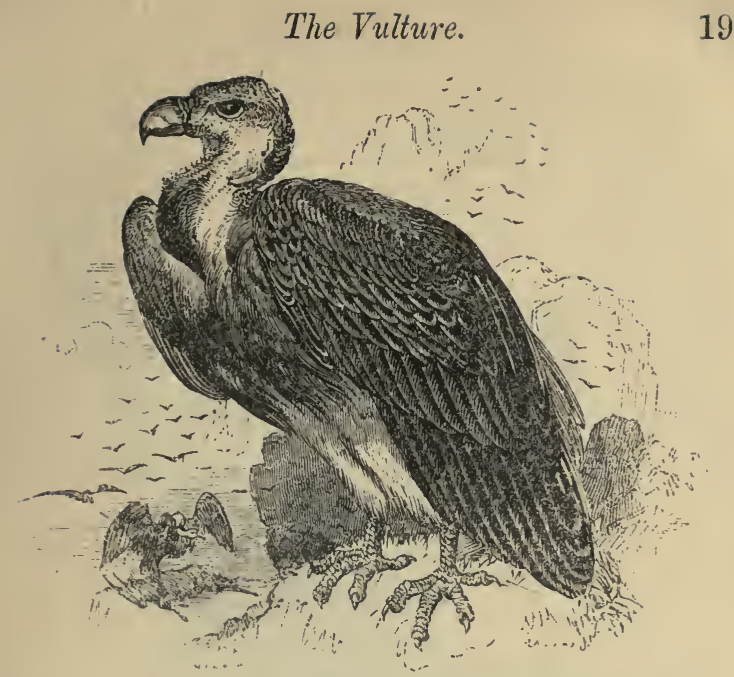

THE KING VULTURE. (Vultur, or Sarcorhamphus papa.)

The King Vultule, or King of the Vultures, is so called, because when he makes his appearance amongst a whole company of other birds of his kind engaged in a feast upon a dead carcase, they all retire before him and wait respectfully at a little distance until this monarch has eaten his fill. He is an inhabitant of South America.

The head and neck of this bird are without feathers; the body above, reddish buff, beneath, yellowish white: quills greenish black; tail black; craw pendulous, and orange-coloured. It is about the size of a turkey; and is chiefly remarkable for the odd formation of the skin of the head and neck: this skin, which is of an orange colour, arises from the base of the bill, whence it stretches on each side of the head; the eyes are surrounded by a red skin, and the iris has the colour and lustre of pearl. Upon the naked part of the neck is a collar formed by soft longish feathers. Into this collar the bird sometimes withdraws his whole neck, and sometimes a part of its head, so that it looks as if it had hidden its neck in its body. 


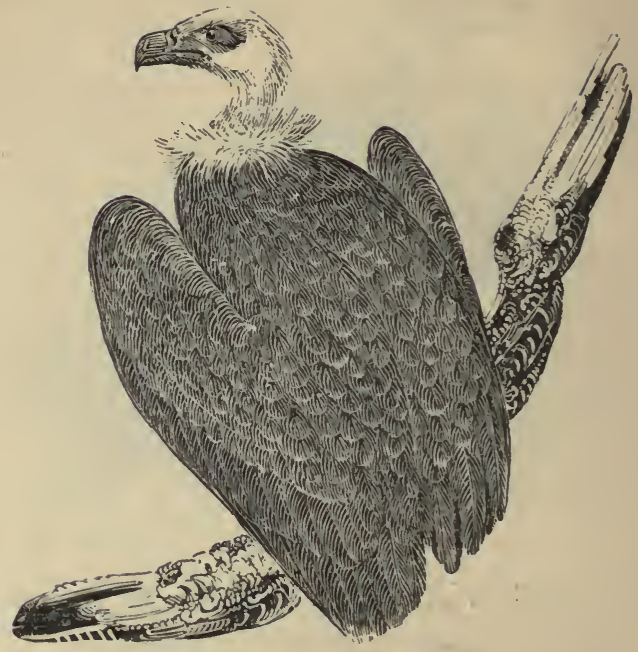

THE CONDOR. (Vultur gryphius.)

Thus bird measures three or four feet long, and its wings, when expanded, from ten to twelve feet. Its bill and talons are exceedingly large and strong; and its courage is equal to its strength. The throat is naked, and of a red colour. 'The upper parts in some individuals (for they differ greatly in colour) are variegated with black, gray, and white, and the body is scarlet. Round the neck it has a white ruff of loose hairy feathers. The feathers on the back are generally quite black, and perfectly bright. These enormous birds, which are inhabitants of South America, breed among the highest and most inaccessible rocks. The female makes no nest, but lays two wlite eggs, somewhat bigger than those of a turkey, on the bare rock. Some writers have affirmed that a Condor can carry off a sheep in its claws, and others that it has carried off children in the same manner; but these tales are manifestly absurd, as the 
Condor's feet and talons are not fitted for carrying any great weight. Both the talons and the bill are indeed of extraordinary strength, but they are intended for tearing objects to pieces; and consequently we find that the Condor feeds chiefly on dead or dying cattle, or horses, which he tears to pieces and devours where they lie. When the Condor is gorged the hunters attack him, but his strength and fierceness are so great, that one of Sir Francis Head's companions, who attempted to seize a gorged Condor, said he never had "such a battle in his life;" though he had been a Cornish miner. and was reckoned an excellent wrestler in his own country.

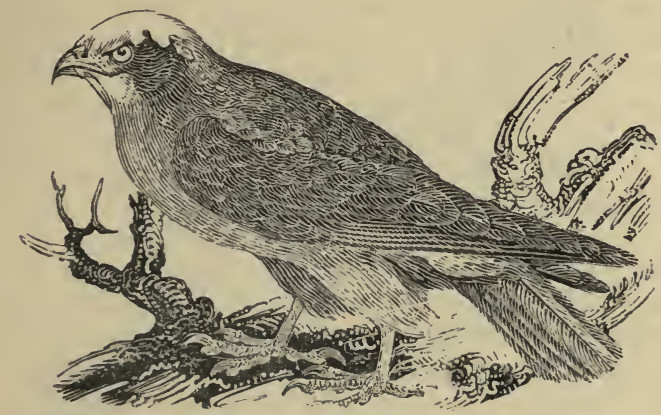

THE BUZZARD. (Falco Buteo, or Buteo vulgaris.)

"The noble Buzzard ever pleased me best; Of small renown, " $t$ is true; for, not to lie, We call him but a Hawk by courtesy."

\section{Hind ANd Panther.}

THIs is a rapacious bird, of the hawk kind, and the most common of all in England. It is of a sluggish, indolent nature, often remaining perched on the same bough for the greater part of the day: as if, indifferent either to the allurements of food or of pleasure, it were doomed, like some of the human species, to pass its allotted span of life in passive contemplation. It feeds 
on mice, rabbits, frogs, and often on all sorts of carrion. Too idle to build itself a nest, it frequently seizes upon the old habitation of a crow, which it lines afresh with wool and other soft materials. In general this bird, whose colour varies considerably, is brown varied with yellow specks; at a certain age its head becomes entirely gray. 'The female generally lays two or three eggs, which are mostly white, though sometimes spotted with yellow. Its length is usually twenty-two inches, and its breadth upwards of fifty.

The following anecdote, related by Buffon, will show that the Buzzard may be so far tamed as to be rendered a faithful domestic. A Buzzard, which had been eaught in a snare, was brought to a gentleman, who undertook to tame it. It was at first wild and ferocious, but by depriving it of food he succeeded in constraining it to come and eat out of his hand. By pursuing this plan he brought it to be very familiar; and, after having shut it up about six weeks, he began to allow it a little liberty, taking the precaution, however, to tie both pinions of its wings. In this condition it walked out into his garden, and returned when called to be fed; after some time, thinking he might trust to its fidelity, he removed the ligatures, and fastened a small bell above its talon, and also attached to its breast a bit of copper with his name engraved on it. He then gave it entire liberty, which it soon abused; for it took wing and flew into the forest of Belesme. The bird was given up for lost; but four hours afterwards, it rushed into the gentleman's hall, pursued by five other Buzzards, which had driven it into its former asylum. After this adventure it preserved its fidelity, coming every night to sleep under the wiudow. It soon became familiar, attended constantly at dinner, sat on a corner of the table, and often caressed its master with its head and bill, emitting a weak, sharp cry, which, however, it sometimes softened. It had a singular propensity of seizing from the head and flying away with the red caps of the peasants; and so alert was it in whipping them off, that they found their heads bare without knowing what was become of their caps; it even treated the wigs 
of the old men in the same way, hiding its booty in the tallest trees.

Wilson says that one he shot in the wing lived with him several weeks: but refused to eat. It amused itself by hopping from one end of the room to the other, and sitting for hours at the window, looking down on the passengers below. At first, he put himself in an attitude of defence when approached; but after some time became quite familiar, permitting himself to be handled. Though he lived so long without food, his stomach was found on dissection to be enveloped in solid fat of nearly an inch in thickness.

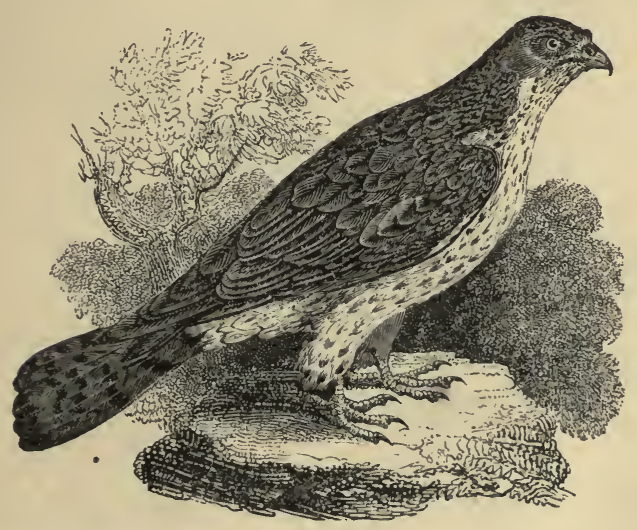

THE HONEY-BUZZARD. (Falco, or Pernis apivorus.)

This Buzzard eats lizards, frogs, and snails. It also feeds upon the larvæ of bees and wasps, which form the chief food of the young birds. Buffon says that in winter, when fat, it is good eating, a very rare circumstance with birds of this genus. It seldom flies, excepting from one bush to another; but, when on the ground, it runs with great rapidity, like a domestic fowl.

Willoughby observes that it builds its nest with twigs, 
on which it lays wool to receive its eggrs. He saw one that took possession of an old kite's nest to breed in, and that fed its young with the larvæ of wasps, for in the nest were found the combs of wasps' nests, and, in the stomachs of the young, fragments of wasp-maggots. In the nest were two young ones, covered with white down, spotted with black. In the crop of one of them were two lizards entire, with their heads lying towards the mouth, as if they sought to creep out.

It would be highly interesting could we discover the manner in which this bird conducts its attack on a wasps' nest. The close feathering round the base of the bill, is, no doubt, a protection against the stings of the insects which they attack.

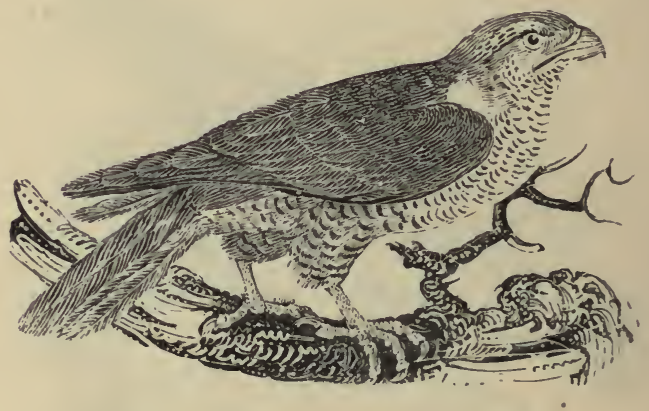

THE GOSHAWK, (Falco, or Astur palumbarius,)

Breeps in lofty trees in Scotland, and destroys a great quantity of small game, which he seizes with his sharp and crooked talons, and carries to his nest. He is of the hawk tribe, and somewhat larger than the common buzzard; his bill is blue, and he has a white stripe over each eye, and also a large white spot on each side of the neck. The general colour of the plumage is deep brown; the breast and belly white, transversely streaked with black; and the legs yellow. Buffon, who brought up two young Goshawks, a male and a female, makes 
the following observations: "The Goshawk, before it has shed its feathers, that is, in the first year, is marked on the breast and belly with longitudinal brown spots; but after it has had two moultings they disappear, and their place is occupied by transverse bars, which continue during the rest of its life." He further observes that, "though the male was much smaller than the female, it was fiercer and more viciuus." The Goshawk is found in France and Germany; it is not common in England, but is more so in Scotland. In former times the custom of carrying a Hawk or Falcon on the hand was confined to men of high distinction; so that it was a saying among the Welsh, "You may know a gentleman by his Hawk, horse, and greyhound." Even the ladies in those times were partakers of this gallant sport, and have been represented in pictures with Hawks on their hands. At present hawking is almost entirely laid aside in this country, as the expense which attended it, being very considerable, confined it to princes and men of the highest rank. In the time of James the First, Sir Thomas Monson is said to have given a thousand pounds for a cast of Hawks. In the reign of Edward the Third it was made felony to steal a Hawk; to take its eggs, even in a person's own grounds, was punishable with imprisonment for a year and a day, together with a fine at the king's pleasure. Such was the delight our ancestors took in this royal sport, and such were the means by which they endeavoured to secure it. The Falcons, or Hawks, chiefly used in these kingdoms were the Goshawk, the Peregrine Falcon, Iceland Falcon, and the Ger Falcon. The game usually pursued were cranes, wild geese, pheasants, and partridges. The Duke of St. Albans is still hereditary grand falconer of England, but the office is not now exercised, except for the Duke's own amusement. 


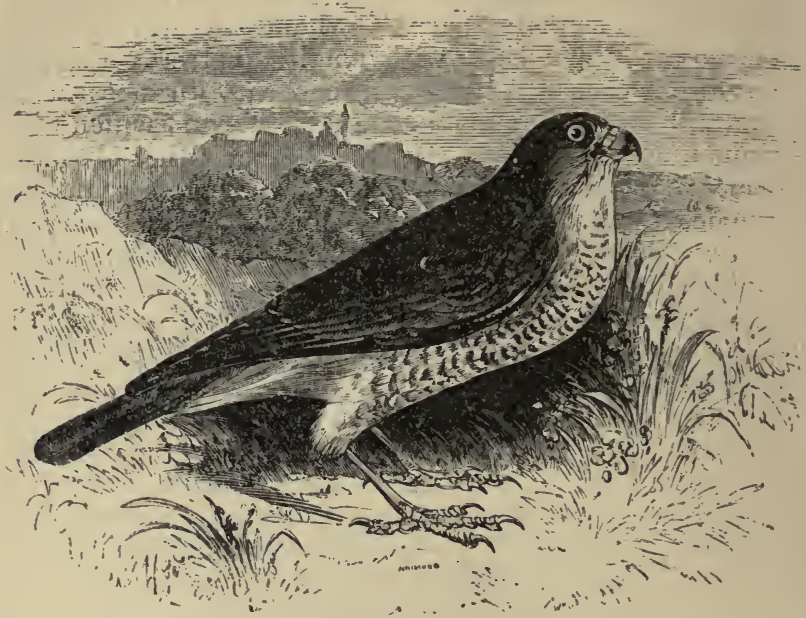

\section{THE SPARROWHAWK. (Falco, or Accipiter nisus.)}

The Sparrowhawk is a bold-spirited bird; the length of the male is twelve inches, that of the female fifteen; the beak is short, crooked, and of a bluish tint, but very black towards the tip; the tongue black, and a little cleft; the eyes of a middling size. The crown of the head is of a dark brown; above the eyes, in the hinder part of the head, there are sometimes white feathers; the roots of the feathers of the head and neck are white, the rest of the upper side, back, shoulders, wings, and neck of a dark brown. The wings, when closed, scarcely reach to the middle of the tail; the thighs are strong and fleshy, the legs long, slender, and yellow; the toes also long, and the talons black. The female lays about five eggs, spotted near the blunt end with brown specks. When wild they feed only upon birds, and possess a boldness and courage above their size; but in a domestic state they do not refuse raw flesh and mice. They can be made obedient and docile, and readily trained to hunt quails and partridges. 


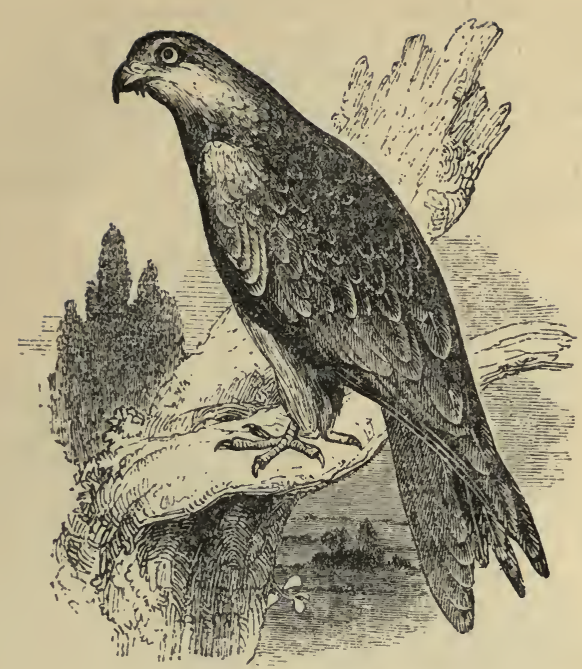

THE KITE. (Falco Milvus, or Milvus regalis.)

Turs bird, though it belongs to the falcon tribe, is called ignoble, because it is never used in hawking. It is easily distinguished from other birds of prey by its forked tail, and the slow and circular eddies it describes in the air whenever it spies from the regions of the clouds a young duck or a chicken which has strayed too far from the brood. When this is the case, the Kite, pouncing on it with the rapidity of a dart, seizes it in its talons, and carries it off to its nest. It is, however, a great coward, and if the hen flies at it, which she always does if she sees it, it will drop the chicken and fly off. It is larger than the common buzzard; and though it weighs somewhat less than three pounds, the extent of its wings is more than five feet. The head and neck are of a pale ash colour, varied with longitudinal lines across the shafts of the feathers; the back is reddish; the lesser rows of the wing feathers are party-coloured, of black, red, and white; the feathers 
covering the inside of the wings are red, with black spots in the middle. The eyes are large, the legs and feet yellow, the talons black. It is a handsome bird, and seems almost always on the wing.' It rests itself on the air, and does not appear to make the smallest effort in flying, but rather to glide along with the gentlest breeze.

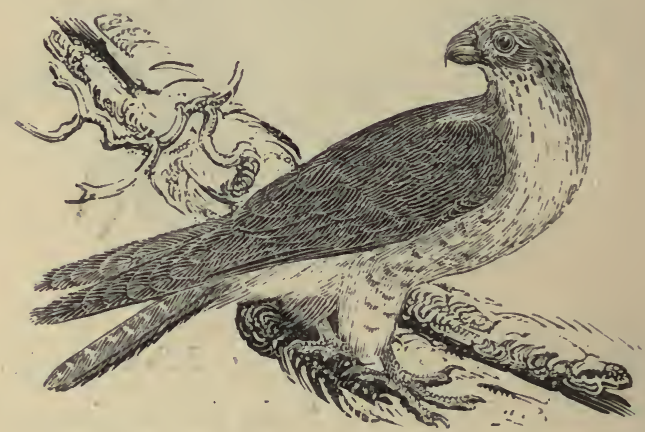

\section{THE FALCON.}

The $\dot{F}_{A L C O N}$ is a predaceous bird, of which there are several species. Of these the Gerfalcon (Falco Gyrfalco) is the largest, and is found in the northern parts of Europe; and, next to the eagle; is the most formidable, active, and intrepid of all voracious birds, and the most esteemed for falconry. The bill is crooked and bluish; the irides of the eye dusky; and the whole plumage of a whitish hue, marked with dark lines on the breast, and dusky spots on the back. 


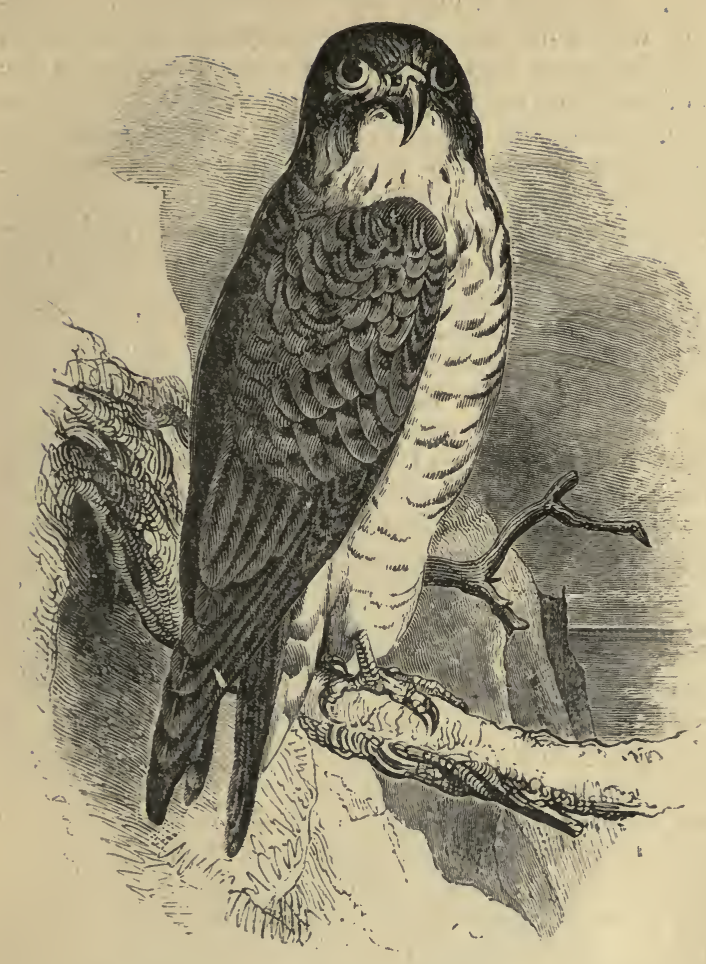

\section{THE PEREGRINE FALCON. (Falco peregrinus.)}

The Peregrine Falcon, which is the most common kind, is from fifteen to eighteen inches in length. The bill is blue at the base, and black at the point; the head, back, scapulars, and coverts of the wing are barred with deep black and blue; the throat, neck, and upper part of the breast are white, tinged with yellow; the bottom of the breast, belly, and thighs are of a grayish white; and the tail is black and blue. Wilson enumerates no less than ten varieties, dependent chiefly upon age, sex, and 
country. It is found, more or less abundantly, throughout the whole of Europe, principally in the mountain districts in North and South America, dwelling in the clefts of rocks, especially such as are exposed to the midday sun. It breeds upon the cliffs in several parts of England, but appears to be more common in Scotland and Wales. Its food consists principally of small birds : but it scruples not to attack the larger species, and sometimes gives battle even to the kite. Falcons rarely take their prey upon the ground, like the more ignoble birds of the class to which they belong; but pounce upon it from aloft, in a directly perpendicular descent as it flies through the air, bear it downwards by the united impulse of the strength and rapidity of their attack, and sticking their talons into its flesh, carry it off in triumph to the place of their retreat. Like most predatory animals, they are stimulated to action by the pressure of hunger alone, and remain inactive and almost motionless while the process of digestion is going on, until the renewed cravings of their appetite stimulate them to further exertion. In different stages of its growth, the Peregrine Falcon has been known by various English names. Its proper appellation among falconers is the Slight Falcon, the term Falcon Gentle being equally applicable to all the species when rendered manageable. In the immature state, this Falcon is also called a Red Hawk, from the prevailing colour of its plumage. 'The male is called a Tiercel, to distinguish it from the female, which, in the Falcon tribe, is commonly one-third larger than the male.

In China there is said to be a variety, which is mottled with brown and yellow, and used by the emperor of China in his sporting excursions, when he is usually attended by his great falconer, and a thousand of inferior rank. Every bird has a silver plate fastened to its foot, with the name of the falconer who has the charge of it, that, in case it should be lost, it may be restored to the proper person; but if it should not be found, the name is delivered to another officer, called the guardian of lost birds, who, to make his situation known, erects his standard in a conspicuous place among the army of hunters.

In Syria there is a species of Falcon, which the in- 
habitants call Shaheen (Falco peregrinator), and which is of so fierce and courageous a disposition, that it will attack any bird, however large or powerful, which presents itself. "Were there not," says Dr. Russel, in his Account of Aleppo, "several gentlemen now in England to bear witness to the fact, I should hardly venture to assert that, with this bird, which is about the size of a pigeon, the inhabitants sometimes take large eagles. This Hawk was in former times tanght to seize the eagle under the pinion, and thus depriving him of the use of one wing, both birds fell to the ground together; but the present mode is to teach the Hawk to fix on the back, between the wings, which has the same effect, only, that as the bird tumbles down more slowly, the falconer has more time to come to his Hawk's assistance; but in either case, if he be not very expeditious, the falcon is inevitably destroyed. Inever saw the Shaheen fly at eagles, that sport having been disused before my time; but I have often seen him take herons and storks. The Hawk, when thrown off, flies for some time in a horizontal line, not six feet from the ground; then mounting perpendicularly, with astonishing swiftness, he seizes his prey under the wing, and both together come tumbling to the ground."

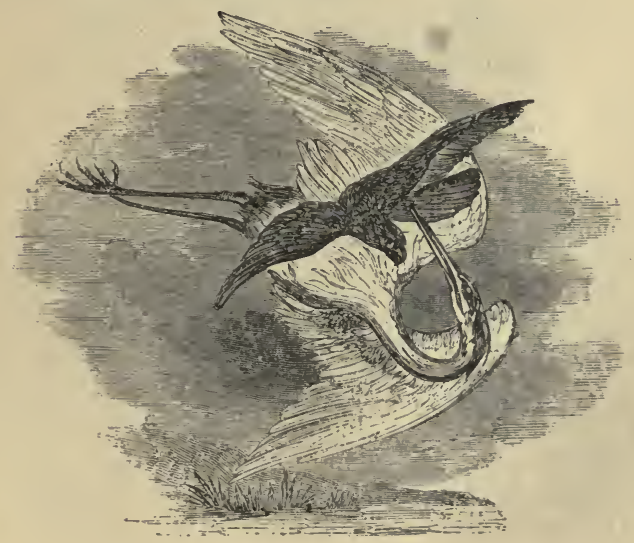




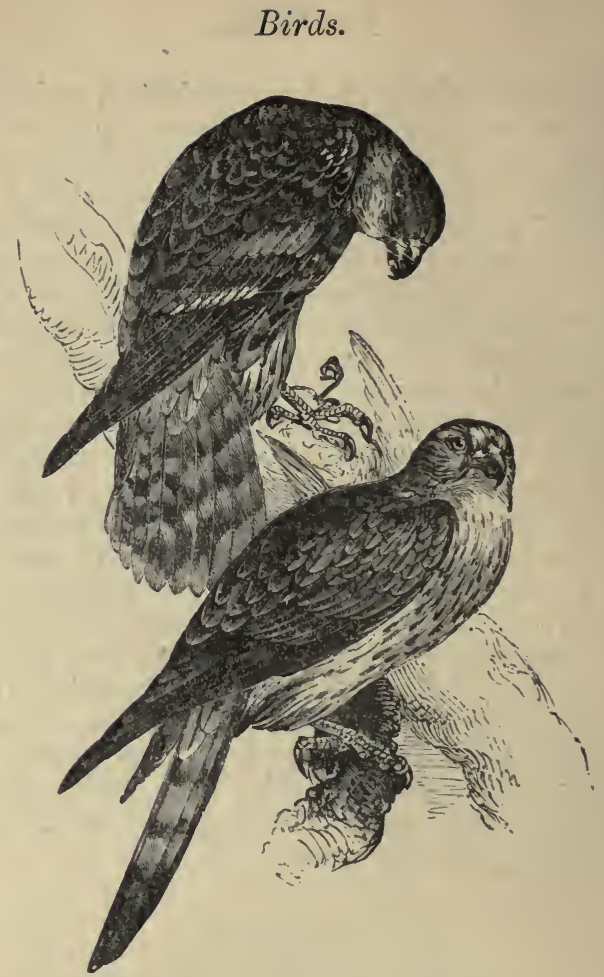

\section{THE MERLIN, (Fulco cesalon,)}

Is the smallest British species of the Falcon tribe, and, as its name implies, is not very different in size from the blackbird; the word Merlin signifying in French a small merle, or blackbird. Though small the Merlin is not inferior in courage to any of the other Hawks; it is noted for its boldness and spirit, often attacking and killing at one stroke a full-grown partridge or a quail; but it differs from the Falcons and all the other rapacious kinds, in the male and female being of equal size. The back of this bird is party-coloured, of dark blue and brown; the quill feathers of the wings black, with 
rusty spots; the tail is about five inches long, of a dark brown or blackish colour, with transverse white bars: the breast is of a yellowish white, with streaks of rusty brown pointing downwards; the legs are long, slender, and yellow; the talons black. The head is encircled with a row of yellowish feathers, not unlike a coronet. In the male the feathers on the rump, next the tail, are bluer; a mark by which the falconers easily discern the sex of the bird. The Merlin does not breed here, but visits us in October: it flies low, and with great celerity and ease. In the days of falconry, the Merlin was considerer the lady's hawk.

In ancient days-in ancient days,

When ladies took a strange delight

In hawks and hounds and sporting ways,

A Merlin was a pleasant sight.

" ' $T$ was gentle when, in trappings gay,

Upon its lady's wrist it stood;

Till its hood was raised and it saw its prey,

When its eye betrayed the bird of blnod."

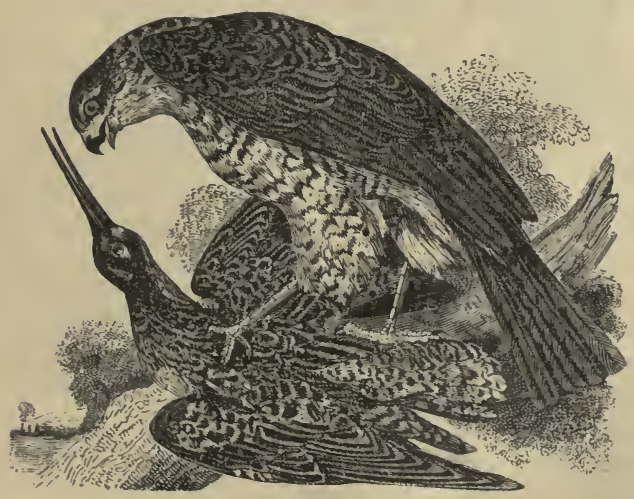




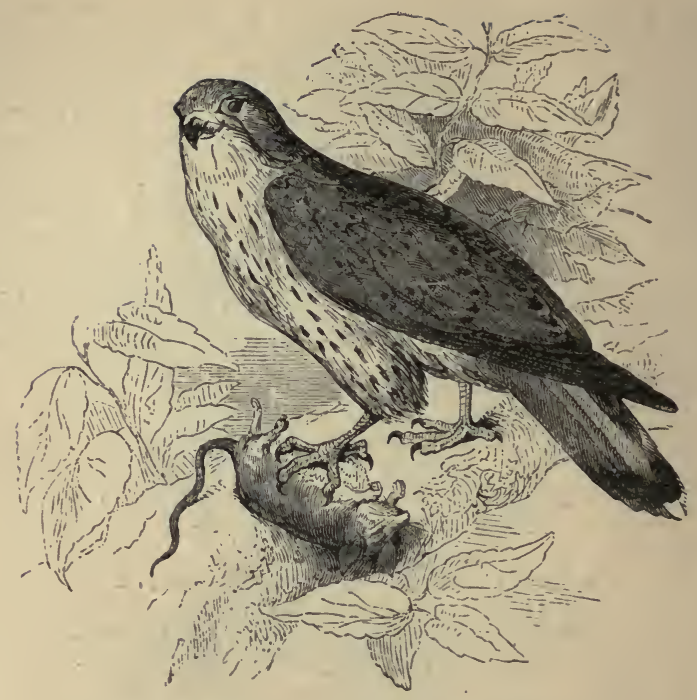

THE KESTREL, (Falco tinnunculus,)

Is the commonest of all the British Hawks, and may be seen in almost all parts of the country hovering over the fields in search of mice and other small animals. His flight is very peculiar. He advances only for a short distance at a time, and then suspends himself in the air by very short but quick movements of his wings. If no prey make its appearance beneath him, he then gues on a little further, and again remains stationary, but the moment a mouse or other small quadruped stirs amongst the grass, his wings close, and he descends with the greatest velocity. The Kestrel will also feed upon small birds and insects.

The Kestrel is a handsome little Hawk, from twelve to fifteen inches in length, with a blue beak and yellow cere and feet. Its plumage is reddish brown or fawn colour, elegantly marked with black spots and bars. Its nest is built among rocks, or in the holes and corners of 
old buildings and church towers, and the female lays four or five eggs, which are reddish white, with brown spots.

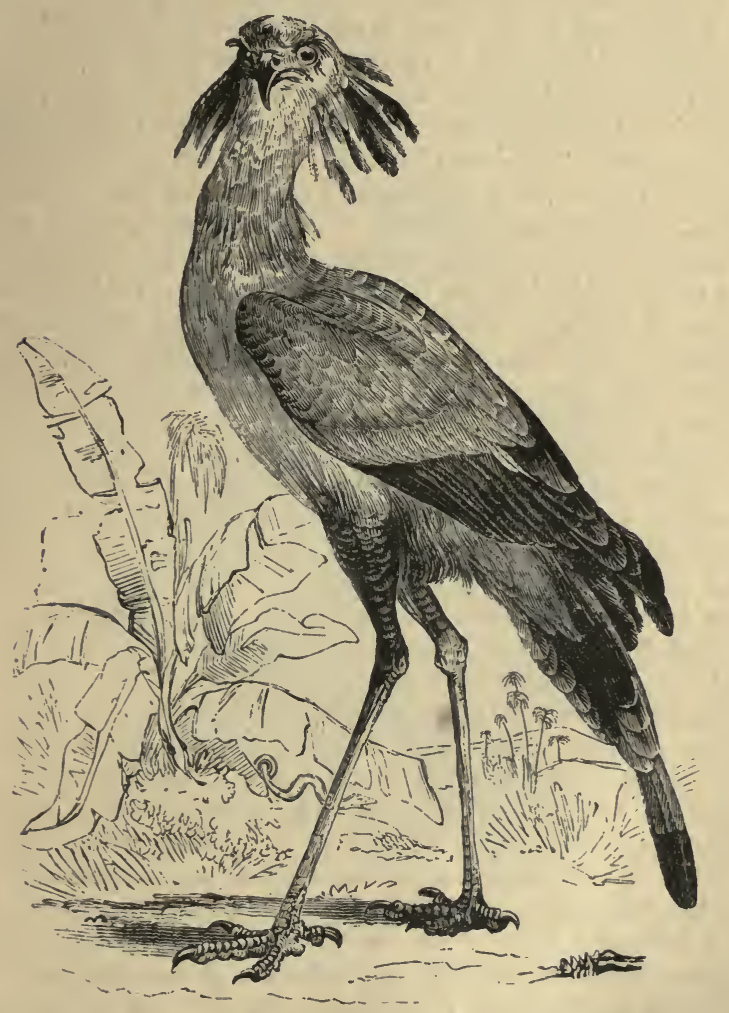

THE SECRETARY BIRD. (Serpentarius reptilivorus.)

'T'H singular bird, which is a native of Southern Africa, differs from all the other predaceous birds in the great length of its legs, which are so long that some naturalists have placed it.among the Wading Birds. It stands be- 
tween three and four feet high when erect, and is of a bluish ash colour on the back and nearly white beneath; its tail is long, and has the two middle feathers much longer than the others and nearly reaching to the ground; and the back of the head is adorned with a tuft of black feathers, which the bird can raise at pleasure. It is from this tuft that the bird has obtained his name; the Dutch colonists of the Cape of Good Hope fancied they saw some resernblance in it to the pen of a clerk stuck behind his ear, and accordingly called him the Secretary Bird. Clerks and secretaries are no doubt useful personages in their way, and the Secretary Bird, although he cannot take his pen from behind his ear, finds abundance of work to do, although of a kind very different from the peaceful labours of his namesakes. He is the great destroyer of the snakes and other reptiles which swarm in many parts of Southern Africa, and which, but for him, would increase in numbers so as to become a positive nuisance. And here we may call our young readers to admire the wonderful manner in which the structure of a hawk has been modified by the hand of the Creator to suit it for a particular mode of life. As the bird advances to attack a snake his long legs, protected by hard horny scales, elevate his body to a considerable height above the ground, thus giving him an advantageous position, and at the same time enabling it to move with great speed. One of the large and powerful wings, armed at the end with a strong spur, is raised a little from the body and held forward like a shield, but constantly shaken, as if to distract the attention of the foe, and thus, like a skilful boxer sparring up to his antagonist, the Secretary makes his way towards his intended prey. As he approackes he watches for the moment when the snake is about to spring upon him; a single blow from the spurred wing is usually sufficient to lay the reptile writhing in the ground in a helpless state; it is then soon despatehed and as speedily swallowed. Some idea of the quantity of reptiles destroyed by this bird may be gained from Le Vaillant's statement, that the crop of one of them examined by him contained eleven lizards, three snakes as lung as a 
man's arm, and eleven small tortoises, together with a good many insects. 'The inhabitants of the Cape Colony are quito aware of the services rendered to them by the Secretary Bird, and sometimes keep him among their poultry to protect them from injurious animals; he is said to behave with great propriety under these circumstances, rarely doing any mischief to his companions, unless his supply of food has been neglected.

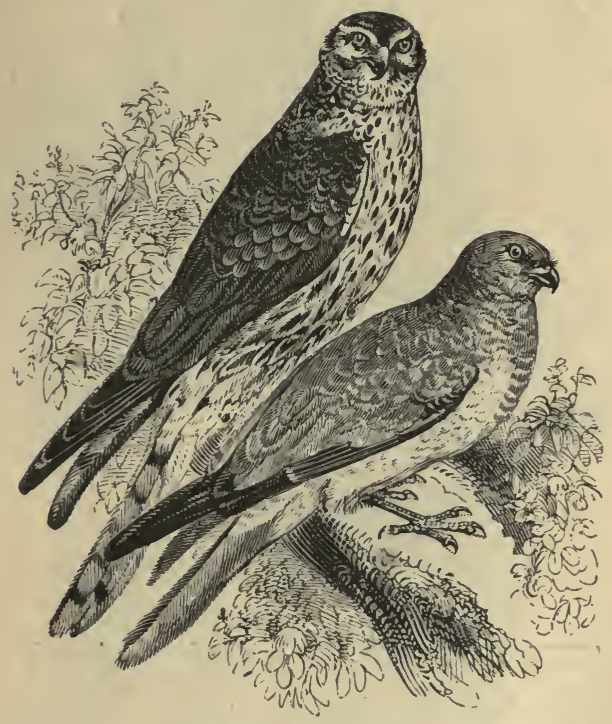

THE HEN HARRIER, (Circus cyaneus,)

Is seen about forests; heaths, and other retired places, especially in the neighbourhood of marshy grounds, where it destroys vast numbers of snipes, woodcocks, and wild ducks. It is about seventeen inches long, and three feet wide; its bill is black, and cere yellow. The upper part of its body is of a bluish gray; and the back of the head, breast, belly, and thighs are white. The legs are long, slender, and yellow; and the claws black. 


\section{§ II.--Nocturnal Birds of Prey.}

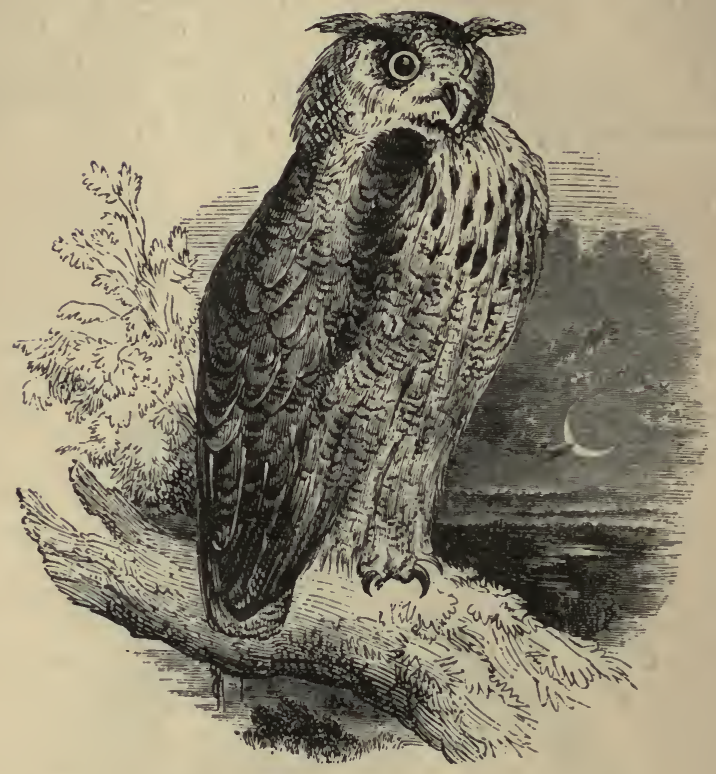

THE HORNED OWL, (Bubo maximus,)

Is one of the largest of the Owls, and has two long tufts growing from the top of its head, above its ears, and composed of six feathers, which it can raise or lay down at pleasure. Its eyes are large, and encircled with an orange-coloured iris; the ears are large and deep, and the beak black; the breast, belly, and thighs, are of a dull yellow, marked with brown streaks; the back, coverts of the wings, and quill feathers, are brown and yellow; and the tail is marked with dusky and red bars. It inhabits the north and west of England, and Wales. The conformation of the organ of sight in the Owl is so 
peculiar, and so much in its nature resembling that of the feline kind, that it can see much better at dusk than by daylight. 'The Barn Owl sees in a greater degreo of darkness than the others; and, on the contrary, the Horned Owl is enabled to pursue his prey by day, though with difficulty. Owls are sometimes tamed by persons in the country, who carefully rear them in a domestic state, from their propensity to. chase and derour mice and other vermin, of which they clear the houses with as much address as cats. The Owl is a solitary bird, and is said to retire into holes in towers and old walls in the winter, and pass that season in sleep.

"The solitary birl of night,

Through the pale shade now wings his flight, And quits the time-shook tower;

Where, shelter'd from the blaze of day,

In philosophic gloom he lay,

Beneath his ivy bower." Canter.

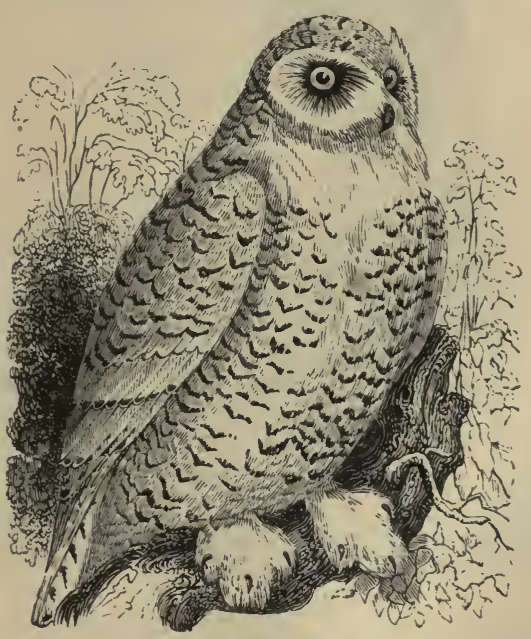

THE HARFANG, OR GREAT SNOWY OWL.

The Harfayg, or Great Sxowy Owt, (Surnia nyctea,) is another species which takes its prey occasionally by day- 
light. It is seldom seen in England, but frequently visits North Britain, particularly the Orkney and Shetland Islands. It is one of the few Owls that feed on fish, into which it strikes its talons while in the water, and carries them off to its nest. 'These Owls are very common in the northern parts of North America, and are eaten not only by the Indians, but by the Europeans engaged in the fur trade.

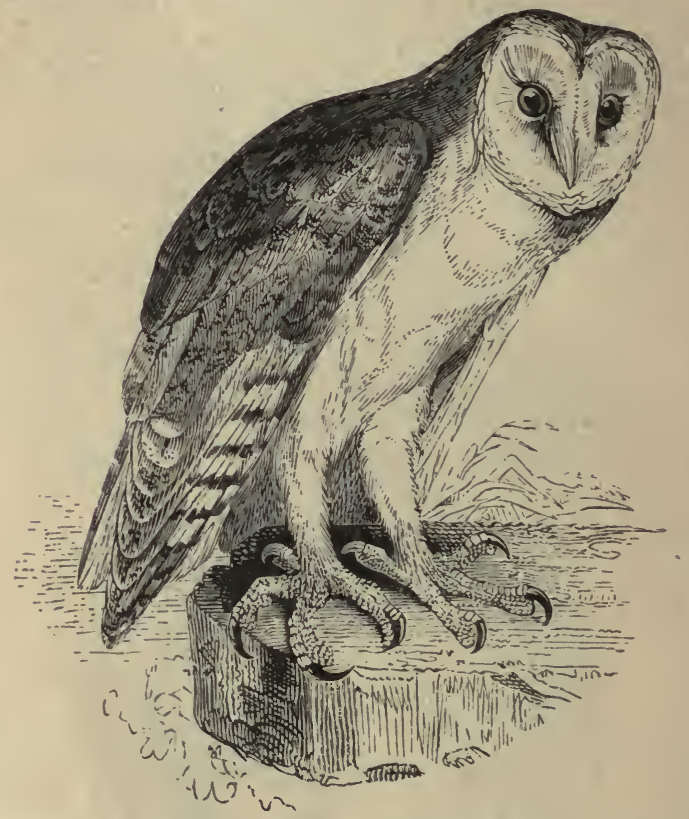

THE WHITE, BARN, OR SCREECH OWL.

(Sirix flammea.)

"___ from yonder ivy-mantled tower,

The moping Owl does to the moon complain

Of such as, wandering near her secret bower,

Molest her ancient solitary reign."

Gray.

T'us bird is about the size of a large pigeon. Its beak, 
hooked at the end, is more than an inch and a half long. There is a circle or wreath of white, soft, and downy feathers, encompassed with yellow ones, beginning from the nostrils on each side, passing round the eye and under the chin, somewhat resembling the hood that women used to wear; so that the eyes appear to be sunk in the middle of the feathers, and only the tip of the beak projects from them. The breast and feathers of the inside of the wings are white, and marked with a few dark spots; the upper parts of the body are of a fine pale yellow colour, variegated with black and white spots. 'I'he legs are covered with a thick down to the feet, but the toes have only thin-set hairs around them.

In ancient mythology, another common species, the Brown Owl (Syrnium aluco), was consecrated to Minerva, the goddess of wisdom; in allusion to the lucubrations of wise men, who study in retirement and during the night.

"Now the Hermit Owlet peeps

From the barn, or twisted brake;

And the blue mist slowly creeps,

Curling on the silver lake."

Cenminghasi.

§ III.-Insessores, or Perching Birds.

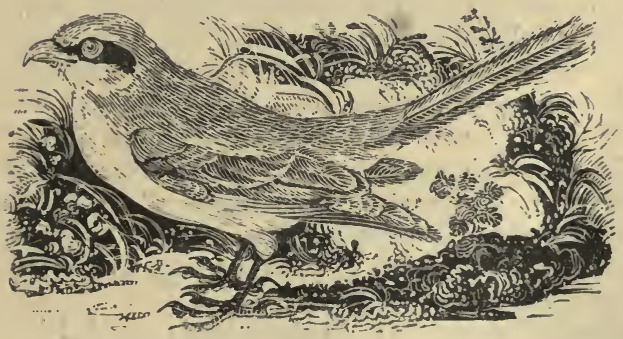

THE BUTCHER-BIRD, OR SHRIKE.

(Lanius excubitor.)

The Great Butcher-birn, or Shrike, is about as large as a thrush ; its bill is black, an inch long, and hooked at the 
end. It is only an occasional visitor to this country, where it is generally found between autumn and spring. "The Shrike," says Mr. Yarrell, "feeds on mice, shrews, small birds, frogs, lizards, and large insects. After having killed its prey, it fixes the body in a forked branch, or upon a sharp thorn, the more readily to tear off small pieces from it. It is from their habit of killing and hanging up their meat, that the Shrikes are called Butcher-biris." The head, back, and rump are ashcoloured; the chin and lower part of the body white; the breast and throat varied with dark lines crossing each other; the tips of the feathers of the wings are, for the most part, white; it has a black spot by the eye; the outermost tail feathers of the male are all over white; the two middlemost have only their tips white, the rest of the feathers being black, as well as the legs and feet. It builds its nest among thorny shrubs and dwarf trees, and furnishes it with moss, wool, and dowuy herbs, where the female lays five or six eggs. A peculiarity belonging to the birds of this kind is, that they do not, like most other birds, expel the young ones from the nest as soon as they can provide for themselves, but the whole brood live together in one family. The Butcherbird will chase all the small birds upon the wing, and will sometimes venture to attack partridges, and even young hares. Thrushes and blackbirds are frequently their prey: the Shrike fixes on them with its talons, splits the skull with its bill, and feeds on them at leisure. On this account Linnæus classed the Shrikes with the birds of prey ; but modern naturalists have placed them with the insect-eaters, as insects are their principal food. It is easy to distinguish these birds at a distance, not only from their going in companies, but also from their manner of flying, which is always up and down, seldom in a direct line, or obliquely.

The Little Butcher-bird (Lanius collurio), called in Yorkshire, Flusher, is about the size of a lark, with a large head. About the nostrils and corners of the mouth it has black hairs or bristles; and round the eyes a large black longitudinal spot; the back and upper side of the wings are of a rusty colour; the head and rump cine- 
reous; the throat and breast white, spotted with red. It builds its nest of the stalks of plants, and the female lays six eggrs, nearly all white, except at the blunt end, which is encircled with brown or dark red marks. The female is somewhat larger than the male; the head is of a rust colour, mixed with gray; the breast, belly, and sides of a dirty white; the tail deep brown; the exterior web of the outer feathers white. Its manners are similar to those of the large Butcher-bird. It frequently preys on young birds,. which it takes in the nest; it likewise feeds on grasshoppers, beetles, and other insects. During the period of incubation, the female soon discovers herself at the approach of any person by her loud and violent outcries.

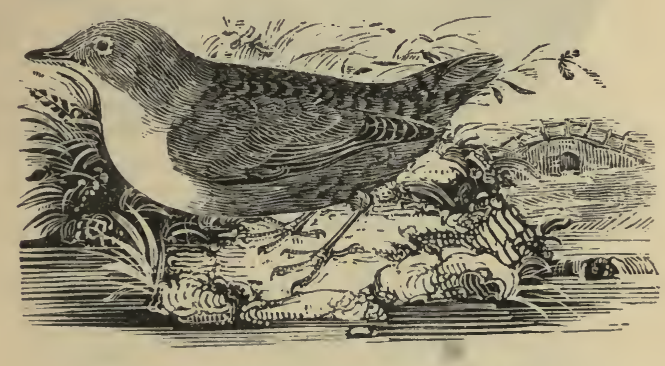

\section{THE WATER OUZEL, OR DIPPER,}

\section{(Cinclus aquaticus,)}

Is found in most parts of this island, and is about the size of the common blackbird. It feeds upon aquatic insects and small fish. The head and upper side of the neck are of a kind of umber colour, and sometimes black with a shade of red; the back and coverings of the wings are a mixture of black and ash-colour, the throat and breast perfectly white.

The Dipper is said to walk along the bottom of a lake or river as easily as on land; but this is far from being the case, as, though it readily plunges into the water, it appears to tumble about in a very extraordinary manner, 
with its head downwards. Even on land the bird walks awkwardly, as its feet are best adapted for the slippery stones on which it passes the greater part of its life, watching for the insects which it picks up on the edge of the water. Its movements under water are really performed by means of the wings, the bird positively flying through the water. When disturbed, it usually flirts up its tail, and makes a chirping noise. Its song in spring is said to be very pretty. In some places this bird is supposed to be migratory.

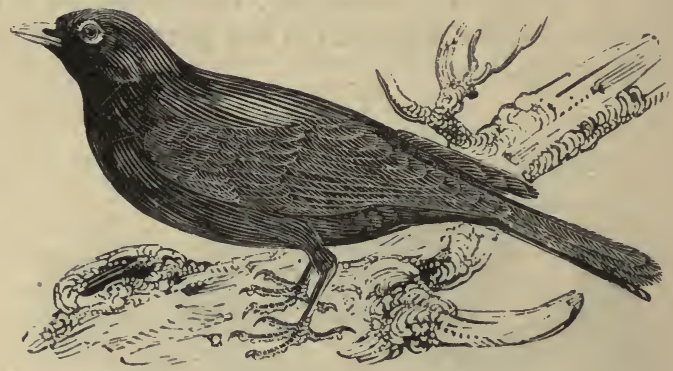

THE BLACKBIRD. (Turdus Merula.)

"The smiling morn, the breathing spring, Invite the tuneful birds to sing;

- And, while they warble from each spray, Love melts the universal lay."

\section{MaLlet.}

This well-kniown songster does not soar up to the clouds, like the lark, to make his voice resound through the air ; but keeps to the shady groves, which he fills with his melodious notes. Early at dawn, and late at dusk, he continues his pleasing melody; and when incarcerated in the narrow space of a cage, still cheerful and merry, he strives to repay the kindness of his keeper by singing to him his natural strains; and beguiles his irksome hours of captivity by studying and imitating his master's whistle. Blackbirds build their nests with great art, making the outside of moss and slender twigs, 
cemented tugether and lined with clay, and covering the clay with soft materials, as hair, wool, and fine grass. The female lays four or five eggs, of a bluish green colour, spotted all over with brown. The bill is yellow, but in the female the upper part and point are blackish; the inside of the mouth, and the circumference of the eyelids are yellow. The name of this bird is sufficiently expressive of the general colour of his body. He feeds on berries, fruit, insects, \&c.

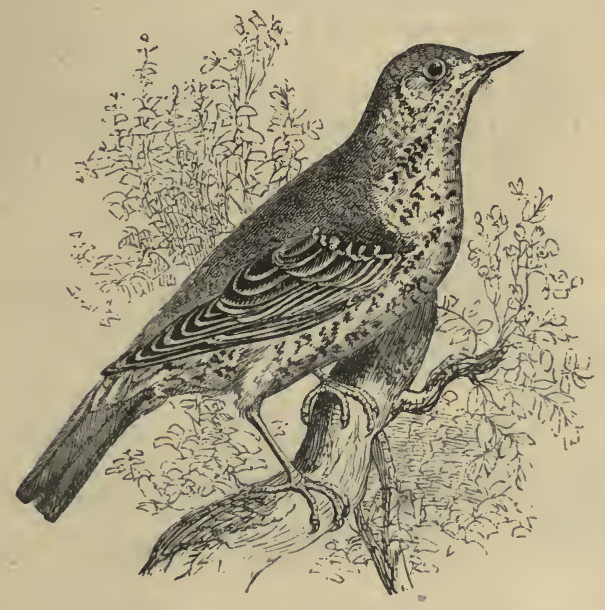

THE MISSEL THRUSH. (Turdus viscivorus.)

The Missir Thrush, so called from its feeding on the berries of the misletoe, differs but little from the Song Thrush, except in size. He is larger than the fieldfare, while the 'Throstle is smaller. The female lays five or' six bluish eggs, with a tint of green, and marked with dusky spots.

The Song Thrush or Throstle, (Turdus musicus,) is one of the best songsters of the evening hymn in the grove. His voice is loud and sweet; the melody of his song is 
varied, and, although not so deep in the general diapason of the woodland concert as that of the blackbird, yet it fills up agreeably, and bursts through the inferior warblings of smaller performers. His breast is of a yellowish white, spotted with black or brown dashes, like ermine spots.

The term Merle for the Blackbird, and Mavis for the Thrush, are used chiefly by the poets.

"Merry is it in the good green wood,

When the Mavis and Merle are singing,

When the deer sweeps by, and the hounds are in cry,

And the hunter's liorn is ringing."

Sсотт.

"Take thy delight in yonder goodly tree,

Where the sweet Merle and warbling Mavis be."

DRATTON.

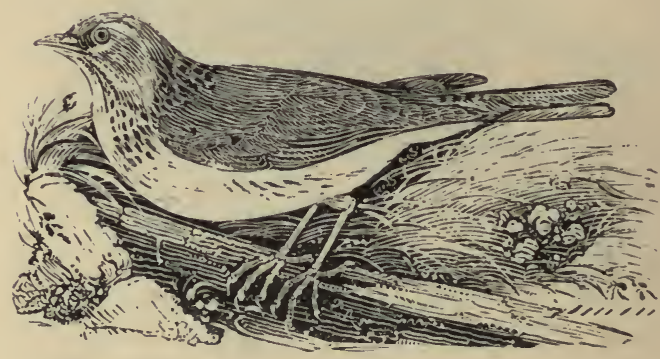

THE REDWING, (Turdus iliacus,)

Is rather less than the song thrush; but the upper part of the body is of the same colour; the breast not so much spotted; the coverings of the feathers of the under side of the wings, which in the thrush are yellow, are of orange colour in this bird; by which marks it is generally distinguished. The body is white, the throat and breast yellowish, marked with dusky spots. It is migratory in this island, builds its nest in hedges, and lays six bluish eggs. Like the fieldfare, it leaves us in spring, for which reason its song is quite unknown to 
us; but it is said to be very pleasing. It is delicate eating; and the Romans held it in such estimation, that they kept thousands of them together in aviaries, and fed them on a sort of paste made of bruised figs and flour, to improve the delicacy and flavour of their flesh. Under this management these birds fattened, to the great profit of their proprietors, who sold them to Roman epicures for three denarii, or about two shillings sterling each, which at that early period was a large price.

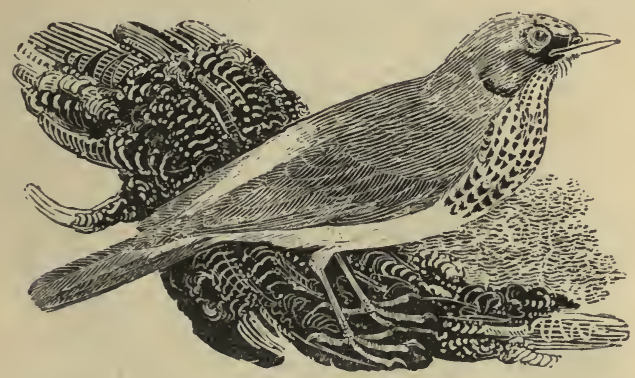

THE FIELDFARE, (Turdus pilaris,)

Is a well-known bird in this country. Fieldfares fly in flocks, together with the redwing and starling, and change their haunts according to the season of the year. 'They abide with us in winter, and disappear in spring, so punctually, that after that time not one is to be seen. The flesh is esteemed a great delicacy, and is highly prized in Germany, where it is known as the Krammsvögel, and is sold in the markets of Westphalia by the dozen. Their favourite food is the juniper-berry, whence its German name. The head is ash-coloured, and spotted with black: the back and coverts of the wings of deep chesnut colour; the rump cinereous; and the tail black, except the lower part of the two middle feathers, which are ash-coloured, and the upper sides of the exterior feathers, which are white. They collect in large flocks; and it is supposed they keep watch, like 
the crow, to mark and announce the approach of danger. On any person approaching a tree that is covered with them, they continue fearless, till one at the extremity of the bush, rising on its wings, gives a loud and peculiar note of alarm. They then all fly away, except one, which continues till the person approaches still nearer, to certify, as it were, the reality of the danger, and afterwards he also flies off, repeating the note of alarm.

Mr. Knapp, in his "Journal of a Naturalist," says, that in the county of Gloucestershire the extensive low-lands of the river Severn, in open weather, are visited by prodigious flocks of these birds.

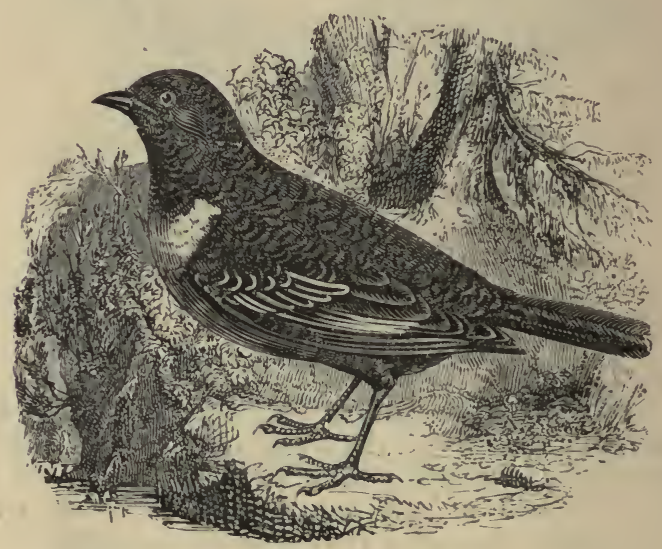

THE RING OUZEL. (Turdus torquatus.)

The Ring Ouzel differs from the fieldfare and redwing, to which it is nearly allied, in being a summer visitor to the British islands, instead of a winter one. It is found only in the wildest and most mountainous districts; particularly among the Welsh mountains and on Dartmoor, in Devonshire, where it has been known to breed. 


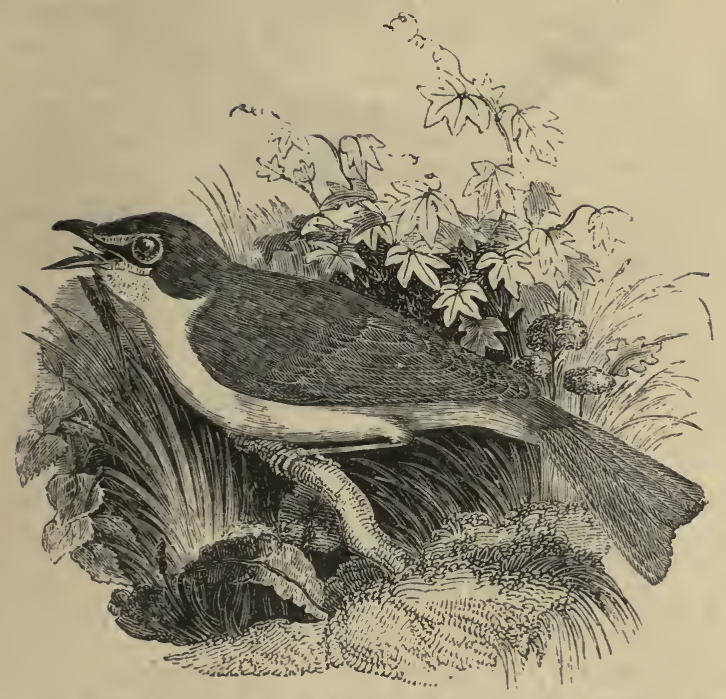

THE MOCKING BIRD, (Turdus polyglottus,)

$\mathrm{WHICH}_{\mathrm{H}}$ is also a species, is found in both North and South America, and in the West Indian islands. $\mathrm{He}$ has a beantiful song, which he varies by imitating the notes of almost all other birds, so that a person passing by his haunt is regaled with a complete ornithological concert, all by a single performer. Unfortunately, the Mocking Bird's taste is not equal to his musical powers. His talent for imitation is so great that he mimics every sound he hears, and as he introduces all his imitations freely into his songs, he often interrupts the most delightful melody with the scream of a hawk, the bark of a dog, the squalling of a cat, or similar discordant noises. 


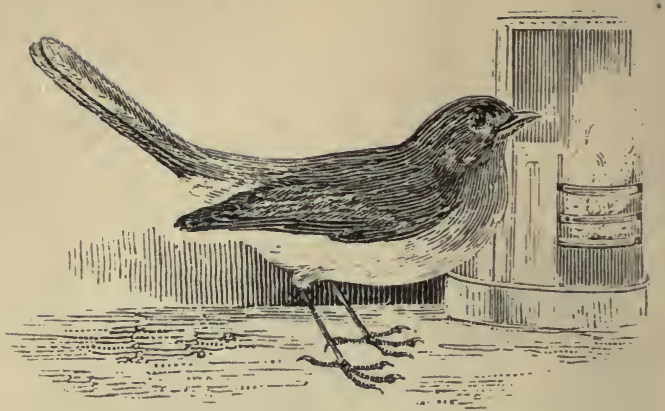

THE ROBIN, OR REDBREAST.

\section{(Erythacus rubecula.)}

" The Redbreast oft, at evening hours,

Shall kindly lend his little aid, With hoary moss, and gathering flowers,

'To deck the ground where thou art laid."

Collixs.

The Redbreast, or Robin, as he is popularly called, seems always to have enjoyed the protection of man, more than any other bird. The prettiness of his shape, the beauty of his plumage, the quickness of his motions, his familiarity with us in winter, and, above all, the melody and sweetness of his voice, claim our admiration, and have insured him that security which he enjoys among us; though the aid of fable has also been called in, to guard him from the assaults of thoughtless boys.

"Little bird with bosom red, Welcome to my humble shed!

Courtly domes of high degree

Have no room for thee and me;

Pride and pleasure's fickle throng

Nothing mind an idle song.

Daily near my table steal,

While I pick my scanty meal;

Doubt not, little though there be,

But I'll cast a crumb for thee; 
Well rewarded if I spy

Pleasure in thy glancing eye;

And see thee, when thou'st eat thy fill,

Plume thy breast, and wipe thy bill."

'LANGHORNE."

In the winter season, impelled by the potent stimulus of hunger, the Redbreast frequents our barns; -gardens, and houses, and often alights, on a sudden, on the rustic floor; where, with his broad eye incessantly open, and looking askew upon the company, he picks up eagerly the crumbs of bread that fall from the table, and then flies off to the neighbouring bush, where, by his warbling strains, he expresses his gratitude for the liberty he has been allowed. $\mathrm{He}$ is found in most parts of Europe, but nowhere so commonly as in Great Britain. His bill is dusky; his forehead, chin, throat, and breast are of a deep orange-colour, inclining to vermilion; the back of his head, neck, back, and tail are of a pale olivebrown colour ; the wings are somewhat darker, the edges inclining to yellow; the legs and feet are the colour of the bill. The female generally builds her nest in the crevice of some mossy bank, near places which human beings frequent, or in some part of a human dwelling. Robins have been known to build in a sawpit where men worked every day, and in various other equally extraordinary places. When the Crystal Palace at Sydenham was being fitted up, several Rubins built their nests in holes of the large roots used to raise the flower beds within the building. So little fear did they exhibit that their bright eyes might be seen glancing from holes close to which men were passing every moment. The elegant poet of The Seasons gives us a very exact and animated description of this bird in the following lines:

"—_ Half afraid, lie first

Against the window beats : then, brisk alights

On the warm hearth ; then, hopping on the floor,

Eyes all the smiling family askance,

And pecks, and starts, and wonders where he is, Till, more familiar grown, the table-crumbs Attract his slender feet."

An old Latin proverb tells us that two Robin Red- 
breasts will not feed on the same tree; it is certain that the Redbreast is a most pugnacious bird, and that he does not live in much harmony and friendship with those of his own kind and sex. The male may be known from the female by the colour of his legs, which are blacker.

The Redbreast attends the gardener when digging his borders; and will, with great familiarity and tameness, pick out the worms almost close to his spade.

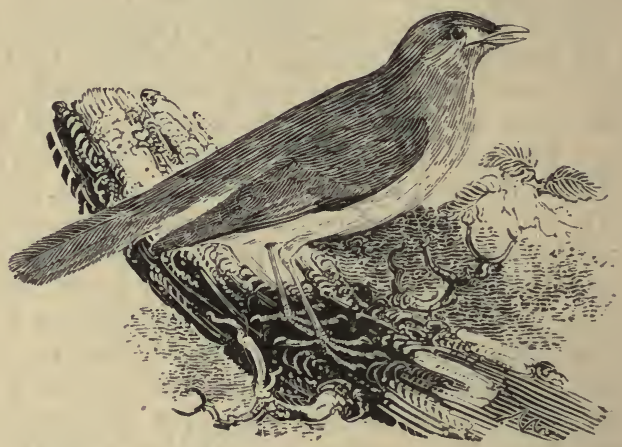

THE NIGH'TINGALE. (Philomela luscinia.)

"Sweet bird, that shunn'st the noise of folly, Most musical, most melancholy!

Thee, chantress, oft, the woods among,

I woo to hear thy even song."

Mruton.

The Nightivgale has little to boast of in respect to plumage, which is of a pale tawny colour on the head and back, dashed with a slight shade of olive; the breast and upper part of the belly incline to a grayish tint, and the lower part of the belly is almost white; the exterior web of the quill feathers is of a reddish brown; the tail of a dull red; the legs and feet ash-coloured; the irides hazel ; and the eyes large, bright, and staring. But it is hardly possible to give an idea of the extraordinary power which this small bird possesses in its throat, as to the extension of sound, sweetness of tone, and versatility of notes. 
Its song is composed of several musical passages, each of which does not continue more than the third part of a minute; but they are so varied, the passing from one tone to another is so fanciful and so rapid, and the melody so sweet and so mellow, that the most consummate musician is pleasingly led to a deep sense of admiration on hearing it. Sometimes, joyful and merry, it runs down the diapason with the velocity of lightning, touching the treble and the base nearly at the same instant; at other times, mournful and plaintive, the unfortunate Plilomela draws heavily her lengthened notes, and breathes a delightful melancholy around. These have the appearance of sorrowful sighs; the other modulations resemble the laughter of the happy. Solitary on the twig of a small tree, and cautiously at a certain distance from the nest, where the pledges of his love are treasured under the fustering breast of his mate, the male fills constantly the silent woods with his harmonious strains, and during the whole night entertains and repays his female for the irksome duties of incubation. The Nightingale not only sings at intervals during the day, but waits till the blackbird and the thrush have uttered their evening call, even till the stock and ringdoves have, by their soft murmurings, lulled each other to rest, and then pours forth his full tide of melody :

"Tistening Philomela deigns
To let them joy, and purposes, in thought
Elate, to make lier night excel their day."

Thouson.

It is a great subject of astonishment that so small a bird should be endowed with such potent lungs. If the evening is calm, it is supposed that its song may be heard above half-a-mile. This bird, the ornament and charm of our spring and early summer evenings, as it arrives in April, and continues singing till June, disappears un a sudden about September or October, when it leaves us to pass the winter in the North of Africa and Syria. Its visits to this country are limited to certain counties, mostly in the south and east; as, though it is 
plentiful in the neighbourhood of London, and along the south coast in Sussex, Hampshire, and Dorsetshire, it is not found in either Cornwall or Wales. As soon as the young are hatched, the song of the male bird ceases, and he only utters a harsh croak, by way of giving alarm when any one approaches the nest. Nightingales are sometimes reared up, and doomed to the prison of a cage; in this state they sing ten months in the year, though in their wild life they sing only as many weeks. Bingley says that a caged Nightingale sings much more sweetly than those which we hear abroad in the spring.

The Nightingale is the most celebrated of all the feathered race for its song. The poets have in all ages made it the theme of their verses; some of these we cannot resist giving:

"The Nightingale, as soon as April bringeth

Unto her rested sense a perfect waking,

Which late bare earth, proud of new clothing, springeth,

Sings out her woes

Sir Philip Sidney.

"— Beast and bird,

They to their grassy couch, these to their nests,

Were slunk; all but the wakeful Nightingale;

She all night long her amorous descant sung."

Milton.

"And in the violet-embroidered vale,

Where the lovelorn Nightingale

Nightly to thee her sad song mourneth well."

Miltos.

“ $O$ Nightingale, that on yon bloomy spray

Warblest at eve, when all the woods are still,

Thou with fresh hope the lover's heart dost fill,

While the jolly hours lead on propitious May,

Thy liquid notes that close the eye of day,

First heard before the shallow cuckoo's bill,

Portend success in love. Oh, if Jove's will

Have linked that amorous power to thy soft lay,

Now timely sing, ere the rude bird of hate

Foretell my hopeless doom in some grove nigh ;

As thou from year to year hast sung too late

For my relief, yet hadst no reason why :

Whether the muse, or love, call thee his mate,

Both them I serve, and of their train am I."

Miltox. 
" Now is the pleasant time,

The cool, the silent, save where silence yields,

'T'o the night-warbling bird, that, now awake,

Tunes sweetest his love-laboured song."

Miltox.

"How all things listen while thy muse complains, Such silence waits on Philomela's strains, In some still evening, when the whispering breeze

Pants on the leaves, and dies upon the trees."

\section{Pope.}

"There's a bower of roses by Bendemeer's stream,

And the Nightingale sings round it all the year long;

In the days of my childhood, ' $t$ was like a sweet dream

To sit in the roses, and hear the bird's song.

"That bower and its music I never forget,

But oft when alone, in the bloom of the year,

I think, Is the Nightingale singing there yet?

Are the roses still bright by the calm Bendemeer?"

Moore.

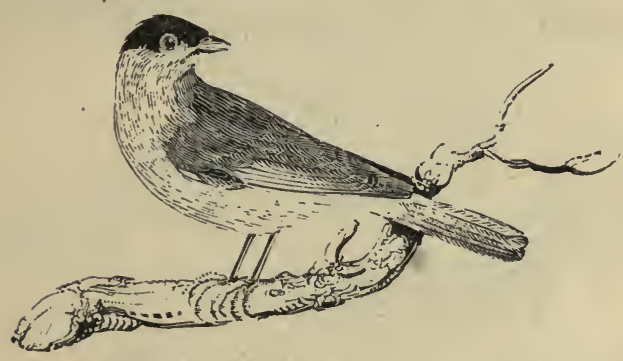

\section{THE BLACK-CAP, (Curruca atricapilla,)}

Is a very small warbler, not weighing above half-anounce. The top of the head is black, whence he takes his name; the neck ash-coloured, the back an ashy-brown, the wings of a dusky colour, the tail nearly the same; the nether part of the neck, throat, and upper part of the breast of a pale ash colour; the lower part of the belly white.

The Black-cap visits us about the middle of April, and retires in September; it frequents gardens, and builds its nest near the ground. 'The female lays five 
eggs of a pale reddish-brown, sprinkled with spots of a darker colour. This bird sings sweetly, and so like the nightingale, that in Norfolk it is called the mock nightingale. White observes, that it has usually a full, sweet, deep, loud, and wild pipe, yet the strain is of short continuance, and its motions desultory; but when it sits calmly, and earnestly engages in song, it pour's forth very sweet but inward melody; and expresses a great variety of modulations, superior perhaps to any of our warblers, the nightingale excepted. While it sings, its throat is greatly distended.

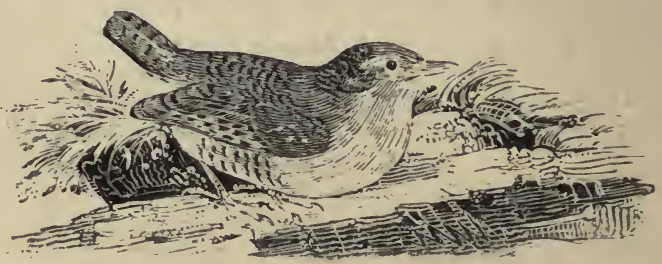

\section{THE WREN. (Troglodytes vulgaris.)}

"Fast by my couch, congenial guest, The Wren has wove her mossy nest; From busy scenes and brighter skies To lurk with innocence slie flies; Her hopes in safe repose to dwell, Nor aught suspects the sylvan cell."

T. WARTON.

Trie Wren is a very small bird: but, as if nature had intended to compensate the want of size and bulk in the individuals, by multiplying them to a greater extent, this little bird is one of the most prolific of the feathered tribe, its nest containing often upwards of eighteen eggrs, of a whitish colour, and not much bigger than a pea. 'The male and female enter by a hole cuntrived in the middle of the nest, and which, by its situation and size, is accessible only to themselves. The Wren weighs no more than three drachms. Its notes are very sweet, and rival those of the robin redbreast, in the middle of winter, when the coldness of the weather has condemned 
the other songsters to silence. Like the redbreast, it frequently approaches the habitation of man, enlivening the rustic garden with its song during the greater part of the year. It begins to make a nest early in the spring, but frequently deserts it before it is lined, and searches for a more secure place. The Wren does not, as is usual with most other birds, begin to build the bottom of the nest first. When against a tree, its primary operation is to trace upon the bark the outline, and thus to fasten it with equal strength to all parts. It then, in succession, closes the sides and top, leaving only a small hole for entrance.

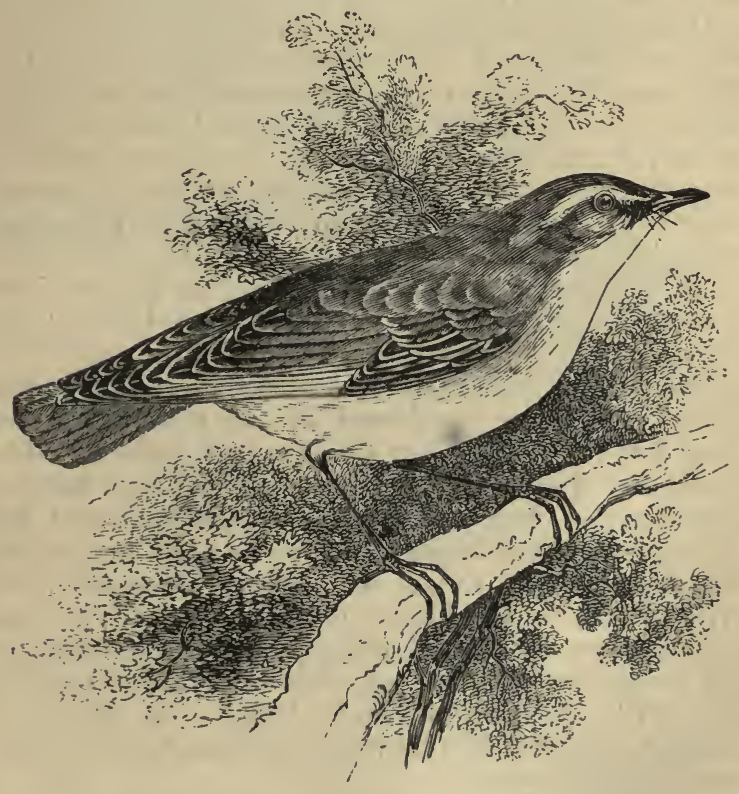

THE WILLOW WREN. (Sylvia trochilus.)

The WILLOW WREN is somewhat larger than the common Wren. The upper parts of the body are of a pale olive- 
green; the under parts are pale yellow, and a streak of yellow passes over the eyes. The wings and tail are brown, edged with yellowish green; and the legs are inclined to yellow. This bird is migratory, visiting us usually about the middle of April, and taking its departure towards the end of September. The female constructs her nest in holes at the roots of trees, in hollows of dry banks, and other similar places. It is round, and not unlike the nest of the Wren. The eggs are dusky white, marked with reddish spots, and are five in number. A Willow Wren had built in a bank of one of the fields of Mr. White, near Selborne. This bird, a friend and himself observed as she sat in her nest, but were particularly careful not to disturb her, though she eyed them with some degree of jealousy. Some days afterwards, as they passed the same way, they were desirous of remarking how the brood went on; but no nest could be found, till Mr. White happened to take up a large bundle of long green moss, which had been thrown, as it were, carelessly over the nest, in order to mislead the eye of any impertinent intruder.

Mr. White distinguished no fewer than three varieties of the Willow Wren. "I have now," he writes, "past dispute, made out three distinct species of the Willow Wrens, which constantly and invariably use distinct notes." "I have specimens of the three sorts now lying before me, and can discern that there are three gradations of sizes, and that the least has black legs, and the other two, flesh-coloured ones. The yellowest bird is considerably the largest, and has its quill feathers and secondary feathers tipped with white, which the others have not. The last haunts only the tops of trees and high beechen woods, and makes a sibilous grasshopperlike noise, now and then, at short intervals, shivering a little with its wings when it sings." Mr. Markwich, however, declared that he was totally unable to discover more than one species. 


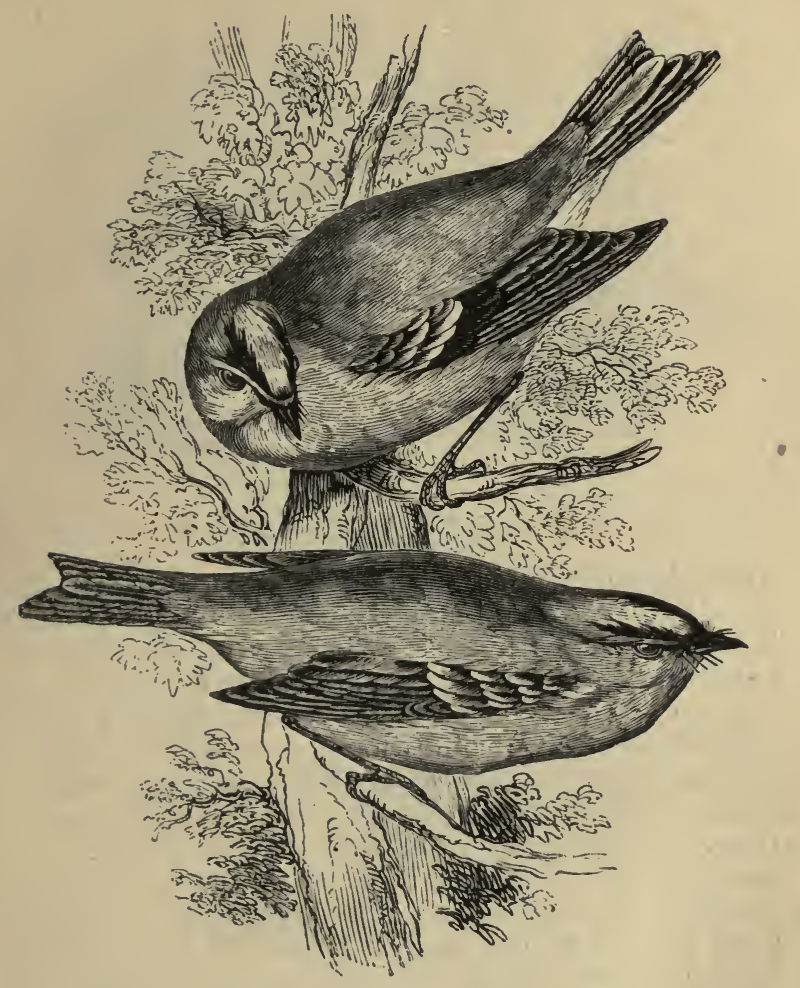

THE GOLDEN-CRESTED WREN, (Regulus cristatus,)

Is the smallest of British birds, measuring only three inches and a half in length. It is of an olive colour, with a beautiful crest of golden yellow feathers on its head. This charming little bird is generally found in fir woods; it feeds on insects, and has a soft and pleasing song. 


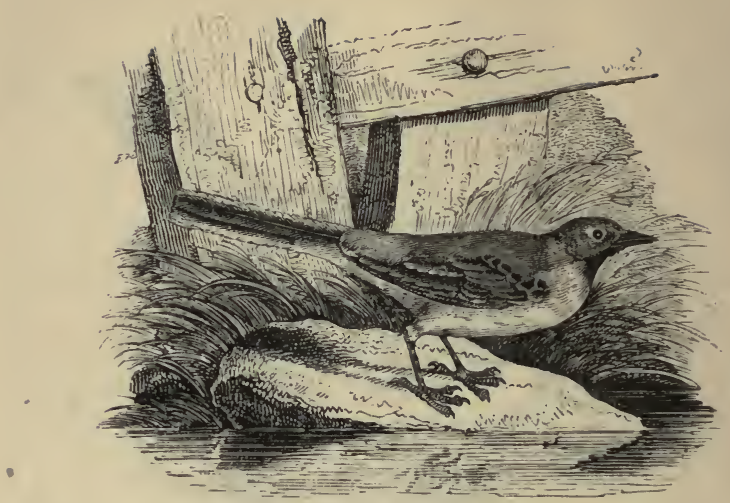

\section{THE GREY WATER WAGTAIL. (Motacilla boarula.)}

THERE is not a brook purling along two flowery banks, not a rivulet winding through the green meadow, which is not frequented by this beautifully coloured and ele. gantly shaped little creature. We even see them in the streets of country towns, following with quick pace the half-drowned fly or moth, which the road-side streamlet carries away. Next to the robin redbreast and the sparrow, they are the boldest in approaching our habitations. The Wagtails are much in motion; seldom perch, and perpetually flirt their long and slender tails, (whence they derive their name,) principally after picking up some fond from the ground, as if that tail were a kind of lever, or counterpoise, used to balance the body on the legs. They are observed to frequent, more commonly, those streams where women come to wash their linen; probably not ignorant that the soap, the froth of which floats upon the water, attracts those insects which are most acceptable to them. 


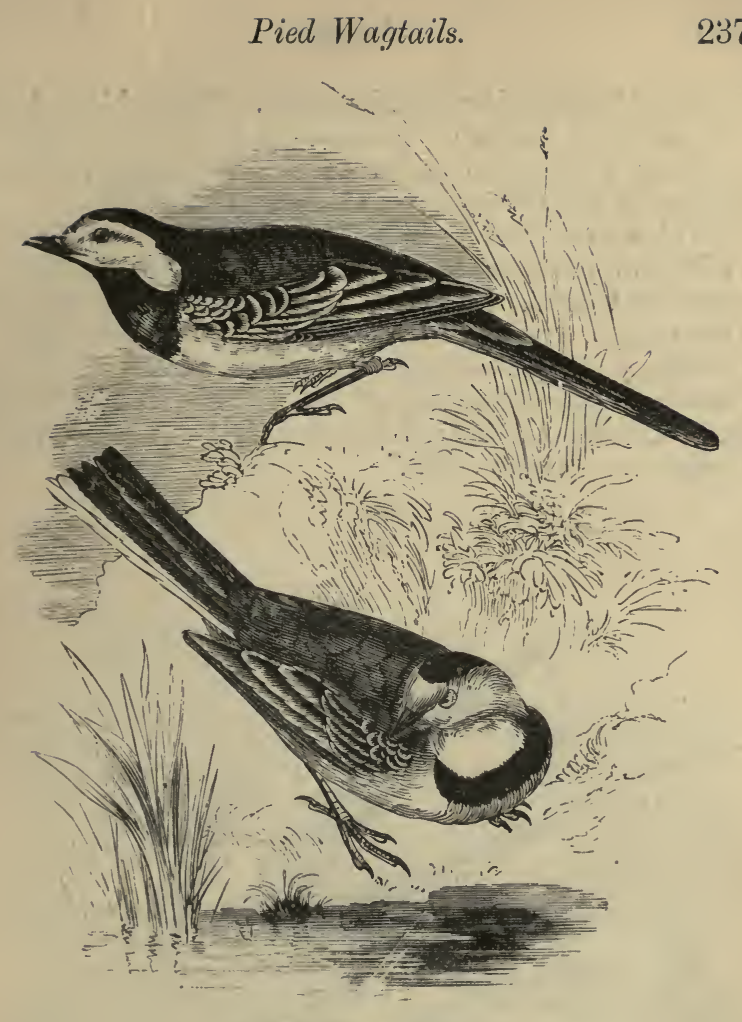

\section{PIED WAGTAILS.}

There are two common species of Wagtails, the Grey kind and the Pied Wagtail. The Grey Wagtail is retiring in its habits, and much.slower in its motions; its breast is yellow, and its wings grayish, but the Pied Wagtail, which is a very lively little bird, and seems always in a bustle, is black, softening into ash-colour and white; it is also bold, and will take the food thrown to it with as much confidence as a robin redbreast.

The Yellow Shepherdess (Budytes flava) is another species of Wagtail. The male is olive-green on the back, and yellow on the lower part of the body, but the 
breast of the female is nearly white. These birds do not frequent the banks of rivers, but are generally found walking among the grass of meadows, and following sheep. They are summer visitors to England.

White says, that "while the cows are feeding in the moist, low pastures, broods of Wagtails, white and grey, run round them, close up to their noses, and under their very bellies, availing themselves of the flies that settle on their legs, and probably finding worms and larvæ that are roused by the trampling of their feet. Nature is such an economist that the most incongruous animals can avail themselves of each other."

"Interest makes strange friendships!"

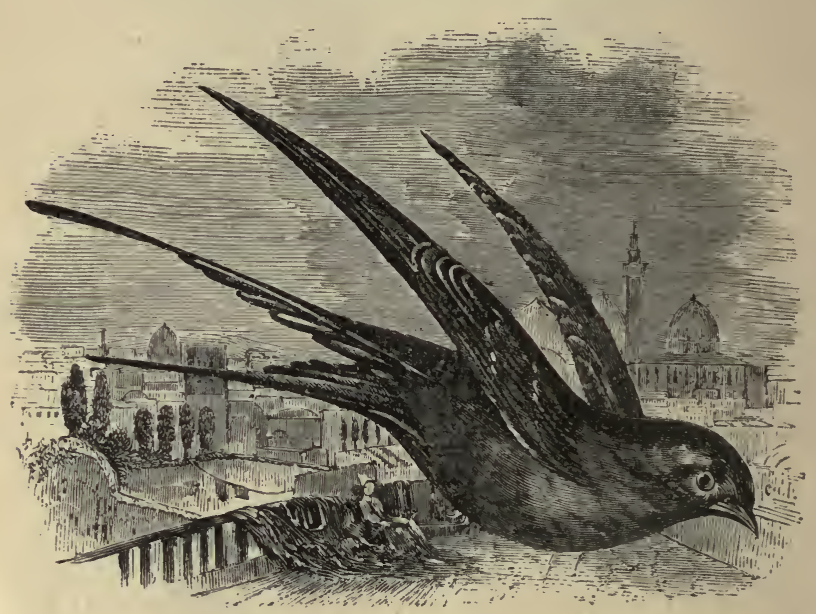

THE SWALLOW. (Hirundo rustica.)

"From the low-roof"d cottage ridge Ste the chattering Swallow spring :

Darting through the one-arch'd bridge, Quick she dips her dappled wing."

Censisghay.

Swallows are easily distinguished from all other birds, not only by their general structure, but by their twitter- 
ing note and mode of flying, or rather darting from place to place.

'They appear in Britain in April, and build in some outhouse, or, in part of a human dwelling, where they lay their eggs and hatch their young. About August they disappear, and do not return till the following spring. Swallows kept in a cage moult about Christmas, and seldom live till spring.

There are several species of the Swallow : the general characters of which are a small beak, but large, wide mouth, for the purpose of swallowing flying insects, their natural food; and long forked tail and extensive wings, to enable them to pursue their prey. The common Swallow builds under the eaves of houses, or in chimneys, near their top; it is frequently called the Chimney Swallow from its preference for the last-mentioned rather singular situation; the Martin also builds under eaves, and most commonly against the upper corner or side of our very windows, and seems not afraid at the sight of man, yet it cannot be tamed, or even kept long in a cage. The nature of the Swallow's nest is worthy of close observation: how the mud is extracted from the seashores, rivers, or other watery places; how masoned and formed into a solid building, strong enough to support a whole family, and to face the "pelting storm," are wonders which ought to raise our mind to Him who bestowed that instinct upon them.

It is related that a pair of Swallows built their nest for two successive years on the handle of a pair of garden shears, that were stuck up against the boards of an outhouse ; and, therefore, must have had their. nest spoiled whenever the implement was wanted. And what is still more strange, a bird of the same species built its nest on the wings and body of an owl that happened to hang dead and dry from the rafter of a barn, and so loose as to be moved by every gust of wind. This owl, with the nest on its wings, and with eggs in the nest, was taken to the museum of Sir Ashton Leaver as a curiosity. That gentleman, struck with the singularity of the sight, furnished the person who brought it with a large shell, desiring him to fix it just where the owl had hung. The man 
did so; and in the following year a pair of Swallows, probably the same, built their nest in the shell and laid eggs.

Modern poets have not been unmindful of the Swallows; and our immortal Shakspeare mentions the Martin, in Macbeth, in the following manner:

"This guest of summer,

The temple-haunting Martlet, does approve, By his loved mansionry, that the Heaven's Breath smells wooingly here. No jutty, frieze, Buttress, nor coigne of 'vantage, but this bird Hath made his pendent bed and procreant cradle: Where they most breed and haunt, I have observed, The air is delieate."

"The Swallow," writes Sir Humphry Davy, "is one of my favourite birds, and a rival of the nightingale, for he cheers my sense of seeing as much as the other does my sense of hearing. He is the glad prophet of the year, the harbinger of the best season-he lives a life of enjoyment amongst the liveliest forms of nature-winter is unknown to him; and he leaves the green meadows of England in autumn for the myrrh and orange groves of Italy, and for the palms of Africa; he has alway's objects of pursuit, and his success is secure. Even the beings selected for his prey are poetical, beautiful, and transient. The ephemeræ are saved by his means from a slow and lingering death in the evening, and killed in a moment when they have known nothing but pleasure. He is the constant destroyer of insects, the friend of man, and may be regarded as a sacred bird. His instinct, which gives him his appointed season, and teaches him when and where to move, may be regarded as flowing from a divine source: and he belongs to the oracles of nature, which speak the awful and intelligible language of a present Deity."

The Chimney Swallow is, on the head, neck, back, an' rump, of a shining black colour, with purple gloss and sometimes with a blue shade; the throat and neck are of the same colour; the breast and bellyare white, with a dash of red. The tail is forked, and consists of twelve feathers. 
The wings are of the same colour with the back. Swallows feed upon flies and other insects; and generally hunt their prey on the wing:

"Away! away! thou summer bird; For Autumn's moaning voice is heard, In cadence wild, and deepening swell, Of winter's stern approach to tell."

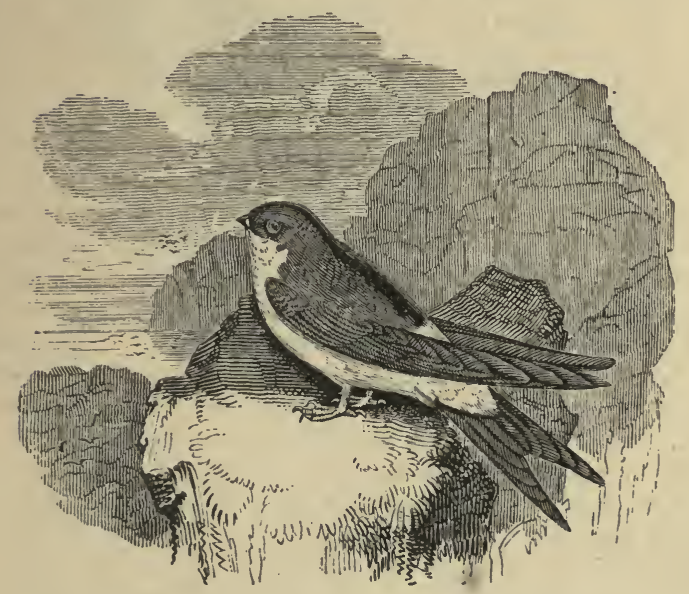

HOUSE MARTIN, OR WINDOW SWALLOW.

\section{(Hirundo urbica.)}

The Martin is something less than the swallow, with a comparatively large head, and a wide mouth; the colour of the upper parts a bluish black, the rump and all the under parts of the body white, the bill black; the legs covered with short white down.

These birds begin to appear about the middle of April, and for some time pay no attention to the business of nidification, but sport and play about as if to recruit themselves from the fatigue of the journey.

Should the weather prove favourable, it begins to build early in May, placing its nest generally beneath the eaves 
of a house, often against a perpendicular wall : without any projecting ledge to support any part of the nest, its utinust efforts are necessary to get the first foundation firmly fixed, so as to carry the superstructure safely. On this oecasion, it not only clings with its claws, but partly supports itself by strongly inclining its tail against the wall, making that a fulcrum; and thus fixed, it plasters the materials into the face of the brick or stone. But that this work may not, while soft, sink by its own weight, the provident architect has the prudence and forbearance not to proceed too fast; but by building only in the morning, and dedicating the rest of the day to food and amusement, he gives it sufficient time to dry and harden. By this method, in about ten days, the nest is formed, strong, compact, and warm, and perfectly fitted for all the purposes for which it is intended. But nothing is more common than for the house-sparrow, as soon as the shell is finished, to seize on it, eject the owner, and line it according to its own peculiar manner. Sometimes, however, the Martins prove too clever for the sparrow; when the intruder obstinately retained possession of the nest, the Martins have been known to collect from all parts of the neighbourhood, each bringing a pellet of mud, with which the orifice of the nest was soon securely closed, and the unfortunate sparrow was then left to die of starvation. The Martin will return for several seasous to the same nest, where it happens to be well sheltered and secured from the injuries of the weather. They breed the latest of all our swallows, often having unfledged young ones even so late as Michuelmas.

The first hatch consists of five eggs, which are white, inclining to dusky at the thicker end ; the second, of three or four; and of a third, of only two or three. While the young birds are confined to the nest the parents feed them, adhering by the claws to the outside; but as soon as they are able to fly they receive their nourishment on the wing, by a quick and almost imperceptible motion.

"Welcome, welcome, feathered stranger,

Now the sun bids Nature smile;

Safe arrived and free from danger,

Welcome to our blooming isle."

Franklix. 


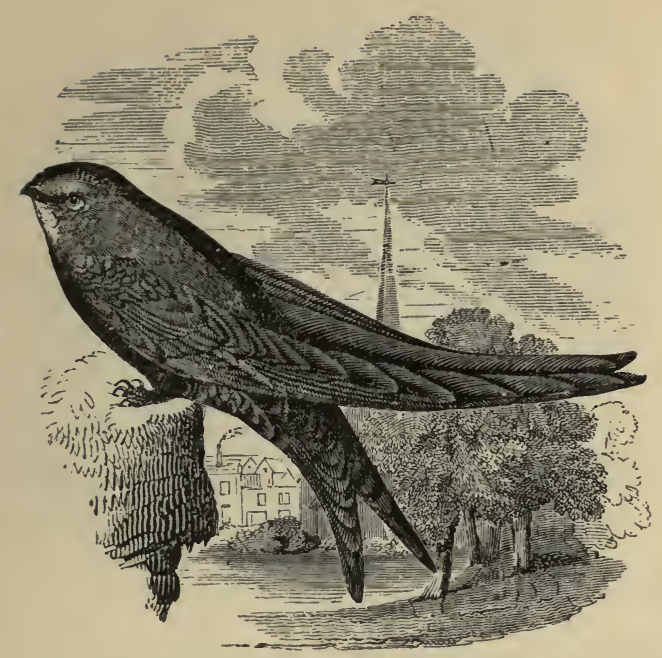

THE SIVIF', (Cypselus ариз,)

WhicH is sometimes called the Black Martin, arrives in England later, and takes its departure earlier than any of our swallows. The Swift is the largest of the swallow tribe, and the most rapid in its flight. Its nest, which is generally built in the crevices of old towers and steeples, is constructed of dried grass, feathers, thread, and similar materials, glued together by a sort of spittle, with which the bird is provided. The bird collects them whilst on the wing, picking them up with great dexterity. They seldom alight upon the ground, and if by accident they fall upon a level surface, they recover themselves with difficulty, owing to the shortness of their legs, and the length of their wings. During the heat of the day they remain within their holes, and at morning and evening sally out in quest of food. They may then be seen in flocks, whirling round some lofty edifice, or describing in mid-air an endless series of circles upon circles. Swifts fly higher, and wheel with bolder wing than the swa?lows, with whom they never intermingle. 


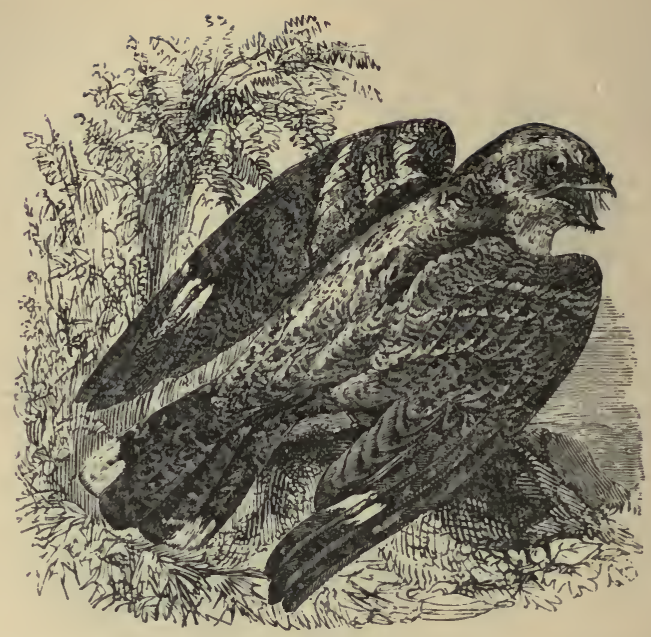

THE GOATSUCKER. (Caprimulgus Europceus.)

This curious bird, called also the Nightjar, and the Fern Owl, comes to this country from Africa about the middle of May and usually leaves by the end of August. These birds are generally found in low bushes, or amongst tufts of large ferns, and generally fly at night: hence their name of Fern Owl. The beak is furnished with bristles, and the middle toe of each foot has a claw toothed like a comb. The female lays her eggs upon the ground, without any nest, and lays only two. The name of Goatsucker originated in an absurd idea that this bird sucked the goat's milk, from its habit of lying on the ground near cows or she goats, and catching the flies that torment them by fixing on their udders. Mr. Waterton, who is certainly the closest observer of nature who ever wrote on Natural History, states, in one of his very interesting works, that he has frequently seen the Goatsuckers catching insects in this manner, and thus prov. ing themselves the best of friends to the animals they are accused of annoying. 


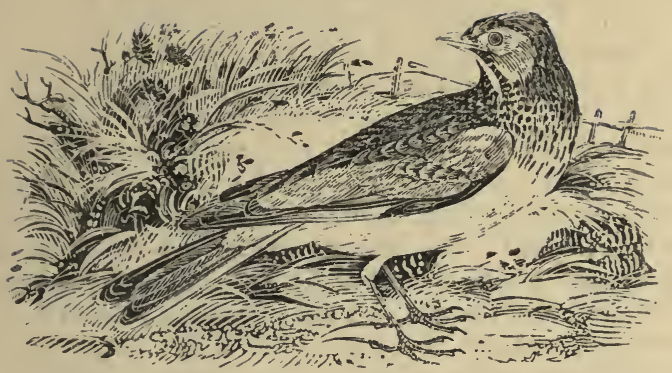

THE SKYLARK. (Alauda arvensis.)

"Go, tuneful bird, that gladd'st the skies, To Daphne's window speed thy way; And there on quivering pinions rise, And there thy vocal art display."

\section{Shenstone.}

The Skylark is distinguished from most other birds by the long spur on the back toe, the earthy colour of his feathers, and by singing as he mounts in the air. These birds generally make their nest in meadows among the high grass, and the tịnt of their plumage resembles so much that of the ground, that the body of the bird is hardly distinguishable as it runs along.

"The daisied lea he loves, where tufts of grass

Luxuriant crown the ridge : there, with his mate,

He founds their lonely louse, of withered lierbs, And coarsest spear-grass; next the inner work, With finer, and still finer fibres lays, Rounding it curious with his speckled breast."

\section{Grahame.}

Larks breed twice a year, in May and July, rearing their young in a short space of time. They are caught in great quantities in winter, and are considered choice and delicate food. It is a melancholy observation, that man should feed upon, and indulge his sense of taste with those very birds which have so often delighted his sense of hearing with their songs, when they usher to 
the gladdened creation the return of their best friend, the sun. The instinctive warmth of attachment which the female Skylark bears towards her own species, even when not her nestling, is remarkable. "In the month of May," says Buffon, "a young hen bird was brought to me, which was not able to feed without assistance. I caused her to be reared; and she was hardly fledged, when I received from another place a nest of three or four unfledged larks. She took a strong liking to these new comers, which were but little younger than herself; she tended them night and day, cherished them beneath her wings, and fed them with her bill. Nothing could interrupt her tender offices. If tho young ones were torn from her she flew to them as soon as they were liberated, and would not think of effecting her own escape, which she might have done a hundred times. Her affection grew upon her; she neglected food and drink; she at length required the same support as her adopted offspring, and expired at last, consumed with maternal solicitude. None of the young ones long survived her. They died one after another; so essential were her cares, which were equally tender and judicious."

'The Lark mounts almost perpendicularly, and by successive springs, into the air, where it hovers at a vast height. Its descent is in an oblique direction, unless threatened by some ravenous bird of prey, or attracted by its mate, when it drops to the ground like a stone. On its first leaving the earth, its notes are feeble and interrupted; but, as it rises, they gradually swell to their full tone. As the Lark's flight is always at sun-rise, there is something in the scenery that renders its song peculiarly delightful : the opening morning, the landscape just gilded by the rays of the returning sun, and the beauty of the surrounding objects, all contribute to heighten our relish for its pleasing melody.

" - _ Up springs the Lark,

Shrill-voiced and loud, the messenger of morn, Ere yet the shadows fly, he, mounted, sings Amid the dawning clouds, and from their haunts Calls up the tuneful nations."

Thomson. 
"Alas! it's no thy neebor sweet,

'The bonnie lark, companion meet!

Bending thee 'inang the dewy weet!

IVi' speckled breast,

When upward springing, blythe to greet

'The purpling eist."

Brrns.

“ Early, cheerful, mounting Lark,

Light's gentle usher, morning's clerk, In merry notes delighting."

Sir John Davis.

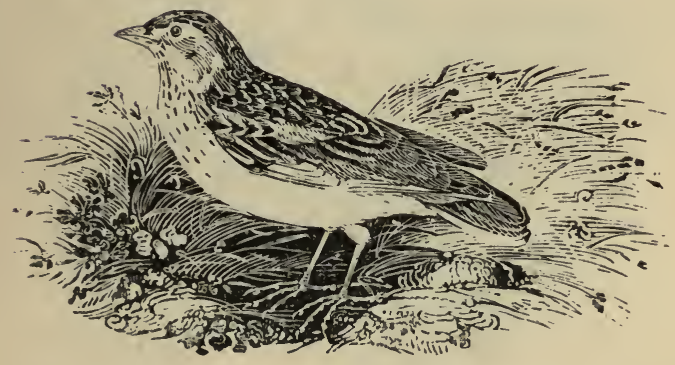

THE WOODLARK. (Alauda arborea.)

THis species is smaller than the skylark, and its roice deeper; it has also a circle of white feathers encompassing the head, from eye to eye, like a crown or wreath, and the utmost feather of the wing is much shorter than the second, whereas in the common lark they are nearly equal. This bird sometimes emulates the nightingale; for which, when pouring forth his sweet melody in the grove, during a silent night, he is often mistaken. These birds sit and perch upon trees, unlike the cornmon lark, which always keeps to the ground. They build their nest at the foot of a bush, near the bottom of a liedge, or in high dry grass. 'The number of their eggs is about four, of a pale hloom colour, beautifully mottled, and clouded with red and yellow. Like the skylark, they assemble in large flocks during frosty weather. 'Their usial food consists of small beetles, caterpillars, and other 
insects, as well as the seeds of numerous kinds of wild plants.

"Bright o'er the green hills rose the morning ray, 'The Woodlark's-song resounded on tl.e plaiı, Fair nature felt the warm embrace of day, And smiled through all her animated reign."

LANGBOCR:.

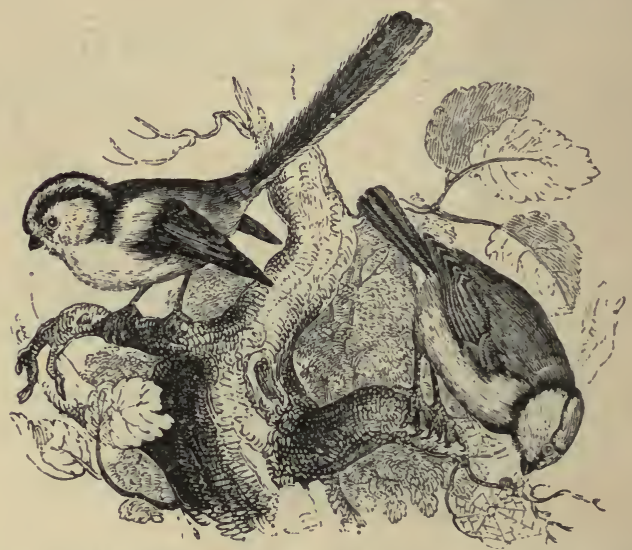

THE TITMOUSE, OR TON-TI'T. (Parus coruleus.) 'I'HE LONG-I'AILED TI'T. (Parus caudatus.)

The common Titmouse or Tom-tit is a very small bird, only four inches and a half in length. He has a blue head, with white cheeks and a white stripe over each eye; his back is greenish, his wings and tail blue, and the lower surface of his body yellow. 'This bird, and all the species related to it, live on insects, as well as on seeds. When . keptin a cage, it is really amusing to see with what quickness the 'litmouse darts at any fly or moth which comes imprudently within its reach. If this kind of food be deficient, as generally happens in winter, it feeds upon sereral kinds of seed, and particularly that of the sunflower, which it dexterously ho!ds upright between its claws and strikes powerfully with its sharp little bill, till the black covering splits, and yields its white contents to the persevering bird. Its general food consists of insects, 
which it seeks in the crevices of the bark of trees, and when thus engaged, clinging in every possible position to the branches, it looks like a very diminutive blue parrot. In winter the 'Titmouse visits our gardens and orchards, where he is often seen picking the buds of fruit trees to pieces; but in doing this he inflicts little or no injury upon the gardener, his object being the capture of insects which would probably cause far more mischief in the ensuing summer. The nest of the 'litmouse is built in the hole of a tree or wall ; the female lays usually eight or ten eggs, and when sitting defends her nest with great courage, pecking at the fingers of boys so vigorously that in some parts of the country she is known by the name of Billy Biter. The Lontg-tailed Tit is also a common bird about hedges, orchards, and plantations. $\mathrm{He}$ is an active lively little fellow, and resembles the common Tit in his habits.

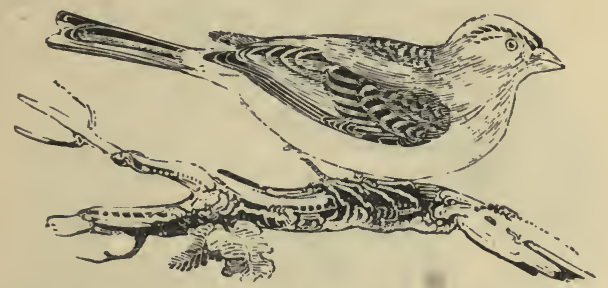

THE YELLOWHAMMER, OR YELLOW BUN'TING. (Emberiza citrinella.)

THIs bird is somewhat larger than the sparrow. Its head is of a greenish yellow, spotted with brown; the throat and belly are yellow; the breast and sides, under the wings, mingled with red. These birds build their nests on the ground, near some bush, where the female lays five or six eggs. The Yellowhammer may be sometimes seen perched on the finger of some poor man or woman in the streets of London, in a state of complete tameness; but this is the transitory effect of intoxication, and soon. after the bird is bought and brought home, it dies, overcome by the power of the laudanum that has been given it. This bird feeds on seeds and various sorts of insects, 
and is common in every lane, on every hedge, thronghout the country, flitting before the traveller, and about the bushes. Happily for him, we have not jet acquired the taste of the natives of Italy, where the Yellowhammer falls a daily victim to the delicacy of the table. and where its flesh is esteemed very delicious eating. There he is often fattened, for the purpose of gratifying the palate of epicures.

'The Ortolan, (Emberiza hortulana,) which is another species of the same genus, is common in the central and southern provinces of Europe, where it is thought exquisitely flavoured as an article of food. When first taken it is frequently very lean, but if supplied with abundance of food, it is said to be so greedy, that it will eat till it dies of repletion.

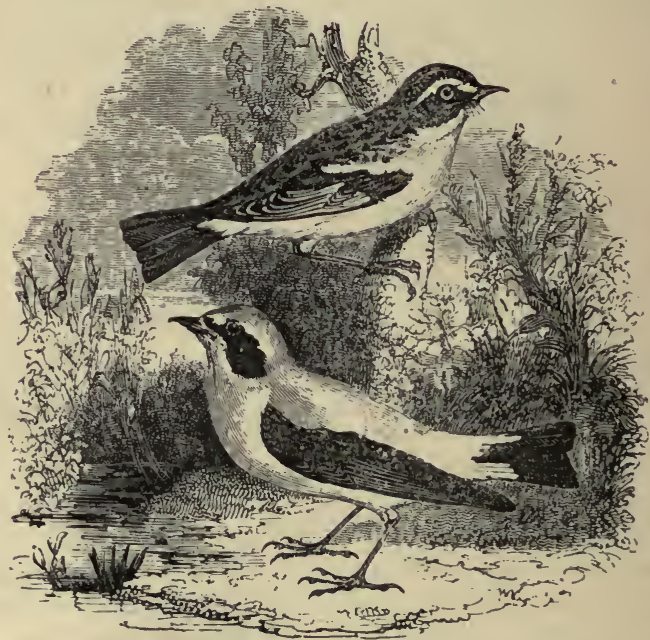

THE WHEATEAR, AND WHIN CHAT.

(Saxicola cenanthe and S. rubetra.)

The Wheatear is one of our earliest visitants, and may be found in every part of Britain. In the North, it generally frequents heaps of stones, ruins, or the dry stone 
walls of burial-grounds, and though it is a very handsome bird, and in the early season sings sweetly, its haunts have obtained it a bad name. The common alarmnote resembles the sound made in breaking stones with a hammer, and as it utters that note from the top of the heap which haply covers the bones of one who perished by the storm, or his own hand, popular fancy has not unnaturally associated the Wheatear with the superstition that belongs to the place of graves. Beneath that heap of stones, or in some neighbouring fallow, its nest may be discovered, formed of moss and dried grass, lined with hair, feathers, or wool, and containing five or six eggs of a delicate bluish white. These birds congregate on the southern downs about the middle of July; they are then caught in vast numbers, in horse-hair nooses, which are set between two pieces of turf turned against each other.

The Whin Chat is a beautiful bird, compact in form, with a rich and elegant plumage. Its song, which is peculiarly soft and sweet, may be heard in spring on the bushy margins and gorse of extensive heaths. Its nest, constructed in thick tufts of grass and under bushes, is most carefully concealed. It is usually approached by a labyrinth to which the rising of the bird affords no clue, and it may long be sought in vain, though perhaps not more than a yard distant all the time. The eggs are bluish green, without any spots, and are never more than six in number.

The following lines, addressed to the English Ortolan, or Wheatear, by Mrs. Charlotte Snith, allude to the foolish timidity of that bird:

“To take you, shepherd boys prepare

The hollow turf, the wiry snare,

Of those weak terrors well aware,

'That bid you vainly dread

The shadows floating over downs,

Or murmuring gale, that round the stones

Of some old beacon, as it moans,

Scarce moves a thistle's head.

And if a cloud obscure the sun,

With faint and fluttering heart you run

Into the pitfall you should shun,

And only leave when dead." 


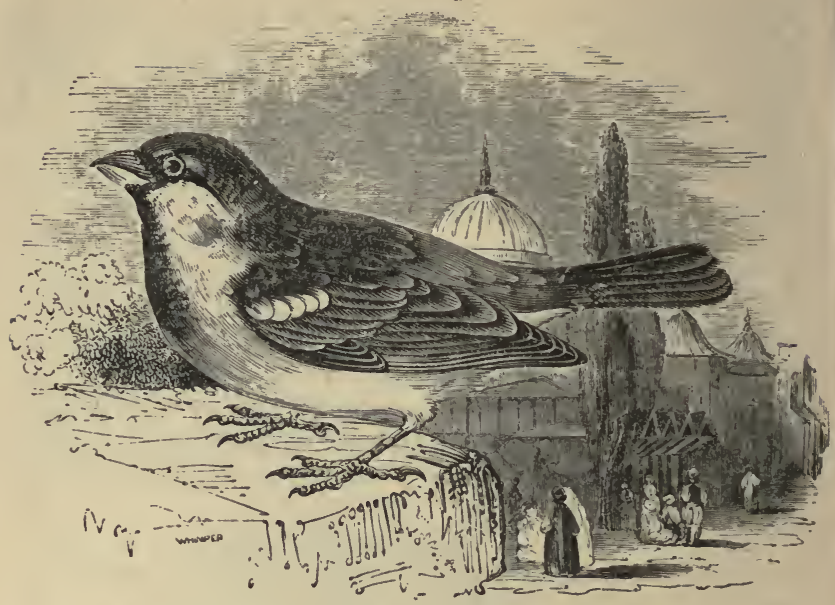

THE SPARROW. (Passer domesticus.)

This bird is, next to the robin redbreast, the boldest of the small feathered tribe which frequent our barns and houses: he is a conrageous little creature, and fights undauntedly against birds ten times bigger than himself. Sparrows are accused of destroying a great quantity of corn, and in several counties the landlord or farmer puts a price on a Sparrow's head; but the farmer is the person most injured by the plan, as the good Sparrows, in ridding land of caterpillars, more than compensate for the loss of grain they destrny. Mr. Bradley, in his Treatise on Husbandry and Gardening, shows, by a calculation, that a pair of Sparrows, during the time they have their young ones to feed, destroy on an average, every week, three thousand three hundred and sixty caterpillars.

This bird is easily tamed, and will hop about the house, and on the table with great familiarity. It will feed on anything, and is particularly fond of meat cut into small pieces. 'The song of the Sparrow, if we can 
so call its chirping, is far from agreeable: this arises, however, not from want of powers, but from its attending solely to the note of the parent bird. A Sparrow, when fledged, was taken from the nest and educated under a linnet: it also heard by accident a goldfinch; and its song was in consequence a mixture of the two. The male is particularly distinguished by a jet-black spot under the bill upon a whitish ground. Sparrows are fuund nearly in every country of the world.

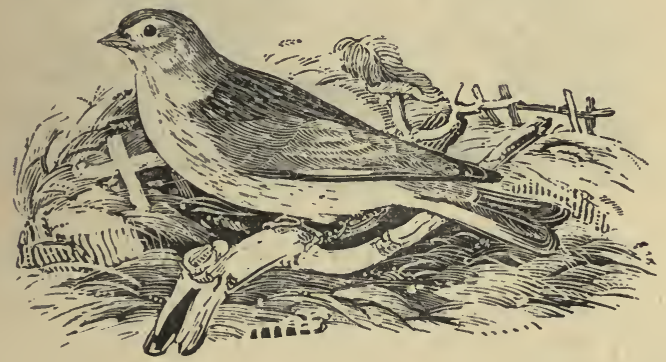

\section{THE LINNE'I', (Fringilla linota ur Linota cannabina,)}

Is about the size of the goldfinch : and compensates, by an extremely melodious voice, the want of variety in its plumage, which, except in the red-breasted species, is nearly all of one colour. Its musical talents are, like those of many other birds, repaid with captivity; for it is kept in cages on account of its singing.

The Redpole (Fringilla linaria) is a small species of Linnet, little more than four inches in length, distinguished by a deep blood-red spot on the crown of his head. He visits Britain in the autumn and stays with us during the winter, his favourite summer residence being far a way in the north. Redpoles are taken in great numbers by the bird-catchers in the autumn. Their only song is a twittering note, but they are often attached by a brace and chain to an open cage and trained to draw their water in a bucket.

The Green Linnet is rather larger than the house sparrow. Its head and back are of a yellowish-green, the 
edges of the feathers grayish; the rump and breast more yellow. 'The plumage of the female is much less vivid, inclining to brown. Its song is trifling, but in confinement it becomes tame and docile, and will catch the notes of other birds.

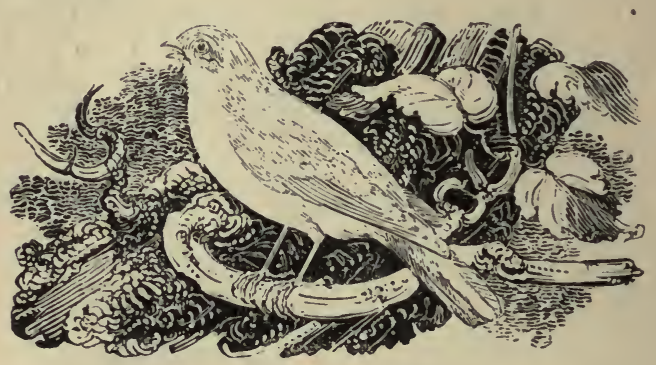

THE CANARY-BIRD. (Fringilla, or Carduelis canaria.)

As his name imports, this bird is a native of the Canary Islands; where, in his wild state, he has a dusky gray plumage, and a much stronger voice than when in a cage. In our northern countries his feathers undergo a great alteration; and the bird often becomes entirely white or yellow. Of this bird, Buffon says, "that if the nightingale is the chantress of the woods, the Canary is the musician of the chamber; the first owes all to nature, the second something to art. With less strength of organ, less compass of voice, and less variety of note, the Canary has a better ear, greater facility of imitation, and a more retentive memory; and as the difference of genius, especially among the lower animals, depends in a great measure on the perfection of their senses, the Canary, whose organ of hearing is more susceptible of receiving and retaining foreign impressions, becomes more social, tame, and familiar; is capable of gratitude and even attachment; its caresses are endearing, its little humours innocent, and its anger neither hurts nor offends. Its education is teasy; we rear it with pleasure, because we are able to instruct it. It leaves the melody of its own natural note, to listen to the melody of our voices and 


\section{The Canary-Bird.}

instruments. It accompanies us, and repays the pleasure it receives with interest, while the nightingale, more proud of his talent, seems desirous of preserving it in all its purity, at least it appears to attach very little value to ours, and it is with great difficulty that it can be taught any of our airs. It despises them, and never fails to return to its own wild woud notes. Its pipe is a masterpiece of nature, which human art can neither alter nor improve; while that of the Canary is a model of more pliant materials, which we can mould at pleasure; and therefore it contributes in a much greater degree to the pleasures of society. It sings at all seasons, cheers us in the dullest weather, and adds to our happiness, by amusing the young and delighting the recluse, charming the tediousness of the cloister, and gladdening the soul of the innocent and captive." It breeds generally twice a year when domesticated; and it sometimes happens that the female lays her eggs for the second time before the first brood is fledged. The male then good-naturedly takes her place on the eggs while she feeds the young ones, and feeds them in his turn, when she sits in tho nest. They are very easily tamed, when brought up with attention and kindness, and take their food out of the hand, often perching on the shoulder of their mistress, and feeding out of her mouth. The Canary-bird is sometimes, and with success, matched with the linnet or the goldfinch; and the produce is a beautiful bird, partaking of the talents and plumage of both.

Canary-birds live twelve or thirteen years in our climate, and sing well to the end of their life.

The following curious anecdote of one of these birds is related by Dr. Darwin: "On observing a Canarybird at the house of a gentleman near'I'utbury, in Derbyshire, I was told it always fainted away when its cage was cleaned; and I desired to see the experiment. The cage being taken from the ceiling, and the bottom drawn out, the bird began to tremble, and turned quite white about the root of the bill: he then opened his mouth, as if for breath, and respired quick; stood up straighter on his perch, hung bis wings, spread his tail, closed his eyes, 
and appeared quite stiff for half-an-hour; till at length, with much trembling and deep respirations, he came gradually to himself."

Some years ago, a Frenchman exhibited in London twenty-four Canary-birds, many of which he said were from eighteen to twenty-five years of age. Some of these balanced themselves, head downward, on their shoulders, having their legs and tail in the air. One of them taking a slender stick in its claws, passed its head between its legs, and suffered itself to be turned round, as if in the act of being roasted. Another balanced itself, and was swung backward and forward on a kind of a slack rope. A third was dressed in military uniform, having a cap on its head, wearing a sword and pouch, and carrying a firelock in one claw : after some time sitting upright, this bird, at the word of command, freed itself from its dress, and flew away to the cage. A fourth suffered itself to be shot at, and falling down as if dead, was put into a little wheelharrow, and wheeled away by one of its comrades !

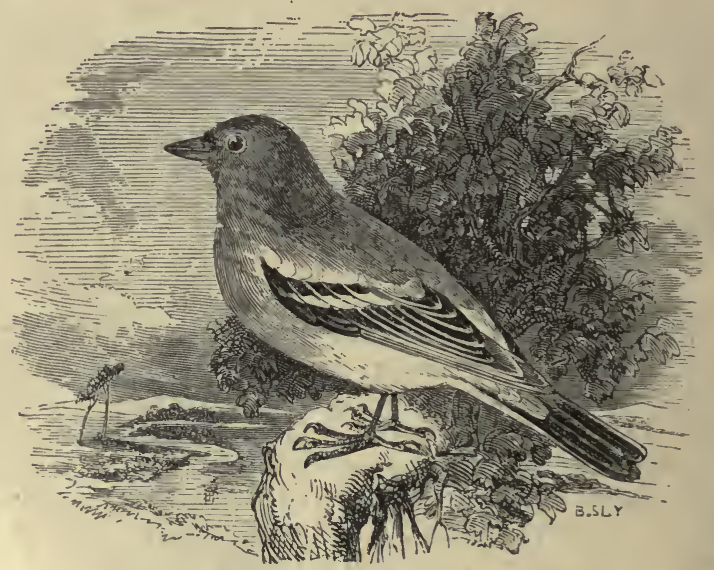

THE CHAFFINCH. (Fringilla colebs.)

The Chaffinch is of the same dimensions as the sparrow, 
but more lightly and elegantly formed. Its nest, which is of the most beautiful and elaborate construction, is composed of mosses and lichens, interwoven and lined with wool, hair, and feathers. " Four or five eggs," says Mr. Waterton, "are the usual number which the Chaffinch's nest contains, and sometimes only three. The thorn, and most of the evergreen shrubs, the sprouts on the boles of forest trees, the woodbine, the whin, the wild rose, and occasionally the bramble, are this bird's favourite places for nidification. Like all its congeners, it never covers its eggs on retiring from the nest, for its young are hatched blind. There is something peculiarly pleasing to $m e$ in the song of this bird. Perhaps association of ideas may add a trifle to the value of its melody; for when I hear the first note of the Chaffinch, I know that winter is on the eve of its departure, and that sunshine and fine weather are not far off. The Chaffinch never sings when on the wing; but it warbles incessantly on the trees, and on the hedgerows, from the early part of February to the second week in July; and then (if the bird be in a state of freedom) its song entirely ceases."

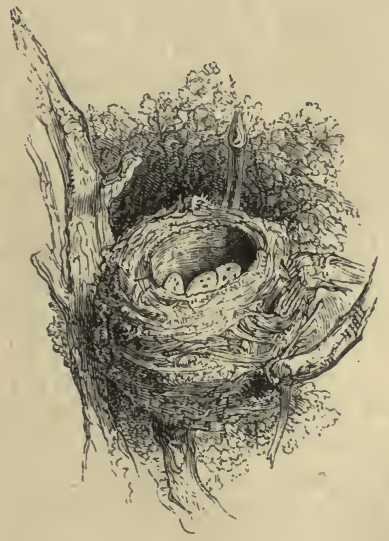




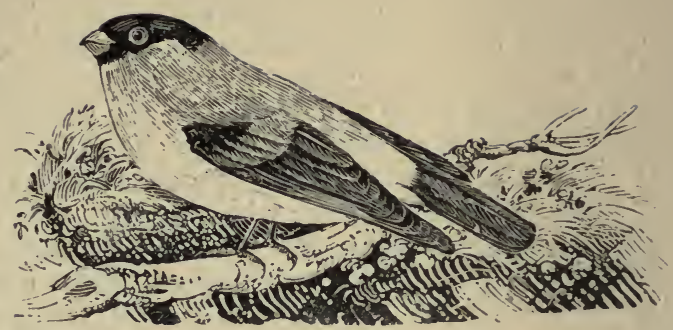

\section{THE BULLFINCH. (Loxia pyrrhula.)}

Thus is a very docile bird, and will nearly imitate the sound of a pipe, or the whistle of man, with its voice, the mellowness of which is really charming. It is, by birdfanciers, considered to excel all other small birds, except the linnet, in the softness of its tones, and in the variety of its notes. In captivity, its melody seems to be as great a solace to itself, as it is a pleasure to its master. By day, and even when the evening has called for the artificial light of candles, the Bullfinch pursues his melodious exertions, and if there be any other birds in the apartment, awakes them gently to the pleasing task of singing in concert with him. His notes are upon one of the lowest keys of the gamut of birds.

The plumage of the Bullfinch is beautiful, though simple and uniform, consisting only of three or four colours. In the male, a lovely scarlet or crimson colour adorns the breast, throat, and jaws, as far as the eyes; the crown of the head is black; the rump and tail are white; the neck and back grey, or lead-coloured. The name of this bird originates from its head and neck being, like those of the bull, very large in proportion to the body. The female does not share with the male the brightness of colours in the plumage. Bullfinches build their nests in gardens and orchards, and particularly in places that abound in fruit-trees, as they are passionately fond of fruit, which they often destroy before it is ripe. 


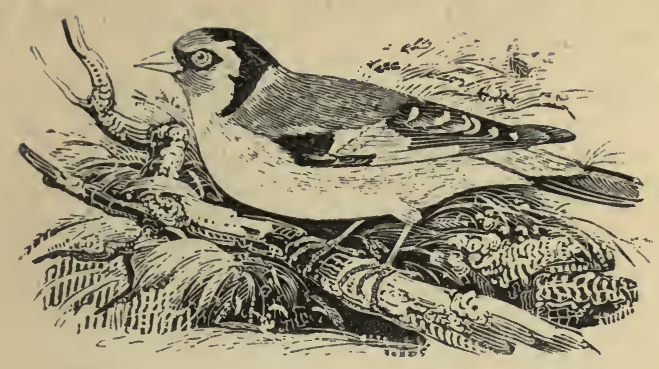

\section{THE GOLDFINCH.}

(Fringilla carduelis, or Carduelis elegans.)

This bird is also called the Thistlefinch, from his fondness for the seeds of that plant. $\mathrm{He}$ is very beautiful, his plumage being elegantly diversified, his form small, but pleasing, and his voice not loud, but sweet. $\mathrm{He}$ is easily tamed, and often exhibited as a captive, with a chain round his body, drawing up with trouble, but yet with amazing dexterity, two small buckets, alternately, one containing his meat, the other his drink. If he is old when caught, the Goldfinch, after a few weeks, if well attended to, and gently treated, becomes as familiar as if he had been brought up by the hand of his keeper. Some have been taught to fire a small piece of artillery, and go through the drilling exercise, to the great astonishment of the spectators; but the cruel and severe treatment that animals undergo, when taught performances altogether contrary to their nature, should prevent us from encouraging such exhibitions.

This bird, as if conscious of the beauty of his plumage, likes to view himself in a glass, which is sometimes fixed for this purpose in the back of the cage. The art with which it composes and builds its nest is really worthy of admiration; it is generally interworen with moss, small twigs, horsehair, and other pliant materials; the inside stuffed most carefully with fine down, and tufts of cotton grass. There the female deposits five or six eggs, 
which are whitish, marked at their upper end with purple dots.

"The Goldfinch weaves, with willow down inlaid, And cannach tufts, his wonderful abode ; And oft suspended at the limber end Of plane-tree spray, among the broad-leaved slıots, The tiny hammock swings to every gale. Sometimes in elosest thickets 'tis concealed; Sometimes in hedge luxuriant, where the brier, The bramble, and the plum-tree branch Warp through the thorn, surmounted by the flowers Of climbing vetch, and honeysuckle wild."

Grahame.

The following lines were written by Cowper on a Goldfinch starved to death in his cage. The Goldfinch speaks:-

"Time was when I was free as air, The thistle's downy seed my fare, My drink the morning dew ; I perched at will on every spray, My form genteel, my plumage gay, My strains for ever new.

"But gaudy plumage, sprightly strain, And form genteel were all in vain, And of a transient date; For caught and caged, and starved to death, In dying sighs my little breath Soon passed the wiry grate.

"Thanks, gentle author of my woes, Thanks for this most effectual close And cure of every ill. Never your cruelty repress! For I, if you had shown me less, Had been your prisoner still." 


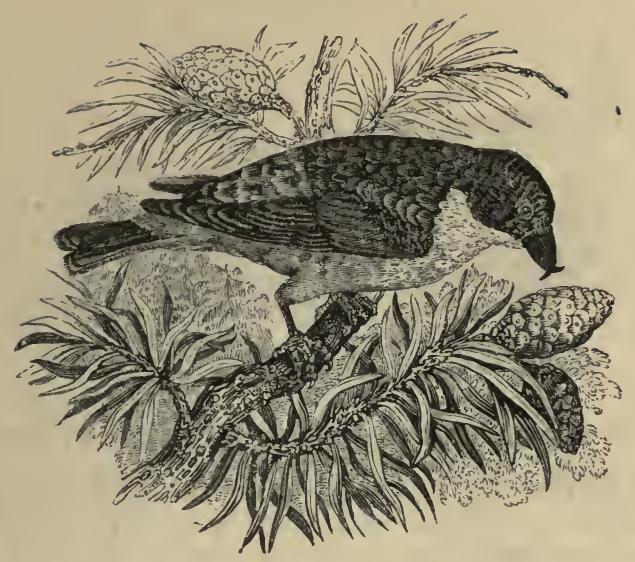

THE CROSSBILL. (Loxia curvirostra.)

The Crossbill is a native of the vast pine forests of northern Europe, and is by no means abundant in England. The bill of this singular bird is of considerable length, and the mandibles towards the point are very sharp and strong, curved in opposite directions, so that when closed the points cross each other, from which the bird derives his name. This curious organization enables them to obtain their food, which chiefly consists of the seeds of the cones of the fir, with the greatest facility These seeds, for a considerable time after they have ripened, are so firmly enclosed within their ligneous scales, that the bill of no ordinary bird could reach them. Fixing itself across the cone, the Crossbill brings the mandibles of its beak immediately over each other, and insinuates them between the seales, then forcing them laterally, the scales open. The mandibles are again brought in contact, between the scales, and the bird then picks out the seed with their tips. It is very interesting to find that a structure so anomalous as that of the bill of the Crossbill is really beneficial to the oreature, and not, as was formerly rather flippantly asserted, a defect or error of nature. 


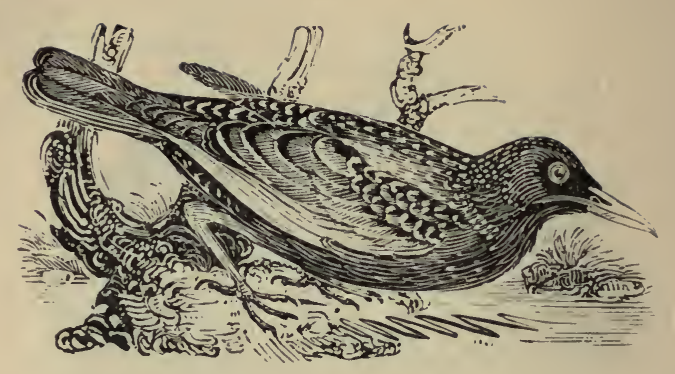

THE STARE, OR STARLING, (Sturnus vulgaris,)

Is about the size and shape of a blackbird; the tips of the feather's on the neck and back are yellow; the feathers under the tail of an ash-colour; the other parts of the plumage are black, with a purple or deep blue gloss, changing as it is variously exposed to the light. In the hen, the tips of the feathers on the breast and belly, to the very throat, are white; which constitutesa material point in the choice of the bird, as the female is no singer. She lays four or five eggs, lightly tinctured with a greenish cast of blue. Starlings build in hollow trees and clefts of rocks and walls, are very easily tamed, and can add to their natural notes any words or modulations which they are taught.

In the winter season Starlings collect in vast flocks, and may be known at a great distance by their whirling mode of flight. The evening is the time when they assemble in the greatest numbers, and betake themselves to fens and marshes. - Sterne has immortalized the Starling in his "Sentimental Journey:" "The bird flew to the place where I was attempting his deliverance, and thrusting his head through the trellis, pressed his head against it,- as if impatient.- - I fear, poor creature,' said I, 'I can't set thee at liberty.'- 'No,' said the Starling, 'I can't get out.' 'Disguise thyself as thou wilt, still, slavery;' said I, 'still thou art a bitter draught!" " 


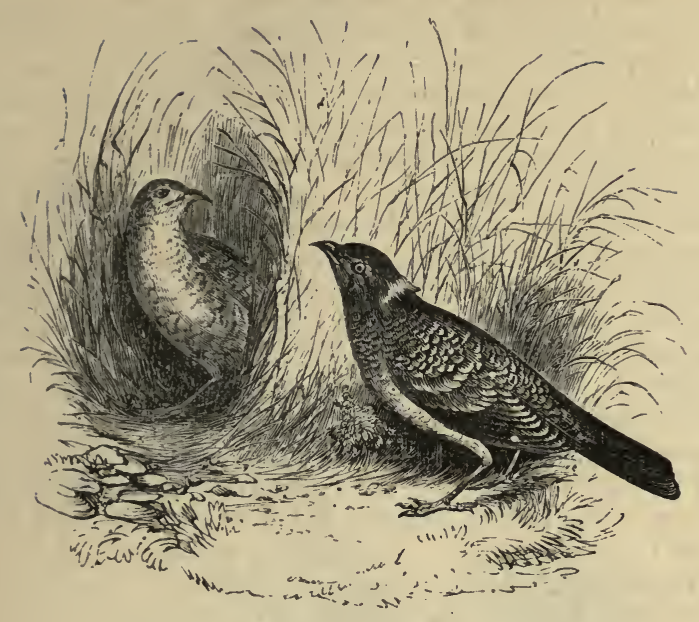

\section{THE SATIN BOWER-BIRD.}

\section{(Ptilonorhynchus holosericeus.)}

THIs singular bird was first brought before the notice of the public by Mr. Gould, in his splendid work, the "Birds of Australia," from which the following extracts are given by permission of its author. The most remarkable circumstance relating to this bird, is its construction of a bower-like tenement, the object of which, it should seem, is a sort of playing-ground, or hall of assembly.

"The Satin Bower-bird," says Mr. Gould, "is not a stationary species, but appears to range from one part of a district to another, either for the purpose of varying the nature, or of obtaining a more abundant supply of food. Judging from the many specimens I dissected, it would seem that it is altogether granivorous and frugivorous; or, if not exclusively so, that insects form but a small portion of its diet. The brushes it inhabits are studded with enormous fig-trees, some of them towering to the height of two hundred feet; among the lofty branches of which the Satin Bower-bird finds, in the 
small wild fig with which the branches are loaded, an abundant supply of a favourite food: this species also commits considorable depredation on ripening corn. It appears to have particular times in the day for feeding, and when thus engaged among the low shrub-like trees, I have approached within a few feet without creating alarm; but at other times I have found this bird extremely shy, especially the old males, which not unfrequently perch on the topmost branch of the loftiest tree, whence they can survey all around, and watch the movements of the females and their young in the brush below. Besides the loud liquid call peculiar to the male, both sexes frequently utter a harsh, unpleasant, guttural note, indicative of surprise or displeasure. The old black males are exceedingly few in number, as compared with the females and young male birds in the green dress, from which, and other circumstances, I am led to believe that at least two, if not three years, elapse before they attain the rich satinlike plumage, which, when once perfectly assumed, is, I believe, never again thrown off. 'The extraordinary bower-like structures alluded to above, are usually placed under the shelter of the branches of some overhanging tree in the most retired part of the forest, and differ considerably in size. The base consists of an extensive and rather convex platform of stick, firmly interwoven, on the centre of which the bower itself is built: this, like the platform on which it is placed, and with which it is interwoven, is formed of sticks and twigs, but of a more slender and flexible description, the tips of the twigs being so arranged as to curve inwards and nearly meet at the top : in the interior of the bower the materials are so placed, that the forks of the twigs are always presented outwards, by which arrangement not the slightest obstruction is offered to the passage of the birds. The interest of this curious bower is much enhanced by the manner in which it is decorated at and near the entrance with the most gaily-coloured articles that can be collected, such as the blue tail-feathers of the Rose-bill and Pennantian parrots, bleached bones, the shells of snails, \&c.; some of the feathers are stuck in among the twigs, while others with the bones and shells are strewed about near 
the entrances. The propensity of these birds to pick up and fly off with any attractive object, is so well known to the natives, that they always search the runs for any small missing article, as the bowl of a pipe, \&c., that may have been accidentally dropped in the brush. I myself found at the entrance of one of them a small neatly-worked stone tomahawk; of an inch and a half in length, together with some slips of blue cotton rags, which the birds had doubtless picked up at a deserted encampment of the natives. For what purpose these curious bowers are made is not yet, perhaps, fully understood; they are certainly not used as a nest, but as a place of resort for many individuals of both sexes, which, when there assembled, run through and around th, bower in a sportive and playful manner, and that so frequently, that it is seldom entirely deserted."

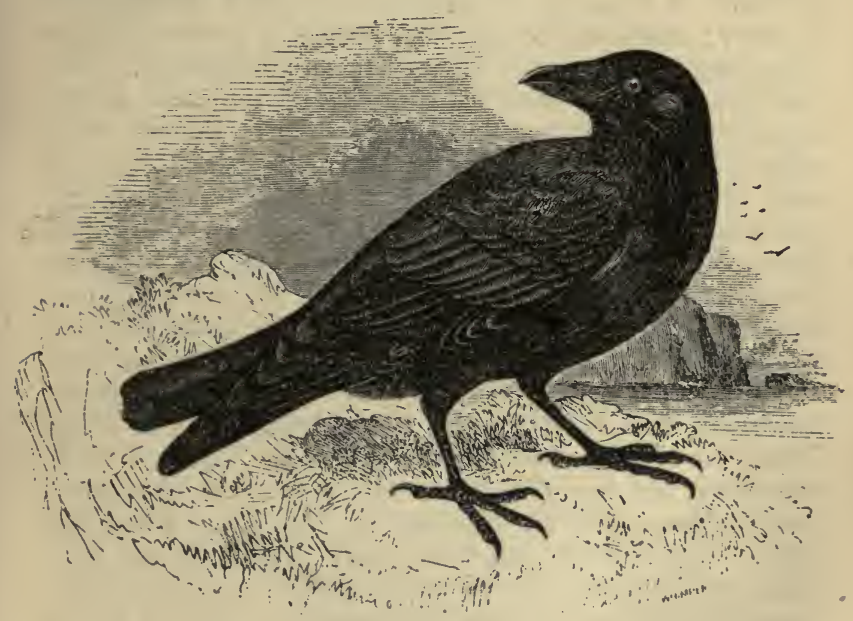

\section{THE RAVEN. (Corvus Corax.)}

"The Raven sits

On the raven-stone,

And his black wing flits

O'er the milk-white bone ; 
To and fro, as the night-winds blow, The carcass of the assussin swings :

And there alone, on the raven-stone, The Raven flaps his dusky wings.

The fetters creak-and his ebon beak Creaks to the close of the hollow sound:

And this is the tune by the light of the moon,

To which the witches dance their round."

Byron's Manfred.

The Raven is about twenty-six inches in length, and his weight about three pounds. The bill is strong, black, and hooked at the tip. The plumage of the whole body of a shining black, glossed with deep blue; the back of the lower part inclining to a dusky colour. $\mathrm{He}$ is of a strong and hardy disposition, and inhabits all climates of the globe. He builds his nest in trees; and the female lays five or six eggs of a palish green colour, spotted with brown. It is said that the life of this bird extends to a century; and even beyond that period, if we can believe the accounts of several naturalists on the subject. The Raven unites the voracious appetite of the crow to the dishonesty of the daw and the docility of almost every other bird. He feeds chiefly on small animals; and is said to destroy rabbits, young ducks, and chickens, and sometimes even lambs, when they happen to be dropped in a weak state. In the northern regions, he preys on carrion, in concert with the white bear, the arctic fox, and the eagle. The faculty of scent in these birds must be very acute ; for in the coldest of the winter days, at Hudson's Bay, when every kind of efluvium is almost instantaneously destroyed by the frost, buffaloes and other beasts have been killed, where not one of these birds was seen; but in a few hours scores of them have been found collected about the spot, to pick up the blood and offal. The Raven possesses many diverting and mischievous qualities; he is active, curious, sagacious, and impudent; by nature a glutton, by habit a thief, in disposition a miser, and in practice a rogue. He is fond of picking up any small piece of money, bits of glass or any thing that shines, which he carefully conceals under the eaves of roofs, or in any other inaccessible place. Ho is easily tamed; and, like the parrot and starling, can 
imitate the human voice, in articulating words. At the seat of the Marquis of Aylesbury, in Wiltshire, a tame Raven, that had been taught to speak, used to ramble about in the park, where he was commonly attended and beset with crows, rooks, and others of his inquisitive tribe. When a considerable number of these were collected round him, he would lift up his head, and with a hoarse and hollow voice shout out Holloa! 'This would instantly put to flight and disperse his sable brethren; while the Raven seemed to enjoy the fright he had occasioned. When domesticated, the Raven is of great service, both as a scavenger and in keeping watch, in the last of which he is more alert and vigilant than almost any other animal. The Raven was the ensign of the invading Danes, and the prejudice thereby engendered against the bird is not yet quite extinct. Of its perseverance in the act of incubation, Mr. White relates the following singular anecdote:

"In the centre of a grove near Selborne, there stood an oak, which, though on the whole shapely and tall, bulged out into a large excrescence near the middle of the stem. On this tree a pair of Ravens had fixed their residence for such a series of years, that the oak was distinguished by the title of ''The Raven-tree.' Many were the attempts of the neighbouring youths to get at this nest: the difficulty whetted their inclinations, and each was ambitious of surmounting the arduous task ; but when they arrived at the swelling, it jutted out so in their way, and was so far beyond their grasp, that the boldest lads were deterred and acknowledgred the undertaking to be too hazardons. Thus the Ravens continued to build, nest upon nest, in perfect security, till the fatal day on which the wood was to be levelled. This was in the month of February, when those birds usually sit. The saw was applied to the trunk, the wedges were inserted into the opening, the wood echoed to the heavy blows of the mallet, the tree nodded to its fall; but still the dam persisted in sitting. At last, when it gave way, the bird was flung from her nest; 'and though her parental affection deserved a better fate, was whipped down by the twigs, which brought her dead to the ground!" 
The croaking of the Raven was formerly considered a note of ill omen:

"The Raven croaked as she sat at her meal, And the old woman kuew what he said; And she grew pale at the Raven's tale, And sickened and went to her bed."

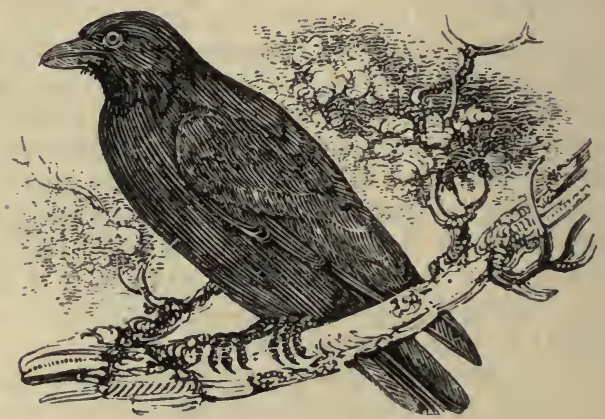

\section{THE CARRION CROW. (Corvus corone.)}

THis bird is less in size than the raven. The bill is strong, thick, and straight. The general colour is black, except the extremities of the feathers, which are of a greyish tint. His delight is to feed upon carcasses and dead animals, or malefactors exposed on the gibbet. $\mathrm{He}$ roosts upon trees, and takes both animal and vegetable food. Crows, like rooks, are gregarious, and often fly in large companies in the fields or in the woods. On the upland moors, Crows occupy the place which rooks fill in the low country; and as the Crow has a very coarse and uncouth voice, the Lowlanders of Scotland are in the habit of saying that the Highland rooks " speak Gaelic." They are great destroyers of partridges' eggs, as they often pierce them with their bills, and carry them in that manner through the air to a great distance to feed their young. The female lays five or six eggs.

Mr. Montagu states that he once saw a Crow in pursuit of a pigeon, at which it made several pounces, like 
a hawk; but the pigeon escaped by flying in at the door of a house. He saw another strike a pigeon dead from the top of a barn. The Crow is so bold a bird that neither the kite, the buzzard, nor the raven, can approach its nest without being driven away. When it has young ones, it will even attack the peregrine falcon, and at a single pounce sometimes bring that bird to the ground.

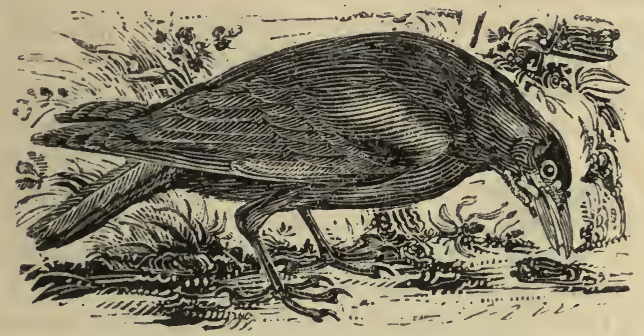

THE ROOK. '(Corvus frugilegus.)

THE cawing of these birds, on the tops of high trees near gentlemen's houses, and in the middle of cities, is not very pleasing; y yet old habits, to which we are reconciled, have as much influence upon us as if they were productive of amusement. Hence it has been seldom attempted to destroy a rookery; although the noise and other inconveniences that accompany these birds render their vicinity often troublesome. They feed entirely on corn and insects, and are little bigger than the common crows. In Suffolk, and in some parts of Norfolk, the farmers find it their interest to encourage the breed of Rooks, as the only means of freeing their grounds from the grub, which produces the cockchafer, and which in this state destroys the roots of corn and grass to such a degree, that instances have been known where the turf of pasture land might be turned up with the foot. The farmers in a northern county, a good many years ago, waged a war of extermination against the Rooks, but the very next year the crops were so completely cut up by grubs, that the same proprietors were at considerable 
expense in getting Rooks back again. Young Rooks are good eating, but should be skinned before they are dressed. 'The colour is black, but brighter than that of the crow, which the Rook resembles in shape. 'The female lays the same number of eggs; and the male shares with her the trouble of fetching sticks, and interweaving them to make the nest, an operation which is attended with a great deal of fighting and disputing with the other Rooks.

New comers are often severely beaten by the old inha. bitants, and are even frequently driven quite away; of this an instance occurred near Newcastle, in the year 1783. A pair of Rooks, after an unsuccessful attempt to establish themselves in a rookery at no great distance from the Exchange, were compelled to abandon the attempt, and take refuge on the spire of that building; and, though constantly interrupted by other Rooks, they. built their nest on the top of the vane, and reared their young ones, undisturbed by the noise of the populace below. The nest and its inhabitants were of course turned about by every change of the wind! They returned and built their nest every year on the same place, till 1793 , soon after which year the spire was taken down. A small copperplate was engraved, of the size of a watchpaper, with a representation of the spire and the nest; and so much pleased were the inhabitants and other persons with it, that as many copies were sold as produced to the engraver a profit of ten pounds. The woodcut by Bewick, in the title-page to his Select Fable givess, a view of the old Exchange, with the Rook's nest on the vane.

It is amusing to see Rooks coming at sunset as thick as a cloud hovering over a grove, and, after several eddies described in the air, and incessant cawings, each repairing to its own nest, and settling in a few minutes to rest, till the dawn calls them up again to their pasture in the neighbouring fields.

Dr. Darwin has remarked, that an instinctive feeling of danger from mankind is much more apparent in Rooks than in most other birds. Any one who has in the least observed them will see that they evidently distinguish 
that the danger is greater when a man is armed with a gun, than when he has no weapon with him. In the spring of the year, if a person happened to walk under a rookery with a gun in his hand, the inhabitants of the trees rise on their wings, and scream to the unfledged young to shrink into their nests from the sight of the enemy. 'The country people observing this circumstance so uniformly to occur, assert that Rooks can smell gunpowder,

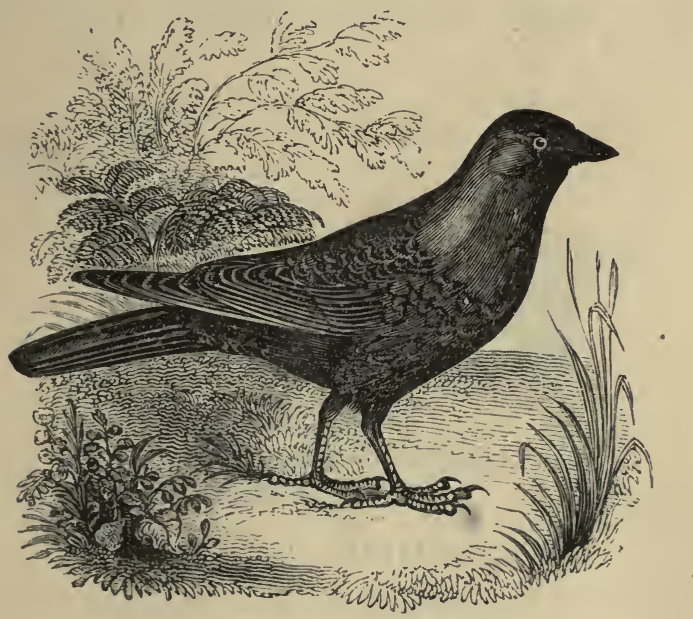

\section{THE JACKDAW. (Corrus monedula.)}

Tris bird is much less than the crow. He has a large head and long bill, in proportion to the size of his body. 'The colour of the plumage is black, but on some parts inclining to a bluish hue; the fore part of the head is of a deeper black. The Jackdaw feeds upon nuts, fruits, seeds, and insects ; and builds in ancient castles, towers, cliffs, and all desolate and ruinous places. The female lays five or six eggs, smaller, paler, and marked with fewer spots than those of the crow.

Jackdaws are easily tamed, and may with little diffi- 
culty be taught to pronounce several words. They conceal such parts of their food as they cannot eat, and often, along with it, small pieces of money or toys, frequently occasioning, for the moment, suspicions of theft in persons who are innocent. In Switzerland there is found a variety of the Jackdaw, which has a white ring round its neck. In Norway, and other cold countries, they have been seen entirely white. In a state of nature, jackdaws and rooks frequently feed together, and the Jackdaws come to meet the rooks in the morning, and also accompany them for some distance on their retreat at night.

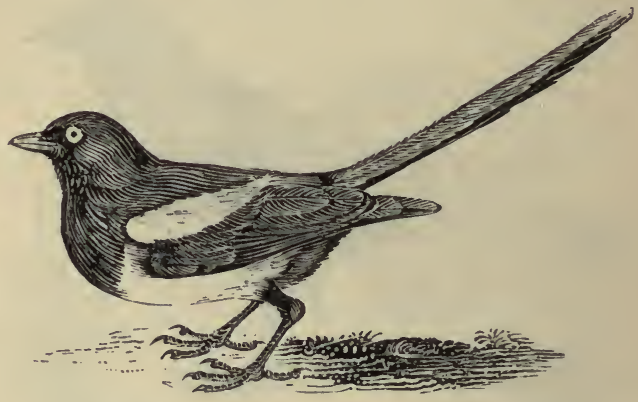

THE MAGPIE. (Pica caudata.)

"From bough to bough the restless Magpie roves, And chatters as he flies."

GisBorNe.

This bird resembles the daw, except in the whiteness of the breast and wings, and the length of the tail. The black of the feathers is accompanied with a changing gloss of green and purple. It is a very loquacious creature, and can be taught to imitate the human voice as well as any of the feathered creation.

Plutarch relates a singular story of a Magpie belonging to a barber at Rome, which could imitate, to a wonderful extent, almost every noise that it heard. Some trumpets happened one day to be sounded before the shop; and for a day or two afterwards the Magpie 
was quite mute, and seemed pensive and melancholy. 'This surprised all who knew it; and they supposed the sound of the trumpets had so stunned the bird as to deprive it at the same time of voice and hearing. 'This. however, was not the case; for, says the writer, the bird had been all the time occupied in profound meditation, and was studying how to imitate the sound of the trumpets; accordingly, in the first attempt, it perfectly imitated all their repetitions, stops, and changes. This new lesson, however, made it entirely forget everything that it had learned before.

The Magpie feeds on everything; worms, insects, meat, cheese, bread, milk, and all kinds of seeds, and also on small birds, when they come in its way: the young of the blackbird and of the thrush, and even a strayed chicken, often fall a prey to its rapacity. It is fond of hiding pieces of money or wearing apparel, which it carries away by stealth, and with much dexterity, to its hole. Its cunning is also remarked in the mannerof making its nest, which it covers all over with hawthorn branches, the thorns sticking outward; within, it is lined with fibrous roots, wool, and long grass, and then plastered all round with mud and clay. The canopy above is composed of the sharpest thorns, woven together in such a manner as to deny all entrance except at the door, which is just large enough to permit egress and regress to the owners. In this fortress the birds bring up their brood with security, safe from all attacks, but those of the climbing ss'hoolboy, who often finds his torn and bloody hands too dear a price for the eggs or the young ones.

There are many superstitions respecting Magpies ; and it is singular that in all the southern and middle districts of England, two Magpies together are thought to betoken luck; while in Lancashire, and other northern counties, they are thought to betoken misfortune. The chattering of Magpies was formerly supposed to foretell the arrival of strangers. 


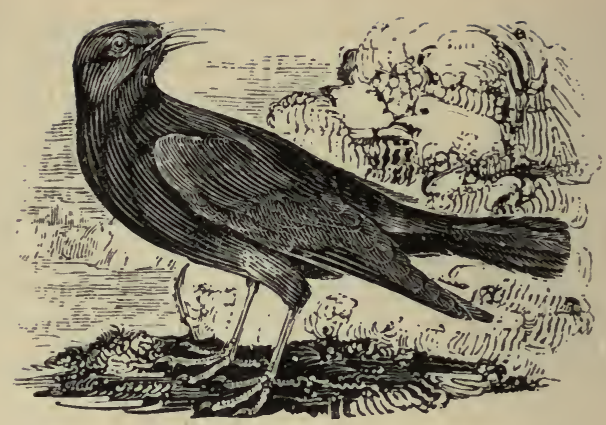

\section{THE CORNISH CHOUGH, (Pyrrhcorax gracueus,)}

Is like the jackdaw in shape and colour, but somewhat larger. 'The bill and legs are of a red colour, and hence the bird is frequently called the red-legged Crow. It is an inhabitant of Cornwall, Wales, and all the western coasts of England, and is generally to be found among rocks near the sea, where it builds, as well as in old ruinous castles and churches on the sea-side. The voice of the Chough resembles that of the jackdaw, except that it exceeds it in hoarseness and strength.

Mr. Montagu describing a Chough in the possession of a friend, says, "his curiosity is beyond bounds, never failing to examine everything new to him : if the gardener be pruning, he examines the nail-box, carries off the nails, and scatters the shreds about. Should a ladder be left against the wall, he instantly mounts, and goes all round the top of the wall: and if hungry descends at a convenient place, and immediately travels to the kitchen window, where he makes an incessant knocking with his bill, until he is fed or let in. If allowed to enter, his first endeavour is to get up-stairs; and if not interrupted, goes as high as he can, and gets into any room on the attic story; but his intention is to get upon the top of the house. He is excessively fond of being caressed, and would stand quietly by the hour to be smoothed; but resents an affront with violence and effect, by both bill and claws, and will hold so fast by the latter, that he is with difficulty disengaged." 


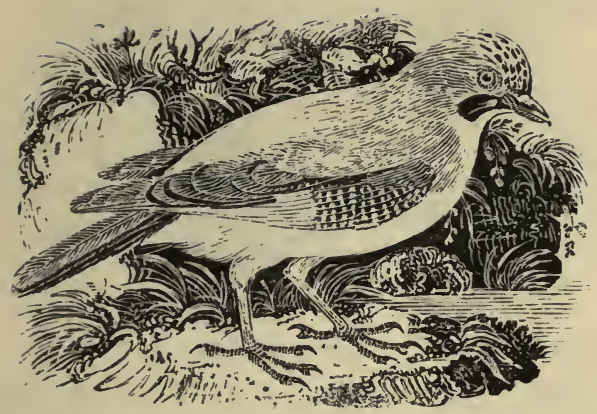

\section{THE JAY, (Garrulus glandarius,)}

Is less than the magpie, and resembles him more in the habits of his life than in the shape and coluur of his body. Like him he is talkative, and ready to imitate all sounds, but boasts of ornamental colours, which the magpie is deprived of. The ablest painter can produce no colour to equal the brightness of the chequered tablets of white, black, and blue, which adorn the sides of his wings. His head is covered with feathers, which are moveable at will, and the motion of which is expressive of the internal affections of the bird, whether he is stimulated by fear, anger, or desire.

A Jay, kept by a person in the north of England, had learned at the approach of cattle to set a cur dog upon them, by whistling and calling him by his name. One winter, during a severe frost, the dog was by this means excited to attack a cow that was big with calf, when the poor thing fell on the ice, and was much hurt. The Jay was complained of as a nuisance, and its owner was obliged to destroy it.

The hen lays tive or six eggs, of a dull white colour, mottled with brown. 


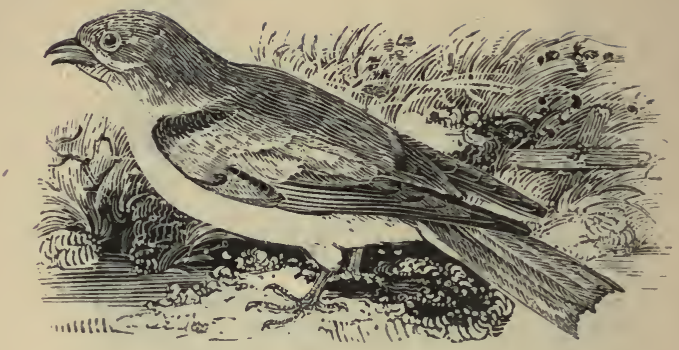

THE ROLLER, (Coracias garrula,)

Is about the size of the jay. Its bill is black, sharp, and somewhat hooked. The head is of a dirty green, mingled with blue; of which colour is also the throat, with white lines in the middle of each feather; the breast is of a pale blue, like that of the pigeon; the middle of the back, between the shoulders, is red; the rump and lesser coverts of the wings are dark blue; the feet are short, and, like those of a dove, of a dirty yellow colour.

'The Roller is wilder than the jay, and frequents the thickest woods; it builds its nest chiefly on birch-trees. It is a bird of passage, and migrates in the months of May and September. In Africa, it is said to fly in large flocks in the autumn, and is frequently seen on cultivated grounds, with rooks and other birds, searching for worms, insects, seeds, berries, roots, and in cases of necessity, small frogs.

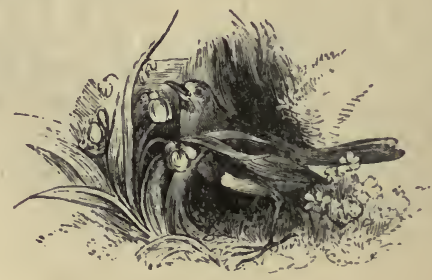




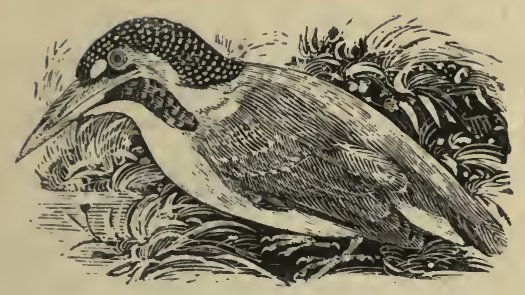

THE KINGFISHER, (Alcedo ispida,)

Is the Halcyon of the ancients, and his name recalls to our mind the most lively ideas. It was believed, that, as long as the female sat upon her eggs, the god of storms and tempests refrained from disturbing the calmness of the waves, and Halcyon days were, for navigators of old, the most secure times to perform their voyages :

"As firm as the rock, and as calm as the flood, Where the peace-loving Halcyon deposits her brood."

But although this bears analogy to a natural coincidence between the time of breeding assigned to the Kingfishers and a part of the year when the ocean is less tempestuous, yet Mythology would exercise her fancy, and turn into wonders that which was nothing else than the common course of nature.

This bird is nearly as small as a common sparrow, but the head and beak appear proportionally too big for the body. The bright blue of the back and wings claims our admiration, as it changes into deep purple or lively green, according to the angles of light under which the bird presents itself to the eye. It generally haunts the banks of rivers, for the purpose of seizing small fish, on which it subsists, and which it takes in amazing quantities, by balancing itself at a distance above the water for a certain time, and then darting on the fish with unerring aim. It dives perpendicularly into the water, where it continues several seconds, and then brings up the fish, which it carries to land, beats 
to death, and afterwards swallows. When it cannot find a projecting bough, it sits on some stone near the brink, or even on the gravel; but the moment it perceives the fish, it takes a spring upwards of twelve or fifteen feet, and drops from that height upon its prey.

The Kingfisher lays its eggs, to the number of seven or more, in a hole in the bank of the river or stream that it frequents. Dr. Heysham had a female brought alive to him at Carlisle by a boy, who said he had taken it the preceding night when sitting on its eggs. His information on the subject was, that "having often observed these birds frequent a bank upon the river Peteril, he had watched them carefully, and at last he saw them go into a small hole in the bank. The hole was too narrow to admit his hand; but, as it was made in soft mould, he easily enlarged it. It was upwards of half a yard long; at the end of it the eggs, which were six in number, were placed upon the bare mould, without the smallest appearance of a nest." 'The eggs were considerably larger than those of the yellow-hammer, and of a transparent white colour. It appears, from a still later account, that the direction of the holes is always upward; that they are enlarged at the end, and have there a kind of bedding formed of the bones of small fish, and some other substances, evidently the castings of the parent animals. This bedding is generally half an inch thick, and mixed with earth; and on it the female deposits and hatches her eggs. When the young ones are nearly full-feathered they are extremely voracious; and as the old birds do not supply them with all the food they can devour, they are continually chirping, and may be discovered by their noise. 


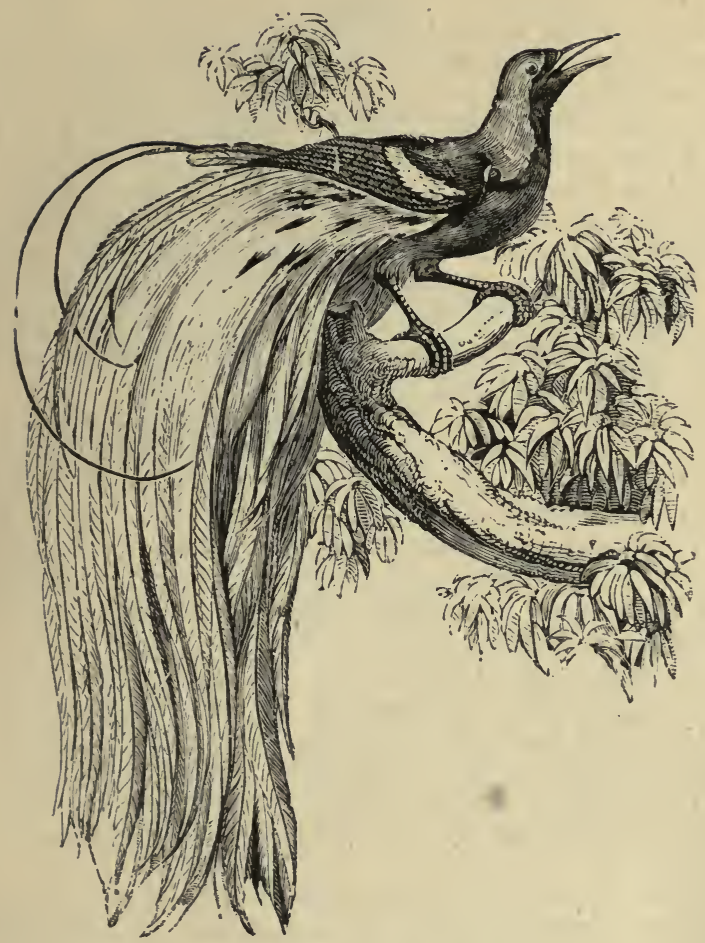

\section{THE BIRD OF PARADISE. (Paradisea apoda.)}

THERE are several distinct species of these birds, of which the best known are the large and small Emerald Birds of Paradise, which are very similar in appearance, and are both imported into Europe as ornaments for ladies' dress. Their appearance when flying in their native forests is said to be most beautiful. M. Lesson, a French naturalist, gives the following account:- "Soon after 
our arrival on this land of promise (New Guinea) for the naturalist, I was on a shooting excursion. Scarcely had I walked some hundred paces in those ancient forests, the daughters of time, whose sombre depth was, perhaps, the most magnificent and stately sight that I had ever seen, when a Bird of Paradise struck my view : it flew gracefully and in undulations; the feathers of its sides formed an elegant and aërial plume, which, without exaggeration, bore no remote resemblance to a brilliant meteor. Surprised, astounded, enjoying an inexpressible gratification, I devoured this splendid bird with my eyes; but my emotion was so great that I forgot to shoot at it, and did not recollect that I had a gun in my hand till it was far away."

The head is small, but adorned with colours which vie with the brightest hues of the feathered tribe; the neck is a beautiful fawn, and the body very small, but covered with long feathers of a browner hue, tinged with gold: the two middle feathers of the tail are little more than filaments, except at the point and near the base. Although the body is no larger than that of a thrush, the total length is two feet. This bird has long been esteemed by ladies as a head-dress; and as those sent to Europe for this purpose always had the legs cut off for the convenience of packing, it was reported, and at one time believed, that the Bird of Paradise had no legs, but that it lived always on the wing. Indeed, a very fierce controversy arose on this subject among the earlier naturalists.

The native place of these birds is New Guinea and the neighbouring islands, where they are generally found in flocks of thirty and forty, roosting on fig or teak trees. 'They always fly against the wind, that it mas not ruffle their light and spreading plumage, as, if the wind came from behind, it would blow their long tails over their back. They take shelter from storms in the most dense thickets, and feed principally on figs, the berries of the teak, and insects. The note of the Bird of Paradise is very unpleasant, and resembles the cawing of a raven ; it is chiefly heard in windy weather, when they dread being thrown on the ground. 


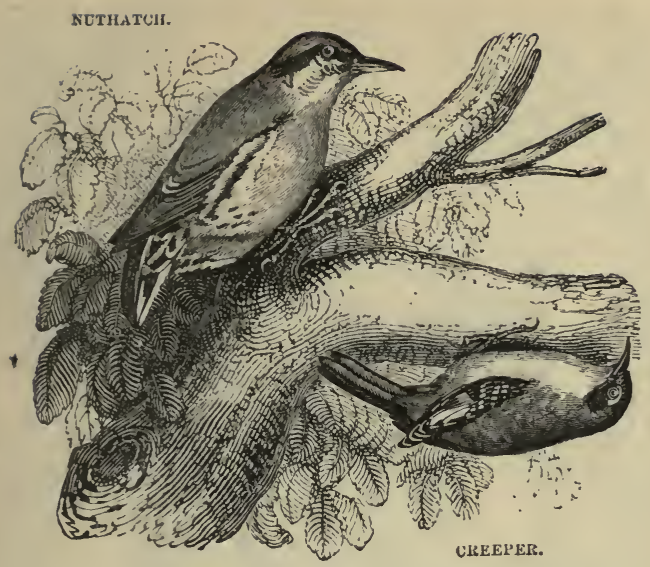

THE NUTHATCH, OR NUTJOBBER, (Sitta Europcea,)

AND THE CREEPER, (Certhia familiaris,)

Is less than the chaffinch. The head, neck, and heak are of an ash-colour; the sides under the wings red; the throat and breast of a pale yellow; the chin white, and the feathers under the tail red, with white tips. The Nuthatch feeds upon insects and also upon nuts, which he hoards in the hollow part of a tree; and it is pleasing to see him fetch a nut out of the hole, place it first in a chink, and standing above it with his head downwards, striking it with all his might, break the shell, and catch up the kernel. The hen is so attached to her brood, that, when disturbed from her nest, she flutters about the head of the depredator, and hisses like a snake. The Nuthatches are shy and solitary birds, and like the woodpeckers frequent woods, and run up and down the trees with surprising facility. They often move their tails in the manner of the wagtail. They do not migrate, but during the winter approach nearer to inhabited places, and are sometimes seen in orchards and gardens. The female lays her eggs in holes of trees. 


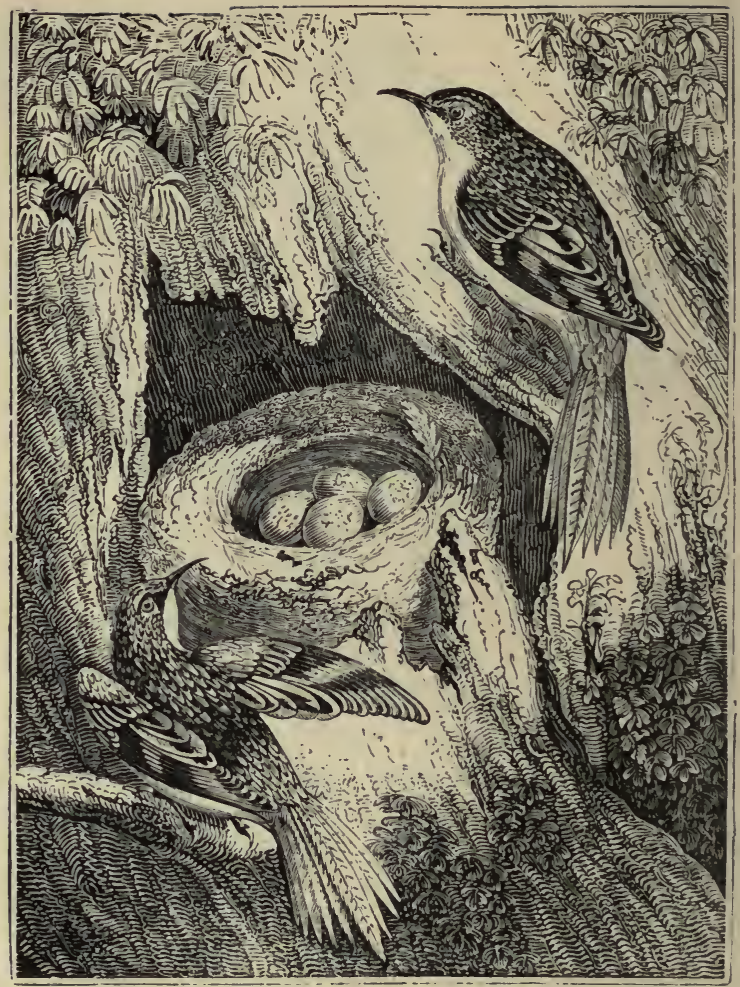

\section{THE CREEPER. (Certhia familiaris.)}

The Creepers are dispersed through most countries of the globe, and feed chiefly on insects, in search of which they run in a spiral direction round the stems and branches of trees, with great agility.

The Common Creeper is about five inches in length; its colour is tawny, the quills being tipped with white or light brown. Its nest is formed of dry grass and bark, and is placed in the hollow of some decayed tree. 


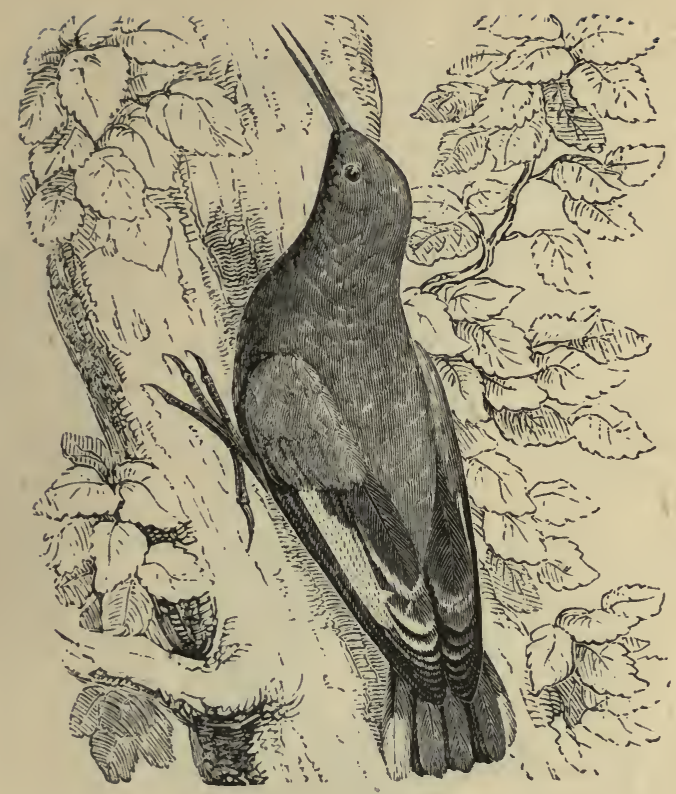

\section{THE WALL CREEPER, OR SPIDER-CATCHER,}

\section{(Tichodroma muraria,)}

Is larger than a house-sparrow. It has a long, slender, black bill; the head, neck, and back are of an ash-colour, the front of the neck and throat being a deep black; the breast is white; the wings a compound of lead-colour and red. It is a brisk and cheerful bird, and has a pleasant note. Clefts and crevices of rocks and the walls of old edifices are its favourite haunts, and sometimes, but very rarely, the trunks of trees. It feeds on insects, and is especially fond of spiders and their eggs. The nest is made in clefts of the most inaccessible rocks, and in the crevices of ruins, at a great height. 


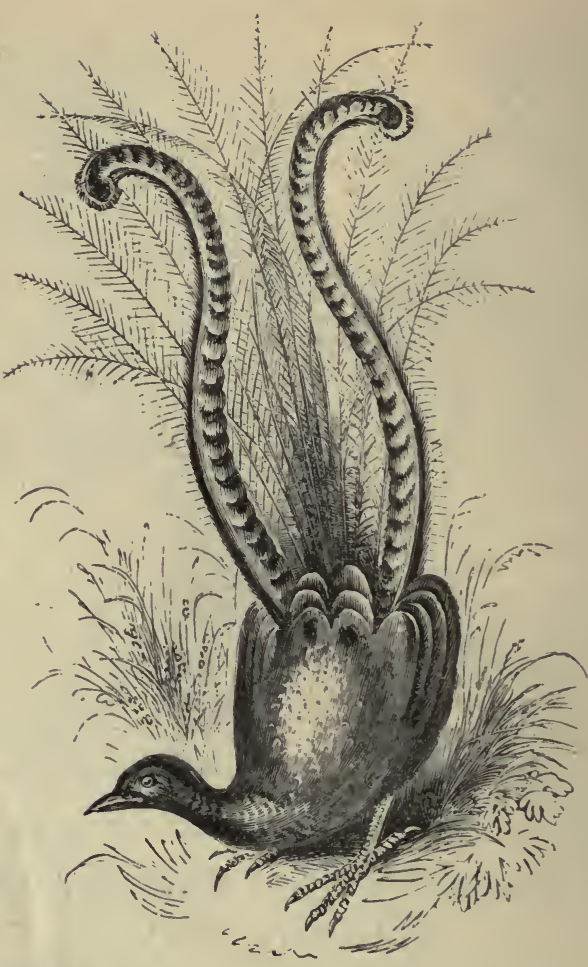

THE LYRE-BIRD OF AUSTRALIA.

(Menura superba.)

This bird is found in New South Wales, near Port Philip, but it is the male only that possesses the splendid tail whence it derives its name. It feeds on snails, and builds a nest like a magpie.

"Of all the birds I have ever met with," says Mr. Gould, " the Menura is by far the most shy and difficult to procure. While among the brushes, I have been surrounded by these birds, pouring forth their loud and 
liquid calls, for days together, without being able to get a sight of them; and it was only by the most determined perseverance and extreme caution that I was enabled to effect this desirable object; which was rendered the more difficult by their often frequenting the almost inaccessible and precipitous sides of gullies and ravines, covered with tangled masses of creepers, and umbrageous trees: the cracking of a stick, the rolling down of a small stone, or any other noise, however slight, is sufficient to alarm it; and none but those who have traversed these rugged, hot, and suffocating brushes, can fully understand the excessive labour attendant on the pursuit of the Menura. Independently of climbing over rocks and fallen trunks of trees, the sportsman has to creep and crawl beneath and among the branches with the utmost caution, taking care only to advance when the bird's attention is occupied in singing, or in scratching up the leaves in search of food: to watch its actions, it is necessary to remain perfectly motionless, not venturing to move even in the slightest degree, or it vanishes from sight, as if by magic. Although I have said thus much on the cautiousness of the Menura, it is not always so alert: in some of the more accessible brushes through which roads have been cut, it may frequently be seen, and even on horseback closely approached, the bird apparently evincing less fear of those animals than of man. At Illawarra it is sometimes successfully pursued by dogs trained to rush suddenly upon it, when it inmediately leaps upon the branch of a tree, and its attention being attracted by the dog which stands barking below, it is easily approached and shot. Another successful mode of procuring specimens is, by wearing a tail of a full-plumaged male in the hat, keeping it constantly in motion, and concealing the person among the bushes, when the attention of the bird being arrested by the apparent intrusion of another of its own sex, it will be attracted within the range of the gun: if the bird be hidden from view by the surrounding objects, any unusual sound, as a shrill whistle, will generally induce him to show himself for an instant, by causing him to leap with a gay and sprightly air upon some neighbouring branch to ascertain the cause of the dis- 
turbance: immediate advantage must be taken of this circumstance, or the next moment it may be half-way down the gully. So totally different is the shooting of this bird to anything practised in Europe, that the most expert shot would have but little chance, until well experienced in the peculiar nature of the country, and the habits of the bird. The Menura seldom, if ever, attempts to escape by flying; it easily eludes pursuit by its extraordinary power of running. None are so efficient in obtaining specimens as the naked black, whose noiseless and gliding steps enable him to steal upon it unheard and unperceived, and with the gun in his hand, he rarely allows it to escape, and in many instances he will even kill it with his own weapons.

"The Lyre-bird is of a wandering disposition, and although it probably keeps to the same brush, it is constantly engaged in traversing it from one end to the other, from mountain-top to the bottom of the gullies, whose steep and rugged sides present no obstacle to its long legs and powerful muscular thighs: it is also capable of performing extraordinary leaps ; and I have heard it stated, that it will spring ten feet perpendicularly from the ground. It appears to be of solitary habits, as I have never seen more than a pair together, and these only in a single instance; they were both males, and were chasing each other round and round with extreme rapidity, apparently in play, pausing every now and then to utter their loud shrill calls; while thus employed they carried the tail horizontally, as they always do when running quickly through the bush, that being the only position in which this great organ could be conveniently borne at such times. Among its many curious habits, the only one at all approaching to those of the Gallinaccea, is that of forming small round hillocks, which are constantly visited during the day, and upon which the male is constantly trampling, at the same time erecting and spreading out his tail in the most graceful manner, and uttering his various cries, sometimes pouring forth his natural notes, at others mocking those of other birds, and even the howling of the native dog, or dingo. The early morning and the 
evening are the periods when it is most animated and active."

There is another kind of Lyre-Bird, also found in New South Wales, to which Mr. Gould has given the name of Menura Alberti, in honour of the late Prince Consort.

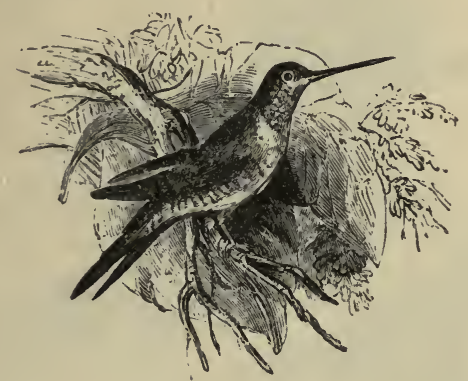

THE HUMMING-BIRD. (Trochilus colubris.)

There are numerous species of Humming-Birds, but that represented above, is one of the most common. They are abundant in South America, particularly in Brazil : and are so small and so brilliant in their colnurs, that when seen fluttering about in the brilliant rays of a tropical sun, they look like flying gems. 'They are extremely active, darting about, and thrusting their long beaks and flexible tongues into every flower they see, in search of food. Sometimes they will remain suspended in the air for a long time together, vibrating their wings with such velocity, that they cannot be seen distinctly, but appear like a mistround the body of the bird, while they make that curious humming noise from which the bird takes its name. Sometimes they quarrel, when their little throats become distended, their crest, tails, and wings expand, and they fight with inconceivable fury, till one of them falls exhausted on the ground. The most common species is Trochilus colubris, the Rubythroated Humming-Bird, and one of them has been kept alive in a cage for more than three months, by feeding it with sugar and water. This species is found in North 
America, where it migrates to the north in summer, and - is there seen even in Canada and the country of Hudson's Bay.

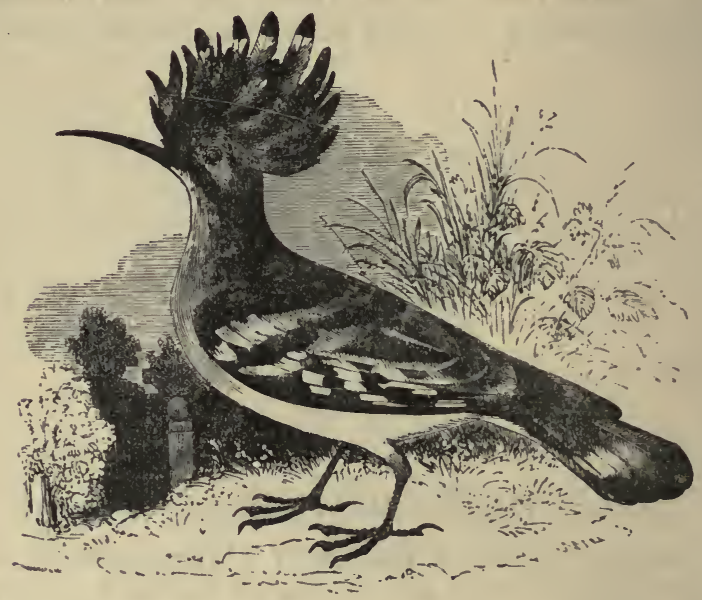

THE HOOPOE. (Upupa epops.)

THIs is a small bird, measuring no more than twelve inches from the point of the bill to the end of the tail. The bill is sharp, black, and somewhat bending. The head is adorned with a very beautiful, large moveable crest, a kind of bright halo, the radiation of which places the head nearly in the centre of a golden circle. This pleasing ornament, which the bird sets up or lets fall at pleasure, is composed of a double row of feathers, reaching from the bill to the nape of the neck, which is of a pale red. The breast is white, with black streaks tending downwards; the wings and back are varied with white and black cross-lines. The food of the Hoopoe consists chiefly of insects, with the remains of which its nest is sometimes so filled as to become extremely offensive. This beautifully crested bird is not at all common in this country, and is solitary, two of them being seldom 
seen together, while in Egypt, where Hoopoes are very common, they are often seen in small flocks. The female generally constructs her nest in a hollow tree, the materials employed, in addition to the remains of their food, being very scanty, consisting in fact of a few dried grass stalks and feathers. She lays from four to seven eggs at a time, of a pale lavender grey, about an inch and a half long. The young are generally hatched in June; it is said, however, that two or three broods are produced in the course of the year. The name alludes to the note of the bird, which resembles the word "hoop" repeated several times in a low voice.

'Though this bird is found occasionally both in England and Scotland, it rarely breeds with us. It is common in Italy, where its strange startling cry is often heard, without the bird being seen, as it keeps itself concealed among trees. It is also not uncommon on the banks of the Garonne in France, where it may be seen skimming along the ground amongst the willows in search of the insects upon which it feeds.

There are several species of this magnificent family. The most brilliant is undoubtedly the Upupa Superba, or Grand Promerops of New Guinea. "There does not perhaps exist," says Sonnerat, " a more extraordinary bird. Its body is delicate and slender, and, although it is of an elongated form, appears excessively small in comparison with the tail. Nature seems to have pleased herself in painting this being, already so singular, with her most brilliant colours. 'The head, the neck, and the belly are a glittering green; the feathers wnich cover these parts have the lustre and softness of velvet to the eye and to the touch; the back is changeable violet; the wings are of the same colour, and appear, according to the lights in which they are held, blue, violet, or deep black, always however imitating velvet." This bird is rare, and a specimen is seldom seen even in the most complete collections. 
$\S$ IV.-Scansores, or Climbers.

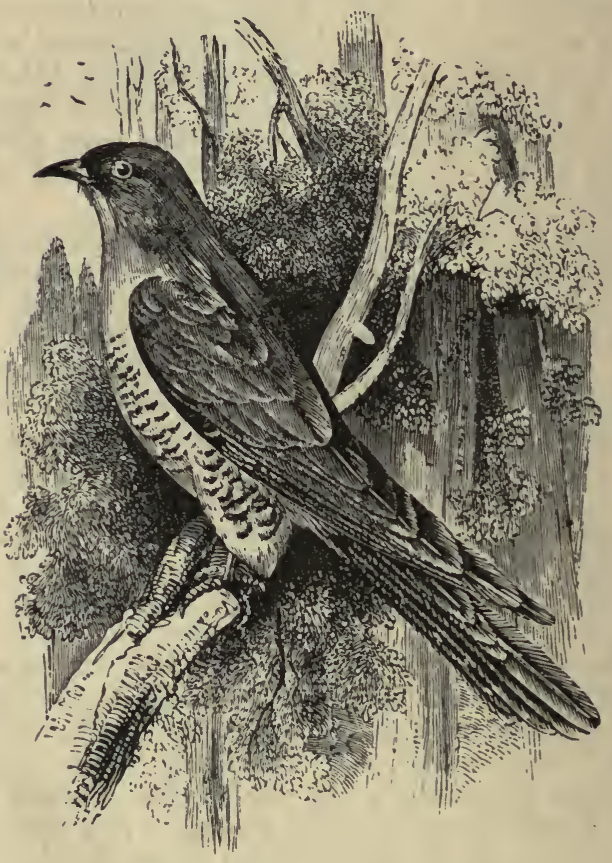

\section{THE CUCKOO. (Cuculus canorus.)}

" Hail, beauteous stranger of the wood, Attendant on the spring!

Now Heaven repairs thy rural seat, And woods thy welcome sing.

"Soon as the daisy decks the green, Thy certain voice we hear;

Hast thou a star to guide thy path, Or mark the rollinir year? 
"Delightful visitant! with thee

I hail the time of flowers,

When heav'n is fill'd with music siveet,

Of birds among the bowers."

LOGAN.

T'HE well-known notes of this bird, in spite of their monotony, are heard with pleasure in spring, as a sure prognostic of fine weather. The Cuckoo is generally first heard about the middle of April, and ceases towards the end of June. This bird is so shy that he is seldom seen when uttering his singular note. The female does not build a nest, but lays her eggs in that of some other bird.

'The Cuckoo is somewhat less than the magpie, his length being about twelve inches from the tip of the bill to the end of the tail. He is remarkable for his round prominent nostrils; the lower part of the body is of a yellowish colour, with black transverse lines on the throat and across the breast; the head and upper part of the body and wings are beautifully marked with black and tawny stripes, and on the top of the head there are a few white spots. The tail is long, and on the exterior part, or edges of the feathers, there are several white marks; the ground colour of the body is a sort of grey. The legs are short, and covered with feathers, and the feet are composed of four toes, two before and two behind.

We are indebted to the observations of Dr. Jenner for the following account of the habits and economy of this singular bird in the disposal of its eggs. He states that, during the time the hedge-sparrow is laying her eggs, which generally occupies four or five days, the Cuckoo contrives to deposit her egg among the rest, leaving the future care of it entirely to the hedge-sparrow. This intrusion often occasions some disorder; for the old hedge-sparrow, at intervals while she is sitting, not only throws out some of her own eggs but sometimes injures them in such a way that they become addled, so that it. frequently happens that not more than two or three of the parent bird's eggis are hatched: but, what is very remarkable, it has never been observed that she has either thrown out or injured the egg of the Cuckoo. 
When the hedge-sparrow has set her usual time, and has disengaged the young Cuckoo and some of her own offspring from the shell, her own young ones and any of her eggs that remain unhatched are soon turned out: the young Cuckoo then remains in full possession of the nest, and is the sole object of the future care of the foster parent. 'The young birds are not previously killed, nor are the eggs demolished; but they are left to perish together, either entangled in the bush that contains the nest, or lying on the ground beneath it. On the 18th June, 1787, Dr. Jenner examined a nest of a hedgesparrow, which then contained a Cuckoo's and three hedge-sparrow's eggs. On inspecting it the day following, the bird had hatched: but the nest then contained only a young Cuckoo and one hedge-sparrow. The nest was placed so near the extremity of a hedge, that he could distinctly see what was going forward in it; and, to his great astonishment, he saw the young Cuckoo, though so lately hatched, in the act of turning out the young hedge-sparrow. The mode of accomplishing this was curious; the little animal, with the assistance of its rump and wings, contrived to get the bird upon its back, and making a lodgment for its burden by elevating its elbows, climbed backward with it up the side of the nest, till it reached the top; where, resting for a moment, it threw off its load with a jerk, and quite disengaged it from the nest. After remaining a short time in this situation, and feeling about with the extremities of its wings, as if to be convinced that the business was properly executed, it dropped into the nest again. Dr. Jenner made several experiments in different nests, by repeatedly putting in an egg to the young Cuckoo, which he always found to be disposed of in the same manner. It is very remarkable that nature seems to have provided for the singular disposition of the Cuckoo in its formation at this period; for, different from other newly-hatched birds, its back, from the scapulæ downward, is very broad, with a considerable depression in the middle, which seems intended for the express purpose of giving a more secure lodgment to the egg of the hedge-sparrow or its young one, while the young Cuckoo is employed in removing 
either of them from the nest. When it is about twelve days old, this cavity is quite filled up, the back assumes the shape of that of nestling birds in general, and at that time the disposition of turning out its companion entirely ceases. 'The smallness of the Cuckoo's egg, which in general is less than that of the hedge-sparrow, is another circumstance to be attended to in this surprising transaction, and seems to account for the parent Cuckoo's depositing it in the nest of such small birds only as these. If she were to do this in the nest of a bird that produced a larger egg, and consequently a larger nestling, the design would probably be frustrated, the young Cuckoo would be unequal to the task of becoming sole possessor of the nest, and might fall a sacrifice to the superior strength of its partners. Dr. Jenner observes, that the eggr of two Cuckoos are sometimes deposited in the same nest; and gives the following instance which fell under his observation. Two Cuckoos and a hedge-sparrow were hatched in the same nest; one hedge-sparrow's egg remained unhatched. In a few hours a contest began between the Cuckoos for possession of the nest; and this continued undetermined till the afternoon of the following day, when the one which was somewhat superior in size, turned out the other, together with the young hedge-sparrow and the unhatched egg. The contest, he adds, was very remarkable; the combatants alternately appeared to have the advantage, as each carried the other several times nearly to the top of the nest, and again sank down oppressed by the weight of its burden; till at length, after various efforts, the strongest of the two prevailed, and was afterwards brought up by the hedge-sparrow.

The American Cuckoo, or Cow bird, is quite different in its habits to the European Cuckoo, as it builds a nest for its eggs, and hatches its young itself like other birds. 


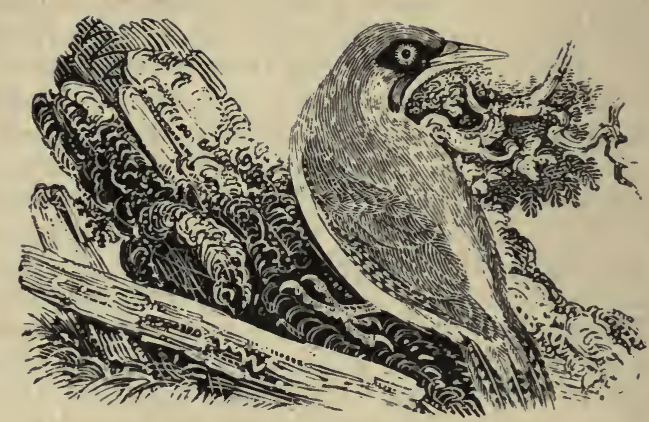

\section{THE COMMON GREEN WOODPECKER,}

\section{(Picus viridis,)}

RECEIVES his name from his habit of pecking the insects from the chinks of trees and holes in the bark. The bill is straight, strong, and angular at the end; and in most of the species is formed like a wedge, for the purpose of piercing the trees. The nostrils are covered with bristles. The tongue is slender, and cylindrical in shape, and to the touch is hard and bony. The Woodpecker, in common with the Humming Bird, though for a different object, possesses the remarkable property of being able to dart out its tongue and secure insects at a considerable distance from its beak. For the purpose of effectually capturing the stronger insects, the tongue is barbed at the end, and provided with glutinous secretion. The toes of this bird are placed two forward and two backward; and the tail consists of ten hard, stiff, and sharp-pointed feathers. A Woodpecker is often seen hanging by his claws, and resting upon his breast against the stem of a tree; when, after darting his beak against the bark, with great strength and noise, he runs round the tree with much alacrity, which manœuvre has made the country people suppose that he goes round 
to see whether he has not pierced the tree through, though the fact is, the bird is in search of the insects, which he hopes to have driven out by his blow.

The following lines, from Moore's beautiful song, allude to the noise which the Woodpecker makes in searching for its food :

"I knew by the smoke that so gracefully curl'd Above the green elms, that a cottage was near, And I said, if there's peace to be found in the world, A heart that was humble might hope for it here. Every leaf was at rest, and I heard not a sound, But the Woodpecker tapping the hollow beech-tree."

The fact is, that this beating against the bark is for no other purpose than to rouse the insects which the chink -contains, and to force them to come out, which they do from their alarm at the noise, when the Woodpecker turning round takes them unawares, and feeds upon them : if the insects do not answer the delusive call, he darts his long tongue into the hole, and brings out, by this means, his reluctant prey. The plumage of this bird is a compound of red and green, two colours, the approximation of which is always productive of harmony in the works of nature. They nestle in the hollows of trees, where the female lays five or six whitish eggs, without making any nest, trusting to the natural heat of her body to hatch them.

The Green Woodpecker is seen more frequently on the ground than the other kinds, particularly where there are ant-hills. It inserts its long tongue into the holes through which the ants issue, and draws them out in abundance. Sometimes with its feet and bill it makes a breach in the nest, and devours the ants and their eggs at its ease. The young ones climb up and down the trees before they are able to fly; they roost very early, and repose in their holes till day. There are many different kinds of Woodpecker, five of which are common to this country. 


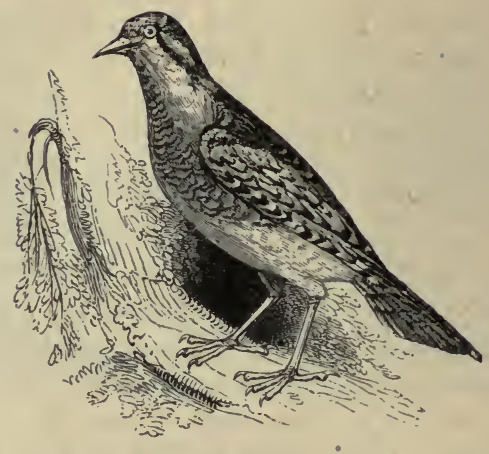

\section{THE WRYNECK. (Yunx torquilla.)}

This bird, Mr. Gould tells us, has received its English name from its habit of moving its head and neck in various directions, and with an undulating motion, like that of a snake; indeed, in some parts of England it is called the snake-bird. When found in its usual retreat in the hole of a tree, it makes a loud hissing noise, raises the feathers of the crown, and writhing its head and neck towards each shoulder alternately, with grotesque contortions, becomes an object of terror to a timid intruder; and the bird, taking advantage of a moment of indecision, darts with the rapidity of lightning from a situation where escape appeared impossible.

The Wryneck deposits its eggs on fragments of decayed wood within a hollow tree, and makes scarcely any nest. The birds when caught young are easily tamed. 


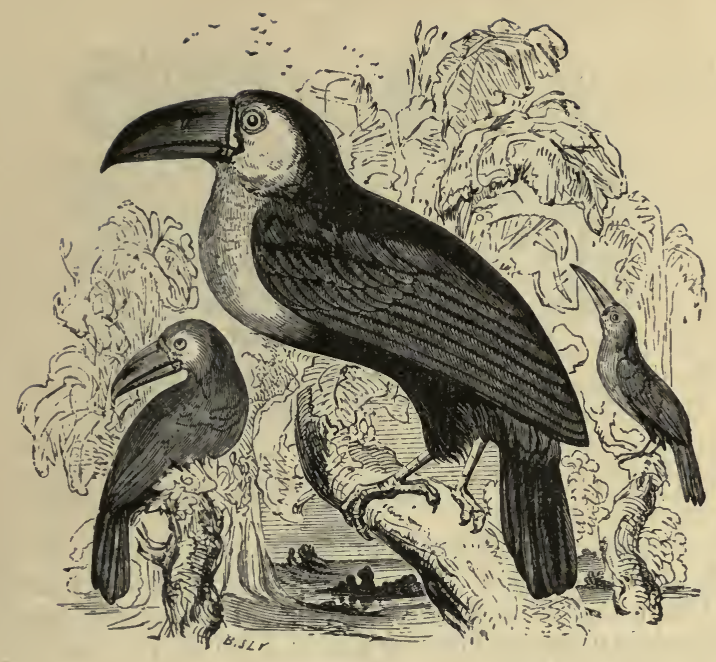

THE TOUCAN, (Rhamphastos tucanus,)

Is a native of South America, very conspicuous for the magnitude and shape of its bill; which, in some of the species, is nearly as long and as large as the body itself. T'he length of its body is about eighteen inches (the size of the magpie); the head is large and strong, and the neck short, in order the more easily to support the bulk of such a beak. The head, neck, and wings are black; the breast of a most lovely orange saffron colour; the lower part of the body and the thighs are vermilion; the tail black. Mr. Gould's specimen represents a narrow straw-coloured belt across the centre of the breast, dividing the orange tint from the vermilion. One of these birds that was kept in a cage was very fond of fruit, which it held for some time in its beak, touching it with great delight with the tip of its feathery tongue, and then tossing it into its throat by a sudden upright jerk; it also fed on small birds, insects, caterpillars, \&c. 


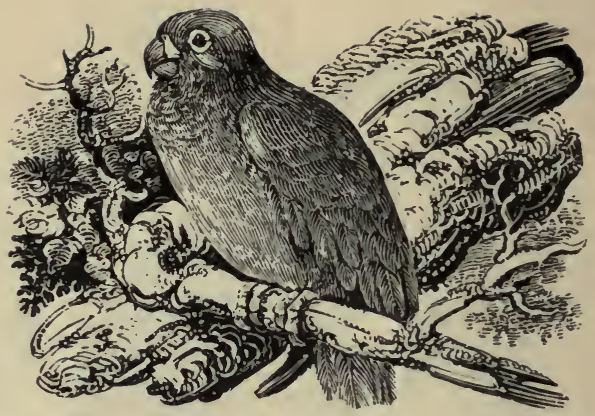

THE GREY PARROT. (Psittacus erythacus.)

The tongue of the Parrot is not unlike a black soft bean, and fills so completely the capacity of its beak, that the bird can easily modulate sounds and articulate words; the beak is composed of two pieces, both moveable, which is a peculiarity belonging almost exclusively to this tribe of birds. The bill of the Parrot is strongly hooked, and assists it in climbing, catching hold of the boughs of the trees with it, and then drawing its legs upwards; then again advancing the heak, and afterwards the feet, for its legs are not adapted for hopping from bough to bough, as other birds do. Several stories are told of the sagacity of these birds, and of the aptitude of their interrogatories and answers, but they have been no doubt the effect of chance.

Dr. Goldsmith says that a Parrot, belonging to King Henry the Seventh, having been kept in a room next the Thames, in his palace of Westminster, had learned to repeat many sentences from the boatmen and passengers. One day, sporting on its perch, it unluckily fell into the water. The bird had no sooner discovered its situation, than it called out aloud, "A boat! twenty pounds for a boat!" A waterman, happening to be near the place where the Parrot was floating, immediately took it up, and restored it to the king; demanding, as the bird was 
a favourite, that he should be paid the reward the bird had called out. This was refused; but it was agreed that, as the Parrot had offered a reward, the man should again refer to its determination for the sum he was to receive. "Give the knave a groat," screamed the bird the instant the reference was made.

'The memory of Parrots is very astonishing, and they can not only imitate discourse, but can sing verses of songs, and mimic gestures and actions. Scaliger saw one that performed the dance of the Savoyards at the same time that it repeated their song. The song was well imitated, but when the bird tried to caper, it was with the worst grace imaginable, as he turned in his toes, and kept tumbling back in a most clumsy manner.

Willoughby tells us of a Parrot, which, when a person said to it, "Laugh, Poll, laugh," laughed accordingly, and the instant after screamed out, "What a fool to make me laugh!" Another, which had grown old with its master, shared with him the infirmities of age. Being accustomed to hear scarcely anything but the words "I am sick;" when a person asked it, "How do you do, Poll ?" "I am sick," it replied in a doleful tone, stretching itself out, "I am sick."

Parrots are very numerous in the East and West Indies, where they assemble in companies, like rooks, and build in the hollows of trees. The female lays two or three eggs, marked with little specks, like those of the partridge. They never breed in our climate, though they live here to a great age. They feed entirely upon vegetables, but, when tame, will take from the mouth of their master or mistress any kind of chewed meat, and chiefly eggos, of which they seem particularly fond. 'They bite or pinch very hard, and some of them possess so much strength in their beak, that they could easily break a man's finger. The Parrot is sensible of attachment, as well as of revenge; and if in their mimic attitudes they show great pleasure at the sight of their feeders, they also fly up with anger to the face of those who once have affronted or injured them. 


\section{THE GREEN PARROT, (Psittacus amazonicus,)}

Wнісн is perhaps more commonly seen in England than the African Grey Parrot, is a native of South America, and receives its name from the great river Amazon, on the banks of which it is common. In its native country it does much damage to the plantations, and indeed many of the Parrots are as injurious in this respect as they are beautiful in their plumage. The Green Parrot resembles the Grey species in its habits, and may likewise be taught to speak with much distinct ness.

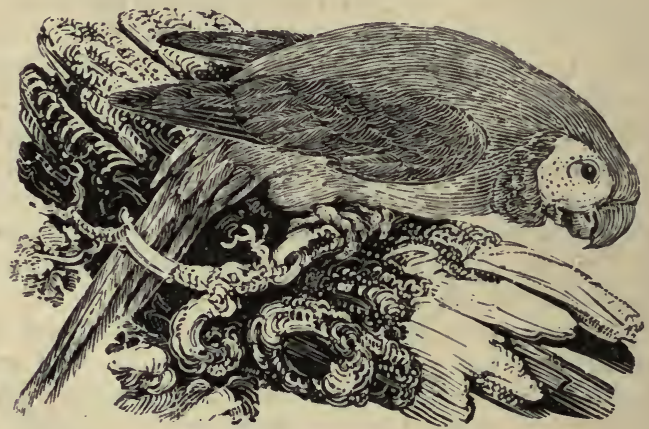

THE BLUE AND YELLOW MACAW,

(Psittacus, or Macrocercus aracanga,)

Is one of the largest of the parrot tribe, and painted with the finest colours Nature can bestow. The beak is uncommonly strong; and the tail proportionally longer than that of any of the parrot tribe. Its voice is fierce and tremulous, sometimes sounding like the laugh of an old man ; and it seems to utter the word "Arara," which occasions its bearing that name in its native country.

When tame, it eats almost every article of human food, and is particularly fond of bread, beef, fried fish, pastry, and sugar. It cracks nuts with its bill, and dexterously picks out the kernels with its claws. It does not chew 
the soft fruits, but sucks them hy pressing its tongue against the upper part of its beak : and the harder sort of food, such as bread and pastry, it bruises, or chews, by pressing the tip of the lower upon the most hollow part of the upper mandible.

The Scarlet Macaw (M. Macao) is another large species, of a bright red colour, with some blue and yellow feathers on the wings, and blue ones about the base of the tail. It was formerly common in the West Indian Islands, but has now become rare there. Its voice is very loud and harsh.

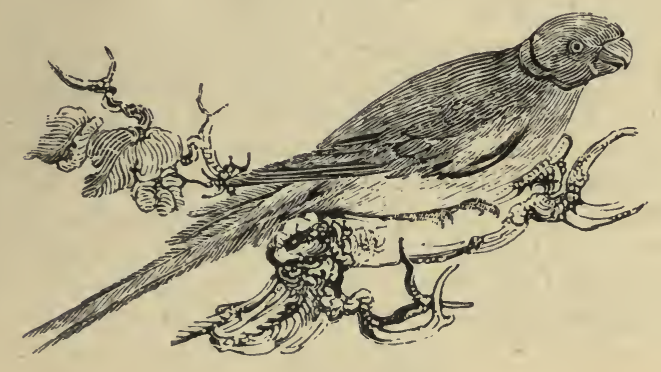

THE RING PAROQUET. (Palaornis Alexandri.)

T'His beautiful species, no less remarkable for the elegance of its form than for its docility and imitative powers, is supposed to have been the first of the parrot species known to the ancients, from the time of Alexander the Great down to the age of Nero. It is about fifteen inches long; its bill is thick and red; the head and the body a bright green; the neck, breast, and the whole of the under side of a paler tint. It has a red circle, or ring, which ensompasses the neck, and is about the breadth of a little finger at the back; but grows narrower by degrees towards the sides, and ends under the lower bill. The lower part of the body is of so faint a green, that it seems almost yellow. The tail also is of a yellowish green, and the legs and feet ash-coloured. - 


\section{THE WARBLING GRASS PAROQUET.}

\section{(Melopsittacus undulatus.)}

Great numbers of Paroquets of different species are found in Australia, and most of these live and seek their food upon the ground rather than in trees. One of them is called the Ground Paroquet, as it is never seen to perch upon trees, but is always running about among the grass and herbage. The Warbling Grass Paroquet is a well known and beautiful little Australian bird, of which considerable numbers have been imported into this country of late years; it is deservedly a favourite, both on account of its elegance, and from its possessing a gentle warbling note very different from the harsh screaming of many species of its tribe. It can, however, scream vigorously for its size. In the interior of Australia these charming little birds occur in countless multitudes. 'They feed chiefly on the seeds of grasses, which they pick up whilst running upon the ground, but they perch in crowds upon the gum-trees for shelter from the noon-day heat, and also before starting on an expedition in search of water.

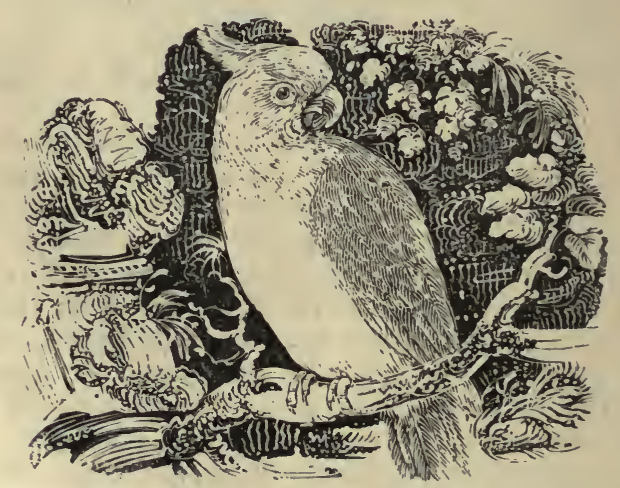

THE COCKATOO. (Plyctolophus galeritus.,

This bird is distinguished from the parrots, by a beau 
tiful crest, composed of a tuft of elegant feathers, which he can raise or depress at pleasure. We meet with some of a beautiful white plumage, and the inside feathers of the crest of a pleasing yellow, with a spot of the same colour under each eye, and one upon the breast. The Cockatoos are natives of the Indian Islands and Australia, where they are found in great abundance. 'Their food consists of seeds and soft and stony fruits, which last their powerful bill enables them to break with ease. 'They are easily tamed when taken at an early age, after which they become familiar and even attached, but their imitative powers seldom go beyond a very few words added to their own cry of Cockatoo.

In a wild state they are shy, and cannot easily be approached. The flesh of the young birds is accounted very good eating. The female is said to make her nest in the rotten limbs of trees, using nothing more than the accumulation of vegetable mould formed by the decayed parts of the bough. The eggs are white, without spots; there are no more than two young at a time. The natives first find the nest by the pieces of bark and twigs which the old birds strip off the trees adjoining that in which the nest is situated. It is a remarkable fact that the bark is never stripped off the tree which contains the nest.

Mr. Bennet, in speaking of the large black Cockatoo of New Holland, says, that if this bird observes on the trunk of a tree indications of a larva being within, it diligently labours to get at it with its powerful beak, and should the object of its pursuit be deep within the wood, as often happens, the trunk becomes so extensively hacked, that a slight gust of wind will lay the tree prostrate. 


\section{§ V.-Gallinaceous Birds.}

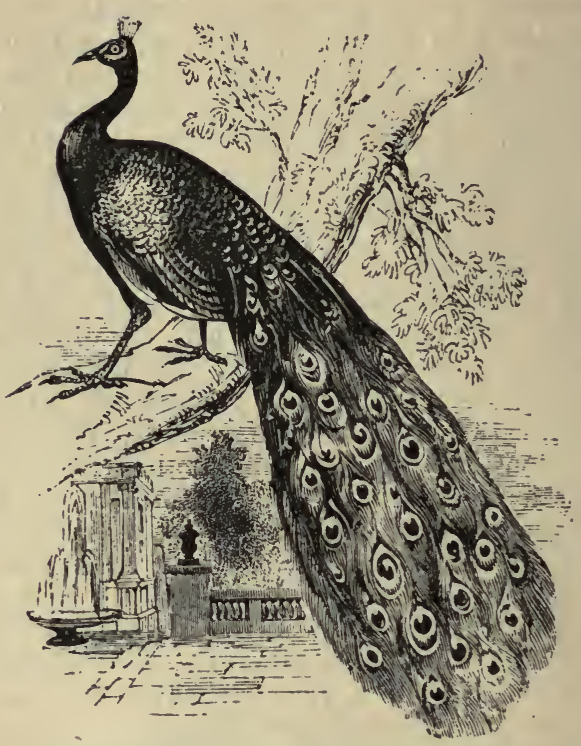

\section{THE PEACOCK. (Pavo cristatus.)}

AsTONISHED at the unparalleled beauty of this bird, the ancients could not help indulging their lively and creative fancy, in accounting for the magnificence of his plumage. They made him the favourite of imperial Juno, sister and wife to Jupiter; and not less than the hundred eyes of Argus were pulled out to ornament his tail ; indeed, there is scarcely anything in nature that can vie with the transcendent lustre of the Peacock's feathers. The changing glory of his neck eclipses the deep azure of ultramarine; and at the least evolution, it assumes the green tint of the emerald, and the purple hue of the amethyst. His head, which is small and finely shaped, has several curious stripes of white and black round the eyes, and is surmounted by an elegant plume, or tuft of 
feathers, each of which is composed of a slender stem and a small tuft at the top. Displayed with conscious pride, and exposed under a variety of angles to the reflections of light, the broad and variegated disks of his train, of which the neck, head, and breast of the bird become the centre, claim our admiration. By an extraordinary mixture of the brightest colours, it displays at once the richness of gold, and the paler tints of silver, fringed with bronze-coloured edges, and surrounding eye-like spots of dark brown and sapphire. The hen does not share in the beauty of the cock, and her feathers are generally of a light brown. She lays only a few eggs at a time, generally at an interval of three or four days; they are white and spotted, like the eggs of the turkey. She sits from twenty-seven to thirty days.

The loud screamings of the Peacock are worse than the harsh croakings of the raven, and a sure prognostic of bad weather; and his feet, more clumsy than those of the turkey, make a sad contrast with the elegance of his plumage:

"Though richest hues the Peacock's plumes adorn, Yet horror screams from his discordant throat."

The spreading of the train, the swelling of the throat, neck, and breast, and the puffing noise which they emit at certain times, are proofs that the Turkey and the Peacock stand nearly allied in the family chain of animated beings.

The flesh of the Peacock was anciently esteemed a princely dish; and the whole bird used to be served on the table with the feathers of the neck and tail preserved; but few people could now relish such food, as it is much coarser than the flesh of the turkey. 'The Italians have given this laconic description of the Peacock: "He has the plumage of an angel, the voice of a devil, and the stomach of a thief." 


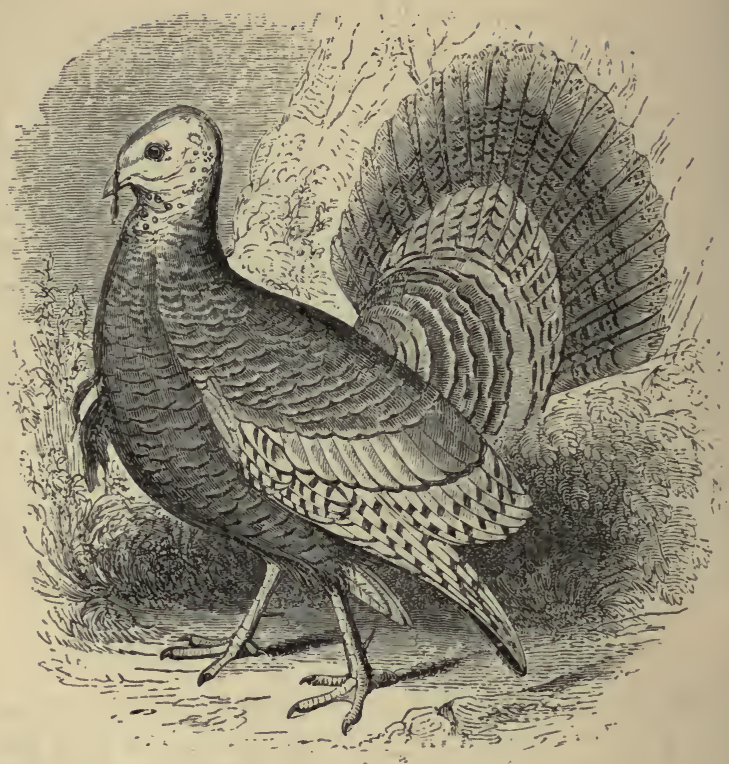

'THE TURKEY, (Meleagris Gallo-Paro,)

WAS originally an inhabitant of America, whence he was brought to Europe by some Jesuit missionaries, which accounts for his being called a Jesuit in some parts of the continent. The general colour of the feathers is buff and black; and turkeys have about the head, especially the cucir, naked and tuberous lumps of flesh of a bright red colour. A long fleshy appendage hangs from the base of the upper mandible, and seems to be lengthened and shortened at pleasure. The hen lays from fifteen to twenty eggs, which are whitish and freckled. The chicks are very tender, and require great care and attentive nursing, until they are able to seek their food. In the county of Norfolk the breeding of 
Turkeys, which is there a considerable branch of trade, is brought to great perfection; and some weighing upwards of twenty pounds each have been raised there. They appear to have a natural antipathy to everything of a red colour.

Though extremely prone to quarrel among themselves, they are, in general, weak and cowardly against other animals, and fly from almost every creature that ventures to oppose them. On the contrary, they pursue everything that appears to dread them, particularly small dogs and children; and after having made these objects of their aversion scamper, they evince their pride and satisfaction by displaying their plumage, strutting about among their female train, and uttering their peculiar note of self-approbation. Some instances, however, have occurred, in which the Turkey-cock has exhibited a considerable share of courage and prowess; as will appear from the following anecdote:-A gentleman of New York received from a distant part a Turkey-cock and hen, and with them a pair of bantams; which were put all together into the yard with his other poultry. Some time afterwards, as he was feeding them from the barn-door, a large hawk suddenly turned the corner of the barn, and made a pounce at the bantam hen: she immediately gave the alarm, by a noise which is natural to her on such occasions; when the Turkey-cock, who was at the distance of about two yards, and without doubt understood the hawk's intention, flew at the tyrant with such violence, and gave him so severe a stroke with his spurs, as to knock him from the hen to a considerable distance; by which means the bantam was rescued from destruction.

The wild Turkey-cock is, in the American forests, an object of considerable interest. It perches on the tops of the deciduous cypress and magnolia:

\section{"On the top}

Of yon magnolia, the loud Turkey's voice

Is heralding the dawn: from tree to tree

Extends the wakening watch-note far and wide,

Till the whole weodlands echo with the cry."

SOUTHEY. 


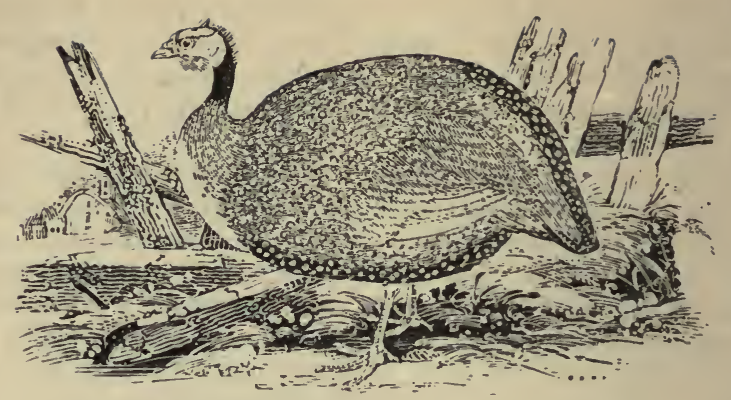

THE GUINEA FOWL, OR PINTADO.

(Numida Meleagris.)

'THis bird, which is also called the Pearled Hen, was originally brought from Africa, where the breed is common, and seems to have been well known to the Romans, who used to esteem the flesh of this fowl as a delicacy, and admit it at their banquets. It went then by the name of Numidian Hen, or Meleagris, because it was fabled that the sisters of Meleager, who unceasingly deplored his death, were metamorphosed into Guinea IIens by Diana. In fact, althuugh they are now domesticated with us, they still retain a great deal of their original freedom, and have a stupid look. Their noise is very disagreeable : it.is a creaking note, which, incessantly repeated, grates upon the ear, and becomes very teasing and unpleasant. They belong to the class of birds called pulveratores; as they scrape the ground and roll themselves in the dust like common hens, in order to get rid of small insects which lodge in their feathers.

The Pintado is somewhat larger than the common hen ; the head is bare of feathers, and covered with a naked skin of a bluish colour; on the top is a callous protuberance of a conical form. At the base of the bill on each side hangs a loose wattle, red in the female and bluish in the male. The general colour of the plumage is a dark bluish grey, sprinkled with round white spots of different sizes, resembling pearls, from which circumstance the 
epithet of pearled has been applied to this bird; which at first sight appears as if it had been pelted by a strong shower of hail.

If trained when young, these birds may easily be rendered tame. II. Bruë informs us, that when he was on the coast of Senegal he received as a present from an African princess two Guinea fowls. Both these birds were so familiar that they would approach the table and tat out of his plate; and, when they had liberty to fly about upon the beach, they always returned to the ship when the dinner or supper bell rang.

In a wild state, it is asserted that the Pintado associates in large flocks. Dampier speaks of having seen between two and three hundred of them together in the Cape de Verd Islands. They were originally introduced into our country from the coast of Africa somewhat earlier than the year 1260 .

In Jamaica, where they have run wild, and become very destructive to the plantations, they are sometimes caught, Mr. Gosse tells us, by the following stratagem :A small quantity of corn is steeped for a night in proof rum and is then placed in a shallow vessel, with a little fresh rum, and the water expressed from a bitter cassava grated. This is deposited within an enclosed ground to which the depredators resort. A small quantity of the grated cassava is then strewed over it, and it is left. The forwls eat the medicated food greedily, and are soon found reeling about intoxicated, unable to escape, and content with thrusting their heads into a corner. It is almost unnecessary to observe that in this state they become an easy prey. Pigeons are sometimes caught in this manner in Germany by the poachers.

This bird has, of late years, greatly increased in this country, and is often seen hanging at the poultry shops and in the markets; the great abundance of them has considerably reduced their value, and they now sell, proportionally, like other fowls. The eggs are smaller and rounder than those of the common hen, and of a speckled reddish-brown colour. They are esteemed a very delicate food. 


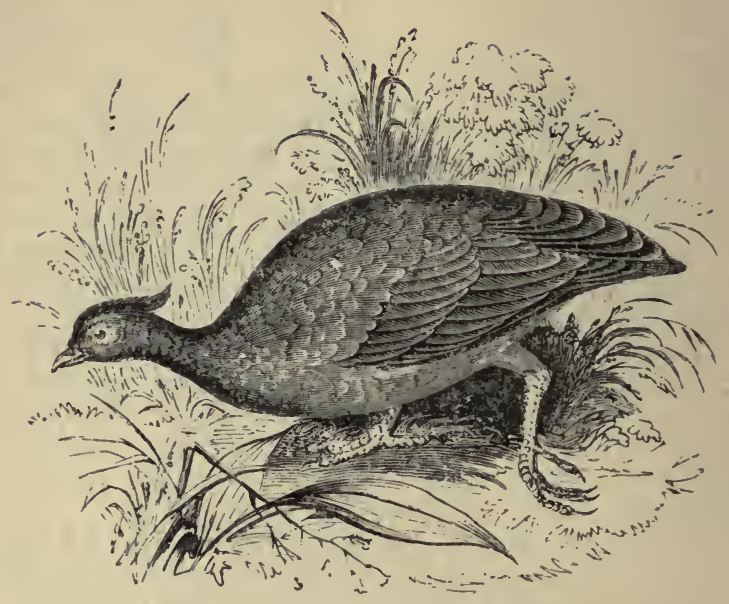

\section{THE MOUND-BIRD OF AUSTRALIA.}

\section{(Megapodius tumulus.)}

IT is remarkable that this bird does not hatch its eggs by incubation. It collects together a great heap of decay. ing vegetables as the place of deposit of its eggs, thus making a hotbed, arising from the decomposition of the collected matter, by the heat of which the young are hatched. This mound varies in quantity from two to four cart-loads, and is not the work or a single pair of birds, but is the result of the united labour of many.

Mr. Gould, in his Birds of Australia, gives the following account of the discovery of one of these nests by Mr. Gilbert:-

"I landed beside a thicket, and had not proceeded tar from the shore, ere I came to a mound of sand and shells, with a slight mixture of black soil, the base resting on a sandy beach, only a few feet above high-water mark; it was enveloped in the large yellow-blossomed Hibiscus, and was of a conical form, twenty feet in circnmference at the base, and about five feet in height. On pointing it 
out to the native, and asking him what it was, he replied, ' Oooregoorga Rambal,' Jungle-fowls' house or nest. I then scrambled up the sides of it, and, to my extreme delight, found a young bird in a hole about two feet deep ; it was lying on a few dry withered leaves, and appeared only a few days old. So far I was satisfied that these mounds had some connection with the bird's mode of incubation; but I was still sceptical as to the probability of these young birds ascending from so great a depth as the natives represented, and my suspicions were confirmed by my being unable to induce the native, in this instance, to search for the eggs, his excuse being that ho knew it would be no use, as he saw no traces of the old hirds having recently been there. I took the utmost care of the young bird, intending to rear it if possible; I therefore obtained a moderate-sized box, and placed in it a large portion of sand. As it fed rather freely on bruised Indian corn, I was in full hopes of succeeding; but it proved of so wild and intractable a disposition, that it would not reconcile itself to such close confinement, and effected its escape on the third day. During the period it remained in captivity, it was incessantly occupied in scratching up the sand into heaps, and the rapidity with which it threw the sand from one end of the box to the other was quite surprising for so young and small a bird, its size not being larger than that of a small quail.

"At night it was so restless, that I was constantly kept awake by the noise it made in its endeavours to escape. In scratching up the sand it only used one foot, and having grasped a handful, as it were, the sand was thrown behind it, with but little apparent exertion, and without shifting its standing position on the other leg: this habit seemed to be the result of an innate restless disposition, and a desire to use its powerful feet, and to have but little connection with its feeding; for although Indian corn was mixed with the sand, I never detected the bird in picking any of it up while thus employed.

"I continued to receive the eggs without having any opportunity of seeing them taken from the mound until the 6th of February ; when, on again visiting linocker's Bay, I had the gratification of seeing two taken from a 
depith of six feet, in one of the largest mounds I had then seen. In this instance the holes ran down in an oblique direction from the centre towards the outer slope of the hillock, so that, although the eggs were six feet deep from the summit, they were only two or three feet from the side. The birds are said to lay but a single egg in each hole, and after the egg is deposited the earth is immediately thrown down lightly, until the hole is filled up; the upper part of the mound is then smoothed and rounded over. It is easily known when a Jungle-fowl has been recently excavating, from the distinct impression of its feet on the top and sides of the mound, and from the earth being so lightly thrown over, that with a slender stick the direction of the hole may readily be detected; the ease or difficulty of thrusting the stick down indicating the length of time that has elapsed since the birds' operations. Thus far it is easy enough; but to reach the eggs requires no little exertion and perseverance. The natives dig them up with their hands alone, and only make sufficient room to admit their bodies, and to throw out the earth between their legs: by grubbing with their fingers alone, they are enabled to fcllow the direction of the hole with greater certainty, which will sometimes, at a depth of several feet, turn off abruptly at right angles, its direct course being obstructed by a clump of wood, or some other impediment."

In all probability, as Nature has adopted this mode of reproduction, she has also furnished the tender birds with the power of sustaining themselves from the earliest period; and the great size of the egg would equally lead to this conclusion, since in so large a space it is reasonable to suppose that the bird would be much more developed than is usually found in eggs of smaller dimensions. The eggs are perfectly white, of a long, oval form, three inches and three quarters long by two inches and a half in diameter.

There are several other Australian birds which adopt the same singular mode of hatching their eggs; one of these is called the Native Pheasant (Leipoa ocellata), and another the Brush 'Turkey (Talegalla Lathami). The latter has its head and neck covered with a naked skin, 
like the turkey, but the lower part of this is much thickened, warty, and bright yellow.

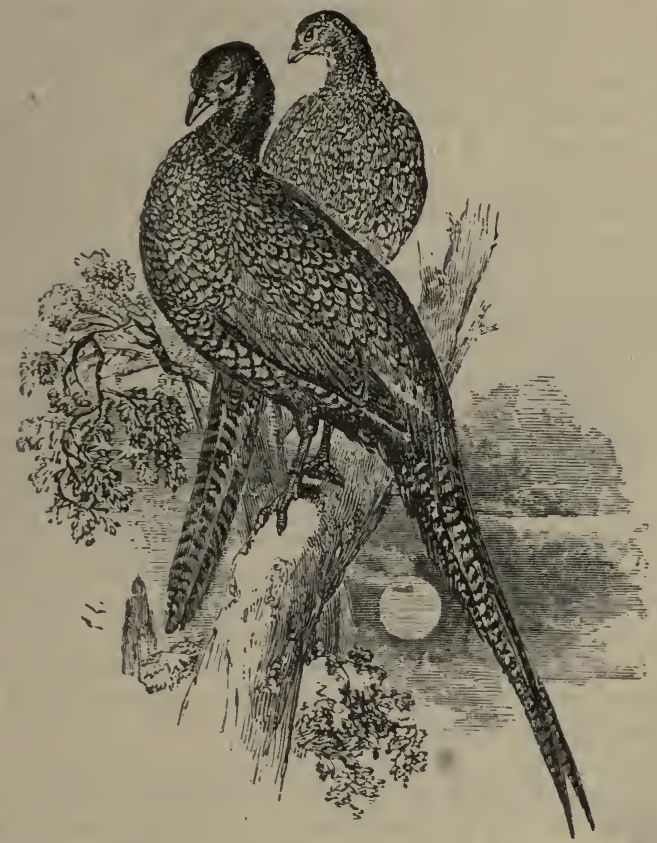

\section{THE PHEASANT. (Phasianus colchicus.)}

THE name of this bird implies that he was originally a native of the banks of the river Phasis, in Armenia; how and when he emigrated, and began to frequent our groves, is unknown. He is of the size of the common cock; the bill is of a pale horn colour; the nostrils arched; the eyes yellow, and surrounded by a naked warty skin, of a beautiful scarlet, finely spotted with black; immediately under each eye there is a small patch of short feathers, of a dark glossy purple; the upper parts of the head and neck are of a deep purple, 
varying to glossy green and blue; the lower parts of the neck and breast are of a reddish chesnut, with black indented edges; the sides and lower part of the breast are of the same colour, with tips of black to each feather, which, in different lights, vary to glossy purple; indeed, the whole colour of this half-domesticated fowl is very beautiful, uniting the brightness of deep yellow gold to the finest tints of the ruby and turquoise, with reflections of green; the whole being set off by several spots of shining black; but in this, as in every other kind of gorgeously-feathered birds, Nature has for some wise purposes, yet unknown to us, denied the female that admirable beauty of plumage which belongs to the male. The Pheasant lives in the woods, which he leaves at dusk to perambulate corn-fields and other sequestered places, where he feeds with his females, upon acorns, berries, grain, and seeds of plants, but chiefly on ants' eggs, of which he is particularly fond. His flesh is justly accounted better meat than any of the domestic or wild fowls, as it unites the delicacy of the common chicken to a peculiar taste of its own. The female lays eighteen or twenty eggs once a year, in the wild state; but it is in vain that we have attempted to domesticate this bird entirely, as she never will remain patiently confined, and if she ever breeds in confinement is very careless of her brood.

There are great varieties of Pheasants, of extraordinary beauty and brilliancy of colours : many of these, such as the Gold and Silver Pheasants (Phasianus pictus and $P$. Nycthemerus), brought from the rich provinces of China, are kept in aviaries in this kingdom.

This beautiful bird is elegantly described in the following passage :-

"See! from the brake the whirring Pheasant springs, And mounts exulting on triumpliant wings;

Short is his joy ; he feels the fiery wound, Flutters in blood, and panting beats the ground :

Ah! what avails his glossy, varying dyes,

His purple crest, his scarlet-circled eyes, The vivid green his shining plumes unfold, His painted wings, and breast that flames with gold !"

Pope's Windsor Forest. 


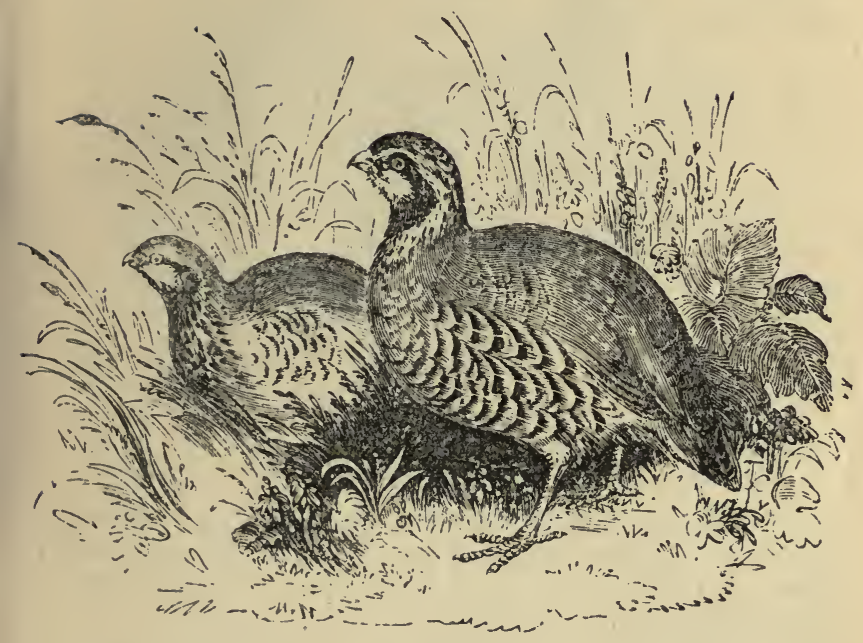

THE RED-LEGGED PARTRIDGE. (Perdix rufus.)

These Partridges are natives of Guernsey and Jersey; but are also very frequently found on the adjoining coasts of France. Of late years they have spread very rapidly in England; and as they are stronger and fiercer than the common partridge, the latter becomes scarce wherever the lied-legged Partridges are abundant. In the Western districts of France they are very abundant, and their flesh is plump and juicy. In England it is as white as in France, but more dry. The side-feathers are very handsomely speckled, and there is a rich black mark beginning behind the eye and forming a kind of gorget on the breast. The eyelids are of a bright red, as are the bill and feet. and the claws are brown. They build their nests on the ground; but are sometimes found perched on trees, or on a fence or paling. 


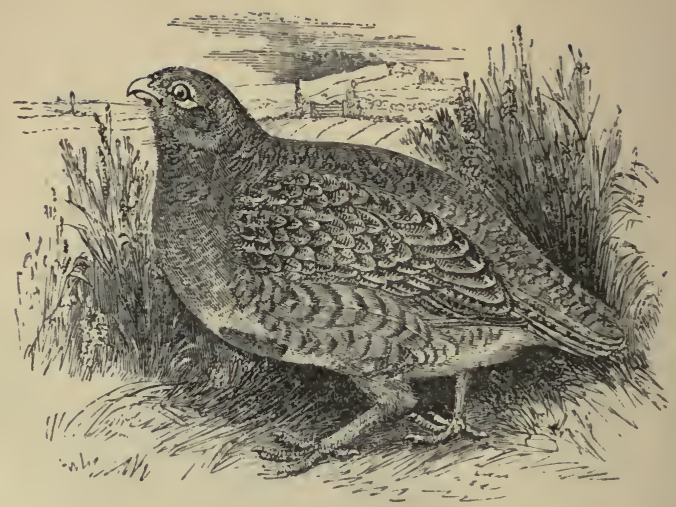

THE COMMON PARTRIDGE, (Perdix cinerea,)

Is in weight about fourteen ounces. The plumage, although it cannot boast of gaudiness, is very pleasing to the eye, being a mixture of brown and fawn-colour, interspersed with grey and ash-colour tints. The head is small and pretty ; the beak strong, but short, and resembling that of all other granivorous birds. The female lays fifteen or eighteen eggs, and leads her brood in the corn-fields with the utmost care. Young Partridges are among the birds which run fleetly the moment they come out of the shell, and may sometimes be found running with a piece of the shell still remaining on their heads. The affection of Partridges for their offspring is peculiarly interesting. Both the parents lead them out to feed: they point out to them the proper places for their fuod, and assist them in finding it by scratching the ground with their feet. They frequently sit close together, covering the young ones with their wings; and from this position they are not easily roused. If, however, they are disturbed, most people acquainted with rural affairs know the confusion that ensues. The male gives the first signal of alarm, by a peculiar cry of distress; throwing himself at the same moment more immediately 
into the way of danger, in ordor to mislead the enemy. He flutters along the ground, hanging his wings, and oxhibiting every symptom of debility. By this stratagem he seldom fails of so far attracting the attention of the intruder as to allow the female to conduct the helpless unfledged brood into some place of security.

The nest is usually on the ground; but on the farm of Lion Hall, in Essex, belonging to Colonel Hawker, a Partridge, in the year 1788, formed her nest, and hatched sixteen eggs, on the top of a pollard oak-tree! What renders this circumstance the more remarkable is, that the tree had fastened to it the bars of a stile, where there was a footpath; and the passengers, in going over, discovered and disturbed her before she sat close. When the brood was hatched, the birds scrambled down the short and rough boughs, which grew out all around the trink of the tree, and reached the ground in safety. It has long been a received opinion among sportsmen, as well as among naturalists, that the female Partridge has none of the bay feathers of the breast like the male. This, however, is a mistake; for Mr. Montague happening to kill nine birds in one day, with very little variation as to the bay mark on the breast, he was led to open them all, and discovered five of them were females. On carefully examining the plumage, he found that the males could only be known by the superior brightness of colour about the head; which alone, after the first or second year, seems to be the true mark of distinction. They fly in coveys till about the third week in February, when they separate and pair; but if the weather be very severe, it is not unusual to see them collect together again. We are told that a gamekeeper, in Dorsetshire, hearing a Partridge utter a cry of distress, was attracted by the sound into a field of oats, when the bird ran round him very much agitated; upon his looking among the corn, he saw in the midst of her infant brood a large snake, which he killed; and perceiving its body much distended, he opened it, when to his astonishment two young Partridges ran from their prison, and joined their mother; two others were found dead in its stomach. Partridges have ever 
held a distinguished place at the tables of the luxurious: we have an old distich :

"If the Partridge had the woodcock"s thigh,

"Twould be tue best bird that e'er did fly."

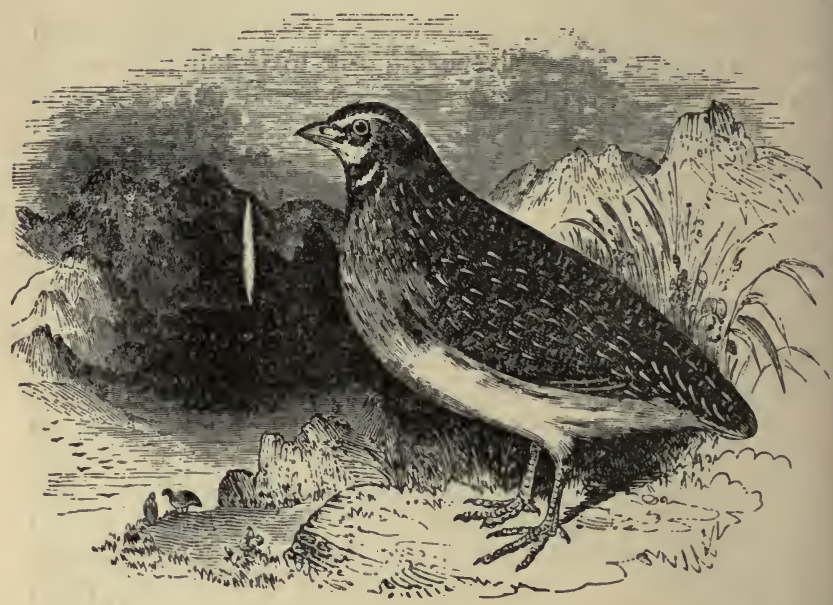

THE QUAIL, (Coturnix dactylisonans,)

Is a small bird, being in length no more than seven inches. The colour of the breast is a dirty pale yellow, and the throat has a little mixture of red : the head is black, and the body and wings have black stripes upon a hazel-coloured ground. Its habits and manner of living resemble those of the partridge, and it is either caught in nets by decoy birds, or shot by the help of the setting-dog, its call being easily imitated oy tapping two pieces of copper one against another. The flesh of the Quail is very luscions, and next in flavour to that of the partridge. Quails are birds of passage, the only peculiarity in which they differ from all other of the poultry kind; and such prodigious numbers have sometimes appeared on the western coast of the kingdom of Naples, that one hundred thousand have been caught in 
one day, within the space of three or four miles. In some parts of the south of Kussia they abound so greatly, that at the time of their migration they are caught by thousands, and sent in casks to Moscow and St. Petersburg. The female seldom lays more than six or seven eggs.

The ancient Athenians kept this bird merely for the sport of fighting with each other, as game-cocks do, and never ate the flesh. The Quail was that wild fowl which God thought proper to send to the chosen people of Israel as a sustenance for them in the desert.

The Chinese Quail is a beautiful little bird, and is often kept in cages in China, for the singular purpose, as it is said, of warming people's hands in winter; as taking the soft, warm body of the bird in the hand diffuses through it an agreeable warmth. It is also very pugnacious, and is employed in fighting.

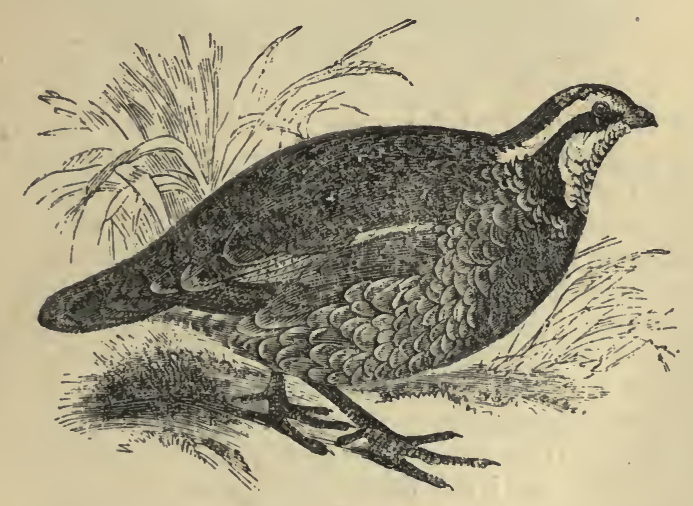

THE AMERICAN QUAIL, (Ortyx Virginianus,)

Is larger than the Common Quail, and is something betweeu a Quail and a Partridge.

The Californian QuaIl (O. Californicus) is distinguished by its possession of a curious crest or tuft of feathers on the crown of the head. 


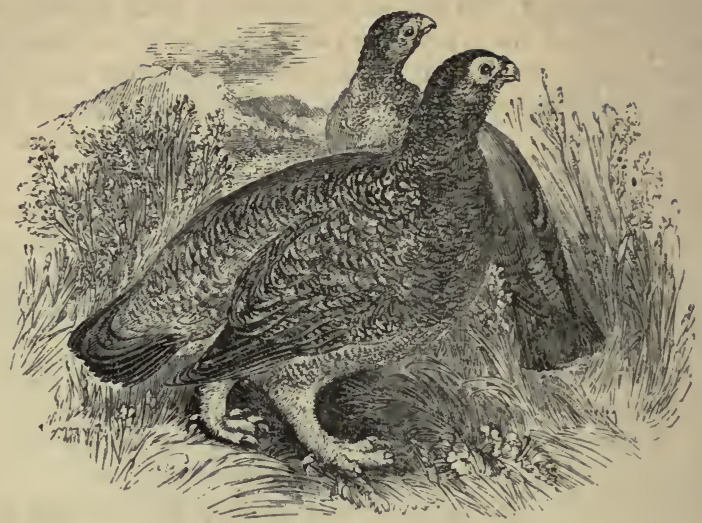

THE RED GROUSE. (Lagopus scoticus.)

"Higa on exulting wing the Heath-Cock rose, And blew his shrill blast o'er perennial suows."

ROGERS

This bird is called by some ornithologists the $\mathrm{Noor}$ Cock, and by others Red Game. The beak is black and short; over the eyes there is a bare sirin of a bright red. The general colour of the plumage is red and black, variegated, and intermixed with each other, except the wings, which are brownish, spotted with red, and the tail, which is black; the feet are covered with thick feathers down to the very claws. It is common in the north of England, in Scotland, and in Wales; and not only affords great diversion to the noblemen and gentlemen of those countries who are fond of shooting, but also repays then well for their trouble, as the flesh is very delicate, and holds on our table an equal place with that of the partridge and the pheasant. T'he season of Grouse shooting commences on the 12th of August. In winter they are found in flocks of sometimes fifty to one hundred in number, which are termed by sportsmen packs, and become remarkably shy and wild, seldom allowing the sportsman to approach them within one hundred yards. 
They keep near the summits of the heathy hills, and seldom descend to the lower grounds. Here they feed on the mountain berries and on the tender tops of the heath. 'The hen lays seven or eight eggs of a reddish black colour.

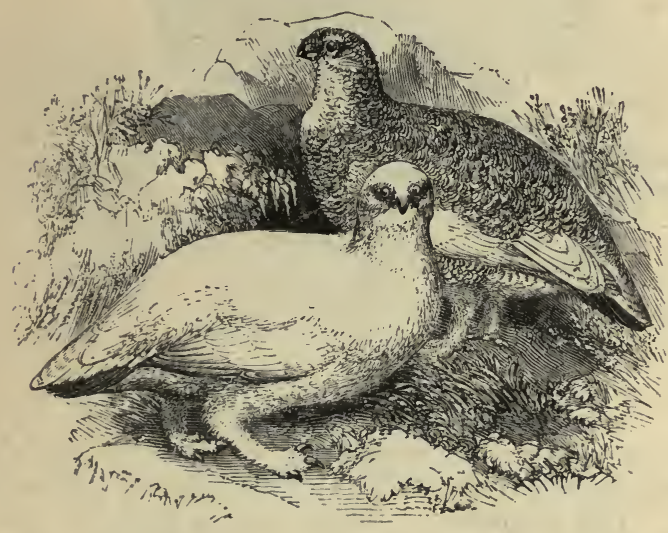

'THE PTARMIGAN, OR WHITE GROUSE,

\section{(Lagopus vulgaris, )}

Is somewhat larger than a pigeon; its bill is black, and its plumage in summer is of a pale brown colour, elegantly mottled with small bars and dusky spots. The head and neck are marked with broad bars of black, rust-colour, and white; the wings and belly are white. The White Grouse is fond of lofty situations, where it braves the severest cold. It is found in most of the northern parts of Europe and America, even as far as Greenland. In this country it is only to be met with on the summits of some of our highest hills, chiefly in Scotland, and in the Hebrides and Orkneys, but sometimes in Cumberland and Wales. Its plumage becomes pure white in winter, with the exception of the tail feathers, which remain black. 


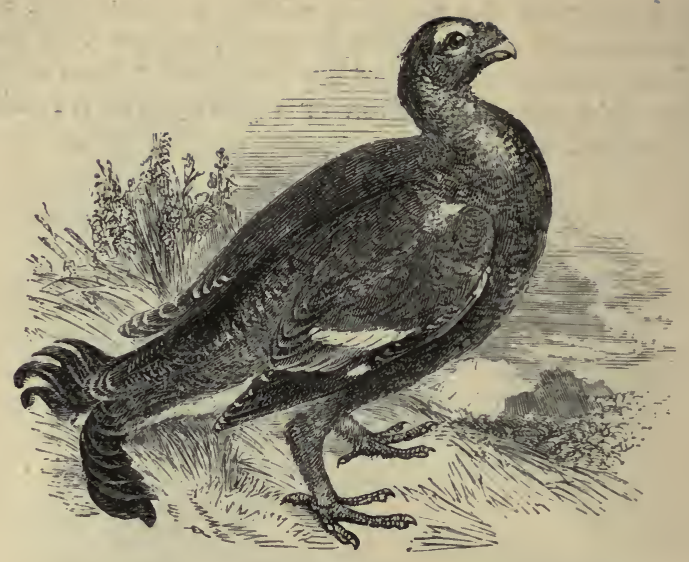

THE BLACK COCK, (Tetrao tetrix,)

Is about four pounds in weight; but the female, which is usually called the Grey Hen, is often not more than two. The plumage of the whole body of the male is black, and glossed over the neck and rump with shining blue; the coverts of the wings are of a dusky brown, with the quill feathers black and white. The tail is much forked in the male. These birds never pair; but in the spring the males assemble at their accustomed haunts on the tops of heathy mountains, where they crow and clap their wings :

"And from the pines high top brought down The giant Grouse, while boastful he display'd His breast of varying green, and crow'd and clapp'd His glossy wings."

Gisborne.

The females, at this signal, resort to them. The males are very quarrelsome, and fight together like game-cocks. On these occasions they are so inattentive to their own safety, that two or three have sometimes been killed at one shot; and instances have occurred of their having been knocked down with a stick. 
Like the Capercalzie, or Cock of the Woods, a larger species of this genus, these birds are common in Russia, Siberia, and other northern countries, chiefly in wooded and mountainous situations; and in the northern parts of our own island on uncultivated moors.

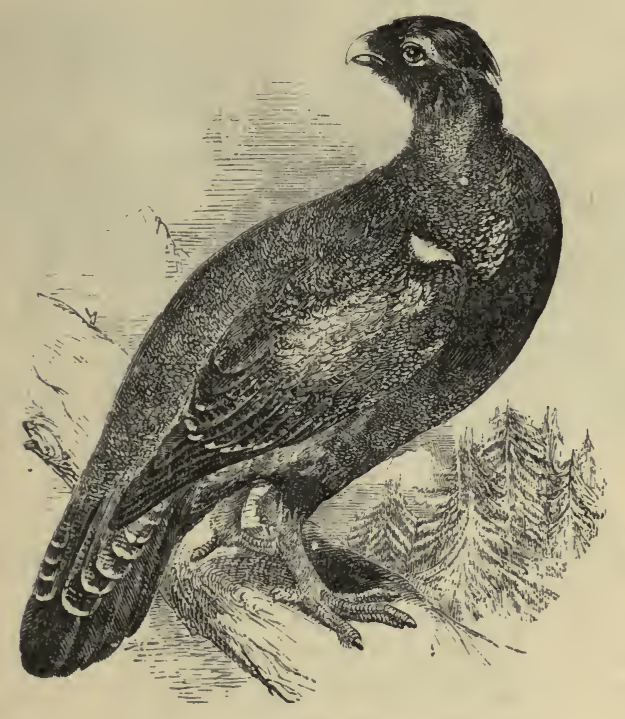

THE CAPERCALZIE, (Tetrao urogallus,)

$W_{A S}$ also formerly an inhabitant of the forests of Scotland, but has been extinct in Britain for many years. The male is as large as a good-sized turkey, the female considerably smaller. Several attempts have been made to rear the Capercalzie, and domesticate it in this couniry, but without effect. 'I'hey are now most numerous in Sweden, where they are much esteemed as food. Of late years they have been brought to the English market, and are considered very good eating. 


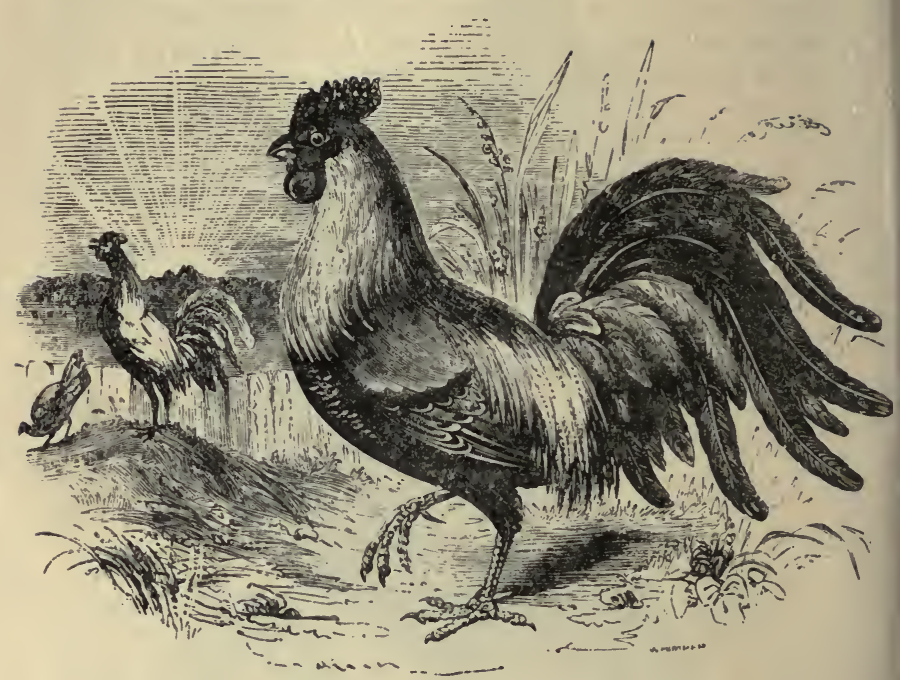

THE COMMON COCK. (Gallus domesticus.)

"While the Cock, with lively din. Scatters the rear of darkness thin; And to the stack, or the barn door, Stoutly struts his dames before."

MintoN.

This bird is so well known that it would be needless to say much of him. His plumage is various and beautiful, his couragre very great and proverbial, and his intuitive knowledge of the period of sunrise has baffled the most scrutinising researches of naturalists. When of a good breed, and well taught to fight, he will die rather than yield to his adversary. The hen lays a great number of eggs, and will hatch as many as thirteen at one sitting; but this is considered the extreme number, being as many as she can well cover. When in the secluded state of incubation she eats very little; and yet is so 
courageous and strong that she will rise and fight any men or animals that dare to approach her nest. It is impossible to conceive how, with such a scanty sustenance as she takes, she can, for twenty-one days, emit constantly from her body as much heat as would raise Fahrenheit's thermometer to ninety-six degrees. The flesh of this bird is delicate and wholesome, and universally relished as nourishing and agreeable food.

There are several varieties of families of this fowl. The Hamburg Cock has a beautiful tuft of feathers about his ears and on the top of his head; and the Bantam has his legs and toes entirely feathered, which is more an impediment than an ornament to the bird.

The cruel sport of cockfighting may be traced back to the earliest antiquity. The Athenians seem to have received it from India, where it is even now followed with a kind of frenzy; and we are told that the Chinese will sometimes risk not only the whole of their property, but their wives and children, on the issue of a battle. The religion of the Greeks could not see that game with pleasure, and therefore cockfighting was allowed only once a year; but the Romans adopted the practice with rapture, and introduced it into this island. Henry VIII. delighted in this sport, and caused a commodious house to be built for the purpose, which, although now applied to a very different use, still retains the name of the Cockpit. The part of our ships so called, seems also to indicate that in former times the diversion of cockfighting was permitted, in order to beguile the tedious hours of a long voyage. The Cock has been a subject of considerable interest with the poets; and has been very commonly called by them "Chanticleer :"

"Within this homestead lived, without a peer

For crowing loud, the noble Chanticleer." Drynex.

"The feathered songster, Chanticleer, Had wound his bugle-horn,

And told the early villager

The coming of the morn."

Chatterton. 
$326 \quad$ Birds.

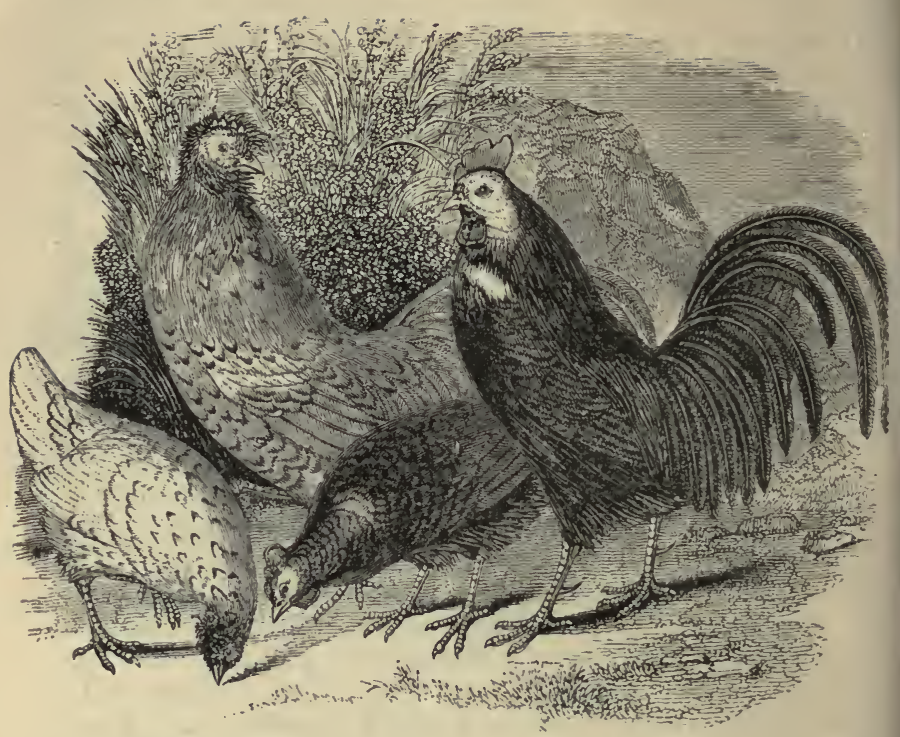

\section{BANKIVA COCK.-JAGO COCK AND HEN.- SPANISH COCK AND HEN.}

Froy the Bankiva fowl nearly all the various kinds of fowls found in British ponltry-yards are said to have sprung. It is a native of the island of Java, and is characterised by a red indented comb, red wattles, and ashgrey legs and feet. The cock has a thin indented or scalloped comb, and wattles under the mouth. The feathers of the neck are long, falling down, and rounded at the tips, and are of the finest gold colour. The head and neck are fawn-coloured, the wing-coverts dusky brownish and black; the tail and belly black. The hen is of a dusky ash-grey and yellowish colour, and has a much smaller comb and beard than the cock. 


\section{THE PADUAN, OR JAGO FOWL.}

\section{(Gallus.giganteus.)}

'THE wild species, termed by Marsden the Jago fowl, is a native of Java and Sumatra, and is supposed by Temminck to be the original of this fine breed, though little is known of the wild sort, further than that it is double the size of the Bankiva, or common fowl. Marsden says he has seen in the East a cock of this species tall enough to pick crumbs from a dining-table. They are said to weigh from eight to ten pounds. The combs of both the cock and hen are large, frequently double, of the form of a crown, with a tufted crest of feathers, which is largest in the hen; the voice is stronger and harsher than that of other fowls; but the most singular peculiarity is, that they do not come into full feather till about half grown. The Cochin-China fowls are said to be a variety of the Jago fowls. There are numerous hybrids and varieties of the Jago fowl found under different names in poultry-yards, but all of them lay fine large eggs, and are highly esteemed for the excellent flavour of their flesh. One of the most interesting of these varieties is called

\section{THE SPANISH FOWL,}

the body and tail feathers of which are of a rich black, with occasionally a little white on the breast. The cock of this variety is a most majestic bird; its deportment is grave and stately, and its eyes are encircled with a ring of brown feathers, from which rises a black tuft that covers the ears. There are other similar feathers behind the comb and beneath the wattles. The legs and feet are of lead colour, except the sole of the foot, which is yellowish.

\section{THE BANTAM FOWL}

is a small variety, with short legs, most frequently feathered to the toes, so as sometimes to obstruct walking. Many Bantam fanciers prefer those which have 
clear bright legs, without any vestige of feathers. The full-bred Bantam cock should have a rose comb, a wellfeathered tail, full hackles, a proud lively carriage, and ought not to weigh more than a pound. The nankeen coloured and the black are the greatest favourites. If of the latter colour, the bird should have no feathers of any other sort in his plumage. The nankeen bird should have his feathers edged with black, his wings barred with purple, his tail feathers black, his hackles slightly studded with purple, and his breast black, with white edges to the feathers. The hens should be small, cleanlegged, and match in plumage with the cock.

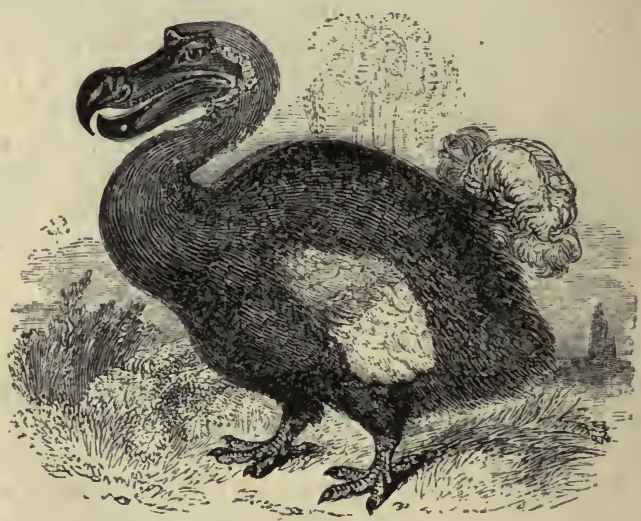

THE DODO. (Didus ineptus.)

SwIFTNEss has generally been considered the attribute of birds, but the Dodo appears never to have had any title to this distinction. Instead of exciting the idea of swiftness by its appearance, in the drawings that have been preserved of it, it strikes the imagination as a thing the most unwieldy and inactive of all nature. Its body is massive, almost round, and covered with grey feathers. 
It is just barely supported upon two short thick legs, like pillars; while its head and neck rise from it in a manner truly grotesque. The neck, thick and pursy, is joined to the head, which consists of two immense jaws, opening far beyond the eye. The Dodo formerly inhabited the Isle of France; but it has been long extinctso long, indeed, that the very fact of its ever having existed at all has been a subject of dispute amongst naturalists and scientific men. A great deal of evidence, in the form of old pictures as weli as in writings, has been brought forward to prove that the Dodo is not a fabulous bird, and its reality is now generally admitted. In fact, we have very reliable testimony that a single specimen was actually exhibited publicly in London in the year 1638.

The Dodo was supposed by the earliest naturalists who described it, to be a kind of turkey, as in the flavour of its flesh it resembled that bird. Later naturalists supposed it to be a kind of swan, and this opinion was followed by the celebrated Buffon. Others thought it was a kind of vulture; and others, judging from the shortness of its wings, placed it in the ostrich tribe. Modern naturalists, however, having carefully examined the bones of the bird, which have been preserved, are of opinion that it was a gigantic pigeon. An entire specimen existed about a hundred years ago in the Ashmolean Museum at Oxford, but only part of the bird and one of the feet remain; there is also a foot preserved in the British Museum. There is a reference to this extinct species in Humboldt's Cosmos. (See Bohn's edition, vol. i. page 29, and a note on the Dodo, by Dr. Mantell, at the end of the volume.)

The Solitaire is another remarkable bird which was formerly found in the Mauritius and the adjoining islands, but which has now become extinct. 


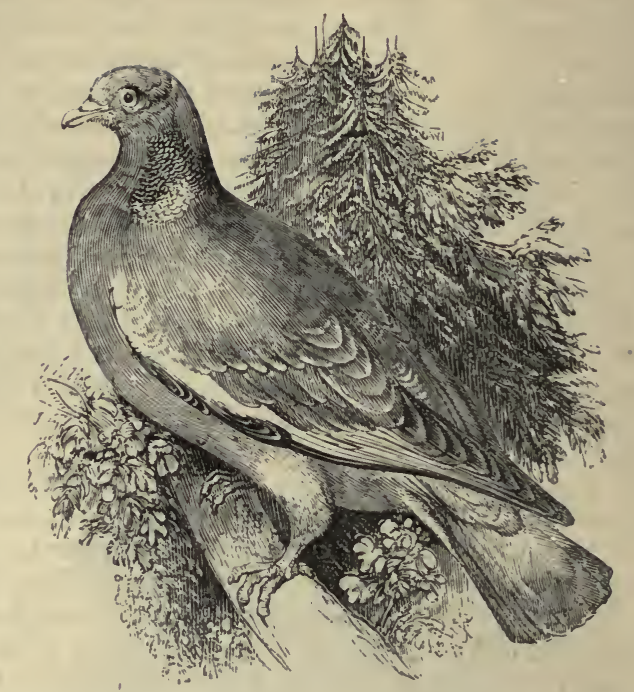

THE RINGDOVE, CUSHAT, OR WOOD PIGEON,

\section{(Columba palumbus,)}

Is the largest Pigeon found in our island, by which it may be distinguished from all others; its weight is about twenty ounces, its length eighteen inches, and its circumference about thirty. It is usually known as the Wood Pigeon. This bird is of a bluish grey colour, with the feathers of the sides of the neck tipped with white, forming several imperfect rings; the breed is common in Britain. Its habits are like those of other birds of the tribe, but it is so strongly attached to its native freedom, that all attempts to domesticate it, with a few rare exceptions, have hitherto proved ineffectual.

These birds build their nests chiefly on the pine, or holly, with dried sticks thrown rudely together; and the eggs, which may frequently be seen through the 
bottom of the nest, are larger than those of the domestic Pigeun.

Mr. Montague bred up a curious assemblage of birds, which lived together in perfect amity; it consisted of a common pigeon, a ringdove, a white owl, and a sparrowhawk; the ringdove was master of the whole.

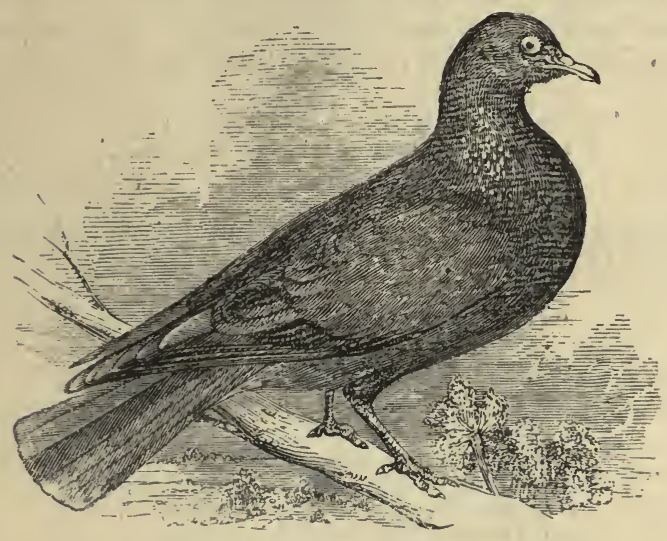

THE STOCKDOVE. (Columba cenas.)

“'The Stockdove, recluse, with her mate, Conceals her fond bliss in the grove, And murmuring seems to repeat,

That May is the mother of love." Cunninghasr.

THIS bird is called the Stockdove, because it builds in the stocks of trees which have been headed down, and are becume thick and bristly; and not, as some have supposed, because it is the stock, or original, from which all the tame pigeons have sprung. Sometimes these birds lay their eggs in deserted rabbit-warrens, on the sod, without making any nest.

The colour of the Stockdove is generally of a deep slate or lead tint, with rings of black about the feathers. While the beech woods were suffered to cover large tracts of ground, these birds used to haunt them in myriads, frequently extending above a mile in length, 
as they went out in the morning to feed. They are still found in considerable quantities in many parts of England, but never in Scotland, forming their nests in the hollows of trees; not like the ringdove, on boughs. Their murmuring strains, or cooings, in the morning and at dusk, are highly pleasing, and throw an agreeable melancholy on the solitude of the grove. The poet of the Seasons expresses this in the following lines, with a beautiful instance of imitative harmony:

" A melancholy murmur through the whole."

Spring.

Wordsworth also gives a pleasing description of the mournful cooing of these birds:

"I heard a Stockdove sing or say His homely tale this very day;

His voice was buried among trees,

Yet to be come at by the breeze ;

He did not cease; but cooed and cooed;

And somewhat pensively he wooed;

He sang of love with quiet blending,

Slow to begin, and never ending;

Of serious faith and inward glee,

That was the song-the song for me."

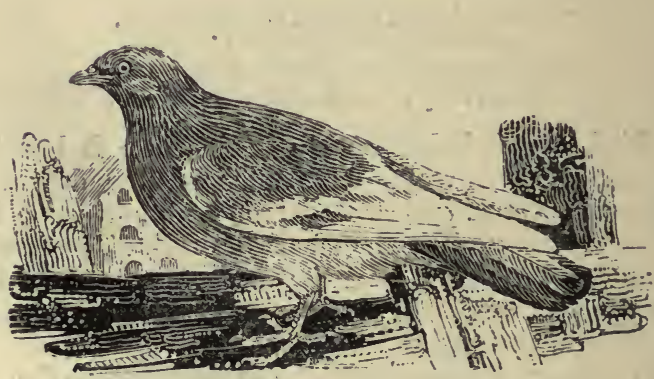

THE ROCKDOVE. (Columba livia.)

THE shape of this bird, which is the original stock of our domestic Pigeons, is well known, and the plumage 
of the wild birds is exactly similar to that of the commonest kind seen in our dove-cots-bluish-grey, with black bands across the wings. In its wild state it inhabits the cavities of high rocks and cliffs on the sea coast, where it is found abundantly in our own country. The female Pigeon lays two eggs at a time, which produce generally a male and a female. It is pleasing to see how eager the male is to sit upon the eggs, in order that his mate may rest and feed herself. The young ones, when hatched, are fed from the crop of the mother, who has the power of forcing up the half-digested peas which she has swallowed to give them to her young. The young ones, open-monthed, receive this tribute of affection, and are thus fed three times a day.

'There are upwards of twenty varieties of the domestic Pigeon, and of these the carriers are the most celebrated. They obtain their name from being sometimes employed to convey letters or small packets from one place to another. The rapidity of their flight is very wonderful. Lithgow assures us that one of them will carry a letter from Babylon to Aleppo (which, to a man, is usually thirty days' journey) in forty-eight hours. 'To measure their speed with some degree of exactness, a gentleman, many years ago, on a trifling wager, sent a Carrier Pigeon from London, by the coach, to a friend at Bury St. Edmunds, and along with it a note, desiring that the l'igeon, two days after its arrival there, might be thrown up precisely when the town clock struck nine in the murning. This was accordingly done, and the Pigeon arrived in London at half-past eleven o'clock on the same morning, having flown seventy-two miles in two hours and a half. An instance of still greater speed is mentioned by Mr. Yarrell, in which a Carrier flew from Roven to Ghent, a hundred and fifty miles in a straight line, in one hour and a half. From the instant of its liberation, its flight is directed through the clouds, at a great height, to its home. By an instinct altogether inconceivable, it darts onward, in a straight line, to the very spot whence it was taken, but how it can direct its flight so exactly will probably for ever remain unknown to us. 
"Led by what chart, transports the timid Dove, The wreaths of conquest, or the vows of love?

Say through the clouds what compass points her flight?

Monarchs have gazed, and nations blessed the sight.

Pile rocks on rocks, bid woods and mountains rise,

Eclipse her native shades, her native skies :-

"Tis vain! through ether's pathless wilds she goes,

And lights at last where all her cares repose.

Sweet bird, thy truth shall Harlem's walls attest,

And unborn ages consecrate thy nest."

Rogers.

The Carrier Pigeon is easily distinguished from the other varieties by a broad circle of naked white skin round the eyes, by the large fleshy wattle at the base of its bill, and by its dark blue or blackish colour.

It would be as fruitless as unnecessary to attempt to describe all the varieties of the Tame Pigeon; for human art has so much altered the colour and figure of this bird, that pigeon-fanciers, by pairing a male and female of different sorts, can, as they express it, "breed them to a feather." Hence we have the various names of Carriers, 'I'umblers, Jacobins, Croppers, Pouters, Bunts, Turbits, Shakers. Fantails, Owls, Nuns, \&c., all of which may, at first, have accidentally varied from the Rockdove, and these have been further improved by crossing, food, and climate. An actual post system, in which pigeons were the messengers, was established by the Sultan Noureddin Mahmoud, which lasted about a century, and ceased in 1258, when Bagdad fell into the hands of the Moguls. 


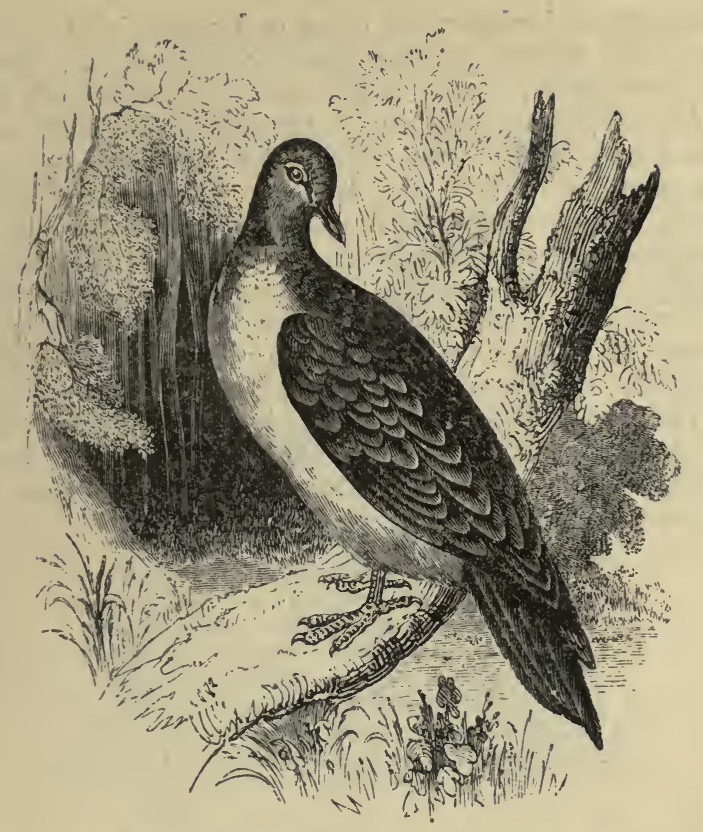

\section{THE TURTLE DOVE. (Columba turtur.)}

"Go, beautiful and gentle Dove, And greet the morning ray;

For lo! the sun shines bright above, And the rain is pass'd away." Bowles.

This Dove brings to the heart and mind the most pleasing recollections; its name is nearly synonymous with faithfulness and unvariable affection. 'The male or female is so much attached to its respective mate that it is said, perhaps with more poetry than truth, that if one die the other will never survive; however, the author of these observations was an eye-witness to the death of a female Turtle Dove, who was unfortunately killed by a spaniel, in the absence of the male; the disconsolate survivor, after having in vain searched 
everywhere for his mate, came and mournfully perched upon the wonted trough, waiting patiently for her tu repair thither in order to get food; but, after two days of unavailing expectation, he, by spontaneous abstinence, pined and died on the place. Such examples are not common; and we believe that, when not domesticated, the appearance of another female, in the time of coupling, sets at defiance all natural propensity to constancy, and puts an end to the much-famed disconsolate widowhood. Their general colour is a bluish grey; the breast and neck of a whitish purple, with a ringlet of beautiful white feathers with black edges about the sides of the neck. Nothing can express the sensation which is excited in a feeling mind when the tender and sweetly plaintive notes of the Turtle Dove breathe from the grove on a beautiful spring evening:

"Deep in the wood, thy voice I list, and love 'I'hy soft complaining song, thy tender couing; $\mathrm{Oh}$, what a winning way thou hast of wooing, Gentlest of all thy race-sweet Turtle Dove? Thine is a note which doth not pass away Like the light music of a summer's day ; Hushing the voice of mirth, and staying folly, And waking in the breast a gentle melancholy."

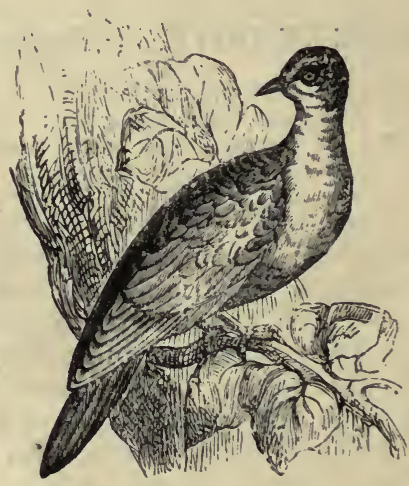


$\S$ VI. Grallatores, or Waders.

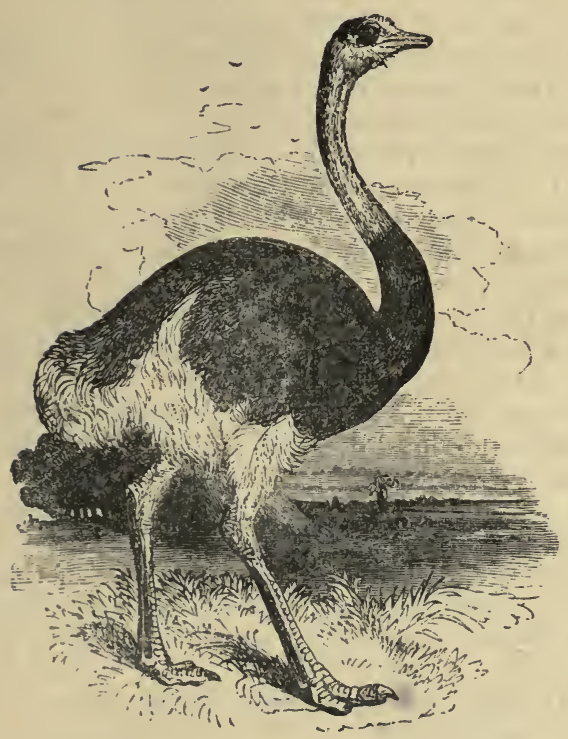

THE OSTRICH. (Struthio camelus.)

This bird is a native of Africa, and is so tall that when it holds up its bead it is seven or eight feet in height. The head is very small in comparison with the body, being hardly bigger than one of the toes, and is covered, as well as the neck, with a kind of down, or thin-set hair, instead of feathers. The sides and thighs are entirely bare and flesh-coloured. The lower part of the neck, where the feathers begin, is white. 'The wings are very short in proportion to the siz.e of the bird, and in fact are too small to enable it to $\mathrm{fly}$; but when it runs, which it does with a strange jumping kind of 
motion, it raises its short wings and holds them quivering over its back, where they seem to serve as a kind of sail to gather the wind, and carry the bird onwards. The speed which it will thus attain is enormous. The swiftest greyhound cannot overtake it; and indeed an Arab on his horse cannot hope to capture an ostrich without having recourse to stratagem. He dexterously throws a stick between its legs as it runs, and so tripping it up, is enabled to secure it.

In its flight it spurns the pebbles behind it like shot against the pursuer. And this is not their only mode of annoyance. They have been known to attack men with their claws, with which they are able to strike with terrific force. The feathers of the back in the cock are coal black, in the hen only dusky, and so soft that they resemble a kind of wool. The tail is thick, bushy, and round; in the cock whitish, in the hen dusky, with white tops. These are the feathers so generally in requisition to decorate the head-dress of ladies and the helmets of warriors.

The Ostrich swallows anything that presents itself, leather, glass, iron, bread, hair, \&c., but the old notion that the Ostrich could digest metals is certainly incorrect. An Ostrich in the Zoological Gardens in the Regent's Park was killed by swallowing a lady's parasol.

"O"er the wild waste the stupid Ostrich strays

In devious search, to pick a scanty meal,

Whose fierce digestion gnaws the temper'd steel."

Muckle's Lustad.

They are polygamous birds, one male being generally seen with two or three, and sometimes with five, females. The female Ostrich, after depositing her eggs in the sand, trusts them to be hatched by the heat of the climate; in the Book of Job there is a beautiful passage relating to this habit of the Ostrich, "which leaveth her eggs in the earth, and warmeth them in the dust; and forgetteth that the foot may crush them, or that the wild beast may break them. She is hardened against her young ones, as though they were not hers. 
Her labour is in vain; without fear, because God hath deprived her of wisdom; neither has he imparted to her understanding. What time she lifteth up her head on high, she scorneth the horse and his rider." It appears, however, that the female Ostrich sits upon her eggs like other birds, although generally at night only, and brings up her young. The eggs are as large as a young child's head, with a hard stony shell, and one has been known to weigh upwards of three pounds. The time ot incubation is six weeks. That Ostriches have great affection for their offspring may be inferred from the assertion of Professor Thunberg, who says that he once rode past the place where a hen Ostrich was sitting in her nest, when the bird sprang up and pursued him, evidently with a view to prevent his noticing her eggs or young. Every time he tumed his horse towards her she retreated ten or twelve paces, but as soon as he rode on again she pursued him till he had got to a considerable distance from the place where he had started her. In the tropical regions, some persons breed Ostriches in flocks, for they may be tamed with very little trouble. When M. Adanson was at Podar, a French factory on the southern bank of the river Niger, two young but full-grown Ostriches, belonging to the factory, afforded him a very amusing sight. They were so tame that two little blacks mounted both together on the back of the largest. No sooner did he feel their weight than he began to run as fast as possible, and carried them several times round the village, and it was impossible to stop him otherwise than by obstructing the passage. This sight pleased M. Adanson so much that he wished it to be repeated, and, to try their strength, directed a fullgrown negro to mount the smaller, and two others the larger of the birds. This burden did not seem at all disproportioned to their strength. At first they went at a tolerably sharp trot, but when they became a little heated they expanded their wings, as though to catch the wind, and moved with such fleetness that they scarcely seemed to touch the ground. The foot of the Ostrich has only two toes, one of which is extremely large and strong. 


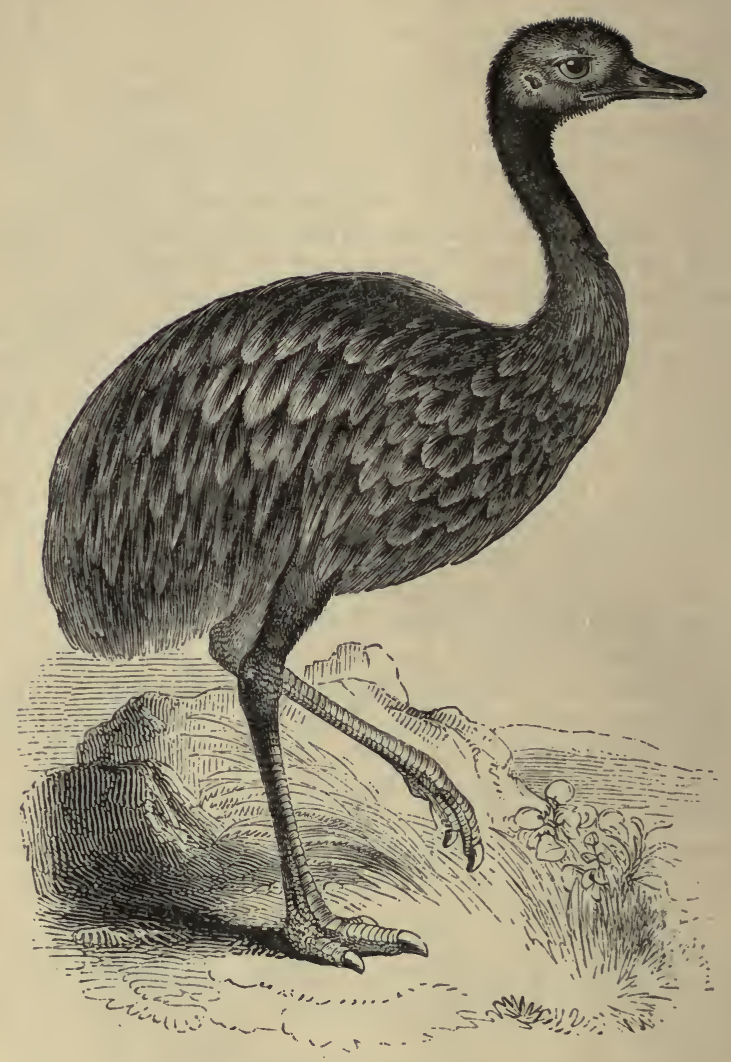

THE RHEA, (Rhea Americana,)

Or American Ostrich, is about half as big as the African species. It has its head covered with feathers, and each of its feet consists of three toes. It is found on the great plains of South America, and, like the African Ostrich, 
is polygamous, but the curions part of the matter is that the females often lay their eggs almost anywhere on the ground, and the male takes the trouble of collecting them into a sort of nest, and sitting on them until the young birds are hatched. When thus occupied, the males often become very fierce, and will attack any one that approaches them too closely.

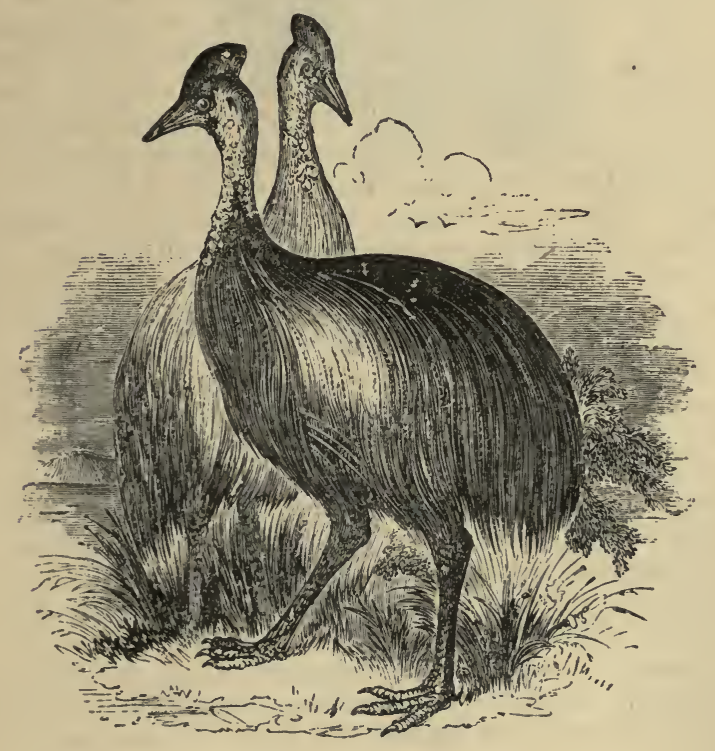

THE CASSOWARY, (Casuarius galeatus,)

INSTEAD of the beautiful plumes of the ostrich, has his wings furnished only with five stiff quills without barbs, which project curiously from the feathers of the body. His plumage is black; his head is small and depressed, with a horny crown or helmet, and covered with a naked red skin; the head and neck are deprived of feathers; 
about the neck are two protuberances of a bluish colour, in shape like the wattles of a cock. The feathers consist of long, slender, separate barbs, which hang down on each side of the body, so that at a distance he louks as if he were entirely covered with the hairs of a bear rather than with the plumage of a bird. His height is about five feet. The Cassowary is as voracious as the ostrich, and eats indiscriminately whatever comes in his way, and does not seem to have any sort of predilection in the choice of his food. The Dutch travellers assert that he can devour not only glass, iron, and stones, but even burning coals, without testifying the smallest fear, or sustaining the least injury; and it is said that the passage of his food is performed so speedily that even eggs will pass unbroken. He is a native of some of the Indian islands. The eggs of the fernale are nearly fifteen inches in circumference, of a greenish colour. It has been said of the Cassowary that he has the head of a warrior, the eye of a lion, the armament of a porcupine, and the swiftness of a courser.

A Cassowary once kept in the menagerie of the $\mathrm{mu}$ seum at Paris, devoured every day between three and four pounds weight of bread, six or seven apples, and a bunch of carrots. In summer it drank about four pints of water in the day, and in winter somewhat more. It swallowed all its food without bruising it. This bird was sometimes ill-tempered and mischievous, and much irritated when any person approached it of a dirty or ragged appearance, or dressed in red clothes, and frequently attempted to strike at them by kicking forward with its feet. It has been known to leap out of its enclosure and to tear the legs of a man with its claws.

The Cassowary is very vigorous and powerful; its beak being, in proportion, much stronger than that of the ostrich, it has the means of defending itself with great advantage, and of easily pulling down and breaking in pieces almost any hard substance. It strikes in a very dangerous manner with its feet either behind or before, not unlike the kicking of a horse, at any object which offends it, and runs with surprising swiftness. 
The Emeu.

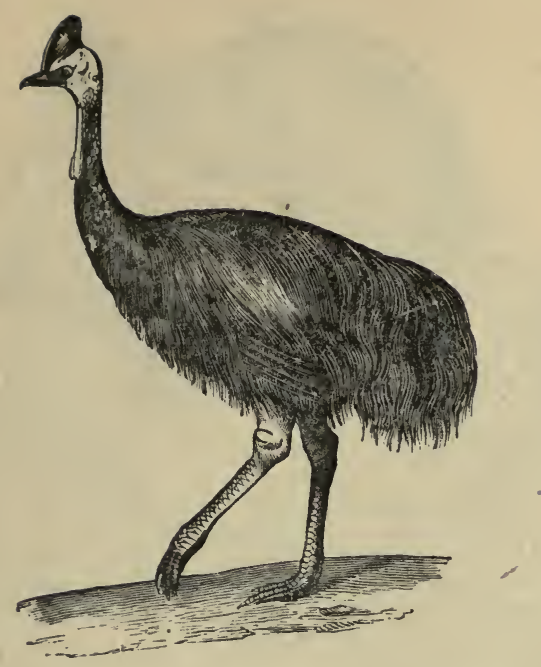

THE EMEU. (Dromaius Novce Hollandice.)

THe head of this bird is without any horny crest, and feathered, but the cheeks and throat are nearly naked. The general colour is a dull brown, mottled with a dingy grey, and the young are striped with black. In appearance it closely resembles the ostrich, next to which it is the tallest bird known, but is of a more thick-set and clumsy make, though at the same time very swift and strong, and able to make a formidable defence against its hunters and their dogs, by kicking in a very vigorous and dangerous manner. It is, however, very docile, and if taken young may be easily tamed. The flesh is considered excellent eating, and is said to possess a flavour something between a sucking-pig and a turkey. The only sound that this bind emits is a low drumming noise, produced by means of a valve attached to the lungs. The female Emeu lays her eggs in different places, but they are afterwards collected by the male, by rolling them to one place, when he sits on them. 


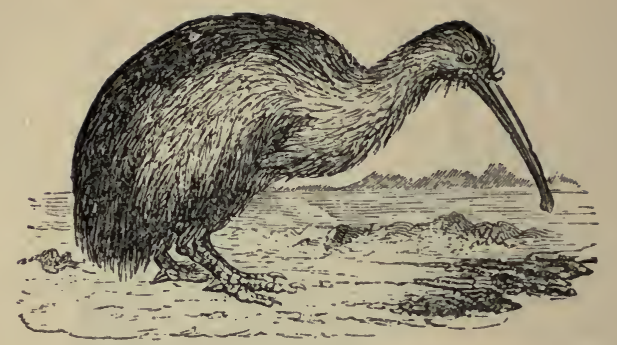

\section{THE APTERYX. (Apteryx Australis.)}

This curious bird, which has the shortest wings of any member of its class, is found only in New Zealand, where it is called Kivi-Kivi by the natives, in imitation of its cry. It is smaller than any of the species of wingless birds just described, and its legs are short and stout; it has three strong front toes on each foot, and a short hinder toe armed with a very strong claw. The body of the Apteryx is something like that of the cassowary in its form; the neck is rather long, and, like the head, clothed with feathers; but the most singular part of the bird is its bill, which is long, rather slender, and slightly curved, and has the nostrils situated quite at its tip. This curious structure of the bill is intended to enable the bird more readily to obtain the worms and insects upon which it feeds, and which it drags out of their holes in the ground. It runs quickly, but only at night, and when in motion it might easily be mistaken for a small dusky-brown quadruped. The plumage resembles that of the emeu in its texture, and the skins are highly esteemed by the New Zealanders, who use them for making cloaks.

Among the many curious characteristics of this bird is its habit of leaning, when at rest, upon the tip of its long bill. When hunted it scrapes a hole in the sand with its powerful feet, in which it hides; or it runs into some natural cavity, if there is any near, where access is difficult for its pursuers, and often makes a valiant defence. 


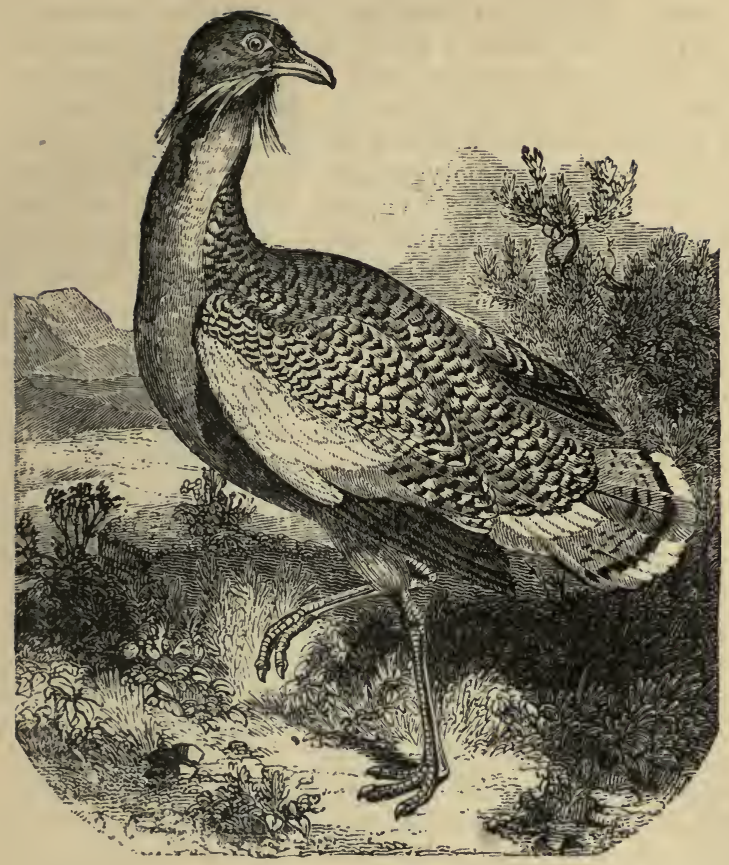

\section{THE BUSTARD, (Otis tarda,)}

Is a large and fine bird which was formerly common in some parts of England, but has now become so rare here that the capture of a specimen is looked upon as something remarkable. It is still abundant in some parts of the continent of Europe. The male Bustard measures nearly four feet in length, and has the head and neck greyish, the back buff or pale chestnut, with a great many black bars, and all the lower part of the body white. From each side of the chin there springs a tuft of slender feathers about seven inches in length, standing out like a pair of stiff moustaches. The female 
is a good deal smaller than the male, or about three feet in length; she is also distinguished from her partner by the want of the tufts on the chin, although in some cases these exist in the female, but shorter than in the male.

The Bustard feeds on green vegetables and insects, and are also said to kill and eat small quadrupeds and reptiles. They are polygamous, and when the female has laid her two or three eggs in a slight depression of the ground, and commenced the business of incubation, the male most ungallantly deserts her, and retires to take his ease in some neighbouring marsh. It was formerly supposed that the male Bustard paid so much attention to his mates as to provide them with water, which he was said to bring to them in a large pouch, capable of holding nearly a gallon, situated under his throat. It is true that the female is without this appendage; but modern naturalists all agree in stating that the male bird is never seen in company with the female after she has begun to sit. The use of this pouch is therefore still a subject of controversy.

The female lays her eggs among clover, or more frequently in corn-fields, the nest being merely a hollow scraped in the ground. The eggs are two, or sometimes three, in number, and their colour is a yellowish-brown, inclining to green.

A peculiarity of the Bustard, noticed by most naturalists, is the extreme rapidity with which they can run. They skim along the ground, raising the wings over the back in the same manner as the ostrich. It is said that in former times, when the breed was commoner, it was a practice to hunt the young birds, before they had acquired the power of flying, with greyhounds.

As an article of food the flesh of the Bustard has always been held in great estimation.

There are several other species peculiar both to Asia and Africa. 


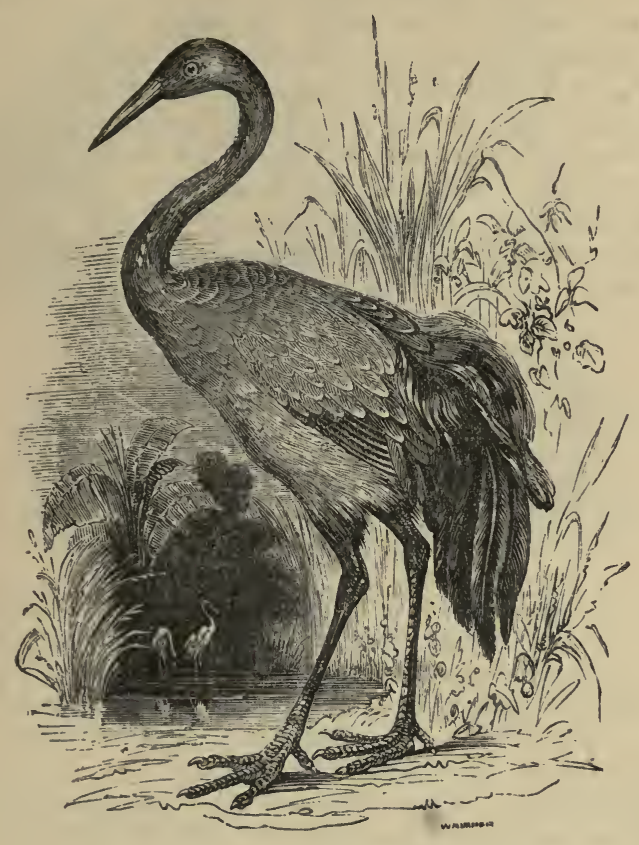

THE CRANE. (Grus cinerea.)

Cranes frequent marshy places, and live upon small fish and water-insects. Their long beaks enable them to search the water and mud for their prey, and their long necks prevent the necessity of their stooping to pick up from between their feet the objects of their search. The top of the head, the throat, and sides of the neck are of a blackish hue; the back, the wings, and the body are ash-coloured. The tertial feathers of the wings are very long, with loose webs, forming elegant plumes, which fall over the sides of the tail. They used to be common in the fen countries, Lincolnshire and Cambridgeshire, 
but are not now so frequently seen in England as formerly. In their flight, Cranes mount high in the air, but their voices can be heard even when the birds cease to be perceptible to the eye, and it is said that their sight is so keen that they discover at a great distance any field of corn or other food which they are fond of, and presently alight and enjoy it. These depredations they generally commit during the night, trampling down the ground as if it had been marched over by an army. They generally form themselves in the air in the shape of a wedge.

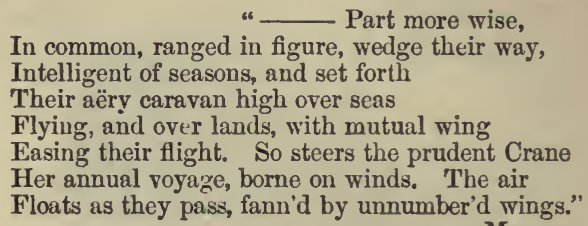

Mruton.

This bird lives to a considerable age, and as it is easily tamed, it has been ascertained that the Crane often reaches his fortieth year. Its nest is usually built amongst the reeds and sedges of a marsh, but sometimes upon a ruined building. The female lays two eggs, of a pale brown colour, with darker spots.

According to Kolben, they are often observed in large flocks on the marshes about the Cape of Good Hope. He says he never saw a flock of them on the ground that had not some placed apparently as sentinels, to keep a look out while the others are feeding, who on the approach of danger immediately give notice to the rest. These sentinels stand on one leg, and at intervals stretch out their necks, as if to observe that all is safe. On notice being given of danger, the whole flock are in an instant on the wing. Kolben also adds that in the night time each of the watching Cranes, which rest on their left legs, hold in their right claw a stone of considerable weight, in order that, if overcome by sleep, the falling of the stone may awaken them. 


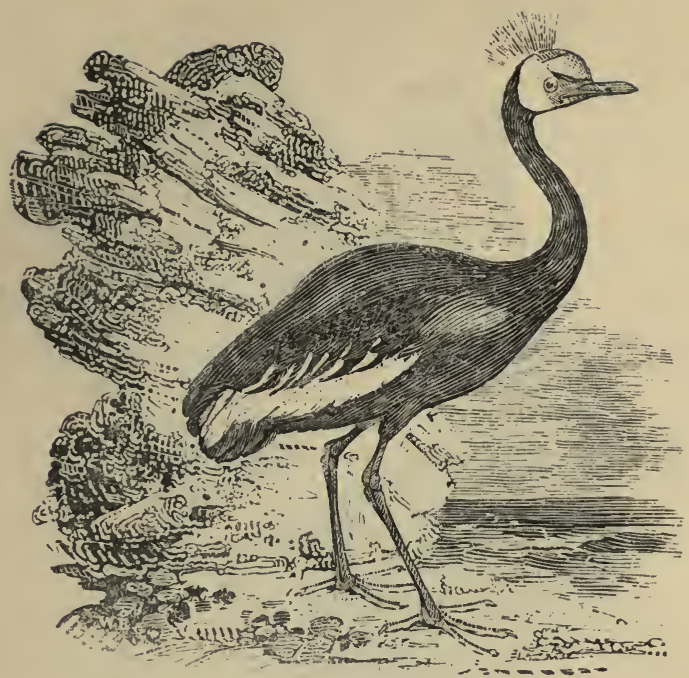

\section{THE BALEARIC CRANE, OR CROWNED}

DEMOISELLE, (Balearica pavonina,)

Is originally, as the name expresses, a native of Majorca and Minorca, in the Mediterranean sea, which were formerly called the Balearic Isles, but is chiefly found now in the Cape Verd Islands. The shape of its body is not unlike that of the common Crane, but it has a principal and distinctive mark on the head; which is, a tuft of hairs, or rather strong greyish bristles, standing out like rays in all directions, from which peculiarity this species takes its other name of the Crowned Heron. They roost and feed in the manner of peacocks.

The Demoiselle, or Numidian Crane (Anthropoides virgo), is remarkable for the grace and symmetry of its form, and the elegance of its deportment. It is rather larger than the species above described. and is a native of many parts of Africa. It frequents damp and marshy places, in search of small fishes, frogs, \&c., which are its favourite food. It is easily domesticated. 


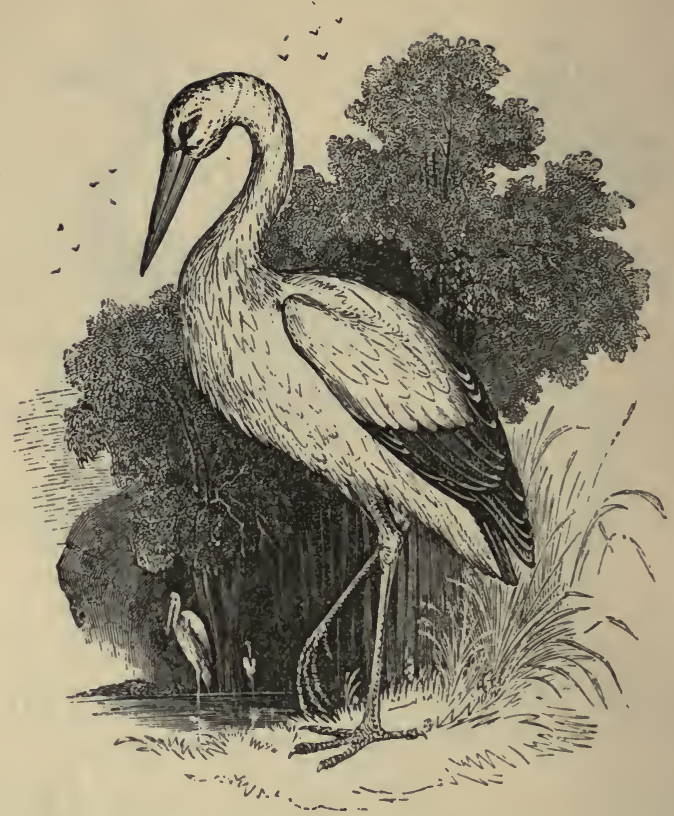

THE STORK. (Ciconia alba.)

THE neck, head, breast, and body of this bird are white, the rump and exterior feathers of the wings black; the eyelids naked; the tail white, and the legs long, slender, and of a red colour. Storks are birds of passage. When leaving Europe they assemble together on some particular night, and all take their flight at once. As they feed on frogs, lizards, serpents, and other noxious creatures, it is not to be expected that man should be inimical to them, and therefore they have been generally a favourite with the nations they risit. The Dutch have laws against destroying them: they are therefore very common in Holland, and build their nests and rear their young on the tops of houses and chimneys in the 
middle of its most frequented and populous cities, and may be seen by dozens familiarly walking about the markets, where they feed on the offal. In some places, the stork is supposed to be a herald of good fortune to the house on which it builds its nest, and the inhabitants place boxes on their roofs to induce the birds to take up their abode there.

The Stork much resembles the crane in its conformation, but appears somewhat more corpulent. 'The former lays four eggs, whereas the latter lays but two.

It is said that Storks visit Egypt in such abundance, that the fields and meadows are white with them. The Egyptians, however, are not displeased with the sight; as frogs are there generated in such numbers, that did not the Storks devour them, they would overrun everything. Between Belba and Gaza, the fields of Palestine are often rendered desert on account of the abundance of mice and rats; and were they not destroyed the inhabitants could have no harvest. The disposition of the Sturk is mild and placid; it is easily tamed, and may be trained to reside in gardens, which it will clear of insects and reptiles. It has a grave air, and a mournful aspect; yet, when roused by example, exhibits a certain degree of gaiety; for it joins in the frolics of children, hopping about and playing with them.

During their migrations, Storks are observed in vast quantities. Dr. Shaw saw three flights of them leaving Egypt, and passing over Mount Carmel, each of which appeared to be nearly half a mile in width; and be says they were three hours in passing over.

The Stork, like the ibis, was an object of worship among the ancients, and to kill them was a crime punishable with death. The Stork is remarkable for its great affection towards its young. 'This was remarkably evinced during the great conflagration of Delft, in Holland, during which a female stork was noticed using every endeavour to carry off her young family, and continuing this labour of love until the smoke and flames prevented her own escape, and she perished with her brood. 


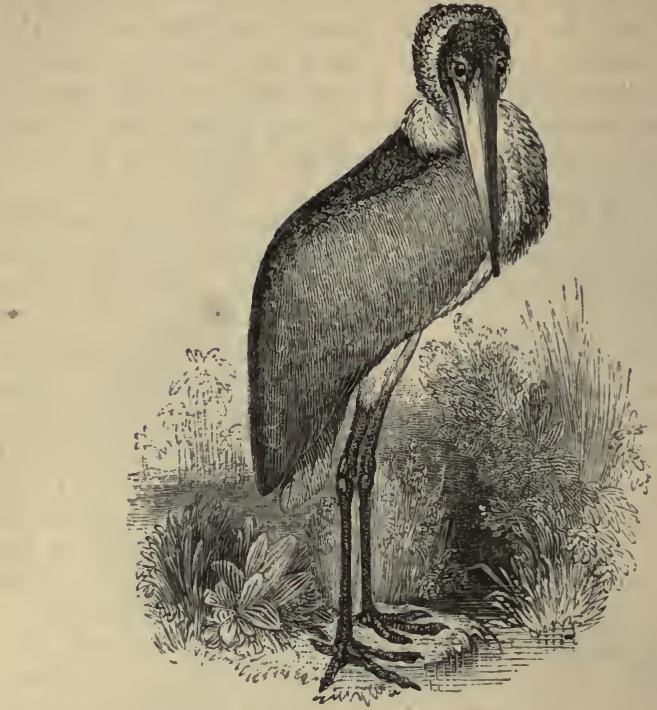

TIIE ADJUTANT, (Leptoptilus argala, )

Also called the Gigantic Crane, is a bird of the stork kind, and a native of India, and other warm countries. The head and neck are bare of feathers, as in the ostrich; the former looking as if made of wood; the latter of a flesh-colour. The coverts of the wings and the back are black, with a bluish cast; the under part of the body whitish; the legs are long, without feathers, and of a greyish hue, as are the thighs, which seem to be as slender as the leg. The bill is of enormous size, and the bird is fond of clatting the two mandibles together. Under the chin, there is a kind of bag or pouch which hangs down in front of the neck, like the dewlap of a cow; in this the Adjutant stores away any provisions that may fall in his way, after his immediate wants are satisfied. $\mathrm{He}$ is a most voracious bird, and derours every kind of food, and as he has no objection to carrion, 
his presence is encouraged in towns, where he assists the vultures, crows, dogs, and jackals, in performing the duties of scavengers. Indeed his rapacity is so great that he swallows such innutritious substances as bone with such engerness and relish as to have received the name of "Bone-eater," or "Bone-taker." When he comes about the houses he requires to be carefully watched, as his power of swallowing is so great that a fowl, a rabbit, or even a leg of mutton, is dispused of at a single mouthful. Sir E. Horne states that in the stomach of an Adjutant were found a tortoise nearly a foot long, and a large black cat; from which we may see that the Adjutant is by no means squeamish in his diet.

The Adjutant is indeed a very gigantic bird. Its wings often measure fourteen or fifteen feet from tip to tip, and it is five feet high when it stands erect.

Dr. Latham, in his "General History of Birds," gives some very interesting information about the habits of this bird. "One of them, a young bird about five feet high, was brought up tame, and presented to the chief of the Bananas, where M. Speakman lived; and being accustomed to be fed in the great hall, soon became familiar, daily attending that place at diuner-time, placing itself behind its master's chair frequently before the guests entered. The servants were obliged to watch narrowly, and to defend the provisions with switches; but, notwithstanding, it would frequently seize something or other, and even purloined a whole boiled fowl, which it swallowed in an instant. Its courage is not equal to its voracity, for a child of eight or ten years old soon puts it to flight with a switch. Everything is swallowed whole, and so accommodating is its throut that not only an animal as big as a cat is gulped down, but a shin of beef broken asunder serves it but for two morsels."

Another species of Adjutant (Leptoptilus marabou) is found in tropical Africa. It is even uglier than the Indian bird, which has not much beauty to boast of, but is valuable not only as a scavenger, but from its furnishing thosè beantiful plumes called marabout feathers, which are so much used for ladies' head-dresses. 


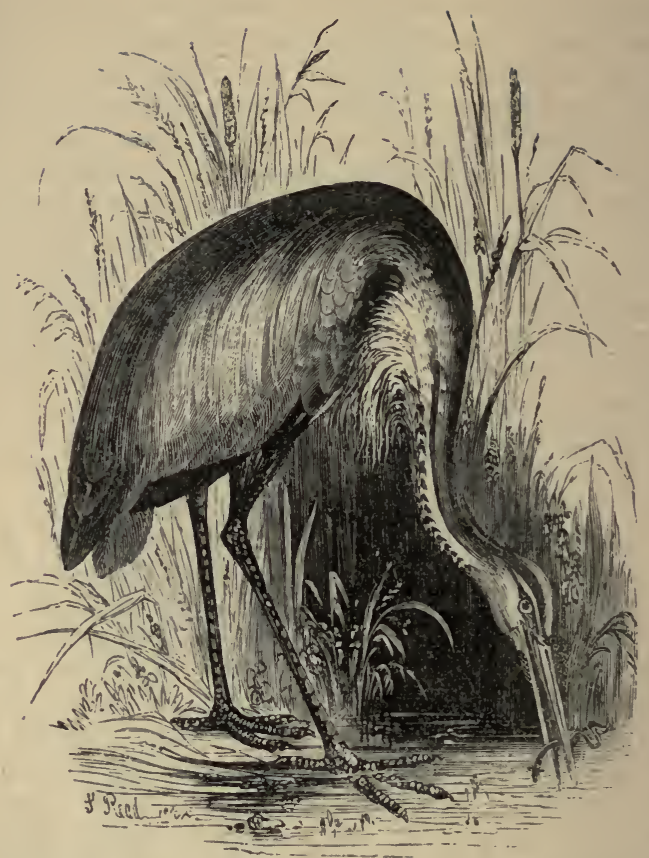

THE COMMON HERON. (Ardea cinerea.)

'T'He habits of the Heron are peculiar. Perched on a stone, or the stump of a tree, by the solitary current of a brook, his neck and long beak half-buried between his shoulders, he will wait the whole day long, patient and unmoved, for the passing of a small fish, or the hopping of a frog; but his appetite is insatiable.

This bird is about four feet long from the tip of the bill to the end of the claws; to the end of the tail about thirty-eight inches; its breadth, when the wings are extended, is about five feet. 'The malo is distinguished hy a crest or tuft of black feathers hanging from the hinder part of his head, which in chivalrous times was 
of great value, and held as a peculiar mark of distinction when worn above the plume of ostrich feathers.

Virgil places the Heron among the birds that are affected by and foretell the approaching storm:

"When watchful Herons leave their watery stand, And mounting upward with erected flight, Gain on the skies, and soar above the sight."

Dryden.

The Heron, though living chiefly in the vicinity of marshes and lakes, forms its nest on the tops of the loftiest trees. It resembles the rook in its habits: a great number of Herons living together in what is called a Heronry, as rooks do in a rookery. The female lays four large eggs, of a pale green colour; the natural term of this bird's life is said to exceed sixty year's.

In England, Herons were formerly ranked among the royal game, and protected as such by the laws; and when falconry was in fashion, the pursuit of the Heron was a favourite amusement.

" - _ _ - Now, like the wearied stag;

That stands at bay, the Hern provokes their rage;

Close by his languid wing in downy plumes

Covers his fatal beak, and cautious hides

The well-dissembled fraud. The falcon darts

Like lightning from above, and in her breast

Receives the latent death: down plumb she falls,

Bounding from earth, and with her trickling gore

Defiles her gaudy plumage. See, alas!

The falconer in despair, his favourite bird

Dead at his feet: as of his dearest friend,

He weeps her fate; he meditates revenge,

He storms, he foams, he gives a loose to rage;

Nor wants he long the means; the Hern fatigued,

Borne down by numbers, yields, and prone on earth

He drops; his cruel fons wheeling around

Insult at will."

SOMERVille.

It is extremely dangerous to go near a wounded Heron, and the utmost caution is necessary in doing so. Though apparently almost dead, he will yet dart at his enemy's face, and sometimes inflict a most severe wound. 


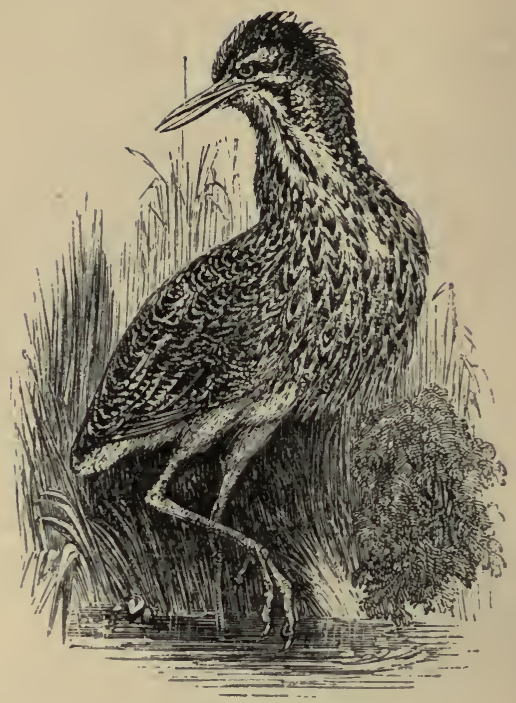

'THE BITTERN, (Botaurus stellaris,)

Is not quite so large as the common heron; its head is small, narrow, and compressed at the sides. The crown is black, the throat and sides of the neck red, with narrow black lines, and the back of a pale red, mixed with yellow. The claws are long and slender, the inside of the middle one being serrated, the better to enable it to hold its prey. The bill is about four inches in length. 'The most remarkable character in this bird is the hollow and yet loud rumbling of his voice; his bellowing is heard at the distance of a mile, at the time of sunset, and it is hardly possible to conceive at first how such a body of sound, resembling the lowing of an ox, can be produced by a bird comparatively so small. The booming, noise was formerly believed to be made while the bird plunged its bill into the mud; hence Thomson : 
" - So that scarce

The Bittern knows his time, with bill ingulf'd

To shake the sounding marsh."

And Southey also describes the peculiar noise of this bird in his poern of Thalaba :

"And when at evening, $o$ 'er the swampy plain,

The Bittern's boom came far,

Distinct in darkness seen-

Above the low horizon's lingering light,

Rose the near ruins of old Babylon."

Sometimes in the evening the Bittern soars on a sudden in a straight, or, at other times, in a spiral line, so high in the air, that it ceases to be perceptible to the eye. When attacked by the buzzard, or other birds of prey, it defends itself with great courage, and generally beats off such assailants; neither does it betray any symptoms of fear when wounded by the sportsman, but eyes him with a keen, undaunted look; and, when driven to extremity, will attack him with the utmost vigour, wounding his legs, or aiming at his eyes with its sharp and piercing bill. It was formerly held in much estimation at the tables of the great, and is again recovering its credit as a fashionable dish. The flesh is considered delicious. In autumn it changes its abode, always commencing its journey at sunset. Its precautions for concealment and security seem directed with great care and circumspection. It usually sits in the reeds with its head erect; and thus, from its great length of neck, sees over their tops, without itself being perceived by the sportsman. The principal food of these birds, during summer, consists of fish and frogs; but in autumn they resort to the woods in pursuit of mice, which they seize with great dexterity, and always swallow whole. About this season they usually become very fat. 


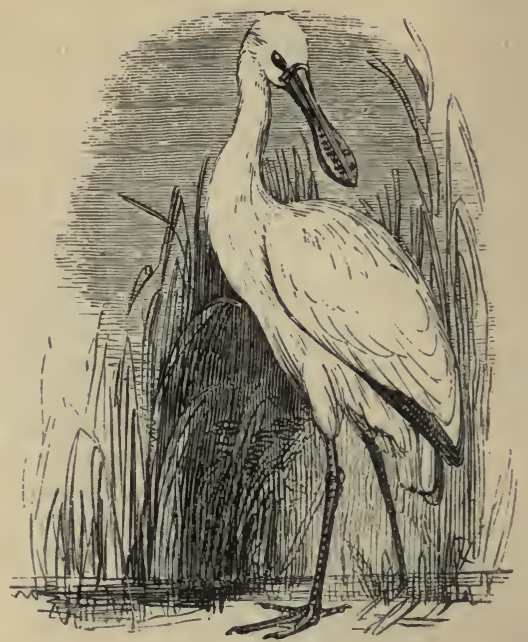

\section{THE SPOONBILL, (Platalea leucorodia,)}

Is a large bird; the colour of the whole body is white, and the resemblance of the bill to a spoon has caused the denomination of the bird. In some specimens the plumage inclines from white to pink colour. On the hind part of the head is a beantiful white crest, reclining backward. The legs and feet are black. The wisdom of Providence is most conspicuous in the conformation of the bill, which is entirely adapted to the habits and manner of feeding of these birds: the frogs and fishes, which constitute the principal food of the Spoonbill, may often escape the thin and narrow beak of the heron and other birds, but the mandibles of this bird are so large at the end, that the prey cannot slip aside. Like rooks and herons, Spoonbills build their nests on the tops of high trees, and lay three or four eggs, which are white, sprinkled with pale red, and the size of those of a hen. These birds are very noisy 
during the breeding season. The Spoonbill migrates northward in the summer, and returns to southern climes on the approach of winter; and is found in all the intermediate low countries between the Faroe Isles and the Cape of Good Hope.

The American or Roseate Spoonbill (Platalea Ajaja) is very beautiful. Its colour is white, tinged with rose, which deepens in the wings and tail into the richest carmine. The feet are half-rwebbed, and the bird is generally found on the sea-coast, where it wades into the sea in quest of the small shell-fish of different kinds, on which it feeds.

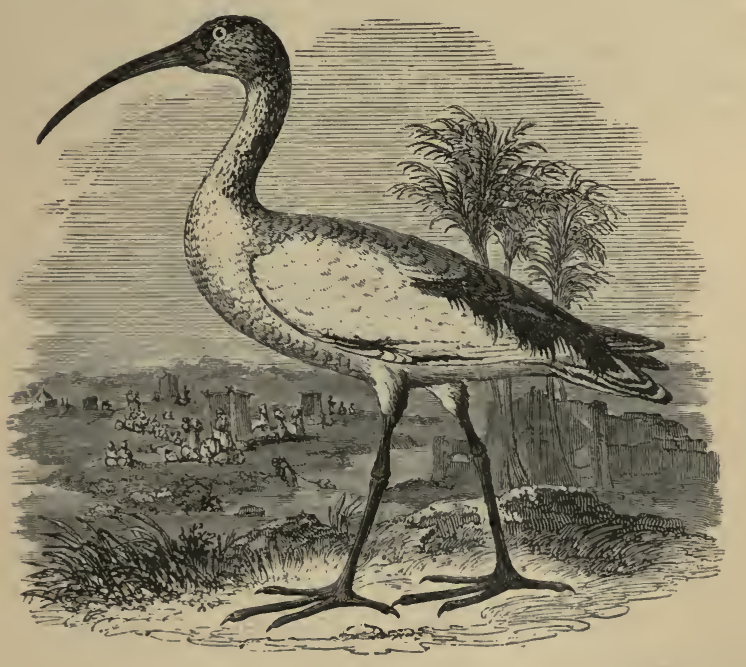

THE IBIS. (Ibis religiosa.)

'THE IBIS was regarded as a sacred hird by the ancient Egyptians, who used to have these birds walking about in their temples, and embalmed their bodies after death with as much care as those of their priests and kings. The cause of this veneration is not clearly ascertained, some authors supposing it to be due to the services 
rendered by the bird in destroying serpents and other noxious creatures; others to a fanciful resemblance between the bird and one of the moon's phases; and others, again, to the arrival of the birds in Egypt at or about the period of the annual inundation of the Nile. The sacred Ibis has a long, stuut, curved black bill; the head and neck are black and naked, and the plumage is white, with the tips of the wings black. Another species, the Glossy Ibis (Ibis falcinellus), shared the veneration of the Egyptians with the Sacred Ibis; it has a more slender bill than the Sacred Ibis, and its plumage, which is beautifully glossy, is dark green above and reddish-brown beneath. 'This bird is common in the south of Europe, and specimens have been shot in Eng"land. The Scarlet Ibis (Ibis rubra) is a beautiful species, which adorns the banks of the great rivers of South America, in company with the Roseate Spoonbill.

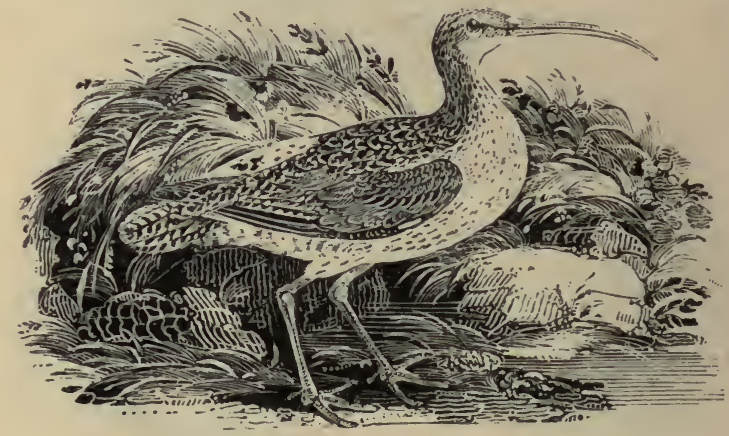

\section{THE CURLEW. (Numenius arquatus.)}

"Soothed by the murmurs of the sea-beat shore, His dun-grey plumage floating to the gale, 'The Curlew blends his melancholy wail With those hoarse sounds the rushing waters rour." Miss Williams.

"Wild as the scream of the Curlew, From rock to rock the signal flew."

Sir Walter Scotr.

THE CURLew is a large bird, weighing about twenty-four 
ounces: and is found in winter on the sea-shore on all sides of England. The middle parts of the feathers of the head, neck, and back are black, the borders or outsides ash-coloured, with a mixture of red; and the lower part of the body white. The beak has a regular curve downward, and is soft at the point. This bird's flesh may challenge for flavour and delicacy that of any other water-fowl, and the people of Suffolk say proverbially:

"A Curlew, be she white, be she black, She earries twelve pence on her back :"

but it must be confessed that the quality and goodness of the flesh of Curlews depend on their manner of feeding, and the season in which they are caught. When they dwell on the sea-shore, they acquire a kind of rankness, which is so strong, that, unless they are basted on the spit with vinegar, they are not' agreeable eating.

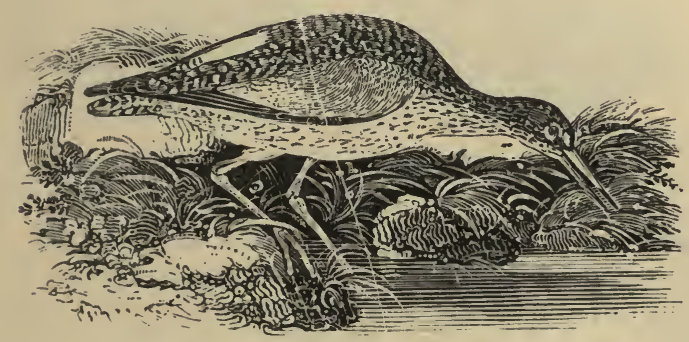

\section{THE REDSHANK. (Totanus calidris.)}

TuIs bird has received its name from the colour of its legs, which are of a crimson red. In size it is between the lapwing and the snipe, and is sometimes called the Pool Snipe. The head and back are of a dusky ashcolour, spotted with black, the throat party-coloured black and white, the black being drawn down along the feathers. The breast is whiter, with fewer spots. The Redshank delights in the fen countries, and in wet and marshy grounds, where it breeds and rears its young. 
The female lays four whitish eggs, with olive-coloured dashes, and marked with irregular spots of black. Pennant and Latham say, that it flies round its nest when disturbed, making a noise like a lapwing. It is not so common on the sea-shore as several others of its kindred. We must here observe, that this bird has often been mistaken for others. The fact is, that several birds changing their plumage, and increasing or diminishing their size according to their age, the season of the year, and the climate they live in, set all nomenclators at defiance, and confound all classifications.

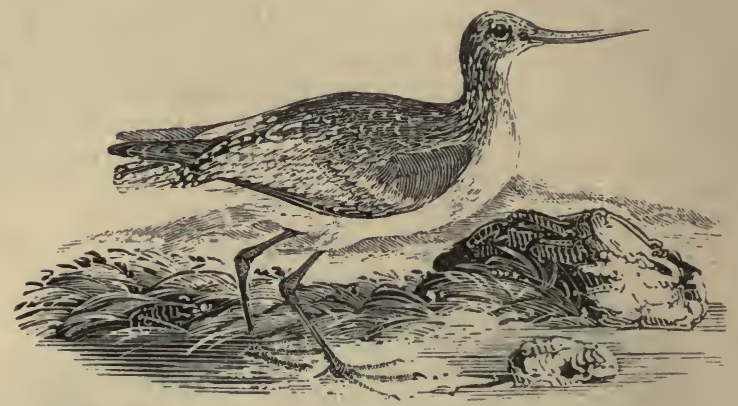

THE GODWIT, (Limosa oegocephala,)

Is met with in various parts of Great Britain, and is rather larger than the woodcock, which it much resenibles in appearance. In spring and summer it resides in the fens and marshes, where it rears its young, and feeds on small worms and insects; but in winter it seeks the salt marshes and the sea-shore, where it feeds upon the shell-fish and marine animals left by the retiring tide. A peculiarity belonging to this bird is the shape of its bill, which is a little turned upwards. The head, neck, and back are of a reddish brown; the under part of the body white; the legs dusky, and sometimes black.

The Godwit is much esteemed by epicures as a great delicacy, and sells very high. It is caught in nets, to which it is allured by a stale or stuffed bird, in the same manner and in the same season as the ruffs and reeves. 


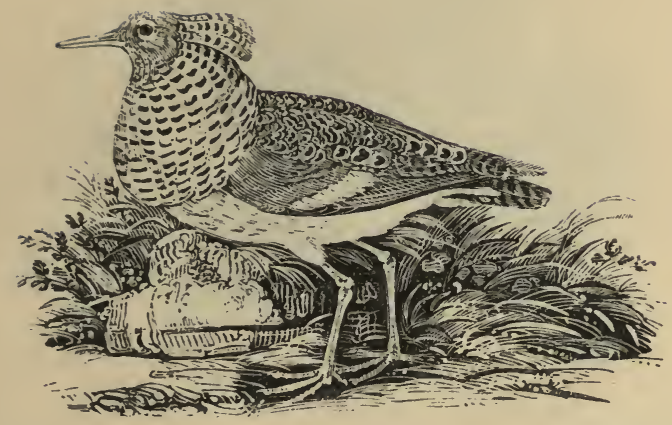

THE RUFF AND REEVE. (Machetes pugnax.)

IT is curious to see, in our observation of natural objects, how the creative power of Providence seems to have tried all forms and shapes in the composition of species. In the cock bird of this species a circle or collar of long feathers, somewhat resembling a ruff, encompasses the neck under the head, whence the bird has received the name of Ruff. It is about a foot in length, with a bill about an inch long. There is a wonderful and almost infinite variety in the colours of the feathers of the males ; so that in spring there can scarcely be found two exactly alike; but after moulting they become all alike again.

The males are sometimes called Fighters, on account of their quarrelsome disposition. It is a bird of passage, and arrives in the fens of Lincolnshire, and other similar places, in the spring. Mr. Pennant tells us, that in the course of a single morning more than six dozen have been caught in one net, and that a fowler has been known to catch between forty and fifty dozen in a season. 


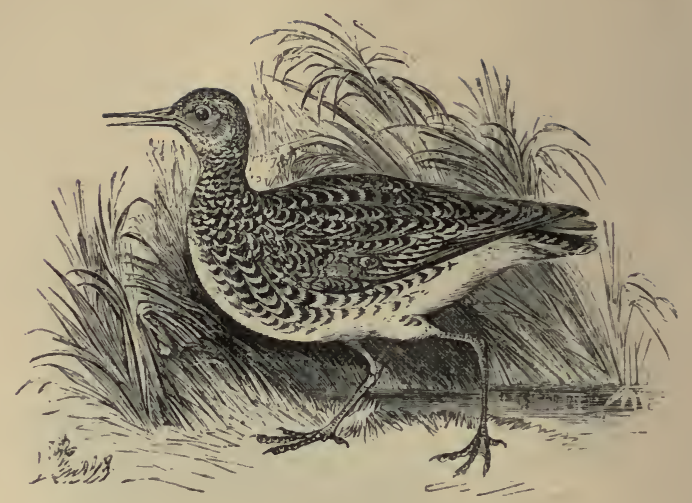

The female is called a Reeve, and its flesh is thought a great delicacy for the table. They are smaller than the cocks, and their feathers undergo no change. The Ruff and Reeve are taken in nets. They used to be seen in vast numbers in many parts of England, especially in the Isle of Ely and the Lincolnshire fens. The improvements in drainage and cultivation that have been made during the present century have deprived these birds of their accustomed haunts, and they are no longer common. A writer of the last century said he had seen the ground so covered with the nests and eggs of Plovers and Reeves that " one could scarce take a step without stepping on them." They are now most common on the shores of southern Scotland and of Northumberland.

Reeves are fattened for the table by feeding them on boiled rice or wheat, bread and milk, hemp seed, \&c. They are obliged to be kept in a dark room during the process, as the least gleam of light is the signal for a furious battle. 


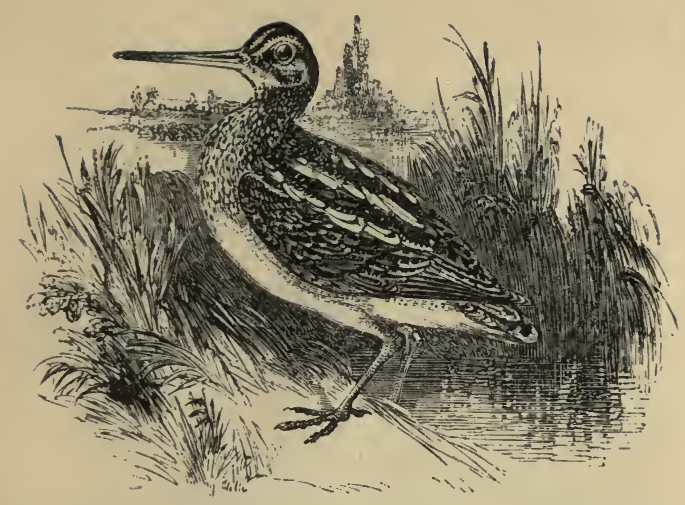

\section{THE SNIPE. (Scolopax gallinago.)}

"The Snipe flies scrtaming from the marshy verge, And towers in airy eireles o'er the wood; Still heard at intervals; and oft returns, And stoops as bent to alight; then wheels aloft With sudden fear, and sereams and stoops again, Her favourite glade reluetant to forsake." Gisborne.

Thk Sripe weighs about four ounces. A pale red line divides the head longways; the chin under the bill is white; the neck is a mixture of brown and red; the lower part of the body is almost all white. The back and wings are of a dusky colour. The flesh is tender, sweet, and in flavour ranks next to that of the woodcock. Snipes feed especially upon small red worms, and insects, which they find in muddy and swampy places, on the banks of rivulets and brooks, and on the clayey margin of ponds. It is said that Snipes remain with us all the summer, and build in moors and marshes, laying four or five eggs; but most of them are migratory, and, when forced by severe frosts to sheltered springs, are often seen in large flights. Mr. Daniel states that, about thirty years ago, Snipes were so abundant in the fens of Cambridgeshire, that as many were taken in Milton fen, by means of a lark-net, in one night, and by a single man, as could be contained in a small hamper. 


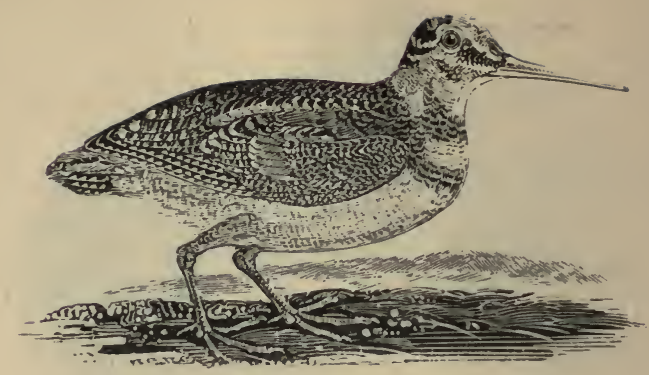

'THE WOODCOCK, (Scolopax rusticola,)

Is somewhat less than the partridge. The upper side of the body is party-coloured of red, black, and grey, and very beautiful. From the bill almost to the middle of the head it is of a reddish ash-coluur. The lower part of the body is grey, with transverse brown lines; under the tail the colour is somewhat yellowish; the chin is white, with a tincture of yellow. Woodcucks are migratory birds, coming over into Britain in autumn, and departing again in the beginning of spring; they pair before they go, and are seen flying in braces.

The colours of this timid bird render it difficult to discern him among the withered stalks and leaves of fern, sticks, moss, and grass, which form the background of the scenery, by which he is sheltered in his moist and solitary retreats. By habit only is the sportsman enabled to discover him, and his leading marks are the full eye and glossy silver white-tipped tail of the bird. The flesh is held in high estimation, and hence he is eagerly sought after. It is hardly necessary to observe that in dressing a Woodcock for the spit the entrails are not drawn, but are allowed to drop upon slices of toasted bread, and are relished as a delicious kind of sauce. By some late observations, it appears that several individuals of the species remain with us the whole year. They frequent especially wet and swampy woods, the thick hedges near rivulets, and places affording them 


\section{The Knot.}

their allotted food, which consists of very small insects found in the moist ground.

"'The Woodcock's early visit and abode

Of long cuntiuuance, in our temperate clime,

Foretell a liberal harvest."

Philips.

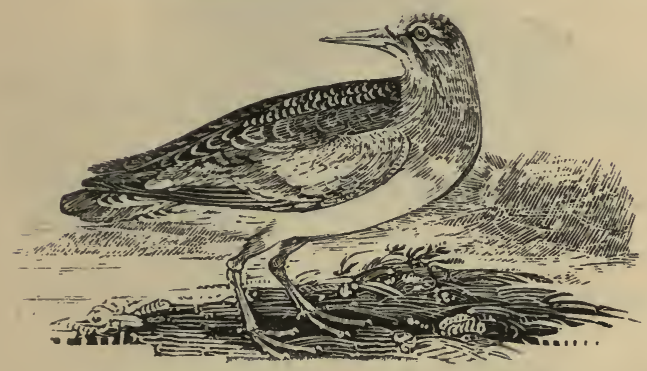

'IHE KNOT, (Tringa Canutus,)

Is a small bird, whose head and back are of a dusky ashcolour, or dark grey ; while the lower part of the body is pure white, or white varied by black lines. The sides under the wings are spotted with brown. The bird weighs about four ounces and a half, and generally makes its appearance in Lincolnshire in the beginning of winter, and abides there for two or three months, after which they fly off in flocks. They are caught in great numbers by nets, into which they are decoyed by carved wooden figures, painted to represent themselves, and placed within them, much in the same way as the ruff. When the knot is fat, its flesh is considered excellent food. It is also fattened for sale, and then considered equal to the ruff in flavour. The season for taking it is from August to November, after which the frost compels it to disappear. This bird is said to have been a favourite dish with Canute the Great; and Camden observes that its name is derived from his-Knute, or Knout, as he was called-which, in process of time, has been changed to Knot. 


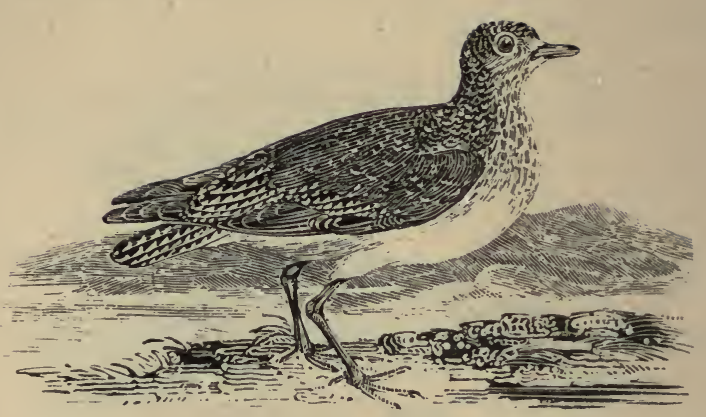

THE GREY PLOVER, (Squatarola cinerea,)

Is about twelve inches long and twenty-four across the wings: the head, back, and coverts of the wings are black, with tips of a greenish white; the chin white: the throat spotted with brown or dusky spots; the breast and thighs white. The flavour of the flesh, when the bird is caught in the proper season, is delicate and savory; at other times it is hard, and has a strong and rank taste. 'This bird is generally found in small packs, and is not nearly so common as the beautiful Golden Plover. The male becomes entirely black on the lower surface in the spring, or black interspersed with patches and spots of white.

The Grey Plover is found in the northern parts of Europe, and, it is said, breeds in Egypt, Java, and Japan. Like the Ruff, it is an exceedingly quarrelsome bird, and fights fiercely in the spring. 'The young. when hatched, are covered with a thick, soft down, and immediately begin to follow their parents about and searck for food. 


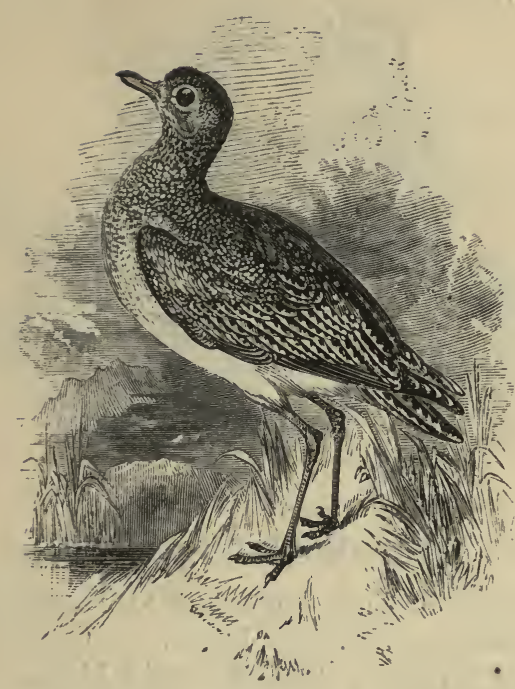

\section{THE GOLDEN PLOVER, (Charadrius pluvialis,)}

Is about the size of the former. The colour of the whole upper side is black, thick set with yellowish green spots ; the breast brown, with spots as on the back; the body is white. The male of this species is also black beneath in the spring. The flesh is sweet and tender, and therefore esteemed a choice dish in this and other countries.

The Golden Plover feeds principally during the night, and during the day time may be seen sitting or standing on the ground, asleep. The parent birds are very careful in guarding their young. When any intruder approaches their nest, they use all sorts of stratagems to divert his attention.

The "Plover eggss" frequently seen at the tables of the opulent and luxurious, are not those of the Plover, but of the Lapwing. 


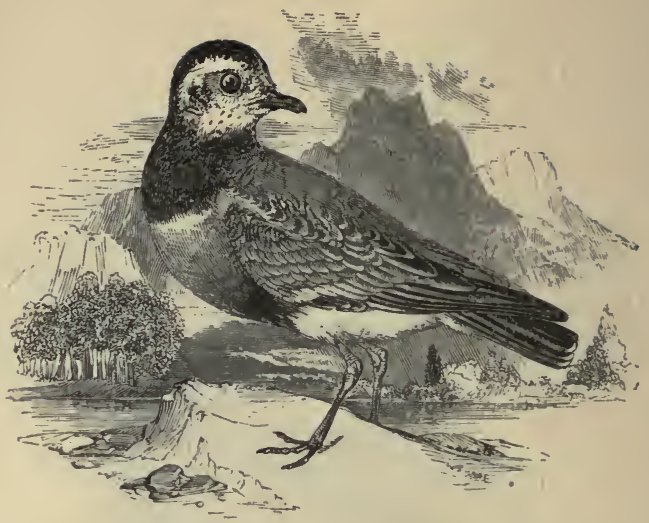

\section{THE DOTTREL, (Charadrius morinellus,)}

Is proverbially accounted a foolish bird, yet why so it is hardly possible to say. Its length is about ten inches; the bill is not quite an inch long, and is black. The forehead is mottled with brown and grey; the top of the head is black; and over each eye there is an arched line of white. The back and wings are a light brown; the breast is a pale dull orange; the middle of the body is black, and the rest and the thighs are of a reddish white. The tail is brown. black towards the end, and tipped with white. This bird is migratory, and makes its appearance in Lircolnshire, Cambridgeshire, and Derbyshire in April, but soon leaves those counties and passes on towards the north, breeding in the mountains of the north of England and Scotland. In A pril, and sometimes in September, Dottrels are seen in Wiltshire and Berkshire. They are generally caught, like other birds, by night; when, dazzled by the light of a terch, they are at a loss to know where to fly for safety, the whole place being in darkness, and generally select the very spot which they should avoid. Many ridiculous stories have been propagated about the gestures of this bird, and its 
endeavouring to imitate the actions of the fowler, and thereby falling into the snare laid for him; but they ought to be entirely disbelieved.

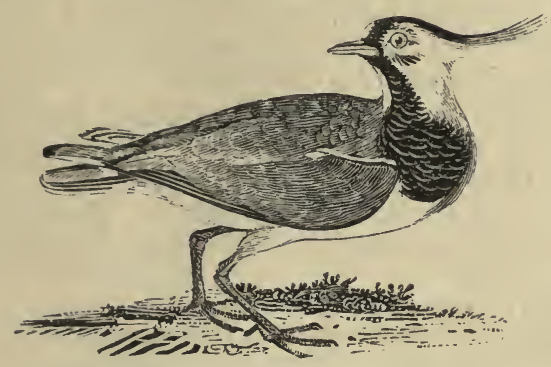

THE LAPWING, OR PEEWIT.

(Vanellus cristatus.)

THIs well-known bird is found in nearly all countries, and is of the size of a common pigeon. 'The female lay's four or five eggs, of a yellow colour, varied all over with large black spots and strokes. Lapwings build their nests on the ground in the middle of some field or heath, open and exposed to view, laying only some few straws under the eggs: so soon as the young are hatched, they instantly forsake the nest, running away with the shell on their back, and following the mother, only covered with a kind of down, like young ducks. The parents have been impressed by nature with the most attentive love and care for their offspring; for if the fowler, or any other enemy, should come near the nest, the female, panting with fear, lessens her call to make her enemies believe that she is much further off, and thereby deceives those that search for her brood; she also sumetimes pretends to be wounded, and utters a faint cry as she limps away, to lead the fowler from her nest. This bird is really beautiful, although it does not exhibit that gaudiness of colours of which other species of the feathered tribe can boast: it weighs about half-a-pound. The head, and the crest which elegantly adorns it, is black; 
this crest, composed of unwebbed feathers, is about four inches in length. 'The back is of a dark green, glossed with blue shades; the throat is black; the hinder part of the neck and the breast are white. The Lapwing, when in search of food, stamps with his feet upon the ground, and when the earth-worms, alarmed at the noise, appear, he seizes and devours them. His voice, on the swampy places along the sea-shores, heard at night, resembles the sound of peewit, or teewit, and hence his name in several parts of Great Britain; he is also called the Great Plover by several ornithologists. This bird is one of those who attract the fowler's attention in winter:

"With slaughtering gun th' unwearied fowler roves,

When frosts have whiten'd all the naked groves;

Where doves in flocks the leafless trees o'ershade,

And lonely woodeocks haunt the watery glade.

He litts his tube, and levels with lis eye;

Straight a short thunder breaks the frozen sky:

Oft, as in airy rings they skim the heath,

The clamorous Lapwings feel the leaden death :

Oft, as the mounting larks their notes prepare,

They fall, and leave their little lives in air."

Pope.

The following anecdote, from Bewick's " History of Birds," exhibits the domestic nature of the Lapwing, as well as the art with which it conciliates the regard of animals materially differing from itself, and generally considered as hostile to every species of the feathered tribe. 'T'wo Lapwings were given to a clergyman, who put them into his garden; one of them soon died, but the other continued to pick up such food as the place afforded, till winter deprived it of its usual supply. Necessity soon compelled it to draw nearer to the house, by which it gradually became familiarised to occasional interruptions from the family. At length one of the servants, when she had occasion to go into the back kitchen with a lirht, observed that the Lapwing always uttered his cry of "pee-wit," to obtain admittance. The bird soon grew more familiar; as the winter advanced, he approached as far as the kitchen, but with much caution, as that part of the house was generally occupied by a dog and cat, whose friendship, however, the Lapwing at 
length conciliated so entirely, that it was his regular custom to resort to the fireside as soon as it grew dark, and spend the evening and night with his two associates, sitting close by them, and partaking of the comforts of a warm hearth. As soon as spring appeared, he discontinued his visits to the house, and betook himself to the garden; but, on the approach of winter, he had recourse to his old shelter and friends, who received him very cordially. Security was productive of insolence; what was at first obtained with caution, was afterwards taken without reserve; he frequently amused himself with washing in the bowl which was set for the dog to drink out of; and while he was thus employed, he showed marks of the greatest indignation if either of his companions presumed to interrupt him. He died in the asylum he bad thus chosen, being choked with something that he had picked up from the floor.

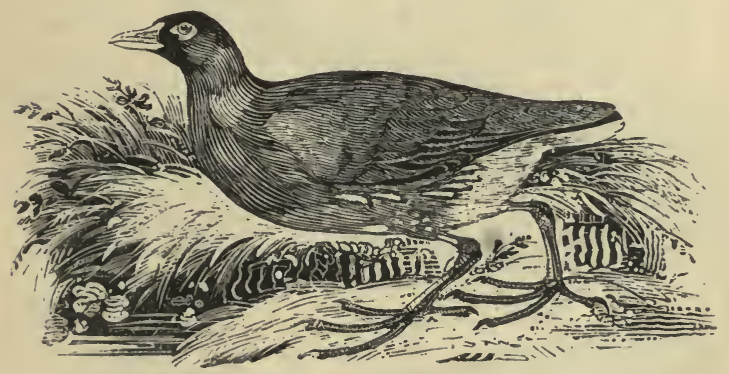

THE WATER-HEN, (Gallinula chloropus,)

Is also called the Moor-Hen, or Moor-Coot, and the Gallinule. The breast is of a lead-colour, the lower part of the body inclining to ash-colour, and the back dark olive brown. As she swims or walks, she often flirts up her tail. Water-hens feed upon aquatic plants and roots, and upon the small insects which adhere to them; they grow fat about the latter end of September, and their flesh is then considered nearly equal to that of the teal; 
yet it can seldom be entirely deprived of its fishy taste. 'They build their nests amongst reeds, long grass, roots, and stumps by the water-side, breeding twice or thrice in the course of a summer; the eggs are white, with a tint of green, dashed with brown spots.

There are very few countries in the world where these birds are not to be found. They generally prefer the cold mountainous regions in summer, and lower and warmer situations during winter.

"The fish are leaping, and the Water-hen Dives up and down. A storm is coming on."

Schiller. Williay Tell.

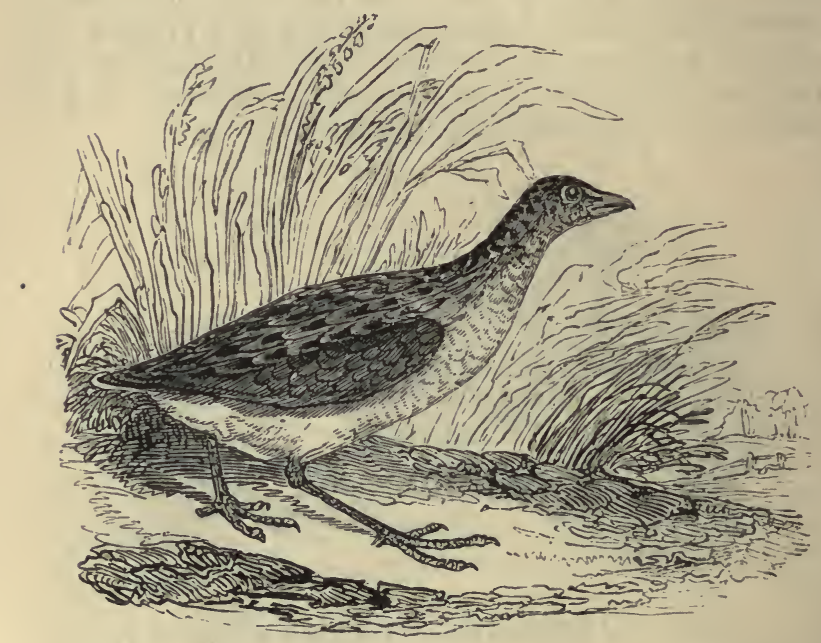

THE CORN-CRAKE, OR LAND-RAIL,

(Ortygometra crex,)

Is a migratory bird, appearing in England in April, and departing in October. At the time of its arrival it is very lean, but becomes excessively fat before it quits the island. Their favourite haunts are cold and humid upland districts, corn-fields in the vicinity of water, and 
marshy grass-lands. Their ery is a peculiar roll of short notes, all in the same key and of the same length. 'The sound, crec, crec, crec, has been compared to the noise made by drawing the finger along the teeth of a comb. The legs of the Corn-Crake are unusually long for the size of the bird, and hang down while it is on the wing. Its flesh is greatly esteemed for its delicate flavour. This bird is never seen on the wing in this country, and is extremely difficult to capture; they cannot be made to rise like partridges and many other birds, nor is it of much use to invade their cover. They glide through the corn, without the least perceptible rustle, and with wonderful rapidity, considering the size of the bird, and if the sportsman follows in the direction of the sound, it ceases for a while, and then, perhaps, is heard far in the rear; if he follows it again, it is not long before the sound is heard setting in its former or some other direction.

It is said by some writers that the Corn-Crake is a sort of natural ventriloquist, and can make his note appear to proceed from quite another direction than the spot in which he lies hid. It is probable, however, that the delusion arises from the astonishing swiftness with which the bird passes through the covers, where it is usually found. And as they can never be made to rise, the observer has very seldom the means of deciding whether the bird was in the place its cry seemed to proceed from or not.

The nest is made in a hole in the ground, and is lined with dead leaves, moss, and other soft substances. There are generally ten, twelve, or fourteen eggs. The peculiar ery by which the bird is recognised is only uttered during the period of incubation.

Corn-Crakes are occasionally found to have a great fondness for water. An anecdote is related by Craven, in his "Young Sportsman's Manual," of a young bird of this species, in the possession of a Mr. Jervis, which had a remarkable partiality for water, in which it would dive and splash, as if unused to any other element. If the habits of this bird could be watched more closely, perhaps we should find that this fondness for water is not uncommon in its wild state. 


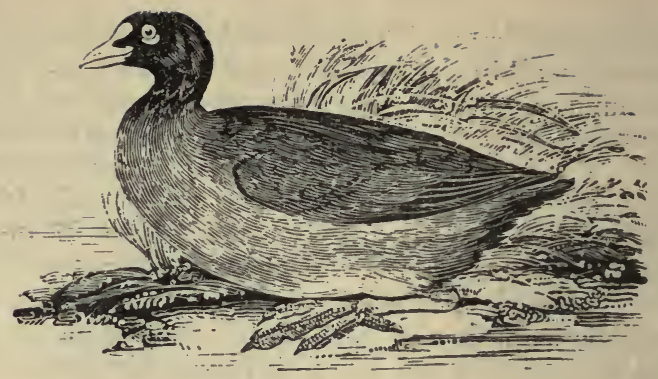

THE COOT. (Fulica atra.)

THIs bird has so many traits in its character, and so many features in its general appearance like the rails and water-hens, that to place it after them seems a natural and easy gradation; and accordingly this has been done by Cuvier, though it was considered by Linnæus to belong to a group distinct from those birds, and from the waders in general, on account of its being fin-footed, and its constant attachment to the waters, which, indeed, it seldom quits. The manner in which Coots build their nest is very ingenious. They form it of interwoven aquatic weeds, and place it among the rushes, in such a way that it may occasionally rise with, but not be washed away by, the stream : and if ever this accident happens, steady on her nest, the hen does not desert her brood, but follows with them the destiny of their floating cradle. This bird, in the figure and shape of its body, resembles the water-hen, and weighs about twenty-four ounces. The feathers about the head and neck are low, soft, and thick. The colour about the whole of the body is black, but of a deeper hue about the head. The sere rises upon the forehead in a peculiar manner, and appears as if Providence had designed it for a means of defence. It changes its whitish colour to a pale red or pink in the breeding season. Coots are very shy, and seldom venture abroad before dusk. When attacked, they defend themselves with their feet, and they do this so energetically. that sportsmen say, "Beware of a winged Coot, or he will scratch you like a cat." 
$\S$ VII. Palmipedes, or Web-footed Birds.

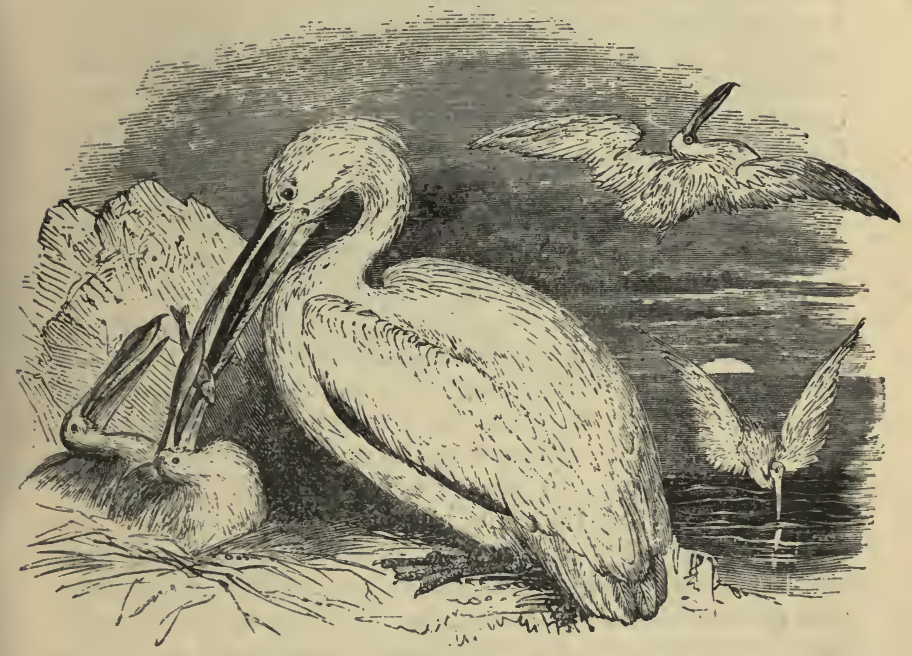

\section{THE PELICAN, (Pelicanus onocrotalus,)}

Is in size about equal to the swan; the colour of the body is white, inclining to pink; the beak is straight and long, with a sharp hook at the end; the skin of the lower mandible is so capable of distension, that it may be dilated to contain fish in large quantities. This pouch Providence has allotted to the bird, that he may bring to his eyrie sufficient food for several days, and sare himself the trouble of travelling through the air, and watching and diving so often. The legs are black, and the four toes palmated. It is a very indolent, inactive, and inelegant bird, often sitting whole days and nights on rocks or branches of trees, motionless and in a melancholy posture, till the resistless stimulus of hunger spurs 
it on, and forces it to the sea in search of nourishment; when thus excited to exertion, the Pelican flies from the spot, and, raising itself thirty or forty feet above the surface of the water, turns its head with one eye downward, and continues to fly in that position till it sees a fish near the surface. It then darts down with astonishing swiftness, seizes its prey with unerring certainty, and stores it. in its pouch. Having done this, it rises into the air, and repeats the same action till it has procured a sufficient stock. The Pelican is by no means destitute of natural affection, either towards its young ones or towards others of its own species. Clavigero, in his "History of Mexico," says, that sometimes the Americans, in order to procure, without trouble, a supply of fish, cruelly break the wing of a live Pelican, and, after tying the bird to a tree, conceal themselves near the place. The screams of the miserable bird attract other Pelicans to the place, which, he assures us, eject a portion of the provisions from their pouches for their imprisoned companion. As soon as the men observe this, they rush to the spot, and after leaving a small quantity for the bird, carry off the remainder.

In America, Pelicans are often rendered domestic, and are so trained, that at command they go in the morning and return before night with their pouches distended with prey, part of which they are made to disgorge, while the rest is left them for their trouble. The bird is said to live sometimes a hundred years.

Our forefathers attributed extraordinary affection to this bird, more than is attested by any save heraldic evidence. Thus, in several crests, it is represented in the act of feeding its young with its own blood, which it procures by striking its breast with the sharp point of its beak. And the ancients fully believed that in times of scarcity the female Pelican resorted to this means of supporting her brood. The nest of the Pelican is made with sedges and grass, close to the water's edge; the female lays two or three white eggs, and the male is said to supply his partner with food while she is engaged in the work of incubation. 


\section{The Cormorant.}

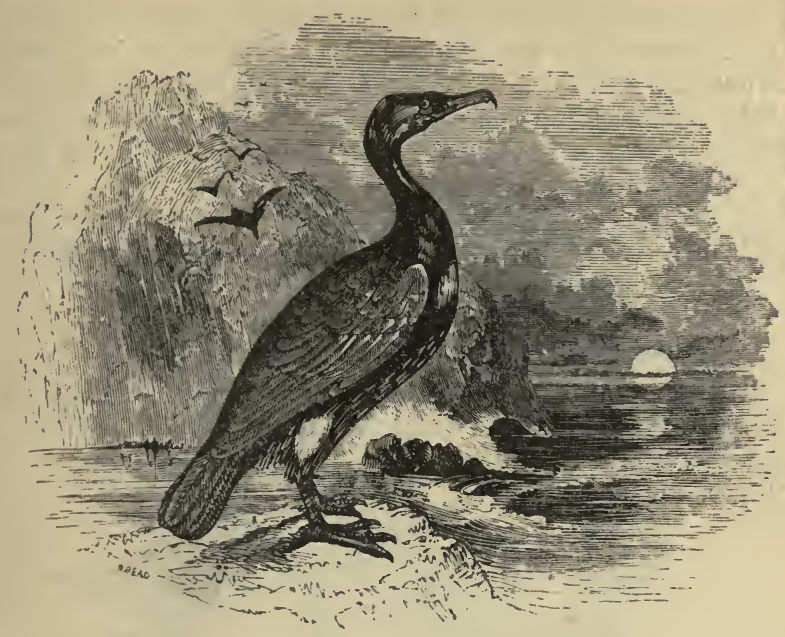

THE CORMORANT, (Phalacrocorax carbo,)

Is a large water-bird, nearly allied to the pelican, possessed with a very roracions appetite, and consequently of a very rapacious disposition. It lives upon all sorts of fish; the fresh water and the briny waves of the sea both paying a large contribution to its craving stomach. The bill is about five inches in length, and of a dusky colour; the predominant tints of the body are black beneath, and dark brown above; on each thigh there is a white patch. The smell of these birds when alive is excessively rank and disagreeable; and their flesh is so disgusting that even the Greenlanders, among whom they are very common, will scarcely eat it. They were formerly tamed in England for the purpose of catching fish, as falcons and hawks were for chasing the fleet inhabitants of the air. This custom is still in practice in China. The birds are taken to the water in a boat, with leather thongs tied round their necks to prevent their swallowing the fish; at the word of command they descend into the water, swim about, and dive in pursuit of 
prey, and bring whatever they capture to their owner's boat. Sometimes two Cormorants will unite their efforts to capture a large fish; and if any of the birds neglect their business the man will slap on the water with a bamboo, as a schoolmaster does with his cane on the desk, to recall the idlers to a sense of their duty. This bird, although of the aquatic kind, is often seen, like the pelican, perched upon trees. Milton tells us that Satan " On the tree of life,

The middle tree, and highest there that grew, Sat like a Cormorant."

In the year 1793, one of them was observed sitting on the vane of St. Martin's steeple, Ludgate Hill, London, and was shot there in the presence of a great number of people.

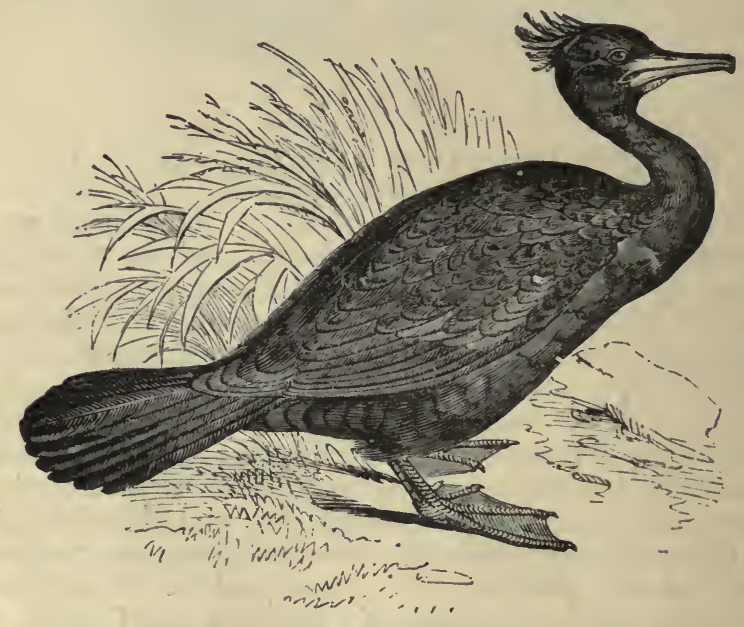

THE SHAG, OR CRESTED CORMORANT,

\section{(Phalacrocorax graculus,)}

Is of a dark green, with a singular tuft on the front of the head in the spring. It breeds in rocky caves on the sea-coast. 


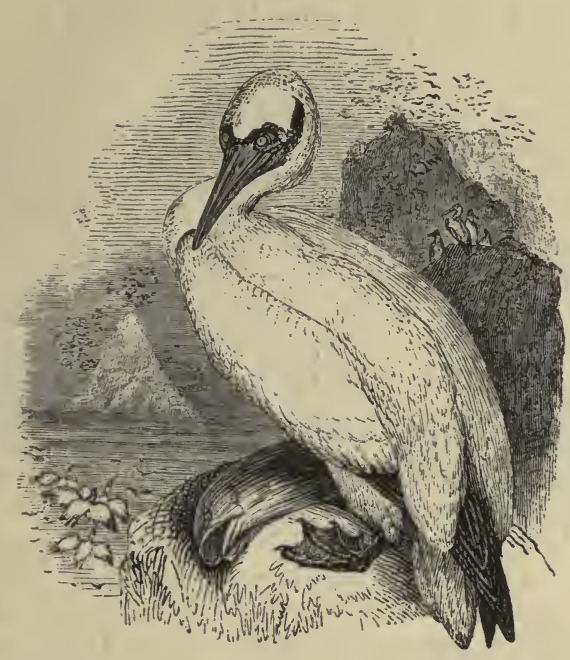

THE GANNET, OR SOLAN GOOSE.

(Sula bassana.)

T'Hese birds are insatiably voracious, but are somewhat particular in their choice of prey ; disdaining, unless in great want, any food worse than herrings or mackerel. No fewer than one hundred thousand Gannets are supposed to frequent the rocks of St. Kilda; and of these, including the young ones, at least twenty thousand are annually killed for food by the inhabitants. The Gannet is somewhat more than three feet in length, and weighs about seven pounds. The bill is six inches long, straight almost to the point, where it is a little bent; its edges are jagged, to enable it the better to secure its prey; and about an inch from the base of the upper mandible there is a sharp process pointing forward. The general 
colour of the plumage is a dingy white, with a greyish tinge. Surrounding each eye there is a naked skin of a fine blue colour; from the corner of the mouth a narrow slip of naked black skin extends to the hind part of the head; and beneath the chin there is a pouch capable of containing five or six herrings. The neck is long; the body flat, and very full of feathers. On the crown of the hear, and the back part of the neck, is a small buffcoloured space. The quill-feathers, and some other parts of the wings, are black; as are also the legs, except a fine pea-green stripe in front. The tail is wedge-shaped, and consists of twelve sharp-pointed feathers.

These birds chiefly resort to those uninhabited islands where man seldom comes to disturb them. The islands to the north, Ailsa Craig, on the west coast of Scotland. the Skelig Islands, off the coasts of Kerry in Ireland, and those that lie in the North Sea off Norway, abound with them. But it is on the Bass Rock, in the Frith of Forth, that they are seen in the greatest abundance. "There is a small island," says the celebrated Harvey, "called the Bass, not more than a mile in circumference; the surface is almost wholly covered during the months of Mlay and June with the nests of the Solan Geese, their eggs, and their young. It is scarcely possible to walk without treading on them : the flocks of birds upon the wing are so numerous as to darken the air like a cloud; and their noise is such, that one cannot without difficulty be heard by the person next to him. When one looks down upon the sea from the precipice, its whole surface seems covered with infinite numbers of birds of different kinds, swimming and pursuing their prey. If, in sailing round the island, one surveys its hanging cliffs; in every crag or fissure of the broken rocks may be seen innumerable birds, of various sorts and sizes, more than the stars of heaven when viewed in a serene night. If they are viewed at a distance, either receding or in their approach to the island, they seem like one vast swarm of bees." 


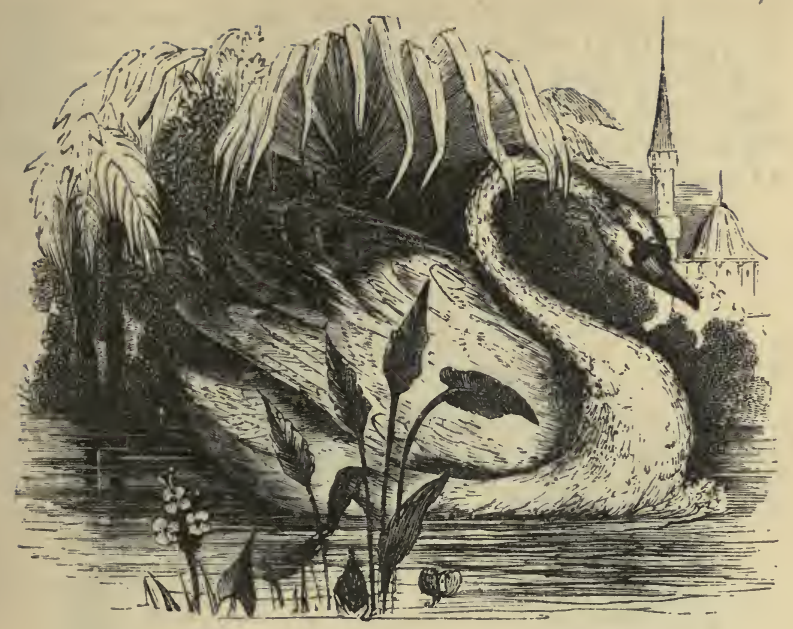

\section{THE SWAN. (Cygnus olor.)}

"Fair is the Swan, whose majesty prevailing O'er breezeless water, on Locarno's lake, Bears him on, while, proudly sailing, He leaves behind a moon-illumined wake: Behold! the mantling spirit of reserve Fashions his neck into a goodly curveAn arch thrown back between luxuriant wings Of whitest garniture, like fir-tree boughs, To which, on some unruffled morning, clings A flaky weight of winter's purest snows! Behold! as with a gushing impulse heaves That snowy prow, and softly cleaves The mirror of the crystal flood; Vanish inverted hill, and shadowy wood, And pendent rocks, where er in gliding state Winds the mute creature, without visible mate Or rival, save the queen of night, Showering dowu a silver light From heaven upon her chosen favourite!"

WORDSWORTH.

THe two best known species of this elegantly-formed and majestic bird are commonly known as the Wild and 
the Tame, or the Whooping and Mute, Swans. They may easily be recognised by the peculiarities of the bill: the Tame Swan has the bill orange-coloured, with its base black, and surmounted by a black knob; the Wild Swan has no knob, and it is the tip instead of the base of the bill that is black.

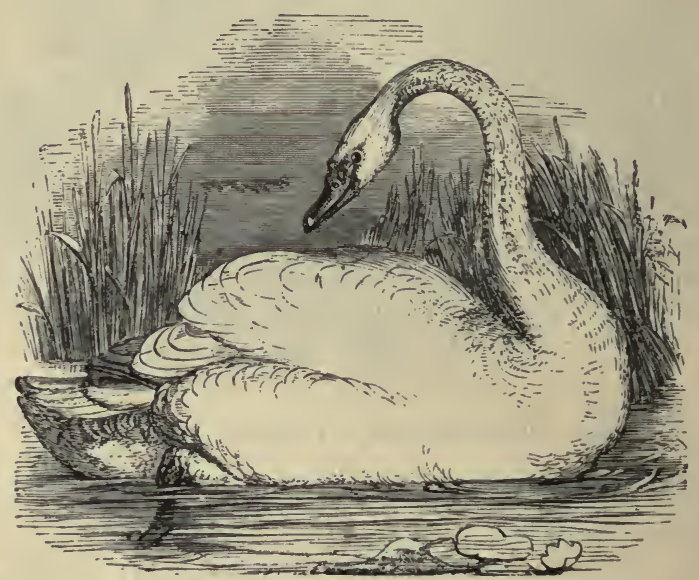

\section{THE WILD SWAN, WHOOPING SWAN, OR WHISTLING SWAN, (Cygnus ferus,)}

Is also a fine bird, with beautifully white plumage; unlike the Tame Swan, which is nearly mute, it has a loud and rather melodious voice, which it utters frequently, as it flies along at a great height in the air, during its migrations. It is found in England in the winter, but resides all the year in the north of Scotland. Its favourite place for breeding is in the extreme north. The Tame Swan is the largest of our web-footed waterfowl, sometimes weighing about thirty pounds: the whole body of the full-grown Swan is covered with a beautiful pure white plumage, but the young ones are grey; under the feathers is a thick, soft down, which 
is of very great use, and often employed as an ornament. The elegance of form which this bird displays, when, with his arched neck and half-displayed wings, he sails along the crystal surface of a tranquil stream, which reflects, as he passes, the snowy beauty of his dress, is worthy of admiration. Thomson describes the Swan in the following beautiful manner:

\section{" The stately sailing Swan}

Gives out his snowy plumage to the gale, And arching proud his neck, with oary feet, Bears forward fierce, and guards his osier isle, Protective of lis young."

Swans have for ages been protected on the river Thames as royal property; and it continues at this day to be accounted felony to steal their eggs : by this means their increase is secured, and they prove a delightful ornament to that noble river. Latham says the estimation in which they were held, in the reign of Edward IV., was such, that only those who possessed a freehold of the clear yearly value of five marks were permitted even to keep any. In those times, hardly a piece of water was left unoccupied by these birds, as they gratified the palate as well as the eye of their lordly owners of that period: but the fashion of those days has passed away, and Swans are by no means as common now as they were formerly, being by most people accounted a coarse kind of food, and consequently held in little estimation : but the Cygnets (so the young Swans are called) are still fattened for the table, and are sold very high, commonly for a guinea each, and sometimes more; hence it may be presumed they are better food than is generally imagined.

At Abbotsbury there was generally a noble Swannery, the property of the Earl of Ilchester, where six or seven hundred birds were kept, but the collection has of late been much diminished. The Swannery belonged anciently to the abbot, and, previously to the dissolution of monasteries, the Swans frequently amounted to double the above number.

From the whiteness of this bird, the expression of a $2 \mathrm{c}$ 
"Black Swan" was used in ancient times as equivalent to a nonentity; but a species nearly entirely black has been lately discovered in Australia. This bird is as large as the white Swan, and its bill is of a rich scarlet. The whole plumage (except the primaries and secondaries, which are white) is of the most intense black.

Swans are very long lived, sometimes attaining the great age of a century and a half.

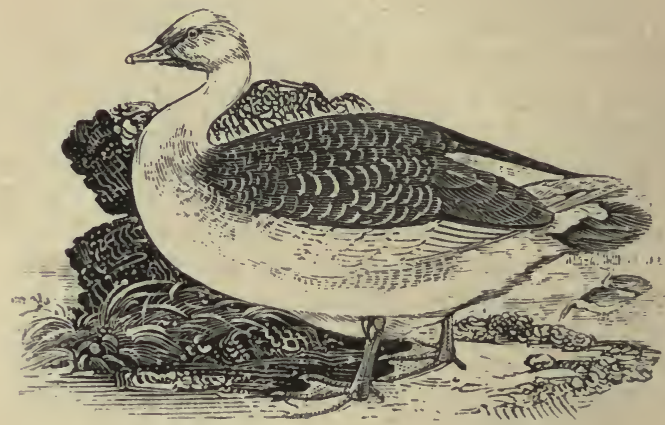

\section{THE WILD GOOSE. (Anser ferus.)}

"The farmer's Goose, who in the stubble

Has fed without restraint or trouble, Grown fat with corn, and sitting still, Can scarce get o'er the barn-door sill; And hardly waddles forth to cool Her body in the neighbouring pool ; Nor loudly cackles at the door, For cackling shows the Goose is poor."

SwIFT.

THE Goose is very different in outward appearance from the last-named bird. Stupidity in her look, uncouthness in her walk, and heaviness in her flight are her principal characteristics. But why should we dwell upon these defects? they are not such in the great scale of the creation. Her flesh feeds many, and is not disdained even by the great; her feathers keep us warm; 
and even the very pen I hold in my hand was plucked from her wing.

These birds are kept in vast quantities in the fens of Lincolnshire; several persons there having as many as a thousand breeders. They breed in general only once a year, but if well kept they sometimes hatch twice in a season. During their sitting, the birds have spaces allotted to each, in rows of wicker pens placed one above another; and the Goose-herd, who has the care of them, drives the whole flock to water twice a day, and bringing them back to their habitations, places every bird (without missing one) in its own nest. It is scarcely credible what numbers of Geese are driven from the distant counties to London for sale, frequently two or three thousand in a drove; and, in the year 1783, one drove passed through Chelmsford, in its way from Suffolk to London, that contained more than nine thousand. However simple in appearance or awkward in gesture the Goose may be, it is not without many marks of sentiment and understanding. The courage with which it protects its offspring and defends itself against ravenous birds, and certain instances of attachment, and even of gratitude, which have been observed in it, render our general contempt of the Goose ill-founded.

The Goose was held in great veneration among the Romans, as having by her watchfulness saved the Capitol from the attack of the Gauls. Virgil says, in the seventh book of the Aneid,

"The silver goose before the shining gate

There flew, and by her cackle saved the state."

Drynen.

The colour of this useful bird is generally white; though we often find them of a mixture of white, grey black, and sometimes yellow. The feet which are palmated, are orange-coloured, and the beak is serrated. The male of the Goose is called the Gander; and the young ones Goslings. Geese are very long-lived, one is known to have lived above seventy years.

The Wild Goose is the original of the tame one, and differ's much in colour from her, the general tint of its feathers being a greyish black. Wild Geese fly by night 
in large flocks to more southern countries; and their clang is heard from the regions of the clonds, although the birds are out of sight.

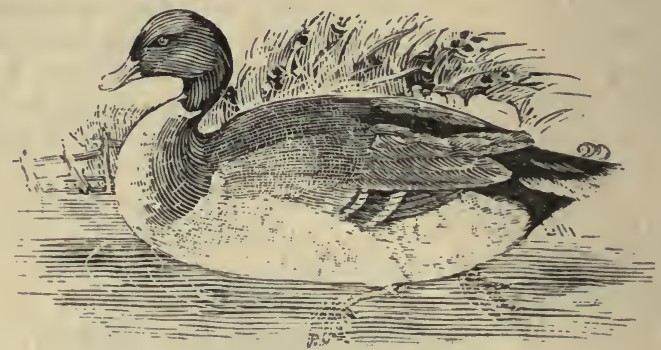

THE DUCK. (Anas boschas.)

The common Duck is of two kinds, the wild and the tame, the latter being but the same species altered by domestication; the difference between them is rery trifling, save that the colour of the Mallard, or male wild Duck, is constantly the same in all the individuals, whereas the Drakes, or tame ones, are varied in their plumage. The females do not share with the males in beanty of plumage: the admirable scarf of glossy green and blue, which surrounds the neck of Drakes and Mallards, being an exclusive prerogative of the male sex. There is also a curious and invariable peculiarity belonging to the males, which consists of a few curled feathers rising upon the rump.

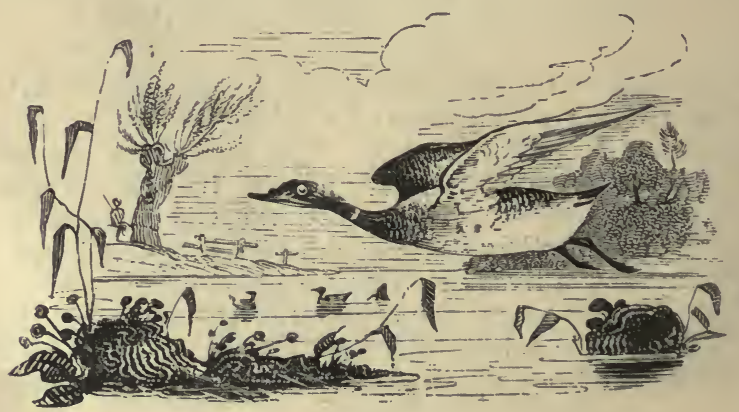


Wild Ducks are caught by decoys in the fen countries, and in such prodigious numbers, that in only ten decoys in the neighbourhood of Wainfleet, as many as thirtyone thousand two hundred have been caught in one season. They do not always build their nests close to the water, but often at a considerable distance from it; in which case the female will take the young ones in her beak, or between her legs, to the water. They have sometimes been known to lay their eggs in a high tree, in a deserted magpie's or crow's nest; and an instance has been recorded of one being found at Etchingham, in Sussex, sitting upon nine eggs in an oak, at the height of twenty-five feet from the ground: the eggs were supported by some small twigs laid cross-ways.

The tame Ducks, reared about mills and rivers, or wherever there is a sufficient quantity of water for them to indulge their sports and to search for food, become a branch of trade, which proves very profitable to their owners.

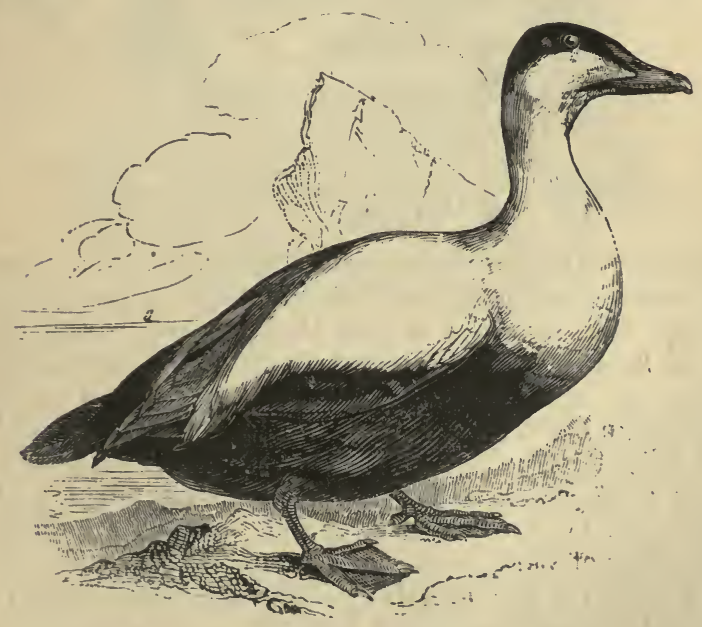

THE EIDER DUCK, (Sornateria mollisima,)

Wнicн is found about the coasts of the north of England 
and Scotland, becomes more numerous as we go further north, and is most abundant on Iceland and the Arctic shores, both of Europe and America. This bird is particularly valuable for the great quantity of down which it furnishes, as this is so light and elastic that beds and quilts made from it are preferable to any others. The birds line their nests with this beautiful material plucked from their own bodies, and it is chiefly by plundering the nests that the down is obtained. Each nest will furnish about half a pound of down in the season, and it is worth about four dollars a pound.

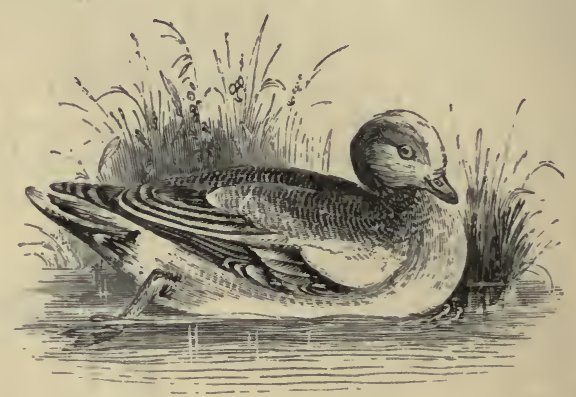

THE WIDGEON, (Mareca Penelope,)

Weighs about twenty-two ounces, and feeds upon grass and roots growing at the bottom of lakes, rivers, and ponds. The plumage of this bird is much variegated, and its flesh esteemed a great delicacy, though not so highly praised as that of the teal. The bill of the Widgeon is black; the head and upper part of the neck of a bright bay; the back and sides under the wingr waved with black and white; the breast purple; the lower part of the body white, and the legs are dusky. The young of both sexes are grey, and continue in this plain garb till the month of February; after which a change takes place, and the plumage of the male begins to assume its rich colourings, in which, it is said, he continues till the end of July; and then again the 
feathers become dark and grey, so that he is hardly to be distinguished from the female.

Widgeons commonly fly in small flocks during the night, and may be known from other birds by their whistling note, while they are on the wing. They quit the desert morasses of the north on the approach of winter, and as they advance towards the ends of their destined southern journey, they spread themselves along the shores, and over the marshes and lakes, in various parts of the continent, as well as those of the British isles; and it is said that some of the flocks advance as far south as Egypt.

The Widgeon is easily domesticated in places where there is plenty of water, and is much admired for its beauty, sprightly look, and busy, frolicsome manners; yet it is generally asserted that they will not breed in confinement, or at least that the female will not make a nest and perform the act of incubation; but that she will lay eggs, which are generally drupped into the water.

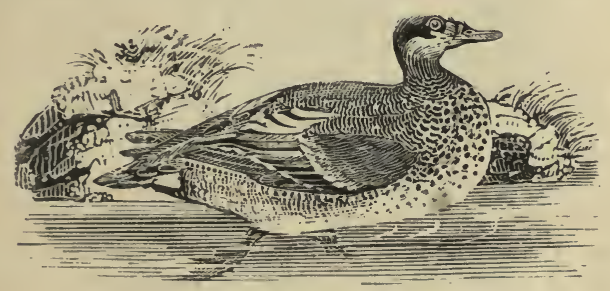

\section{THE TEAL, (Querquedula crecca,)}

Is the least of the duck tribe, weighing only twelve ounces. The lower part of the body is of a dingy white, inclining to a grey tint. The back and sides under the wings are curiously varied with lines of white and black; the wings are all over brown, and the tail of the same colour. This bird is common in England during the winter months, and it is still uncertain whether it does not breed here as it does in France. Dr. Heysham says it is known to breed in the neighbourhood of Carlisle. The female makes her nest of reeds interwoven with 
grass; and, as it is reported, places it among the rushes, in order that it may rise and fall with the water. Their eggs are of the size of those of a pigeon, six or seven in number, and of a dull white colour, marked with small brownish spots; but it appears that they sometimes lay ten or twelve eggs, for Buffon remarks that that number of young are seen in clusters on the pools, feeding on cresses, chervil, and some other weeds, as well as upon seeds and small insects that swarm in the water. The flesh of the Teal is a great delicacy in the winter season, and has less of the fishy flavour than any of the wild duck kind. It is known to breed and remain throughout the year in various temperate climates of the world, and is in the summer met with as far northward as Iceland.

\section{THE COMMON GULL. (Laruscanus.)}

The Gulls, of which there are a great many different kinds, are very common birds around our coasts and at the mouths of rivers; they have long wings, and fly with great rapidity and buoyancy. Their plumage is thick, and they float very lightly on the surface of the water, but do not dive. The Gulls are very voracious, and not only devour great quantities of fishes, shellfish, and other marine animals, but even condescend to feed upon the dead bodies of animals which they find floating on the water or cast up on the shore. Some of the smaller kinds come inland, and catch insects on the wing, in the same way as the Swallows.

The Common Gull is rather a large species, being more than eighteen inches in length when full grown. Its plumage is pearly grey abore and white beneath; the largest wing feathers are black, with white tips and white spots near the tip; and the bill and feet are greenish grey. This bird breeds in the salt marshes or on the ledges of cliffs. The female lays two or three eggs, which are olive brown, with dark brown and black spots.

It is a very pretty sight to watch from the top of a lofty cliff the multitudes of these birds that often haunt 
our coasts; gliding with beautiful ease and swiftness through the air, skimming the surface of the water in pursuit of their prey, or reposing upon its bosom. Even their rather harsh and discordant cry is in harmony with the wild and imposing heights on which they love to dwell. This, however, does not protect them from the frequenters of our seaside towns, with whom seagull shooting is a favourite amusement; an amusement the more to be reprehended as the flesh of the bird is quite useless.

Gulls are frequently caught alive, and, after having their wings clipped to prevent their escape, are kept to satisfy their voracious appetite on snails, slugs, and other garden pests.

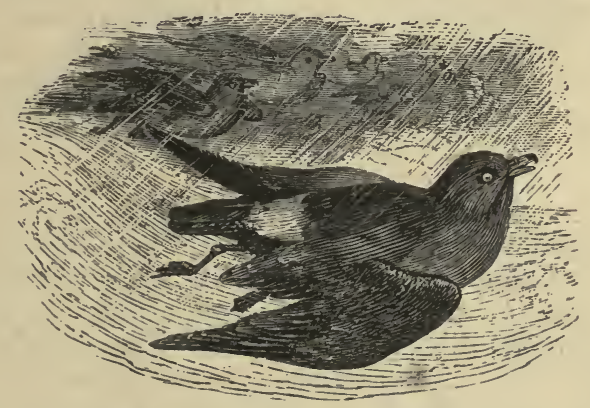

\section{THE STORMY PETREL, OR MOTHER CARY'S}

\section{CHICKEN. (Thalassidroma pelagica.)}

"O'er the deep! o'er the deep!

Where the whale, and the shark, and the sword-fish sleep,

Outflying the blast and the driving rain,

The petrel telleth her tale in vain;

For the mariner curseth the warning bird,

Who bringeth him news of the storm unheard!

Oh ! thus does the prophet, of good or ill,

Meet hate from creatures he serveth still;

Yet he ne'er falters :- So, Petrel! spring

Once more o'er the waves on thy stormy wing." Procter.

The Srormy Petreu is not larger than a swallow; and its 
colour is entirely black, except the coverts of the tail, the tail itself, and the vent-feathers, which are white: its legs are slender. Ranging over the expanse of the ocean, and frequently at a vast distance from the land, this bird is able to brave the utmost fury of the storms. Even in the most tempestuous weather it is frequently observed by the mariners skimming with almost incredible velocity along the billows, and sometimes over their summits. They often follow vessels in great flocks, to pick up anything that is thrown overboard; but their appearance is looked upon by the sailors as the sure presage of stormy weather in the course of a few hours. It seems to seek protection from the fury of the wind in the wake of the vessels; and it is probable that for the same reason it often flies between two surges. The nest of this bird is found in the Orkney Islands, under loose stones, in the months of June and July. It lives chiefly on small fish; and although mute by day, it is very clamorous by night. The young of this bird are fed with an oily matter or chyle, which is ejected from the stomachs of the parents.

Mudie, in his very entertaining work on British Birds, says that they are called Petrels, or " little Petrels," because they move along the surface as if they were literally walking on the water. He also informs us that they are at times very full of oil, and that the Faroese, taking advantage of this circumstance, convert them into lamps, by fixing them in an upright position and drawing a wick through their bodies, which they light at the mouth. 


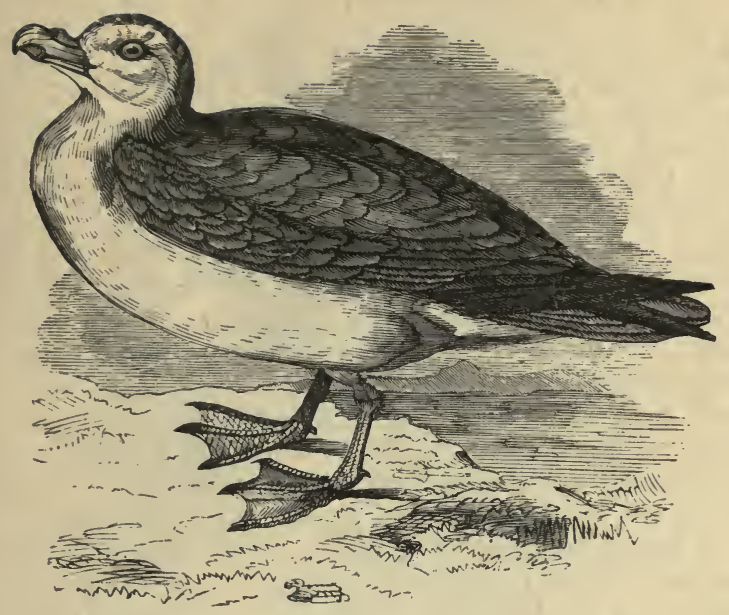

THE FULMAR, (Procellaria glacialis,)

Is a larger kind of Petrel, which is found not uncommonly on the British coasts, and is exceeding abundant in the Arctic seas. Here it is a regular attendant upon the whale-fishers when they are engaged in cutting up a whale. Any fragments of blubber that happen to fall into the water are immediately snapped by these greedy birds, which clamour and squabble over the feast with so little regard to the vicinity of the sailors, that they may be knocked on the head with a boat-hook. They are in high estimation in the countries they inhabit, on account of the large amount of oil they contain. It is only rarely they are seen in England, nor do they regularly frequent any part of Great Britain, except a few of the northernmost islands of Scotland. Like the other Petrels, they feed their young with a sort of oil, which they have the power of exuding at will. 


\section{THE ALBATROSS, (Diomedea exulans,)}

Also resembles the diminutive Petrels in some respects ; but instead of being a pigmy it is a giant among birds. Its wings often measure as much as fifteen feet in extent and are of corresponding power, as they have to support the Albatross by the day together above the stormy waves of the great Southern Ocean. Indeed, so enormous is their strength and endurance, that they have been known to follow ships for whole days together, without once resting upon the water. From time to time the gigantic bird plunges down into the sea to capture the fishes with which he satisfies his hunger; and it is said that where Albatrosses are numerous they will even attack sailors who may happen to fall overboard. From their abundance at the Cape of Good Hope they are often called by mariners Cape sheep.

Albatrosses generally weigh from twenty to thirty pounds. The plumage is white, except some narrow bars upon the back, and some of the long wing feathers, which are black, and of the head, which is a reddish grey. The beak is long and powerful, and curved at the end, and would be a most terrible weapon if the owner were of a pugnacious disposition. It is, however, quite inoffensive, and is even sometimes attacked by much smaller birds, when it invariably takes to flight, and the immense power of its wings generally enables it to distance its pursuers. The Albatross, like most sea birds, has a most insatiable appetite, and devours immense quantities, not only of fish, but of other seaanimals,-such as molluscs. They are so greedy that they are caught by a line baited with a piece of flesh, which the ever-hungry bird swallows at a gulp, paying with his life for the dear repast. They are taken by the natives of the countries they frequent, not for their flesh, which is tough and insipid, but for the sake of their entrails, which are very large and elastic, and are used for a number of useful purposes. 


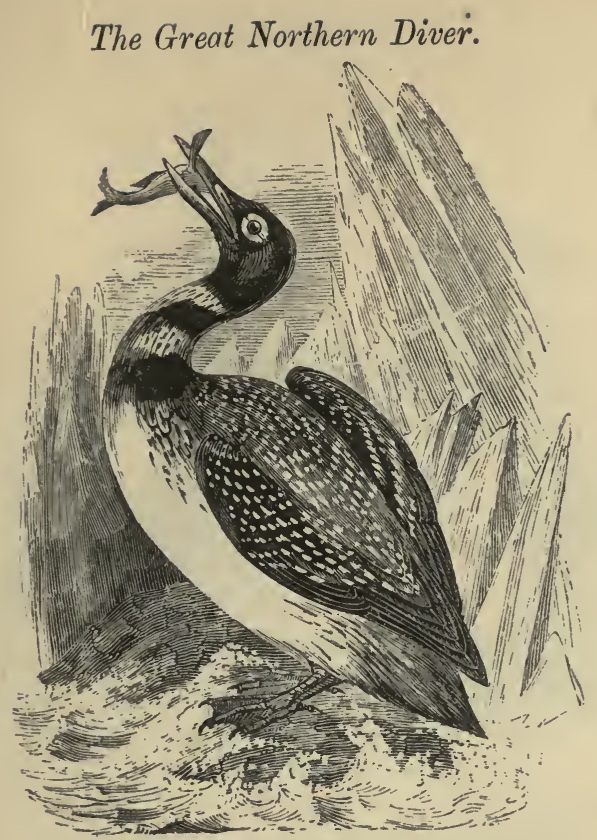

'THE GREAT NORTHERN DIVER.

(Colymbus glacialis.)

The Great Northern Diver is found most abundantly in the Arctic seas, but a considerable number of them dwell on the shores of Scotland. It has a rather long, strong, and sharply pointed bill; its back and wings are black, ornamented with numerous white spots; its lower surface is greyish-white; and its head and neck are black, with a couple of white collars across the front of the neck. The Great Northern Diver is a large bird, measuring nearly three feet in length; its wings are small in proportion to its size, but yet the bird is able to fly very rapidly. It is, however, in the water that it is most active ; it swims and dives with the most remarkable ease, and even under water goes as fast as a four-oared boat. Its food consists of fishes, and it breeds amongst the herbage of the sea-shore, the female laying two or three eggs in a neat nest made of grass. 


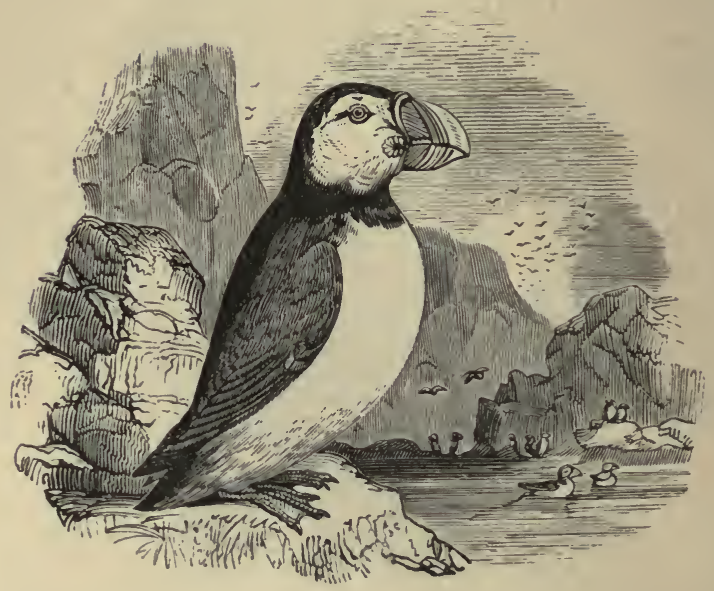

THE PUFFIN, (Fratercula arctica,)

Is another short-winged water bird, but, unlike the Northern Diver, it visits us in the summer, and breeds on our shores. It is ahout a foot long, and has the back and wings black, the cheeks and all the lower parts of the body, except a band round the neck, white, and the feet orange. Its bill is very curious, and has obtained for it the names of Sea Parrot and Coulterneb in some places. This organ is large and strong, but flattened at the sides; it is of a bluish colour, with three grooves and four ridges of an orange colour. The Puffin flies swiftly, and swims and dives almost as well as the Great Diver; it breeds sometimes in crannies amongst the rocks, and sometimes in a hole which it digs in the turf or in a rabbit-warren. 


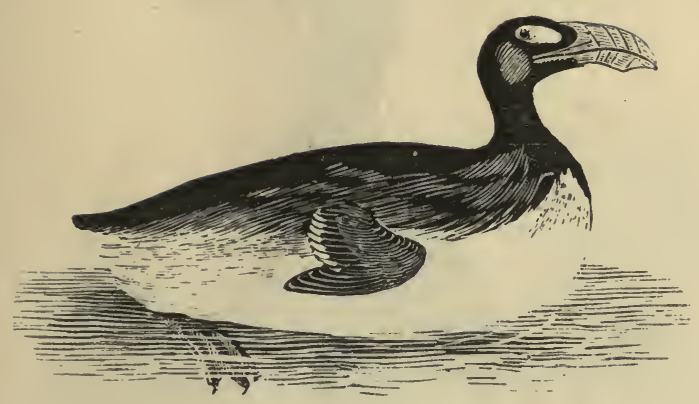

THE GREAT AUK, (Alca impennis,)

Wнгсн is sometimes called the Northern Penguin, is a large bird, furnished with very small wings, which, although formed of regular feathers, like those of other birds, are far too weak to raise their owner into the air. They are, however, of use in another way. When the Auk dives, which it frequently does, they serve as fins, and, with its powerful webbed feet, enable it to swim underneath the water with even greater rapidity than on the surface. This bird was formerly seen occasionally on the northern coasts of Britain, and became more plentiful towards the Arctic seas; but no specimens have now been met with for many years, and there is reason to believe that the bird is quite extinct on our coasts. In othe water the Great Auk, like the Diver, is wonderfully active, swimming on the surface or beneath the waves with equal ease. Mr. Bullock, when in the Orkneys, pursued a male bird for several hours in a six-oared boat without being able to kill him.

The Great Auk is generally about three feet long, and changes its plumage in summer. The breeding-season is in June and July, when the female lays one large egg, of a yellowish colour, marked with black spots. 


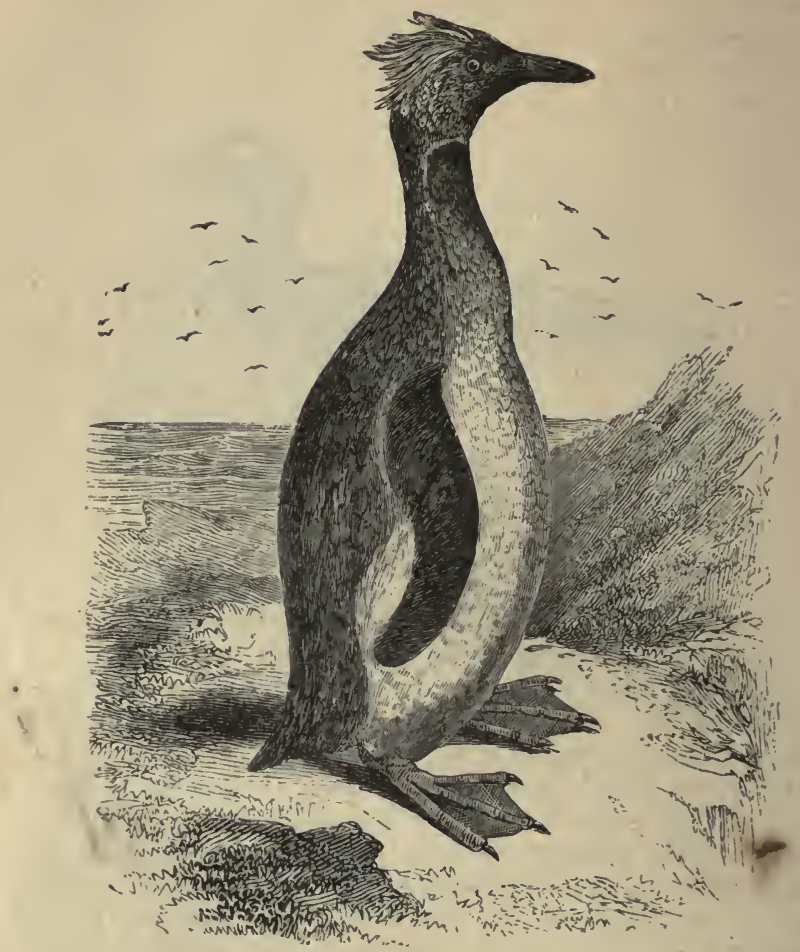

THE PENGUIN, (Speniscus demersus,)

OF which numerous species abound on the shores and islands of the great Southern Ocean, is remarkable for its almost incredible agility in the water; it swims and dives like a fish, and in fact is described as coming to the surface for air, and descending again so suddenly as to give rise to the impression that it is a fish jumping in sport. It is found in vast numbers in hiding places, where the females are seen sitting upright and holding their single egg between their legs. 


\section{Book III.}

\section{INHABITANTS OF THE WATER.}

$\S$ I. Cetacea, or Sea Mammalia.

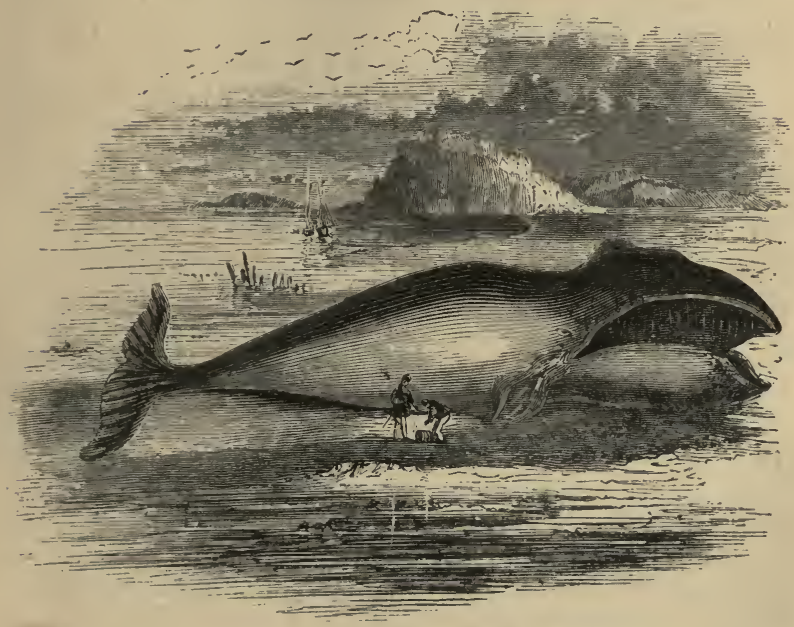

\section{'THE COMMON, OR GREENLAND WHALE.}

\section{(Balana mysticetus.)}

"Nature's strange work, vast Whales of different form, Toss up the troubled flood, and are themselves a storm; Uneouth the sight, when they in dreadful play, Discharge their nostrils, and refund a sea; Or angry lash the foam with hideous sound, And scatter all the watery clust around; Fearless, the fierce destruetive monsters roll, Ingulf the fish, and drive the flying shoal; In deepest seas these living isles appear, And deepest seas can scarce their pressure bear; Their bulk would more than fill the shelvy strait, And fathom'd depths would yield beneath their weight."

The Whale is not properly a fish; since, though it lives 
in the sea, and has fins and a tail instead of legs and feet, it resembles in most other respects a seal, and differs from fishes, properly so called, in many important points. Indeed, it is always included in the class Mammalia, by zoologists, as it brings forth its young alive, and nourishes them with its railk; and hence a conceited person, who said he knew every fish from the shrimp to the Whale, was justly laughed at, as neither the Whale nor the shrimp are included in the fishes by zoologists.

The general form of the Whale's body is that of a fish; but the tail is placed horizontally instead of vertically, and the skeleton of the fins exactly resembles that of a hand affixed to a contracted arm, though it is covered with so thick a skin that no trace of the formation of the bones can be discovered externally. There are only two fins, which are very small, and close to the head. 'The Whale, however, differs from fishes most materially in its having warm blood; and in its lungs, which are exactly the same as those of quadrupeds. Hence, though the Whale can remain a long time under water without breathing, it is compelled to come to the surface whenever it does breathe, and for this purpose it is furnished with two large nostrils, or blow-holes as they are called. The blow-holes are most beautifully and curiously contrived to close when the animal sinks under water; so that not a drop of water can enter the lung's, however great the pressure may be. The Whale is also provided with a very thick skin, containing an immense quantity of liquid oil, called the blubber, which is so easily detached from the flesh, that when a Whale is killed, the blubber, which is sometimes two feet thick, is taken off by passing a common spade between it and the body. This thick oily skin is a non-conductor of heat, and is thus admirably adapted for preventing the warm blood of the Whale from being chilled by the cold of the water. The true fishes, which are unprovided with such a covering, have cold blood, and are therefore not susceptible of chills.

The common Whale has no teeth in either jaw, but its mouth is furnished with a kind of fringe of numerous long horny laminæ, which are what we call whalebone, 
and which form a kind of strainer, admitting only the small fish on which the Whale feeds. This Whalebone is one of the valuable products of the whale, though the oil is most important.

"As when enclosing harpooners assail, In hyperborean seas, the slumbering Whale;

Soon as the javelins pierce the scaly side,

He groans, he darts impetuous down the tide;

And, rack'd all o'er with lacerating pain,

He flies remote beneath the flood in vain."

Falconer.

Whales are taken in great numbers about Spitzbergen, Greenland, and other northern countries by the English, the Dutch, \&c. Considerable fleets of ships are sent out every spring for this purpose. When they begin their fishery, each ship is fastened or moored with nose-hooks to the ice. Two boats, each manned with six men, are ordered by the commodore to look out for the coming of the fish for two hours, when they are relieved by two more, and so by turns; the two boats lie at some small distance from the ship, each separated from the other, fastened to the ice with their boat-hooks, ready to let go in an instant at the first sight of the Whale. Here the dexterity of the Whale hunters is to be admired; for as soon as the animal shows itself, every man is at his oar, and they all rush on the Whale with prodigious swiftness; at the same time taking care to come behind its head, that it may not see the boat, which sometimes so alarms it, that it plunges down again before they have time to strike it. But the greatest care is to be taken of the tail, with which it many times does very great damage, both to the boats and seamen. The harpooner, who is placed at the head or bow of the boat, seeing the back of the Whale, and making the onset, thrusts the harpoon with all his might into its body by the help of a staff fixed to the iron for this purpose, and leaves it in, a line being fastened to it of about two inches in circumference, and one hundred and thirty-six fathoms long. Every boat is furnished with seven of these lines, from the motion of which, when let run, they. observe the course of the Whale. 
As soon as the Whale is struck, the third man in the boat holds up his oar, with something on the top, as a signal to the ship; at the sight of which the man who is appointed to watch gives the alarm to those that are asleep, who instantly let fall their other four boats, which hang on the tackles, two at each side, ready to let go at a minute's warning, all furnished with six men each, harpoons, lances, lines, \&c. Two or three of these boats row to the place where the Whale may be expected to come up again; the others to assist the boat that first struck it with line; as the Whale will sometimes run out three more boats' lines, all fastened to each other, for when the lines of the first boat are almost run out, they throw the end to the second to be fastened to theirs, and the second boat does the same to the third, and so on. In this manner line is supplied to such an extent that a large Whale has been known to carry off three miles of it.

A Whale, when he is first struck, will run out above a hundred fathoms of line, before the harpooner is able to take a turn round the boat's stern ; and with such swiftness that a man stands ready to throw water on the line to quench it, in case it should take fire, which it frequently does. There was, many years ago, a boat to be seen in the South Sea Dock at Deptford, the head of which was sawed off by the swiftness of the line running out. The harpoon would be of but little avail in the destruction of this animal; but part of the rowers, either at the first onset, or when, in order to fetch his breath, he rises to the surface and discovers himself to view, throwing aside their oars, and taking up their very sharp lances, thrust them into his body, till they see him spurt the blood through the blow-holes, the sight of which is a sign of the creature's being mortally wounded. The fishermen, upon the killing of a Whale, are each entitled to sume small reward. After the Whale is killed, they cut all the lines that were fastened to it, and then cut off the tail ; upon this it instantly turns on its back; and in this manner they tow it to the ship, where they fasten ropes to keep it from sinking; and, when it is cold, begin to cut off the blubber. 
The blubber of a Whale is frequently fornd to be eighteen or twenty inches thick: which yields fifty or sixty puncheons of oil, each puncheon containing seventyfour gallons; and the upper jaw yields about six hundred pieces of whalebone, most of which are about twelve feet long, and six or eight inches broad; the whole produce of a Whale being worth one thousand pounds, more or less, according to the size of the animal. Whilst the men are at work on the back of the Whale they have spurs on their boots, with two prongs, which come down on each side of their feet, lest they should slip, the back of the Whale being very slippery.

When the Whale feeds, it swims with considerable velocity below the surface of the sea, with its jaws widely extended. A stream of water consequently enters its mouth, carrying along with it immense quantities of cuttle-fish, sea-blubber, shrimps, and other small marine animals. The water escapes at the sides; but the food is entangled, and, as it were, sifted by the fringe of whalebone within the mouth; this kind of strainer is rendered necessary by the very small gullet, which in a Whale of sixty feet long, does not exceed four inches in width, The sailors say that a penny-loaf would choke a Whale.

The Whale bellows fearfully when wounded or in distress. Its young is called a cub.

There is also an extensive Whale fishery in the Southern Ocean, carried on chiefly by the Americans. The Whale found in those seas is distinct from the Greenland Whale, and is described by naturalists under the name of Balona Australis. 
Fishes.

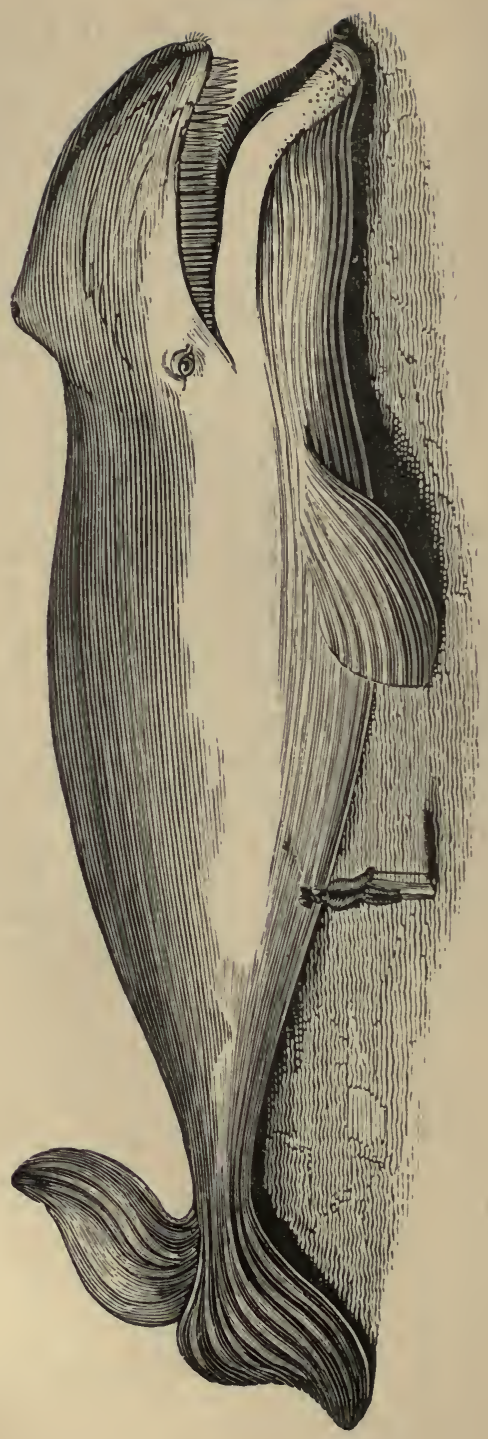




\section{THE RORQUAL, OR FIN-BACKED WHALE,}

\section{(Balcenoptera boops,)}

Is a very large Whale, specimens sometimes measuring as much as one hundred feet in length. It is distinguished by its smaller head, and by the existence of a sort of fin on the lower part of its back. The Rorqual is found in the northern seas, and specimens are sometimes seen off our coasts. It is not of much value, as it furnishes far less blubber than the common Whale, and the baleen or whalebone is so short as to be useless.

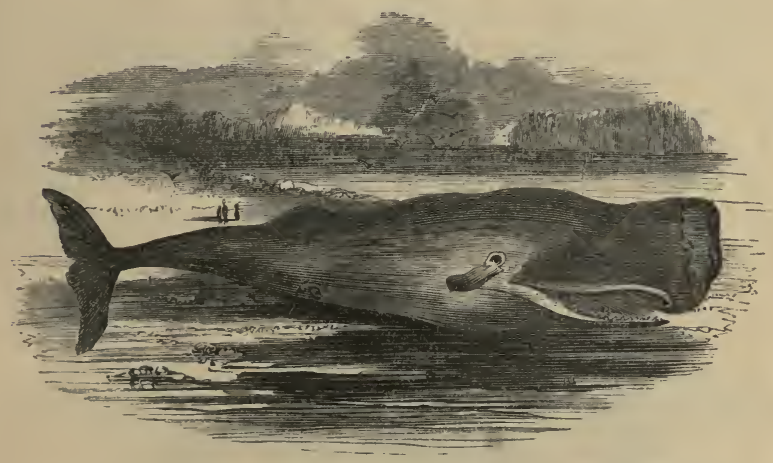

THE SPERMACETI WHALE, OR CACHALOT.

(Physeter macrocephalus.)

THIs animal has teeth in the lower jaw only ; and no whalebone. The substance called spermaceti is extracted from its immense head, which is nearly half the size of the entire animal; and the throat is so large that it could swallow a shark.

The quantity of oil produced from the Spermaceti Whale is not so considerable as that obtained from the common or Greenland Whale, but in quality it is far preferable, as it yields a bright flame, without exhaling any nauseous smell. The substance known by the 
name of ambergris is also obtained from the body of this animal. It is generally found in the stomach, but sometimes in the intestines; and, in a commercial point of view, is a highly valuable production. The spermaceti is in a fluid state while the animal is living, and as soon as it is dead a hole is made in the head, and the liquid taken out with buckets. It becomes solid as it cools, and it is afterwards made into candles, \&c.

When we reflect that the same Power whose will has formed the immense bulk of this marine monster has also given animation, senses, and passions to the smallest of the microscopic animalcules, how lowered must be the pride of man, who, standing in the middle, and nearly at equal distance from both, is yet unable to comprehend the mechanism which puts them in motion, and much less that intelligence and power which has given them life, and has assigned to them their respective stations in the universe! Let us then exclaim, with astonishment and gratitude, with the Psalmist: "O Lord, how inscrutable are thy ways, how magnificent thy works !"

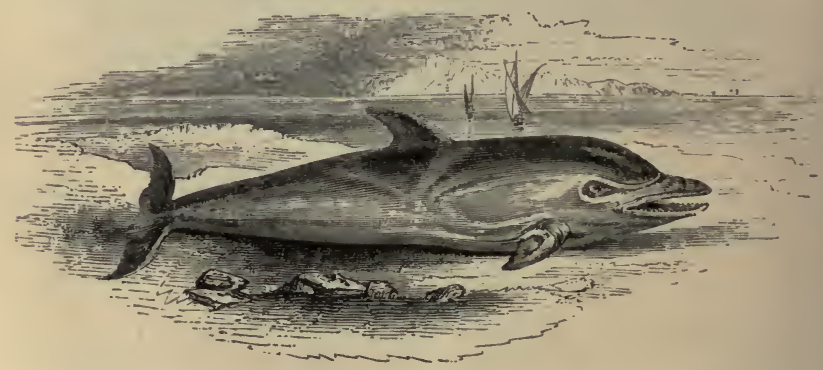

THE DOLPHIN. (Delphinus delphis.)

THis animal, like the whale, is not considered a fish, though it lives in the water, as it has warm blood and suckles its young, which are born alive. It has also lungs instead of gills, and is therefore obliged to raise its head above the surface of the water to breathe.

The Dolphin is from six to ten feet in length. The 
body is roundish, gradually diminishing towards the tail; the nuse is long and pointed, the skin smooth, the back black or dusky blue, becoming white below. It has numerous small teeth in each jaw; a dorsal and two pectoral fins, and a tail in the shape of a crescent. 'The beak-like snout has probably made the French call the Dolphin the sea-goose.

Several curions stories have been related of this animal, most of which are fabulous. 'The anecdote of Arion, the musician, who, being thrown overboard by pirates, was indebted for his life to one of these animals, is well known, and acquired great credit among ancient poets, as it was said to be by his music that Arion charmed the Dolphin. There are several other fables mentioned by ancient authors to prove the philanthropy of the Dolphin. Since the province of Daupliné in France has been united to the crown, the heir-apparent has been called "Dauphin," and quarters a Dolphin on his shield. Falconer, in his beautiful poem, "The Shipwreck," describes the death of the Dolplin in the following elegant manner:

" - - Beneath the lofty vessel's stern-

A shoal of sporting dolphins they discern, Beaming from burnished scales refulgent rays, Till all the glowing ocean seems to blaze.

In curling wreaths they wanton on the tide; Now bound aloft, now downward swiftly glide. A while beneutl the waves their tracks remain, And burn in silver streams aloug the liquid plain;

Soon to the sport of death the crew repair,

Dart the long lance, or spread the bated snare.

One in redoubling mazes wheels along,

And glides, unhappy, near the triple prong.

Rodmond, unerring, o'er his head suspends

The barbed steel, and every turn attends:

Unerring aim'd, the missile weapon flew, And plunging, struck the fated victim through.

The upturning points his poud'rous bulk sustain; On deck he struggles with convulsive pain;

But while his heart the fatal javelin thrills, And fleeting life escapes in sanguine rills, What rudiant clianges strike the astonish'd sight, What glowing hues of mingled shade and light!

No equal beauties gild the lucid west

With parting beams all o'er profusely dressed; 
No lovelier colours paint the vernal dawn,

When orient dews impearl the enamell'd lawn;

Than from his sides in bright suffusion flow,

That now with gold empyreal seem to glow;

Now in pellucid sapphires meet the view,

And emulate the soft celestial hue;

Now beam a flaming crimson to the eye,

And now assume the purple's deeper dye :

But here description clouds each shining ray;

What terms of art can Nature's power display?"

Unfortunately for poetry, the beautiful colours of the dying Dolphin exist entirely in the fancy of the poet; as the Dolphin in a dying state displays no tints but black and white, and it is believed that the notion so prevalent among the ancients of the change of colour in this animal was derived from a true fish, the Dorado, which does exhibit this phenomenon.

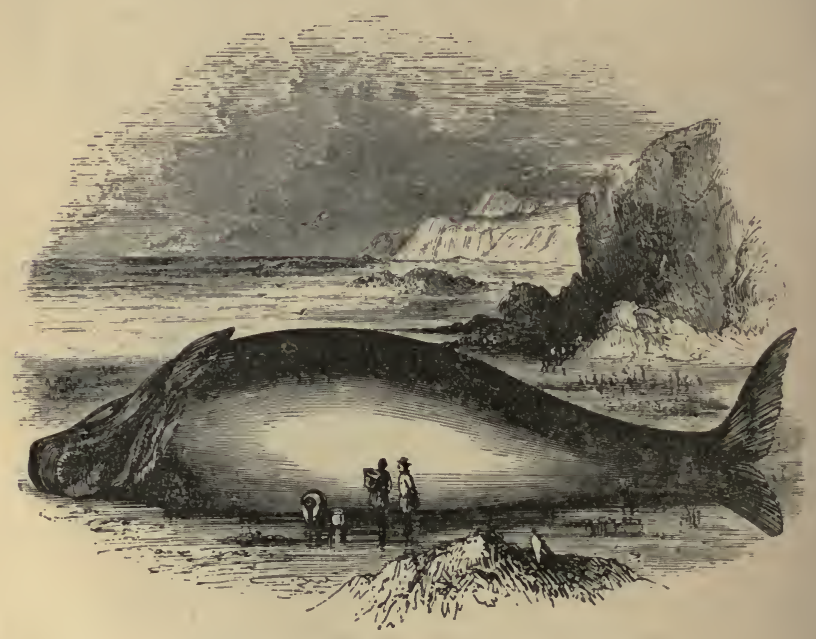

THE WHITE WHALE. (Beluga leucas.)

The White Whale, or Beluga, is included among the dolphins. The body is white, tinged with yellow, or 


\section{The White Whale.}

rose-colour, and its proportions are more agreeable than those of most of the cetacea. It measures from twelve to eighteen feet in length. .White Whales are gregarious, assembling in flocks or herds, and playing abont with rapid and graceful movements. The female has two young ones at a time, over which she watches with the greatest apparent affection. They follow all her movements, and do not quit her till they are nearly full grown. This Whale is generally confined to the northern latitudes, though one was taken in the Firth of Forth in 1815. The oil is of excellent quality, and the flesh eats like beef. According to some writers the flesh, when pickled with vinegar and salt, is as well tasted as pork; and thus the body, which is generally thrown away when the sailors have cut off the blubber, might be nsed by them as food. The internal membranes are used by the Greenlanders for windows, and the sinews for thread, and the fins and tail, when properly prepared, are said by some of the old writers to be good eating.

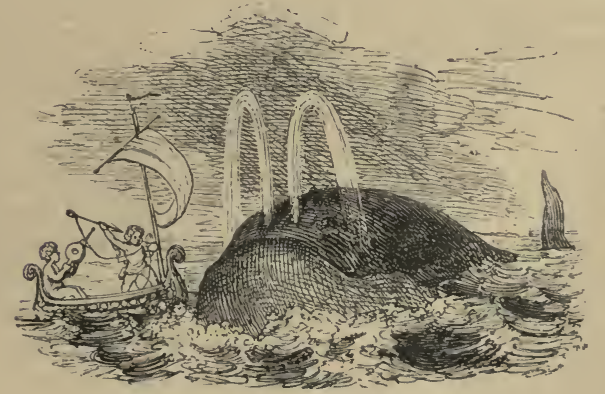


Fishes.

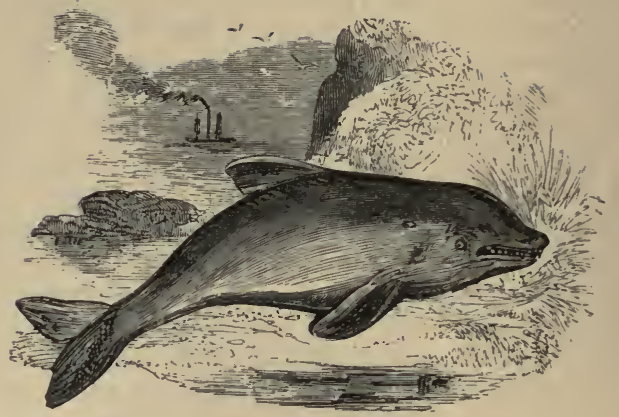

\section{THE PORPOISE. (Phoccena vulgaris.)}

The Porpoise is one of the cetacea, and nearly allied to the dolphin, but it has not the beaked snout of that animal. The length of the Porpoise, from the tip of the snout to the end of the tail, is from four to eight feet, and its girth about two feet and a half. The figure of the whole body is conical; the colour of the back is deep blue, inclining to shining black: the sides are grey, becoming white below. The tail is crescentshaped. There are only three fins, one on the back, and one on each shoulder. The eyes are very small. When the flesh is cut up, it looks very much like pork; but although it was once considered a sumptuous article of food, and is said to have been occasionally introduced at the tables of the old English nobility, it certainly has a disagreeable flavour. Porpoises live on small fish, and appear generally in large shoals, particularly in the mackerel and herring seasons, at which time they do very great damage to fishermen, by breaking and destroying the nets to get at their prey. Their motion in the water is a kind of circular leap; they dive deep, but soon again rise up in order to breathe. They are so eager in the pursuit of their prey, that they sometimes aseend large rivers, and have even been seen above West- 
minster Bridge. They have no gills, and blow out the water with a loud noise, which in calm weather may be heard at a great distance. They are seen nearly in all seas, and are very common upon the British coasts, where they sport with great activity, chiefly at the approach of a squall.

The Grampus (Phoccera Orca) is a species of Porpoise, and a decided and inveterate enemy to whales; which they attack in great flocks, fastening round them like so many bull-dogs, making them roar with pain, and frequently killing and devouring them. They are usually from twenty to twenty-five feet in length, and in general form and colour resemble the common Porpoise; but the lower jaw is considerably wider than the upper, and the body is somewhat broader and more deep in proportion. The back-fin sometimes measures six feet in length. In one of the poems of IIaller, a story (founded on fact) is recorded of the parental affection of these animals. A Grampus and her cub had got into an arm of the sea, where, by the desertion of the tide, they were enclosed on every side. 'The men oll shore saw their situation, and ran down upon them with such weapons as they could at the moment collect. The poor animals were soon wonnded in several places, so that all the immediately surrounding water was stained with their blood. They made many efforts to escape; and the old one, by superior strength, forced itself over the shallow into the ocean. But though in safety herself she would not leave her young one in the hands of assassins. She therefore again rushed in; and seemer resolved, since she could not prevent, at least to share the fate of her offspring. The story concludes with poetical justice; for the tide coming in, conveyed them both off in safety; and it is probable, from the great thickness of their skins, that their wounds hal not been very deep. 


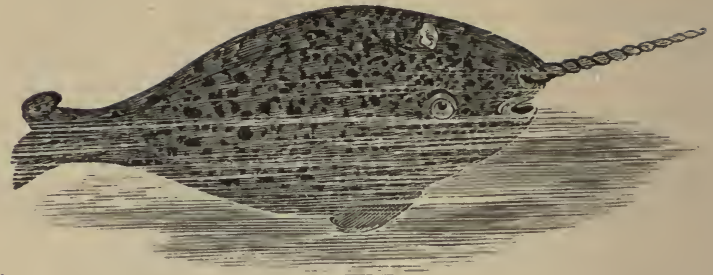

THE SEA-UNICORN, OR NARWHAL,

\section{(Monodon monoceros,)}

A MaRine animal, differing from all the cetacea, to which it belongs, in not having any teeth, properly so called, and in being armed with a horn of seven or eight feet in length, which projects from the head. This horn is white, spirally twisted throughont its whole length, and tapering to a point: it is harder, whiter, and more valuable than the ivory of the elephant, and was formerly in high repute for its supposed medical properties: small ones may be sometimes seen set with an elegant head as a walking-stick, and large specimens have been employed as bed-posts. The animal itself is from twenty to forty feet in length, and is occasionally found with two horns; indeed, there is always the germ of a second horn both in the male and female, though it is rarely developed in the former, and never in the latter, from which we may conjecture that the females trust entirely to the males for their defence, as we know is the case with several of the mammalia. When there is only one horn, it is always on the left side of the head; and when there are two, the horn on the left side is always larger than the other. This animal chiefly inhabits the arctic seas, and its food is said to consist of the smaller kinds of flat fish and other marine animals; its horn is useful in breaking away the ice when it wants to come up to breathe. The blubber supplies a small quantity of very fine oil, and the Greenlanders are very partial to the flesh. 


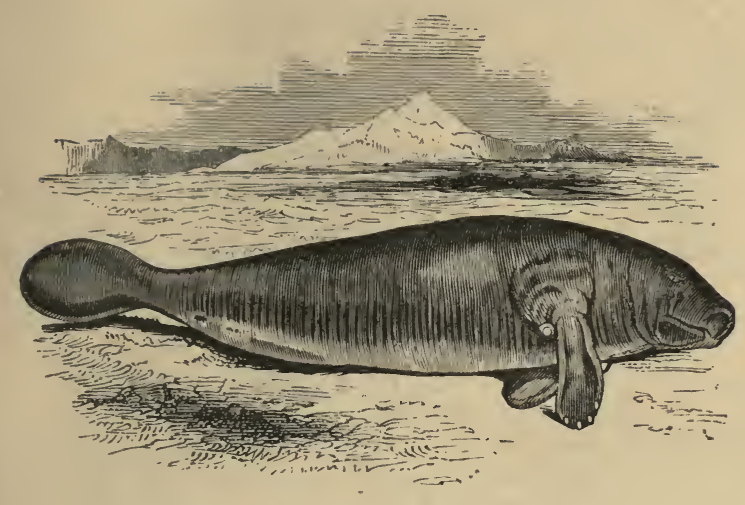

THE MANATEE, (Manatus Australis,)

Arso called the Sea Cow, is a great deal smaller than the other cetacea just described, and differs from them in its diet, which consists entirely of marine plants. It haunts the coasts and estuaries of South America, and measures nine or ten feet in length; its head is comparatively small, its jaws are furnished only with grinding-teeth, of which it has thirty-two, its skin is provided with a good many scattered bristles, and its flippers, $\circ$ or fins, with four small nails: This animal not unfrequently raises its head and shoulders out of the water, when it is said to have some resemblance to a human being, and it is probable that the distant view . of a nearly related species, the Lamantin, which inhabits the shores of Africa, may have given the ancients their first notion of the Mermaid. The Manatee is captured with harpoons, and its flesh is said to be very good. eating. When salted and dried it will keep for a year. It also furnishes an excellent oil, and its skin is used for making harness and whips. The Dugong (Halicore Dugong) is a very similar animal, inhabiting the eastern seas. It grows to a length of eighteen or twenty feet. 


\section{§ II. Cartilayinous Fishes.}

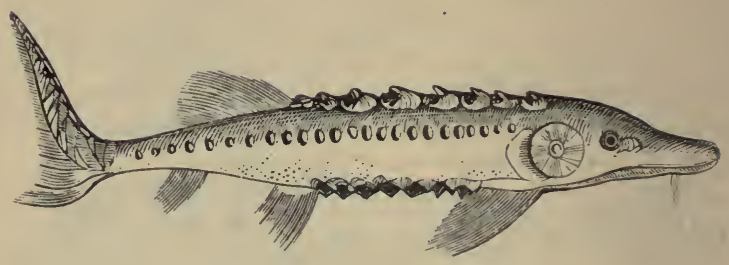

THE STURGEON, (Acipenser sturio,)

Sometimes grows to the length of eight or ten feet, and has been found to weigh five hundred pounds. It has a long, slender, pointed nose, small eyes, and a small month destitute of teeth, placed beneath and unsupported by the maxillæ; so that when the animal is dead, the mouth remains always open. The body is covered with five rows of large bony tubercles, and the under side is flat; it has one dorsal fin, two pectoral, two ventral, and one anal. 'The upper part of the body is of a muddy olive colour, and the under part silvery. The tail is bifurcated, the upper part being much longer than the under. Sturgeons subsist principally on insects and marine plants, which they find at the bottom of the water, where they mostly resort.

The Sturgeon annually ascends our rivers in the summer, particularly those of the Eden and Esk; and when canght, as it sometimes is, in the salmon-nets, it scarcely makes any resistance, but is drawn ont of the water apparently lifeless. One of the largest Sturgeons ever caught in our rivers was taken in the Esk a good many years ago: it weighed four hundred and sixty pounds. 'This fish is found in most of the rivers in Europe; it is also common in those of North Arerica, and especially in the lakes and rivers of Northern Asia.

The flesh of the Sturgeon is delicious; and it was so much valued in the time of the Emperor Severus, that it 
was brought to table by servants with coronets on their heads, and preceded by music. ' In London, every Sturgeon that is caught in the Thames is presented by the Lord Mayor to the Sovereign. 'The roe, when preserved with salt and oil, is called caviar, and is a favourite dish with many persons; the best is made in Russia. The flesh is also pickled or salted, and sent all over Europe. So prolific is this fish, that Catesby says the females frequently contain a bushel of spawn each; and Leeuwenhoek found in the roe of one of them no fewer than one hundred and fifty thousand million eggs!

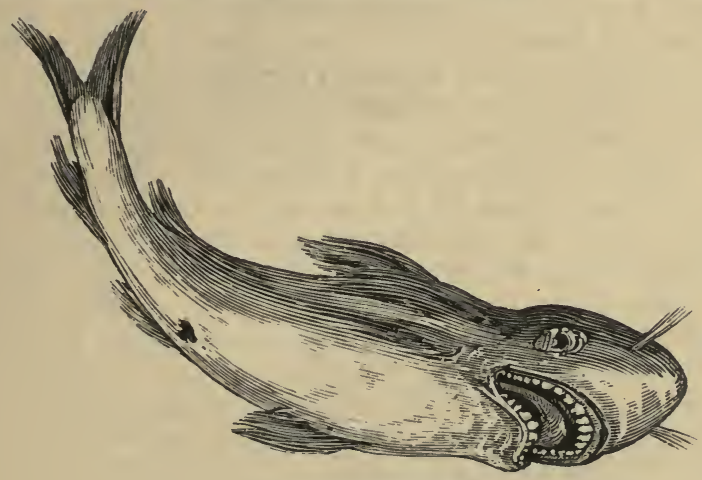

\section{THE SHARK.}

(Squalus carcharias, or Carcharias vulgaris.)

"Increasing still the terrors of the storms, His jaws horrific arm'd with threefold fate, Here dwells the direful Shark."

The Shark differs from the whale in not being one of the mammalia. - It is cold-blooded, and does not suckle its young. It has no lungs, and its mode of breathing is like that of other fishes, except that its gills are fixed, and the water escapes by five apertures on each side. 'The body of the Shark is elongated, and tapers gradually from the head to the tail, or is very slightly dilated in the middle. Its muzzle or nose is rounded, and projects very much over the mouth, the nostrils being situated $2 \mathrm{E}$ 
on the under side. The male shark is smaller than the female, and differs from it in appearance, in possessing two elongated appendages, one of which is attached to the hinder edge of each of the ventral fins. The purpose which these appendages are intended to serve is notknown. Some of the Sharks produce their young alive, and others lay eggs contained in horny cases of an oblong shape, with long tendrils at each of the four corners. After the young Sharks are hatched, these curious cases are often washed on shore, and are called mermaids' purses.

The bones of the Shark are like gristle, and very dif- ferent from those of most other fishes. Hence all the fishes with bones similar to those of the Shark are placed in a separate order, and called cartilaginous fishes.

The White Shark is sometimes found weighing nearly two thousand pounds. The throat is often large enough to swallow a man; and a human body has sometimes been found entire in the stomach of this tremendous animal. He is furnished with six rows of sharp triangular teeth, which amount in all to a hundred and forty-four, serrated on their edges, and capable of being erected or depressed at pleasure, owing to a curious muscular mechanism in the palate and jaws of the Shark. The whole body and fins are of a light ash-colour; the skin rough, and employed to smooth cabinet work, or to cover small boxes or cases. His eyes are large and staring, and he possesses great muscular strength in his tail and fins. Whenever he spies, from the deepest recesses of the sea, a man swimming or diving, he darts from the place, up to his prey, and if unable to take in the whole, or snatch away a limb, he follows for a long time the boat or vessel in which the more nimble swimmer has found a safe and opportune retreat: but seldom does he let any one escape his jaws, and get off entire. Sir Brook Watson was swimming at a little distance from a ship, when he saw a Shark making towards him. Struck with terror at its approach, he cried out for assistance. A rope was instantly thrown; but even while the men were in the act of drawing him up the ship's side, the monster darted after him, and, at a single snap, tore off his leg. 
We are told that, in the reign of Queen Anne, some of the men of an English merchant-ship, which had arrived at Barbadoes, were one day bathing in the sea, when a large Shark appeared, and was rushing upon them. A person from the ship called out to warn them of their danger; on which they all immediately swam to the vessel, and arrived in perfect safety, except one poor man, who was cut in two by the Shark, almost within reach of the oars. A comrade and intimate friend of the unfortunate victim, when he observed the severed trunk of his companion, was seized with a degree of horror that words cannot describe. The insatiate Shark was seen traversing the bloody surface in search of the remainder of his prey, when the brave youth plunged into the water, determining either to make the Shark disgorge, or to be buried himself in the same grave. He held in his hand a long and sharppointed knife, and the rapacious animal pushed furiously towards him; he had turned on his side, and had opened his enormous jaws, in order to seize him, when the youth, diving dexterously under, seized him with his left hand, somewhere about the upper fins, and stabbed him several times in the belly. The Shark, enraged with pain, and streaming with blood, plunged in all directions in order to disengage himself from his enemy. The crews of the surrounding vessels saw that the combat was decided: but they were ignorant which was slain, until the Shark, weakened by loss of blood, made towards the shore, and along with him his conqueror; who, flushed with victory, pushed his foe with redoubled ardour, and, by the aid of an ebbing tide, dragged him on shore. Here he ripped up the bowels of the animal, obtained the severed remainder of his friend's body, and buried it with the trunk in the same grave. This story, however incredible it may appear, is related in the History of Barbadoes, on the most satisfactory authority.

Had nature allowed this fish to seize his prey with as much facility as many others, the Shark tribe would have soon depopulated the vcean, and reigned alone in the vast regions of the sea, till hunger would have forced 
them to attack and ultimately destroy each other; but the upper jaw of this devouring animal, is so constructed as to offer, by its prominency, an impediment to the Shark's easily seizing his prey; and consequently when on the point of catching hold of anything, he is obliged to turn on one side, which troublesome evolution often gives the object of his pursuit time to escape. The flesh of this fish is of a disagreeable taste, and cannot be eaten with any kind of relish, except the part near the tail.

Twenty different species of this family are known, and the number of different families of the Shark tribe is very great.

\section{THE GREENLAND SHARK, (Selachus maximus,)}

Is another very voracious species; and one extremely difficult to kill. It is the great enemy of the whale, and devours the bodies of those left by the fishers. Its teeth are very small, pointed, and numerous. The snout is short. It is sometimes known as the Basking Shark.

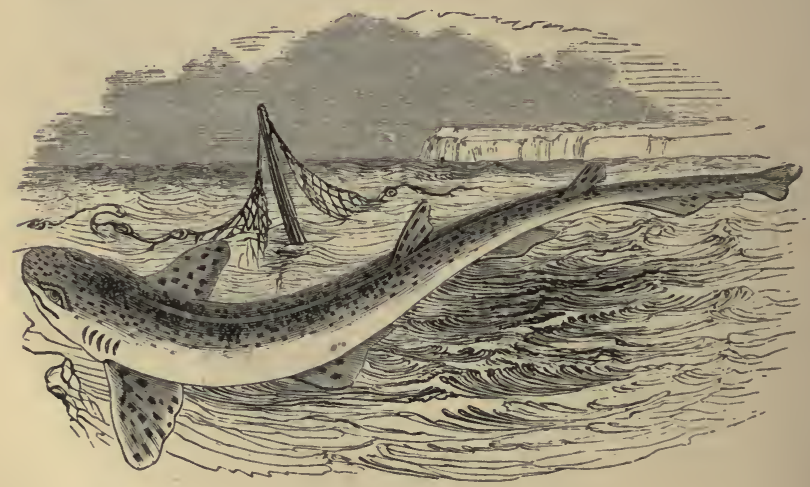

\section{THE DOG-FISHES}

ARE so excessively voracious, that they are altogether 
fearless of mankind. 'They follow vessels with great eagerness, seizing with avidity everything eatable that is thrown overboard; and have sometimes been known to throw themselves on fishermen, and on persons bathing in the sea. As, however, they are much smaller and weaker than most of the other Sharks, they do not always attack their enemies by open force, but generally have recourse to stratagem. 'They, consequently, conceal themselves in the mud, and lie in ambush, like the ray or skate-fish, (also one of the cartilaginous fishes,) until they have an opportunity of successfully attacking their prey. On the coasts of Scarborough, where haddocks, cod, and Dog-fish are in great abundance, the fishermen universally believe that the Dog-fish make a line or semicircle to encompass a shoal of haddocks and cod, confining them within certain limits near the shore, and eating them as occasion requires: they are therefore considered very destructive to this fishery. The flesh of the Dog-fish is hard and disagreeable; its skin, when dried, is made into the well-known shagreen, and from the liver a considerable quantity of oil may be extracted. Shagreen is also made from the skin of other cartilaginous fishes.

\section{THE HAMMER-HEADED SHARK, (Zygcena malleus,)}

Is a very curious kind, having a transverse head like that of a hammer, with an eye at each extremity; and the Fox-Shark, or Thresher (Carcharias vulpes), is remarkable for the enormous length of the upper lobe of its tail, with which it is able to strike with tremendous force. This fish is one of the great enemies of the whale. 


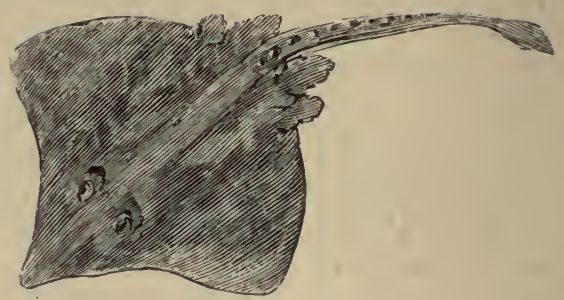

THE SKATE, (Raia batis,)

Is a species of the Ray, which was long disregarded in this country as a coarse, bad-tasted food, but which now appears upon our best tables. It is still, however, disregarded in Scotland and the north of England, where its flesh is principally used as a bait for other fish. On some parts of the continent, where these fish are caught in great abundance, they are dried for sale. The best season for Skate is the spring of the year. The body is broad and flat, of a brown colour on the back, and white on the lower side: the head is not distinct from the body, so that this fish and all belonging to this genus are apparently acephalous, or without a head. The peculiar form of this fish is owing to the large size of the pectoral fins, which extend from the head to the base of the tail, and are very wide in the middle, and so, combined with the sharpness of the snout, give the fish the shape known as rhomboidal. Dr. Monro has remarked, that in the gills of a large Skate there are upwards of one hundred and forty-four thousand subdivisions, or folds; and that the whole extent of this membrane, whose surface is nearly equal to that of the whole human body, may be seen by a microscope to be covered with a network of vessels, that are not only extremely minute, but exquisitely beautiful. 'The tail of the Skate is long, and generally prickly. The mouth is, as it were, paved with teeth, which are flat, and nearly square in shape. In the full-grown male the centre teeth are pointed, at least in some species. The eggs 
deposited by the female Skate are very similar to those laid by the shark, being in the shape of a square bag, with two horns at each end as here represented.

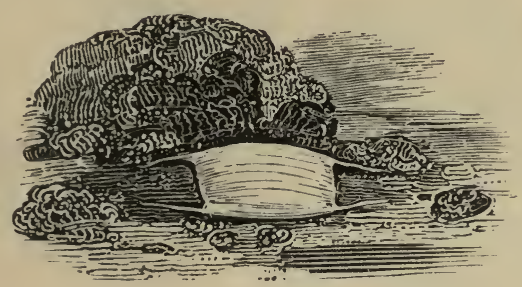

In this horny case the embryo is contained, and grows till it has acquired strength enough to burst through its prison. The colour of the bag is maroon, and the substance like thin brown parchment or leather. The female begins to drop these singly in the month of May, and continues to do so for several months, to the number of two or three hundred. In some parts of Cumberland they are called, by the common people, Skatebarrows, on account of their resemblance to the barrows which are carried by two men, and used for the conveyance of goods, \&c.

The Skate sometimes attains a very large size. Willoughby speaks of one so huge that it would have served one hundred and twenty men for dinner. Some naturalists are of opinion that these fishes are the largest inhabitants of the deep, and that only the smallest of them come near the surface of the water, the biggest remain ing flat at the bottom of the sea, where an unfathomable deep secures them against the wiles of man.

Nine species of the Skate or Ray are found on the British coasts. 


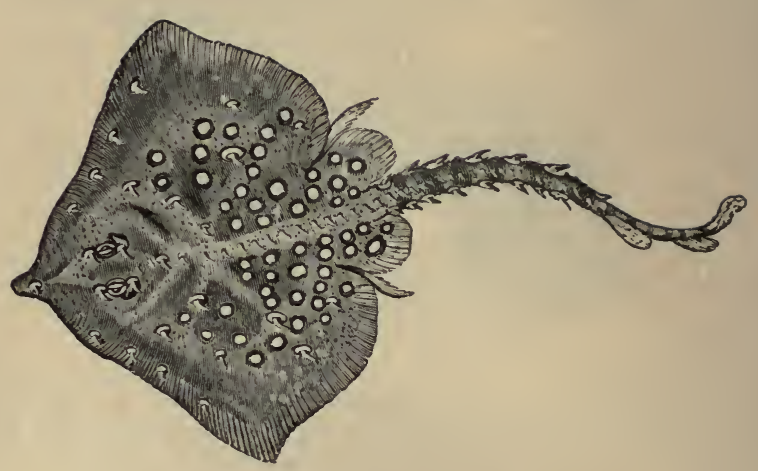

THE THORNBACK, (Raia clavata,)

RESEMBLES the Skate in its general appearance; the principal difference consists in the latter having sharp teeth, and a single row of spines upon the tail, while the former has blunt teeth, and several rows of spines both upon the back and tail. A Thornback was caught near the island of St. Kitt's, in the year 1634, which measured twelve feet in length, and nearly ten in width. It is sometimes eaten ir England, but as its flesh is inferior to that of the Skate, it is generally sold at a low price. The young ones, however, which have the denomination of Maids, are delicate eating. 


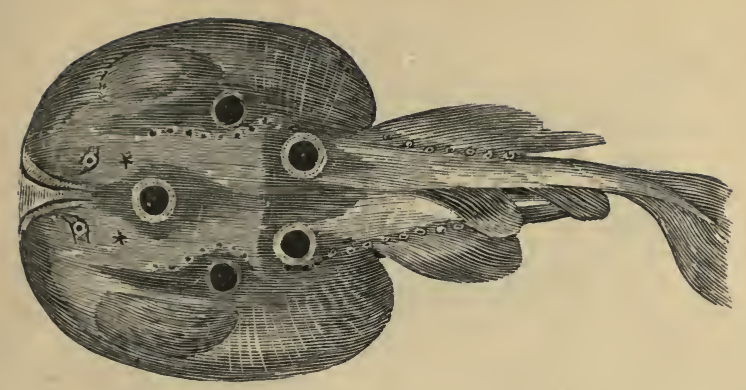

THE TORPEDO, OR ELECTRIC RAY.

\section{(Torpedo vulgaris.)}

This curious fish is capable of giving a violent shock, like that produced by the electrical machine, to the person who handles it. The body is nearly circular, and thicker than any other of the Ray kind, and is sometimes so large as to weigh between seventy and eighty pounds. The skin is smooth, of a dusky brown colour, and white underneath. The ventral fins form on each side, at the end of the body, nearly a quarter of a circle. The tail is short, and the two dorsal fins are near its origin. The mouth is small, and as in the other species, there are on each side below it five breathing apertures.

The shock imparted by the touch of the Cramp-fish, as the Torpedo is vulgarly called, is often attended with a sudden sickness at the stomach, a general tremor, a kind of convulsion, and sometimes a total suspension of the faculties of the mind. Such power of self-defence has Providence allowed this lumpish and inactive fish. Whenever an enemy approaches, the Torpedo emits from its body that benumbing shock, which incapacitates the other instantly, and it thereby gets time to escape. Nor is it merely a means of defence, but an advantage in other respects, for the Torpedo thus benumbs its prey, and easily seizes upon it. The animals thus killed are also supposed to become more easy of digestion. 


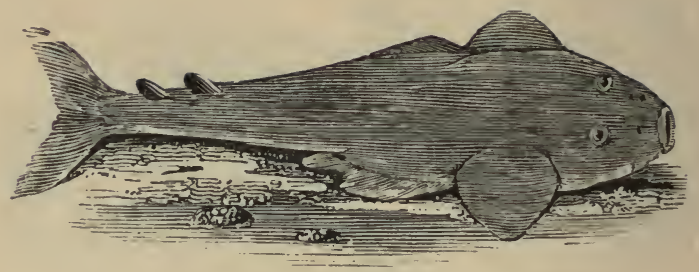

\section{THE MONK-FISH, OR ANGEL-FISH,}

\section{(Squatina Angelus,)}

Is very voracious, and feeds upon all kinds of flat fish, as soles, flounders, \&c. It is often caught on the coasts of Great Britain, and of such a size as to weigh sometimes a hundred pounds. This fish seems to be of a middle nature between the rays and sharks, and is called by Pliny the Squatina; a name which seems to bring this species near that of the skate. Its head is large ; the mouth has five rows of teeth, which are capable of being raised or depressed at pleasure. The back is of a pale ash-colour; the belly white and smooth. The shores of Cornwall are often frequented by this fish, but its flesh does not deserve to be praised, being hard, and of a very indifferent flavour.

It is supposed to have acquired the name of Angel-fish, from its extended pectoral fins bearing some similarity to wings, certainly, as Mr. Yarrell has remarked, not for its beauty ; and of monk-fish, from its rounded head, appearing as if enveloped in a monk's hood. The skin is rather rough, and is used for polishing, and other works in the arts. Mr. Donovan says that the Turks of the present day make shagreen of it. 


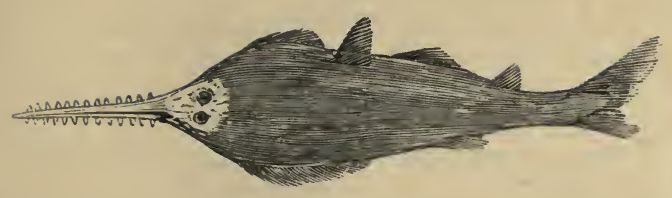

\section{THE SAW-FISH. (Tristis antiquorum.)}

THIs fish is found in the European and Atlantic seas. Its body is flattened anteriorly with four or five branchial openings below on each side; two spiracles behind the eyes; no anal fin; the head prolonged into a depressed bony beak, with strong pointed spines on each side; the lips are rough and sharp like a file, supplying the place of teeth. With its formidable weapon, which resembles a toothed saw, this fish attacks the largest whales, and inflicts very severe wounds. The colour of its body is of a greyish brown above, and paler below; its length about fifteen feet, the saw being about a third of the whole.

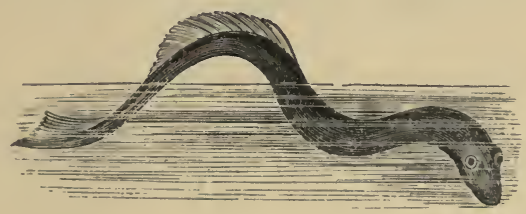

\section{THE LAMPREY. (Petromyzon marinus.)}

The Lamprey belongs to the last family of cartilaginous fishes, and is one of the lowest in the scale of vertebrated animals. It grows to the length of about three feet, although the British species, with which we are best acquainted, seldom exceeds twelve inches. To avoid the constant muscular exertions necessary to prevent their being carried away by the current, they attach themselves by the mouth to stones or rocks, and hence are called Petromyzon, Stone-suckers. The Lamprey, although 
no longer maintaining its ancient repute, is still considered a delicacy; those taken in the Severn being preferred to all others. Henry the First, as is well known, died of a surfeit of them; and in the reign of Henry the Fourth their importation was encouraged by immunities. The Roman epicures prized this fish so highly, that they bestowed the utmost care, and expended enormous sums in rearing them. Pliny tells us that Lucullus formed a fish-pond of such extent, that the fish it contained were, at his death, sold for four million sesterces. These polished barbarians sometimes threw a slave into the ponds where they kept their Muroence, or Lampreys, and considered that by this means they fattened the fish and gave them a superior flavour.

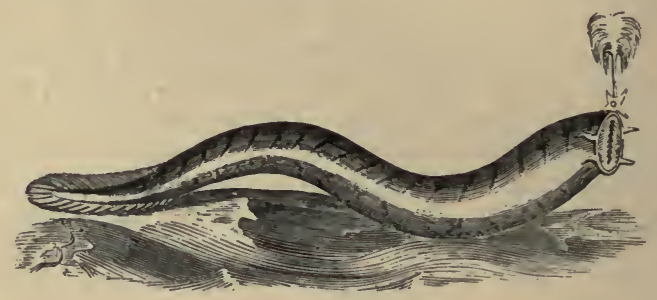

THE HAG-FISH, (Myxine glutinosa,)

A Cartilaginous Fish, which in its general appearance bears a near resemblance to the Lamprey. Its colour is dusky bluish above, and reddish towards the head and tail ; its length from four to six inches. The Hag-fish is remarkable for its total want of eyes; its mouth is of an oblong form, with two beards or cirri on each side, and on the upper part four. On the top of the head is a small spout-hole, furnished with a valve, by which it can be closed at pleasure. A double row of pores extends beneath the budy, from one extremity to the other, which on pressure exude a quantity of viscid fluid, which, when attacked by large fish, the Hag throws out, so as to cloud the surrounding element in such a manner as to render itself invisible to its assailants. "The habits of this fish are highly singular : it will enter the bodies of such 
fishes as it happens to find on the fishermen's hooks, and which consequently have lost the power of escaping its attack; and gnawing its way through the skin, will devour all the internal parts, leaving only the bones and the skin. If put into a large vessel of sea-water, it is said in a very short space to render the whole water so glutinous that it may easily be drawn out in the form of threads."

\section{§ III. Bony Fishes.}

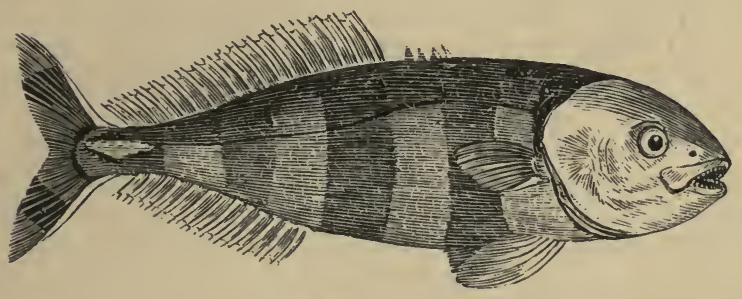

THE PILOT-FISH. (Naucrates ductor.)

THE body of this fish is long, the head compressed, rounding off in front, without scales as far as the operculum. The mouth is small, the jaws of equal length, and furnished with small teeth; the palate has a curved row of similar teeth in front, and the tongue has teeth all along. 'The colour varies in several species. The Pilotfish will frequently attend a ship during its course at sea for weeks, or even months together; and there are many curions stories told respecting its habits, in occasionally directing a shark where to find a good meal, and also in warning him how to avoid a dangerous bait. Whether this be true or not will be difficult to determine; but it is certain that this little fish is generally found in company with the shark, and picks up the smaller pieces of food which his predatory master drops, either by accident or design. 


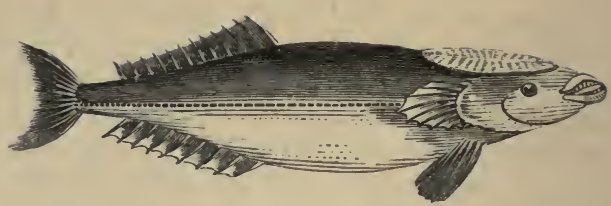

THE REMORA, OR SUCKING-FISH,

(Echeneis Remora,)

Resembles the herring; its head is thick, naked, depressed, and marked on the upper side with a curious sucker composed of numerous transverse, movable, serrated plates. The fins are seven in number; the under jaw is longer than the upper, and both furnished with teeth. This fish is provided by nature with a strong adhesive power, and, by means of the grooved space on its head, can attach itself to any animal or body whatever. We might suppose that a small fish with seven acting fins, armed like a galley with oars, would have a great power of motion in the water, but, for some reason unknown to us, Providence has contrived for him an easier way of travelling, by enabling him to fix himself to the hull of a ship, and even to the body of a larger animal than himself, as the whale, the shark, and others. Our forefathers believed that, small as he is, this fish had the power of arresting the progress of a ship in its fastest sailing by adhering to the bottom.

"The Sucking-îsh beneath, with secret chains, Clung to the keel, the swiftest ship detains. The seamen run confused, no labour spared, Let fly the shects, and hoist the topmast yard. The master bids them give her all the sails, To court the winds aud catch the coming gales. But, though the canvas bellies with the blast, And boisterous winds bend down the cracking mast, The bark stands firmly rooted in the sea, And will, unmoved, nor winds nor waves obey: Still, as when calms have flatted all the plain, And infant waves scarce wrinkle on the main. No ship in harbour moor'd so careless rides, When ruffling waters tell the flowing tides; Appall'd, the sailors stare, through strange surprise, Believe they dream, and rub their waking eyes." 


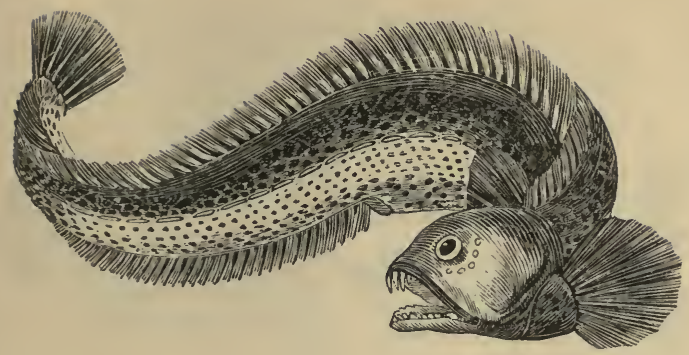

THE SEA-WOLF, OR SEA-BAT,

(Anarrhichas lupus,)

Is often caught in the European seas; and is about five or six feet in length, and has a larger and flatter head than the shark. The back, sides, and fins are of a bluish colour; the body is nearly white; the whole skin is smooth and slippery, without any appearance of scales. It is of a very voracious nature, and has a double row of sharp and round teeth, both in the upper and lower jaw. Its appetite, however, does not lead it to destroy fishes similar in shape to itself, as it is supposed to feed chiefly on crustaceous and molluscous animals, whose shells it breaks easily with its teeth. It is sometimes found in the northern seas exceeding twelve feet in length, and owes its name to its natural fierceness and voracity. The fishermen dread its bite, and endeavour as speedily as possible to strike out its fore-teeth, which are so strong, that they are capable of leaving an impression on an anchor. The fins nearest the head spread themselves, when the animal is swimming, in the shape of two large fans, and their motion contributes considerably to accelerate its natural swiftness. The flesh is good, and as it bears salting well it is an important article of food to the Icelanders, in whose seas this fish occurs in great abundance and of large size. 


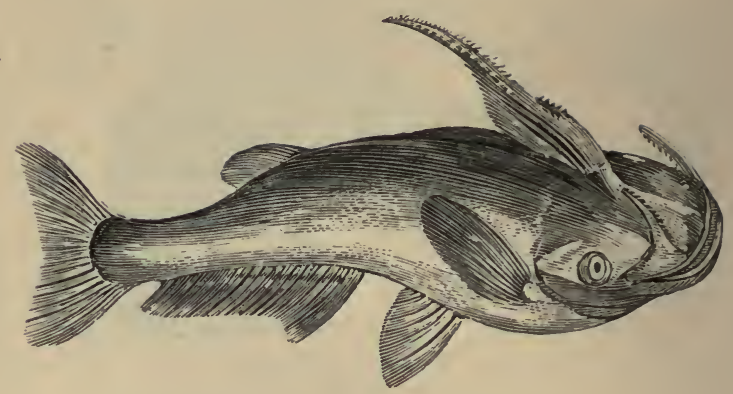

THE HORNED SILURE,

(Silurus, or Ageneiosus militaris,)

Grows to a large size, weighing sometimes three hundrer pounds, and measuring eight to ten feet in length, and two in breadth. It has a broad, flat, thin head; and the horns, which are on each side of the upper lip, are armed with short crooked spines, like teeth. A remarkable peculiarity in this fish is the dorsal fin, which is close to the head, and is long, stiff, dentated like the horns, and is, no doubt, an instrument of defence. In colour it resembles the eel, and has no scales; only one small fin on the back, and a forked tail ; its flesh is esteemed next to that of the eel, and has a similar flavour. This fish is a great depredator, and makes considerable havoc among the smaller inhabitants of the rivers and lakes which it inhabits. It is a native of the fresh waters of Asia. The Danube, and several other rivers of Germany, and the lakes of Switzerland and Bavaria contain numerous specimens of Silurus. 


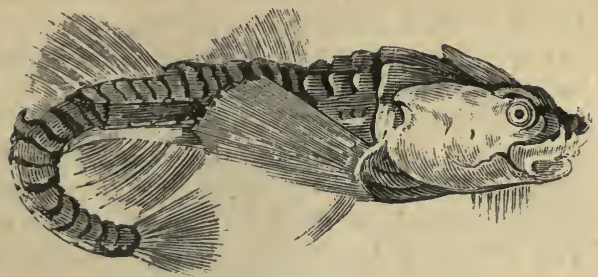

THE FATHER LASHER. (Cottus scorpius.)

'THe whimsical denomination of Father Lasher, given to this fish, cannot be easily accounted for; perhaps it may be ascribable to the quick and repeated lashings of its tail, when the fish is caught and thrown upon the sand. The length is about eight or nine inches, and it is usually found under stones, on the rocky coasts of our island. In Greenland these fish are so numerous, that the inhabitants depend largely upon them for their food. When made into soup, they are nutritive and wholesome. The head is large, and armed with spines, by which this fish combats every enemy that attacks it, swelling out its cheeks and gill-covers to an musual size. Its colour is a dull brown, mottled with white, and sometimes mixed with red; the fins and tail are transparent, and the lower part of the body a shining white.

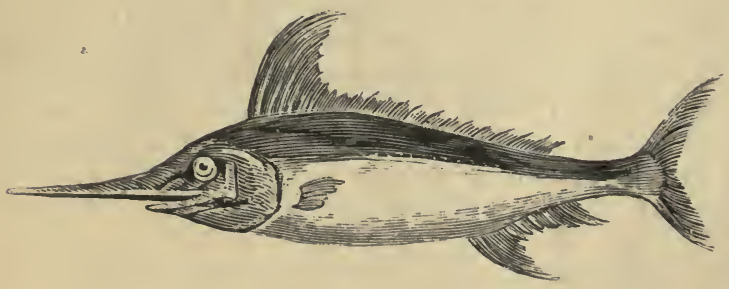

THE SWORD-FISH, (Xiphias gladius,)

Wнicr belougs to the mackerel family, has received its 
name from its long snout resembling the blade of a sword. It sometimes weighs above one hundred pounds, and is fifteen or even twenty feet in length. The body is of a conical form, black on the back, white under the body; the mouth large, with no teeth; the tail is remarkably forked. The Sword-fish is often taken off the coast of Italy, in the Bay of Naples, and about Sicily. They are struck at by the fishermen, and their flesh is considered as good as that of the sturgeon by the Sicilians, who seem to be particularly fond of it. Other European seas are not destitute of this curious animal.

The Sword-fish and the whale are said never to meet without coming to battle; and the former has the reputation of being always the aggressor. Sometimes two Sword-fishes join against one whale; in which case the combat is by no means equal. 'T'he whale uses his tail in his defence; he dives deeply into the water, head foremost, and makes such a blow with his tail, that, should it take effect, it kills the Sword-fish at a single stroke; but the latter is in general sufficiently adroit to avoid it, and immediately rushes at the whale. and buries its weapon in his side. When the whale discovers the Sword-fish darting upon him, he dives to the bottom, but is closely pursued by his antagonist, who compels him again to rise to the surface. The battle then begins afresh, and lasts until the Sword-fish loses sight of the whale, who is at length compelled to swim off, which his superior agility enables him to do. In piercing the whale's body with the tremendous weapon at his snout, the Sword-fish seldom inflicts a dangerous wound, not being able to penetrate beyond the blubber. This animal can drive its sword with such force into the keel of a ship, as to bury it wholly in the timber. A part of the bottom of a vessel, with the sword imbedded in it, is to be seen in the British Museum. 


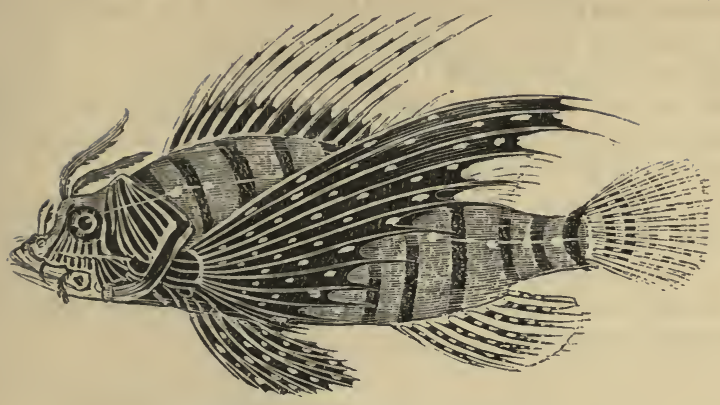

\section{THE FLYING SCORPION.}

How admirable is Nature! how extensive her power and how various the forms with which she has surrounded the united elements of animated matter! From the uncouth shape of the wallowing whale, of the unwieldy hippopotamus, or ponderous elephant, to the light and elegant form of the painted moth or fluttering humming-bird, she seems to have exhansted all ideas, all conceptions, and not to have left a single figure untried. The fish represented above is one of those, in the outlines and decorations of which appear the discordant qualities of frightfulness and beauty. Armed cap-à-pie, surrounded with spines and thorns bristling on his back, and fins like an armed phalanx of lance-bearers, and decorated on the body with yellow ribands, interwoven with white fillets, and on the purple fins of his breast with the milky dots of the pintado, the Sea Scorpion presents a very extraordinary contrast. His eyes, like those of which poets sang when celebrating the Nereids and Naiads, consist of black pupils, surrounded with a silver iris, radiated with alternate divisions of blue and black. 'The rays of the dorsal fin are spiny, spotted brown and yellow, conjoined below by a dark brown membrane, and separate above; the ventral fins are violet with white drops, and the tail and anal fins are a sort of tesselated work of blue, black, and white, united with the greatest symmetry, 
and not unlike those ancient fragments of Roman pavements often found in this island.

' $\mathrm{I}$ 'his variegated fish is found in the rivers of Amboyna and Japan; its flesh is white, firm, and well tasting, like our perch, but it does not grow so large; it is of a very voracious disposition, feeding on the young of other fish, some of which, two inches in length, have been found in its craw. The skin has both the appearance and smoothness of parchment. To the tremendous armour of its back, fins, and tail, this fish owes the name of Scorpion.

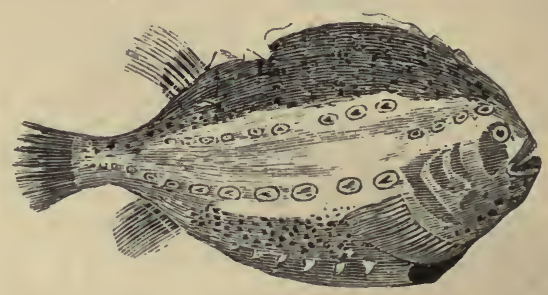

'THE LUMP-SUCKER, OR SEA-OWL.

(Cyclopterus lumpus.)

TuIs odd-shaped fish derives its name chiefly from the clumsiness of its form; it is also called the Cock Paddle. Its colour, when in the highest perfection, combines various shades of blue, purple, and rich orange; the abdomen is red; it has no scales, but on all sides sharp black tubercles, in shape like warts; on each side are three rows of sharp prickles, and on the back two distinct fins. The great resort of this species is in the Northern seas, about the coast of Greenland; it is also canght in many parts of the British seas during the spring season, when it approaches the shore for the purpose of depositing its spawn; and in the month of March it may be seen at the stalls of the Iondon markets. This unseemly fish is usually about a foot in length, and ten or more inches in breadth, and sometimes weighs seven pounds. The flesh is but indifferent. 
The Lump-sucker is very remarkable for the manner in which its ventral fins are arranged. They are united by a membrane so as to form a kind of oval and concave disc, by means of which it is enabled to adhere with great force to any substance to which it fastens itself. Pennant says, that, on throwing an individual of this species into a pail of water, it adhered so firmly to the bottom that, on taking the fish by the tail, the whole pail was lifted up, though it held some gallons.

In the Northern seas great numbers of the different species of Lump-suckers are devoured by the seals, who swallow all but the skins, quantities of which thus emptied are seen floating about in the spring months; it is said that the spots where the seals carry on their depredations can be readily distinguished by the smoothness of the water.

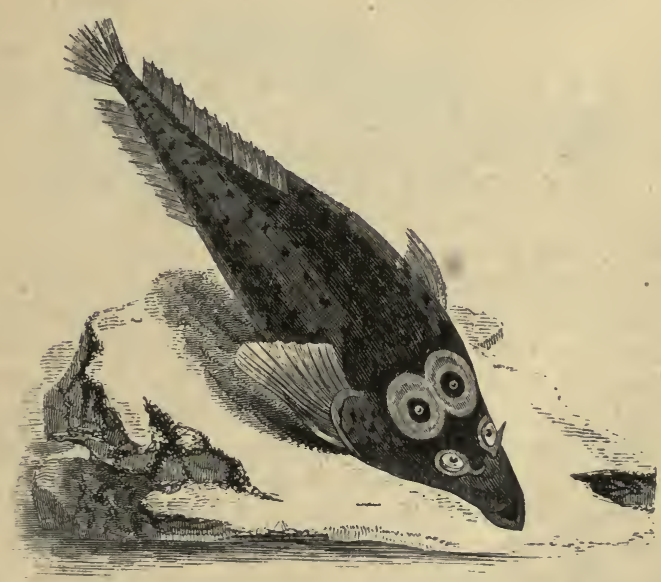

THE OCELLATED SUCKER, (Lepadogaster cornubicus,)

Another Malacopterygious fish, a relative of the Lump. 
sucker, and chiefly remarkable for the singular appendage observable on its head. It possesses similar tenacity of suction. The utility of this faculty to animals inhabiting the rocky shores and turbulent seas of Greenland is sufficiently obvious.

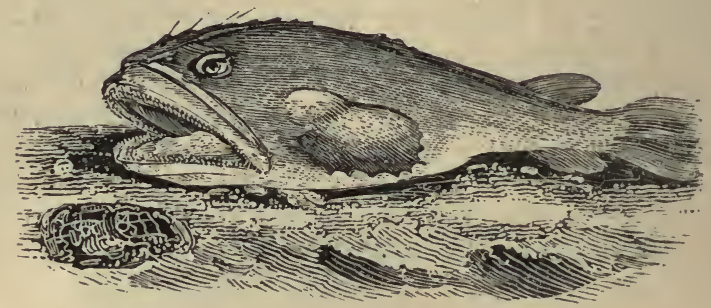

THE ANGLER. (Lophius piscatorius.)

This extraordinary fish is occasionally met with on our coasts, and is commonly known by the names of the Fishing Frog, Toad Fish, and Sea Devil. In shape it is the most uncouth and unsightly of the piscatory tribe, resembling the frog in its tadpole state. It grows to a large size. A specimen taken in the sea, near Scarborough, was between four and five feet in length, the head considerably larger than the body, round at the circumference, flat above; the mouth is of a prodigious size, being a yard in width, and armed with sharp teeth. It lives, as it were, in ambush at the botton of the sea. and by means of its fins stirs up the mud and sand, so as to conceal itself from other fishes on whom it preys. The manner in which it procures its prey is very extraordinary, the peculiarity of its construction forbidding the possibility of rapid movement. T'wo long tough filaments are placed above the nose, each of them furnished with a thin appendage, closely resembling a fishing-line when baited and flung out. The back is provided with three others, united by a web, and forming the first dorsal fin. Pliny notices these remarkable appendages, and explains their use. "The Fishing 
Frog," says he, "puts forth the slender horns situated beneath his eyes, enticing by that means the little fish to play around till they come within his reach, when he springs upon them." But it is not only the lesser inhabitants of the water that the Angler ensnares! Codfish of good size are often found in his stomach, and he occasionally seizes upon fishes as they are being drawn up by the line. Mr. Yarrell mentions an instance of an Angler attacking a conger-eel under these circumstances: the eel wriggled through the branchial aperture of his captor, and both were drawn up together.

Cicero also notices this extraordinary creature, in his Treatise on the Nature of the Gods. He observed its wonderful construction when musing on the shores of Sicily.

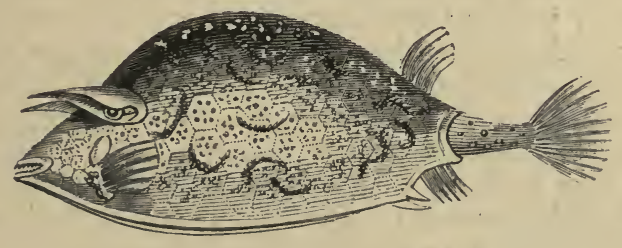

'THE FOUR-HORNED TRUNK FISH.

(Ostracion quadricornis.)

THESE singular fishes are distinguished from most others by the bony covering which envelopes them. The head and body are covered with plates of bone, forming an inflexible cuirass, and leaving exposed only the tail, fins, mouth, and a portion of the gill opening. They have no ventral fins, and the dorsal and anal are placed far back. Their liver is large, and abounds with oil. The Trunk-fish is a native of the Indian and American seas. Some of the species are considered excellent eating. 


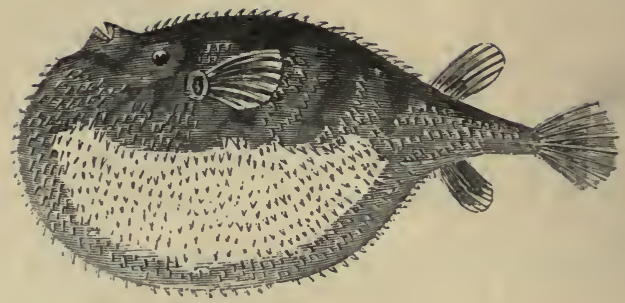

THE GLOBE FISH, (Tetraodon hispidus,)

Is an oblong fish, inhabiting the seas of Carolina, and endowed with an extraordinary power of swelling its under surface into a large globe. This sudden enlargement not only alarms the enemies of the Tetrodon, but prevents them from making good their hold, by presenting to their grasp little more than an inflated bag. It is also covered with spines, which merely adhere to the skin, and are capable of being erected on any sudden emergency; thus giving to an innocent and defenceless creature a most formidable appearance.

When inflated, they roll over on their backs, floating in this position, without any power of directing their course. Some species are reckoned poisonous. One is electrical, (Tetraodon lineatus,) and is found in the Nile; when left on shore by the inundations, it always inflates its body, becomes dried in this condition, and is then picked up by the children, and used as a ball. 


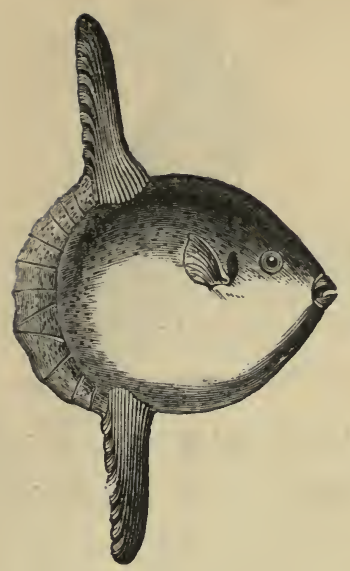

\section{THE SUN FISH, (Orthagoriscus mola,)}

APPEARs like the fore part of the body of a large fish, which has been amputated in the middle. The mouth is small, with two broad teeth only in each jaw. Its nearly circular form, and the silvery whiteness of the sides, together with their brilliant phosphorescence during the night, have obtained for it very generally the appellations of sun or moon fish. While swimming, it turns round like a wheel, and sometimes floats with its head above water, when it appears like a dying fish. It grows to a large size; sometimes being four or five feet in length, and weighing from three to five hundred pounds. The back of this curious marine animal is of a rich blue colour. It frequents the coasts of both the ancient and new continent, and has been found on the shores of. England. 


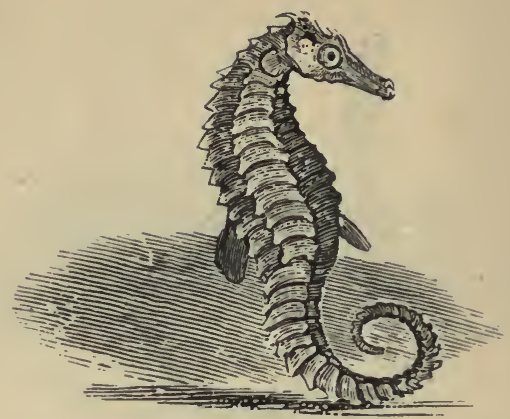

THE CAVALLO-MARINO, OR SEA-HORSE.

\section{(Hippocampus brevirostris.)}

THIs is a small fish, of a curious shape. The length is from six to ten, and sometimes twelve, inches: the head bears some resemblance to that of a horse, whence originates its name. A series of longitudinal and transverse ridges run from the head to the tail, which is spirally curved and prehensile.

The following account of two specimens taken alive at Guernsey, in June, 1835, by F. C. Lukis, Esq., is extracted from Yarrell's "British Fishes." These creatures were kept about twelve days in a glass vessel, and their actions were equally novel and amusing. "An appearance of search for a resting-place induced me," says Mr. Lukis, " to consult their wishes, by placing seaweed and straws in the ressel: the desired effect was obtained, and has afforded me much to reflect upon in their habits. They now exhibit many of their peculiarities, and few subjects of the deep have displayed, in prison, more sport or more intelligence.

"When swimming about, they maintain a vertical position; but the tail is ready to grasp whatever meets it in the water, quickly entwines in any direction round the weeds, and, when fixed, the animal intently watches the surfounding objects, and darts at its prey with the greatest dexterity. 
"When the animals approach each other, they often twist their tails together, and struggle to separate or attach themselves to the weeds: this is done by the under part of their cheeks or chin, which is also used for raising the body when a new spot is wanted for the tail to entwine afresh. The eyes move independently of each other, as in the chameleon, and this, with the brilliant changeable iridescence about the head, and its blue bands, forcibly reminds the observer of that animal."

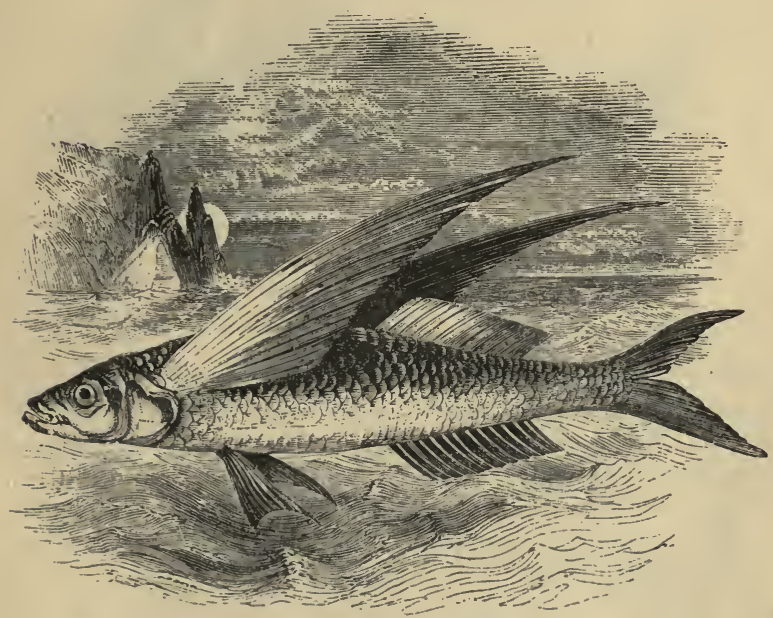

THE FLYING FISH OF THE OCEAN.

\section{(Exoccetus volitans.)}

THis fish has a slender body, a projecting under-lip, and very large and prominent eyes. The ventral fins are small, but the pectoral fins are so long and wide as to answer the purpose of wings, and aided by them the fish is enabled to rise out of the water, and support itself in the air. It must not be supposed, however, that the Flying-fish can soar like a bird; on the contrary, it can 
only spring from the water to a considerable height (sometimes as much as twenty feet), and fly about a hundred and fifty, or two hundred yards; most commonly, however, it does not rise above two or three feet from the water, and remains fluttering over the surface for about a hundred yards, when it again drops into its native element. There is another Flying-fish (Exocoetus exiliens) in the Mediterranean.

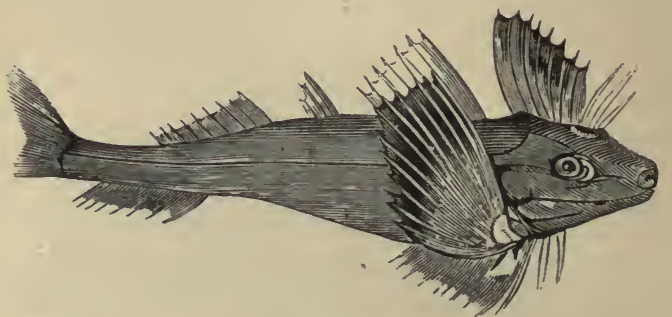

THE GURNARD. (Trigla cuculus.)

THIs genus is divided into several species. The Red Gurnard has fins and body of a bright red colour; and the head is large, and covered with strong bony plates. The eyes are large, round, and vertical; the mouth is large; and the palate and jaws are armed with sharp teeth. The gill-membrane has seven rays. The back has a longitudinal spinous groove on each side. There are slender articulate appendages at the base of each pectoral fin. This fish is not unfrequently met with on the southern shores of England; and is often seen $e x-$ posed in the fish-markets of the maritime towns of Dorset and Devonshire, as well as in Cornwall. It is a pleasant-tasting fish, when properly stuffed and baked, the flavour being similar to that of the haddock.

Whilst in the water, the colours of the Red Gurnard are almost inconceivably brilliant and beautiful, particularly in the broad glare of sunshine, as they then vary, in the most pleasing manner, with every motion of the fish. 
'The Grey Gurnard (Trigla gurnardus) usually measures from one to two feet in length. 'The extremity of the head, in front, is armed on each side with three short spines. 'The forehead and the covers of the gills are silvery; the latter being finely radiated. The body is covered with small scales; the upper parts are of a deep grey, spotted with white and yellow, and sometimes with black; and the lower parts silvery. About the months of May and June, the Grey Gurnards ap proach the shores in considerable shoals, for the purpose of depositing their spawn in the shallows; at other times they reside in the depths of the ocean, where they have a plentiful supply of food in crabs, lobsters, and other shell-fish, on which it is supposed they for the most part feed. They are occasionally found on the shores of Great Britain and Ireland, in the spawning season.

The Lucerna is caught in the Mediterranean Sea, and is of a very curious shape; its fins about the gills being so large, and spreading so much like a fan on each side, that they appear somewhat like wings. The tail is bifid, and the scales very small. The flesh is esteemed among the Italians, and the Lucerna is often seen in the fish-markets of Naples, Venice, and other towns on the sea-shore. This fish much resembles the Father Lasher and the Gurnard ; and it is called Lucerna because it shines in the dark.

The Flying Gurnard (Dactyloptera Mediterranea), which is the commonest flying-fish of the Mediterranean Sea, is about a foot long; it is brown above, reddish below, and has blackish fins spotted with blue. The pectoral fins with which it supports itself in the air are of immense extent. On each operculum there is a long and pointed spine, with which the fish can inflict severe wounds. 


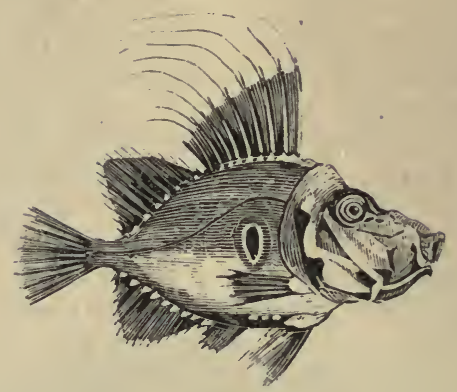

\section{THE JOHN DORY. (Zeus faber.)}

Ir would be an inexcusable neglect to pass this fish unnoticed, not on account of its disputing with the haddock the honour of having been pressed by the fingers of the apostle, nor of its having been trodden upon by the gigantic foot of St. Christopher, when he carried on his shoulders a divine burden across an arm of the sea, but for the excellence of its flesh. It has been for some years in such favour with our epicures, that one of them, a comedian of high repute (Quin), took a journey to Plymouth merely to eat this fish in perfection. Its body presents the shape of a rhomboid, but the sides are much compressed; the mouth is large, and the snout long, composed of several cartilaginous plates, which wrap and fold one over another, in order to enable the fish to catch its prey. The colour is a dark green, marked with black spots, with a golden gloss, whence the name originated. They inhabit the coasts of England, and particularly Torbay, whence they are sent to the fish-markets of London.

When the Dory is taken alive out of the water, it is able to compress its internal organs so rapidly that the air, in rushing through the openings of the gills, produces a kind of noise somewhat like that which, on similar occasions, is emitted by the gurnards. 


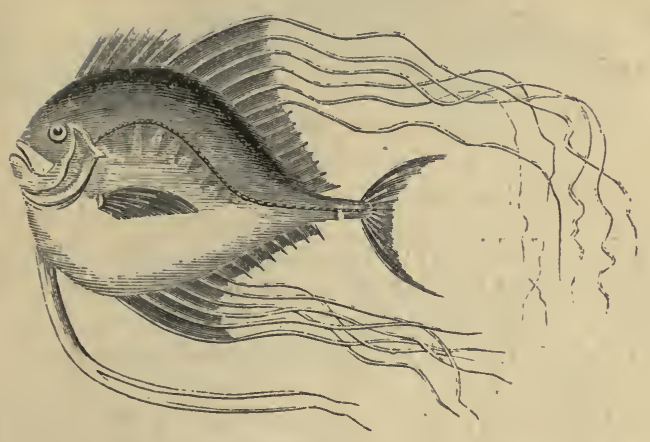

THE BLEPHARIS. (Blepharis ciliaris.)

This species of the Dory is of a bright silver colour, with a cast of bluish-green on the back. Several of the last rays, both of the dorsal and anal fin, extend beyond the membrane, reaching even farther than the tail itself. It has been supposed that the smaller kind of fishes may be attracted with these long flexible filaments, and mistake them for worms, while the Zeus, concealed among the sea-weeds, lies in wait for its prey. It is a native of the Indian seas.

\section{THE OPAH, OR KING FISH. (Lampris guttatus.)}

This is a most splendid fish, of a fine green colour on the back, and yellowish green on the belly. The back and sides exhibit brilliant purplish and golden tints, the whole surface is covered with numerous white spots, and the fins are of a beautiful vermilion colour; so magnificent is its costume, that it has been justly remarked that it looks " like one of Neptune's lords dressed for a court day." The King Fish is found apparently in the seas of all parts of the world; it is nowhere common, but seems to be more abundant in warm climates. 


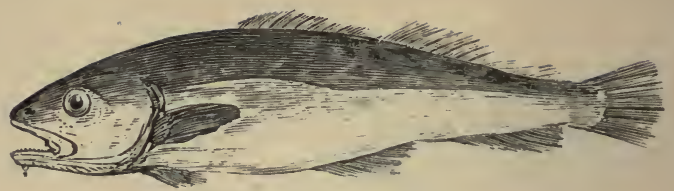

\section{THE COD-FISH, (Gadus morrhua,)}

Is a noble inhabitant of the seas; not only on account of its size, butalso for the goodness of its flesh, either fresh or salted. The body measures sometimes above three, and even four feet in length, with a proportionable thickness. The back is of a brown olive colour, with white spots on the sides, and the lower part of the body is entirely white. The eyes are large and staring. The head is broad and fleshy, and esteemed a delicious dish.

The fecundity of all fishes must be an object of the greatest astonishment to every observer of nature. In the year 1790, a Cod-fish was sold in Workington market, Cumberland, for one shilling: it weighed fifteen pounds, and measured two feet nine inches in length, and seven inches in breadth: the roe weighed two pounds ten ounces, one grain of which contained three hundred and twenty eggs. The whole, therefore, might contain, by fair estimation, three million nine hundred and four thousand four hundred and forty eggs. From such a trifle as this we may observe the prodigious value of the fishing trade to a commercial nation, and hence draw a useful hint for increasing it; for, supposing that each of the above eggs should arrive at the same perfection and size, its produce would weigh twenty-six thousand one hundred and twenty-three tons; and consequently would load two hundred and sixty-one sail of ships, each of one hundred tons burden. If each fish were brought to market, and sold as the original one, for one shilling, the produce then would be one hundred and ninety-five thousand pounds; that is to say, the first shilling would produce twenty times one hundred and ninety-five thousand, or three million nine hundred thousand shillings.

In the European seas, the Cod begins to spawn in 
January, and deposits its eggs in rough ground among rocks. Some continue in roe until the beginning of April. Cod-fish are reckoned best for the table from October to Christmas. The air-bladders, under the name of sounds, are pickled, and sold separately.

The chief fisheries for Cod are in the Bay of Canada, on the great bank of Newfoundland, and off the isle of St. Peter, and the isle of Sable. The vessels frequenting these fisheries are from a hundred to two hundred tons burden, and will each catch thirty thousand Cod, or more. The best season is from the beginning of February to the end of April. Each fisherman takes only one Cod at a time, and yet the more experienced will catch from three to four hundred in a day. It is a fatiguing work, owing particularly to the intense cold they are obliged to suffer during the operation.

Cod frequently grow to a very great size. The largest that is known to have been caught in this kingdom was taken at Scarborough, in the year 1775 ; it measured five feet eight inches in length, and five feet in circumference, and weighed seventy-eight pounds. The usual weight of this fish is from fourteen to forty pounds.

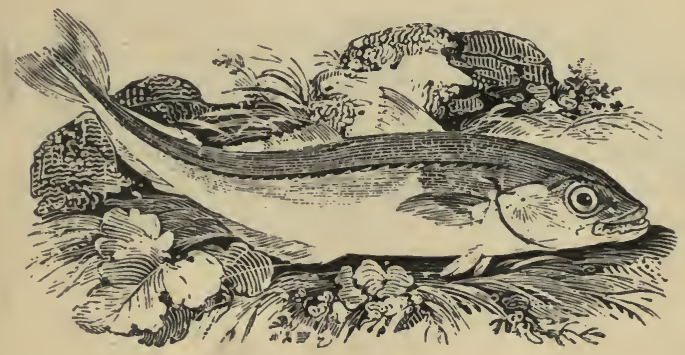

THE HADDOCK, (Gadus ceglefinus,)

Is much less in size than the cod-fish, and differs somewhat from it in shape; it is of a bluish colour on the back, with small scales; a black line is carried on from the upper corner of the gills on both sides down to the tail ; in the middle of the sides, under the line a little 
beneath the gills, is a black spot on each shoulder, which resembles the mark of a man's finger and thumb; from which circumstance it is called St. Peter's fish, alluding. to the fact recorded in the seventeenth chapter of St. Matthew: "Go thou to the sea, and cast an hook, and take up the fish that first cometh up; and when thou hast opened his mouth, thou shalt find a piece of money; that take, and give unto them for me and thee." $\Lambda$ nd while St. Peter held the fish with his fore-finger and thumb, it is fabled, that the skin received, and preserved to this day, the hereditary impression.

Haddocks migrate in immense shoals, which usually arrive on the Yorkshire coast about the middle of winter. These shoals are sometimes known to extend from the shore nearly three miles in breadth, and in length from Flamborough Head to Tynemouth Castle, a distance of fifty miles ; and, perhaps, even farther. An idea of the number of Haddocks may be formed from the following circumstance : three fishermen, within a mile of the harbour of Scarborough, frequently loaded their boat with these fish twice a day, taking each time a ton weight of them!

'The flesh of the Haddock is harder and thicker than that of the whiting, and not so good; but it is often brought upon the table, either broiled, boiled, or baked, and is by many much esteemed. The Haddocks caught on the Irish coast, near Dublin, are unusually large, and of a fine flavour, and unite to the firmness of the turbot much of its sweetness. They are in season from October to January. 


\section{The Whiting-The Ling.}

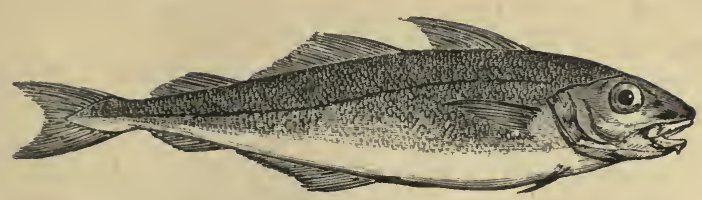

THE WHITING,

(Gadus Merlangus, or Merlangus vulgaris,)

Is seldom more than twelve inches, in length, and of a slender and tapering form. The scales are small and fine. The back is silvery, and when just taken out of the sea reflects the rays of light with great lustre and gloss. The flesh is light, wholesome, and nourishing; and is often recommended to sick or convalescent patients, when other food is not approved of. The Whiting is found on the coasts of England, and is in its proper season from August to February.

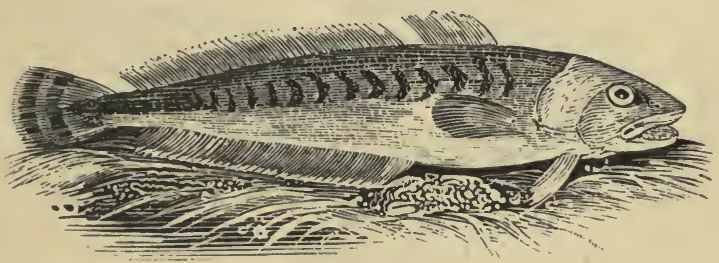

THE LING, (Lota molva,)

Is usually from three to four feet in length, though some have been caught much larger. The body is long, the head flat, the teeth in the upper jaw small and numerous, with a small beard on the chin; its dorsal and anal fins are very long.

These fish abound on the coasts of Great Britain and Ireland, and great quantities are salted for home con- 
sumption and exportation. On the eastern coasts of England they are in their greatest perfection from the beginning of February to the end of May. They spawn in June: at this season, the males separate from the females, who deposit their eggs in the soft oozy ground at the mouth of large rivers.

In a commercial point of view, the Ling may be considered a very important fish. Nine hundred thousand pounds weight are annually exported from Norway. In England, these fish are caught and cured in somewhat the same manner as the cod. Those which are caught off the shores of America are by no means so much esteemed as those which frequent the coasts of Great Britain and Norway; and the Ling in the neighbourhood of Iceland are so bad, that the inhabitants are unable to find a sale for them in any country except their own. 'The roe and air-bladders, or sounds of the Ling, are pickled, and sold separately.

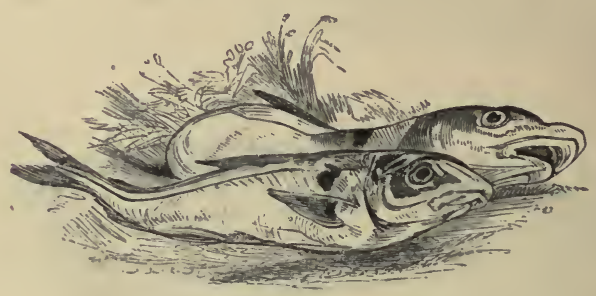

THE HAKE, (Gadus merluccius,)

Is a coarse fish, nearly allied to the Ling, and is caught in great abundance on the Devonshire and Cornwall coast. It is also found on the coasts of Ireland and Scotland, where it is called stock-fish, and is often confounded with cod. 


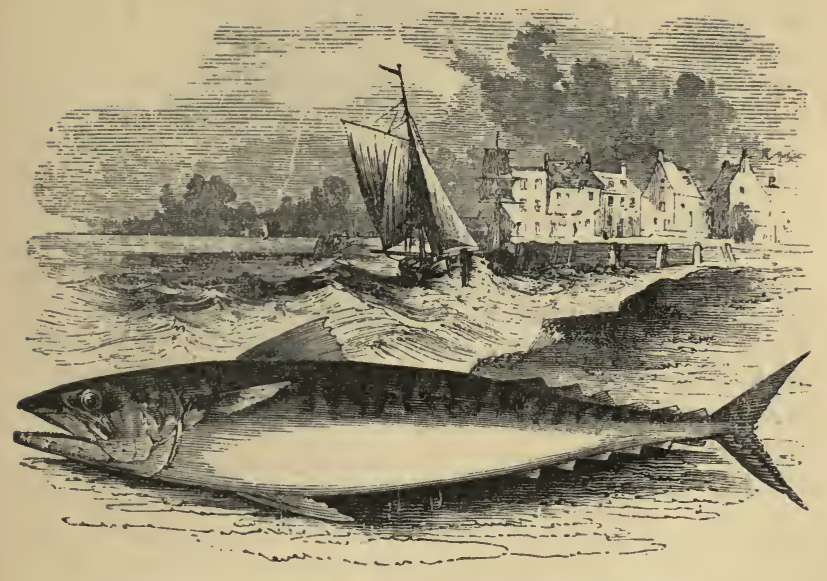

THE MACKEREL, (Scomber Scomber,)

Is taken and well known in all parts of the world. It is usually about a foot or more in length : the body is thick, firm, and fleshy, slender towards the tail; the snout sharp, the tail forked, the back of a lovely green, beautifully variegated, or, as it were, painted with black strokes; the under part of the body is of a silvery colour, reflecting, as well as the sides, the most elegant tints of the opal and the mother-of-pearl. Nothing can be more interesting and pleasing to the eye than to see Mackerel, just caught, brought on shore by the fishermen, and spread, with all their radiancy, upon the pebbles of the beach, at the first rays of the rising sun; but when taken out of their element, they quickly die.

Mackerel visit our shores in vast shoals; but, from being very tender and unfit for long carriage, they are found less useful than other gregarious fish. The usual bait is a bit of red clath, or a piece of the tail of the Mackerel. The great fishery for them is in some parts of the south and west coasts of England: this is of such an extent as to employ, in the whole, a capital of nearly 
two hundred thousand pounds. The fishermen go out to the distance of several leagues from the shore, and stretch their nets, which are sometimes miles in extent, across the tide during the night. A single boat has been known to bring in, after one night's fishing, a cargo that has been sold for nearly seventy pounds. The roes of the Mackerel are used in the Mediterranean for caviar. In Cornwall, and also in several parts of the continent, Mackerel are preserved by pickling and salting; and in this state possess a flavour somewhat like that of the salmon. Their voracity has scarcely any bounds; and when they get among a shoal of herrings, they will make such havoc as frequently to drive it away. Mackerel are in season from March to June.

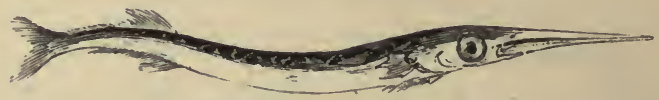

\section{THE GAR-FISH, (Belone vulgaris,)}

OF which the figure above is an exact representation, is of a very extraordinary form. The body, in shape and colour, is not unlike that of a mackerel, but is much more elongated, and the jaws are protracted into a kind of lance, nearly half as long as the rest of the body. It is vulgarly supposed that this fish leads the phalanxes of mackerel through the regions of the deep; and, like a faithful and experienced pilot, traces their journey, points out their dangers, and conducts them to their destination. A curious singularity of this creature is, that its bones are of a bright green colour; the flesh is not so firm nor of so good a flavour as that of the mackerel, but it sells pretty well whenever it comes to market. 


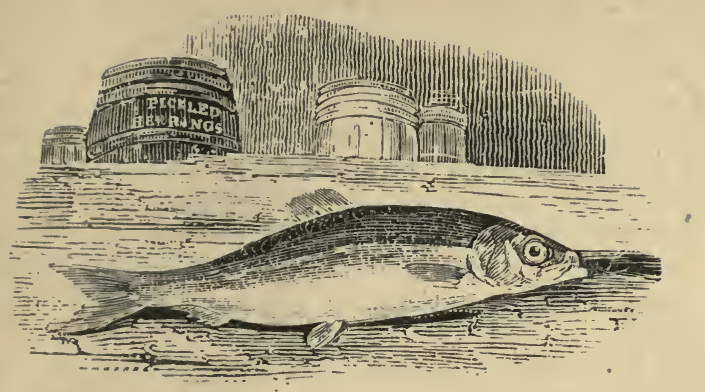

THE HERRING. (Clupea Harengus.)

'THIs fish is somewhat like the mackerel in shape, as well as in delicacy of taste, although it differs much in flavour. It is about nine or ten inches long, and about two and a half broad, and has blood-shot eyes; the scales large and roundish ; the tail forked; the body of a fat, soft, delicate flesh, but more rank than that of the mackerel, and therefore less wholesome. Yet some people are so very ford of it, that they call the Herring the King of Fishes. They swim in shoals, and spawn once a year, about the autumnal equinox, at which time they are the best. They come into shallow water to spawn, like the mackerel; and hence they periodically visit our coasts, retiring again to the deep waters when the spawning season is over.

The fecundity of the Herring is astonishing. It has been calculated that if the off'spring of a single pair of Herrings could be suffered to multiply unmolested and undiminished for twenty years, they would exhibit a bulk ten times the size of the earth. But, happily, Providence has contrived the balance of nature by giving them innumerable enemies. All the monsters of the deep find them an easy prey; and, in addition to these, immense flocks of sea-fowl watch their outset, and spread devastation on all sides.

In the year 1773, the Herrings for two months were in such immense shoals on the Scotch coasts, that it 
appears from tolerably accurate computations, no fewer than one thousand six hundred and fifty boat-loads were taken in Loch 'Torridon in one night. These would, in the whole, amount to nearly twenty thousand barrels.

This fish is prepared in different ways, in order to be kept for use through the year. The white, or pickled Herrings, are washed in fresh water, and left the space of twelve or fifteen hours in a tub full of strong brine, made of fresh water and sea-salt. When taken out, they are drained, and put in rows or layers in barrels, with salt.

Red Herrings are prepared in the same manner, with this difference, that they are left in the brine double the time above mentioned; and when taken out, placed in a large chimney constructed for the purpose, and containing about twelve thousand, where they are smoked by means of a fire underneath, made of brushwood, for the space of twenty-four hours.

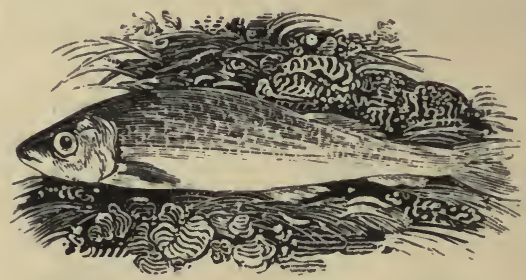

THE SPRAT, (Clupea Sprattus,)

A WELL-KNowr fish, between four and five inches in length, the back fin very remote from the nose; the lower jaw longer than the upper, and the eyes bloodshot, like those of the herring, to which it is nearly allied. Sprats arrive yearly in the beginning of November in the river Thames; and generally a large dish of them is presented on the table at Guildhall, on Lord Mayor's Day, November 9th. They continue through the winter, and depart in March. They are sold by measure, and yield a great deal of sustenance to poor people in the winter season. It is reported that they have been 
taken yearly about Easter-time in a lake in Cheshire, called Kostern Mere, and in the river Mersey, in which the sea ebbs and flows seven or eight miles below the lake.

The Sardine (Clupea Sardina) is caught on the southern shores of France, where it is held in great repute; and from its abounding in the neighbourhood of the island of Sardinia, it is called the Sardine. It is sent here pickled in the same way as herrings, and packed in barrels.

\section{THE PILCHARD. (Clupea Pilchardus.)}

THe chief difference between this fish and the herring is, that the body of the Pilchard is more round and thick; the nose shorter in proportion, turning up; and the under jaw shorter. The back is more elevated, and the belly not so sharp. The scales adhere very closely, whilst those of the herring easily drop off. It is also, in general, of considerably smaller size.

About the middle of July, Pilchards appear in vast shoals off the coast of Cornwall. These shoals remain till the latter end of October, when it is probable they retire to some undisturbed deep, at a little distance, for the winter.

'The Pilchard fishery is an important branch of commerce. From a statement of the number of hogsheads exported each year, for ten years, from 1747 to 1756 inclusive, from the four ports of Fowy, Falmouth, Penzance, and St. Ives, it appears that Fowy exported yearly one thousand seven hundred and thirty-two hogsheads; Falmouth, fourteen thousand six hundred and thirty-one; Penzance and Mount's Bay, twelve thousand one hundred and forty-nine; St. Ives, one thousand two hundred and eighty-two: in all, twenty-nine thousand seven hundred and ninety-four hogsheads. Every hogshead, for ten years last past, together with the bounty allowed for exportation, and the oil made out of it, has amounted, one year with another, at an average, to the price of one pound thirteen shillings and three pence; so that the cash paid for Pilchards exported has, at a 
medium, annually amounted to the sum of forty-nine thousand five hundred and thirty-two pounds. The above was the state of the fishing several years ago; at present it is still more extensive, the average annual produce of the Cornish fisheries amounting to about twenty-one thousand hogsheads, which contain no less than sixty millions of Pilchards.

\section{THE WHITEBAIT. (Clupea alba.)}

This beautiful little fish is a pure white, without spots on either side. Immense quantities are caught from the beginning of April to the end of September, in the Thames; but they are so delicate as scarcely to bear carriage, and are therefore thought best when eaten as near as possible to the place where they were taken; and hence the custom of having Whitebait dinners at the taverns at Greenwich and Blackwall. It was long supposed that the Whitelait was the fry of the shad, but it is now proved to be a distinct species.

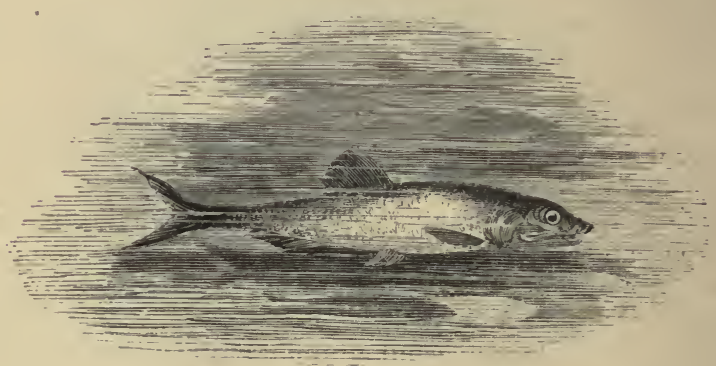

THE ANCHOVY. (Engraulis encrasicolus.)

LiKe the herring and sprat, these fish leave the depths of the open sea, in order to frequent the smooth and shallow places of the coast, for the purpose of spawning. The fishermen generally light a fire on the shore, for the purpose of attracting the Anchovies, when they fish 
for them in the night. After they are cleaned, and their heads cut off, they are cured in a particular way, and packed in small barrels for sale and exportation. Anchovies are occasionally found both in the North Sea and in the Baltic ; but they are in much greater number in the Mediterranean than in any other part of the world. 'They have sometimes, though rarely, been caught in the river Dee, on the coasts of Flintshire and Cheshire. The upper jaw of this fish is longer than the under; the back is brown; the sides silvery; fins short; the dorsal fin, opposite the ventrals, transparent; the tail finforked. Its length is about three inches.

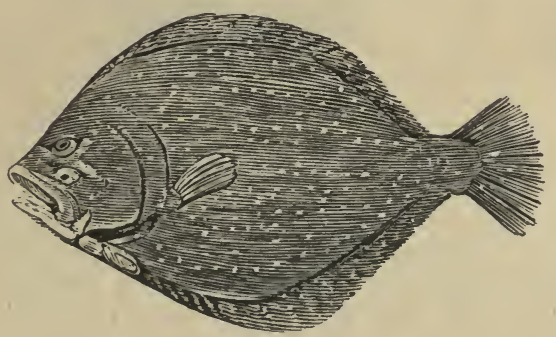

THE TURBOT. (Rhombus maximus.)

'The Turbot is a well-known fish, and much esteemed for the delicate taste, firmness, and sweetness of its flesh. Juvenal, in his fourth Satire, gives us a very ludicrous description of the Roman emperor Domitian assembling the Senate to decide how and with what sauce this fish should be eaten. The Turbot is sometimes two feet and a half long, and about two broad. The scales on the skin are so very small that they are hardly perceptible. The colour of the upper side of the body is a dark brown, spotted with dirty yellow; the under side a pure white, tinged on the edges with a somewhat flesh-colour, or pale pink. There is a great difficulty in baiting the Turbot, as it is very fastidious in its food. Nothing can allure it but herrings or small slices of haddocks, and lampreys; and as it lies in deep 
water, flirting and paddling on the ooze at the bottom of the sea, no net can reach it, so that it is generally caught by hook and line. It is found chiefly on the northern coasts of England, Scotland, and Holland.

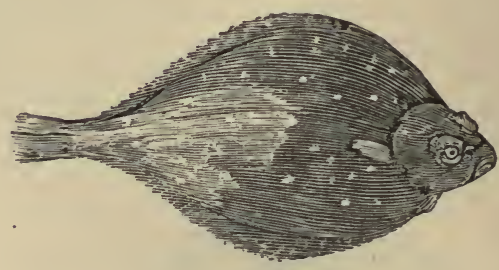

\section{THE PLAICE, (Platessa vulgaris,)}

A weLL-KNown English fish, nearly allied to the turbot. It has smooth sides, an anal spine, and the eyes and six tubercles are placed on the same side of the head. The body is very flat, and the upper part of the fish of a clear brown colour, marked with orange-coloured spots, and the belly white. Plaice spawn in the beginning of February, and when full-grown assume something like the shape of a turbot; but the flesh is very different, being soft and nearly tasteless.

When near the ground they swim slowly and horizontally, but if suddenly disturbed they change the horizontal to the vertical position, darting along with meteor-like rapidity, and then again quickly resuming their inactive habits at the bottom of the water. Plaice feed on small fish and young crustacea, and have sometimes been taken on our coasts weighing fifteen pounds, but a fish half that weight is considered very large. The finest kind, called Diamond Plaice, are caught on the Sussex coast. These fish are in considerable demand as food, though by no means equal to the turbot and sole. Those of a moderate size are reckoned the best eating. 


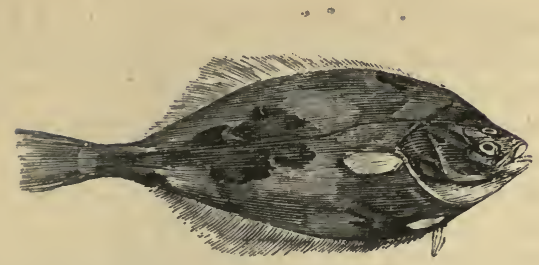

\section{THE FLOUNDER. (Platessa flesus.)}

THE principal distinction between the plaice and the Flounder consists in the former having a row of six tubercles behind the left eye, of which this fish is entirely destitnte; it is also a little longer in the body, and, when full-grown, somewhat thicker. The back is of a dark olive colour, spotted. In taste, they are reckoned more delicate than the plaice. They live long after being taken out of their element, and are often cried in the streets of London, but they seldom appear on the tables of the rich and dainty. They are common in the British rivers, and in all large rivers which obey the impression of the tide, and they feed upon worms bred in the mud at the bottom of the water.

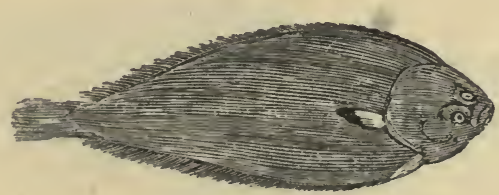

THE SOLE, (Solea vulgaris,)

Is well known as a very excellent fish, whose flesh is firm, delicate, and of a pleasing flavour. Soles grow to the length of eighteen inches, and even more, in some of our seas. They are often found of this size and superiority in Torbay, whence they are sent to market at Exeter and several other towns in Devonshire and the 
adjacent counties. They are found also in the Mediterranean and several other seas, and, when in season, are in great requisition for the most luxurious tables. The upper part of the body is brown; the under part white; one of the pectoral fins is tipped with black, the sides are yellow, and the tail rounded at the extremity. It is said that the small Soles, caught in the northern seas, are of a much superior taste to the large ones, which the southern and western coasts afford.

This fish has also the quality of keeping sweet and good for several days, even in hot weather, and is thought to acquire a more delicate flavour by being thus kept. On this account it is that Soles in the London markets are frequently more esteemed than those which are.cooked immediately after they are taken out of the sea.

In the economy of flat fish we have an account of one circumstance which is very remarkable: among various other marine productions, they have been known to feed on shell-fish, although they are furnished with no apparatus whatever in their mouth which would seem to be adapted for reducing these to a state calculated for digestion.

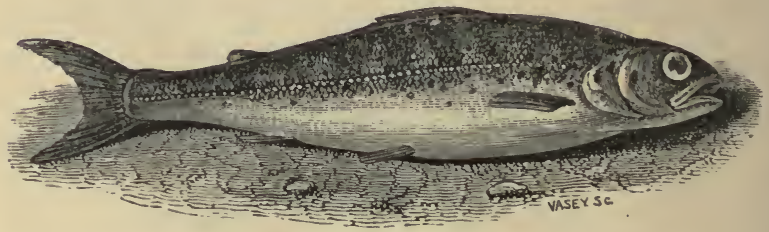

THE SALMON-PINK, BRANDLING, PAR, OR SKEGGER.

THus brilliant little fish is the smallest of the salmonida, and is only found in rivers frequented by salmon; for whenever a river becomes deserted by them, the samlet also disappears. This fish is considered to be the fry 
of the true salmon, and Mr. Young, in a recent essay, has, we think, fairly established the fact; but Mr. Yarrell and other naturalists assert it to be a distinct species.

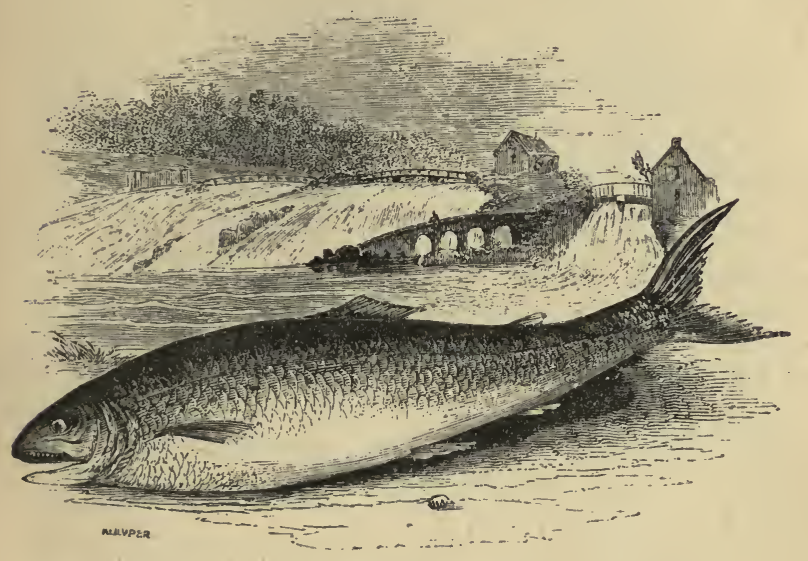

THE SALMION, (Salmo salar,)

Is the boast of large rivers, and one of the noblest inhabitants of the sea, if we esteem it by its bulk, colour, and the sweetness of its flesh. Salmon are found of a great weight, and sometimes measure five feet in length. The colour is beautiful, a dark blue dotted with black spots on the back, merging to silvery white on the sides, and white with a little shade of pink below. The fins are comparatively small. These fisb, though they live principally in the sea, come up the rivers at the spawning season, to a considerable distance inland, where the female deposits her eggs. Soon after, both she and the male take an excursion to the vast regions of the sea, and do not visit any of the land streams again till the next year, when they return for the same purpose. They are so powerfully impelled by this natural impulse, that, if they are stopped when swimming up a river by a fall 
of water, they spring up with such a force through the descending torrent, that they stem it till they reach the higher bed of the stream; and on this account small cascades on the Tweed and other rivers are often called Salmon-leaps. The Salmon is in a great measure confined to the northern seas, being unknown in the Mediterranean, and in the waters of other warm climates. The flesh is red when raw, rather paler when salted or boiled; it is an agreeable food, fat, tender, and sweet, and excels in richness all other fresh-water fish: however, it does not agree with every stomach, and is often injurious when eaten by sick persons.

In the river 'Tweed, about the month of July, the capture of Salmon is astonishing: often a boat-load, and sometimes nearly two, may be taken at a tide; and in one instance more than seven hundred fish were caught at a single haul of the net. From fifty to a hundred at a haul are very common. Some of these are sent to London by the railway; but part are slightly salted and pickled, in which state they are called kipper. The season for fishing commences in the Tweed in February, and ends about old Michaelmas-day. On this river there are about forty considerable fisheries, which extend upwards, about fourteen miles from the mouth; besides many. other's of less consequence. These, several years ago, were let at an annual rent of more than ten thousand pounds; and to defray this expense, it has been calculated that upwards of two hundred thousand Salmon must be caught there, one year with another. The principal Salmon fisheries in Europe are in the rivers, or on the sea-coasts adjoining the large rivers of England, Scotland, and Ireland. The chief English rivers in which they are now caught are the Tyne, the Trent, the Severn, and the Tweed. They were formerly found in the Thames, but none have been taken there for many years. The Salmon fry go down the river to the sea in April. A young Salmon under two pounds in weight is called a Salmon Peel, and a larger one a Grilse. Salmon cannot be eaten too fresh, and is very unwholesome when stale. 


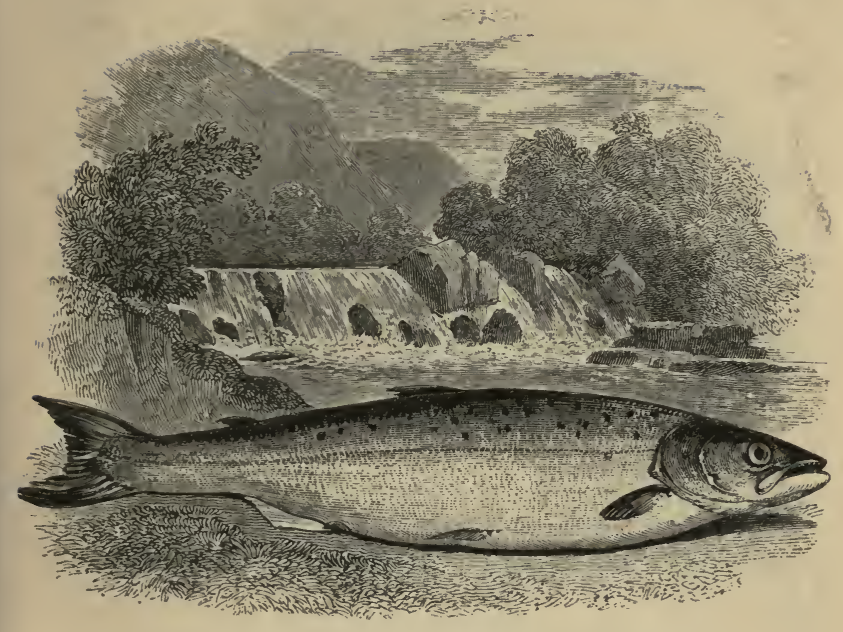

THE SALMON TROUT, (Salmo Trutta,)

Also called the Bull Trout, or Sea Trout, is thicker in the body than the common trout, and weighs about three pounds; it has a large smooth head, which, as well as the back, is of a bluish tint, with a green gloss; the sides are marked with numerous black.spots, and the tail is broadest at the end. It is said that in the beginning of summer the flesh of this fish reddens, and remains this colour till the month of August; which is very probably owing to their being on the point of spawning. Like the salmon, this fish inhabits the sea; but in the months of November and December it enters the rivers, in order to deposit its roe ; and consequently, in the spawning season, it is occasionally found in lakes and streams, at a great distance from the sea. It is very delicate, and much esteemed on our tables. Some people prefer this fish to salmon; but they are both apt to cause illness when eaten in too great a quantity. 


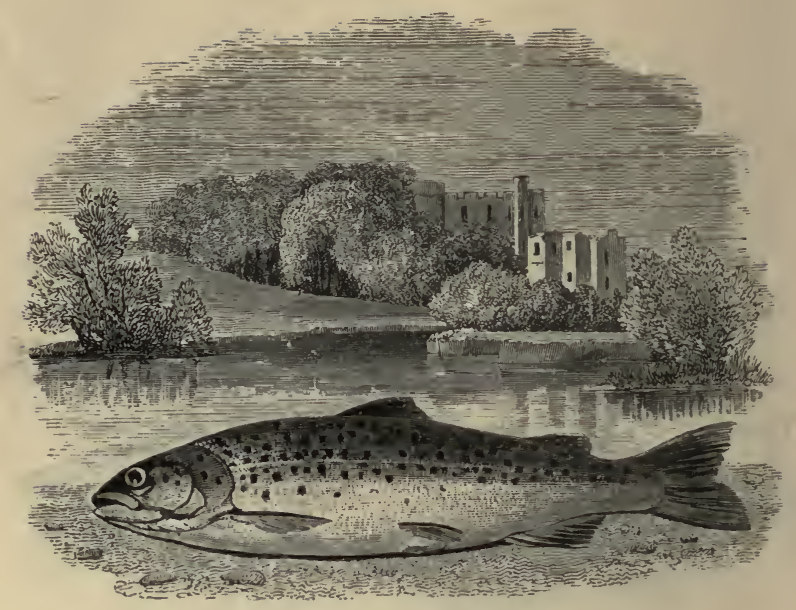

THE TROUT. (Salmo-fario.)

This fish, in figure, resembles the salmon; it has a short roundish head, and a blunt snout. Trouts are freshwater fish, and they breed and live constantly in rivers and small pellucid streams which sparkle over clean pebbles and beds of sand.

They feed on river flies and other water insects, and are so fond of them, and so blindly voracious, that anglers deceive them with artificial flies made of feathers, wool, and other materials, which resemble very closely the natural ones. In Lough Neagh, in Ireland, Trouts have been caught weighing thirty pounds; and we are told, that in the Lake of Geneva, and in the northern lakes of England, they are found of a still larger size. It holds the first place among the river fish, and its flesh is very delicious, but difficult of digestion when old, or kept too long. They spawn in the month of December, and deposit their eggs in the gravel at the bottom of rivers, dykes, and ponds. Unlike most other fish, the 
Trouts are least esteemed when near spawning. 'They are properly in season in the months of July and August, being then fat and well-tasted.

The beantiful silvery Trout is the most voracious of fresh-water fish, and will devour every living thing which the water produces-even its own spawn in all its stages, and will lie upon the bed or hill, watching to seize its young fry, as they become vivified and rise from under their gravelly birthplace. Neither does he confine himself to any given sort of fish, but luxuriates his rapacious stomach upon all the varieties, from instinct occasionally changing his food to larvæ, caddis, ephemera, worms, and even the young of the watersnail, all of which act as alteratives. Owing to his large fins and broad tail, his movements are extremely rapid, and, from his muscular power and pliability, he seldom misses his prey. His habits are solitary, being only accompanied by one, and that at some distance from him, in the summer season; and as the autumn approaches, when larvæ, \&c., are diminishing, he keeps entirely alone until the pairing season returns. The period of spawning differs in various rivers from natural causes, such as snow, cold rains, or inclement weather; fur, as Trout, like salmon, spawn on gravel beds in shallow water, the cold readily affects them. When they cannot reach the spot prepared for the deposit of their eggs, they frequently abstain from spawning for weeks. The younger 'Trout generally hill, as it is termed, earlier than those of larger growth. They begin to throw up their bed early in December, when the female and male may be seen working together, the former mostly in advance. By constant labour they dig a hollow in the gravel, throwing it up on each side, and at last forming a heap, which is called a hill, or bed. At this period they are very shy and stupid, and even the shadow of a cloud will frighten them from their hill, when they retreat into deeper water; but upon finding all quiet they return. This preparation generally occupies two or three weeks; and frequently the hill is shared both in labour and occupation by several pairs of Trout. It often measures many feet in diameter, and is two or 
three feet higher than the bed of the stream. From the middle of December to the end of January the Trout is in full spawning operation; when the fish deposit their eggs in the hollow, and afterwards work the gravel over them to the depth of about three inches. If the temperature of the water is not altered during the period of incubation, the young make their appearance on the fiftieth day; never earlier, frequently later. Nature has endowed the young fry with so much instinct of self-preservation, that for many days they keep under the gravel, and it is curious to see the shoal hiding together under large stones' to protect themselves from danger: this they continue to do until the eggshell, in which they remain partially enveloped, falls off from their delicate frames. This shell, which adheres to them for fourteen days, contains a proportion of fluid necessary for their support during this period of helplessness. After this they resort to the shallows and scours to avoid the larger fish, where they remain solitary for a year, during which time, in good keep, they attain the weight of three to four ounces; the second year, eight to ten ounces; after which they begin to breed. A fish, like every animal, becomes fat when it has abundance of food with little or no exertion; so that the growth is entirely regulated by the relative proportion of food and labour. I have observed this difference in the same brood of Trout, artificially bred upon my system: the one brood being placed in water well supplied with food, the other in a spring-stream where little food existed; the former, at ten months old, were four inches long; and three and a half ounces in weight, while the latter were only an inch and a half long, and less than an ounce in weight. Although Trout are not migratory; yet, when they become large, they run up stream to purer water. The small 'Trout are carried down the stream against their habit, by the flushes of water or floods during the autumn months, being unable to stem the thickened torrent, which fills their gills with alluvial deposit, and hinders their respiration, whence they become weak and sickly. In this state of water all fish sicken more or less, and it destroys vast numbers in the 
very young state. I have known thousands destroyed by the overflowing of a river, as well old as young. 'The cause of all our rivers falling off in the quantity of fish, is from the increasing impurity of the water, as fish especially require pure water.

The above interesting notice of the Trout has been communicated to the publisher by Mr. Boccius, who devotes himself professionally to the increase of fish in rivers and ponds, and has performed martels.

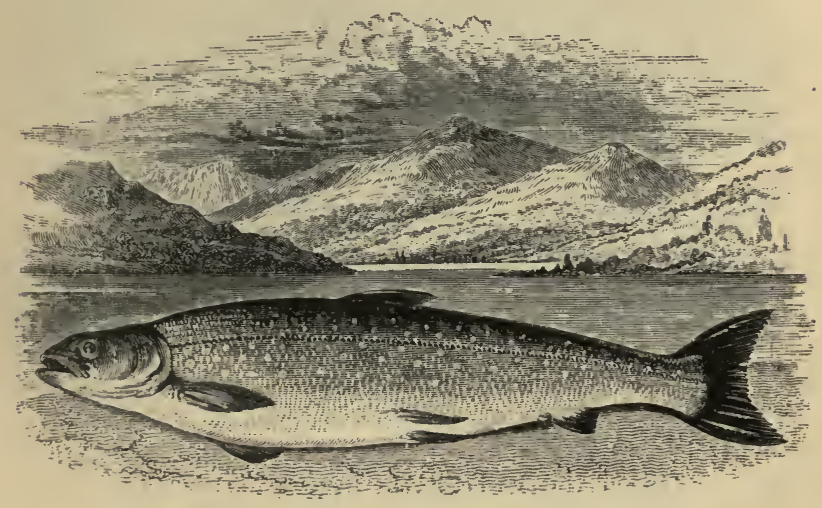

THE CHAR, OR ALPINE-TROUT, (Salmo salvelinus,)

Is not unlike the trout; the scales are very small; the colour of the body marked with numerous spots and points of black, red, and silver, mixed with yellow, and without a circle; the back tinged with olive-green; the belly white, the snout bluish. All the fins, except those of the back, are reddish, and the adipose one is red on its edge. This fish is about twelve inches in length, and is esteemed very delicate as an article of food, especially by the Italians. It is abundant in the Lago di Garda, near Venice; and is also found, not only in our northern lakes in Westmoreland and Scotland, but also in the large sheets of water at the foot of the mountains in Lapland. The potted Char enjoys a high and deserved reputation in several parts of the Continent, as 
well as in England. The Char is a fresh-water fish, and is generally found in the deepest parts of lakes; it is never taken by the angler, only by the net.

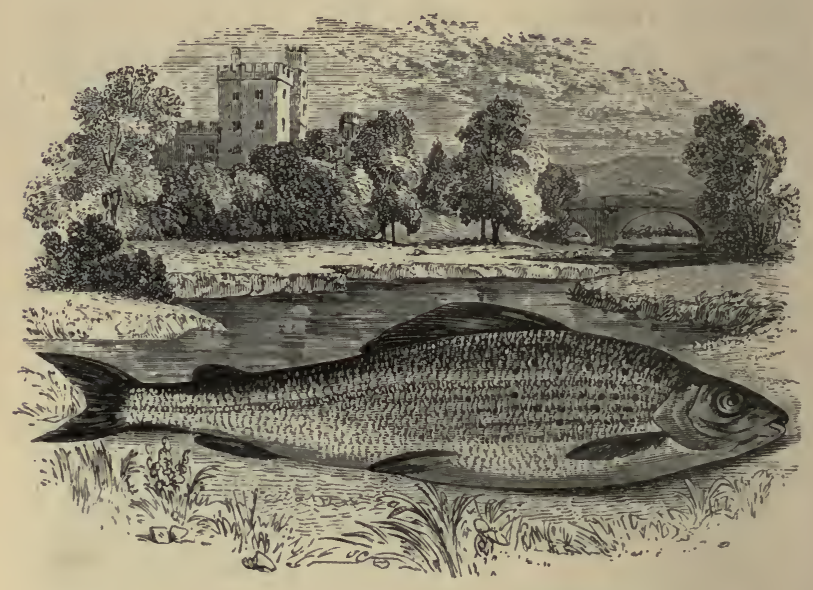

\section{THE GRAYLING. (Salmo thymallus.)}

THIs fish never exceeds fifteen inches in length, and seldom arrives at three pounds weight. The back and sides are of a silvery grey, and when the fish is first taken out of the water, slightly varied with blue and gold. The coverts of the gills are of a glossy green, and the scales are large.

The Grayling is a fresh-water fish, and delights chiefly in clear and not too rapid streams, where it affords great amusement to the angler, as it is very voracious, and rises eagerly to the fly. 'They are bolder than trout, and even if missed by the hook several times successively, they will still pursue the bait. They feed principally on worms, insects, and water-snails; and the shells of the latter are often found in great quanti ies on their stomachs. They spawn in the months of April and May. The largest fish of this species ever heard 
of was one caught in the Severn, and weighed five pounds.

Ancient writers strongly recommended this fish as food for sick persons, as they considered it peculiarly wholesome and easy of digestion.

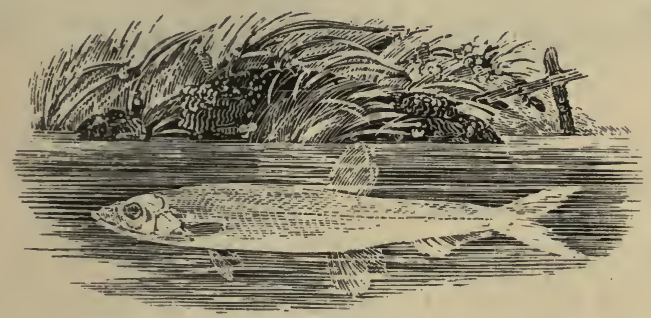

THE SMELT, OR SPARLING. (Osmerus eperlanus.)

THis fish is in length about eight or nine inches, and nearly one in bread th; the body is of a light olive green, inclining to silver white. The smell, when the fish is fresh and raw, is not unlike that of ripe cucumbers, but it goes off in the frying-pan, and the Smelt then yields a tender and most delicious food. Smelts are sea-fish, and inhabit the sea-coast and harbours; but they are often taken in the Thames, the Medway, and other large rivers. which they ascend in the spawning season. The skin of this fish is so transparent, that with the help of a microscope, its blood may be seen to circulate.

Smelts are found on the coasts of all the northern countries of Europe, and also in the Mediterranean. They vary considerably in size. Mr. Pennant states that the largest he had ever heard of measured thirteen inches in length, and weighed half a pound. 


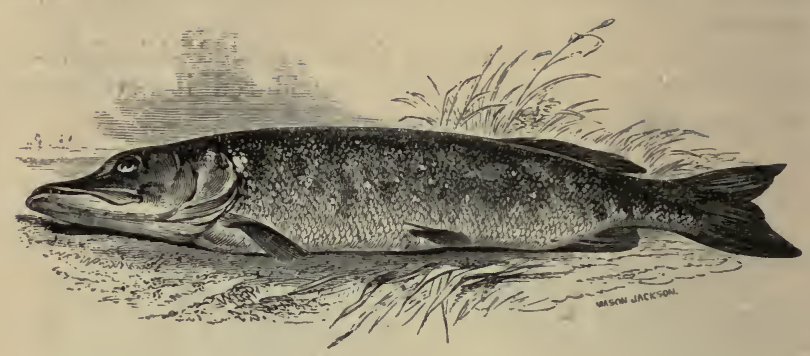

\section{THE PIKE. (Esox lucius.)}

The body of this fish is a pale olive-grey, deepest on the back, and marked on the sides by several yellowish spots or patches; the abdomen white, slightly spotted with black; its length is from one to eight feet, and its weight from one or two to forty or fifty pounds. The flesh is white and firm, and considered very wholesome: the larger and older it is, the more it is esteemed. There is scarcely any fish of its size in the world that in voracity can equal the Pike.* It lives in rivers, lakes, and ponds; and in a confined piece of water will soon destroy all other fish, as it generally does not feed upon anything else, and often swallows one nearly as big as itself; for through its greediness in eating, it takes the head foremost, and so draws it in by little and little at a time, till it has swallowed the whole. A gudgeon of good size has been found in the stomach of a large Pike, the head of which had already received clear marks of the power of digestion, whilst the rest of the fish was still fresh and unimpaired.

"I have been assured (says Walton) by my friend Mr. Seagrave, who keeps tame otters, that he has known a Pike, in extreme hunger, fight with one of his otters for a carp that the otter had caught, and was then bringing out of the water."

* Mr. Boccius has, however, shown that the Trout is even moro voracious. 
Boulker, in his Art of Angling, says, that his father caught a Pike, which he presented to Lord Cholmondeley, that was an ell long, and weighed thirty-six pounds. His lordship directed it to be put into a canal in his garden, which at that time contained a great quantity of fish. Twelve months afterwaras the water was drawn off, and it was discovered that the Pike had devoured all the fish, except a large carp that weighed between nine and ten pounds, and even this had been bitten in several places. 'The Pike was again put in, and an entire fresh stock of fish for him to feed on : all these he devoured in less than a year. Several times he was observed by workmen who were standing near, to draw ducks and other water-fowl under water. Crows were shot and thrown in, which he took in the presence of the men. From this time the slaughtermen had orders to feed him with the garbage of the slaughter-house; but being afterwards neglected, he died, as is supposed, from want of food.

In December, 1765, a Pike was caught in the river Ouse, that weighed upwards of twenty-eight pounds, and was sold for a guinea. When it was opened, a watch with a black riband and two seals were found in its body. These, it was afterwards found, had belonged to a gentleman's servant, who had been drowned in the river about a month before.

'The Pike is a very long-lived fish. In the year 1497, one was caught at Heilbrun, in Swabia, to which was affixed a brazen ring, with the following words engraved on it in Greek characters: "I am the fish, which was first of all put into this lake, by the hands of the governor of the universe, Frederick the Second, the fifth of October, 1230." 


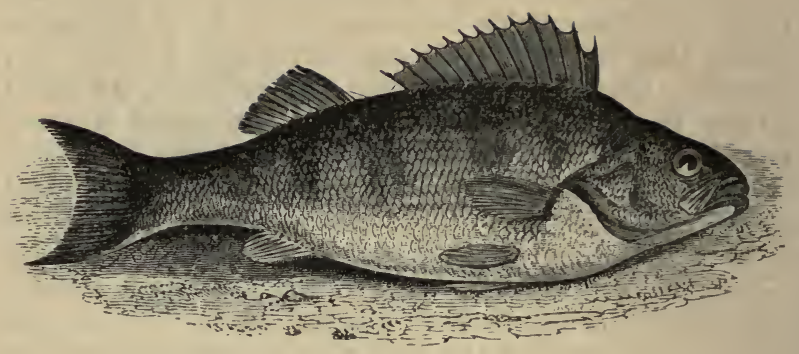

THE PERCH, (Perca fluviatilis,)

SELDom grows to any great size; yet we have an account of one which is said to have weighed nine pounds. The body is deep, the scales rough, the back arched, and the side-lines placed near the back. For beauty of colours, the Perch vies with the gaudiest inhabitants of the waters; the back glows with the deep reflections of the brightest emeralds, divided by five broad black stripes; the abdomen imitates the tints of the opal and motherof-pearl; and the ruby hue of the fins completes an assemblage of colours most harmonious and elegant. It is a gregarious fish, and is caught in several rivers of these islands; the flesh is firm, delicate, and much esteemed.

It is generally believed that a pike will not attack a full-grown Perch : he is deterred from so doing by the spiny or dorsal fin on the back, which this fish always erects at the approach of an enemy. Perch are so voracious, that, if an expert angler happens to find a shoal of them, he may catch every one. If, however, a single fish escape that has felt the hook, all is over; as this fish becomes so restless, as soon to occasion the whole shoal to leave the place. Perch are so bold, that they are generally the first fish caught by a young angler; they will also soon learn to take bread thrown into the water to feed them. A large-sized Perch weighs about three pounds; but generally the Perches caught in ponds do not exceed eight or ten ounces in weight. 


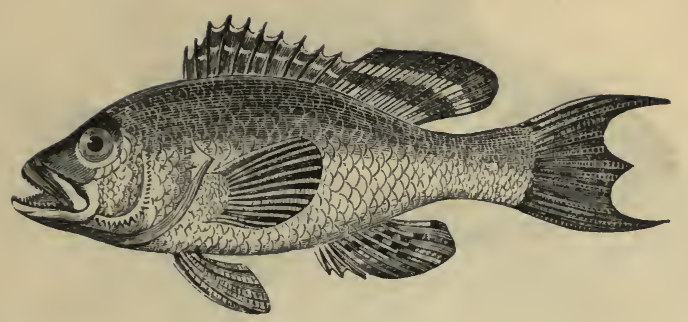

THE BASSE, OR SEA PERCH, (Labrax lupus,)

Is found in abundance on our southern coasts, and is still more common in the Mediterranean. It has one long dorsal fin, like the ruffe. The flesh of this fish is highly esteemed.

The Climbing Perch, (Anabas scandens,) a native of the fresh waters of India, possesses a very singular apparatus for enabling it to quit the water, and pass a considerable time on dry ground. 'I'his consists of a curiously folded portion of thin bone on each side of the head near the gills, in the cavities of which a good deal of water is contained; this keeps the gills in a moist state while the fish is out of the water, and thus enables it to breathe in the air. This fish is said to employ its singular power of quitting the water for the purpose of climbing trees, although what it expects to gain by so doing is quite unknown. Its power of climbing has been denied by some naturalists, but Daldorf says that he once caught one which had clambered to a height of six feet un the stem of a palm, and was in the act of going still higher. 


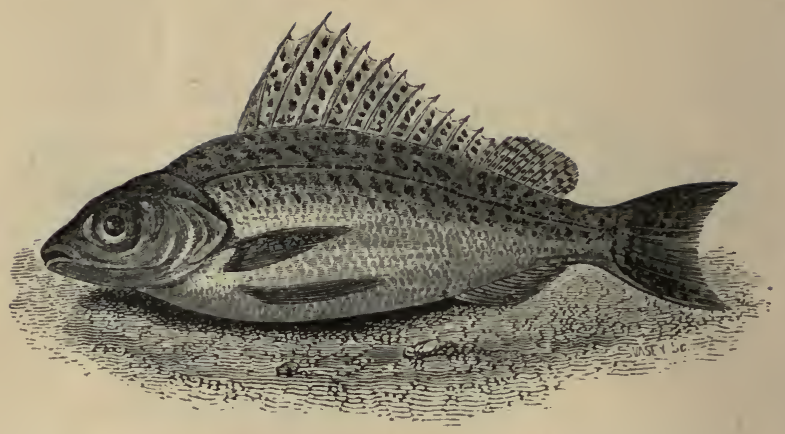

THE POPE, OR RUFFE. (Acerina cernua.)

The Pope is very like a small perch, but with a curiously formed single dorsal fin: the colour of the back is a dusky olive green; the sides light brownish green and copper colour; and small brown spots are spread over the dorsal fin, the back, and tail. 'The pectoral, ventral, and anal fins are pale brown. This fish rarely exceeds six inches in length; but it is nearly as good as a perch of the same size, which it resembles, both in its haunts and habits; it spawns in April, and feeds on small fry, worms, or aquatic insects.

Cuvier assigns the credit of the first discovery of this fish to an Englishman of the name of Caius, who found it in the river Yare, near Norwich, and called it Aspredo, a translation of our name Ruffe, (rough,) which is well applied to it, on account of the harsh feel of its denticulated scales.

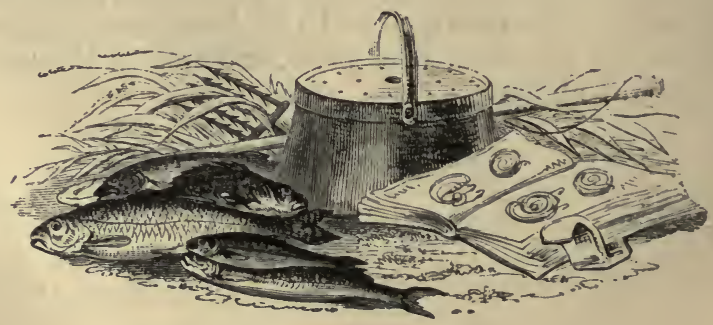




\section{The Carp.}

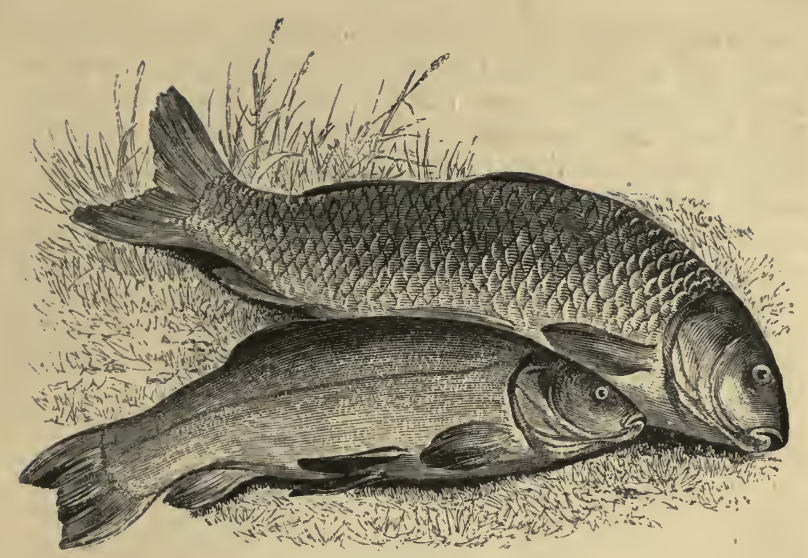

THE CARP, (Cyprinus carpio,)

Is famous for the sweetness of its flesh, when of moderate size, that is, when measuring about twelve to fifteen inches in length, and weighing about three pounds. The scales are large, with a golden gloss upon a dark green ground. These fish sometimes grow to the length of three or four feet, and contain a great quantity of fat. The soft roe of the Carp is esteemed a great delicacy among epicures. In the canals of Chantilly, formerly the seat of the Prince of Condé, Carps have been kept for above one hundred years, most of them appearing hoary through old age, and so tame that they answered to their names when the keeper called them to be fed. This fish has large molar teeth only, situate at the back part of the head or throat, and a broad tongue; the tail is widely spread as well as the fins, which are inclined to a reddish tint. Carp that live in rivers and runring streams are preferred for the table, as those which inhabit pools and ponds have generally a muddy and disagreeable taste. Though so cunning in general as to be called the River Fox, yet at spawning time they suffer themselves to be tickled and canght without attempting to escape. It is said that Carp were first brought to 
England about three hundred years ago. They are very tenacious of life, and at the inns in Holland are often kept alive a month or six weeks, by being fed with bread and milk, and laid on wet moss in a net, which is hung from the ceiling in an airy place. The moss is kept moist, and water is thrown over the fish twice a day.

Carp is always considered a delicacy for the table, especially when stewed in port wine; and it appears to have been long held in high estimation on that account, as we find, from the privy purse expenses of Henry VIII., that the bluff king was exceedingly fond of Carp.

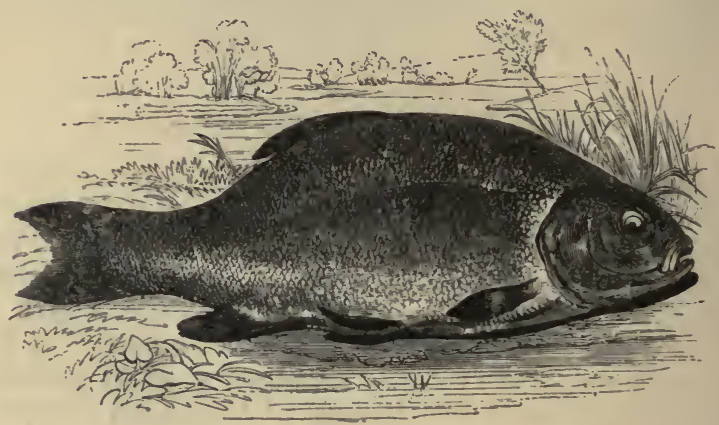

THE TENCH, (Cyprinus tinca,)

LIKE the carp, is remarkably tenacious of life. Its body is thick and short, and seldom exceeds twelve inches in length, or four pounds in weight. The eyes are red; the back, dorsal, and ventral fins dusky; the head, sides, and abdomen of a greenish hue, mixed with gold; and the tail very broad. The 'T'ench delights in still water, in the muddy parts of ponds, where it is the most secure from the voracious ramblings and fierce attacks of the tyrant pike, and from the hook of the angler; here it lives nearly motionless, lurking beneath flags, reeds, and weeds. This inactive life has enabled some individuals 
of this species to attain an extraordinary bulk. We have read, as a well-anthenticated fact, that in the northern part of England, in a piece of water, which having been long neglected, was filled with timber, stones, and rubish, two hundred Tench, and as many perch of good size were found; and that one fish in particular, which seemed to have been shut up in a nook, had not only surpassed all the others in size, but had also taken the form of the hole in which it had been accidentally confined. The body was in the shape of a half-moon, conforming in the convexity of its outlines to the concavity of the dungeon where this innocent sufferer had been immured for a number of years; it weighed eleven pounds.

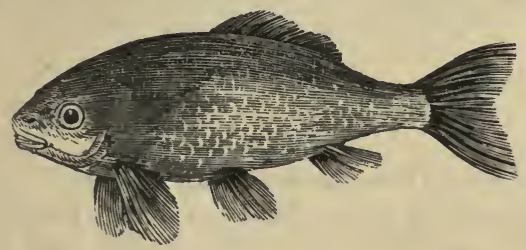

THE GOLD-FISH, OR GOLDEN CARP,

(Cyprinus auratus,)

WAS originally brought from China, and first introduced into England in 1661, but is now become quite common, and will breed as freely in ponds as the carp. The average size is about five inches, and it scarcely ever exceeds seven and a half. Gold-fish are highly prized in China, and are extensively introduced in the ornamental waters of our own country. Nothing is more pleasing than to see them glide along and play in the transparent crystal, whilst their broad and glittering scales reflect the rays of the sun. They are often kept within the small compass of a glass bowl, where they become tame and docile, and after a short time seem to recognise their feeders. 
The smallest fish are preferred, not only from their being the most beautiful, but because a greater number of them can be kept in a small circumference. These are of a fine orange red colour, appearing as if sprinkled over with gold-dust. Some, however, are white, like silver; and others white, spotted with red.

When Gold-fish are kept in ponds, they are often taught to rise to the surface of the water at the sound of a bell, to be fed.

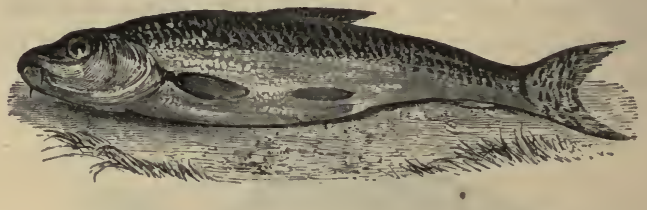

THE GUDGEON, (Cyprinus gobio,)

A WELL-KNOWN fresh-water fish, generally found in gentle streams, on gravelly scours. The average length of this fish is from six to eight inches, and its weight is from two to three ounces. The back is brown, the abdomen white, and the sides tinged with red; the tail is forked. It is beautified with black spots both on the body and tail. Gudgeons spawn early in summer, and feed upon worms and aquatic insects. Their flesh is white, of excellent flavour, and easy of digestion. In the months of September and October these fish are taken in the rivers of some parts of the Continent in great abundance; and the markets are well supplied with them. They are not uncommon in the river Thames, where persons are frequently to be seen fishing for them from punts. As these fish bite with great eagerness, large numbers are often taken in this manner. They are also caught in nets, as well as with hooks and lines. 


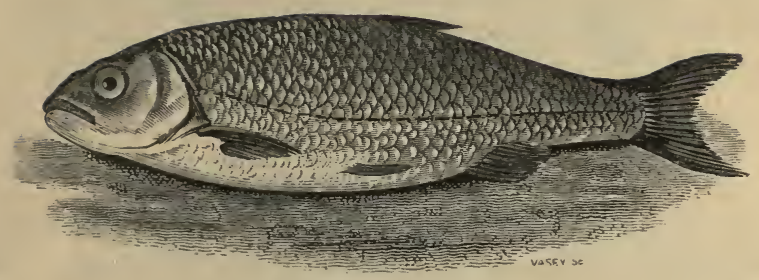

THE CHUB, (Cyprinus cephalus,)

Is of a coarse nature, and full of bones; it seldom exceeds the weight of five pounds. The body is of an oblong shape, nearly round; the head, which is large, and the back, are of a deep dusky green; the sides silvery, and the abdomen white; the pectoral fins are of a pale yellow, the ventral and anal ones red; and the tail brown, tinged with blue at its extremity, and slightly forked. This fish frequents the deep holes of rivers, but in the summer, when the sun shines, it rises to the surface, and lies quiet under the shade of the trees, that spread their foliage on the verdant banks; but yet, though it seems to indulge itself in slumber, it is easily awakened, and at the least alarm dives rapidly to the bottom. Although a leather-mouthed fish, it takes every species of food, including small fish, the same as a trout, though it is not so voracious. In March and April this fish may be caught with large red worms; in June and July, with flies, snails, and cherries; in Angust and September, with cheese pounded in a mortar, niixed with saffron and butter. When the Chub seizes a bait, it bites so eagerly that its jaws are often heard to chop like those of a dog. It, however, seldom breaks its hold, and, when once struck, is sion tired. 


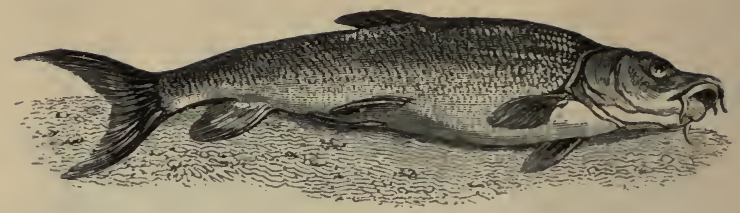

THE BARBEL. (Cyprinus Barbus.)

The BanbeL is readily distinguished from the other carps by the four barbs or wattels attached to its mouth. Its rpper jaw is very considerably extended beyond the lower jaw. The Lea, the Thames, and various other rivers in the neighbourhood of London, abound in this fish, which affords excellent sport to the angler. "During summer," says Mr. Gorrell, "this fish, in shoals, frequents the weedy parts of the river; but as soon as the weeds begin to decay in autumn it seeks the deeper water, and shelters itself near piles, locks, and bridges, which it frequents till the following spring." It is sometimes found to weigh from fifteen to eighteen pounds. and to measure three feet in length, but its usual length is from twelve to eighteen inches. The flesh is coarse and unsavory, and held in no estimation.

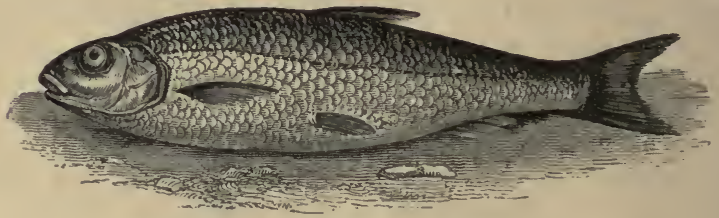

'THE DACE, (Cyprinus leuciscus,)

RESEMBLes the chub in its form, but is smaller, and of a lighter colour; it is gregarious and remarkably prolific. It is seldom more than ten inches in length; the back is of a dusky colour, tinged with yellow and green, and the sides have a silvery cast. 
Dace spawn in March, and are in season about three weeks afterwards. They improve, and are good about Michaelmas; but in February they are best. 'The flesh is, however, at all times woolly and insipid. They are very lively creatures, and, if kept in ponds, may live a considerable time.

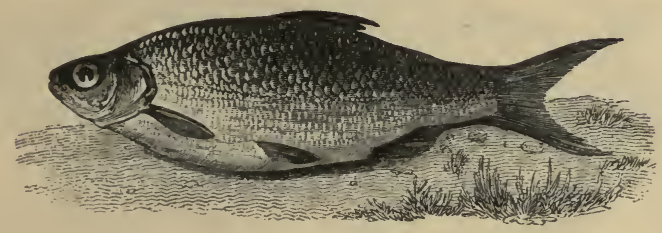

THE ROACH, (Cyprinus rutilus,)

BeLoNgs also to the carp family, and is remarkable for its numerous progeny. It is a deep yet thin-made fish, in shape somewhat resembling the bream, but approaching the carp in the breadth and shape of its scales, which are large and deciduous. The soundness of the flesh is become proverbial, and pleases the taste by a peculiar delicacy of flavour. The ventral fins are, like those of the perch, of a bright crimson, and the irides of the eye sparkle like rubies and garnets. The length of the Roach is commonly between nine and ten inches, but sometimes much greater.

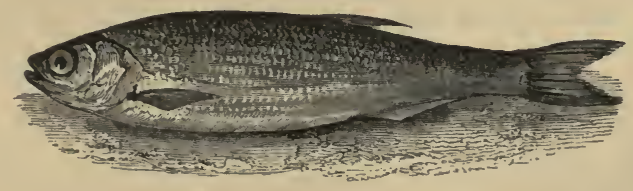

\section{THE BLEAK, (Cyprinus alburnus,)}

Is nearly allied to the roach. It is a small glittering fish, familiar ta most persons from its playing about on warm 
summer evenings on the surface of rivers in chase of flies, bread-crumbs, \&c. The scales are employed in making artificial pearls.

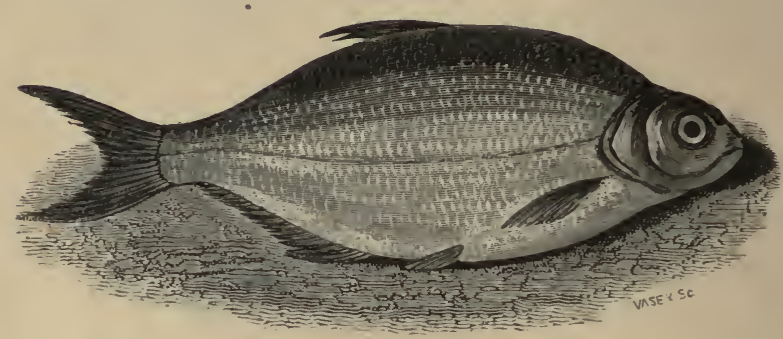

'THE BREAM, (Cyprinus Brama,)

Is a flattish fish, not unlike the carp in several points, but much broader in proportion to its length and thickness. Its head is truncated, the upper jaw a little projecting; the forehead a bluish black; cheeks yellowish; body olive, paler below ; fins obscure, with an oblong conical process at the base of the ventral fins; twenty-nine rays in the anal fin; its greatest length is about two feet. The scales are large, and of a bright colour; the tail has the form of a crescent. It frequents the deepest parts of rivers, lakes, and ponds. These fish spawn in May, secluding themselves at that time so carefully in the ooze at the bottom of the water that they are seldom found with either soft or hard roe in them, so that in sume countries the name is often used to denote sterility. The flesh is not comparable to that of the carp.

The White Bream never exceeds a pound in weight, and is consequently much smaller than the Common or Carp Bream, which frequently weighs seven or eight pounds.

In some of the lakes of Ireland great quantities of Bream are taken, many of them of very large size, sometimes weighing as much as twelve or even fourteen pounds 
each. A place conveniently situated for the fishing is baited with grain, or other coarse food, for ten days or a fortnight regularly, after which great sport is usually obtained. The party frequently catch several hundredweight, which are distributed among the poor of the vicinity, who split and dry them with great care, to eat with their potatoes.

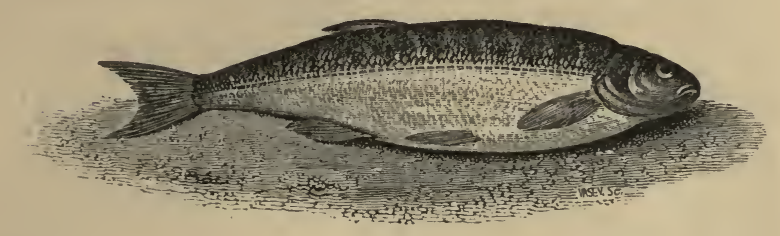

THE MINNOW. (Cyprinus phoxinus.)

THE body of the Minnow is of a blackish green, with blue and yellow variegations; the abdomen silvery; scales small; ten rays in the ventral, anal, and dorsal fins; tail forked, and marked near the base with a dusky spot. Its length is about three inches.

This beautiful and well-known fish is gregarious, and is frequent in clear gravelly streams and rivulets in many parts of Europe. In Britain it appears in March, and is seldom seen after October. It spawns in June, and is, indeed, found in roe during the greater part of the summer. It is easily tamed : and, in captivity, may be taught to pick flies or filaments of beef from the hand.

The flesh of the Minnow is extremely delicate, but the fish is so small that it would take a great number to make a dish, and consequently it is seldom used for human food. Its chief value is as a bait for catching other fish. In some parts of England it is so abundant as sometimes to be used as manure. 


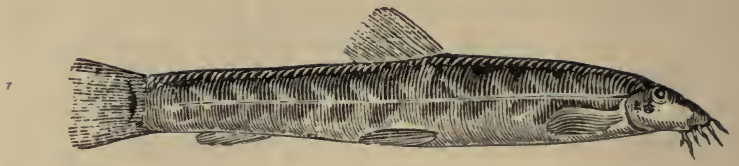

\section{THE LOACH, (Cobitis barbatula,)}

WHICH also belongs to the family of the carps, is a small fish, with six barbs at the mouth. It inhabits small, gravelly streams, and lies at the bottom among the stones; it is easily caught with a small worm.

It is considered an extremely well-flavoured fish, though, on account of its small size, and the difficulty of catching a sufficient quantity, seldom seen at table. The Loach is very sensitive to atmospheric changes, which it shows by its restless movements. They have sometimes been kept alive in glass ressels, in which state they indicate the approach of storms with almost the accuracy of a barometer.

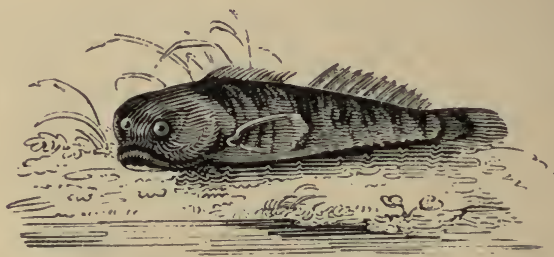

\section{THE BULL-HEAD, OR MILLER'S THUMB,} (Cottus gobio,)

Is found in clear brooks and rivers in most parts of Europe. It is from four to five inches long; the head is large in proportion to the body, broad and depressed: the gill fins round, and beautifully notched. The mouth is large and full of small teeth; the general colour of the body is a dark brownish black. This fish is remarkably stupid, and may be caught with ease by the most inex- 
perienced angler, even with a bent pin and coarse thread. Its hiding-places are among loose stones, under which the peculiar flattened form of its head enables it to thrust itself. Its popular name seems to have suggested itself from the resemblance the head of the fish is supposed to bear to the form of a miller's thumb, the peculiar conformation of which is produced by his mode of testing samples of meal.

\section{THE STICKLEBACK, (Gastuostius aculiatus,)}

Is one of our smallest fishes, and appears to live indifferently in fresh and salt water. It is exceedingly common in every pond, and may be caught easily, either with a hand-net, or by fishing for it with a small worm tied to the end of a piece of cotton; he bites at this so boldly that he may be drawn out of the water without the aid of a hook. His name of Stickleback is given to him from his having thin spines on the back instead of a fin; the sides of his body are covered with thin bony plates, and his ventral fins consist of single, strong, and sharp spines, which constitute formidable offensive weapons.

The Stickleback, although so common, is one of the most interesting of fishes, on account of the singularity of its habits in the breeding season. Instead of depositing its eggs in the sand or mud, and leaving them to take care of themselves, the Stickleback builds a curious nest of fragments of vegetable matter, and defends this most valiantly against all intruders until the hatching of the young; the parental solicitude does not cease until the young Sticklebacks have grown too big to be any longer controlled. One curious feature in the business is, that it is the male that takes all this trouble; he builds the nest, exposes himself to every danger in its defence, and watches anxiously over the vagaries of his young progeny, the female having nothing to do but to deposit her eggs in the already prepared nest.

The Stickleback is an extremely pugnacious fish. The males fight together furiously, and the colours of their bodies become much more brilliant while they are so occupied than at any other time. 


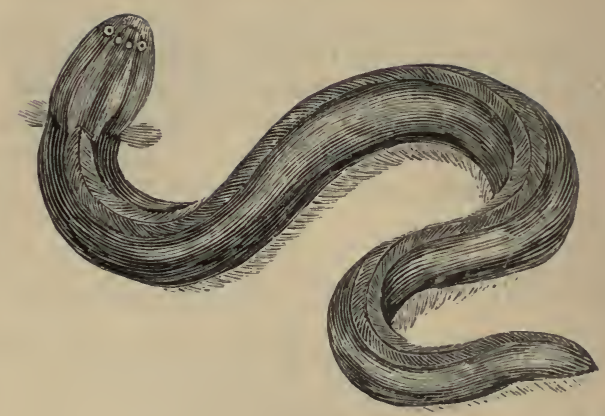

\section{THE ELECTRICAL EEL. (Gymnotus Electricus.)}

TuIs very remarkable fish is abont five or six feet in lerigth, and twelve inches in circumference, in the thickest part of the body. 'The head is broad, flat, and large; the mouth wide and destitute of teeth; the rostrum obtuse and rounded; the eyes small and of a bluish colour ; the back of a darkish brown, the sides grey, and the abdomen of a dingy white. Across the body there are several annular divisions, or rather ridges of the skin, which give the fish the power of contracting or dilating itself at pleasure. There is no dorsal fin, and the ventral fins are also wanting, as in all the Eels. It is able to swim backwards as well as forwards.

Mr. Bryant mentions an instance of the shock from one of these fish being felt through a considerable thickness of wood. One morning, while he was standing by, as a servant was emptying a tub, in which an Electrical Eel was contained, he had lifted it entirely from the ground, and was pouring off the water to renew it, when he received a shock so violent as occasioned him to let the tub fall. He then called another person to his assistance, and they lifted up the tub together, each laying hold only on the outside. When they were pouring off the remainder of the water, they received a shock so smart that they were compelled to desist.

Persons have been knocked down with a stroke. One 
of these fish having been taken from a net and laid upon the grass, an English sailor, notwithstanding all the persuasions that were used to prevent him, would insist on taking it up; but the moment he grasped it he dropped down in a fit; his eyes were fixed, his face became livid, and it was not without difficulty that his senses were restored. He said that the instant he touched it "the cold ran swiftly up his arm into his body, and pierced him to the heart."

Humboldt tells us that when the Indians wish to catch these Eels they drive some wild horses through the pools which the fish inhabit; and that when the Eels have exhausted their electrical power upon the horses, the Indians take them without difficulty. He relates an instance in which he says that the horses, stunned with the shocks they received, sank under water, but most of them rose again, and gained the shore, where they lay stretched out on the ground, apparently quite exhausted and without the power of moving, so much were they stupefied and benumbed. In about a quarter of an hour, however, the Eels appeared to have exhausted themselves, and, instead of attacking fresh horses that were driven into the pond, fled before them. The Indians then entered the water and caught as many fish as they liked.*

This most singular fish is peculiar to South America, where it is found only in stagnant pools, at a great distance from the sea.

* See a very animated account of the capture of this fish, in Humbolclt's "Views of Nature," page 16 (Bohn's Edition). 


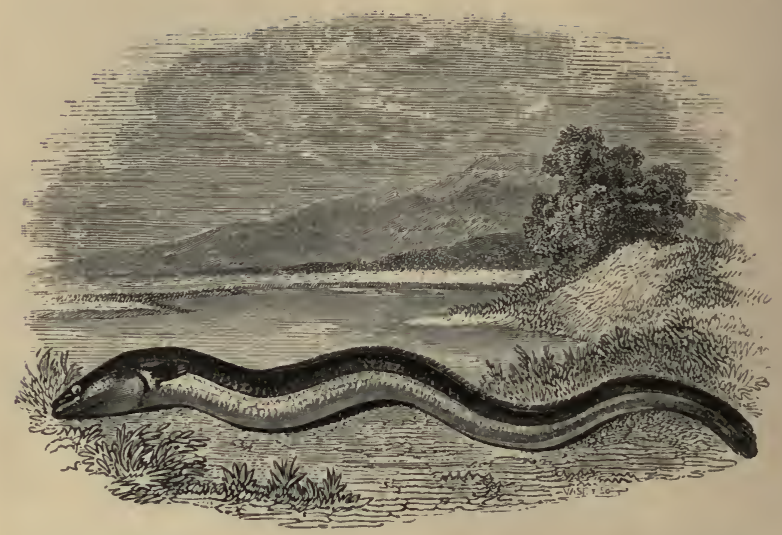

THE EEL. (Anguilla vulgaris.)

The EeL resembles a serpent in its form, though no two animals can be more different in every other respect. Eels are fresh-water fish; but as they are very susceptible of cold, those which inhabit rivers go down every autumn towards the sea, which is always warmer than a river, and return in spring. They are said also to spawn in the sea, and great numbers of young Eels are seen in spring ascending tidal rivers. Mr. Edward Jesse, in his edition of " Walton's Angler," says : " A column of them has been traced in the Thames from Somerset House to Oxford, about the middle of May, and I have watched their progress with much interest. No impediment stops them. They keep as much as possible close alongshore, and as they pass watercourses, open ditches, and brooks, \&c., some of them leave the column and enter these places, along which they eventually make their way to ponds, smaller rivers, \&c. So strong is the migratory instinct in these little eels, that when I have taken some in a bucket and returned them to the river at some distance from the column, they have immediately rejoined it without any deviation to the right or 
left. On the banks of the Thames the passage is called Eel-fare. Two observers, watching their progress at Kingston, calculated that from sixteen to eighteen hundred passed a given line per minute. Rennie saw (on the 13th of May) a column of young eels of uniform size, about as thick as a crow-quill, and three inches long, returning to the river Clyde, in almost military order, keeping within parallel lines of about six inches. $\mathrm{He}$ traced it for several hours without perceiving any diminution." Those that live in ponds seek the deep water for their winter quarters, and sometimes bury themselves in the mud at the bottom. They are very tenacious of life, and will live for a long time out of water; they are even sometimes found on the grass, passing from one pond to another, in search, it is said, of food.

They are voracious feeders, eating frogs, snails, and other molluscous animals, worms, the fry of fishes, and the larvæ of various insects, as well as grass and aquatic weeds. Mr. Jesse states that he has known them to eat young ducks, and even water-rats.

The Eel is caught in many different ways. As.it seldom stirs during the day, the best method is found to be by setting night-lines. The baits most commonly used are lob-worms, loach, minnows, small perch, with the fins cut off, or small pieces of any fish; but such is the voracity of this animal that it will take almost any bait.

Spearing for Eels is a method very commonly resorted to during the winter, when Eels imbed themselves in a state of torpidity in the muddy banks of streams and ponds. Eel-spears have usually six or seven prongs, with long handles. The process consists merely in plunging them into the mud in likely places, and pulling them out again.

There seems to be no reason for supposing, as is commonly done, that Eels are viviparous; parasitic worms have sometimes been mistaken for the young animals.

The common Eel often weighs upwards of twenty pounds. The flesh is tender, soft, and nourishing, but does not agree with all stomachs. 


\section{THE CONGER, OR SEA EEL, (Conger vulgaris,)}

Is very large and thick. Its body is dusky above, and silvery below; the dorsal and anal fins are edged with black; and the lateral line is dotted with white. Its flesh is firm, and was much esteemed by the ancients. It is still eaten by the poorer classes, especially in seaside towns, but would be considered coarse and tasteless by most people in the present day.

The voracity of the Conger Eel is very great, and it is one of the most powerful enemies with which the fishermen of the British islands have to contend. Being usually caught by a hook and line, it requires some care to land and kill the large ones without danger. We are informed that, on such occasions, they have been known to entwine themselves round the legs of a fisherman, and fight with the utmost fury. They are almost incredibly strong and tenacious of life. When pulled up by the line and landed in a boat, they make a loud, hoarse, grating sound, almost resembling the angry snarling of a dog, which often terrifies the amateur fisherman. Unless seized with great care, they bite most severely. It is even said that men have occasionally been permanently maimed by them. A Conger, six feet in length, was caught in the Wash, at Yarmouth, in April, 1808: but not without a severe contest with the man who had seized it. The animal is stated to have risen half erect, and to have actually knocked the fisherman down before he could secure it. This Conger weighed only about sixty pounds: but some of the largest exceed even a hundredweight. 


\section{Book IV. .}

\section{REPTILES.}

$\S 1$. Serpents, or Ophidian Reptiles.

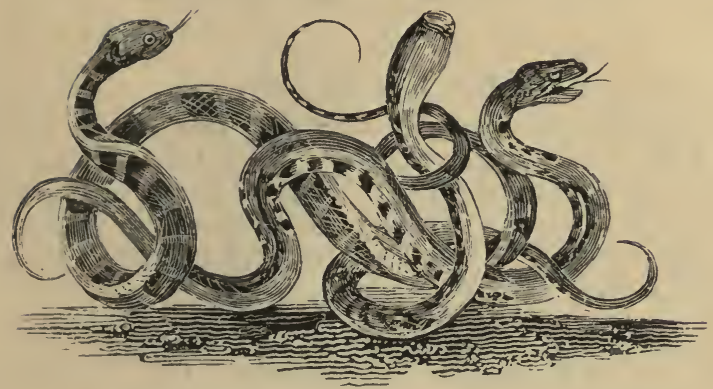

SERPENTS.

SERPENTS are characterised by an elongated body, clothed in scales and destitute of limbs, but furnished with a tail. They move by lateral undulations of the body; and in this manner they glide with equal ease along the bare ground, through entangled thickets or water, and up the trunks of trees. They possess the power of fasting a great length of time, and when they feed always swallow their prey whole, which they are enabled to accomplish by their faculty of dilating their bodies to an enormous size. This power is carried to such an extent that a Boa Constrictor can swallow a bullock whole, suffering no other inconvenience than that of lying in a state of torpor while digestion is proceeding. Serpents generally roll themselves up when in a state of repose, with the head in the centre; and when disturbed raise the head before they uncoil the body. The Serpent is often made a subject of poetry; and as it was the form adopted by the arch fiend to seduce Eve, it is generally considered the emblem of insinuation and flattery : on his rear,

Circular base of rising folds that tower'd Fold above fold, surprising maze, his head Crested aloft, and carbuncle his eyes. 
With burnish'd neck of verdant gold, erect Amidst his circling spires that on the grass Floated redundant; pleasing was his shape And lovely . . . . Oft he bow'd

His turret crest and sleek enamell'd neck,

Fawning, and lick'd the ground whereon she trod."

Paradise Lost.

The ancients paid great honours to Serpents, and sometimes called them good genii : they frequented sepulchres and burying-places, and were addressed like the tutelary divinities of these places. We read, in the fifth book of the Aneid, that when the Trojan hero sacrificed to his father's ghost, a Serpent of this kind made his appearance :

“ and from the tomb began to glide

His hugy bulk on seven high volumes roll'd;

Blue was his breadth of back, and streak'd with scaly gold.

Thus riding on his eurls he seemed to pass

A rolling fire along, and singe the grass;

More various colours through his body run,

Than Iris when her bow imbibes the sun.

Between the rising altars and around,

The sacred monster shot along the ground;

With harmless play among the bowls he pass'd,

And with his lolling tongue assay'd the taste:

Thus fed with holy food, the wondrous guest

Within the hollow tomb retired to rest."

Drydex.

This animal was exalted to the honour of being an emblem of prudence, and even of eternity; and is often represented as the latter in Egyptian hieroglyphics, biting his tail, so as to form a circle. Serpents are very numerous in Africa ; and Lucan, in his "Pharsalia," gives us a very extraordinary account of the different species, which he seems to have drawn partly from ancient Greek authors, partly from actual traditions. He says :

"Why plagues like these infect the Libyan air;

Why deaths unknown in various shapes appear;

Why, fruitful to destroy, the cursed land

Is temper'd thus by Nature's secret hand;:

Dark and obscure the hidden cause remains,

And still deludes the vain inquirer's pains." 
Serpents differ very much in size. We are told of Serpents in the Isle of Java measuring fifty feet in length; and in the British Museum there is a skin of one thirty-two feet long.

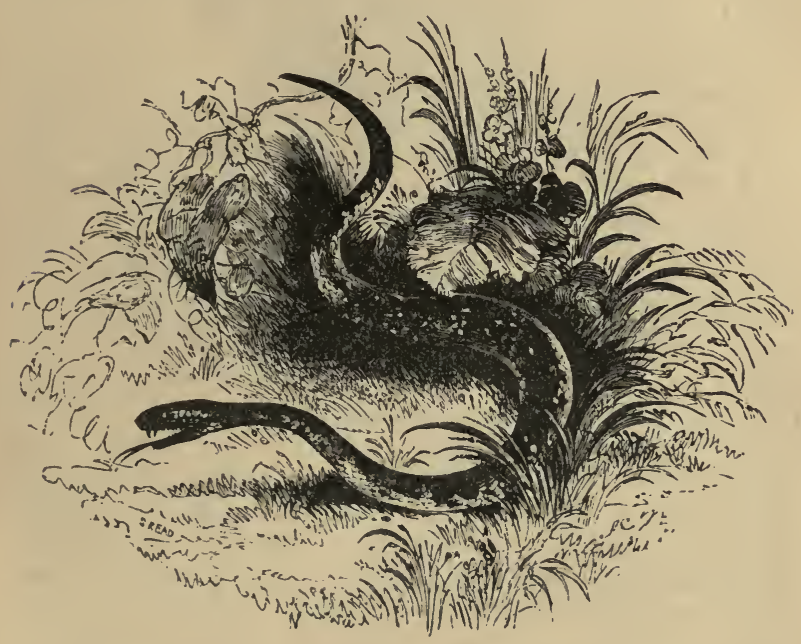

THE VIPER, OR ADDER, (Vipera berus,)

Is a venomous species of serpent that seldom exceeds the length of two or three feet, and is of a dull yellowish brown colour with black, spots, the abdomen being entirely black; the head is nearly in the shape of a lozenge, and much thicker than the body. 'The Viper is viviparous: yet it is ascertained that the eggs are formed, though they are hatched in the body of the mother.

The Reverend Mr. White, of Selborne, in company with a friend, surprised a large female Viper, as she lay on the grass, basking in the sun, which seemed very heavy and bloated. As Vipers are so venomous that they should be destroyed, they killed her; and afterwards, being curious to know what made her so large, they opened her, and found in her abdomen fifteen 
young ones, about the size of full-grown earth-worms. 'This little fry issued into the world with the true Viper spirit about them, showing great alertness as soon as they were disengaged from the body of their parent. T'hey twisted and wriggled about, set themselves up, and gaped very wide when touched with a stick; exhibiting manifest tokens of menace and defiance, though as jet no fangs could be discovered, even by the help of glasses.

Vipers attain their full growth in seven years; they feed on frogs, toads, lizards, and other animals of that kind, and it is even asserted that they catch mice and small birds, of which they seem very fond. They cast their skin every year. The two front teeth in the upper jaw of the Viper are furnished with a small bladder containing poison. There is no doubt but this poison, which appears to have been infused into the jaws of the Tiper and other serpents by Providence, as a means of revenge upon their enemies, is so harmless to the animal itself, that when swallowed by it it only serves to accelerate its digestion. These venomous teeth or fangs stand, each by itself, upon a small movable bone; this arrangement enables the creature to fold down its fearful weapons in the mouth, and to erect them instantly when it has occasion to make use of them. The Viper is very patient of hunger, and may be kept more than six months without food. When in confinement, it refuses all sustenance, and the sharpness of its poison decreases in proportion : when at liberty, it remains torpid throughout the winter; yet, when confined, it has never been observed to take its annual repose.

The Viper is a native of many parts of this island, chiefly the dry and chalky counties. Its flesh was formerly used for broth, and much esteemed in medicine, particularly to restore debilitated constitutions. It was also used as a cosmetic, being supposed to render the complexion fair. It was probably from the use made by the ancients of this animal in medicine that Esculapius is represented with a serpent. The best remedy against the bite of the Viper is to suck the wound, which may be done without danger, and after this to rub it with sweet oil, and poultice it with bread and milk. 


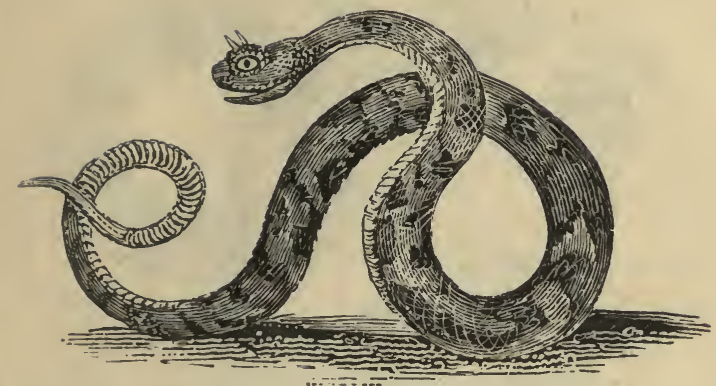

THE HORNED VIPER. (Cerastes Hasselquistii.)

THIs species of Viper is nearly allied to the asp, and has a pointed and solid horny substance on each eyelid, formed of two projecting scales: its body is of a pale yellowish or greyish colour, with distant sub-ovate transverse brown spots; and in length it is from one to two feet.

'This species is often mentioned by the ancients. Pliny tells us that "the serpent Cerastes hath many times four small horns, standing out double; with moving whereof she amuseth the birds, and traineth them unto her for to catch them, hiding all the rest of her body."

It is found in the sandy deserts of Egypt and the neighbouring countries, and is believed to be the Asp with which Cleopatra eluded the disgrace of becoming a prisoner to her Roman conqueror. 


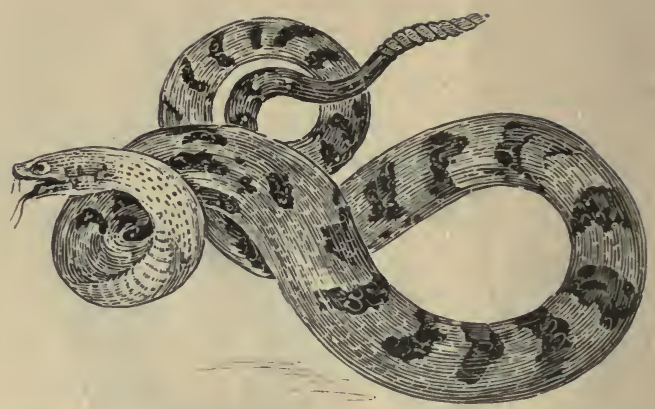

'I'HE RAT'ILE-SNAKE, (Crotalus horridus,)

Is a native of the New World, and grows to five or six, and sometimes to eight feet in length, and is nearly as thick as a man's leg. It is not unlike the viper, having a large head and small neck, and inflicting a very dangerous wound. Over each eye is a large pendulous scale, the use of which has not yet been ascertained; the body is scaly and hard, variegated with several different colours. The principal characteristic of this justly dreaded serpent is the rattle, a kind of instrument resembling the curb-chain of a bridle, at the extremity of the tail; it is formed of thin, hard, hollow bones, linked together, and rattling on the least motion. When disturbed, the creature shakes this rattle with considerable noise and rapidity, striking terror into all the smaller animals, which are afraid of the destructive venom that this serpent communicates to the wounded limb with his bite. The wound the Rattle-snake inflicts, through the uncommon sharpness and rapid fluency of the poison, generally terminates the torment and life of the unhappy victim in the course of six or seven hours.

A snake of this kind exhibited in London at a menagerie of foreign animals, in the year 1810, wounded a carpenter's hand, who was repairing its cage, and seeking for his rule. The man suffered the most excruciating pain, and his life could not be saved, although medical assistance was immediately applied, and every effort 
made to prevent the dire effect of the poison. The proprietor was condemned to pay a deodand for the injury done by the serpent.

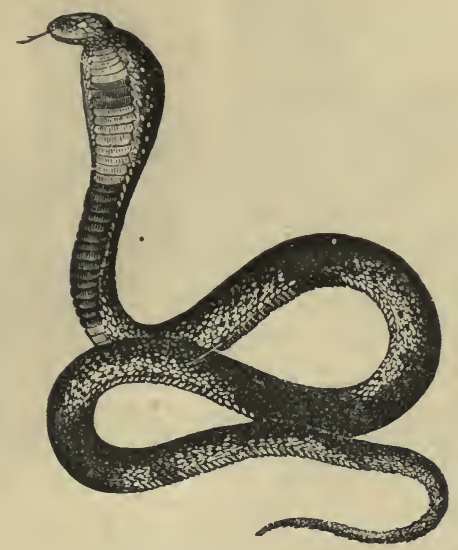

THE HAJE, OR EGYPTIAN ASP. (Naja Haje.).

The HaJE, or Egyptian Asp, is from three to six feet in length; it has two teeth longer than the rest, through which the venom flows. The body is covered with small round scales, and is of a greenish colour, bordered with brown; its neck is capable of inflation. The jugglers of Egypt, by pressing this Asp on the nape of the neck with the finger, throw the animal into a kind of catalepsy, which renders it stiff and immovable; when they say that they have changed it into a rod. The habit which this species has of raising itself up when approached, induced the ancient Egyptians to believe that it guarded the fields where it was found; and it is sculptured on the gates of their temples as an emblem of the protecting divinity of the world. 


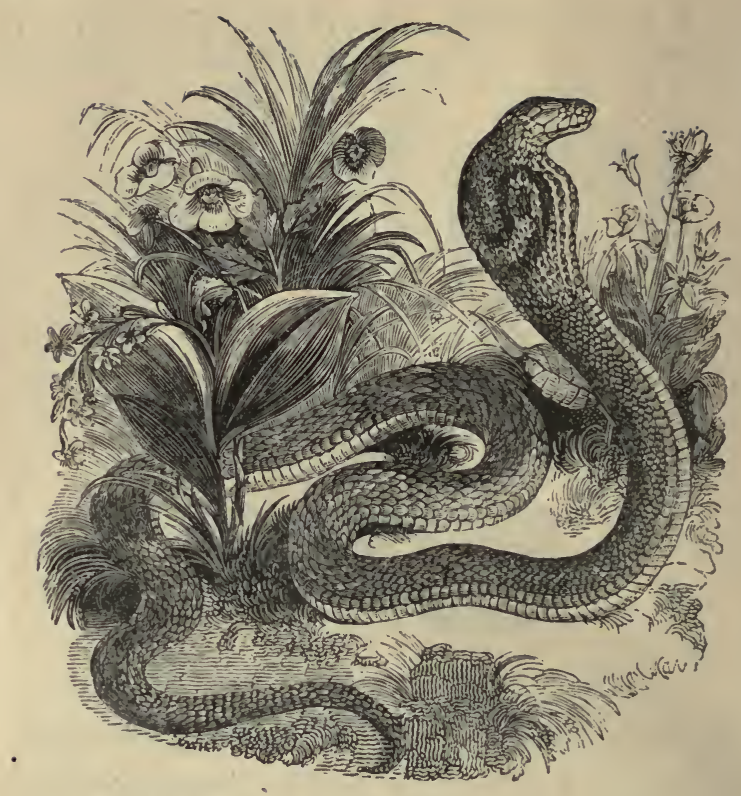

THE HOODED SERPENT, OR COBRA DI CAPELLO, (Naja tripudians,)

Called by the Indians the Nagao, is from three to eight feet long, with two long fangs in the upper jaw. It has a broad neck, and a mark of dark brown on the forehead; which, when viewed frontwise, looks like a pair of spectacles; but behind, like the head of a cat. The eyes are fierce and full of fire; the head is small, and the nose flat, though covered with very large scales, of a yellowish ash-colour: the skin is white, and the large tumour on the neck is flat and covered with oblong smooth scales. This serpent is extremely dreaded by the British residents in India, as its bite has hitherto been found to be incurable, and the sufferer generally dies in half an hour. 
Of this kind are the dancing-snakes, which are carried in baskets throughout Hindoostan, and procure a maintenance for a set of people, who play a few simple notes on the flute, with which the snakes seem much delighted, and keep time by a graceful motion of the head; erecting about half their length from the ground, and following the music with gentle curves, like the undulating lines of a swan's neck. It is a well-attested fact, that, when a house is infested with these snakes, and some other of the coluber genus, which destroy poultry and small domestic animals, as also by the larger serpents of the boa tribe, the musicians are sent for; who, by playing on a flageolet, find out their hiding places, and charm them to destruction: for no sooner do the snakes hear the music, than they come softly from their retreat, and are easily taken. I imagine these musical snakes were known in Palestine, from the Psalmist comparing the ungodly to the deaf adder, which stoppeth her ears, and refuseth to hear the voice of the charmer, charm he never so wisely.

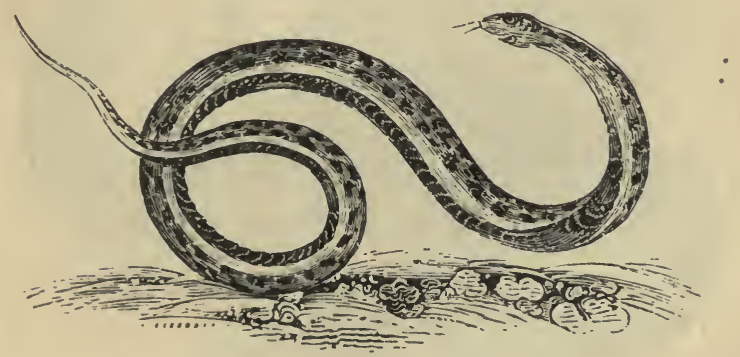

THE SNAKE, (Coluber natrix, )

Is the largest of all English serpents, sometimes exceeding four feet in length. 'I'he colour of the body is variegated with yellow, green, white, and regular spots of brown and black. They seem to enjoy themselves when basking in the sun, at the foot of an old wall. This animal is perfectly innoxious, although many reports have been circulated and believed to the contrary; it feeds on 
frogs, worms, mice, and various kinds of insects, and passes the greater part of the winter in a state of torpidity. In the spring they re-appear, and at this season uniformly cast their skins. This is a process that they also seem to undergo in autumn. Mr. White says: "About the middle of September we found in a field, near a hedge, the slough of a large snake, which seemed to have been newly cast. It appeared as if turned wrong side outward, and as if it had been drawn off backward, like a stocking or a woman's glove. Not only the whole skin, but even the scales from the eyes were peeled off, and appeared in the slough like a pair of spectacles. The reptile, at the time of changing his coat, had entangled himself intricately in the grass and weeds, in order that the friction of the stalks and blades might promote this curious shifting of his exuvia."

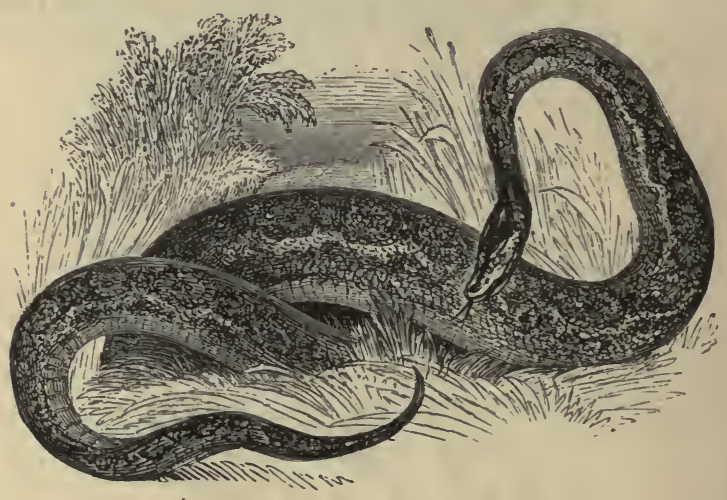

THE BOA CONSTRICTOR.

'I'Hıs inmense animal is often twenty feet in length, and sometimes even thirty-five; the ground colour of its skin is yellowish grey, on which is distributed, along the back, a series of large cliain-like, reddish bruwn, and sometimes perfectly red, variegations, with other smaller and more irregular marks and spots. It is a native of 


\section{The Amphisbæna.}

South America, where it chiefly resides in the most retired situations in woods and marshes.

The bite of this snake is not venomous, nor is the animal believed to bite at all, except to seize its prey. It kills its prey by twining round it and crushing its bones.

The Python and the Anaconda, which are at least as large as the Boa Constrictor, are found chiefly in the Indian Islands: they are very similar both in form and colouring to the Boa, and have exactly the same habits.

-These monsters will attack and devour the largest animals, of which the following is an instance: A Boa had for some time been waiting near the brink of a pool in expectation of its prey, when a buffalo appeared. Having darted upon the affrighted beast, it instantly began to encircle him with its voluminous twistings, and at every twist the bones of the buffalo were heard to crack as loud as the report of a gun. It was in vain that the animal struggled and bellowed; its enormous enemy entwined it so closely that at length all its bones were crushed to pieces, like those of a malefactor on the wheel, and the whole body was reduced to one uniform mass : the serpent then untwined its folds in order to swallow its prey at leisure. 'To prepare for this, and also to make it slip down the throat more smoothly, it licked the whole body over, covering it with a mucilaginous substance. It then began to swallow it, at the end that afforded the least resistance, and in the act of swallowing, the throat suffered so great a dilation as to take in a substance that was thrice its own ordinary thickness.

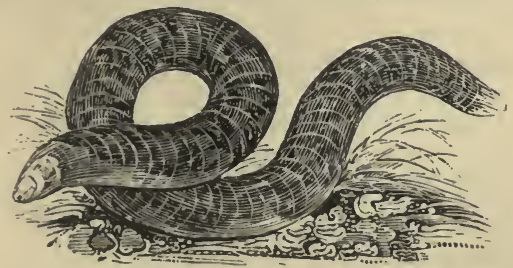

THE AMPHISBANA. (Amphisbona fuliginosa.)

THIs name is now applied only to a genus of South 
American reptiles, which are of a harmless nature, being destitute of those fangs which prepare the venom in poisonous serpents. It is indeed doubtful whether the Amphisbænas are really snakes, and by many naturalists they are arranged amongst the lizards, although they have no limbs. The head is so small, and the tail so thick and short, that at first sight it is difficult to distinguish one from the other; and this circumstance, united to the animal's habit of proceeding either backwards or forwards as occasion may require, gave rise to the supposition throughout the native regions of the Amphisbæna, that it had two heads, one at each extremity, and that it was impossible to destroy one by simple cutting, as the two heads would mutually seek one another and reunite! The colour of the commonest species is a deep brown varied with patches of white. The body is ornamented by more than two hundred rings, and the tail by about twenty-five. 'The eyes are almost concealed by a thick membrane, and this, together with their small size, has given rise to the idea that the Amphisbæna is blind. It grows to the length of eighteen inches or two feet. Its food consists of worms and insects, and especially ants, in the mounds of which it generally conceals itseif. The ancients gave the name of Amphisbæna to what they considered a two-headed serpent; but it is not known with certainty which of the serpent tribe they meant, as their Amphisbæna is described by Lucan as venomous, though in his lines elegance of language, beauty of versification, and liveliness of fancy, have perhaps a greater claim than truth to the admiration of the reader :-

"With hissings fierce, dire Amphisbænas rear

Their double heads, and rouse the soldier's fear.

Eager he flies : more eager they pursue;

On every side the onset quick renew !

With equal swiftness face or shun the prey, And follow fast when thought to run a way. Thus on the looms the busy shuttles glide, Alternate fly, and shoot at either side." 


\section{§ II. Batrachian Reptiles.}

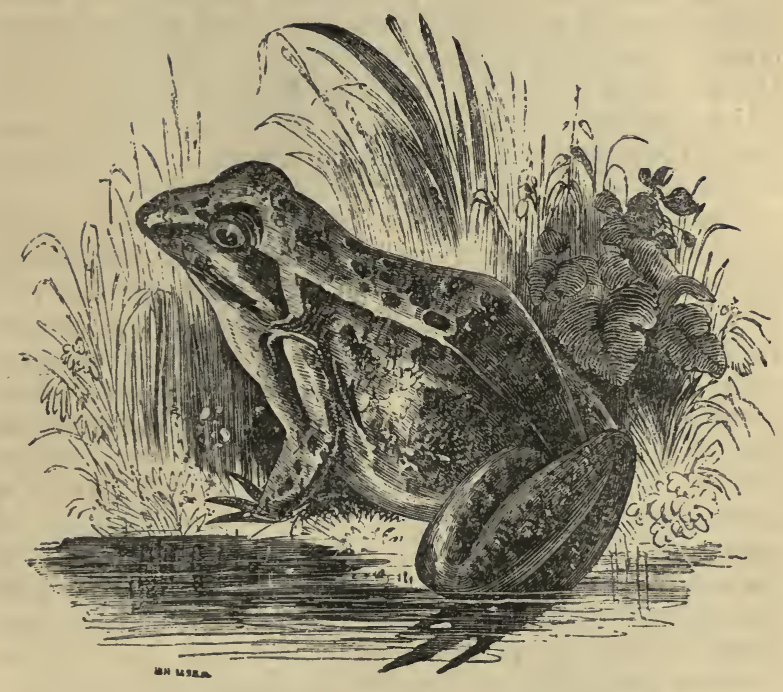

THE FROG. (Rana temporaria.)

WHEN this reptile issues from the egg it is merely a black, oval mass, with a slender tail. This tadpole, as it is then called, is the embryo of the Frog, and when it has attained a certain size its body gradually acquires the form of that of the Frog, its legs sprout from its sides, and finally its tail is cast off. 'This metamorphosis is one of the most curious in nature, and deserves our observation. Like other reptiles, it is not necessary for it to breathe in order to put its blood into circulation, as it has a communication between the two ventricles of the heart. It lives during spring in ponds, brooks, muddy ditches, marshy grounds, and other watery places, in summer in corn-fields and pasture land. Its voice proceeds from two bladders, one on each side of the mouth, which it can fill with wind. When it croaks, it puts its head out 
of the water. The hinder legs of the Frog are much longer than the fore ones, to help it in its repeated and extensive leaps. The whole of the body bears a little resemblance to some of the warm-blooded animals, principally about the thighs and the toes. The Frog is extremely tenacious of life, and often survives the abscission of its head for several hours. It is supposed that Frogs spend the whole winter at the bottom of some stagnant water in a state of torpidity.

There are several species of the Frog; they are all oviparous, and the eggs are gelatinous. 'The Edible Frog is the species used in France and Germany for food; it is considerably larger than the common kind, and though rare in England, is very plentiful in France, Germany, and Italy. Its colour is olive green, marked with black patches on the back, and on its limbs with transverse bars of the same. From the tip of the nose three distinct stripes of pale yellow extend to the extremity of the body, the middle one slightly depressed, and the lateral ones considerably elevated. The upper parts are of a pale whitish colour, tinged with green, and marked with irregular brown spots. These creatures are brought from the country, thirty or forty thousand at a time, to Vienna, and sold to the great dealers, who have froggeries for them, which are pits four or five feet deep. dug in the ground, the mouth covered with a board, and in severe weather with straw. In the year 1793, there were but three great dealers in Vienna, by whom those persons who brought them to the markets ready for the cook were supplied. Only the legs and thighs are eaten, and these are always skinned. They are rather dear, being considered a great delicacy. The Edible Frogs are caught in various ways, sometimes in the night, by means of nets, into which they are attracted by the light of torches that are carried out for the purpose, and sometimes by hooks, baited with worms, insects, flesh, or even a bit of red cloth. They are exceedingly voracious, and seize everything that moves before them. 


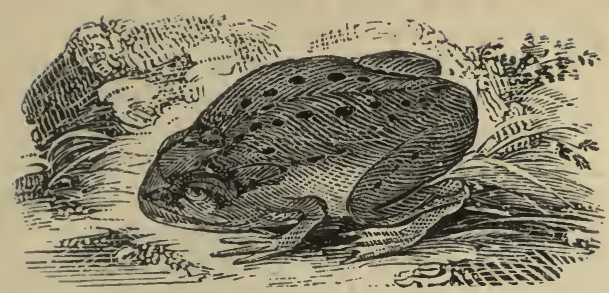

THE TOAD, (Bufo vulgaris,)

Whose very name seems to carry with it something of an opprobrious meaning, is not unworthy the attention of the observer of nature: for, though prejudice and false associations have affixed a stigma on certain species of animals, none of the works of our Creator are despicable, but all, the more minutely they are examined, the greater claim they are found to have to our admiration. Somewhat like the frog in the body, it also resembles that animal in its habits; but the frog leaps, while the Toad crawls. It is an error to suppose the Toad to be a noxious and venomous animal; it is as harmless as the frog, and, like some of the human kind, only labours under the stigma of undeserved calumny. Several stories have beett related of its spitting poison, or knowing how to expel the venom it may have received from the spider or any other animals ; but.these fables have been long exploded. A curious and yet inexplicable phenomenon is that Toads have been said to be found alive in the centre of large blocks of stone, where they must have subsisted without food and respiration for a number of years. The following are recorded examples: In the year 1719, M. Hubert, professor of philosophy at Caen, was witness to a living Toad being taken from the solid trunk of an elm-tree. It was lodged exactly in the centre, and filled the whole of the space that contained it. The tree was in every other respect firm and sound. Dr. Bradley saw a Toad taken from the trunk of a large oak. In the year 1733, a live Toad was discovered by M. Grayburg in a hard and solid block 
of stone which had been dug up in a quarry in Gothland. On being touched with a stick upon the head, he informs us, it contracted its eyes as if asleep, and when the stick was moved gradually opened them. Its mouth had no aperture, but was closed round with a yellowish skin. On being pressed with the stick on the back, a small quantity of clear water issued from it behind, and it immediately died. A living 'l'oad was found in a block of marble at Chillingham Castle, belonging to Lord Tankerville, near Alnwick, in Northumberland.

Some of these cases are related in a manner which renders it difficult to doubt that the observers described what they thought they saw; but the occurrence of the phenomena, as described, seems to be so utterly impossible that we are forced to suppose that those writers have been misled in some way. 'That there is some foundation for many of the stories in question we can have no doubt, but we must look forward to further observations for their explanation; as Mr. Bell says: "To believe that a Toad, inclosed within a mass of clay, or other similar substance, shall exist wholly without air or food, for hundreds of years, and at length be liberated alive, and capable of crawling, on the breaking up of the matrix, now become a solid rock, is certainly a demand upon our credulity which fow would be ready to answer."

With regard to the length of life of these animals, it is impossible to state anything decisive, but several facts prove that some of them have been gifted with astonishing longevity.

A correspondent of Mr. Pennant's supplied him with some curious particulars respecting a domestic Toad, which continued in the same place for thirty-six years. It frequented the steps before the hall-door of a gentleman's house in Devonshire. By being constantly fed, it was rendered so tame as always to come out of its hole in the evening when a candle was brought, and to look up as if expecting to be carried into the house, where it was frequently fed with insects. An animal of this description being so much noticed and befriended excited the curiosity of all who came to the house, and even females 


\section{- The Surinam Toad.}

so far conquered the horrors instilled into them by their nurses as generally to request to see it fed. It appeared most partial to flesh-maggots, which were kept for it in bran. It would follow them on the table, and, when within a proper distance, would fix its eyes and remain motionless for a little while, apparently to prepare for the stroke which was to follow, and which was instantaneous. It threw out its tongue to a great distance, and the insect, stuck by the glutinous matter to its tip, was swallowed by a motion quicker than the eye could follow. After having been kept more than thirty-six years it was at length destroyed by a tame raven, which one day seeing.it at the mouth of its hole pulled it out, and so wounded it that it died.

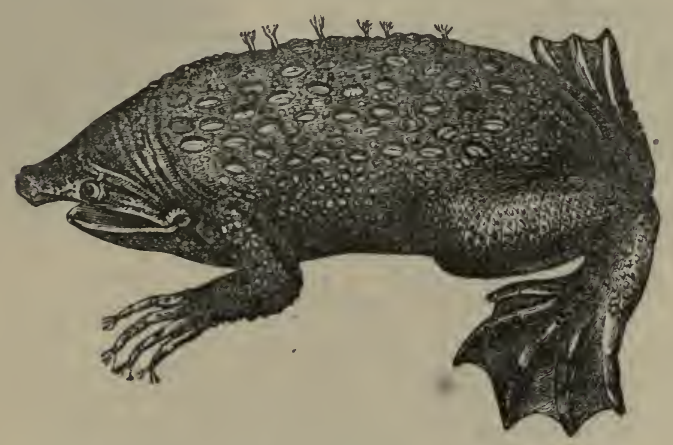

THE SURINAN TOAD, (Pipa Americuna, )

Which is one of the ugliest of all Toads, is remarkable for the mode in which the young are developed. The female, like that of the common Toad, deposits her eggs at the edge of the water, but instead of leaving them there, the male takes the mass of eggs and places them on the back of his partner, pressing them down into a number of curious pits, which are produced in that part at the breeding season. When each of the pits has received its egg, the orifice becomes closed by a sort of lid, and the young animal goes through all its changes 
from the tadpole to the perfect Toad in this rather confined space. This curious Toad is found in Guiana; it frequents the dark corners of the houses, and, notwithstanding its intense ugliness, is eaten by the natives.

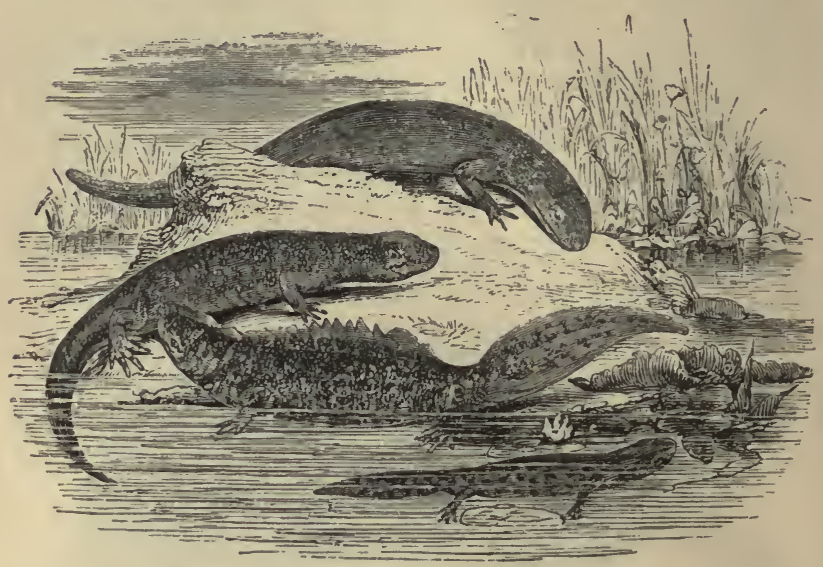

THE COMMON NEW'T. (Triton aquaticus.)

BESIDEs the frogs and toads, which have no tails when arrived at their perfect form, there are several Batrachian Reptiles in which this appendage is permanent. The best known of these are the Newts, of which two kinds are very common in ponds during the spring. The common Newt is three or four inches in length, and is of a pale brown colour above, and orange with black spots below. It has four little webbed feet and a flattened tail. In swimming, the legs are turned backwards to lessen resistance, and the animal is propelled principally by the tail. Their progression at the bottcm of the water and on land is performed creepingly with their small and weak feet. 'These animals live during the autumn and winter under stones and clods of earth, and come down to the water in February or March for the purpose of depositing their eggs there. The eggs 
are carefully inclosed by the parents in the leaves of aquatic plants. The young, when first hatched, are in the form of tadpoles; the legs afterwards sprout from the sides of the body, but the tail is not cast off, as in the frogs. The old Newts remain in the water until July or August.

\section{THE GREAT NEWT. (Triton palustris.)}

THIs, the largest British species of the Newt, is by no means uncommon in our ponds and ditches. It is about six inches in length; its back is dark, and its under side is orange-coloured, sprinkled with small black spots; altogether it is darker and richer in colour than the common species. During the breeding season the males of both species, but especially those of the larger one, are adorned with membranous crests, and their colours become much more vivid. Their tenacity of life is very great; when mutilated, they will reproduce the lost parts, and they may be frozen into a solid lump of ice without losing their vitality. With regard to its habits, this animal is a most voracious creature, and devours unsparingly aquatic insects, and, in fact, any small animal which happens to come in its way. For tadpoles it seems to have a special predilection, and its greediness is such that it has not escaped the charge of cannibalism. These Newts have more than once been taken in the act of devouring individuals of the smaller species, but of such a size that there seems to have been considerable difficulty in swallowing them. 
§ III. Saurian Reptiles.

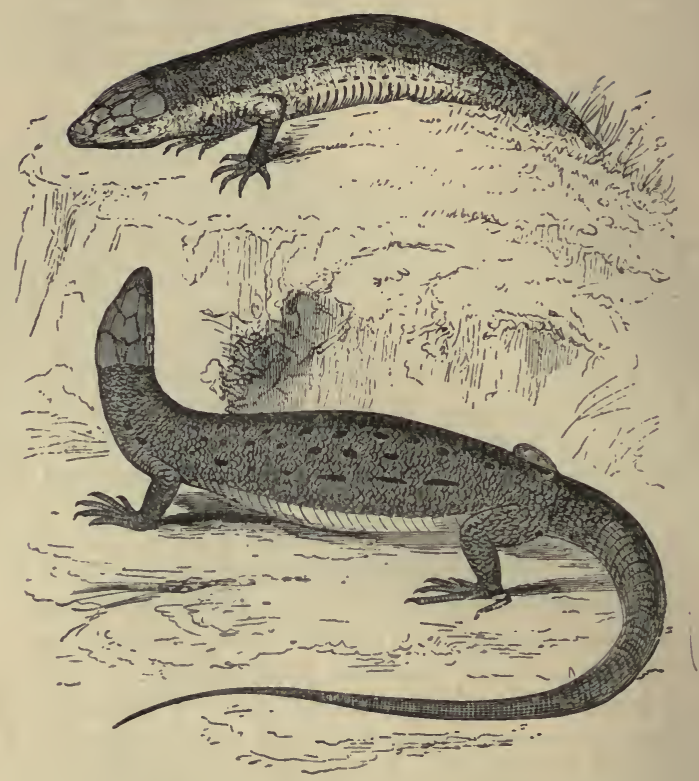

THE LIZARD. (Lacerta vivipara.)

This is a British species, and is one of the very few reptiles found in Ireland. Its movements are most graceful. It comes out of its hiding-place during the day to bask in the sun, and when it sees an insect it darts like lightning upon it, seizing it with its sharp little teeth, and soon swallowing it. The young are produced in eggs, which are generally hatched the moment they are laid, the skin of the egg being so thin that the young Lizard can be seen through it.

The Green Lizard (Lacerta viridis) is a beautiful creature. Its colours are more brilliant and beautiful than those of any other European species, and exhibit 
a rich and varied mixture of darker and lighter green, interspersed with specks and marks of yellow, brown, black, and sometimes even red. The head is covered with large angular scales, and the rest of the upper parts with very small ones. The tail is generally much longer than the body. Beneath the throat there is a kind of collar, formed by scales of much darker colour than the rest of the animal.

The Lizard seems occasionally to lay aside its natural gentleness of disposition, but no further than for the purpose of obtaining food. Mr. Edwards once surprised a Lizard in the act of fighting with a small bird, as she sat on her nest in a vine against a wall, with newlyhatched young. He supposed that the Lizard would have made a prey of the latter, could it have driven the old bird from her nest. He watched the contest for some time; but, on his near approach, the Lizard dropped to the ground, and the bird flew off.

\section{THE IGUANA, (Iguana tuberculata,)}

Whicr is found commonly in the tropical parts of America, is a large kind of lizard, often measuring four or five feet in length. It has a crest of long teeth, looking like a comb, along its back; its tail is long, tapering, and slender; and beneath its throat it has a sort of pouch which it can dilate considerably. The colour of this lizard is greenish, with brown bands on the tail. The Iguana is found in trees, and feeds chiefly on fruits and other vegetable substances. It is usually caught when reposing upon a branch, and by a very simple process: the hunter approaches it whistling, and the animal is stupid enough to sit still, no doubt enjoying the music, until a noose, attached to the end of a stick, is passed over its head. It is captured for the sake of its flesh, which is regarded as very delicate.

An Iguana, which was kept for some time in a hothouse at Bristol, was fed on the leaves of kidney bean plants, which it devoured eagerly, after refusing every other kind of food that had been offered it. It seems certain that Iguanas in their natural state are not entirely herbi- 
vorous, but feed on insects, the eggs of birds, and other animal matter, as well as on plants. They will occasionally take to the water, and seem to swim with ease. Notwithstanding its repulsive and even frightful appearance, the Iguana is perfectly harmless and inoffensive.

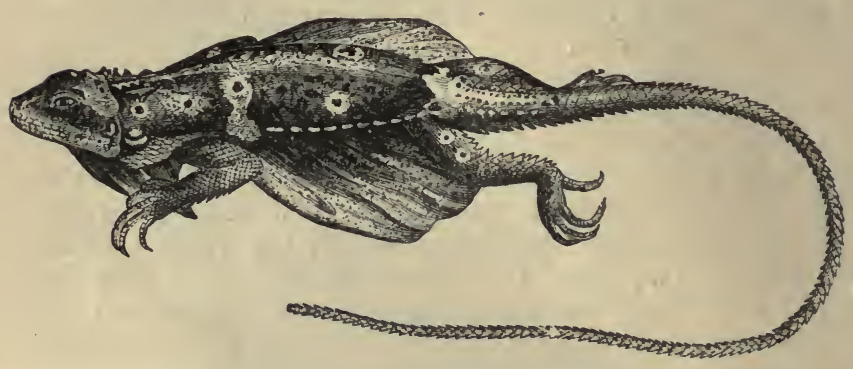

THE FLYING LIZARD, OR DRAGON.

\section{(Draco volans.)}

'The Flying Dragons, those terrible creatures described by the older naturalists, are undoubtedly fabulous and, indeed, impossible creatures, and either entirely products of the imagination of the vulgar, or founded upon specimens manufactured for the express purpose of taking in the naturalist, who, in old times, was a little too ready to believe in wonders of this kind. The wings of a bat attached to a body and legs made up from half a dozen animals would furnish a capital Dragon in former times. Modern naturalists apply the name of Dragon to some little lizards inhabiting the East Indies. and which have none of those terrible qualities ascribed to the fabled monsters of antiquity. They are related to the Iguanas, but have on each side of the body a membranous expansion, stiffened by the prolongation into it of the first six false ribs; this acts as a sort of parachute, and enables the little creatures, not to fly, but to leap or glide through the air to considerable distances between one tree and another. They live entirely in trees, and feed on insects. 


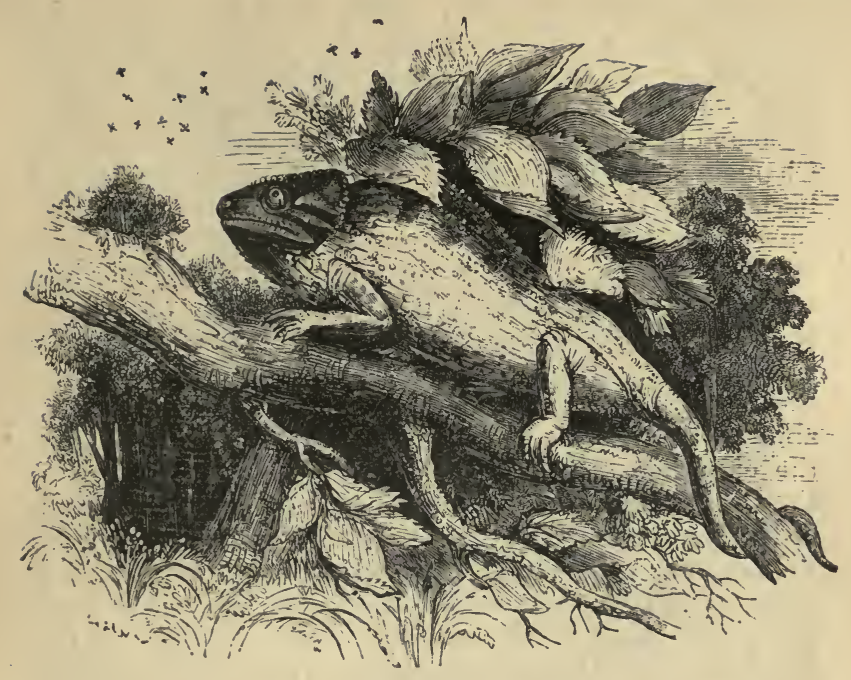

'THE CHAMELEON. (Chamœleo vulgaris.)

"A lizard's budy, lean and long, A fish's head, a serpent's tongue; Its foot with triple claw disjoin'd; And what a length of tail behind! Huw slow its pace! and then its hue!"

MERRICK.

'The Chameleon is a small animal, about ten inches long, and its tail nearly the same length. Its body is covered with small compressed scaly granules; its back is edged, and its tail round, long, and tapering. Its feet have each five toes, which are situated three one way and two another, in order to enable it to lay firm hold of the branches: but wherever it happens that these are too large for the animal to grasp with its feet, it coils round them its long, prehensile tail, and fixes its claws strongly into the bark. When walking on the ground, it steps forward in an extremely cautious manner, seeming never to lift one foot until it is well assured 
of the firmness of the rest. From these precautions, its motions have a ridiculous appearance of gravity, when contrasted with the smallness of its size, and the activity that might be expected from an animal so nearly allied to some of the most lively in the creation. Though the Chameleon is repulsive in its appearance, it is perfectly harmless. It feeds only on insects, for which the structure of its tongue is well adapted, being long and protrusive, and furnished with a dilated, glutinous, and somewhat tubular tip. With this it seizes on insects with the greatest ease, darting it out and immediately retracting it, with the prey thus secured, which it swallows whole. The strange notion that Chameleons were able to feed on air, seems to have arisen merely from the circumstance of these animals, like all others of the lizard family, being able to subsist for a great length of time without food. The eyes of the Chameleon have the singular property of looking at the same instant in different directions; one of them may be seen to move when the other is at rest, or one will be directed forward, whilst the other is attending to some object behind, or in a similar manner upward and downward. It has the power of inflating its body to double its ordinary size, and at these times it is transparent. It can undoubtedly change its colour, but it is not true that it takes that of any object it may be near. On the contrary, its change of colour depends on its being exposed to a very strong light; and it only changes from its natural dull grey to a beautiful green, spotted unequally with red. Africa is the native country of the Chameleons, of which there are fuurteen species; but two of them are found also in different parts of Asia and New Holland, and one (C. vulgaris) in the south of Europe; but this animal has never been found in any part of America. 


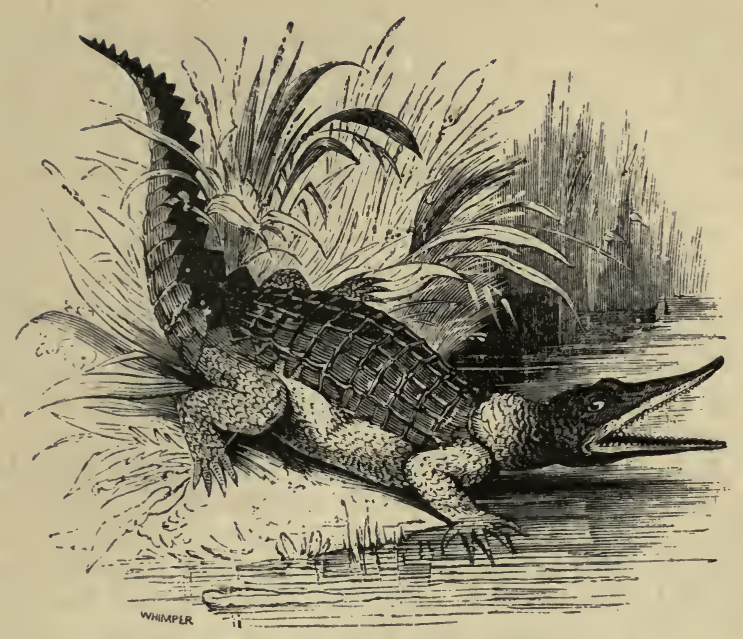

THE CROCODILE OF 'THE NILE.

(Crocodilus vulgaris.)

Turs animal is frequently thirty feet long. The female lays its eggs in the sand, where they are hatched by the heat of the sun; and the mother is said to take no care of the young ones. The head of this species, as of all the true Crocodiles, is twice as long as it is broad; the snout is pointed and unequal, and the eyes, which are small, are placed very far asunder. The colour is a greenish bronze, speckled with brown, and of a yellowish green underneath: six rows of nearly equal-sized plates run along the back. This Crocodile is less ferocious than some of the other kinds, and, when taken young, may be tamed, It is common in Senegal and other parts of Africa, as well as in the Nile.

The method which the African adopts to kill this formidable creature displays considerable ingenuity and courage. Having wrapped a thick cloth round his arm, and provided himself with a long knife, he proceeds to the known haunt, usually a reedy swamp or river. The 
moment the Crocodile perceives him it rushes at him with open mouth, but is coolly received by its antagonist, who thrusts his covered arm between its jaws. The teeth cannot pierce through the thick folds of the cloth, so that his arm only gets a smart squeeze, and before the creature can disengage itself, he adroitly cuts its throat.

The Gavials have very long, slender snouts, and their hind feet are webbed to the ends of the toes. These animals grow to the length of twenty-five feet, and when large are as dangerous and destructive as the Nilotic Crocodile. 'They are found abundantly in the Ganges, and in the fresh waters of most parts of India and its islands.

A short time before M. Navarette was at the Manillas, he was told that, as a young woman was washing her feet at one of the rivers, an Alligator seized and carried her off. Her husband, to whom she had been but just married, hearing her screams, threw himself headlong into the water, and, with a dagger in his hand, pursued the robber. He overtook and fought the animal with such success as to recover his wife; but, unfortunately for her brave rescuer, she died before she could be brought to the shore.

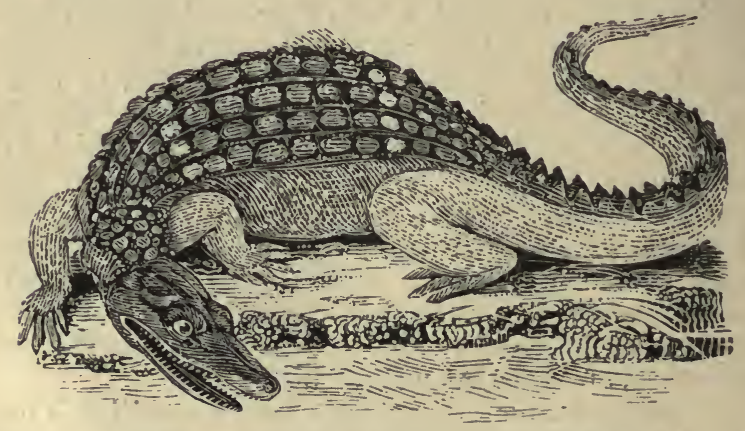

THE ALLIGATOR, OR CAYMAN.

(Alligator lucius.)

THE habits of the Alligator are much the same as those 
of the crocodile. The principal mark of distinction is, that the former has its head and part of the neck more smooth than the latter, and the snout is considerably more wide and flat, as well as more rounded at the extremity. 'The largest of these animals do not usually exceed eighteen feet. Alligators are natives of the warmer parts of America, and are the dread of all living animals. Their voracity is so great that they do not spare even mankind.

The voice of the Alligator is loud and harsh. They have an unpleasant and powerful musky scent. M. Pagés says, that near one of the rivers in America, where they were numerous, their effluvia was so strong as to impregnate his provisions, and even to give them the nauseous taste of rotten musk. This effluvium proceeds chiefly from four glands, two of which are situated in the groin, near each thigh, and the other two at the breast, under each fore leg. Dampier informs us that, when his men killed an Alligator, they generally took out these glands, and, after having dried them, wore them in their hats by way of perfume.

The following anecdote of the voracity of this animal is related by Waterton, in his "Wanderings in South America":- " One Sunday evening, some years ago, as I was walking with Don Felipe de Ynciarte, governor of Angustura, on the bank of the Oroonoque, 'Stop here a minute or two, Don Carlos,' said he to me, ' while I recount a sad accident. One fine evening last year, as the people of Angustura were sauntering up and down here, in the Alameda, I was within twenty yards of this place, when I saw a large Cayman rush out of the river, seize a man, and carry him down, before anybody had it in his power to assist him. The screams of the poor fellow were terrible, as the Cayman was running off with him. He plunged into the river with his prey: we instantly lost sight of him, and never saw or heard him more." 


\section{§ IV. Chelonian Reptiles.}

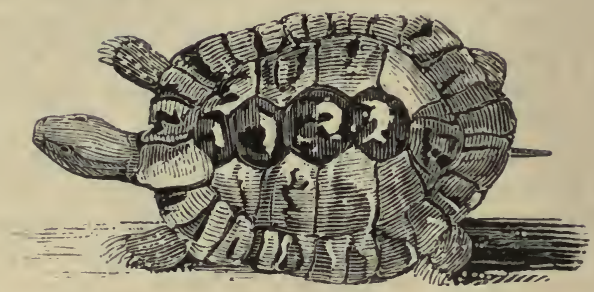

THE COMMON, OR GREEK TORTOISE.

(Testudo Groca.)

ThIs animal has a small head, four feet, and a tail, which it can gather within the shell in such a way that the top and under part meet together, and so closely, that the greatest strength cannot separate them. The eye is destitute of an upper lid, the under one serving to defend that organ. 'The upper shell, composed of thirtyseven compartments, is convex, and so strong, that a loaded cart can pass over it without injuring the creature inside. In winter, Tortoises are said to bury themselves in the ground, or retire to some cavern or hole, which they line with moss, grass, and leaves, and where they pass in safe and solitary retirement the whole of this season. The 'Tortoise is very tenacious of life, and is no less remarkable for its longevity, as it is ascertained that one lived upwards of one hundred and twenty years in the garden of Lambeth Palace.

This animal is found in most of the countries near the Mediterranean Sea, in Corsica, Sardinia, and some of the islands of the Archipelago, as well as in many parts of the north of Africa. 


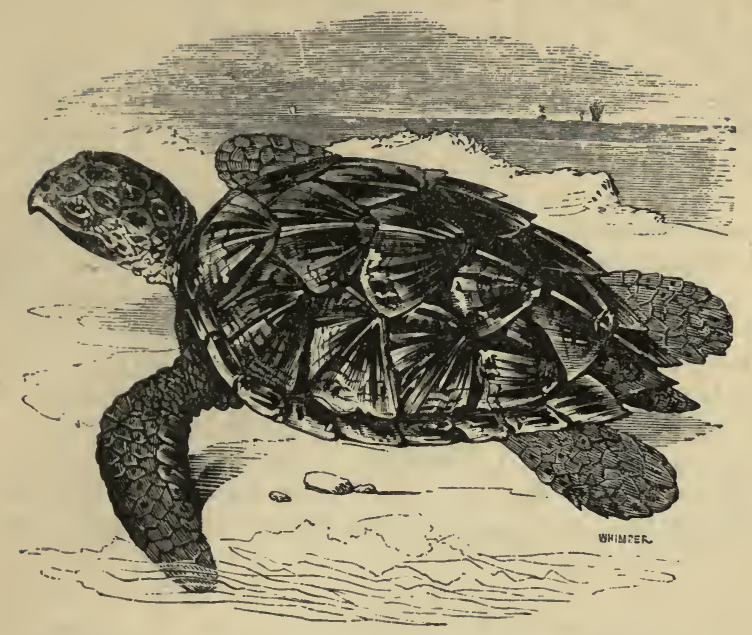

THE GREEN TURTLE. (Chelonia midas.)

Most of the Turtles are considered very delicate food, especially the green species. Some of them are so large as to weigh from four to eight hundred pounds. Dampier mentions an immensely large one that was caught at Port Royal, in the Bay of Campeachy. It was nearly six feet long, and four feet broad. A son of Captain Roch, a boy about ten years old, went in the shell, from the shore to his father's ship, which was about a quarter of a mile distant.

Turtle generally ascend from the sea, and crawl on the beach, for the purpose of laying their eggs (which are as large sometimes as those of a common hen), sometimes to the number of fifty or sixty at a time. The young ones, as soon as they are hatched, crawl down to the water. Turtles are caught, when sleeping on land, by turning them on their backs; for as they cannot turn themselves over again, all means of escape is denied them. The lean of the Green Turtle tastes and looks like veal, without any fishy flavour. The fat is as green 
as grass, and very sweet. The introduction of Turtle as an article of food into England, appears to have taken place within the last eighty or ninety years. They are common in Jamaica, and in most of the islands of the East and West Indies. Green Turtles are sometimes caught on the shores of Europe, driven thither by stress of weather. In the year 1752, one, six feet long and four feet broad, weighing between eight and nine hundred pounds, was caught in the harbour of Dieppe, after a storm. In 1754, a still larger one, upwards of eight feet long, was caught near Antiocne, and was carried to the Abbey of Longveau, near Vannes, in Brittany ; and in the year 1810, a small one was caught amongst the submarine rocks near Christchurch, in Hampshire.

The reader will remember how delighted Robinson Crusoe was to find a large Turtle which, he says, contained three score eggs. Behold him dragging it home.

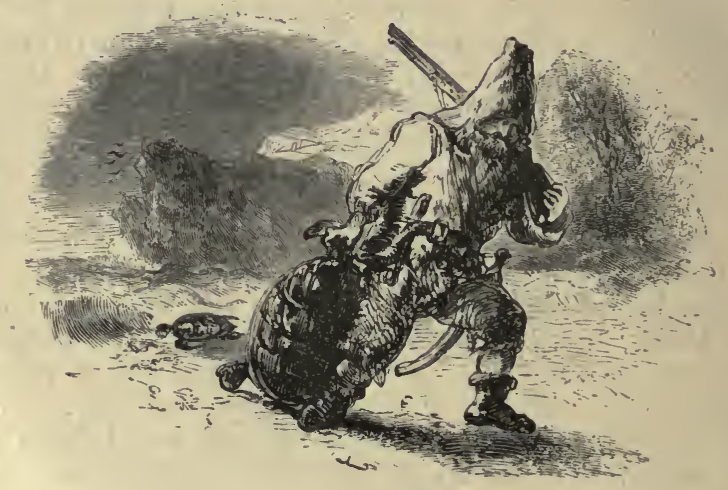




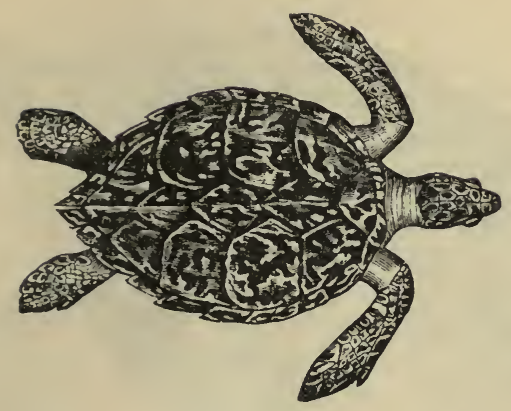

THE HAWK'S-BILL 'TURTLE, (Chelonia imbricata,)

Has received its name from the peculiar formation of the upper jaw, which terminates in a curved point, like the beak of a bird of prey. It is smaller than the Green 'Turtle, the largest specimens being about three feet in length. Its flesh is a very indifferent, if not unwholesome, article of food; but the horny plates with which its back is covered, and which lie over one another like the slates on the roof of a house, are beautifully mottied, and constitute the well-known tortoiseshell of commerce, which is so much used for making combs and various ornamental articles. It is only the best kind of tortoiseshell, however, that is taken from the Hawk's-bill Turtle. The shell that is usually seen is taken from commoner kinds. A very large quantity of tortoise-shell is imported into Europe every year, and the traffic in it forms a very important part of the trade of those countries in which turtles abound. 


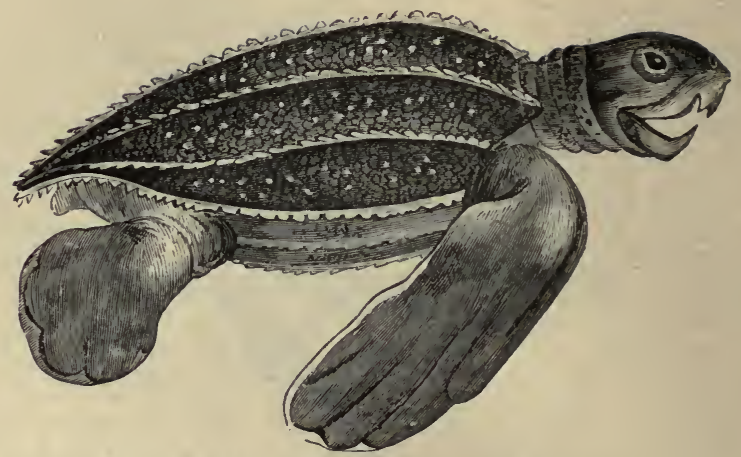

THE LEATHERY TURTLE, (Sphargis coriacea,)

HAs its back covered with a sort of leathery skin, instead of the horny plates of the other turtles. It is a very large species, measuring eight feet or more in length, and weighing as much as a thousand pounds. It is chiefly found in the Mediterranean ; it is, howerer, occasionally found on the other coasts of Europe, and a few specimens, some of them weighing seven or eight hundred pounds, have been caught in England. The flesh is not considered good, and in some cases great suffering has been occasioned by eating it. In 1748, a Leathery Turtle, which had been caught near Scarborough, was purchased by a gentleman, who invited several friends to taste it. Though warned that the flesh was unwholesome, one of the guests ate some, but was seized soon after with dreadful sickness. 'This should be a warning to the curious to be careful how they " eat strange flesh." 


\section{Bоoк V.}

\section{MOLLUSCOUS ANIMALS.}

§ I. Bivalves, or those having two shells.

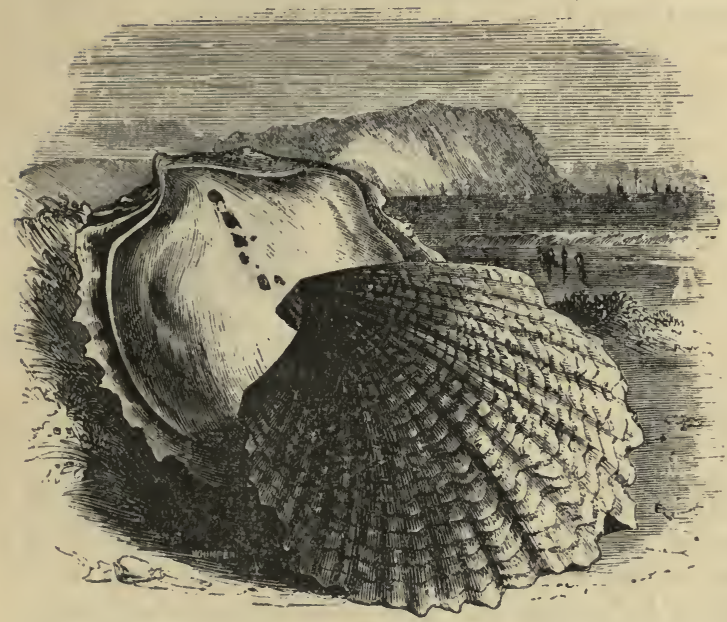

THE PEARL OYSTER. (Avicula Margaritifera.)

Wно that sees the beauty and delicacy of pearls would imagine that they were the production of disease? Such, however, is the case, as they are either formed in the body of the oyster which inhabits the shell; or they rise from cracks in the shell itself, the delicate, silvery, half-transparent lining of which forms the substance generally called Mother-of-Pearl, or Nacre. Their formation is generally caused by the introduction of some foreign body between the mantle or skin of the animal and its shell ; the irritation thus produced causes successive coats of pearly matter to be deposited on the intruding object, and thus the pearl is formed. The best pearls are those which are fairly imbedded in the substance of the mantle. These shells are found in the 
Persian Gulf and at Ceylon, where they form an important article of commerce.

The Chinese form pearls by easting into the shell of a certain kind of muscle artificial beads, which at the end of a year become covered with a pearly crust, in such a manner that they cannot be distinguished from the natural pearl.*

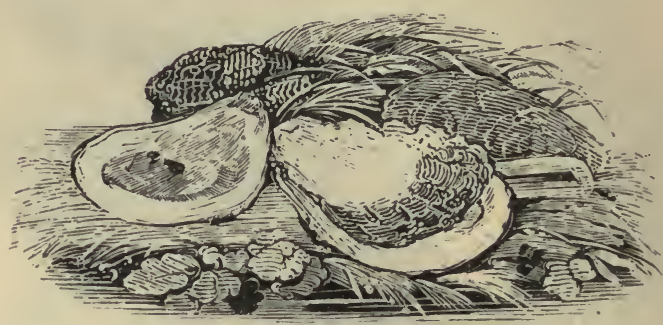

\section{THE COMMON OYSTER, (Ostrea edulis,)}

Has long been in favour with man for its delicacy as an article of food; the Lucrine lake used to be as much in renown among the Romans for the choicest kind of Oysters, as Cancalle Bay with the French, and the Colchester beds with us. The two shells of the Oyster are generally unequal in size; the hinge is without teeth, but furnished with a somewhat oval cavity, and generally with lateral transverse grooves. Oysters sometimes grow to a very large size; in the East Indies they are said sometimes to measure nearly two feet in diameter.

The principal breeding season of oysters is in the months of April and May, when they cast their young. which are enveloped in slime, and in this state called spats by the fishermen, upon rocks, stones, shells, or any other hard substance that happens to be near the place where they lie; and to these the spats immediately adhere. 'I'ill they obtain their film or crust, they are somewhat like the end of a candle, but of a greenish hue. The substances to which they adhere, of whatever

* For a very interesting article on this subject, see Beckmann's "History of Inventions," vol. i. p. 259. (Bohn's Standard Library.) 
nature, are called cultch. From the spawning time till about the end of July, Oysters are said to be sick; but by the end of August they become perfectly recovered; from May till August they are out of season and unwholesome. The Oyster-fishery of our principal coasts is regulated by a court of admiralty. In the month of May the fishermen are allowed to take the Oysters, in order to separate the spawn from the cultch, the latter of which is thrown in again, for the purpose of preserving the bed for the future. After this month it is felony to carry away the cultch, and otherwise punishable to take any Oyster, between whose shells, when closed, a shilling will rattle. The reason of the heavy penalty on destroying the cultch is, that when this is taken away, muscles and cockles will breed on the bed; and, by gradually occupying all the places on which the spawn should be cast, will destroy the Oysters.

The Oyster has been represented, by many authors, as an animal destitute not only of motion, but of every species of sensation. It is able, however, to perform movements which are perfectly consonant to its wants, to the dangers it apprehends, and to the enemies by which it is attacked. The gills, through which the Oyster breathes, are what is commonly called the beard, and are very indigestible. The scallop is nearly allied to the Oyster.

\section{THE COMMON COCKLE. (Cardium edule.)}

Few of our shell-fish are more common, in inlets and bays near the mouths of rivers, than these. In such situations they are usually found immersed at the depth of two or three inches in the sand, the place of each being marked by a small, circular, depressed spot. When they open their shells, the entrance into them is protected by a soft membrane, which entirely closes up the front, except in two places, at each of which there is a small, yellow, and fringed tube; by means of which they receive and eject the water which conveys to their body the nutriment necessary for their support.

Cockles are in great request as food among the labour- 
ing classes, and are caught chiefly in the winter months. Their size varies from five or six inches to half an inch in diameter. The shell is generally white; it has twenty-six longitudinal ridges, is transversely wrinkled, and has somewhat imbricated striæ. The foot of these animals is largely developed, and is to them a most important organ, as they use it not merely for progression, but in the excavation of hollows in the sand or mud in which they dwell.

The Chama, which is akin to the cockle, was used by the ancients to engrave various figures upon, from which circumstance those small bas-reliefs, so valued now, have obtained among the Italians and collectors the name of Cameos. 'T'he shells of some of these ares decorated with red or yellow stripes, diverging from the hinge, and spreading to the edges. 'The Giant Chama has been found to weigh more than five hundred pounds, and the oyster-like animal within was large enough to furnish a meal for twenty men. The animals which inhabit these shells are sometimes called Clams. The shells are often used in Catholic countries for containing holy water.

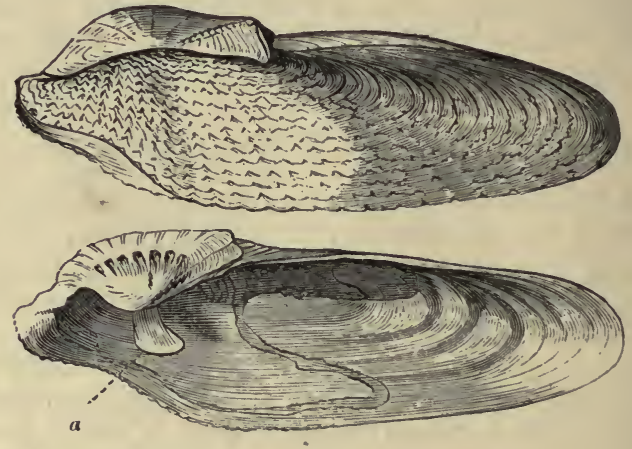

THE PHOLAS. (Pholas dactylus.)

This is a shell of a rather elongated form, gaping at both 
ends, and terminated in front by a point; it is white and chalky in its appearance, and the anterior end is roughened by numerous sharp spines and tubercles. The animal which inhabits this shell bores deeply into the rocks of the sea-shore, forming cylindrical holes, in which it lives; and the water which it requires for its food and respiration is conveyed to and from the interior of the shell by a pair of tubes which reach to the outer orifice of its dwelling-place. It is supposed that the Pholas is enabled to bore into the hard rock by means of its large and strong foot, but this is still a matter of dispute.

There are many other boring shells, most of which are related to the Pholas. Some of them burrow in rocks, others in wood, and some indifferently in either material. Of the wood-borers, the most remarkable is the Ship Worm (Teredo navalis), which penetrates deeply into floating or submerged timber, and lines the cavity of its burrow with a coating of shell. In this way the Teredo has often done much injury to piles and other woodwork exposed to the sea, and in 1731 and 1732 it excited so much alarm in Holland by attacking the piles of the great dikes, that even statesmen condescended to study its natural history. We must remember, however, that in the grand economy of nature even this destructive creature has its use; by penetrating in every direction through any floating mass of timber it promotes the breaking up of the latter, and prevents the surface of the sea from being encumbered with quantities of wreck. 


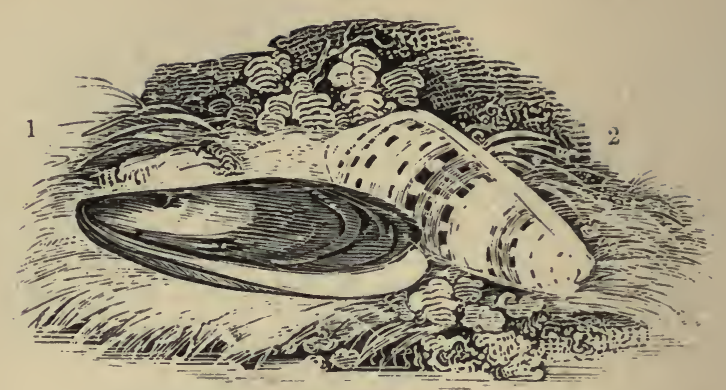

\section{THE MUSSEL. (Mytilus edulis.)}

Like the oyster, the Mussel inhabits a bivalve shell, to which it adheres by a strong cartilaginous tie. The shells of several of the species are beautiful. The Mussel possesses the property of locomotion, which it performs with the member called its tongue, by which it gets hold of the rock, and is enabled to draw itself along; it has also the property of emitting a kind of thread, called the byssus, which, fixing the sides of the shell upon the ground, answers the purpose of a cable, to keep the body of the fish steady.

\section{§ II. Univalves. \\ 2. THE ADMIRAL.}

Oxe of the cone-shells, the inhabitant of which is a kind of snail, with a very distinct head. If nature has taken a delight in painting the wings of birds, the skins of quadrupeds, and the scales of fishes, she seems not to have been less pleased in pencilling the shells of these inlabitants of the deep. The variety, brightness, and versatility of the colouring have long been deservedly the object of man's admiration; and we cannot help being astonished at the richness which a cabinet of well-selected shells presents to the eye. 


\section{THE TIGER COWRY. (Cyprca Tigris.)}

THE Cowries or Porcelain shells are amongst the must beautiful of the univalves. The shells are generally of an elegant oval form, with no visible spire; the mouth is a long slit on the middle of the lower surface, with two nearly equal lips toothed along their margins; the surface is most beautifully polished, and generally adorned with rich colours, arranged in varied and elegant patterns. The Tiger Cowry, which is one of the commonest, is rather broad, and very convex; it is of a white colour, covered with numerous dark brown spots. It is usually four or five inches in length, and inhabits the seas of India. The Money Cowry (Cyproea moneta) is a little Indian species, which is used in place of money in some countries, especially the interior of Africa. It is imported into England for exportation to Africa in large quantities; as much as 300 tons having been landed at Liverpool in one year.

\section{THE WHELK, (Buccinum undatum,}

Is a common British shell-fish of considerable size, which is obtained in large quantities by dredging, and used as food. In London it is sold commonly at stalls in the streets, we believe in a pickled state. The mouth of this animal is furnished with a powerful rasping proboscis, by means of which it is able to bore through the shells of other mollusca. 


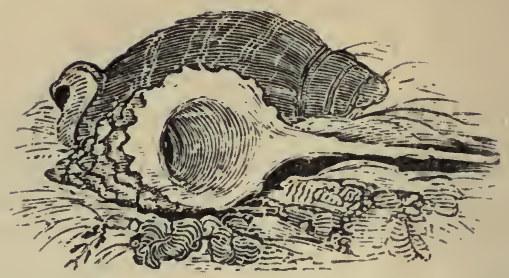

THE SNIPE SHELL, (Murex haustellus, or cornutus,)

So called on account of the length of a prominency coming out of the shell. It is surrounded with blunt prickles, and the colour of the whole is elegantly variegated.

\section{THE PERIWINKLE, (Littornia littorea,)}

Is too well known to require any description. It is found in incalculable numbers all round the European coasts, and captured in immense quantities as an article of food.

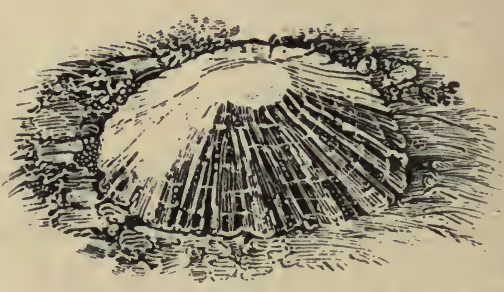

\section{THE LIMPET. (Patella.)}

'I'He shape of this shell is pyramidal; it adheres to the rock with such strength, that it can only be removed by means of a knife or a strong blow. The apex of the shell is sometimes sharp, sometimes obtuse, and often surrounded with points and sharp prickles. When thoroughly cleansed the shell is generally of a beantiful purple tint of great brilliancy, though the animal that 
lives under this magnificent roof is a kind of snail, disagreeable to the eye and insipid to the palate. 'They are found on the rocks, which are incessantly beaten by the surges and breakers, on the sea-shores of almost every country in the world. It is not by any glutinous liquid, as it has been asserted, that this tish adheres so strongly to the rock; but by the simple process of producing a vacuum between its foot and the rock to which it affixes itself.

The variety which is thrown into the sum of animated beings is so wonderfully great, that naturalists have reckoned more than a hundred and twenty-nine species of Limpets, and nearly allied genera; the difference arising principally out of the diversity of the shells in form and colour.

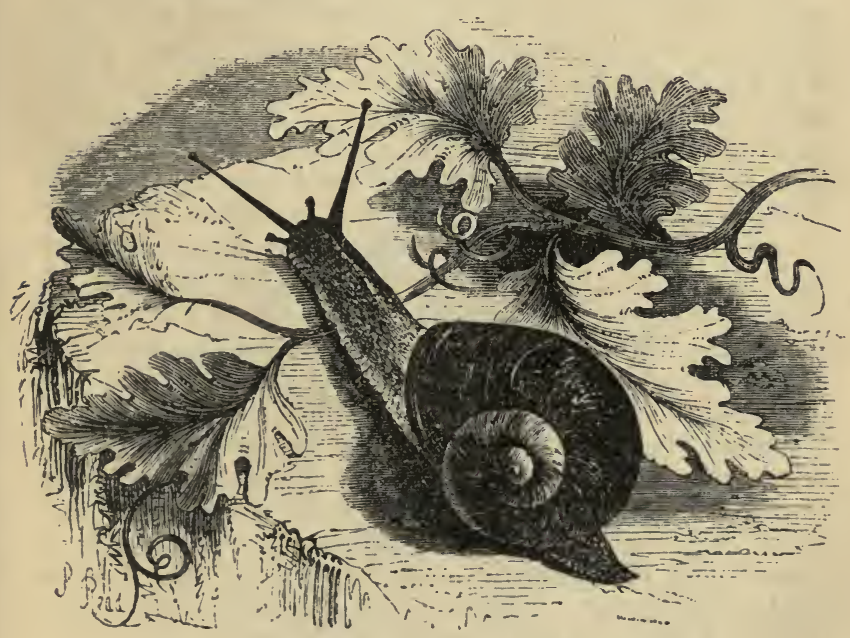

THE GARDEN SNAIL, (Helix aspersa,)

Is furnished with four tentacula, two of which are smaller than the others; at the end of these tentacula, which the animal pushes out or draws back, like telescopes, are blackish knobs, which are the eyes. The 
snail lays eggs, which are about the size of small peas, semi-transparent, and of a soft substance. By closely examining with a magnifying lens the eggs which a Water Snail, kept in a bottle of water, had deposited against the glass, the young Snail was seen in the egg, with its embryo shell on its back; two have also been observed in one egg, each of them with the rudiments of the shell.

'The Garden Snail is extremely tenacious of life, and remains in a state of torpor during the winter. It is said, indeed, that it can remain in this state for many years, and the following instance is probably without parallel in any other animal :-Mr. S. Simon, a merchant of Dublin, whose father, a Fellow of the Royal Society, and a lover of natural history, left him a small collection of fossils and other curiosities, had, among them, the shells of some Snails. About fifteen years after his father's death, he gave to his son, a child of ten years old, some of these Snail-shells to play with. The boy placed them in a flower-pot, which he filled with water, and the next day put them into a basin. Having occasion to use this. Mr. Simon observed that the animals had come out of their shells. He examined the child respecting them, and was assured that they were the same which had been in the cabinet. The boy said he had a few more, and brought them. Mr. S. put one of these into water, and, in an hour and a half afterwards, observed that it had put out its horns and body, which it moved but slowly, probably from weakness. Major Vallancy, Dr. Span, and other gentlemen, were afterwards present, and saw one of these Snails crawl out; the rest being dead, probably from their remaining some days in the water. Similar observations have since been so frequently repeated, that, there is now no doubt that Snails of various kinds may retain their vitality for years when preserved in a dry state.

THE SMALL GREY SLUG, (Limax cinereus,)

Resembles a Snail in all points except that. it has no shell, consequently the brown skin of the back is 
rougher and stronger than that of the Snail. Its progress on the ground may easily be traced by the slime which it leaves in its track. Few animals are more destructive to vegetation than these.

\section{THE BLACK SLUG, (Arion ater;)}

Is a well-known inhabitant of our fields and meadows, during the summer season. The country people consider its appearance as an indication of approaching rain; but this is rather to be accounted for by the moisture of the ground and plants. Indeed, it very seldom appears abroad during dry weather. The Black Slug feeds on the leaves of different kinds of plants.

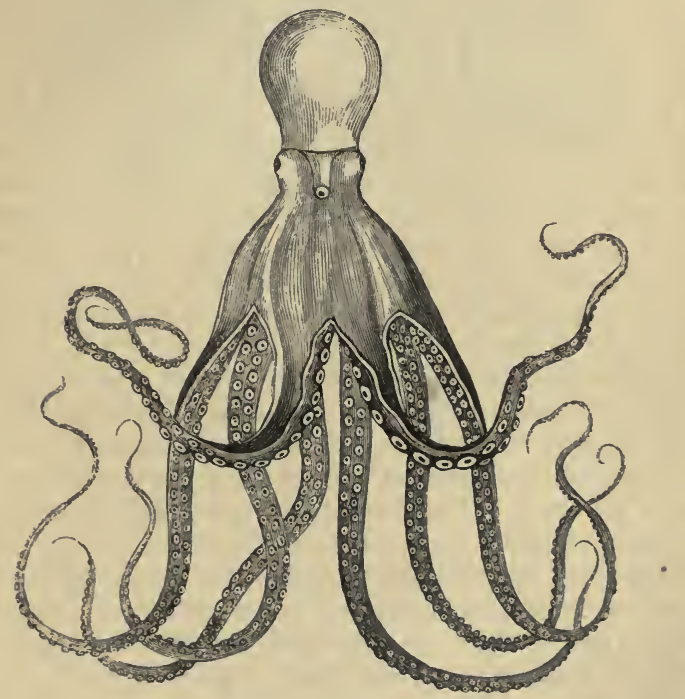

'I'HE SEPIA, OR CU'T'TLE-FISH. (Sepia officinalis.)

The structure of these animals is very remarkable. Their body is nearly cylindrical, and, in some of the 
species, entirely covered with a fleshy sheath; in others the sheath reaches only to the middle of the body. They have eight arms, or rather legs, and in general two feelers, much longer than the arms. Both the feelers and arms are furnished with strong circular cups or suckers. The mouth is hard, strong, and horny, resembling in texture the beak of the parrot. The body is of a jelly-like substance, and usually covered with a coarse skin, having the appearance of leather. This skin contains cells of different colours, which are capable of changing their relative position, so that the Cuttle-fish is able to change the colour of its skin. By means of the numerous circular cups or suckers with which the arms are furnished, they seize their prey, and firmly attach themselves to the rocks. 'Their adhesive power is so great, that it is generally more easy to tear off the arms than to separate them from the substance to which they are affixed: if the arms happen to be broken off, they are soon reproduced. 'The size to which this creature grows has been variously stated; and, although evidently exaggerated by some authors, it undoubtedly attains to a very considerable magnitude. When attacked in its own element, it has been known to overcome a large dog. Its jaws are extremely strong and powerful, and with its beak it can crush in pieces the shells of the fish on which it feeds. In the body is a bladder filled with a dark inky fluid, which it emits when alarmed, and which not only tinges the water so as to conceal its retreat, but is so bitter as immediately to drive off its enemies. This inky fluid, when dried, forms a very valuable colour, used by artists, and known as Sepia.

The bone, or calcareous plate of the Sepia Officinalis, a species common on our coasts, is a well-known substance, and is much employed in the manufacture of toothpowder; and by silversmiths for moulds, to cast their small work, such as rings, \&c. It is also converted into that useful article of stationery, called pounce. 
THE POULPE, (Octopus vulgaris,)

Has only eight arms, the two long tentacles of the Sepia being absent. It is found on our coasts, and is especially abundant in the Mediterranean, where it is regularly brought to market as an article of food.

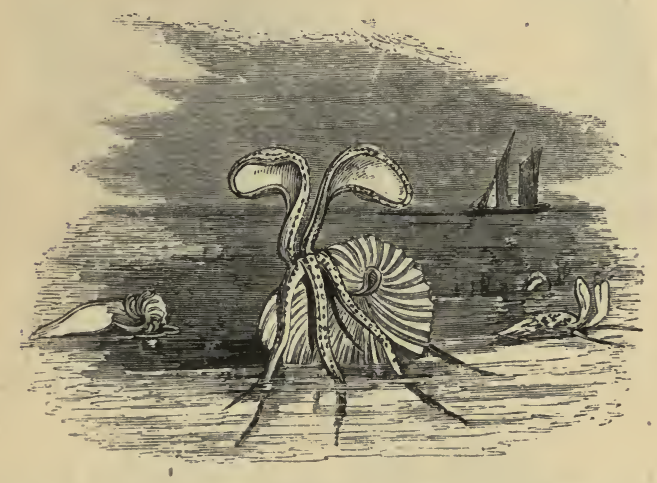

'THE ARGONAUT, OR PAPER NAUTILUS,

Is a kind of Poulpe, in which only six of the arms present the ordinary form, the other pair being expanded into broad, flat organs. It was supposed by the ancients, and, indeed, until very recently, that these expanded arms were used by the animal as sails; it was described as floating at the surface of the sea, with the back of the shell downwards, the six arms sticking into the water like so many oars, and the two broad members elevated to catch the breeze; but it is now known that the so-called sails are used to embrace the shell when the animal is swimming backwards, in the same way as its allies, and it also appears that it is by these arms that the shell is enlarged. The Argonaut is found in the Mediterranean. 


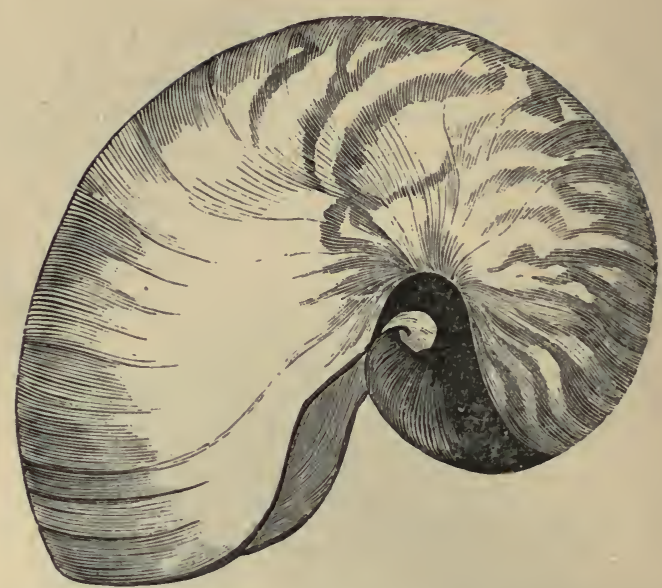

\section{THE NAUTILUS, OR PEARLY NAUTILUS,}

(Nautilus Pompilins,)

Is a very different creature, and instead of the eight arms of the Argonaut has its head surrounded by numerous ringed and sheathed tentacles. It is remarkable for the structure of its shell, the cavity of which is divided into numerous chambers by transverse partitions : these chambers, of which the outermost alone is occupied by the animal, are filled with air, but a narrow tube passes through the whole of them, and communicates with the cavity of the body. By this arrangement the Nantilus is enabled to alter his specific gravity so as either to rise to the surface or sink to the bottom of the water. The few existing species of Nautilus are all found in the Indian and South Pacific Oceans. 


\section{Book VI.}

\section{A RTICULATED ANIMALS.}

§ I. Annelida, or Ringed Animals.

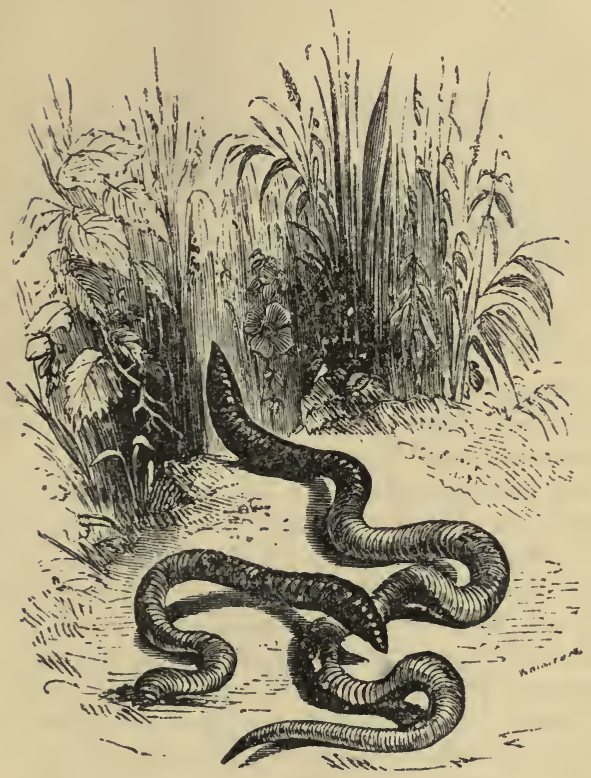

WORMS. (Vermes.)

'I'HESE creatures constitute a class by themselves, under the name of Annelida, in the works of modern naturalists. They are distinguished from the caterpillar and maggot, by undergoing no change, and crawling by means of the annular structure of their bodies.

The Earth Worm has neither bones, eyes, or ears; it has a round, annulated body, with generally an elevated fleshy belt near the head. Though considered a great 
nuisance by gardeners, Earth Worms perforate, and loosen the soil, and render it pervious to rains and the fibres of plants, by drawing into it straws and the stalks of leaves: and chiefly by throwing infinite numbers of lumps called worm-casts, which form a fine manure for grass and corn. They are, however, very injurious to plants in pots.

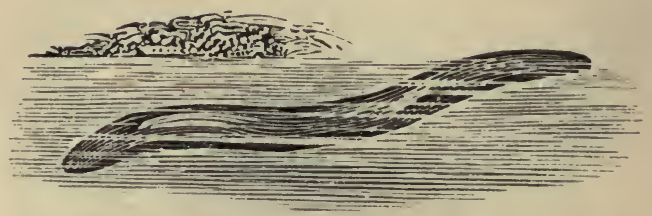

\section{THE LEECH, (Sanguisuga officinalis,)}

Is about three inches in length, and in its exterior form somewhat resembles the worm, when extended, but often contracts itself greatly in length, at the same time expanding in thickness. It has a small head, a black skin, with six yellow lines above, and spotted with yellow below. The mouth of the Leech is of curious construction; it has three jaws, each of which is armed with two ranges of very fine teeth, with which it pierces the skin; and then draws up, as through a siphon, the blood, upon which it feeds. The progressive movement of the Leech is effected by sticking, by suction, its mouth to a certain spot, then bringing its tail, which also has the property of sticking, in the same manner as the head, and then advancing its head further on, quickly followed by the tail, and so on. The common Leech is very often met with in brooks and rivulets. Its uses in medicine are well known, as by its means the blood can be extracted from diseased parts, to which the lancet cannot be applied.

The blood which the Leech sucks out of the wound it makes supplies it with nutriment for so great a period of time, that a Leech, after having been satisfied with blood, has been known to live three years without 
any food. It is usual, however, to make them disgorge the greater part of the blood they have swallowed by sprinkling them with salt; as otherwise they would nut bite again till the blood they had taken was fully digested.

Leeches lay eggs, which are covered with a kind of membrane, which serves to protect them when they are deposited in the clay and holes in the sides of ponds. They appear to live on the eggs of fish or frogs, but eagerly attach themselves to the legs of human beings, horses, or cows, whenever they have an opportunity. As there is a prejudice among the country people that Leeches never breed well till they have tasted blood, it is said that they drive their horses and cows into the water inhabited by the Leeches, and consequently that the Leech districts are remarkable for their wretchedlooking horses and cattle. Leeches must be five years old befure they are fit for medical purposes; and they are caught in shallow water in spring by people going in with naked feet and ankles, to which the Leeches adhere, when they are picked off and put in baskets provided for the purpose. In summer a raft is made of twigs, and the waters being disturbed with a stick, the Leeches rise to the surface, and get entangled in the raft. When caught, they are washed in water with a very little salt in it, and packed in wet linen cloths, which are put into a barrel with a canvas cover, and sent away for sale. London used to be chiefly supplied from the fenny districts of Lincolnshire, but the consumption of these useful worms has been so great that most of our Leeches are now imported through Hambro' from the east of Europe. Some years since Dr. Pereira stated that the number of Leeches imported by the four principal dealers in London amounted to $7,200,000$ annually. They are also, when kept in a glass bottle with water, a good barometer, as they always come up to the neck of the hottle when rainy weather is approaching, remain at the bottom in dry weather, and move anxiously up and down when the weather is stormy. Horse-Leeches are larger than the common species, more voracious, and narrower at each extremity. 


\section{§ II. Crustacea.}

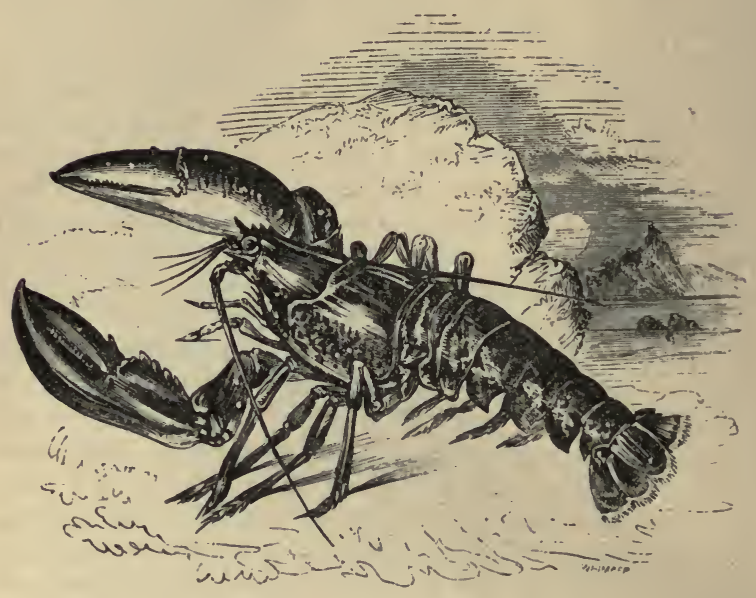

THE LOBSTER, (Astacus marinus,)

Has a cylindrical body, long antennæ, and a broad tail. Its large claws enable it to seize on its prey, to fix itself on the small prominences of rocks in the sea, to resist the motion of the waves, and to defend itself against its enemies. When the Lobster wants to spring off the rocks, it makes a fulcrum of its tail, which has the action of a powerful spring. Its gait is awkward, as in all the crustacea. Besides its claws, it has four small legs on each side, to assist it in its movements. Under the tail the hen Lobster preserves her eggs till they are hatched. They are extremely prolific. Dr. Baxter says he counted twelve thousand four hundred and forty-four eggs under the tail of a female Lobster, besides those that remained in the body undeveloped. Like the rest of their tribe, they cast their shells annually, previous to which they appear languid and restless : they acquire an entirely new covering in a few days. 


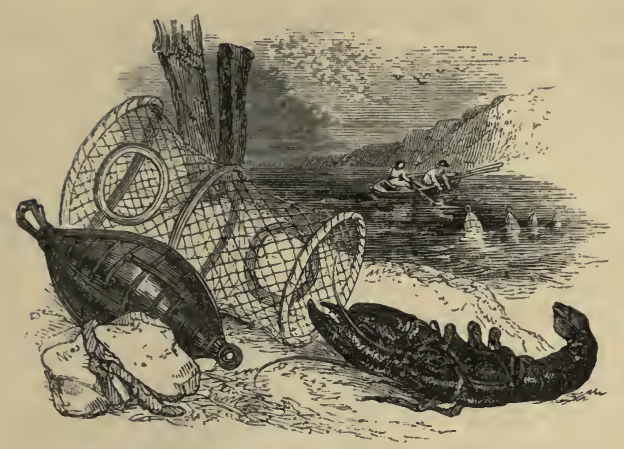

'I'HE CRAYFISH, (Astacus fuviatilis, )

MAY be called the lobster of fresh water, and its presence is generally esteemed an evidence of the goodness of the water. Crayfish are considered a very strengthening food. They are caught in shallow brooks, hid under large stones, out of which they crawl backwards to seek for their prey, which consists of small insects; the hooks employed to catch them are baited with liver or flesh, which they nibble most greedily.

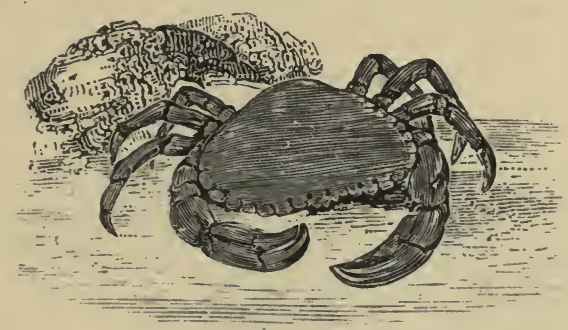

THE CRAB. (Cancer pagurus.)

CRABS are of various sizes, some weighing several pounds, and others only a few grains, all of different species. They do not move forward, but sideways. They have a small tail closed on the body; which forms a con- 
siderable and essential difference between them and the lobsters, prawns, shrimps, and crayfish.

The most remarkable circumstance in the history of these animals is the changing of their shells and the renewal of their broken claws. The former, as it is stated, take place once a year, and usually between Christmas and Easter. During the operation they retire among the cavities of rocks, and under great stones. Crabs are naturally quarrelsome amongst themselves, and frequently have serious contests, by means of those formidable weapons, their great claws. With these they lay hold of their adversary's legs; and wherever they seize, it is not easy to make them forego their hold. The animal seized has, therefore, no other alternative but to leave part of the leg behind in token of victory.

An experiment was tried to prove the extremely tenacious disposition of the Crab. By irritating it, a fisherman made a Crab seize one of its own small claws with a large one. The animal did not distinguish that it was itself the aggressor, but exerted its strength, and soon cracked the shell of the small claw. Feeling itself wounded, it cast off the piece in the usual place, but continued to hold it with the great claw for a long time afterwards.

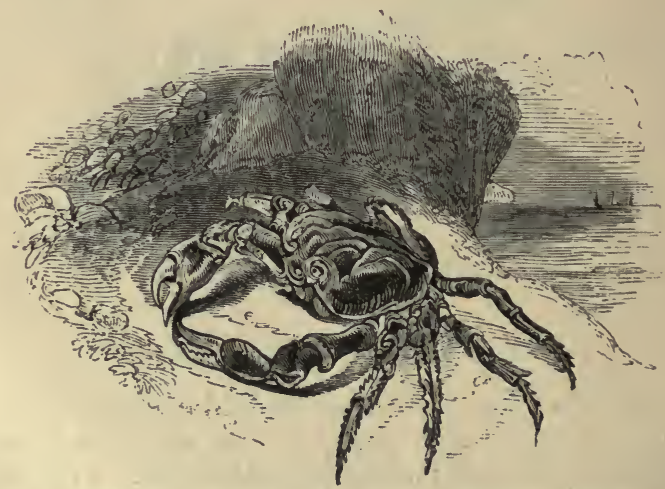

The Violet Land-Crabs of the Caribbee Islands are 
most singular in their habits; they descend in annual and regular caravans from the mountains, their natural abode, to the sea-shores, in order to deposit their spawn, after which they again return to the mountains. These Crabs form, in their procession, a body of fifty paces broad, and three miles in length. 'This battalion moves slowly, but with regularity and uniformity, either when they descend or ascend the hills. They abound in Jamaica, where they are accounted a great delicacy by the natives, and are common in the adjacent islands.

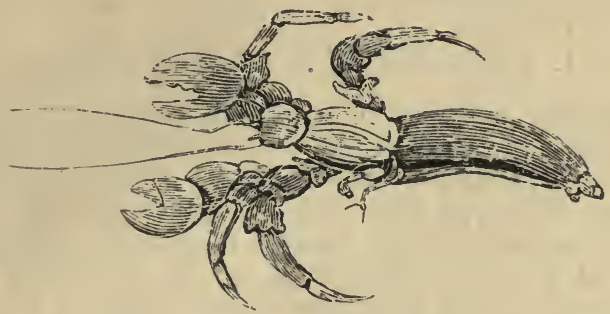

THE SOLDIER CRAB, OR HERMIT CRAB, (Pagurus bempardus,)

Is a curious animal, and ought to he noticed here for its singular habits. It is somewhat like a lobster divested of its shell; it is about four inches in length, and has no shell on the hinder part, but is covered down to the tail with a rough skin; it is also armed with strong hard nippers. This Crab has not been provided by nature with a shell, and is obliged to seek for one which has been deserted by its legitimate tenant; but as this covering cannot grow of course proportionally with him, he is forced out of it by his increasing size, and finds himself under the necessity of looking out for a new one : it is curious to see him when in want of a new house, crawling from one empty shell to another, examining and trying his new habitation. Sometimes, when two competitors happen to eye the same premises, a great contest arises, and of course the strongest gets the manor. 


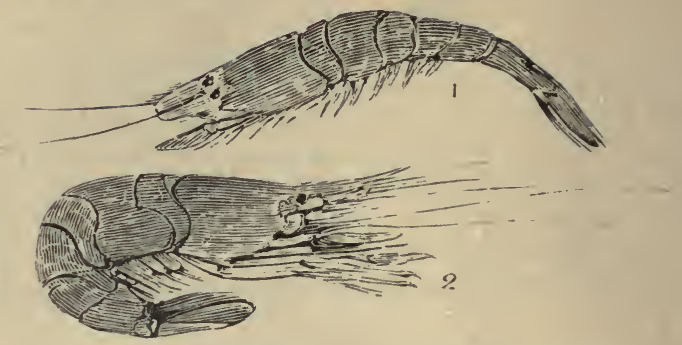

\section{THE SHRIMP. (Crangon vulgaris.)}

The Shrimp is a well-known small crustaceous animal, nearly allied to the lobster, which it resembles in shape. Its length is rather more than two inches; in colour it is greenish-grey, dotted with brown. It has long slender feelers, between which are two projecting laminæ; ten feet and five fins, but no claws. This animal breeds on all the sandy shores of Great Britain: it is frequently found in harbours, and even in the ditches and ponds of salt marshes; it is also very common on the Freneh coast. During life the body is semi-transparent, and so much resembles sea-water that the animal is distinguished with difficulty. Its ordinary motion consists of leaps. Its flavour is very delicate.

\section{THE PRAWN. (Palomon serratus.)}

The Prawn is not unlike the shrimp, but exceeds it considerably in size, its length being between three and four inches. It has a projecting ridge down the back, furnished with sharp teeth. Its natural colour is greyish, with small red and brown spots, but when boiled it assumes a most beautiful pink tint. The flesh is very delicate, although perhaps inferior in flavour to that of the shrimp.

Prawns are very common on the coasts of France and England; they are chiefly found among sea-weed, and in the vicinity of rocks, at a little distance from the shore. 
They seldom enter the mouths of rivers. 'They feed on all the smaller kinds of marine animals, which they seize and devour with great voracity. In their turn, they are the prey of numerous species of fish, although the sharp and serrated horn in front of their head constitutes a powerful weapon of defence against the attacks of all the smaller kinds. At the side of the head there is frequently to be observed a large and apparently unuatural lump. This, if examined, will be found to contain, under the thoracic plate, a species of parasitic animal, which occupies the whole cavity, and there feeds and perfects its growth. The same tumour or lump may also be observed on the shrimp.

Being in great request for the table, both shrimps and Prawns are eagerly sought for by fishermen, who catch them either in osier baskets, similar to those employed in catching lobsters, or in a kind of net called a Putting-net. These, which are well known to all frequenters of the sea-coast, are five or six feet in width, and flat at the bottom; and are pushed along in the shallow water, upon the sandy shores, by a man who walks behind. There is a great number of other species belonging to the same family as the shrimp and prawn, but they are for the most part inhabitants of foreign seas, and what other British species exist are rare in comparison to the two we have described.

Fossil crustaceans, which are apparently members of the same family, have also been found in France and Germany. 


\section{§ III. Arachnida.}

THIS ORDER, according to Lamarck, and other modern zoologists, contains the Spiders, Scorpions, and Mites, which do not undergo any metamorphoses. 'These creatures differ from the true insects in the number of their feet, which are generally eight, while those of the true insects never exceed six.

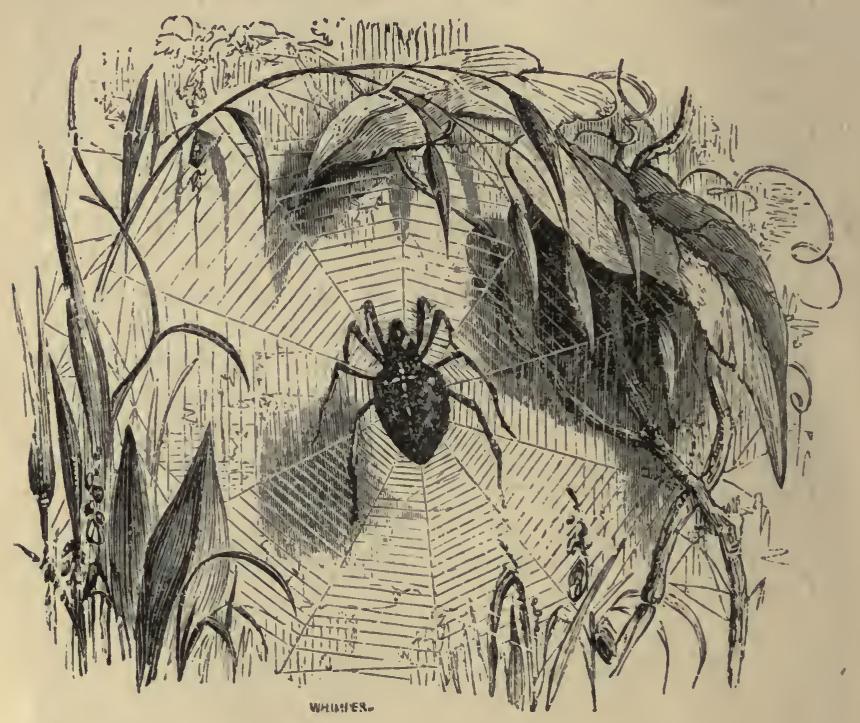

THE GARDEN SPIDER. (Epeïra diadema.)

A th the Spiders are distinguished by having no antennæ, eight legs, and generally eight eyes; mandibles terminated by a movable claw, which sometimes emits poison; and an abdomen without rings, furnished at its point with four or six spinnerets, from which the Spider emits the threads used in spinning its web. 'This web is wonderful 
in its formation. It consists of a number of stout threads radiating from the centre to various objects in the neighbourhuod, and crossed by a great quantity of finer threads arranged in a close spiral, so as to produce the impression of a number of concentric circles. These fine threads are braided and glutinous, so that any unfortunate fly that comes in contact with them adheres readily:

"The Spider's touch, how exquisitely fine!

Feels at each thread, and lives along the line." Pope.

The Spider sits in the middle, and at the least motion caused by a fly or other insect pressing against it, rushes on his prey, and sucks its juices: if, however, it should appear at all formidable, the Spider carefully encloses it in a shroud of web, which, of course, quite disables it; and then feasts on it at his convenience. The most difficult part of the business is to eject the remains, which is often attended with great detriment to the net. The female generally lays from nine hundred to a thousand eggs, which are contained in a kind of bag, and thus an immense number of Spiders are hatched every year, which would soon become troublesome from their numbers, if they were not kept in check by the numerous birds which prey upon them. The silk which the Spider protuces is not strong enough to be employed for any useful purposes, thongh, out of curiosity, gloves and stockings have been woven out of it. A great difficulty, however, arises in the pugnacious habits of Spiders, as, when a number of them are kept together, they fight so dreadfully, that in a short time only a very few are left alive; and a great number would be required, as twelre Spiders do not produce so much silk as a single silkworm. Spiders resemble the crustacea in having the power of reproducing the legs which they lose.

THE HOUSE SPIDER, (Tegenaria domestica,)

Is a very different species from the Garden Spider. It dwells in the dark corners of houses and outbuildings, forming a dingy web of irregular threads, all of which communicate with a concealed chamber or den in which the Spider lurks. 
THE DIVING SPIDER, (Argyroneta aquatica,)

Is another kind, which forms a sort of tent by stretching its threads between the stems of aquatic plants far below the surface. In this den it dwells, and here it devours the prey which it captures during its excursions ; and in order to provide a stock of air for its respiration, it carries down successive small portions entangled amungst the hairs of its abdomen. This process is exactly similar to that by which diving-bells used to be supplied with air, and indeed the dome-like habitation of this. Spider is constructed precisely on the same principle as the diving-bell.

There are also several kinds of Wuter Mites, the most abundant of which is of a rich red colour, and grows to nearly the bulk of a pea. It may commonly be seen swimming among the plants in pools and ditches.

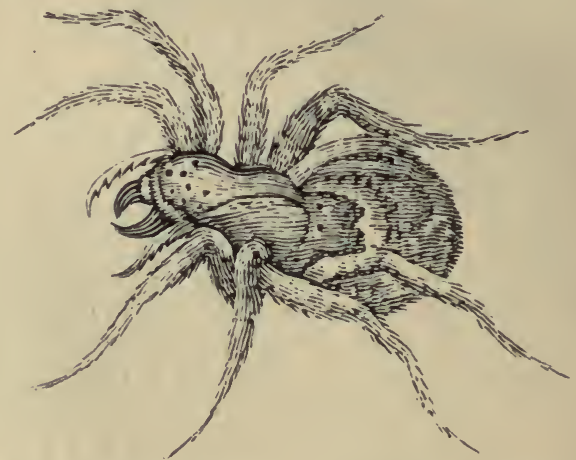

THE TARANTULA. (Lycosa Tarantula.)

'THIS Spider is a native of the South of Europe. It lives in fields, and its dwelling is about four inches deep in the ground, half an inch wide, and closed at the mouth with a net. 'They lay about seren hundred and thirty eggs, which are hatched in the spring. These Spiders do not live quite a year; the parents never survive the winter. 
Inflammation, difficulty of breathing, and sickness, are said to be the inevitable consequences of the bite of this animal. Dr. Mead, and other medical men, have countenanced the popular story of these effects being counteracted by the power of music. It is, however, now well known, that this singular mode of cure was nothing. more than a trick frequently practised on credulous travellers, who were desirous of witnessing it. Mr. Swinburne, when he was in Italy, minutely investigated every particular relative to the Tarantula. The season was not far enough advanced, and it was pretended that no persons had as yet been bitten that year: he, however, prevailed upon a woman, who bad formerly been bitten, to dance the part before him. Several musicians were summoned, and she performed the dance, as everyone present assured him, to perfection. At first she lolled stupidly on a chair, while the instruments played a dull strain. They touched at length the chord supposed to vibrate to her heart; and up she sprung with a hideous yell, staggered about the room like a drunken person, holding a handkerchief in both hands, raising them alternately, and moving in very true time. As the music grew brisker, her motions quickened, and she skipped about with great vigour, and in a variety of steps, every now and then shrieking very loud. The scene was unpleasant, and, at his request, an end was put to it before the woman was tired.

He informs us, that, whenever they are to dance, a place is prepared for them, hung round with bunches of grapes and ribbons. The patients are dressed in white, with red, green, or yellow ribbons; on their shoulders they have a white scarf; they let their hair fall loose about their ears, and throw the head quite back. $\mathrm{He}$ says that they are exact copies of the ancient priestesses of Bacchus. The introduction of Christianity abolished all public exhibitions of heathenish rites; but the women, unwilling to give up their darling amusement, in performing the frantic character of Bacchantes, devised other pretences; and he supposes that accident led them to the discovery of the Tarantula, of which they took advantage for that purpose. 


\section{THE CHEESE MITE. (Acarus siro.)}

THese destructive little creatures differ from spiders in having the thorax and abdomen united and covered with the same skin, though it is contracted in one part. They have also, when young, only six legs, though the two others appear afterwards; and their feet are armed with strong hooks, which enable them to retain hold of the cheese or other food, in which they take up their abede. Their bodies are covered with hair, and their mouths are furnished with strong mandibles, with which they soon hew down huge rocks and mountains of cheese. The eggs of these Mites are so small, that it has been computed that a pigeon's egg would contain thirty millions of them. It must be observed that this Mite is only found in dry cheese, in which it looks like reddish dust. The cheese-hopper, found in moist rotten cheese, is the maggot, of a kind of fly. (Piophila Casei.)

\section{§ IV. Insects.}

INSECTS have all six legs and two antennæ or feelers; and though the transformations they undergo differ slightly in the different kinds, the following is the order in which they occur:-The perfect insect lays eggs, which when hatched produce larva; and which are called grubs when they belong to beetles, maggots to flies, and caterpillars to butterflies and moths. 'These larvæ eat voraciously; and as they rapidly increase in size, they generally moult, that is, change their skins, two or three times. When the larvæ are full grown, they go into the pupa state, in which they remain torpid and without food for a considerable length of time, sometimes first spinning a loose covering for the pupa called a cocoon. The pupa is generally called a chrysalis; but it is also sometimes called a nymph, and sometimes an aurelia. The last transformation is when the insect breaks from its covering in a perfect form, when it is called the 
imago. There are, however, some insects which are active throughout their lives, and in these the larvæ and pupæ are very similar to the perfect insect. The perfect. insect is divided into three segments, or parts, called the head, the thorax, and the abdomen.

\section{Order I. Coleoptera, or Beetles.}

THe larva of the beetle is a grub, which often continues in that state three or four years, eating voraciously during the whole period. When full grown it in most cases either descends into the ground, where it undergoes its transformations, first into a nymph, or pupa, and then into a beetle; or it makes itself a rough cocoon of bits of stick and dead leaves, in which it changes into a pupa, and afterwards into a beetle. The wood-eating beetles undergo their transformations in the tree on which they feed. 'The pupa of the beetle is termed incomplete, because all the parts of the insect are visible in it, instead of being enclosed in one thick covering, as in the moths and butterflies. The head of the beetle is furnished with two compound eyes; two antennæ (differing in shape in the various species, but having usually eleven joints); and a mouth, consisting of a labrum, or upper lip, a labium, or under lip, two mandibles, or upper jaws, and two maxillæ, or under jaws. There is also the mentum, or chin, and a part called the clypeus, to which the upper lip is attached.

The thorax is the part which supports the legs and wings. The legs are divided into five portions, of which the part terminated by the claw is called the tarsus. There are two membranous wings, covered by two hardened wings or wing-cases, called the elytra, which generally open by a straight line down the back; and hence the name of Coleoptera, which signifies wing in a case : the abdomen is simply the body.

The number of beetles is very great, and indeed $\mathrm{Mr}$. Westwood informs us that more than thirty thousand species have been described, of which about three thousand five hundred are natives of Britain. 


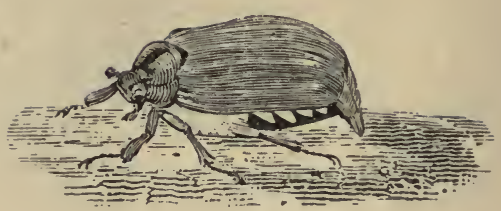

\section{THE COCKCHAFER. (Melolontha vulgaris.)}

The Cockchafer is one of the lamellicorn beetles. The female lays her eggs in the ground, and the grubs, when hatched, are soft, thick, and whitish. It is from its white appearance that the grub of the Cockchafer is called le ver blanc by the French. These grubs, sometimes in immense numbers, work between the turf and the soil in the richest meadows, devouring the roots of the grass to such a degree that the turf rises, and will roll up with almost as much ease as if it had been cut with a turfing knife; the soil underneath appearing, for more than an inch in depth, like the bed of a garden. In this the grubs lie, on their backs, in a curved position, the head and tail uppermost, and the rest of the body buried in the mould. It is also said that a whole field of fine flourishing grass has become, in a few wceks, withered, dry, and as brittle as hay, in consequence of these grubs devouring the roots.

In the year 1688 great numbers of Cockchafers appeared on the hedges and trees of the south-west coast of the county of Galway, in clusters of thousands, clinging to each others' backs, in the manner of bees when they swarm. During the day they continued quict, but towards sunset the whole were in motion; and the humming noise of their wings sounded like distant drums. Their numbers were so great that, for the space of two or three square miles, they entirely darkened the air. Persons travelling on the roads, or who were abroad in the fields, found it difficult to make their way home, as the insects were continually beating against their faces, and occasioned great pain. In a very short time 
the leaves of all the trees, for several miles round, were destroyed, leaving the whole country, though it was near midsummer, as naked and desolate as it would have been in the middle of winter. The noise which these enormous swarms made, in seizing and devouring the leaves, was so loud, as to be compared to the distant sawing of timber. Swine and poultry destroyed them in vast numbers; waiting under the trees for the clusters of insects to drop, and then devouring such swarms as to become fat upon them alone. Even the native Irish, from the insects having eaten up the whole produce of the ground, adopted a mode of cooking them, and thus used them as food. Towards the end of the summer they disappeared so suddenly that in a few days there was not one left.

Rooks are very fond of eating these grubs, and often, when they are seen in a newly-sown field, apparently devouring the grain, they are, in fact, rendering the greatest service to the farmer, by destroying his great enemy, the white worm.

\section{THE DOR, OR BLIND BEETLE.}

(Geotrupes stercorarius.)

THis well-known inseci, which is sometimes also called "the shard-borne beetle," has been often noticed by the poets. Amongst others, Shakespeare makes Macbeth say :

"Ere to black Hecate's summons

The shard-borne beetle, with its drowsy hum,

Hath rung night's yawning peal, there shall be done A deed of dreadful note."

This beetle, which is a British insect, lays its eggs in a mass of cow-dung, which it afterwards buries in the earth. It makes a dull drowsy noise when it flies, and often strikes itself against any person or object it may meet, as though it were blind. It has also the habit of stretching out its limbs and pretending to be dead when caught. 


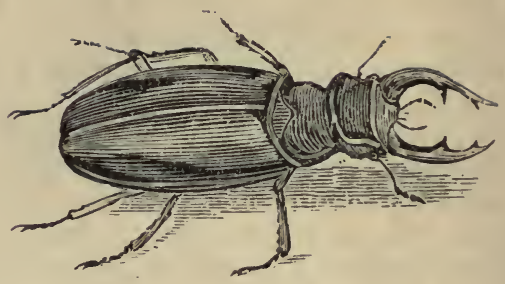

THE STAG BEETLE. (Lucanus cervus.)

"See the proud giant of the beetle race;

What shining arms his polished limbs encase!

Like some stern warrior, formidably bright, His steely sides reflect a gleamy light:

On his large forehead spreading horns he wears, And high in air the branching antlers bears;

O'er many an inch extends his wide domain, And his rich treasury swells with hoarded grain."

Barballd.

This insect is the largest, and most singular in shape, of any in this country. It is known by two horn-like mandibles, projecting from its head, and resembling those of a stag, with which it is able to pinch very severely. These mandibles are strongly dentated from the root to the point. The wing-cases have neither streaks nor spots. The whole insect is of a deep brown. It is sometimes found in hollow oaks and beeches, near London.

The larvæ, or grubs, lodge under the bark, or in the hollow of old trees; which they bite and reduce to fine powder. The larvæ are supposed to exist three or four years before they form their cocoons. These insects are mostly found in Kent and Sussex. In Germany there is a popular but idle notion, that they sometimes, by means of their jaws, carry burning coals into houses ; and that, in consequence of this mischievous propensity, dreadful fires have been occasioned. The Stag Beetle is one of the lamellicorn Coleoptera. 


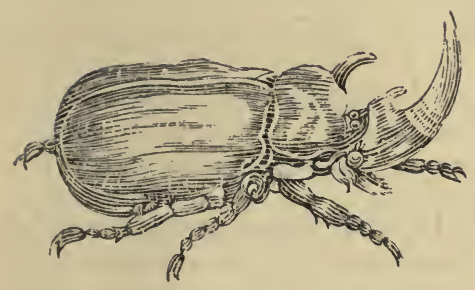

\section{THE ELEPHANT BEETLE,}

(Scarabceus, or Dynastes Elephas,)

Is found in South America, particularly in Guiana and Surinam, as well as near the river Orinoko. It is one of the largest beetles of its kind; it is black, and the whole body is covered with a very hard shell, quite as thick and as strong as that of a small crab. Its length, from the hinder part to the eyes, is almost four inches; and from the same part to the end of the large horn on the head (from the resemblance of which to the proboscis of an elephant, and its great size, the beetle has obtained its name) four inches and three quarters. The transverse diameter of the body is two inches and a quarter; and the breadth of each case, for the wings, upwards of an inch. The horns are about an inch long, and terminate in points. The head-horn is an inch and a quarter long, and turns upwards, making a crooked line terminating in two horns, each of which is nearly a quarter of an inch long. Above the head is a prominence, or small horn, which, if the rest of the trunk were away, would cause this part to resemble the horn of a rhinoceros. There is, indeed, a beetle named after that animal, whose lower horn resembles this: its scientific name is Oryctes Rlinoceros. 


\section{THE MUSK BEETLE, OR GOAT CHAFEER.}

\section{(Cerambyx moschatus, or Aromia moschata.)}

THIs is one of the longicorn beetles. It is a very beautiful insect, of a glossy bluish-green colour, with a cast of shining gold; the under part of the body is bluish. It is about an inch and a half in length, and is elongated in form, its breadth being small in proportion to its length; the wings under the case are black; the legs are of the same bluish-green colour, only somewhat paler; and the breast is pointed at each extremity. Between these points are three little tubercles near the wings, and three smaller towards the head. The cases of the wings are oblong, and somewhat in the shape of a lance, with three ribs a little raised, and running lengthwise. The feelers are as long as the body, composed of many joints, which grow smaller near the ends. This Beetle is very common in the south of England, and is chiefly to be found on old pollard willows. It emits a strong and agreeable odour, which is not unlike attar of roses. It certainly has not the slightest resemblance to musk, though those who named it appear to have thought that it had.

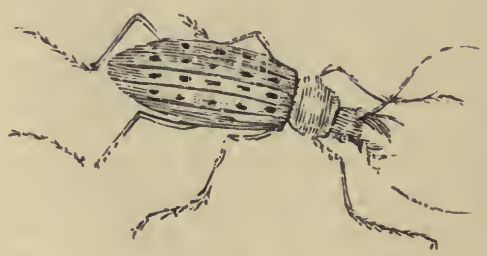

\section{THE GROUND BEETLE. (Carabus clathratus.)}

The Ground Beetre is not only one of the largest, but the most beautiful and brilliant that this country produces. The head, breast, and wing-cases are of a cop- 
pery green; the latter having three longitudinal rows of oblong raised spots. All the under part of the insect is black. Having only very short wings beneath the cases, Nature has providentially supplied it with such legs as enable it to run with amazing swiftness. This insect is frequently found in damp places, under stones and heaps of decayed plants in gardens. There are several species, one of which (Carabus violaceus) is of a beautiful purple.

The larvæ live under ground, or in decayed wood, where they remain until metamorphosed to their perfect state, when they proceed to devour the larvæ of other insects, and all weaker animals that they can conquer.

The Ground Beetles are found as early as the begin ning of March, in paths and near old walls, where the sun warms the earth with its vivifying beams. Many of the large species have been found between the decayed bark and wood of willow trees.

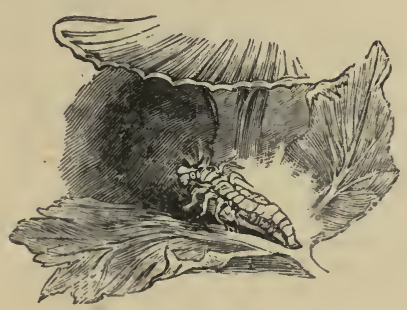

\section{THE GLOWWORM. (Lampyris noctiluca.)}

IT is only the female Glowworm which produces the beautiful light for which the insect is so well known, and she frequently communicates this light to her eggs. She is without wings or wing-cases, and possesses no beauty when seen by daylight. The male has wings, and leathery elytra. The larva is a very ugly and very voracious grub, which feeds greedily on snails and slugs. 


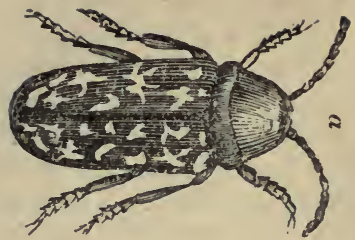

\section{THE DEATH-WATCH. (Anobium tesselatum.)}

'T'Hs creature is called the Death-Watch, from a superstitious notion that, when its beating is heard, it is a sign that some one in the house is going to die. The insect lives in wood, and the noise is produced by its striking its head against whatever is near it. These insects, in the larva state, do a great deal of mischief to old furniture, in which they perforate numerous round holes. To enable them to do this they are furnished with two maxilla formed like two cutting pincers, with the help of which they bore the holes so neatly that the French call them vrillettes, from vrille, a gimlet. They also perforate books in the same way, and thus do much damage in old libraries:

"Insatiate brute, whose teeth abuse The sweetest servants of the muse!

His roses nipt in every page,

My poor Anacreon mourns thy rage;

By thee my Ovid wounded lies ;

By thee my Lesbia's sparrow dies;

'Thy rubid teeth have half destroyed

The work of love in Biddy Floyd;

'They rent Belinda's locks away,

And spoiled the Blouzelind of Gay ;

For all, for every single deed,

Relentless justice bids thee bleed.

'Then fall a victim to the Nine,

Myself the priest, my desk the shrine." PARxel.L.

Sometimes two of these insects may be heard ticking, answering each other; and sometimes the Death-Watch may be made to tick by tapping with the finger-nail upon a table. 'These creatures imitate death with great exactness when they are caught, or when they think themselves in danger. 


\section{THE SPANISH FLY, OR CAN'THARIS.}

(Cantharis vesicatoria.)

THESE insects are found but rarely in this country; they are more common in France, but Spain, Italy, and Russia seem to be their favourite localities. They make their appearance in July, and are generally found upon ash trees, the leaves of which form their food. 'They are of great commercial importance, for they are found very useful in medicine on account of their remarkable blistering powers. They have a very disagreeable smell, and emit a fluid of so corrosive a nature that many persons have suffered greatly from gathering them; and it is said to be extremely dangerous to sleep under a tree infested by thern, as their smell produces a lethargic sleep, which frequently terminates in death. They are generally caught by laying linen cloths under the trees they infest, and beating the boughs; they are then put into hair sieves, and held over vessels of boiling vinegar, till the vapour kills them. After this they are dried in ovens, or on hurdles, exposed to the sun, and then packed up for sale. When dried, fifty of them hardly weigh a drachm, but they do not lose their medicinal properties by age unless allowed to get damp. Though bearing the name Spanish Flies, the greatest quantity is obtained from St. Petersburg, the Russian insects being considered the best.

They are of a highly poisonous nature, and there are many instances, some even recent, of their producing violent hæmorrhage and death.

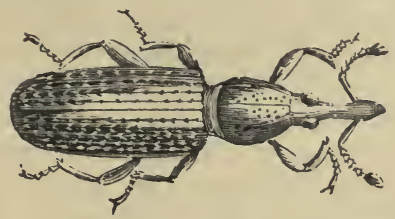

THE CORN-WEEVIL. (Calandra granaria.)

THIS is a little beetle about an eighth of an inch in length, of a reddish-brown colour, with a slender pro- 
boscis projecting from the front of the head, at the extremity of which the mouth is situated. As this proboscis is not thicker than a fine needle, our readers may form some notion of the minute size of the jaws with which the mouth is furnished; nevertheless, they are sufficiently powerful to enable the little creature to eat corn and biscuit. In the larva state they are exceedingly destructive to corn in granaries, sometimes abounding to such an extent in a heap of grain as to leave nothing of it but the husks.

There are an immense number of Weevils, all of which have the front of the head elongated into a proboscis or beak. A very common one is the Nut-Weevil (Balaninus micum), which has a very long and slender beak; with this the female eats into the soft shells of young nuts, and deposits her eggs in the hole; the grubs devour the kernel of the nut, and leave nothing but dust in the interior of the shell.

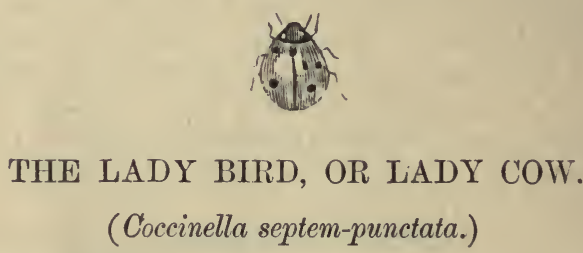

The larva of this well-known and beautiful little beetle is disagreeable and almost disgusting in its appearance; but to compensate for this it is extremely useful in destroying the aphis, or green fly. In the perfect insect the elytra are scarlet, beautifully spotted with black; some species having seven, and others five spots, and one of the most beautiful, eighteen. The head is very small, the antennæ and legs very short, and the body nearly round. This beetle is generally regarded with much favour in almost all countries, and in Catholic times was in a manner dedicated to the Virgin Mary. Hence its name of Lady Bird. 


\section{Order II. Orthoptera.}

IN this order the elytra, or wing-cases, are much softer and more flexible than in the beetles; they are frequently membranous or webbed, and when closed they do not form a straight line down the back. The mouth is also different; the maxillæ being terminated by a horny, toothed piece called the galea. There is also a kind of tongue, and the metamorphosis is incomplete.

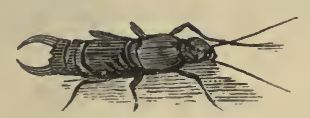

\section{THE EARIVIG. (Forficula auricularia.)}

UNLIKE most other insects, the female Earwig watches over her eggs until they are hatched, and afterwards attends upon her young progeny for some time. At the beginning of the month of June, M. de Geer found, under a stone, a female Earwig, accompanied by many little ones, evidently her young. They continued close to her, and often placed themselves under her body, as chickens do under a hen.

This little animal is very nimble, and perfectly harmless, except to flowers, notwithstanding the fabulous charge which was so long believed against it, of its entering the human ear, and depositing its' eggs there, which were said to cause intolerable pain when hatched, and the young began to gnaw the inside of the ear. The Earwig possesses wings, which, when extended, cover nearly the whole insect. The elytra, or wing-cases, are short, and do not extend along the whole body, but only over the breast. The wings are concealed beneath these, and are somewhat of an oval shape. There is great elegance in the manner in which the insect folds its wings beneath its elytra.

THE BLACK BEETLE, OR COCKROACH, (Blatta Orientalis,)

So common in London kitchens, is nearly allied to the Earwig. 


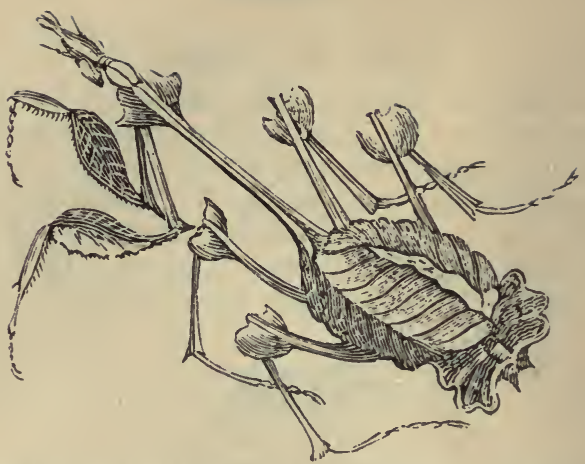

THE LEAF MANTIS. (Empusa gongylodes.)

'THis inseot is remarkably shaped. The head is joined to the body by a neck, longer than the rest of the body. It has two polished eyes, and two short feelers. This neck consists of the first segment of the waist or thorax. The wing-cases, which cover two-thirds of the body, are veined and reticulated, or netted. 'The wings are veined and transparent. The hinder legs are very long, the next shorter; and the foremost pair of thighs are terminated with spines: the others have membranous lobes, which serve them as wings in their flight. The top of the head is membranous, shaped like an awl, and divided at its extremity. This animal is one of the innumerahle instances which Nature affords of the infinite wisdom of the Creator; for, whenever an animal is found to deviate in shape from the general system, it is still formed to answer the design of its existence. Thus this insect, having such long legs, could never have sustained itself in the air had not Providence bestowed on the legs themselves a species of wings to balance their weight. These are instances with which Nature teems ; and which would make the atheist tremble did he but contemplate the admirable design and system with which they are characterised as

"Parts of one stupendous whole;

Whose body Nature is, and God the soul."

These insects are partly of a pale yellowish green, and partly brown; so that they look like dead leaves, 
whence their English name. They are found in the East Indies and China.

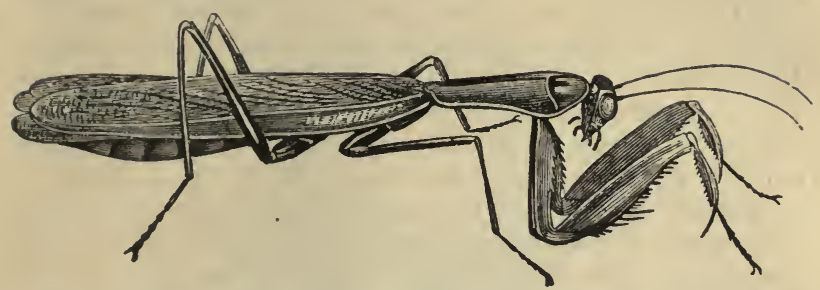

T'He ordinary Mantides, or Praying Insects, as they are sometimes called, from their apparently devotional attitudes, resemble the species just described in their general structure, but are seldom furnished with so long a neck and so leaf-like a body. They carry the head erect, and the long fore-feet, which shut together like a claspknife, are used in catching their prey; it is while thus engaged that their postures have been considered to resemble an attitude of devotion.

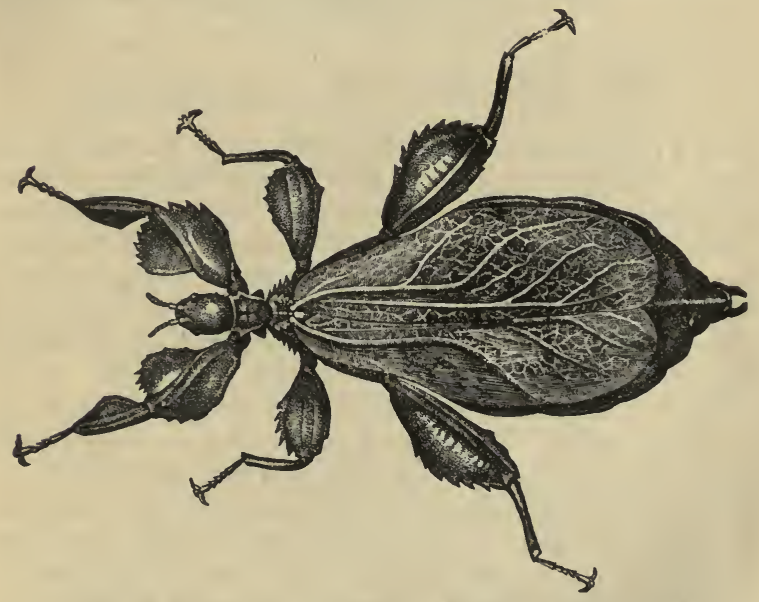

THE WALKING LEAF, (Phyllium siccifolium,)

HAS a shorter neck than the Mantis, and its fore-legs are 
not constructed as claspers, but the body is very flat and leaf-like, and the wing-cases are veined so as to look exactly like a leaf; indeed, if seen adhering motionless to the branch of a tree, it would certainly be mistaken for a leaf. They are found in the East Indies. It is curious that while these creatures present such a deceptive resemblance to leaves, there are some near relatives of theirs which are equally similar to sticks and twigs, so that the semblance of a leafy branch might easily be made by fixing the former upon the latter. Some of these Walking Sticks are eight or nine inches in length, and the whole body and legs are of precisely the colour and texture of hark.

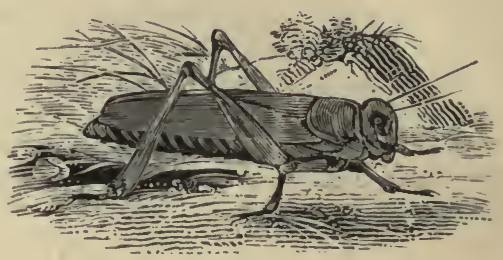

THE GRASSHOPPER, (Locusta flavipes,)

Is of a green colour, with the wing-cases brown, and the head somewhat resembling that of a horse; the corselet is armed with a strong buckler. Of its six legs the hinder two are much longer than the others, to assist the insect in leaping. The male makes a chirping noise, which is caused by the thighs being rubbed against the sides of the wing-cases : if handled roughly, the Grasshopper bites very sharply.

Toward the end of autumn the female deposits her eggs in a hole, which she makes in the earth for the purpose. These eggs sometimes amount to a hundred and fifty; they are about the size of caraway-seeds, white, oval, and of a horny substance. The female, having thus performed her duty, soon languishes and dies. In the beginning of May following a small white larva issues out of each egg. The creature passes about twenty days under this humble form; after which, having assumed the pupa 
shape, while all the rudiments of the future Grasshopper are concealed under a thin outward skin, it retires under a thistle or a thorn-bush, most likely in order to be more secure; and there, after a variety of laborious exertions, writhings, and palpitations, the temporary covering divides, and the insect jumps out of its exurioe.

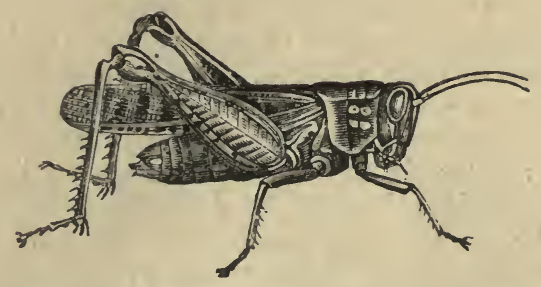

\section{THE LOCUST. (Locusta migratoria.)}

The Bible, which was written in a country where the Locust made a distinguished figure among natural productions, has given us several very striking images of these animals' numbers and rapacity. It compares an army to a swarm of locusts : it describes them as rising out of the earth, where they are produced; as pursuing a settled march to destroy the fruits of the earth; and as the frequent instruments of Divine indignation.

The native countries of the Locust. are Central Asia and the North of Africa, but they migrate every year to Europe, where they destroy every green thing they meet with. Other species of Locusts are met with in various parts of the world, which, like the true migratory Locust, pass from place to place in vast flocks, causing immense damage wherever they take up their temporary abode.

When the Locusts take the field they have a leader . at their head, whose flight they observe, and to whose motions they pay a strict attention. They appear at a distance like a black cloud, which, as it approaches, gathers upon the horizon, and almost hides the light of the day. It often happens that the husbandman sees this imminent calamity pass away without doing him any 
mischief; and the whole swarm proceed onward, to settle upon the labours of some less fortunate country. But wretched is the district upon which they fix ; they ravage the meadow and the corn land; strip the trees of their leaves, and the gardens of their beauty; the visitation of a few ininutes destroys the expectations of a year; and a famine but too frequently ensues. In their native climates they are not so injurious as in the south of Europe, for in Syria and Palestine, though the plain and the forest be stripped of their verdure, the power of vegetation is so great, that an interval of three or four days repairs the calamity; but our verdure is the produce of a season; and we must wait till the ensuing spring repairs the damage. Besides, in their long flights to this part of the world, the Locusts are famished by the tediousness of their journey, and are therefore more voracious wherever they happen to settle. But it is not by what they devour that they do so much damage as by what they destroy. 'Their very bite contaminates the plant, and injures its future vegetation. To use the expression of the husbandman, they burn whatever they touch, and leave the marks of their devastation for two or three years ensuing. And if so noxious while living, they are still more so when dead; for wherever they fall they infect the air in such a manner that the smell is insupportable.

In the year 1690 clouds of Locusts were seen to enter Russia in three different places; and thence to spread themselves over Poland and Lithuania in such astonish. ing multitudes, that the air was darkened, and the earth covered with their numbers. In some places they were seen lying dead, heaped upon each other to the depth of four feet; in others they covered the surface like a black cloth : the trees bent beneath their weight, and the damage which the country sustained exceeded computation.

- In Barbary their numbers are formidable, and their visits frequent. In the year $1724 \mathrm{Dr}$. Shaw was a witness of their devastations in that country. Their first appearance was about the latter end of March, when the wind had been southerly for some time. In the beginning of April their numbers were so much increased, that in the heat of the day they formed themselves into large swarms, 
which appeared like clouds, and darkened the sun. In the middle of May they began to disappear, retiring into the plains to deposit their eggs. In the next month, being June, the young brood began to make their appearance, forming many compact bodies of several hundred yards square; which, marching forward, climbed the trees, walls, and houses, eating everything that was green in their way:

" To their general's voice they soon obeyed

Innumerable. As when the potent rod

Of Amram's son, in Egypt's evil day,

Waved round the coast, upcalled a pitchy cloud

Of Locusts, warping on the eastern wind,

That o'er the plains of impious Pharaoh hung

Like night, and darkened all the land of Nile;

So numberless were those bad angels seen,

Hovering on wings, under the cope of Hell,

"Twixt upper, nether, and surrounding fires."

Muton.

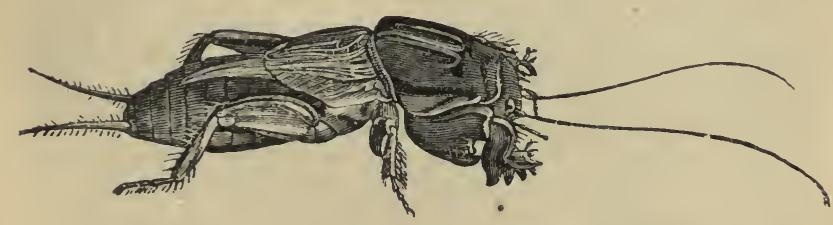

THE MOLE CRICKET. (Gryllotalpa vulgaris.)

THE two fore-feet of this insect, placed very near the head, are short and broad, and, like those of the mole, are contrived to help the insect in burrowing under ground. The Mole Cricket is very destructive in gardens, as it attacks the roots of young plants, and causes them soon to rot and die. The female forms a nest of clammy earth, in which she lays from two to four hundred eggs. The nest is carefully closed up on every side, to secure the brood from the incursions of grubs and other subterraneous depredators. The song of the Mole Cricket is a low, dull, jarring note, which is continued for a long time with great pertinacity. 


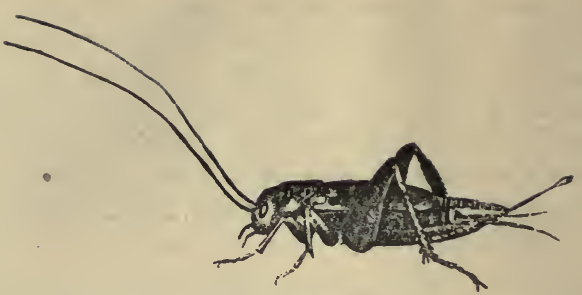

\section{THE CRICKET. (Acheta domesticata.)}

The domestic Crickets generally inhabit houses, selecting for their place of retirement the chimneys or backs of ovens; and feeding upon anything that comes in their way, flour, bread, meat, and especially sugar, of which they seem to be particularly fond. The chirping noise, which they make nearly without intermission, proceeds only from the males, who produce it by rubbing the bases of their wing-cases one over the other.

Crickets are generally of a brown rusty colour, and the organ of vision appears in them to be very weak and imperfect, as they find their way much better in the dark than when dazzled by the sudden light of a candle. The Field Cricket ( $A$. campestris) has the same form, but is of a different species to the House Cricket, and is black, with a fine gloss. Its noise is heard at a great distance, and is so similar to that of the grasshopper, that it is difficult to distinguish one from the other.

\section{Order III. Hemiptera.}

THese insects have neither mandibles nor maxillæ, but in lieu of them they have a tubular articulated rostrum, adapted for suction. Insects thus formed are called haustellated. The four wings are all membranous, but the outer ones are leathery at the base. Some of the species are without wings. The antennæ are often small, and sometimes scarcely perceptible. The metamorphoses of these insects are incomplete. 
The Lantern Fly-The Cochineal Insect. 571

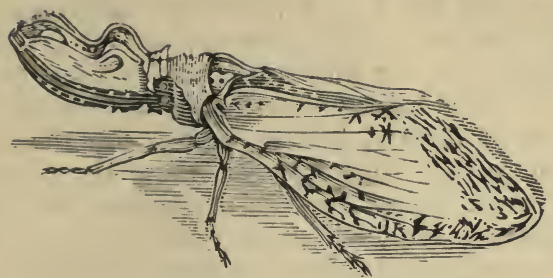

THE LANTERN FLY. (Fulgora laternaria.)

THis Lantern Fly is a nocturnal insect, with a hood or bladder on the head, which is semi-transparent, and very curiously ornamented with red and green stripes. By some writers it has been affirmed that this part of the insect shines brilliantly at night, so that it is even possible to read by it. No modern entomologist has, however, witnessed this phenomenon, and it is generally believed that the supposed luminosity of the Lantern Fly exists only in the stories of the natives of South America. The wings and whole body are elegantly adorned with a mixture of red, green, yellow, and other splendid colours.

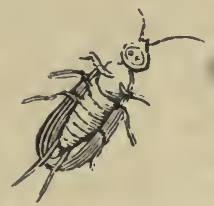

THE COCHINEAL INSECT. (Coccus cacti.)

THE Cochineal Insect is of the same genus as the scale insect on the vine, which looks like a little bit of wool attached to the branch, but which, when pressed, stains the fingers with a red liquid. The Cochineal Insect in the like manner affixes itself to the leafy stems of the nopal-tree, a kind of opuntia, or prickly-pear, common in Mexico and South America, whence the Cochineal used in Europe is principally imported. 
When the Mexicans have gathered the Cochineal Insects, they put them into holes in the ground, where they kill them with boiling water, and afterwards dry them in the sun; or they kill them by putting them into an oven, or laying them upon hot plates. From the various methods of killing them arise the different colours in which they appear when brought to us. While they are living, they seem to be sprinkled over with a white powder, which they lose when the boiling water is poured upon them, but preserve when killed in an oven. Those dried upon hot plates are the best.

The quantity of Cochineal annually exported from Mexico and Sonth America is said to be worth more than five hundred thousand pounds sterling-a vast sum to arise from so minute an insect; and the present annual consumption of Cochineal in England has been estimated at about one hundred and fifty thousand pounds weight. The Mexicans think so highly of their trade in this insect, that the republic has adopted the nopaltree as part of its arms.

It is for dyeing scarlet that Cochineal is chiefly in demand; but, although a peculiarly brilliant dye is now obtained from it, this substance gave only a dull crimson colour until a chemist of the name of Kuster, who lived at Bow, near London, about the middle of the seventeenth century, discovered the art of preparing it with a solution of tin. Cochineal, if kept in a dry place, may be preserved without injury for a great length of time. An instance has been mentioned of some of this dye, one hundred and thirty years old, having been found to produce the same effect as though it had been perfectly fresh.

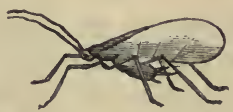

THE PLANT LOUSE, OR GREEN FLY. (Aphis.)

The Aphides are sometimes viviparous, and at other times oviparous, according to the season of the year. 
Those of the rose-tree have been particularly noticed, and of ten generations produced in one spring, summer, and autumn, the first nine-were viviparous, and the last oviparous. The first nine generations consisted of females only; but in the tenth there were males. In this singular aberration from the common laws of nature this insect is a remarkable anomaly. They multiply at such an extraordinary rate-the whole ten generations within three months-that from a single Aphis ten thousand million millions may be produced in that short period, and it has been calculated that the progeny of a single Aphis during a single summer, supposing its multiplication to be subject to no check, might exceed in weight the entire human population of China.

The moss-rose, the hop, the vine, the apple-tree, the bean, the willow, and privet, are all particularly liable to be infested with this insect; the various species of which take their names accurding to the plants on which they are usually found. The red tumours, commorily called galls, which are seen on the surfaces of leaves, especially on those of the willow, varying from the size of a ladybird to that of a pigeon's egg, are produced by $A$ phides, and contain thousands of small lice. From a pair of small tubes placed near the end of the body of these insects exudes a saccharine fluid, of which ants are very fond; and it is this fluid dropped upon the adjacent leaves, or the extravasated sap flowing from the wounds caused by the punctures of the insects, which is known under the name of honeydew.

After a mild spring, most of the species of Aphis become so numerous as to destroy all the young shoots of the plants on which they are found. No successful mode of destroying them has yet been discovered, but the best remedy against them is to wash the infested shoots with tobacco water or suap lees; and to repeat the operation when any Aphides are seen. 


\section{Order IV. Neuroptera.}

THESE insects have four transparent wings, strongly and beautifully varied, so as to resemble net-work. The mouth has mandibles and maxillæ. The abdomen of the female has neither ovipositor nor sting.

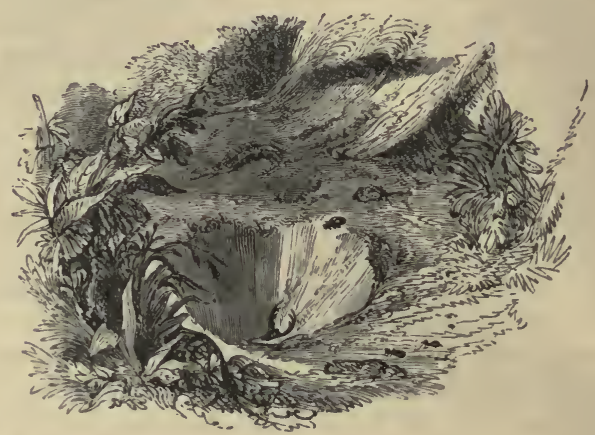

THE ANT-LION. (Myrmeleon formicarium.)

THis insect is hatched from, an egg laid in soft moving ground, or sand; the larva soon increases in size, and assumes the shape of a small spider-with this difference, that the legs are constructed in such a way that it can only proceed backwards or sideways. The abdomen is very large and fleshy; and the head, which is small, is armed with two long jaws like horns, somewhat resembling those of the stag-beetle. What must create our utmost admiration is, that this insect, which can only move in a retrograde direction, is doomed by nature to feed upon flies and ants, the quickness and agility of which would at all times deprive him of his prey were he not endowed with an uncommon instinct, which prompts him to the following stratagem:- - He makes a kind of funnel-shaped hole in the loose earth or sand, and, placing himself at the bottom of it, waits there with the utmost patience, till an incautious ant or 
giddy fly falls into the deathful pit. Then all his skill is put in requisition; he throws out, by the shaking of his large jaws, a great quantity of sand upon the insect, to prevent its climbing up the steep sides of the hole; and when the prey appears strong and nimble, he gives such a general comnotion, that the whole construction crumbles down, and the unfortunate insect, overwhelmed with the ruins, falls into the jaws of the Ant-lion, which open like a pair of forceps. When the Ant-lion has sucked out the blood and inside of his prey, he takes it upon his head, and, by a sudden jerk, throws the carcase to a distance from his abode. When the larva has attained its full size, it spins for itself a cocoon of white shining silk, with an external covering of sand. In about three weeks there bursts from this pupa case a slender-waisted winged insect, which, after fluttering about for a few weeks, and depositing eggs in the sand, resigns its life. The winged insect resembles a beautiful dragon-fly; it has a head of a chestnut colour; the body is of a pearly grey, the legs short, and the wings, which resemble the finest lace, are beautifully marked with dark lines and spots. This fly is often seen fluttering about the sides of roads and dry banks exposed to the east, in the months of June and July; it continues for a little time, and then entirely disappears. 'The Antlion is not found in this country; but in the south of France and Italy there is not a bank on the sides of a public road, or a sandy ridge at the foot of an old wall, which does not harbour a great number of these insects. 


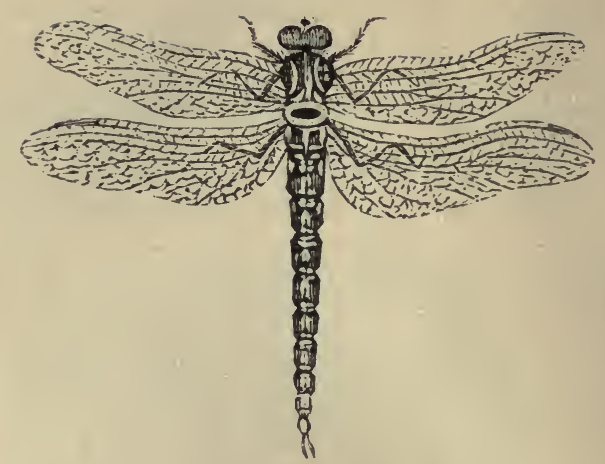

THE GREAT DRAGON FLY. (Libellula grandis.)

This genus of insects is well known to every one. The larva lives in the water, and wears a kind of mask, which it moves at will, and which serves to hold its prey while it devours it. The pupa closely resembles the larva in its form, except that at the sides of the body the wings are seen enclosed in thin cases. The period of transformation being come, the pupa goes to the water-side, and fixes on a plant, or sticks fast to a piece of dry wood, in which position it remains for some little time, when the skin of the nymph splitting at the upper part of the thorax, the winged insect issues forth gradually, throws off its slough, expands its wings, flutters, and then flies off with gracefulness and ease. The elegance of its slender shape, the richness of its colours, the delicacy and resplendent texture of its wings, render it a beautiful object. It is in length about four inches.

The fomale deposits her eggs in the water, from which spring the larvæ, which afterwards undergo the same transformations.

The Day Fly (Ephemera), so called on account of the shortness of its life, is a small insect originating from a larva residing in rivers. After remaining several months in the creeping state, a nymph is formed, from which 
the perfect insect changes, three or four hours after midday, into the fly form, and dies soon after. This fly has the singular characteristic of casting off its entire skin very soon after it has attained its perfect state; and the empty coat may often be seen lying about after its occupant has deserted it.

\section{Order V. Hymenoptera.}

Is this order the wings are neither so large nor so strongly veined as in the previous one. The mouth is furnished with mandibles, maxillæ, and an upper and lower lip; and the abdomen of the female is terminated either with an ovipositor or a sting. The metamorphosis of these insects is complete.

This order contains the Bees, of which there are hundreds of different species. The most interesting of these is the common Hive Bee, from whose industry we obtain wax, and by whose provident habits we are supplied with honey. The inhabitants of a hive are of three kinds : one Queen, a few hundred drones or males, and several thousand workers. The Queen, or Parent Bee, is the soul of the community; to her all the rest are so attached, that they will follow her wherever she goes. She has the power of quelling any disturbance which may arise among her subjects by making a peculiar humming noise. She is so prolific as to lay fifteen or eighteen thousand eggs, which produce about eight hundred males or drones, four or five Queen Bees, and the rest Working Bees or Neuters. The combs of a hive consist of a number of cells, formed of wax; a substance which is secreted by the Working Bees after gorging themselves with honey. These cells are for the habitation and breeding of the young Bees, and are also used as stores for honey, and bee-bread, or the pollen of flowers. The royal cells, in which are laid the eggss of future Queens, are the largest, and shaped like the cup of an acorn. All the other cells are of a beautiful hexagonal form, and of two kinds, one larger than the other: the larger for the young drones, the smaller for 
the workers. In two or three days the eggs are hatched, when the Neuters nurse the young grubs, whom they feed most tenderly with bee-bread and honey. After twenty-one days, the young Bees are able to form cells with such indefatigable activity that they will then do more in one week than during all the rest of the year. No more than one Queen is ever permitted to inhabit a hive. When a young Queen is about to be hatehed, the old one leads away a swarm from the old colony to form a new one. If the Queen die or is lost to the hive by accident, and there be no young Queens in the royal cells, the Bees can repair their loss. They chouse a grub of the Neuter species, enlarge its cell by adding to it three or four adjacent ones, feed the young grub on royal food, and it is then developed into a Queen. Sometimes there are Bees who, less laborious than the others, support themselves by pillaging the hives of the rest; upon which a battle ensues between the industrious and the despoiling insects. Their foes are the wasp, the hornet, and various kinds of birds.

'The Bee collects the honey by means of its proboscis, or trunk, which is a most astonishing piece of mechanism, consisting of more than twenty parts. Entering the hive, the insect disgorges the honey into cells, for winter subsistence; or else presents it to the labouring Bees.

The combs of cells formed by these industrious insects are constructed with an instinctive ingenuity which must always be regarded as one of the most marvellous things in nature. Each comb consists of two sets of hexagonal cells placed back to back, and not only do the insects adopt this form which enables them to construct the gieatest number of cells of the requisite size within the smallest possible space, and with the least possible amount of material, but each cell on one side of the comb is placed opposite to the junction of three cells on the opposite side, so that its centre may be deepened without interfering with the latter, the three diamond-shaped pieces forming the bottom of each cell belonging to three distinct cells of the opposite side of the comb. By all these contrivances the Bees manage to get the greatest possible amount of accommodation in 
the smallest possible space; and it has been found, by mathematical calculation, that if it were desired to construct a series of cavities of a given size within the smallest possible space and with the smallest possible amount of materials, we should have to adopt precisely the same plan, even to the forms of the sides of the cells and the angles at which they are attached to each other, that has been instinctively adopted by the little Bee. At the entrance of every cell the Bee architect places a flange of wax, which fortifies the aperture, and prevents the injuries it might receive from the frequent ingress and egress of the Bees.

Bees produce honey, which they lay up for winter consumption; wax, of which they form their cells; and a substance called bee-bread, which they extract chiefly from the pollen of flowers, and which they use for feeding their young.
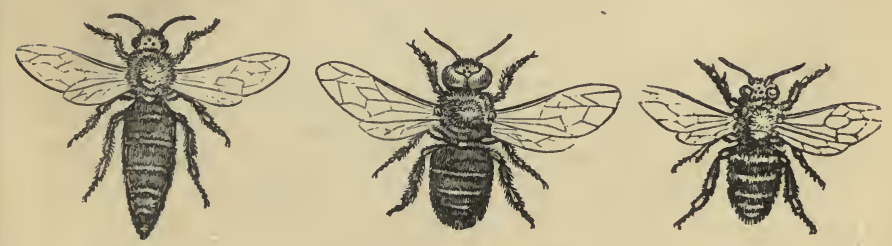

Above are given representations of, first, the Queen Bee, placed on the left-hand side; second, the Drone; and, third, the Working Bee.

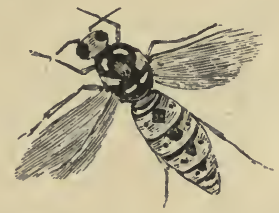

\section{THE WASP, (Vespa vulgaris,)}

Is a very fierce, dangerous, and rapacious insect; it is much larger than the bee, and furnished with a powerful sting. The abdomen is striped with yellow and black. 
All kinds of Wasps make curious nests; some attach them to the beams of a barn or other building, or place them in the hollow of a large tree, but the common Wasp digs a hole in the ground. Wasps do not construct their combs with quite the same care and accuracy as the bee; nevertheless, their nests are often very ingeniously made, and the material employed by most of them is curious, being a sort of paper or card made from fibres of wood masticated between the jaws of the insects. As they do not lay up a store of honey for their support during winter, they mostly die at that season; and the few that live remain in a torpid state till spring. 'Their sting is very large; and the poisonous liquor of it, when introduced into the human body, excites inflammation and creates very considerable pain.

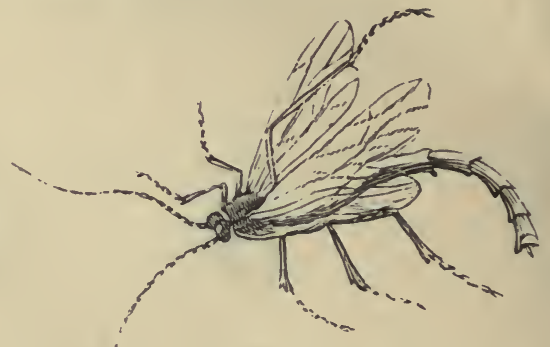

\section{THE ICHNEUMON FLY. (Pimpla persuasoria.)}

THE mouth of this insect has jaws, but no sucking tongue. The antennæ contain more than thirty joints; and the abdomen is joined to the body by a slender pedicle. The ovipositor is enclosed in a cylindrical sheath, composed of two valves.

One distinguishing and striking characteristic of all the species of this kind of fly is the almost continual agitation of their antennee. The name of Ichneumon has been applied to them from the service they do us by destroying caterpillars, plant-lice, and other insects; as 
the Ichneumon or Mangouste destroys the crocodile in the East. The tip of the abdomen of the females is armed with an ovipositor, visible in some species, though not in others; and this instrument, though so fine, is able to penetrate through mortar and plaster. The female fly uses it to deposit her eggs in the body of other insects when in the egg, caterpillar, or pupa state ; so that the young as soon as they are hatched may feed upon the caterpillar, penetrating to its very entrails. These larva, however, contrive to suck out the nutritious juices of their prey without attacking its vitals ; for the caterpillar continues to live for a long time, so as to afford them food till they have attained their full size. It is not uncommon to see caterpillars fixed upon trees, as if they were sitting upon their eggs; when it is afterwards discovered that the larvæ, which were within their bodies, have spun their threads, with which, as with cords, the caterpillars are fastened down, and so perish miserably.

"A friend of mine," says Dr. Derham, "put about forty large caterpillars, collected from cabbages, on some bran and a few leaves in a box, and covered it with gauze to prevent their escape. After a few days we saw, from the backs of more than three-fourths of them, about eight or ten little caterpillars of one of the Ichneumon flies come out and spin each a small cocoon of silk; and in a few days the large caterpillars died."

The Ichneumons performed great service in the years 1731 and 1732 , by multiplying in the same proportion as the caterpillars, and their larvæ destroyed more of these destructive creatures than could any efforts of human industry.

They are found of all sizes, suitable to the various insects they are parasitic upon, and in their ceaseless rummaging about in every hole and corner, millions of destructive larvæ are discovered and destroyed by them, which would otherwise have reached maturity, and left a progeny to renew their ravages in the ensuing summer. Even those larvæ which feed in concealment are readily discovered by the Ichneumons destined to live upon them, and the farmer is often made aware of the presence of his enemies by observing the activity of his friends. 

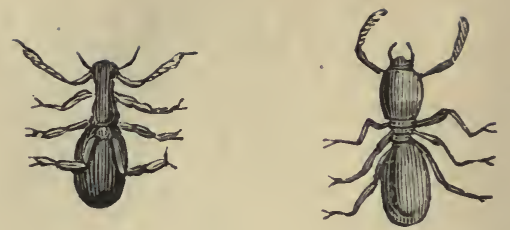

THE LABOURING AND SOLDIER ANT.

\section{(Formica rufa.)}

THE colour of the Ant is in general a dark red or brown, with a fine gloss on the abdomen. They are like the bees, divided into three kinds-males, females, and neu ters. The females and neuters are furnished with stings for their defence; the males are wholly destitute of them. The males and females are in proper season furnished with wings, but the neuters have none, and they are doomed always to labour and drudgery on the hill. This hill is constructed with considerable art and labour; it is composed of leaves, bits of wood, sand, earth, and gum from the trees, which are all united into a mass, perforated with galleries to give access to the numerous cells which it contains. From this hill there are several paths, worn by the constant passing and repassing of these creatures; and it is worthy the admiration of the naturalist to consider how busy the whole legion appears in bringing bits of straw, dead bodies of other insects, or. in carrying away their eggs, if any danger threatens their republic. Their sense of smell is very keen, and they discover at a great distance any food they may be in search of.

\section{ORDER VI. Lepidoptera. The Moths and Butterfies.}

THE insects included in this order are all remarkable for their beauty. Their wings are membranous and veined, like those of the dragon flies and their allies, but instead 
of being naked they are covered by close-set scales of the most delicate texture and most brilliant colours. The mouth is furnished with a spiral trunk or tongue, by which nectar is sucked from the flowers: but in other respects it only differs from the mouths of the masticating mandibulated orders in the smallness of its parts. The antennæe vary in the different kinds : but those of all the diurnal lepidoptera, or butterflies, are terminated by a small inflation or knob; while those of the nocturnal species, or moths, taper to a point, and are often feathery, or comb-shaped. 'I'he transformations of the species belonging to this order are all complete.

Over the larvæ of this order the ichneumons reign with undisputed sway; attacking all indiscriminately, from the minute insect that forms its labyrinth within the thickness of a leaf, to the giant caterpillar of the hawk moth. The most useful of all, however, the silkworm, appears, at least with us, to be exempted from this scourge. De Geer, out of fifteen larvæ that were mining between the two cuticles of a rose-leaf, found that fourteen were destroyed by one of these insects.

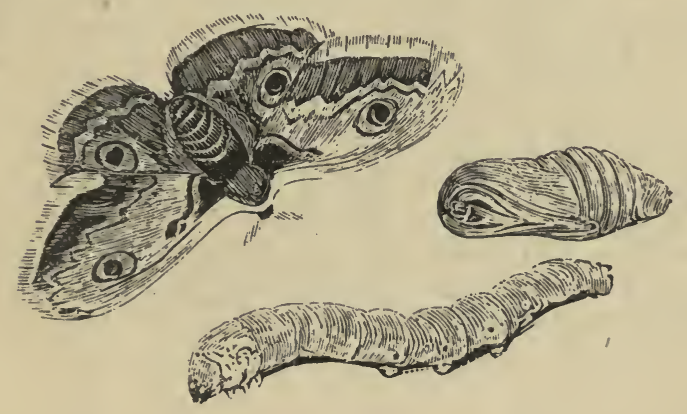

THE EMPEROR MOTH WITH ITS CHRYSALIS AND CATERPILLAR.

The larva of all the lepidoptera is a Caterpillar composed of twelve ring-like segments, exclusire of the head, which is harder than the other parts, and always of a deeper 
colour than the body. Each Caterpillarhas nine breathingholes on each side; and each of the three segments nearest the head is furnished with a pair of short legs, ending in a kind of claw, which are the true legs of the insect. The Caterpillar has, however, eight or ten other legs on the hinder segments of its body. The head has twelve eyes, and two very short conical antennæ; and the mouth is furnished with two strong mandibles, two maxillæ, a labrum, and four palpi.

The habits of Caterpillars differ: some, which are called Geometers, or Loopers, advance by a succession of steps, first extending the body to its full length and adhering by the fore legs, then drawing up the hinder part of the body close to the forepart so as to form a loop, and then again repeating this process; these Caterpillars, when at rest, often adhere by their hinder feet, and extend the body stiffly, like a little dry twig; others, which are furnished with more prolegs, adhere by these to the branch or leaf, and raise the forepart of the body a little, an attitude which induced Linnæus to give the name of Sphinx to the moths in whose Caterpillars this habit prevails; some small pecies live between the upper and lower surfaces of leares, in which they excavate mines; others dwell in small cases, which they manufacture of various materials; whilst others, dwelling in large societies, spin for themselves a sort of silken tent, in which they take their repose, and from which they issue daily in search of food in a regularly marshalled procession. Many make themselves cocoons; but others have no other covering in the pupa state than a smooth shining skin, or a dark mummy-like cerement. The chrysalis of a butterfly is generally angular, and that of a moth cylindrical. 


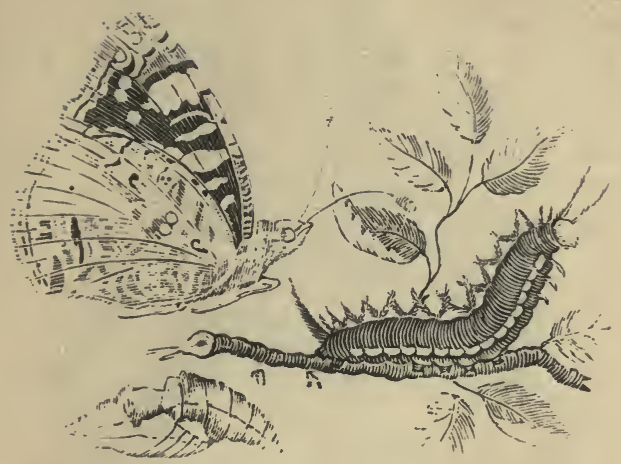

TORTOISE-SHELL BUTTERFLY.

(Vanessa urticce.)

The Caterpillar, which feeds on the nettle, is about an inch in length, covered with bristles, and of a reddish brown colour. After having changed its skin three times when in the shape of a Caterpillar, it crawls up to a branching part of the stalk; and, hanging itself by the hinder part or tail, swells and bursts in such a curious way, that the Caterpillar's skin drops to the ground, and the chrysalis, or aurelia, remains suspended; till after a fortnight of torpor it bursts its skin again, and escapes into the air, under the beautiful form of a variegated Butterfly. 'The golden line which shines through the pupa case of this Butterfly is supposed to have suggested the words chrysalis and aurelia, both of which signify golden. The wings of the perfect insect are about two inches in extent, of a deep orange colour above, and their base and hinder margin black, with a series of blue crescents. These Butterflies, which are very common in England, appear in spring, and at the end of June and beginning of September. 


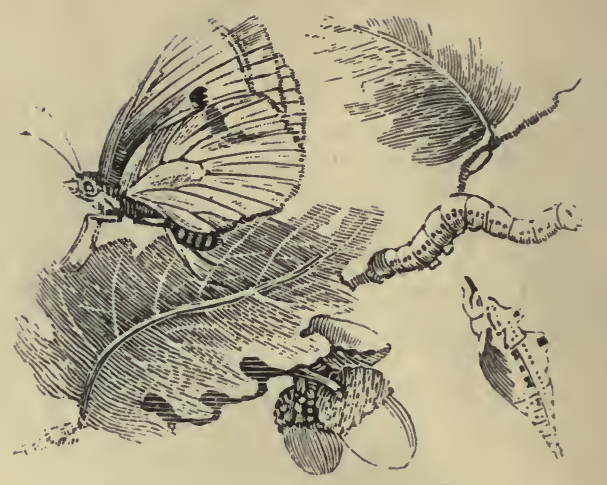

THE CABBAGE BUTTERFLY.

\section{(Pontia, or Pieris Brassica.)}

WHEN the colewort and cauliflower are nearly mature, the perfect insect of this Caterpillar is found depositing her eggs upon the leaves. The heat of the sun soon vivifies them and brings forth the Caterpillars, which immediately proceed to consume the vegetables on which they received being. They bear the heat of the sun without inconvenience, but cannot endure long rains, and in wet weather they soon disappear. There are several species of this Butterfly, but the common white, with a black spot on each of the under wings, is the earliest seen in our gardens. It lays its eggs in May; and its Caterpillars, which are soon hatched, feed together till the end of June, when they go into the pupa state, from which the perfect Butterfly appears in July. The eggs laid by the second brood of Butterflies produce Caterpillars which feed during the remainder of the summer, and remain in the pupa state all the winter, to be hatched the following spring.

From the astonishing fecundity of these insects, it may be wondered that they do not, in the course of time, completely overspread the face of the earth, and totally consume every green plant. This would certainly be the case 
if Providence had not provided a check to their progress. One of the kinds of the ichneumon fly deposits her eggs within the caterpillar of this Butterfly, and they are there hatched. In their larva state they continue preying on the vitals of the animal; they then pass to the pupa condition, and eventually emerge as perfect insects. So greatly are we indebted to this apparently contemptible little parasite, for keeping down the increase of an insect which would otherwise become a serious and alarming evil.

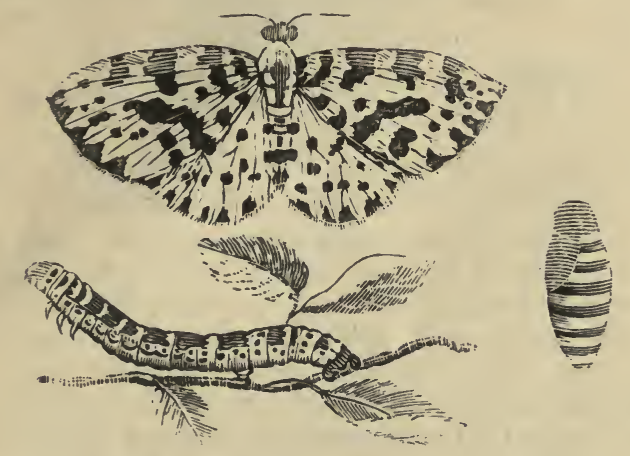

THE MAGPIE, OR CURRANT MOTH. (Geometra, or Abraxas grossulariata.)

The Caterpillar of this Moth is one of the kind called loopers, and is very destructive. The chrysalis is naked and shining; and its colour is a bright yellow with black bands. The Moth is white, spotted with black, and hence its name of Magpie.

The black and white caterpillar of this Moth is very destructive to currant and gooseberry bushes, and in soine seasons particularly so. Mr. Kirby especially cites the devastations at Hull in the spring of 1814 . He also confirms Boerhaave's assertion, that the severity of winter has no effect in destroying the larvæ of those insects, as these abounded even more after a winter when Fahrenheit's thermometer stood at zero, than after a winter which was remarkably mild. 

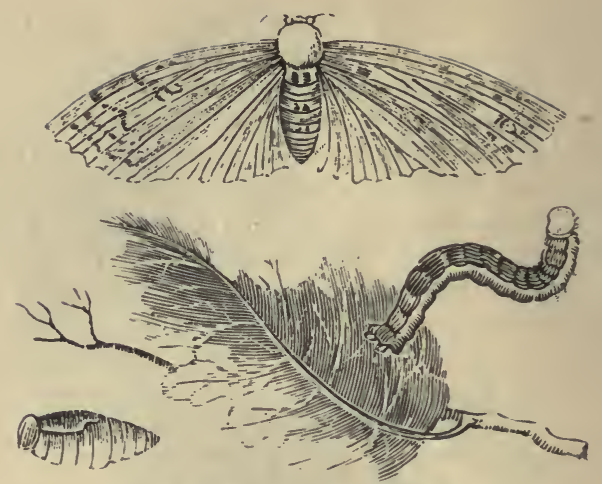

THE WIN'TER MOTH.

(Geometra, or Cheimatobia brumata.)

The Caterpillar delights in newly-opened leaves; it is not so ravenous as many others, making long intervals between its meals, but it seldom quits a leaf until it has entirely consumed it. The colour is very elegant. The upper part of the body is of a fine yellowish green; but it is by no means so beautiful after as before feeding, its skin being so thin as to transmit the hue of whatever food it eats. They are also called looper Caterpillars, because when they crawl they draw their hind and fore feet together, so as to form their bodies into a loop. They go into the pupa state towards the end of June, burying themselves for that purpose in the earth ; and in November or December the perfect insect is brought forth.

It is evident that they possess great muscular power, and hence their positions during repose are very striking. Fixing themselves by their hinder feet alone, they extend their bodies in a straight line, holding. it in that position for a long time. This, together with their obscure colours, and the warts on their bodies, render it often difficult to distinguish them from the twigs of the trees on which they feed. When alarmed, these Caterpillars have the instinct to drop from the leaves, and suspend themselves by a thread, which enables them to remount when the danger is over. 


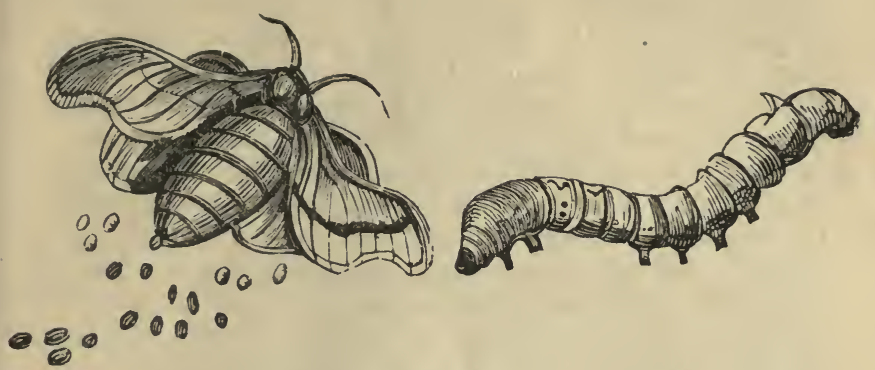

THE SILKWORM. (Bombyx mori.)

Wirнout entering into a very minute description of this Caterpillar, we shall confine ourselves to what we think will be at once more interesting and more useful. As the Silkworm is an insect of universal service, and not of singular beauty, we are induced to prefer giving an account of its utility, rather than any elaborate description of its figure or colour.

This larva feeds on the leaves of the mulberry tree, and when first produced is extremely small, and entirely black. In a few days it appears in a new habit, which is white, tinged with the colour of its food; and before it goes into its chrysalis state it changes its skin several times. When full grown it spins its cone of silk, which is its cocoon, in the same manner as other insects. The Moth possesses no beauty. The Silkworm is a native of China, whence the greater part of our silk is still imported; but the insect was introduced into the sonth of Europe during the reign of the Emperor Justinian, and is now reared in large quantities both in France and Italy.

The art of manufacturing silk was known to the ancicnts. We are informed that, in the third century, the wife of the Roman emperor Aurelian entreated him to give her a robe of purple silk, which he refused on account of its enormous price.

It is not certain at what precise period the manufacture of silk was first introduced into England; but in 
the year 1242, we are told that part of the streets of London were covered or shaded with silk, for the reception of Richard, the brother of Henry III., on his return from the Holy Land. In 1454 the silk manufactures of England are said to have been confined merely to ribbons, laces, and other trifling articles. Queen Elizabeth, in the third year of her reign, was furnished by her silkwoman with a pair of black knit silk stockings, which she is stated to have admired as "marvellous delicate wear ;" and after the using of which she no longer had cloth ones as before. James I., whilst king of Scotland, requested of the Earl of Mar the loan of a pair of silk stockings to appear in before the English ambassador, enforcing his request with the cogent appeal, "For ye would not, sure, that your king should appear as a scrub before strangers."

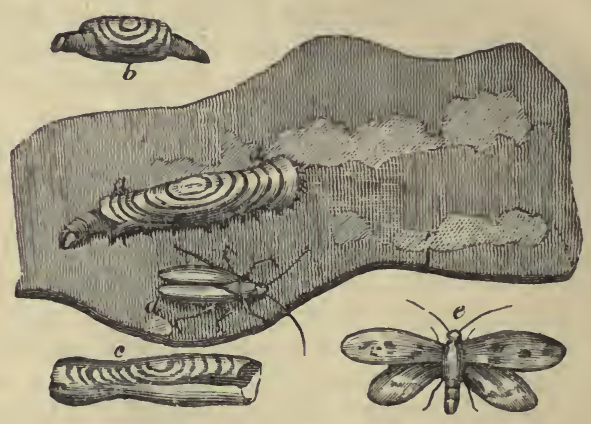

THE CLOTHES MOTH. (Tinea pellionella.)

The larva of this little Moth is well known from the damage it commits in woollen cloth and furs. These substances constitute the principal support of the Caterpillar, and therefore the parent is, by its natural instinct, directed to deposit its eggs in them. As sonn as it quits the egg, the Caterpillar begins to form for itself a nest: for this purpose, after having spun a fine coating of silk 
immediately around its body, it eats the filaments of the cloth or fur, close to the thread of the cloth, or to the skin. This operation is performed by its jaws, which act in the manner of scissors. The pieces are cut into convenient lengths, and applied, with great dexterity, one by one, to the outside of its case ; and to this it fastens them by means of its silk. Its covering being thus formed, the little Caterpillar never quits it but on the most urgent necessity. When it wants to feed, it puts out its head at either end of its case, as best suits its conveniency. When it wishes to change its place. it puts out its head and its six fure legs, by means of which it moves forward, taking care first to fix its hind legs into the inside of the case, so as to drag it along. After having changed within its case into a chrysalis, it issues, in about three weeks, a small, winged, mealy-looking Moth, of silvery drab colour, too well known to almost every mistress of a family. The best mode of destroying this insect, when in the cloth, is to place a saucer of oil of turpentine with the articles affected in a close place, when the vapour raised by the warm air will immediately destroy it. Should the Caterpillar be old and strong, it may be necessary to brush the clothes with a brush, the points of which have heen dipped in turpentine. Camphor wrapped up with furs will protect them from the Moth.

\section{Order VII. Diptera, or Flies.}

THIs order is characterised by having only two wings, which are transparent, and which have two little movable bodies, called halteres or balancers, placed close behind them. 'The head is almost covered with a pair of enormous eyes; and the mouth is furnished with a proboscis or sucker. The legs are long in proportion to the body, and are in many species terminated by two or three small cushion-like expansions, which, it is supposed, enable them to walk on glass. Each foot has also two hooks or claws. 


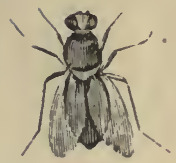

\section{THE HOUSE FLY. (Musca domestica.)}

THis insect lays its eggs in sinks, dunghills, or any other place where there is decaying vegetable matter tolerably moist. The larvæ, or maggots, are thick and fleshy, without legs, but having the mouth furnished with hooks, by means of which they drag themselves along when they wish to move. 'They go into the pupa state without throwing off the skin of the maggot; and when the perfect insect appears, it forces off a kind of cap from one end of the pupa case, in order to make its escape. The Blue Bottle flies (Musca erythrocephala and Vomitoria) are only too well known from their habit of depositing their eggs upon our meat in summer. In the Flesh fy (IIusca or Sarcophaga carnaria) and some allied species, the eggs are hatched within the body of the parent, which thus deposits living larvæ upon the decomposing animal matter that constitutes their food. These flies are so prolific and their larvæ so voracious that Linnæus says the progeny of them would devour a horse as quickly as a lion could do it.

\section{THE GNAT. (Culex pipiens.)}

THIs is an insect which deserves the observation of the naturalist, not only for the very curious conformation of its proboscis (which so quickly and powerfully penetrates into our skin, and through which it sucks our blood into its body), but also for the several metamorphoses it undergoes before it arrives at its winged state. The Gnat deposits its eggs upon the surface of stagnant water, and sets them upright one against another, in the form of a small boat: after floating upon the water for several days, as soon as the time of hatching arrives the 


\section{The Gnat.}

larvæ, which the eggs contain, escape into the water in which they swim about with vigorous jerking movements. They are compelled to visit the surface to take in a supply of air, and for this purpose the tail is furnished with a short tube, surrounded at its extremity with a star of bristles, which, when spread out, prevent the water from flowing into the air tube. 'The change to the pupa state is a curious one. In this condition the insect exhibits a rather slender body with a bulky anterior extremity, in which the head, wings, and limbs are enclosed; the tail is furnished with a pair of leaves or membranous plates, the matting tube has vanished from this part and in place of it we find two tubes situated on the sides of the thorax : having passed about ten days in this state, its increase being at an end, it keeps longer near the surface, and at last the outer skin bursts, and the winged insect, standing upon the exuvice it is going to leave behind. smooths its new-born wings, springs into the air, and begins its depredations. The fecundity of the Gnat is so remarkable, that in the course of orie summer they might increase to the amazing number of five or six hundred thousands, if Providence had not ordered that they should become the prey of birds, who by this means prevent their multiplying more than they generally do. 'These insects are very annoying from their blood-sucking propensities; and as the sucker is horny at the tip, it inflicts a serere wound, into which the insect emits a small quantity of poison, which occasions the pain and inflammation always felt from a Gnat bite. 


\section{ORDER VIII. Suctoria.}

THrse insects are withont wings. The mouth is furnished with a trunk or beak, formed to wound as well as to suck.

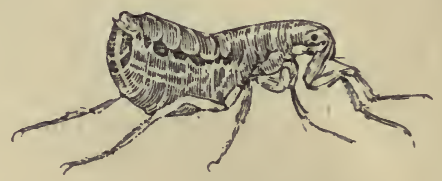

THE FLEA, (Pulex irritans,)

Is one of those little creatures with which want of cleanliness in mankind is punished. It is one of the most aunoying insects that infest the human race, as, by its leapings; it often escapes being caught. It is oviparous, and the egg, which is hardly discernible with the naked eye, contains at maturity a small whito worm, beset with hairs. This worm soon spins for itself a little silk cocoon, from which the perfect insect issues. The Flea is an active, troublesome, blood-thirsty insect; it has a small head, large eyes, and a roundish, but compressed body, which is covered with a kind of armour resembling the tortoise shell in colour and transparency. The plates of which this skin is composed are also armed with spines or bristles. It has six legs, two of which are much longer than the others, in order to enable the insect to make such wondrous leaps, as to raise the body above two hundred times its diameter. The great strength and agility of the Flea are well known, from the exhibition of the industrious Fleas. 


\section{Воок VII. \\ RA D I T A.}

THE STAR-FISH. (Asterias, or Uraster rubens.)

'T'HIs animal is often found adhering to rocks on the seashores. The common species is furnished with fiverays, and is of a yellow or red colour. It has a slow progressive motion, and is often found on the beach among seaweeds after a storm.

Mr. Bingley describes an animal of this kind, which he kept by him for some time alive; it had more than four thousand tentacula on the under sides of the rays. These it frequently retracted, and again pushed out, as a snail does its horns; and by means of them it was enabled firmly to adhere to the dish containing the salt-water. in which it was kept. Whenever he touched the tentacula with his finger, all those of that ray or limb were gradually withdrawn, but those of the other rays were not in the least affected by it.

There are many other kinds of Star-fishes, especially in warm climates. Amongst our native species we may notice the Great S"un Star (Solaster papposa) with a large disc and thirteen short rays; the Luidia fragilissima with five long rays, which it usually casts off immediately on finding itself in danger, so as to render it a most difficult matter to obtain perfect specimens of this species. The Feathered Star (Comatula rosacea) is also deserving of mention.-This is a small species, with the arms distinct from the body as in the last species and jointed, but furnished with numerous slender jointed tentacles which give them the appearance of plumes. There are ten of these arms and the number of little calcareous joints contained in them is most astonishing. The small cuplike body of the Feather Star bears other slender jointed appendages, by means of which the creature clings to the rocks with its month and arms directed upwards; and in the young state it is even supported on a jointed stalk, from which it eventually casts itself free. 


\section{THE SEA-URCHIN. (Echinus miliaris.)}

'THIS animal, which lodges in the cavities of rocks just beneath low-water mark, on most of the British coasts, is nearly of a globular shape, not much unlike that of an orange, having its shell marked into ten partitions, with rows of projections like beads, which divide it. On the outside of the shell there are a great number of sharp, moveable spines, of a dull violet and greenish colour, curiously articulated, like balls and sockets, with tubercles on the surface, and connected by strong ligaments to the skin or epidermis with which the shell is covered. The mouth is situated in the under part. and is armed with five strong and sharpened teeth. The animal can move from place to place by means of its contractile tubular feet and its spines; but its movements are slow and laborious. So tenacions of life are the Sea-urchins, that the ancients, according to Appian, believed that the body retained life even when cut to pieces.

"If in the sea the mangled parts you cast,

The conscious pieces to their fellows haste;

A gain they aptly join, their whole compose,

Move as before, nor life nor vigour lose."

In Marseilles, and some other towns on the continent, the Sea-urchin is exposed for sale in the markets, as oysters are with us, and is eaten boiled as an egg. The Romans adopted it as food, and dressed it with vinegar, mead, parsley, and mint.

\section{ZOOPHYTES.}

Zoophytes were long supposed to hold a middle station between animals and vegetables. Most of them, deprived altogether of the power of locomotion, are fixed by stems that take root in the crevices of rocks, ainong sand, or in such other situations as Nature has destined fur their abode; these, by degrees, send off branches, till at length some of them attain the size and extent of large shrubs. 
The Zoophytes were placcd by Linnæus in two divisions. The stony branches of the first division, which have the general appellation of coral, are full of hollow cells, which are habitations of the animals. The next division consists of such Zoophytes as have softer, fleshy, or horny, stems, and in which the individual polypes are, as it were, amalgamated with their common plant-like habitation.

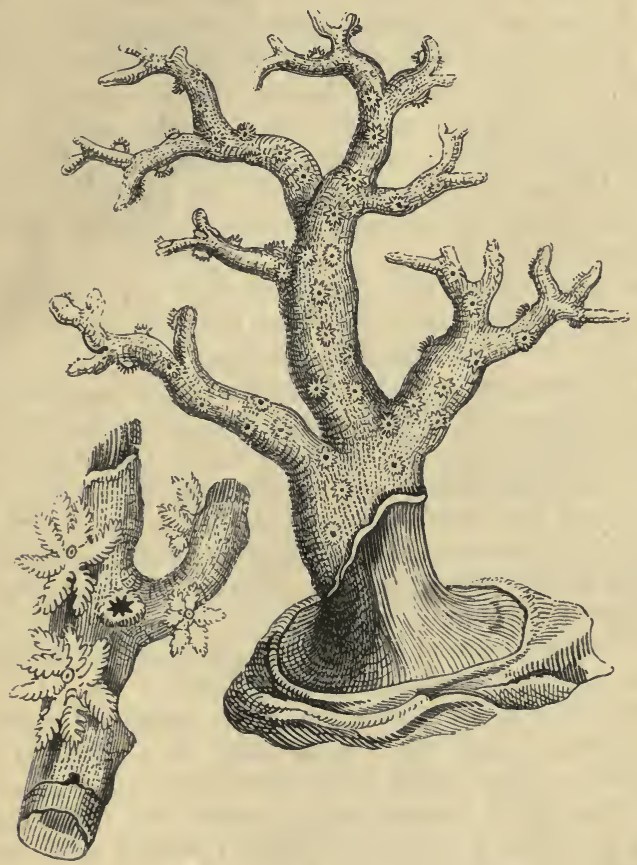

Magnified branch, exhibiting the Animals.

Gorgonia Nobilis.

\section{THE RED CORAL.}

The Coral, or Gorgonia, is a hard, stony, branched, and cylindrical substance, which is formed at the bottom of 
the sea by animals called polyps, or, to use the Latin and now established term, polypi. The whole form a living mass, or polypidom, all the polypi in which are united under one skin, and have one common stomach. Each of these polypi resides in a distinct cell; they are generally dormant during winter, and like the blossoms of plants, push forth buds, and expand in the summer season. The stems and branches of the Gorgonix, which are of a somewhat horny and flexible nature, may be considered as the true skeletons of the nests of the sea polypi, being covered with a fleshy or pulpy substance, the surface of which is porous. These pores are the months or openings of the cells, in which the polypi are lodged; and it is the number, disposition, and varied structure of these, in addition to the general aspect of the plant-like nest of habitations, that constitute the distinguishing difference of the species.

The bone of the Red Coral constitutes that beautiful and much esteemed production, the true or red coral of the jewellers. It is found in the Mediterranean, Adriatic, and Red Sea, and appears to be nowhere more abundant than in the seas abont Marseilles, Corsica, Sicily, the coasts of Africa, and in the vicinity of Barbary ; where the Coral fisheries are carried on with great spirit, and prove very lucrative. It is equal in hardness and durability to the most compact marble; and these qualities, in addition to its beantiful texture and colour, have rendered it valuable in all ages. Thus in the book of Job, "No mention shall be made nf corals, or of pearls ; for the price of wisdom is above rubies."

Travellers in tropical lands often speak of the exquisite beauty of the coral beds that lie at the bottom of the ocean. The water is so clear in those regions, that these wonderful formations are clearly visible at a great depth, growing like stony forests, mingled with waving seaweeds of many brilliant dyes.

The mode of obtaining Coral is by a very simple machine, consisting of two strong bars of wood or iron, tied across each other, with a weight suspending from their centre of union. Each of the bars is loosely surrounded, throughout its whole length, with twisted hemp; and, at 
the extremity, there is a small open net. The machine is suspended by a rope, and dragged along those rocks where the Coral is most abundant: and such as is broken off either becomes entangled in the hemp, or falls into the nets.

Coral is hought by weight, and its value increases according to its size. Beads of large size are worth about forty shillings an ounce, whilst small ones do not sell for more than four shillings. Large pieces of Coral are sometimes cut into balls, and exported to China, to be worn as insignia in the caps of officers of state. These, if perfectly sound and of good colour, and upwards of an inch in diameter, have been known to produce in that market, as much as three to four hundred pounds sterling each. There are extant many beautiful pieces of scnlpture in coral, as this substance has in all ages been considered an admirable material on which to exhibit the artist's taste and skill. Probably the finest. specimen of sculptured Coral yet known is a chess-board and men in the palace of the Trileries.

The Chinese have, within the last few years, succeeded in cutting coral beads of much smaller dimension than has hitherto been effected by any European artist. These, which are not larger than small pins' heads, are called Seed Coral, and are now imported from China into this country, in very considerable quantity for necklaces. There are modes by which Coral may be so exactly imitated, that without a close inspection, it is sometimes impossible to detect the counterfeit. 


\section{STIONY CORALS.}

'T'He Red Coral, just described, belongs to the section of zoophytes called Asteroida by Cuvier, in which the surface of the polypidom is fleshy, and each polypus has only eight arms. The polypi which form the massive stony corals of the tropical reefs, are furnished with numerous tentacles, and resemble in their general conformation the Sea Anemones which are so well known nowa-days as inhabitants of aquaria. The coral consists of a deposit of carbonate of lime, and each polypus dwells in a cell which exhibits a number of thin stony rays nearly meeting in the middle. The masses of coral differ exceedingly in size, some consisting of the habitations of only two or three polypi, whilst other's are the gradual production of a vast and constantly succeeding population; some form branched trees and shrubs of the most various and elegant forms, others grow in solid masses, but all, when living, present a most beautiful appearance from the charming and often brilliant diversity of colours with which they are adomed.

In the Pacific Ocean several of the coral reefs are extremely beautiful, and the voyager is astonished with the curious and fantastic forms of the rarious marine productions of which they are composed. II heat-sheaves. mushrooms, cabbage leaves, with innumerable plants and flowers, are vividly represented by different kinds of Coral, and glow beneath the water in brilliant tints of brown and purple, white or green; each with a peculiar form and shade of colouring, equal in richness and variety to the most beantiful productions of the vegetable world. Corals and fungi start from between the fissures of the rocks; while large portions of the former. in a dead state, connected into a solid mass, of a dull white colour, cumpose the stone-work of the reef. Solid masses, termed negro heads, of different dusky hues, and generally dry and blackened by exposure to the weather, are also occasionally conspicuous. Even these are not without ornament, for nature delights in the variety of 
her decorations. They are studded with small shells, and beautifully marked with outlines expressive of their origin. The edges of the reefs, particularly those exposed to the waves, partake of a considerable degree of lightness, and form small coves and caverns, the resort of live corals, sponges, sea-egrss, and trefangs, or sea traces, (valued in China, for their invigorating quality,) and enormous cockles, which are scarcely to be distinguished from the rock, excepting when they suddenly close their shells, and discharge living fountains, which rise to the height of four or five feet.

With regard to the formation of coral reefs, it has been conjectured, from the appearance of the low islands in some parts of the South Sea and Indian Ocean (where they occur in rows or groups, while they are totally absent in other parts of the same seas), that Coral animals rear their habitations on marine shoals, or, to speak more properly, at or near the top of sub-marine mountains. As it is known, however, that the polypes can only build their coral within a small distance of the surface of the sea, and the water is often of immense depth close to the coral reefs, it has been supposed that in the Pacific Ocean, where the greater part of the Coral reefs and islands are met with, the bottom of the sea has been gradually undergoing changes, deepening in some places and becoming shallower in others, and by this supposition most of the peculiarities of the Coral reefs and islands may easily be accounted for. Where reefs are formed the bottom is generally sinking; islands indicate that the bottom is stationary or rising. In the latter case, when the Corals approach close to the surface, floating substances of every kind are caught by their stony tree-like fabrics, till at length a solid mass of rock is formed, which gradually advances to the surface of the water. The deposits of the ocean no longer tenaciously adhere, but reniain in a loose state, and form what is termed by mariners a køy upon the summit of the reef; while the sea, by throwing up sand and mud on the top of these animal rocks, progressively raises them above its level. The new island, for such it may now be called, is soon visited by sea-birds; plants successively appear, 
and carpet the sterile soil with a luxuriant covering. As these decay, vegetable mould is gradually deposited; cocoa-nuts, or some floating seeds, flung on shore by the impetuosity of the waves, take root, and soon begin to grow ; land-birds, attracted by the verdant appearance of the bank. fly thither in quest of provisions, and deposit the seeds of shrubs and trees; every high tide and every gale adds some new treasure : the appearance of an island is gradually assumed, and at length man comes to take possession.

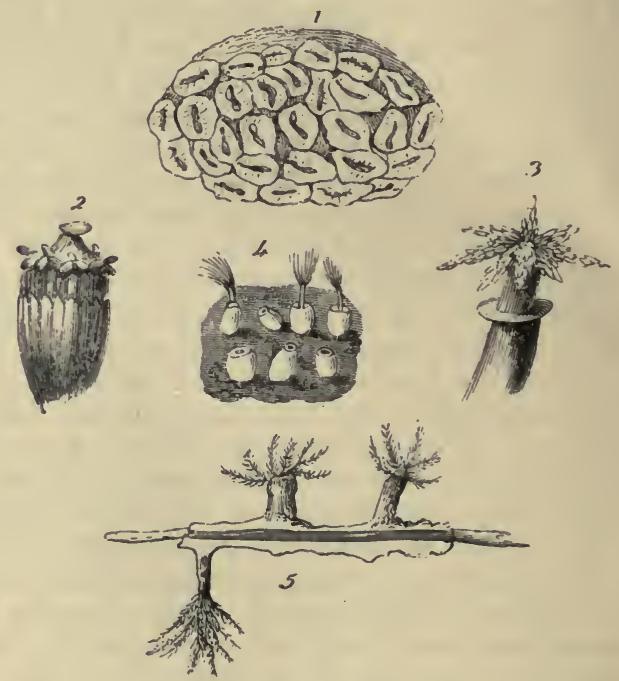

CORAL POLYPI, MAGNIFIED.

1. Coral of the Astrea annanas.

2. Animal of the Caryophyllia solitaria.

3. Animal of the Tubipura musica.
4. Animal and dwelling of the Cellepora hyalina.

5. Animal and central axis of the Gorgonia patula. 


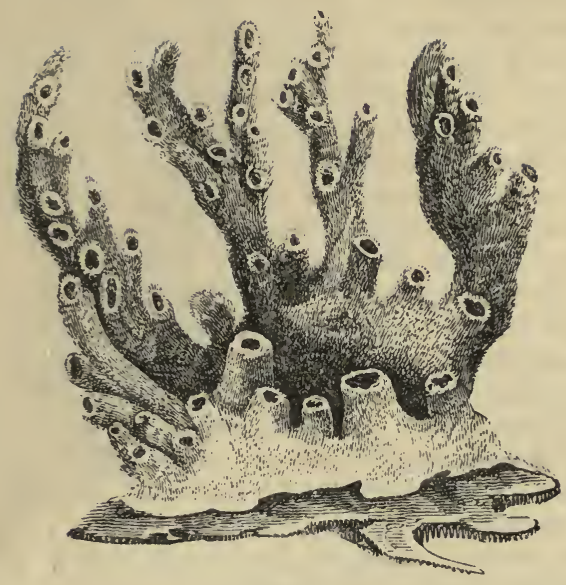

\section{SPONGE.}

Sponge is a substance of a soft, light, porous, and elastic nature, which is found adhering to rocks at the bottom of the sea, in several parts of the Mediterranean, and particularly near the islands of the Grecian Archipelago: and which, in its natural state, is filled with animal jelly. The general uses of Sponge, arising from its ready absorption of fluids, and distension by moisture, are well known and of great importance. It is collected from rocks, in water five or six fathoms deep, chiefly by divers. When first taken from the sea, it has a strong and fishy smell, from the animal matter it contains, of which it is divested by being washed in clear water. No other preparation than this is requisite previously to its being packed up for exportation and sale. The growth of Sponge is so rapid, that it is frequently found in perfection on rocks, from which, only two years before, it had been entirely cleared.

As they are never designed to move from their places of abode, the surface of the Sponges is covered with innu. 
merable small apertures or pores, communicating with a network of fine canals, which permeate every part of the substance and convey to the minute and simple creatures which form the living part of this curious compound animal, the food and water necessary for their support and respiration. These fine canals unite into larger passages, leading tu orifices of considerable size usually placed on prominences of the surface; from these the water streams forth with such force, according to some observers, as to be perceptible by the eye.

'I'he inherent chemical properties of this curious Zoophyte are very remarkable. II hen a Sponge has been immersed for fourteen or sixteen days in nitric acid (diluted with three parts of distilled water) it becomes nearly transparent, and when touched with ammonia, assumes a deep orange colour, inclining to a brownish red. But if much softened by the acid, the whole fabric inmediately disappears, on being immersed in ammonia, and forms a deep orange-coloured solution. A Sponge, when boiled, gives out a considerable portion of animal jelly. The infusion of a small quantity of oak bark causes this to fall to the bottom of the vessel, as a sediment, and so entirely changes the nature of the Sponge, that, when dry, it crumbles between the fingers; and, when moist, it may be torn like wetted paper. In this state we should naturally conclude that it is entirely useless: but no; the operations of chemistry resemble a magic wand. Boil the same in water, with caustic potash, its latent qualities will be called forth; and, behold, a deposition of animal soap!

\section{THE FRESH-WATER POLYPI AND THEIR MARINE ALLIES. (Hydroida.)}

These are two species, which will fully illustrate the nature of the whole tribe. They are found in clear waters, and may generally be seen in small ditches and trenches of fields, especially in the months of April and May. They affix themselves to the under-parts of leaves, and to the stalks of such vegetables as happen to grow in 


\section{The Fresh-Water Polypi.}

the same water; and feed on the various species of small worms and other aquatic animals within their reach. When any of these pass near a Polyp, the latter suddenly catches it with its arms, and dragging it to its mouth, swallows it by degrees, much in the same manner as a snake gorges its prey. Two Polypi may occasionally be seen in the act of seizing the same worm at different ends, and dragging it in opposite directions with great force. It sometimes bappens, that while one is swallowing the end it has seized, the other is employed in the same manner; and thus they continue swallowing, each his part, until their mouths meet. 'They then rest for some time in this situation, till the worm breaks between them, and each goes off with his share. But sometimes when the mouths of both are thus joined together a combat ensues, and the largest Polyp usually swallows his antagonist; the animal thus swallowed, however, seems to be a gainer by its misfortune, as after it has lain in the conqueror's body for about an hour it issues unhurt, and often in possession of the prey that had been the original cause of contention. 'The remains of the animal, on which the Polyp feeds, are evacuated at the mouth, the only opening in the body. The species are multiplied by a kind of vegetation, one or two, or even more young ones, emerging gradually from the sides of the parent animal: and these young ones are frequently again prolific before they drop off; so that it is no uncommon thing to see two or thrce generations at once on the same Polyp. But the most astonishing fact respecting this animal is, that if a Polyp be cut in pieces, it is not destroyed, but is multiplied by dissection. It may be cut in every direction that fancy can suggest, and even into very minute divisions, and not only the parent stock will remain minjured, but every section will become an animal. Even when turned inside out, it suffers no material injury; for, in that, state it will soon begin to take food, and to perform all its other natural functions.

M. Trembley, of Geneva, ascertained that different portions of one Polyp could be engrafted on another. Two transverse sections brought into contact will quickly 
unite and form one animal, though each section should belong to a different species. The head of one species may be engrafted on the body of another. When one Polyp is introduced by the tail into another's body, the two heads unite and form one individual. Pursuing these strange operations, M. Trembley gave scope to his fancy by repeatedly splitting the head and part of the body; he thus formed hydras more complicated than ever struck the imagination of the most romantic fabulist.

Though so difficult, to destroy by division, all the Polyps, even those which form the corals, may be easily killed by depriving them of moisture, when they soon shrivel up, and the tissue of their skins is completely destroyed.

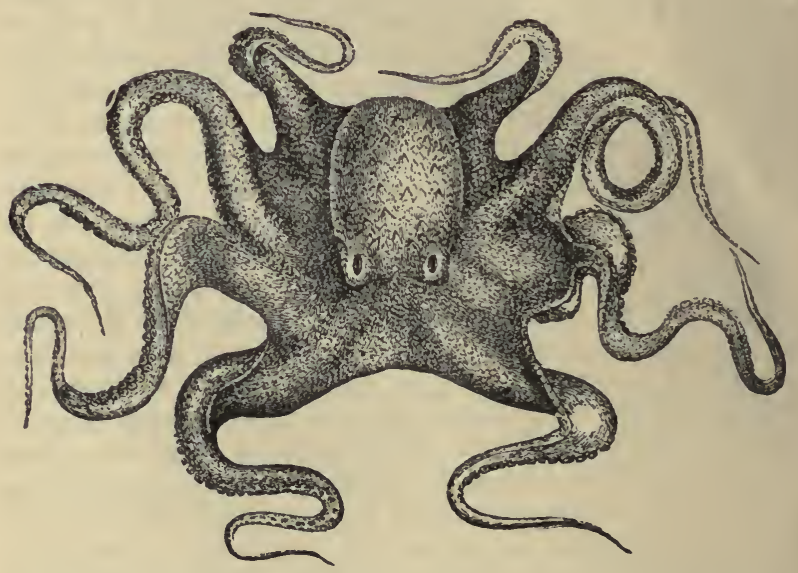

Of these Fresh-water Polypi, only a few kinds are known, but the sea nourishes a multitude of species which closely resemble the Hydras in their structure, from hence called Hydroid Polyps by Cuvier and many other naturalists. Most of these are compound creatures, of the kind shown in the above engraving, of which many species may be found on all our shores. A horny tube runs branching over the surface of a seaweed, or 
some other object, and from this, at intervals, rise slender stalks, often branched in the most elegant manner. Upon the delicate branches we find little horny cups, each of which is the habitation of a tiny Polyp, furnished with a mouth and stomach, and with a circlet of slender arms to enable it to capture its prey. Other species are enclosed only in a suft membrane, but all rise from creeping roots.

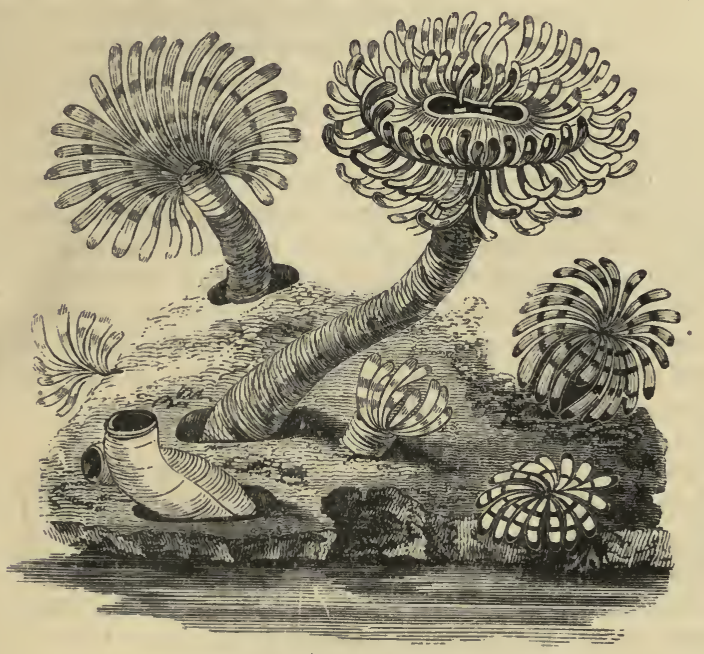

THE SEA ANEMONES.

Besides the Polypi just mentioned as nearly related to the fresh-water Hydra and those forming the different kinds of Corals, the sea produces a vast number of other Zoophytes, the commonest kinds of which are well known as Sea Anemones. These animals are found adhering to rocks on all shores; they consist of a rather thick column, the base of which forms an adhesive disc, while its summit, which is also a disc, shows a puckered mouth in the centre surrounded by several rows of 
tentacles. The tentacles are sometimes short and stout, sometimes long and slender; they are generally adorned with vivid or delicate colours, often disposed in rings and contrasting beantifully with the colours of the stem and disc. In their expanded state they present a close resemblance to a flower, and indeed vie with many flowers in beauty ; hence the name of Animal Flowers was given to them formerly, and has now given place to that of Sea Anemones, althuugh they are rather to be compared with those composite flowers in which numerous petal-like flowerets radiate from a central disc. When contracted, the Sea Anemones resemble soft knobs or buttons, with a depression at the top.

In describing the Stony Corals, the fact has been mentioned that the Polyps, which may be regarded as the architects of those extraordinary structures, are very similar to the Sea Anemones. In the latter, the cavity surrounding the central stomach is partially divided into chambers, by partitions, which run inwards from the circumference towards the centre: in the Coral Polyps each of these partitions produces a stony plate. in its substance, and these plates form the rays which occupy the interior of the Polyp-cell.

The Sea Anemones move slowly along by the action of their adhering disc, somewhat in the same way that a snail or slug crawls upon the gromnd. Their food is obtained by means of the tentacles which give them their beautiful flower-like character, and to render them efficient organs for this purpose they are endowed with a singular provision. 'The skin of the tentacles, and, indeed, of most parts of the Sea Anemone is filled with little cells or vesicles, each containing a spiral thread, which when tonched instantly darts forth, and penetrates the body coming in contact with it. In this way, if a worm, a small fish, or any other soft animal touches the tentacles of an Anemone, it is instantly transfixed with innumerable delicate darts, which not only assist the tentacles in holding the destined prey, but also seem to exercise a sort of numbing influence upon the victim, deadening his struggles and rendering him an easy conquest. He is then specdily passed by the tentacles 
to the orifice of the mouth, and swallowed without mercy.

One of the commonest kinds of these Polyps is the Mesembryanthemum (Actinia Mesembryanthemum), a large, usually liver-coloured species, with a row of blue warts round the margin just outside the tentacles. It is found abundantly on the rocks of our Southern coast especially. 'The Thick-horned Anemone (Actinia or Brusodes crassicornis) is another large and fine species, usually of a red colour, with very thick tentacles, which are generally white with pinkish bands.-The Sea Cereus (Anthea Ctreus) has long slender tentacles, which are not retracted in the same way as those of the Sea Anemones generally. 'T'he tentacles are usually tipped with a pink or purple tint; they are constantly waving about in the water in search of prey; and instantly seize upon any creature that passes over them.-The Parasitic Anemone (Actinia parasitica) and the Cloak Anemone (Adamsia palliata) alway's attach themselves to univalve shells which are uccupied by Hermit Crabs.

\section{JELLY FISHES.}

The animals commonly known as Jelly Fishes are freeswimming Kadiata; they were described by Cuvier and most succeeding naturalists under the name of Acalephoe, from a Greek word signifying " nettles," because many of them produce a stinging sensation when they come in contact with the skin. "Their name in several languages signifies "Sea Nettles." The Acalephr of Cuvier are now regarded as belonging to the same class as the Hydroid Polyps.

The common Medusa (Medusa amita), which may serve as an example of this group, is found in great abundance round our coasts; it is of a circular form, convex above, concave beneath, like an umbrella, the stick of which is represented by a thick stalk, containing the mouth and stomach, and terminated by four long arms for seizing the animal's food. 'T'he skin of these, and of the body and its appendages generally is full of the thread-cells 
described as occurring in the Sea Anemones, and it is to these that the stinging power of the Medusæ is due. 'I'he motion of the Medusæ through the water is effected by the alternate expansion and contraction of its umbrella, which is slightly inclined in the direction towards which the creature is moving, and it is a most beautiful sight to look down upon a fleet of these animals, all advancing in the same direction at a depth of two or three feet in the water, as may often be seen in fine weather at the mouths of our rivers.

At first sight it may be thought that the Medusæ have but little in common with the Hydroid or any other Polyps, but it has been fully proved by late researches that the young animal produced from the egg of the Medusa is a regular Polyp, which adheres by its base, and obtains its food by the agency of a crown of tentacles surlounding its mouth; nay, it even propagates in this form by pushing out buds exactly in the manner described in the case of the fresh-water Hydra. In course of time, however, the body of this Polyp becoines elongated, and its surface is marked into rings, the grooves separating which gradually become deeper until the whole body breaks up into a number of saucer-like segments, each of which becomes a Medusa. How fully does this extraordinary mode of reproduction show that the wonders of the Creator are no less striking in the lowest than in the highest of his creatures, and that for all, from the highest to the lowest, the same prescient care has been exercised, the same goodness evinced. Verily, we may follow the pious example of the great Linnæus, and exclaim with the Psalmist, " $O$ Lord, how manifold are thy works! in wisdom hast thou made them all." 


\section{A P P EN D IX}

\section{OF \\ FABULOUS ANIMALS.}

OUR OBJECT in the previous pages has been to combine interest with amusement, and to present truth unnixed with fable. Yet considering that some fictitious animals are conventionally recognised in poetry and painting, we have thought it desirable to subjoin an account of them. The Sphinx, the Dragon, the Unicorn, Pegasus, and the Centaur, are so familiar to us, both in sculpture and fable, that some notice of these mythological creations seems indispensable.

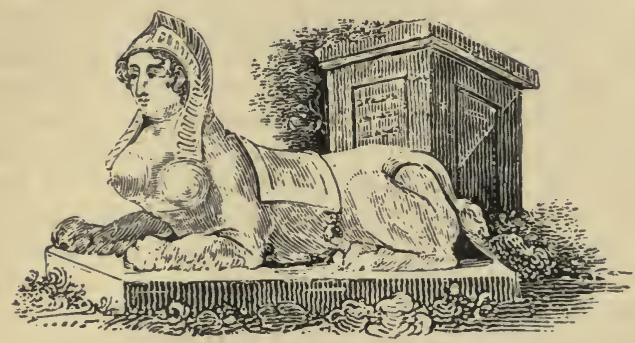

THE SPHINX.

Providence has ordered, that as the plains of Egypt are not visited by showers, they should be fertilized by the overflowing of the Nile, which takes place annually, 
a little after the summer solstice. This phenomenon, the source of unfailing fertility in the vales of the Delta up to Memphis, and around the bases of the majestic and venerable pyramids, was of the greatest importance to the people of Misraim, from the far-famed Pharos to the frontiers of Ethiopia. It was therefore their interest to calculate correctly the season, the month, and nearly the hour, when the flood should begin; the more so, as the sudden invasion of the waters was dangerous to the inhabitants of the low lands, the meadows, and the fens, and often destroyed the cottages, and drowned the flocks and the improvident villagers. The star Sirius was remarked to emerge from the blazing halo of the sun about the time of the rising of the Nile; it was a warning, and was accordingly called the Dog-star, as if barking from the heavens to apprise the inhabitants of the valleys of the impending rise of the waters. The Egyptian astronomers, to mark the period, combined the signs of the zodiac answering to the two months during which the overfowing took place. These signs happening to bo Leo and Virgo, the mystical fancy of the ancient Egyptians united them in one, and thus formed the figure of the Sphinx, which has the head and breast of a woman, and the body of a lion. This was a great enigma to the Greeks and Phœnicians who travelled to Egypt; they saw the monster, but could not comprehend its meaning. On returning to their respective countries, they invented. the fable of the Sphinx offering riddles at the gates of Thebes, and destroying those who could not unravel them; having probably been told by the supercilious sages of that nation, that they who could not guess the meaning of the Sphinx were to forfeit their life in atonement for their ignorance. Long afterwards, the real sense of the symbol was forgotten, and Egypt in her superstition began to worship the emblem, of which innumerable figures still exist in that once flourishing country.

'The Sphinx has been introduced in heraldry to adorn the gorgets of those general officers who distinguished themselves against the French on the banks of the Nile; it has also been adopted as an ornament in various decorations ; and two specimens, exquisitely wrought, are seen 
on the front wall of Syon House, at Brentfurd, the seat of his Grace the Duke of Northumberland.

This chimerical figure is generally represented as sitting and at rest; a graceful attitude adopted by Egyptian sculptors, and imitated by the Greeks and Romans.

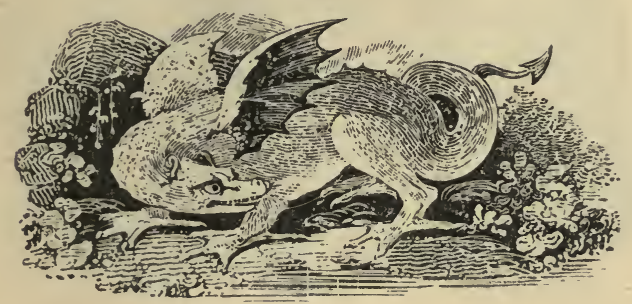

\section{THE DRAGON.}

Turs fabulous animal, which figures largely in ancient romances, was supposed to be the tutelary genius of fresh-water springs in the bosom of dark forests and enchanted rocks. Dragons were harnessed to the car of Ceres; they were the guardians of the golden apples of the Hesperides, and of the golden fleece of Colchis; and in several parts of the world set as protectors to the carbuncles and other precions stones hidden at the bottom of wells and fountains. They are represented as scaly serpents, with webbed feet, and with wings similar to those of a bat; having been, it seems, originally a hieroglyphic emblem of the dangerous influence of an undue combination of air and water. Thus the serpent Python was the allegory of a pestilence, originating from a union of mephitic air and moisture. They have been long supporters to the arms of the city of London, as if the guardians of the wealth which commerce brings hither from all the parts of the world. Four of them are placed in fanciful attitudes, and beautifully carved, on the pedestal of the monument of London. 


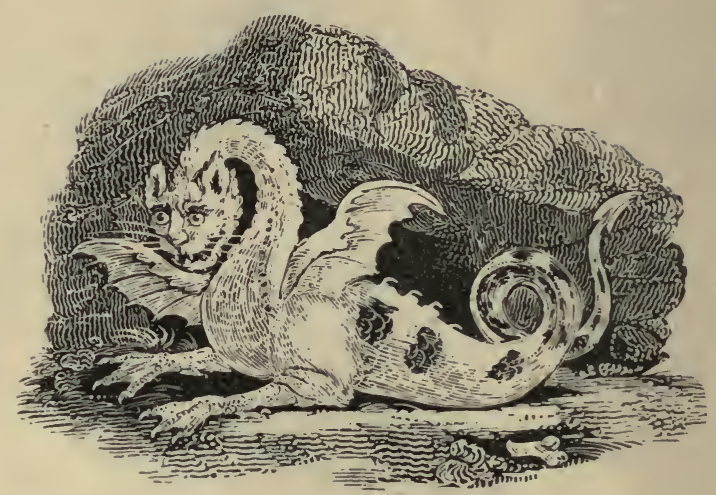

THE WIVERN, WOLVERINE.

'T'H fs fabulous animal somewhat resembles the dragon, only that, instead of fuur, it has two legs, which are webhed, and armed with claws. There is no doubt that this imaginary being was originally conceived in the brains of the poets and romancers, in times of chivalry, when the Crusaders overran the plains of Palestine and Assyria. The heat of the climate in some vales at the foot of the mountains, which intersect the deserts of those countries, was favourable to the breeding of all sorts of serpents, some of an immense size. The European soldiers of Godfrey and Richard, unaccustomed to such rights, were easily frightened, whenever they met those monsters on the sedgy banks of small lakes, under the shade of cedars and palm-trees, where they appeared as if posted to guard the sacred waters, so precious in so hot a country: and magnified in their idle tales, when inactive in camps, the bulk of the serpent they had seen. The castle of Lusignan, in the province of Poitou, was supposed to contain one of those winged serpents. It is a very ancient armorial bearing, and now stands as supporter to the arms of several illustrious houses. 


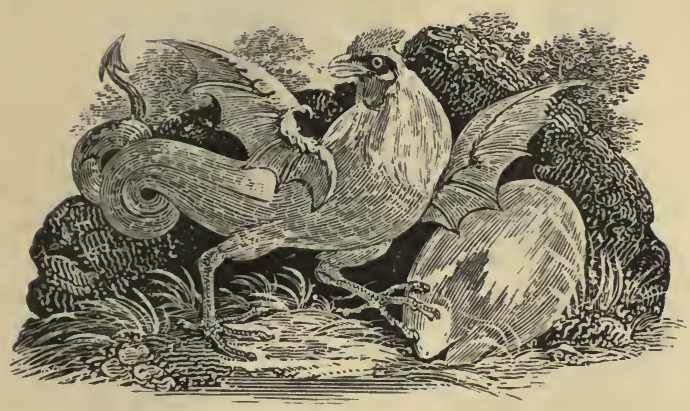

\section{THE COCKATRICE, OR BASILISK.}

THE fruitful imagination of man know's hardly any bounds. The animal which bears the name of Basilisk was originally supposed to be a serpent, with a sort of comb or crown on its head: but that was not sufficiently marvellous. It was supposed also to be hatched from a cock's egg, upon which a snake had performed the office of incubation; and the animal had the head of a cock, and the wings and tail of a dragon. Hatched near a spring of water, the common resort of serpents, it was asserted that, frightened at his own extraordinary shape, he soon precipitated himself to the bottom, whence, by the mortal look from his fiery eyes, he had the power of killing whoever dared to gaze at him. There are no less than four kinds of basilisks mentioned by various authors. One burnt up everything near him, and reduced the place he lived in to a complete desert; another kind had the power of producing a stony rigidity in whoever lonked at them, which was followed by death; or the gazers' flesh fell from their bones. The basilisk was said to be killed by carrying a mirror to its lair; and the creature encountering the reflection of its own baleful glance, was killed with its own weapons. 


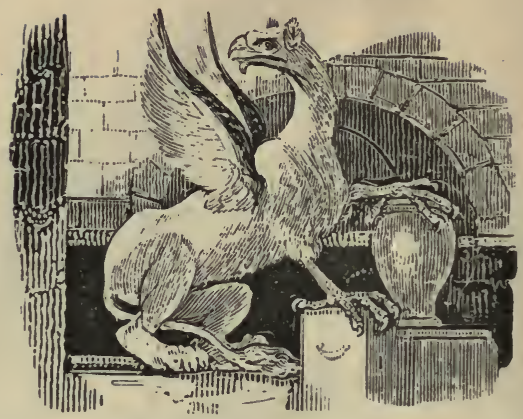

\section{THE GRYPHON, OR GRIFFIN,}

WAS originally an emblem of life. It was used to adorn funeral monuments and sepulchres. The upper part of this allegorical animal resembles the eagle, the king of the birds, and the rest the lion, the king of beasts; which is said to imply that man, who lives upon the earth, cannot subsist without air. In later times it was supposed that the Gryphon was posted as a jailor at the entrance of enchanted castles and caverns where subterraneous treasures were concealed. Milton compares Satan in his flight to the Gryphon, in the following beautiful passage :

"As when a Gryphon through the wilderness,

With winged course o'er hill or moory dale,

Pursues the Arimaspian, who, by stealth,

Had from his wakeful custody purloined

The guarded gold; so eagerly the fiend,

O'er bog or stcep, through strait, rough, dense, or rare,

With head, hands, wings, or feet, pursues his way,

And swims, or sinks, or wades, or creeps, or flies."

The Arimaspians were Asiatic wizards, who, by magic, used to obtain a knowledge of the.places where treasures lay hidden. Their incessant wranglings with the Gryphons about gold-mines are mentioned by Herodotus and Pliny. Lucan says that they inhabited Scythia, and adorned their hair with gold; that they had but one eye in the middle of the forehead, and lived on the banks of the gold-sanded river Arimaspes. 
Virgil, in his eighth Pastoral, mentions this animal as if really existing, but does not give us any description of it; and Claudian, in his Epistle to Serena, alludes to the supposed fact of their keeping watch over masses of gold in the bosom of northern mountains.

\section{THE PHQENIX.}

Heronotus, Pliny, and nearly sixty other classical authors, have related marvellous stories of this bird, all of which are of course fabulous. The Phonix, they say, inhabits the plains of Arabia, and is about the size of an eagle, with gorgeous plumage of purple and gold. $\mathrm{He}$ is the only one of his kind in the world. At the approach of death, he builds himself a nest of aromatic herbs, and on it yields up his life. From his marrow proceeds a worm, which shortly becomes a young Phœnix, whose first duty is to discharge the obsequies of his sire. For this purpose he collects a quantity of myrrh, which he moulds into the shape of an egg, as large as he can conveniently carry, and then scooping it out, he deposits the body of his sire in the inside. Having stopped it up again with myrrh, he carries it to the Temple of the Sun in Egypt, where he devoutly places it on the altar. This is the only time that he is seen during his life, which lasts five hundred years. According to others, after preparing a funeral pile of rich herbs and spices, he burns himself, but from his ashes revives in all the freshness of youth.

From late mythological researches it is conjectured that the Phœnix is a symbol of five hundred years, of which the conclusion was celebrated by a solemn sacrifice, in which the figure of a bird was burnt. His being restored to youth signifies that the new springs from the old.

\section{THE MERMAID, OR SIREN.}

THE existence of this animal, half a woman and half a fish, has long been talked of, believed, disbelieved, and doubted. Homer is the first who speaks of such beings, 
which he styles Sirens; but we do not find that he gives any description of their shape; however, it was soon asserted that the Sirens were, as Horace, in his "Art of Poetry," describes them:

"Above, a lovely maid; a fish below."

The Sirens were three sisters, whose voice was so delightfully harmonious and enticing, that no resistance could be made against its powerful charms; but " 'twas death to hear," for they led the navigators and their ships to certain destruction among the rocks that bordered the dangerous coasts which they inhabited, near the shores of Italy.

The belief in the existence of Mermaids has been current at different periods ; indeed, some years ago, several persons made depositions before a magistrate, that they had seen Mermaids come out of the sea and play on the rocks, but that they sprang into their element before they were able to secure them.

A creature, said to be a dried Mermaid, was exhibited in London about the year 1828 ; but it was afterwards discovered to be the body of a monkey artfully attached to the dried tail of a salmon.

\section{THE KRAKEN.}

This creature is another fabulous inhabitant of the sea. It is said to be three or four miles in breadth, and to live generally at the bottom of the sea, on the Norway coast. When it moves the commotion of the sea is so violent that it upsets boats and even small ships; and when it comes to the surface, it is generally mistaken for an island. 


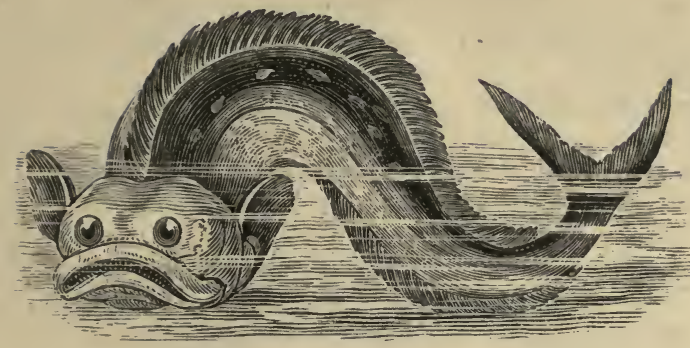

THE DOLPHIN.

'I'HIs is the Dolphin of heraldry, and as fabulous an animal as any here mentioned, as may be seen by comparing it with the figure of the real Dolphin, given with the description in a former part of this work. This fish was said to curl up his back to carry his favourites over the seas without wetting them ; and to assume the most brilliant colours in dying, changing from a bright blue to as bright a yellow, and then to red and green, \&c. \&c.

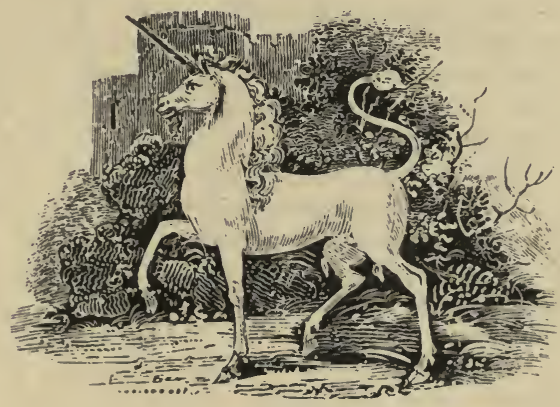

\section{'IHE UNICORN.}

THIs is another offspring of the lively and fruitful fancy of man. It is represented as a compound of the horse and stag, the head and body belong to the former, and the hoofs to the latter, while the horn, the tufts, and the 
tail are anomalies. This animal holds a high rank in heraldry, and is one of the supporters of the royal arms of England.

The Unicorn is often mentioned in the Scriptures, and by many commentators is supposed to be the rhinoceros. From the book of Job we learn that it was not only an animal of considerable strength, but also of a very fierce and intractable disposition - "Will the Unicorn be willing to serve thee, or abide by thy crib? Canst thou bind the Unicorn with his band in the furrow? or will he harrow the valleys for thee? Wilt thou trust him, because his strength is great? or wilt thou leave thy labour to him? Wilt thou believe him, that he will bring home thy seed, and gather it into thy barn?" Ch. xxxix. ver. $9-11$. In the book of Psalms, xcii. ver. 10. "My hor"u shalt thou exalt like the horn of a Unicorn."

\section{THE PEGASUS.}

AxотнеR liberty has been taken with the horse. Mythology has added wings to its elegant figure, and called it Pegasus. This animal, it is said, sprang from the blood of Medusa, when Perseus had cut off her head; and immediately afterwards flew upwards towards heaven, but stopped short, and alighted on Mount Helicon, where he struck the ground with his foot, and instantly the fountain Hippocrene burst from the ground. During his residence on Mount Helicon, Pegasus became a great favourite with the Muses, who resided occasionally on that lofty mountain; and still, when any one attempts extravagant flights of poetry, he is said to have mounted on his Pegasus, as it was difficult to approach the Muses when raised so high. On the contrary, the Castalian fountain on Mount Parnassus was more accessible, and inspired poetry of a gentler nature. But to return to Pegasus; he was at length tamed by Neptune, or Minerva, and lent by the latter to Bellerophon, to enable him to conquer the horrid monster called the Chimera, which was.always shifting its place, and romiting forth flames and smoke. After the victory was achieved, Bellerophon attempted 
to fly up to heaven; but Pegasus threw his rider, and flying up to heaven without hin, was changed into the constellation of stars which still bears his name. Pegasus is sometimes confounded with the Hippogriph, or Ippogrifo of Ariosto, which is often seen in coats of arms.

\section{THE CENTAUR.}

Like the Sphinx, this creature is a compound of the brute and human form, exhibiting the body of a man united to that of a horse, the former rising from the chest of the latter. Absurd as such a combination must appear to the anatomist, and ill adapted as it seems for agility, it is not wholly devoid of grace, and is very frequently met with in antique sculpture. According to Grecian mythology, these beings inhabited Thessaly; and poetry has celebrated their combats with Hercules, Theseus, and Pirithous, the latter of whom was the leader of the Lapithæ, a people who vanquished the Centaurs. Their fabulous existence had its origin in that love of the marvellous, which is always found to exist in the earlier stages of society. Hence the natives of Thessaly being distinguished for their skill in horsemanship, at a time when their neighbours were unacquainted with the art of riding, they would be described as combining the powers both of the human and the equine race; in the same manner as some of the American tribes, when they first beheld the Spaniards mounted on horses, mistook them for a different race of beings from themselves, supposing them to be half men and half quadrupeds. It is by such errors that fiction, whether poetry or painting be its vehicle, creates those fanciful beings and shapes which delight the imagination.

\section{THE SATYR.}

Although the Satyr of the ancient poets can hardly be termed an aninal, as the human form predominates, he may be introduced here as our final example of fabulous 
creatures. Satyrs and Fauns are represented as men with goats' legs and horns, and were supposed to be the attendants of Bacchus, with whose worship they are generally connected. The idea of such beings was probably derived from some of the larger species of apes. They are described as inhabiting woods and forests, of which they were regarded as the protecting deities. Probably they were partly personifications, intended to express the debasing influence of animal propensities and sensual indulgence : and as nothing tends more than intoxication to rednce man to a level with the brutes, since it deprives reason of all control over the passions, the form of the Satyr may have been ingeniously intended as a visible representation of the degraded state of those who surrender up the noblest prerogative of man. Whether such was really or not the idea of those who first feigned the existence of such creatures, we may very rationally adopt this explanation, and thereby deduce an important moral lesson from what is in itself an extravagant fiction. 


\section{N D EX.}

A.

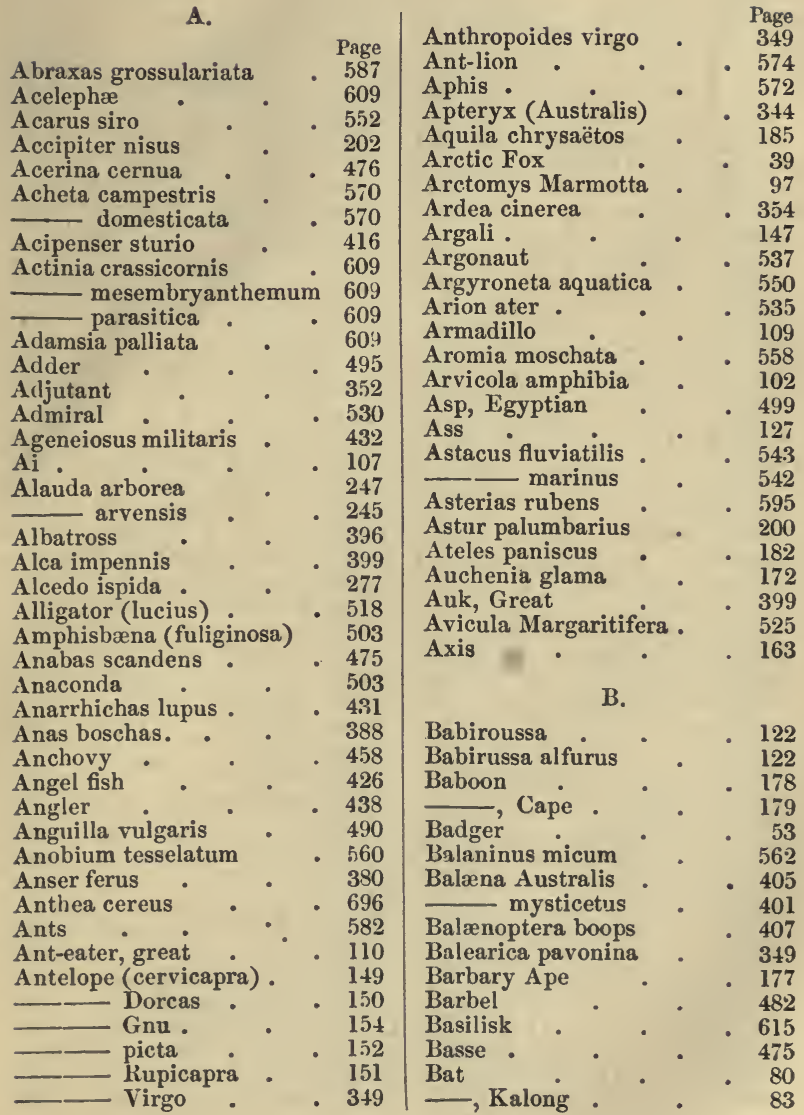




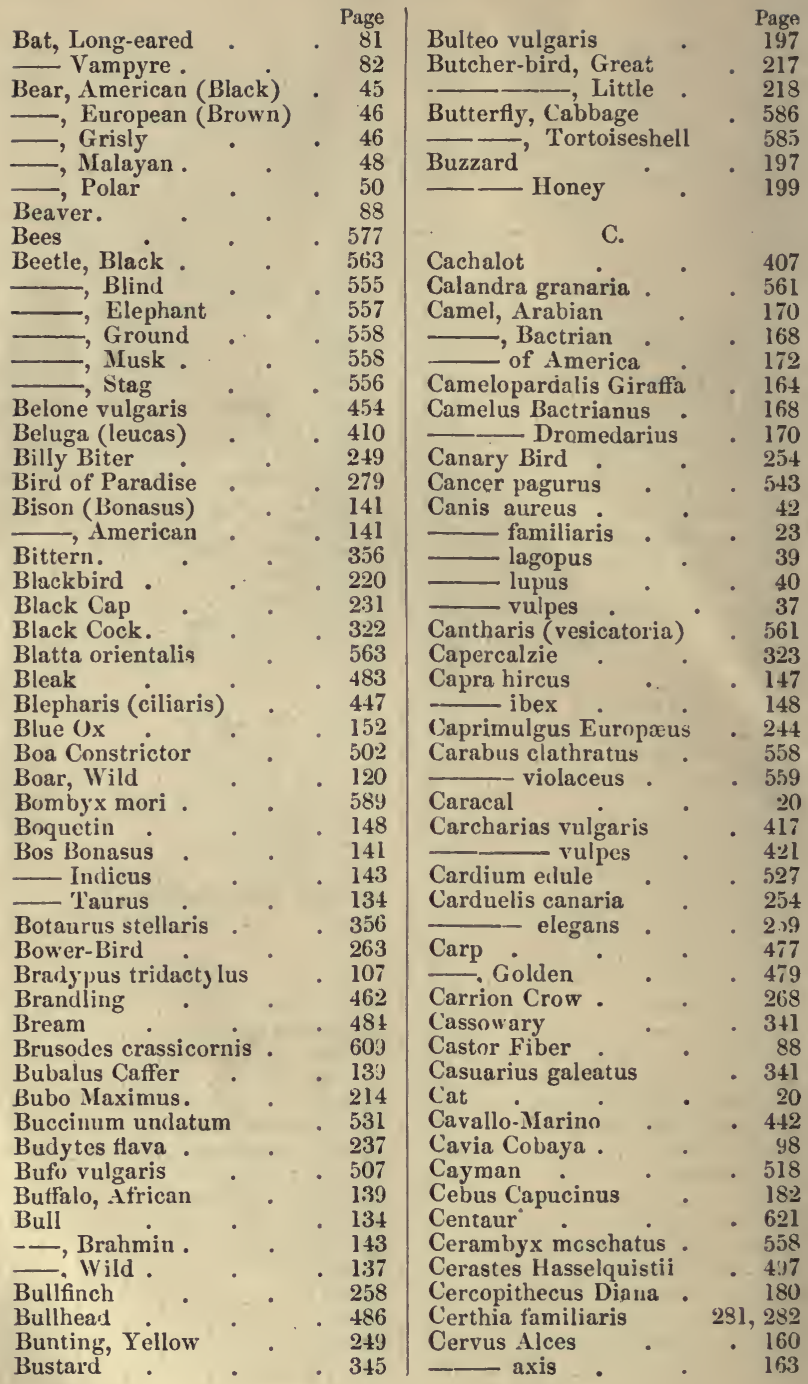




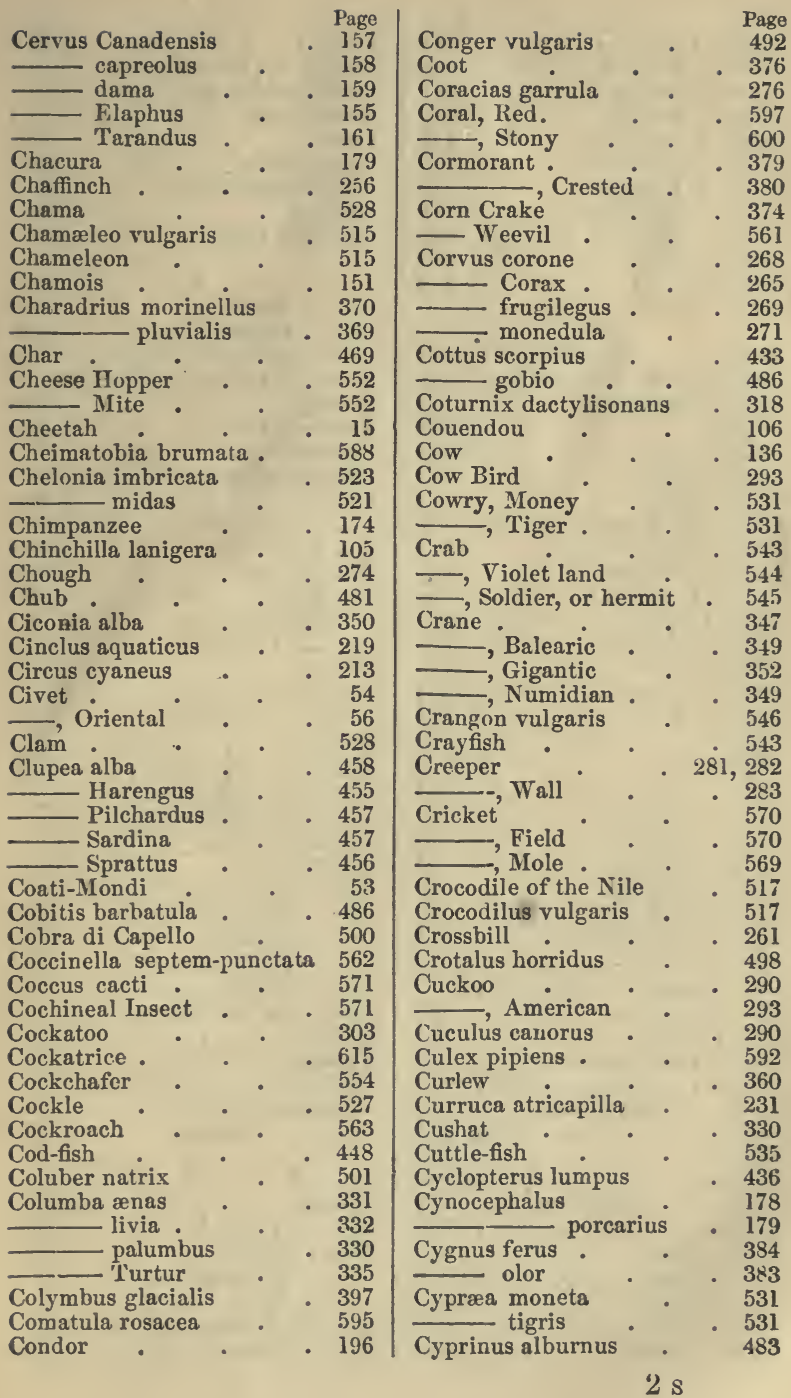




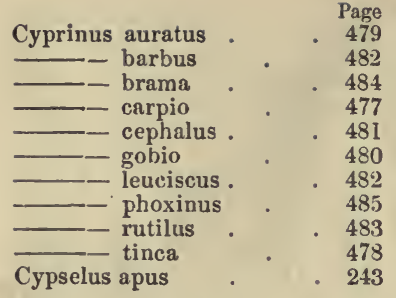

D.

Dace

Dactyloptera Ḿediterranea Dasypus sexcinctus . Day-fly

Death-Watch . .

Deer, Fallow . Musk .

Delphinus Delphis $\quad 408$

Demoiselle. . . 343

Dicotyles lahiatus . $\quad 122$

Didelphis Virginiana $\quad . \quad 86$

Didus ineptus . $\quad 328$

Diomedea exulans . $\quad$. 396

Dipper $\quad . \quad 219$

Dipus Fgyptius . 104

Djeggetai . $\quad 131$

Dodo . . 328

Dog-fishes . . 420

Dog . . 23

$\underline{ }$ Bloodhiound . $\quad 25$

- Bulldog . • 30

- Foxhound . 27

Greyhound . . 36

- Mastiff . . $\quad 29$

- Newfoundland - . 34

- Pointer. . 28

- Shepherd's . . 23

- Spaniel . . 32

- Terrier . 31

\begin{tabular}{lr} 
Water Spaniel . & 33 \\
\hline Dolphin & 408
\end{tabular}

Dolphin of mythology $\quad \cdot \begin{array}{r}408 \\ \hline\end{array}$

Dor . 555

Dorado . . 410

Dormouse . • . 96

Dormerican . $\quad 97$

Dottrel . . . 370

Dove, Ring . $\quad 330$

一, Rock • . 332

--, Stock . . 331

-, Turtle . . 335

Draco volans
Dragon

Dragon-fly, Great

Dromaius Nove Hollain

Novæ Hollandiæ 343

• • 170

Duck Fider • • 388

Duck-billed Platypus . 111

Dugong • • 415

Dynastes elephas . $\quad 557$

E.

Eagle, Black . . 192

$\longrightarrow$, Giolden • • 185

, Sea, or White-tailed 188

, White-headed or Bald 189

Earwig . . 563

Echeneis remora - . 430

Echidna hystrix $\quad 112$

Echinus miliaris . 596

Eel • . . 490

--, Conger, or sea . _ 492

--, Electrical . . 488

Flectric Ray . • 425

Elephant . . 113

Elephas Africanus . $\quad 115$

Indicus . 113

Elk • • . . 160

Emberiza citrinella . $\quad 249$

- hortulana - 250

Emeu . . 343

Empusa gongylodes • 564

Engraulis encrasicolus $\quad \mathbf{4 5 8}$

Enhydra Lutris . . 68

Epeîra diadema $\quad$ • $\quad 548$

Ephemera • . $\quad 576$

Equus Asinus . $\quad$. 127

Burchel.ii . . 133

caballus $\quad 124$

- Hemionus . $\quad 131$

Z Zebra . $\quad 132$

Erinaceus Europæus • 74

Ermine $\quad 62$

Erythacus rubecula $\quad$. 226

Esox lucius . . 472

Exocætus exiliens . $\quad$. 444

volitans . 443

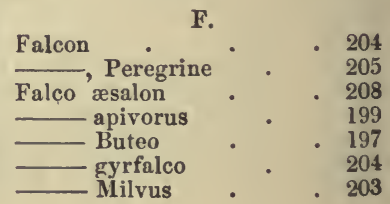




\section{Index.}

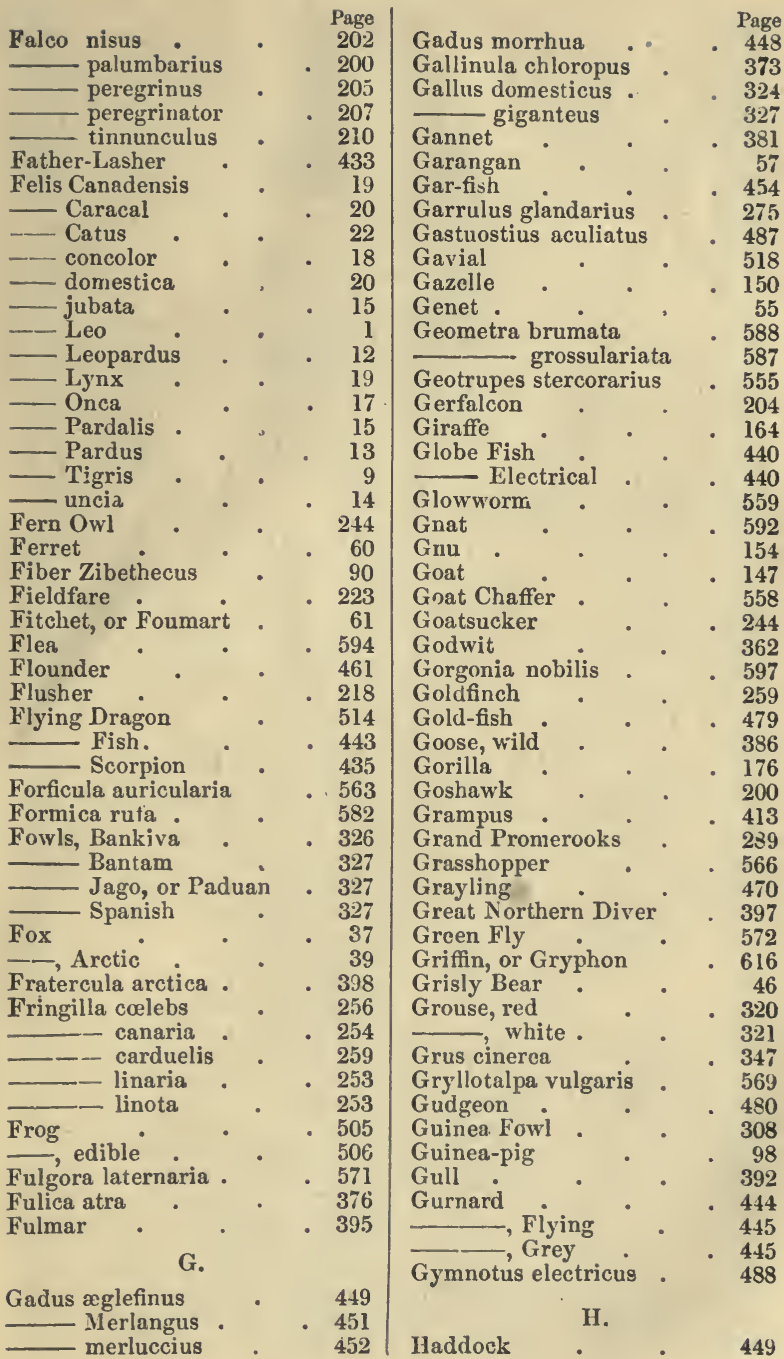




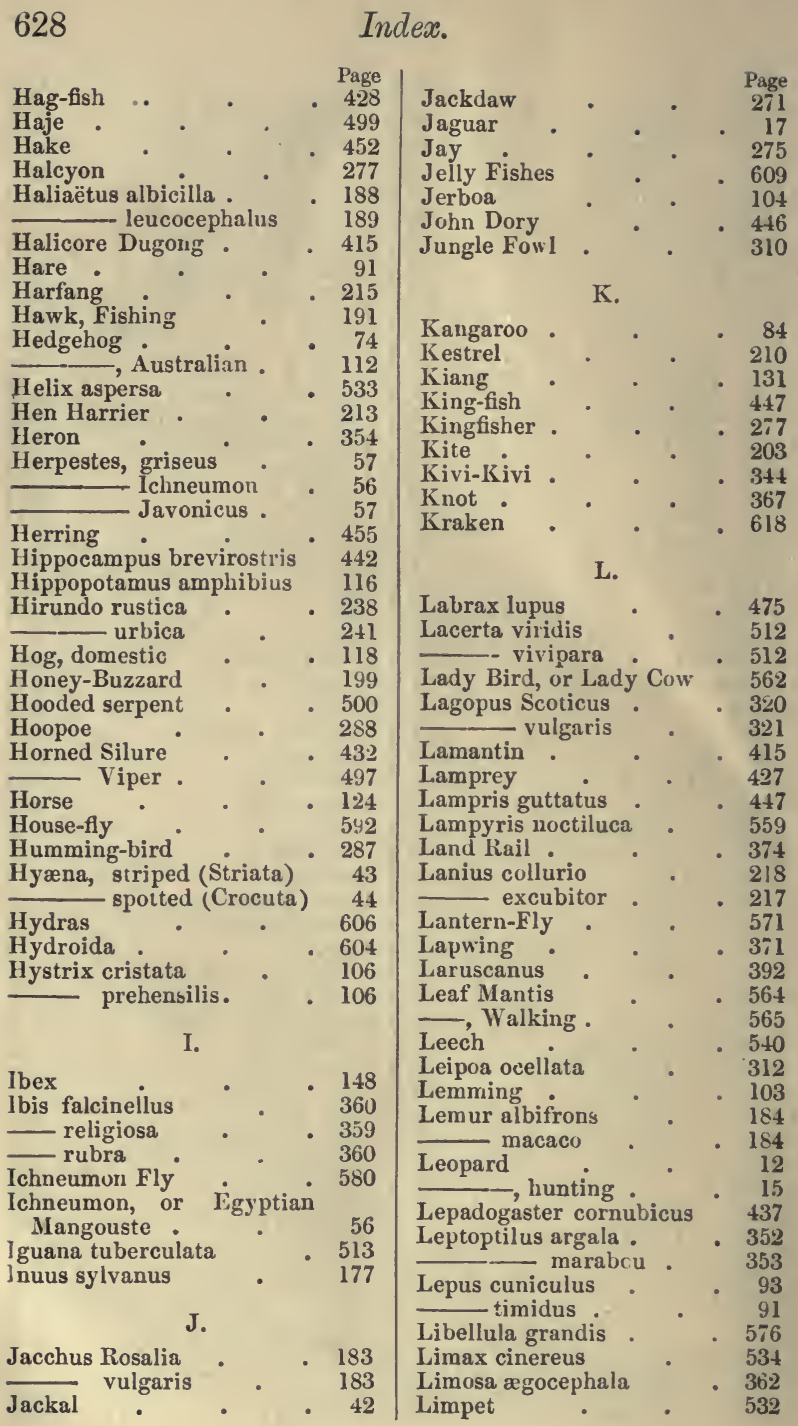




\begin{tabular}{|c|c|c|c|c|c|}
\hline & & $\begin{array}{r}\text { Page } \\
-\quad 451\end{array}$ & & & $\begin{array}{r}\text { Page } \\
22 \% 2\end{array}$ \\
\hline $\begin{array}{l}\text { Ling } \\
\text { Linnet }\end{array}$ & - & $\begin{array}{r}451 \\
253\end{array}$ & $\begin{array}{l}\text { Mavis } \\
\text { Medusa amita }\end{array}$ & & - $\begin{array}{r}222 \\
603\end{array}$ \\
\hline Linota cannabina & - & . 253 & Megapodius tumulus & & 310 \\
\hline ion. & . & 1 & Meleagris Gallo-Pavo & . & 306 \\
\hline oness and Cubs & . & 7 & Meles I'axus & & 53 \\
\hline ttornia littorea & • & 532 & Melolontha vulgaris & & 554 \\
\hline izard & & - 512 & Melopsittacus undulat & us & - 302 \\
\hline , Flying and & Green & 514 & Menura Alberti & . & 87 \\
\hline amá & . & - 172 & - superba & & 284 \\
\hline ch & - & 486 & Mephitis Americana & - & 63 \\
\hline ster & - & $5+2$ & Merlangus vulgaris & & 451 \\
\hline ocust & - & 567 & Merle . & - & 222 \\
\hline $\begin{array}{l}\text { usta migratoria } \\
\text { un flavipes }\end{array}$ & & $\begin{array}{l}567 \\
566\end{array}$ & Mermaid & & $\begin{array}{l}208 \\
617\end{array}$ \\
\hline phius piscatorius & & - 438 & Miller's Thumb & & \\
\hline olva & - & 451 & Milvus regalis & - & 203 \\
\hline curvirostra & - & - $\quad 261$ & Minnow $\cdot$ & & 485 \\
\hline nus cervus & & - 556 & Mite, Cheese & • & 102 \\
\hline rna & & 44 & , Water & . & 550 \\
\hline dia fragilissima & & 59 & Mocking-bird & & 225 \\
\hline -sucker & & 436 & Mole & - & \\
\hline Ira & - & - & - Cricket & & 。 \\
\hline antula & & . 550 & Mongoos & & • \\
\hline mon & & 19 & Monkey, Capuchin & . & 18 \\
\hline e-Bird of Aus & & - 284 & _ D Diana & & 18 \\
\hline M. & & & 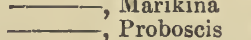 & & 180 \\
\hline [acaw & - & - 300 & Spider & & - 182 \\
\hline achetes pugnax & - & $\begin{array}{r}301 \\
-\quad 363\end{array}$ & $\begin{array}{l}\text { Monk-fish } \\
\text { Monodon monoceros }\end{array}$ & - & 414 \\
\hline ackerel & - & 45 & Moongus & - & 57 \\
\hline acrocercus araca & nga & - 300 & Moor Cock & & 320 \\
\hline ıcropus giganteu & & - & nga proboscidea & & 71 \\
\hline $\cot ^{2}$. & - & 177 & Morse . & - & 72 \\
\hline pie & & 272,587 & Moschus moschiferus & & 63 \\
\hline d. & - 4 & 422,424 & cilla boarula & . & 36 \\
\hline hatee - & & - 41 & Moth, Clothes & & 590 \\
\hline atus Australis & - & 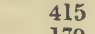 & -, Emperor & & 583 \\
\hline ouste, Egypti & an & $\begin{array}{r}179 \\
-\quad 56\end{array}$ & -, Magpie, or $\mathrm{Cu}$ & $\operatorname{rrar}$ & 588 \\
\hline$s$, Leaf & 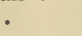 & 56 & other Cary's Chick & & 39 \\
\hline a Penelope & - & 35 & d-Bird of Austr & alia & 3 \\
\hline ina Monkey & & 183 & louse & • & 99 \\
\hline not & • & 97 & $\longrightarrow$, Field & & 99 \\
\hline ozet . & & 183 & -, Harvest & 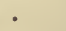 & 100 \\
\hline en, Common or & $\begin{array}{l}\text { r Beech } \\
\text { ow-brea }\end{array}$ & $\begin{array}{l}\text { h } \quad 65 \\
\text { asted } 66\end{array}$ & Mule & 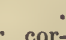 & 130 \\
\hline rtes foina & - & 65 & nutus & 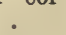 & 532 \\
\hline & - & & Musca domestica . & & 592 \\
\hline$\stackrel{\operatorname{artin}}{ }, \mathrm{Black}$ & - & - $\begin{array}{r}241 \\
243\end{array}$ & - messorius & & 100 \\
\hline
\end{tabular}




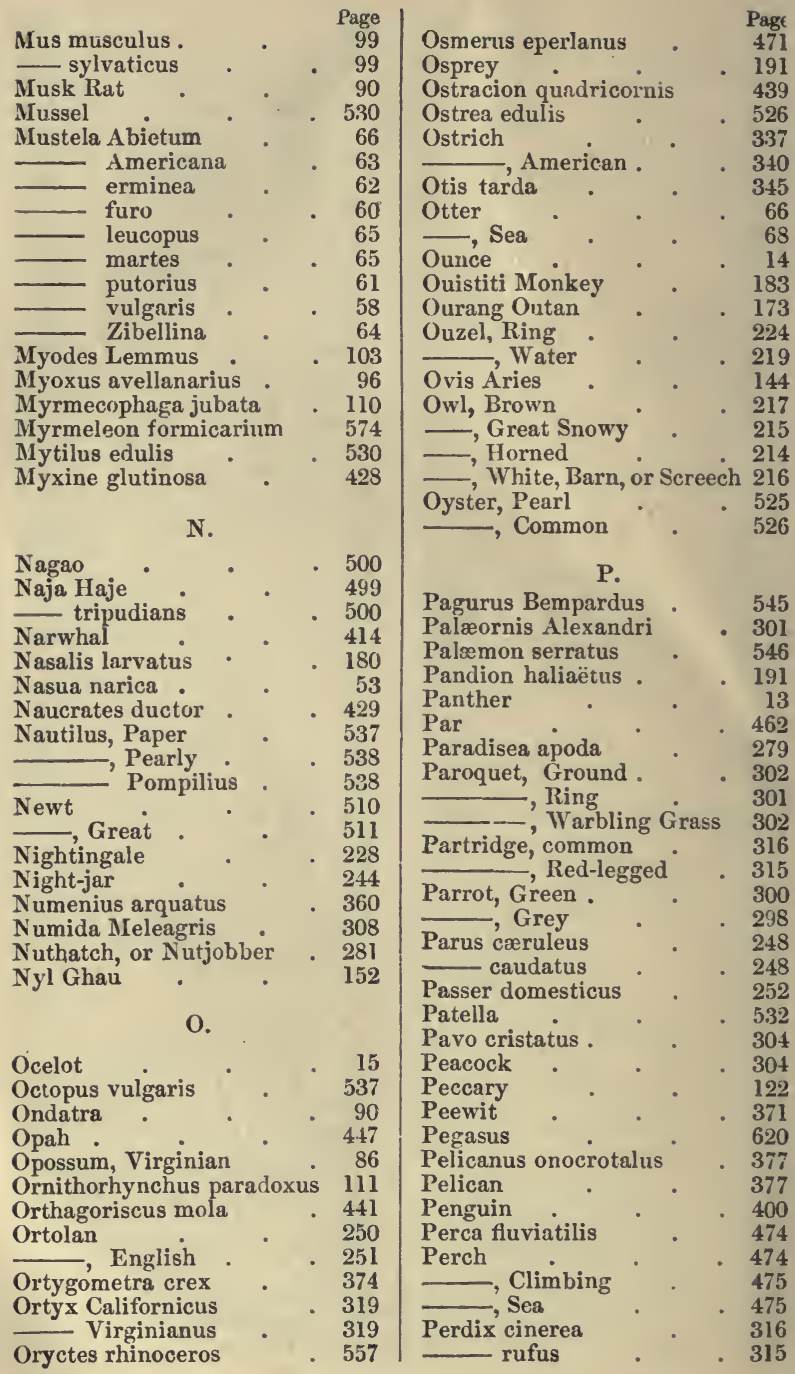


Pearled Hen Page

Pernis apivorus 199

Petrel, Stormy $\quad 393$

Petromyzon marinus $\quad$. 427

Phalacrocorax carbo . $\quad 379$

Praculus . 380

Phalanger Phalangista vulpina $\cdot \quad 87$

Pharaoh's Rat . . $\quad 56$

Phasianus colchicus : . 313

- Nycthemerus 314

Phonix pictus • . $\quad 31$. 617

Pheasant . 313

—_, Australian .

\section{$\longrightarrow$, Gold , Silver}

Philomela luscinia .

Phoca vitulina

Phocæna orca

Pholas dactylus

Phyllium siccifolium.

Phyllostoma spectrum

Physeter macrocephalus

Pica caudata.

Picus viridis .

Pieris Brassicæ

Pigeon, carrier

\section{Pike}

Pilchard . • •

Pilot Fish • •

Pimpla persuasoria

Piophila casei

Pipa Americana

Pipistrelle .

Plaice.

Plant Louse

Platalea Ajaja

- leucorodia

Platessa flesus

Platypus, duck-billed

Plecotus auritus

Plover, golden

, grey

Plyctolophus galeritus

Polar, or White Bear

Polecat

Polypi

Pontia Brassica

Pool Snipe .

565

82

407

272

294

586

333

330

472

457

429

580

308

552

509

81

460

572

359

358

461

460

111

81

369

368

30.3

50

61

604

586

361
Pag

476

Porcelain shells . $\quad 531$

Porcupine . . 106

Porpoise . . 412

Poulpe $\quad 537$

Praying insects . $\quad 563$

Prawn . . . 546

Procellaria glacialis $\quad 395$

Procyon lotor $\quad 51$

Promerooks, Grand $\quad 289$

Psittacus Amazonicus . $\quad 300$

—— aracanga $\quad 300$

- - erythacus . 298

Ptarmigan . . . 321

Pteromys volucella . $\quad 95$

312 Pteropus edulis . 83

314 Ptilonorhynchus holoseri-

ceus . .263

Puffin . • . 398

Pulex irritans . . 594

Puma . . . 18

Pyrrhcorax graculus $\quad 274$

Python . 503

\section{Q.}

\begin{tabular}{lrr} 
Quagga & & 133 \\
Quail & $\cdot$ & 318 \\
\hline A American & $\cdot$ & 319 \\
\hline , Californian & & 319 \\
\hline , Chinese & & 319 \\
Querquedula crecca &. & 391
\end{tabular}

R.

Rabbit, wild . $\quad 93$

$\longrightarrow$, domestic . $\quad$. 94

Racoon . . 51

Raia batis . . . 422

- clavata . . 424

Ram . 146

-, Wallachian . 146

Rana temporaria . . 505

Rangifer Tarandus . 161

Rat . 100

- Alpine $\quad 97$

—, Mlusk . . . 90

-, Water . . 102

Rattle Snake • • 498

Raven. . 265

Red Game . • • • 320

Redpole . . 253

Redshank . . . 361

Redwing . . ${ }_{222}$

Reeve . . . 364

Regulus cristatus . 235 


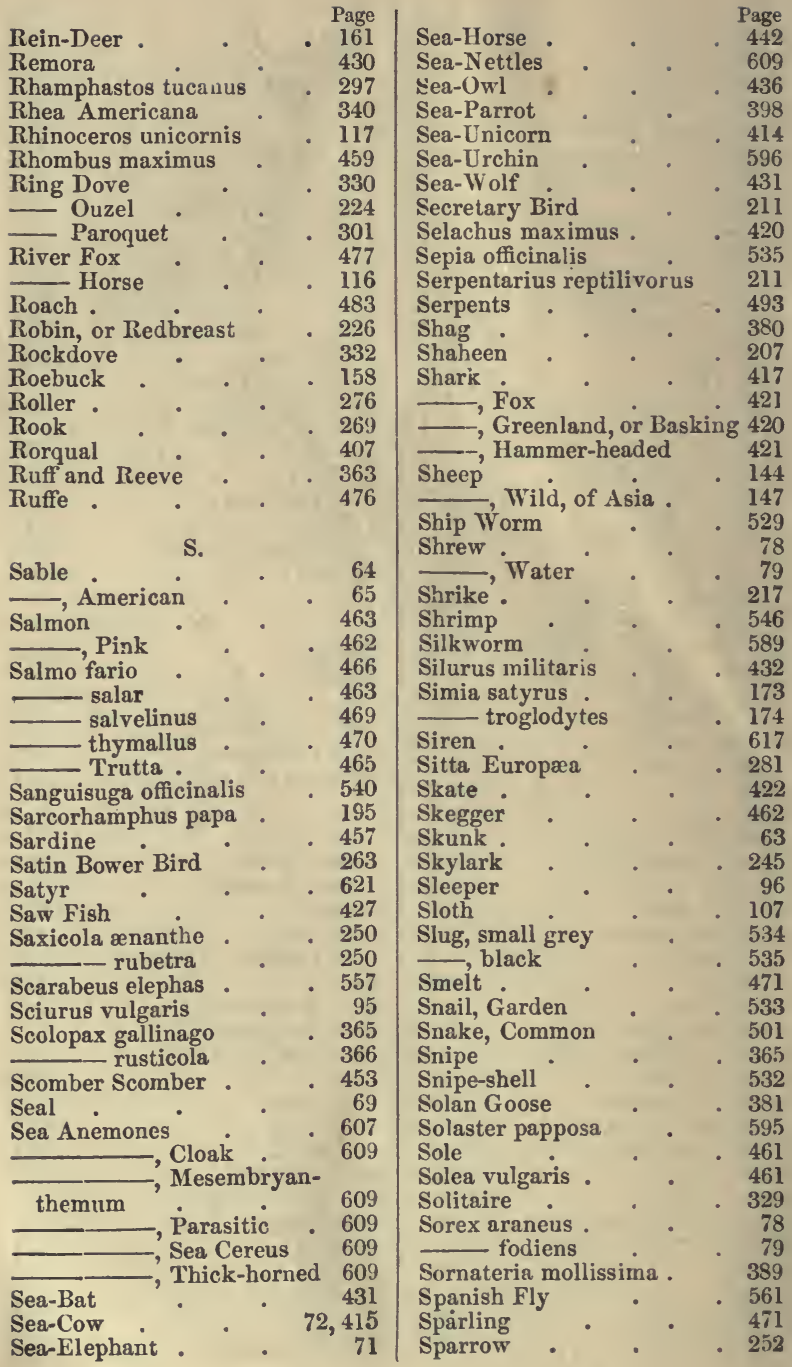




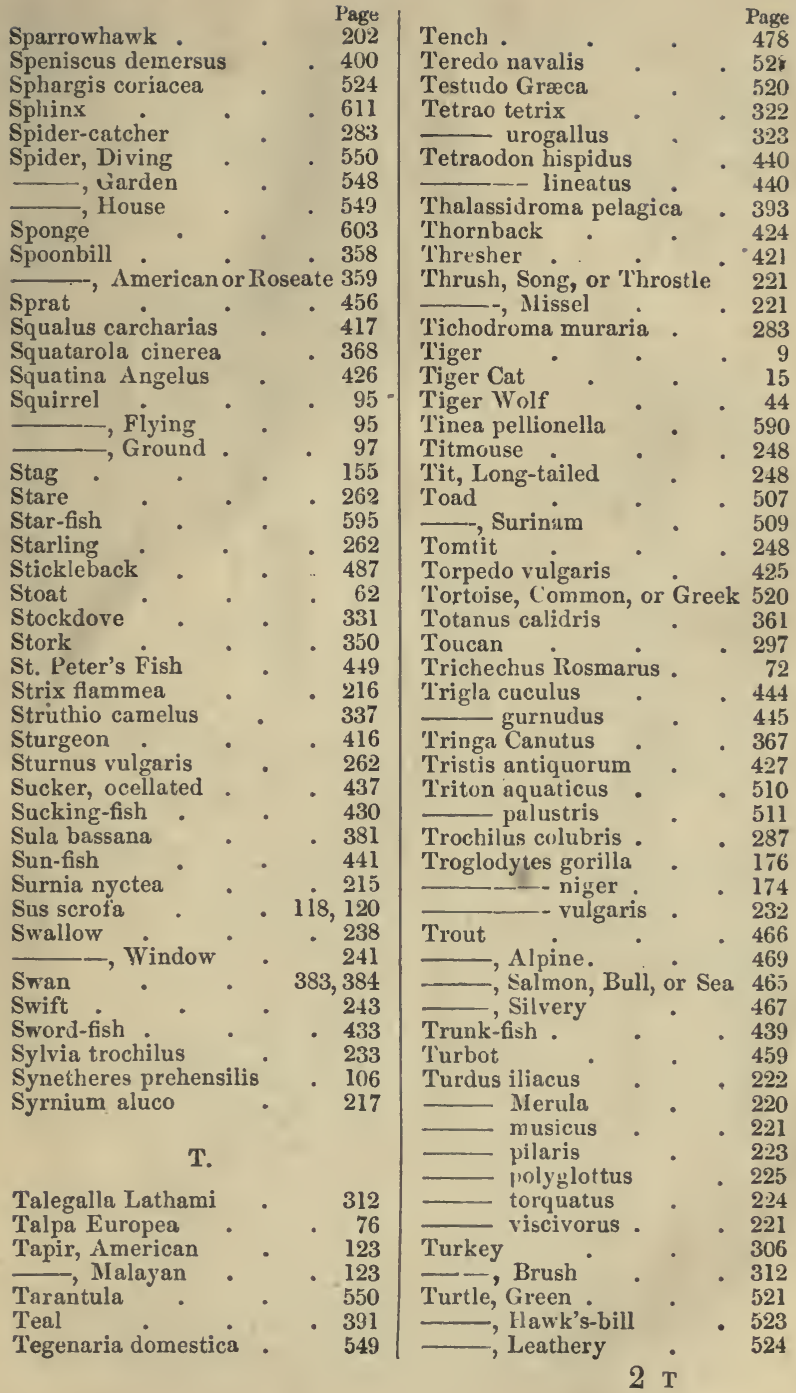




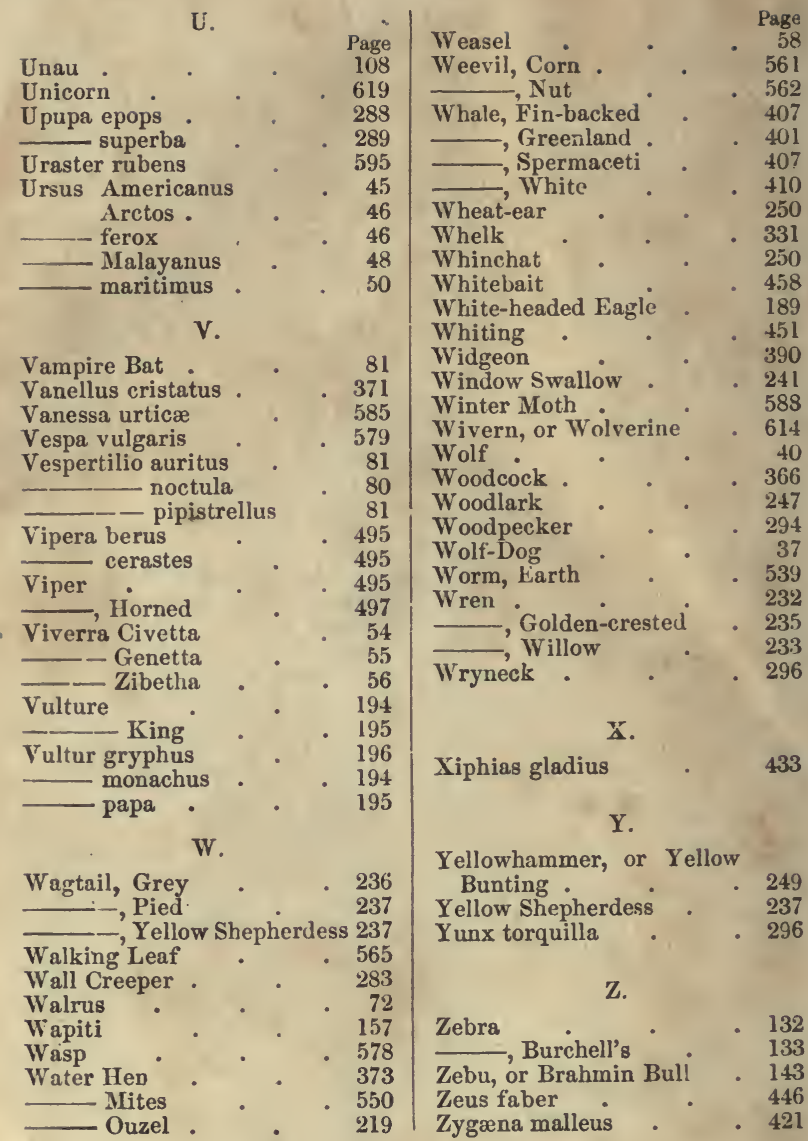




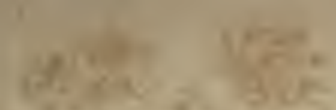

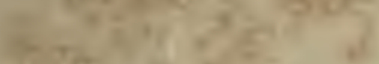

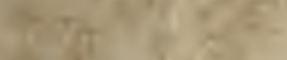

$1 \div \frac{12}{12}$

$-2+1+$

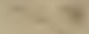

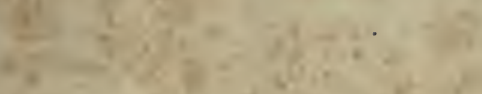

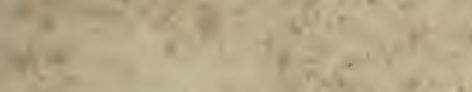

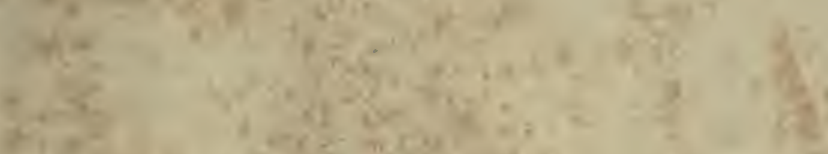

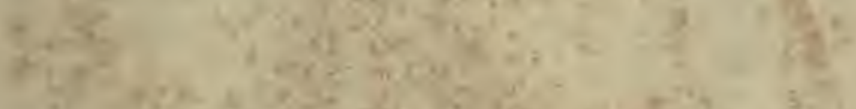

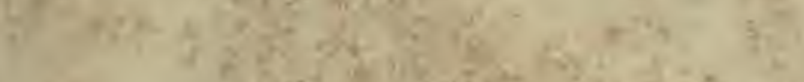

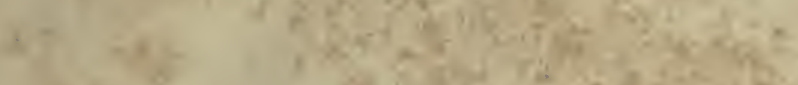

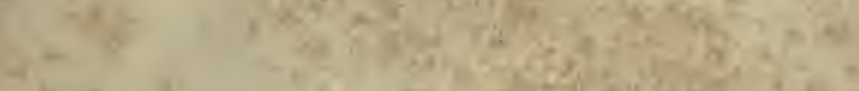

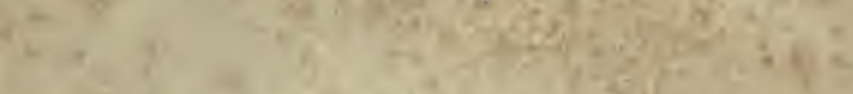

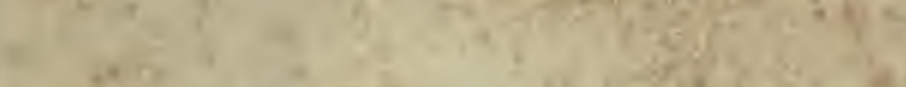

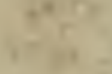

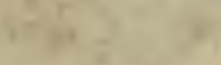
$7+1$

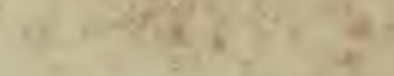

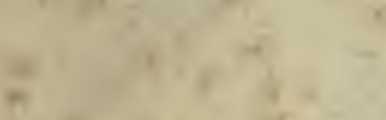

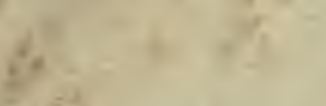

$v^{4}$

$2+1$

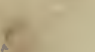

r

s. 


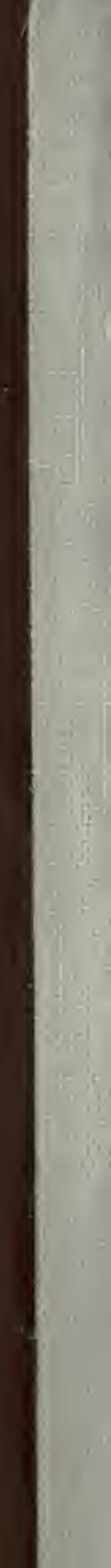


QL

49

L6

1867
Loudon, Jane (Webb)

Mrs. Loudon's

Entertaining naturalist

A new ed., rev. and enl.

Biological

\& Medical

PLEASE DO NOT REMOVE

CARDS OR SLIPS FROM THIS POCKET

UNIVERSITY OF TORONTO LIBRARY 
